$$
\begin{aligned}
& \text { MEIO AMBIENTE } \\
& \text { SUSTENTABILIDADE } \\
& \text { \& } T \text { T C O LOG।A }
\end{aligned}
$$
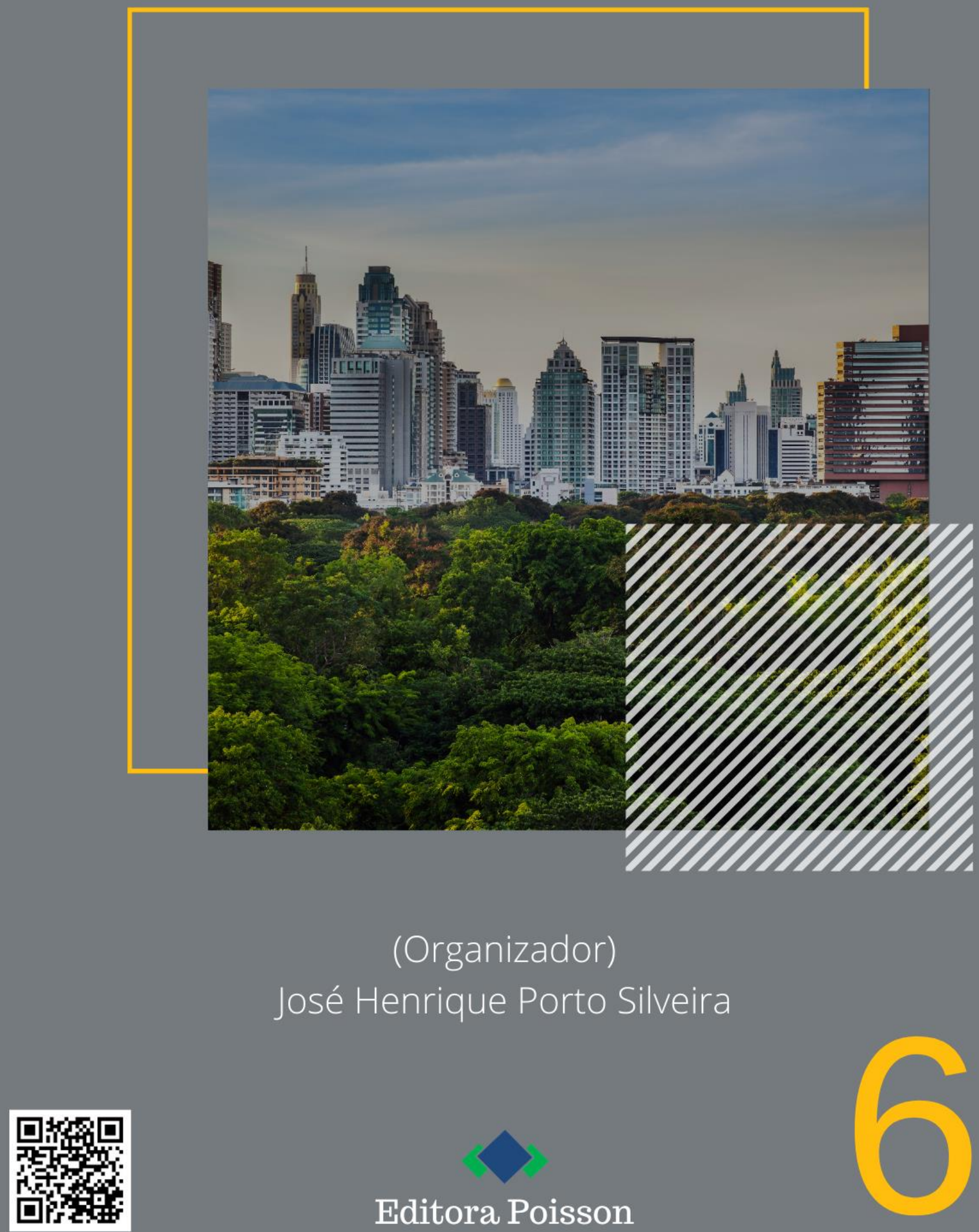

\author{
(Organizador) \\ José Henrique Porto Silveira
}


José Henrique Porto Silveira

\title{
Meio Ambiente, Sustentabilidade e Tecnologia Volume 6
}

\author{
1a Edição
}

Belo Horizonte

Poisson

2021 
Editor Chefe: Dr. Darly Fernando Andrade

\section{Conselho Editorial}

Dr. Antônio Artur de Souza - Universidade Federal de Minas Gerais

Ms. Davilson Eduardo Andrade

Dra. Elizângela de Jesus Oliveira - Universidade Federal do Amazonas

Msc. Fabiane dos Santos

Dr. José Eduardo Ferreira Lopes - Universidade Federal de Uberlândia

Dr. Otaviano Francisco Neves - Pontifícia Universidade Católica de Minas Gerais

Dr. Luiz Cláudio de Lima - Universidade FUMEC

Dr. Nelson Ferreira Filho - Faculdades Kennedy

Ms. Valdiney Alves de Oliveira - Universidade Federal de Uberlândia

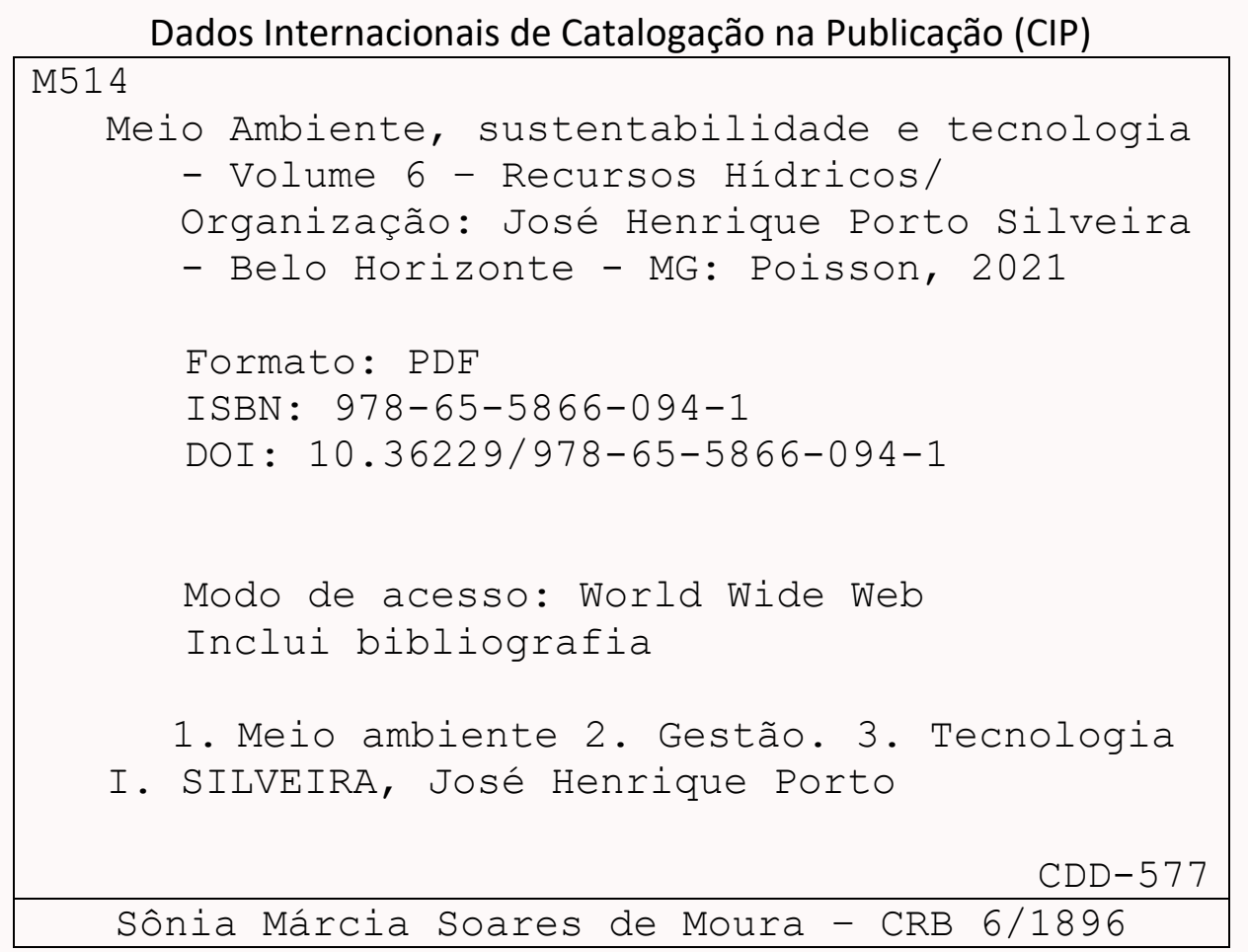

O conteúdo dos artigos e seus dados em sua forma, correção e confiabilidade são de responsabilidade exclusiva dos seus respectivos autores.

$\underline{\text { www.poisson.com.br }}$

contato@poisson.com.br 


\section{Prefácio}

A trajetória dos seres humanos vem sendo escrita com ênfase sempre na nossa infinita capacidade de subjugar a natureza, extrair dela o que nos interessa e descartar o que não nos serve na forma de resíduos. Tais resíduos no ar, na água ou no solo representam o que deve ser evitado, mitigado ou controlado. É poluição ou degradação. Em grande parte essa trajetória desastrada é decorrente da evolução das ciências e suas tecnologias.

Mas quando se começa perceber o desastre, mesmo que lenta e gradativamente a ciências e suas tecnologias podem se constituir em reversão da catástrofe prenunciada. Novos tempos, tempos de pensar de forma sistêmica e ecológica.

Nessa perspectiva, meio ambiente e sustentabilidade são expressões fundamentais. Conceitos distintos, mas indissociáveis para podermos pensar para agir e agir para construir o futuro da humanidade. É assim que as ciências atuam, buscando respostas com a ampliação dos conhecimentos e encontrando soluções com novas tecnologias. Nesta busca incessante para criar e construir soluções para os problemas ambientais e de encontrar caminhos para manifestação dos preceitos da sustentabilidade, tecnologias são ensaiadas e sugeridas como viáveis e mesmo projetadas para execução.

E este é o verdadeiro papel das ciências nas academias e nos centros de pesquisa, envolvendo as muitas disciplinas que se integram na construção do conhecimento socioambiental: engenharia, arquitetura, sociologia, psicologia, geografia, antropologia, biologia, pedagogia e tantas outras. Quase sempre são processos que envolvem a multi, a inter e a transdisciplinaridade.

Nessa coletânea, a intenção principal é mostrar possibilidades, algumas mais outras menos detalhadas, mas todas dotadas de intencionalidades em relação à busca de um futuro melhor.

Como ambientalista e profissional com muitos anos de atuação nas áreas de avaliação de impactos e educação ambiental vejo como muito promissor as ideias e soluções técnicas que estão sendo gestadas no meio acadêmico nas áreas de meio ambiente e sustentabilidade.

Reitero que as temáticas como meio ambiente e sustentabilidade devem estar em constante interação na construção do futuro, já que inevitavelmente a nossa permanência como espécie depende da permanência de outras espécies da flora e da fauna e da boa qualidade dos elementos ar, água e solo. Nunca é tarde na busca de reverter a nossa trajetória, usando bom senso e o conhecimento proporcionado pelas ciências e pelas culturas milenares sobre o meio ambiente. 


\section{Sumário}

Capítulo 1: Caracterização morfométrica da Microbacia Hidrográfica do Ribeirão Concórdia, Espírito Santo.

Rafael Esteves Dohler, Natália Gomes de Souza Mendes, Vitor Heringer Silva, Roberto Avelino Cecílio, Ralph Bonandi Barreiros

DOI: $10.36229 / 978-65-5866-094-1 . C A P .01$

Capítulo 2: Aplicação de Inteligência Geoespacial na análise da declividade da Bacia do Rio Montividiu, Goiás, Brasil.

Hevrli da Silva Carneiro Pilatti, Wellmo dos Santos Alves, Maria Antonia Balbino Pereira, Wilker Alves Morais, Derick Martins Borges Moura

DOI: 10.36229/978-65-5866-094-1.CAP.02

Capítulo 3: Análise da declividade da Bacia Hidrográfica do Córrego Indaiá (Rio Verde, Goiás) por meio de geotecnologias. 22

Maria Antonia Balbino Pereira, Wellmo dos Santos Alves, Hevrli da Silva Carneiro Pilatti, Derick Martins Borges Moura, Wilker Alves Morais

DOI: 10.36229/978-65-5866-094-1.CAP.03

Capítulo 4: Avaliação do potencial de contaminação de águas subterrâneas por paracetamol, através de ensaios de cinética de adsorção em solo.

Ebenézer de França Santos, Manuella Virgínia Salgueiro Gondim, Antônio Celso Dantas Antonino, Valmir Felix de Lima

DOI: 10.36229/978-65-5866-094-1.CAP.04

Capítulo 5: Qualidade da água e comunidades de macroalgas em recursos hídricos na área urbana de Manaus/AM. 37

Domitila Pascoaloto, Núbia Abrantes Gomes, Climéia Corrêa Soares

DOI: 10.36229/978-65-5866-094-1.CAP.05

Capítulo 6: Alterações em tratamentos do tipo lagoa estabilizada devido à influência de chuvas 47

Diogo Botelho Correa de Oliveira, Marco Aurélio Calixto Ribeiro de Holanda, Camila Barrêtto Rique de Barros, Ariela Rocha Cavalcanti, Willames de Albuquerque Soares

DoI: 10.36229/978-65-5866-094-1.CAP.06

Capítulo 7: Viabilidade econômica de um sistema de aproveitamento de água pluvial em condomínio do Programa Minha Casa Minha Vida, Rio de Janeiro 55

Diego Sebastian Carvalho de Souza, Celso Romanel, Ricardo de Freitas Cabral

DOI: 10.36229/978-65-5866-094-1.CAP.07 


\section{Sumário}

Capítulo 8: Reúso de água nas indústrias: Desafios e oportunidades 61

Maria Gabriela de Souza Damaceno, Karla Alcione da Silva Cruvinel

DOI: 10.36229/978-65-5866-094-1.CAP.08

Capítulo 9: Fontes naturais de águas em área urbana e nossas expectativas de uso. 68

Cícero Wislei Fernandes Guerellus, Grasiele da Silva Gouveia, Lucas Caillot Schroeder, Maria Magdalena Ribas Döll

DOI: $10.36229 / 978-65-5866-094-1 . C A P .09$

Capítulo 10: Pluviosidade histórica do município de Campina Grande-PB

Edgleidson Lima Rodrigues, Renato Francisco Cândido Lopes, Francisco de Assis Salviano de Sousa DOI: $10.36229 / 978-65-5866-094-1 . C A P .10$

Capítulo 11: Características dos principais afluentes da margem esquerda da bacia do médio Rio Negro, Amazônia Central. 79

Domitila Pascoaloto, Núbia Abrantes Gomes, Hillândia Brandão da Cunha

DOI: $10.36229 / 978-65-5866-094-1 . C A P .11$

Capítulo 12: Efeito da redução da vazão de restrição defluente da Barragem de Xingó na salinidade da água no baixo trecho do Rio São Francisco 88

Sândira Lívia Moraes Fonseca, Aline Almeida de Jesus Magalhães, Vânia Palmeira Campos, Yvonilde Dantas Pinto Medeiros

DOI: $10.36229 / 978-65-5866-094-1 . C A P .12$

Capítulo 13: História e principais legislações da defesa do meio ambiente no Brasil

Antonio Jorge Barbosa da Silva, Ires Paula de Andrade Miranda

DOI: 10.36229/978-65-5866-094-1.CAP.13

Capítulo 14: A institucionalização do Programa Ambiente Legal, no âmbito do Ministério Público do Estado do Amazonas: Um estudo de caso sob o enfoque socialconstrucionista 119

Edson de Paula Rodrigues Mendes

DOI: $10.36229 / 978-65-5866-094-1 . C A P .14$ 


\section{Sumário}

Capítulo 15: As servidões por utilidade pública nos assentamentos da reforma agrária. 133

David Hermes Depiné, Fabiana Telles David Depiné

DOI: 10.36229/978-65-5866-094-1.CAP.15

Capítulo 16: Modelo para delimitação automática de áreas de preservação permanente conforme o Novo Código Florestal: Aplicação em três municípios no Bioma Amazônia em Mato Grosso. 140

Weslei Butturi, Vinicius de Freitas Silgueiro, Edgley Pereira da Silva, Bruno Diego Cardoso dos Santos DOI: 10.36229/978-65-5866-094-1.CAP.16

Capítulo 17: 0 senso comum e conhecimento científico no contexto da pandemia... 148 Letícia Cristina Alves de Sousa, Bruno Rogério Ferreira, Cristiana Paula Vinhal, Fernando Antônio de Souza Ferreira, Letícia Moraes de Faria, Lorena da Fonseca Ferreira, Mariana Luize Ferreira Mamede, Isabela Jube Wastowski

DOI: $10.36229 / 978-65-5866-094-1 . C A P .17$

Capítulo 18: A agricultura urbana agroecológica como instrumento de concretização da função social da cidade. 156

Vanessa de Castro Rosa, Cryfort Stone Ribeiro Silva

DOI: 10.36229/978-65-5866-094-1.CAP.18

Capítulo 19: Logística reversa de pós-consumo: Concepção dos usuários no município de Aracaju (SE) 166

Lucivaldo de Jesus Teixeira, Allana Karla Costa Alves, Heloísa Thaís Rodrigues de Souza

DOI: 10.36229/978-65-5866-094-1.CAP.19

Capítulo 20: Turismo ecológico na preservação de igarapés em Santo Antônio do TauáPA. 174

Marco Valério de Albuquerque Vinagre, Gabriela Doce Silva Coelho de Souza, Edwin Hennington Pereira Malheiros, Fernanda Caroline de Oliveira Carneiro, Peri Guilherme Monteiro da Silva, Miroslawa Luczynski DOI: $10.36229 / 978-65-5866-094-1 . C A P .20$

Capítulo 21: Aproveitamento de resíduos da lama de barragem de mineração como pigmento para tintas

Jorge David Alguiar Bellido, Aline Cristina da Silva, Clara de Oliveira Hespanhol, Jeniffer Santos Ferreira, Jéssica Carolaine Vieira de Azevedo, Vanessa Carolina Matosinhos Gonçalves, Yasmim Ribeiro Meirelles DOI: 10.36229/978-65-5866-094-1.CAP.21 


\section{Sumário}

Capítulo 22: Utilização de fibras como adjunto na produção de telhas 190

Jorge David Alguiar Bellido, Lisbeth Zelayaran Melgar, Felícia Maria Silva Moreira, João Victor Sales Castro, Pamela Lopes Soares

DOI: $10.36229 / 978-65-5866-094-1 . C A P .22$

Capítulo 23: Sobrevivência e viabilidade de patógenos emergentes em meio aquático 194

David Américo Nakagawa, Claudia Telles Benatti

DOI: $10.36229 / 978-65-5866-094-1 . C A P .23$

Capítulo 24: Estudo do crescimento de microalgas em meio de cultivo CHU e dejeitos suínos. 205

Beatriz Jacob Furlan, Pedro Henrique Siqueira Zatta, Valeria Cristina Pereira Antezana, Lauber de Souza Martins, André Bellin Mariano

DOI: $10.36229 / 978-65-5866-094-1 . C A P .24$

Capítulo 25: Indicadores biológicos de qualidade de um latossolo cultivado com soja inoculada com Trichoderma ssp no cerrado do Oeste Baiano 212 Luan dos Santos Silva, Diony Alves Reis, Roberto Bagattini Portella, Jackson Roberto de Souza Santos, Magno Rodrigues de Carvalho Filho

DOI: $10.36229 / 978-65-5866-094-1 . C A P .25$

Capítulo 26: Avaliação da emissão de metano $\left(\mathrm{CH}_{4}\right)$ pela pecuária no município de Anchieta, Santa Catarina

Luciane Luvizon, Silvia Mara Zanela Almeida, Elisangela Bini Dorigon

DOI: 10.36229/978-65-5866-094-1.CAP.26

Autores: 


\section{Capítulo 1}

\section{Caracterização morfométrica da Microbacia Hidrográfica do Ribeirão Concórdia, Espírito Santo}

\section{Rafael Esteves Dohler}

Natália Gomes de Souza Mendes

Vitor Heringer Silva

Roberto Avelino Cecílio

Ralph Bonandi Barreiros

Resumo: A utilização de índices morfométricos possibilita a realização de inferências sobre indicadores físicos de uma bacia hidrográfica e oferece subsídios à avaliação de alterações ambientais. Este trabalho teve como objetivo realizar a caracterização morfométrica da microbacia hidrográfica do Ribeirão Concórdia, localizado no estado do Espírito Santo. Calcularam-se índices morfométricos relacionados a hidrografia, ao relevo e à geometria da microbacia hidrográfica. A microbacia possui área de 45,23 km2 e perímetro igual a $35,7 \mathrm{~km}$. Os índices morfométricos indicaram que a microbacia possui canais pouco sinuosos, baixa capacidade de gerar novos cursos d'água e pouca tendência a enchentes.

Palavras-chave: Caracterização física, Morfometria, Sistema de Informação Geográfica. 


\section{INTRODUÇÃO}

O uso incorreto do solo pelo homem tende a inviabilizar ao longo do tempo a produção agrícola e causam distúrbios nos processos físicos e ecológicos, que levam a degradação dos recursos naturais. Assim, o planejamento e o manejo conservacionista são atividades que auxiliam no controle e adequação do uso das terras com a intuito de aumentar a produção e minimizar os distúrbios ambientais (OLIVEIRA et al., 2013).

As características físicas de uma bacia hidrográfica são elementos importantes para avaliação de seu comportamento hidrológico, pois, ao se estabelecerem relações e comparações entre eles e dados hidrológicos conhecidos, podem-se determinar indiretamente os valores hidrológicos em locais com ausência de dados (VILLELA \& MATTOS, 1975). Segundo Tonello et al. (2006) as características físicas e bióticas de uma bacia possuem importante função nos processos do ciclo hidrológico, influenciando principalmente o escoamentos superficial e sub-superficial, a infiltração de água no solo e a evapotranspiração.

Conforme Guerra \& Guerra (2003), a caracterização morfométrica de bacias hidrográficas é o estudo quantitativo de seu relevo. Deste modo, a utilização de parâmetros morfométricos possibilitam a realização de inferências acerca dos indicadores físicos de uma bacia, de forma a fornecer subsídios ao manejo e a conservação desses. Dentre os estudos de caracterização morfométrica em bacias utilizando Sistemas de Informações Geográficas - SIG's, destacam-se os trabalhos de Benatti et al. (2015), Lorenzon et al. (2015) e Abud et al. (2015).

O Ribeirão Concórdia é o principal contribuinte do rio Novo no trecho superior, cuja confluência com este ocorre na divisa do município de Vargem Alta-ES com Rio Novo do Sul-ES. A bacia hidrográfica do Rio Novo, possui uma extensa diversidade paisagística, e tem em sua área as atividades econômicas de mineração, pecuária e agricultura (SARMENTO SOARES \& MARTINS PINHEIRO, 2012). Diante do exposto, o presente trabalho teve como objetivo realizar a caracterização morfométrica da microbacia hidrográfica do Ribeirão Concórdia, localizada no Estado do Espírito Santo, Brasil.

\section{METODOLOGIA}

A área de estudo corresponde à microbacia hidrográfica do Ribeirão Concórdia, afluente do Rio Novo, que abrange parte dos municípios de Vargem Alta e Rio Novo do Sul, localizados no Estado do Espírito Santo, e encontra-se inserida entre as coordenadas geográficas $41^{\circ} 0^{\prime} 19,0^{\prime \prime}(\mathrm{W}), 20^{\circ} 41^{\prime} 25,4^{\prime \prime}(\mathrm{S}), 40^{\circ} 55^{\prime} 41,4^{\prime \prime}$ (W) e $20^{\circ} 46^{\prime} 50,6^{\prime \prime}(S)$. Segundo a classificação climática de Köppen, essa região é classificada como Cfb, no qual trata-se do clima subtropical com verão ameno (ALVARES et al., 2013).

Para a geração do Modelo Digital de Elevação (MDE), foram utilizadas as curvas de nível originárias da base cartográfica do IBGE. 0 interpolador utilizado foi o Topo to Raster, conforme descrito por Peluzio et al. (2010). A remoção das depressões espúrias do MDE com células (pixel) de $10 \mathrm{~m}$ de resolução espacial e o mapeamento da declividade da microbacia estudada foi realizada conforme orientações de Santos et al. (2010). A reclassificação foi realizada em seis intervalos distintos sugeridos pela Empresa Brasileira de Pesquisa Agropecuária (EMBRAPA, 1979).

A microbacia hidrográfica do Ribeirão Concórdia foi delimitada manualmente utilizando o software ArcGIS 10.3®. Para a delimitação manual, utilizaram-se as cotas altimétricas da curva de nível do Instituto Brasileiro de Geografia e Estatística - IBGE (1978), Folha Cachoeiro de Itapemirim (SF-24-V-A-V-4), na escala de 1:50.000, com equidistância de 20 metros.

Dentre as características geométricas utilizadas neste estudo, foram calculadas o coeficiente de compacidade (Kc), o fator de forma (Kf), a razão de elongação (Re) e o índice de circularidade (Ic), que são apresentados nas equações abaixo:

$$
\begin{aligned}
& K c=0,28 \frac{P}{\sqrt{A}} \\
& K f=\frac{A}{L_{\text {axial }}^{2}} \\
& \operatorname{Re}=1,128 \frac{\sqrt{A}}{L_{\text {axial }}}
\end{aligned}
$$




$$
I c=12,57 \frac{A}{P^{2}}
$$

Em que:

$\mathrm{Kc}, \mathrm{Kf}, \mathrm{Re}$ e Ic = adimensional;

$\mathrm{P}=$ perímetro da bacia, $\mathrm{km}$;

$\mathrm{A}=$ área da bacia, $\mathrm{km}^{2}$;

Laxial $=$ comprimento axial da bacia, $\mathrm{km}$.

Com relação as características da hidrografia estudadas, utilizou-se a base de dados do IBGE e assim foram calculados a densidade de drenagem (Dd), a densidade de confluência (Dc), a densidade hidrográfica (Dh), a extensão média do escoamento superficial (I), a sinuosidade dos cursos d'águas (SIN) e o índice de sinuosidade (Is), conforme descritos nas equações abaixo:

$$
\begin{aligned}
& D d=\frac{L_{t}}{A} \\
& D c=\frac{N C}{A} \\
& D h=\frac{N}{A} \\
& I=\frac{A}{4 L_{t}} \\
& S I N=\frac{L_{\text {rio }}}{L_{\text {talvegue }}} \\
& I S=100 \frac{L_{\text {rio }}-L_{\text {talvegue }}}{L_{\text {talvegue }}}
\end{aligned}
$$

Em que:

Dd = km.km-2, Dc = Confluências.km-2, Dh = Curso.km-2, I e SIN = Adimensional, Is = \%;

$\mathrm{Lt}$ = somatório do comprimento de todos os cursos d'água, $\mathrm{km}$;

$\mathrm{NC}$ = número de confluências;

$\mathrm{N}$ = número de cursos d'água;

Lrio = comprimento do curso d'água principal, km;

Ltalvegue= comprimento do talvegue do curso d'água principal, $\mathrm{km}$.

E dentre as características de relevo, foram calculados a altitude média (Hmédia), máxima (Hmáx), mínima (Hmin), a declividade média (Imédia), máxima (Imáx) e mínima (Imín), o coeficiente de rugosidade (Cr), o índice de rugosidade (HD) e a razão de relevo (Rr) da microbacia.

$$
\begin{aligned}
& C r=D d \times \bar{d} \\
& H D=D d * \Delta_{a} \\
& R r=\frac{\Delta_{a}}{L_{\text {axial }}}
\end{aligned}
$$


Em que:

$\mathrm{Cr}$ e HD = Adimensional e $\mathrm{Rr}=\mathrm{m} \cdot \mathrm{m}-1$;

$\Delta_{\mathrm{a}}=$ amplitude altimétrica, $\mathrm{km}$;

$\bar{d}$ = Declividade média, $\%$.

\section{RESULTADOS}

Os índices morfométricos referentes à caracterização geométrica são apresentados na Tabela 1 . A microbacia hidrográfica do Ribeirão Concórdia possui área total de 45,23 km² , perímetro de $35,7 \mathrm{~km}$ e comprimento axial de $10,32 \mathrm{~km}$. Os índices morfométricos da caracterização da hidrografia são apresentados na Tabela 2 .

Tabela 1 - Índices morfométricos relacionados à geometria da microbacia hidrográfica do Ribeirão Concórdia (Espírito Santo, Brasil).

\begin{tabular}{|c|c|}
\hline \multicolumn{2}{|c|}{ Características geométricas } \\
\hline Área total (A) & $45,23 \mathrm{~km}^{2}$ \\
\hline Perímetro (P) & $35,7 \mathrm{~km}$ \\
\hline Comprimento Axial (Laxial) & $10,32 \mathrm{~km}$ \\
\hline Coeficiente de compacidade (Kc) & 1,48 \\
\hline Fator de forma (Kf) & 0,42 \\
\hline Razão de elongação (Re) & 0,08 \\
\hline İndice de circularidade (Ic) & 0,45 \\
\hline
\end{tabular}

Fonte: o autor.

Tabela 2 - Índices morfométricos relacionados à hidrografia da microbacia hidrográfica do Ribeirão

Concórdia (Espírito Santo, Brasil).

\begin{tabular}{|c|c|}
\hline \multicolumn{2}{|c|}{ Características da hidrografia } \\
\hline Comprimento do curso d'água principal (Lp) & $12,92 \mathrm{~km}$ \\
\hline Densidade de drenagem (Dd) & $2,73 \mathrm{~km}_{\mathrm{km}}^{-2}$ \\
\hline Densidade de confluência (Dc) & $2,79 \mathrm{conf} . \mathrm{km}^{-2}$ \\
\hline Densidade hidrográfica (Dh) & $2,92 \mathrm{cursos} \cdot \mathrm{km}^{-2}$ \\
\hline Extensão média do escoamento superficial ( I) & $1394,64 \mathrm{~km}$ \\
\hline Sinuosidade dos cursos d'águas (Sin) & 1,27 \\
\hline Índice de sinuosidade (Is) & $21,05 \%$ \\
\hline
\end{tabular}

Fonte: o autor.

A microbacia possui extensão média do escoamento superficial de 1394,64 km e comprimento do curso d'água principal de $12,92 \mathrm{~km}$. A bacia apresentou densidade de drenagem apresentou de $2,73 \mathrm{~km} . \mathrm{km}^{-2}$, indicando bacia com boa drenagem, conforme proposto por Villela \& Mattos (1975). A mesma pode variar de 0,5 km.km-2 em bacias com drenagem pobre, ou acima de 3,5 km.km-2, em bacias excepcionalmente drenadas. Segundo Rocha \& Kurtz (2001), a densidade de drenagem está relacionada com a declividade do relevo, cobertura vegetal, resistência e permeabilidade do solo.

A densidade de confluência encontrada foi de $2,79 \mathrm{~km} \cdot \mathrm{km}^{-}{ }^{2}$, o que pode significar que a cada $\mathrm{km}^{2}$ há probabilidade de encontrar pelo menos 2 confluências de cursos d'água. 0 valor de 1,27 de sinuosidade dos cursos d'água (Sin) indica que o canal tende a ter forma transicional entre regular e irregular (Coutinho et al., 2011). De acordo com Christofoletti (1980), considera-se o canal meândrico quando o índice é igual ou superior 1,5 .

A altitude na bacia hidrográfica varia de 90,15 a 1142,19 m, resultando numa amplitude altimétrica de 1052,04 m. A declividade média da bacia foi de 42,66\%, considerada pela EMBRAPA (1979) como relevo fortemente ondulado. Com relação ao mapeamento da declividade na bacia (Figura 1), houve o predomínio das classes de declividade de relevo fortemente ondulado e relevo montanhoso. 
Figura 1 - Representação do relevo da microbacia do Ribeirão Concórdia.

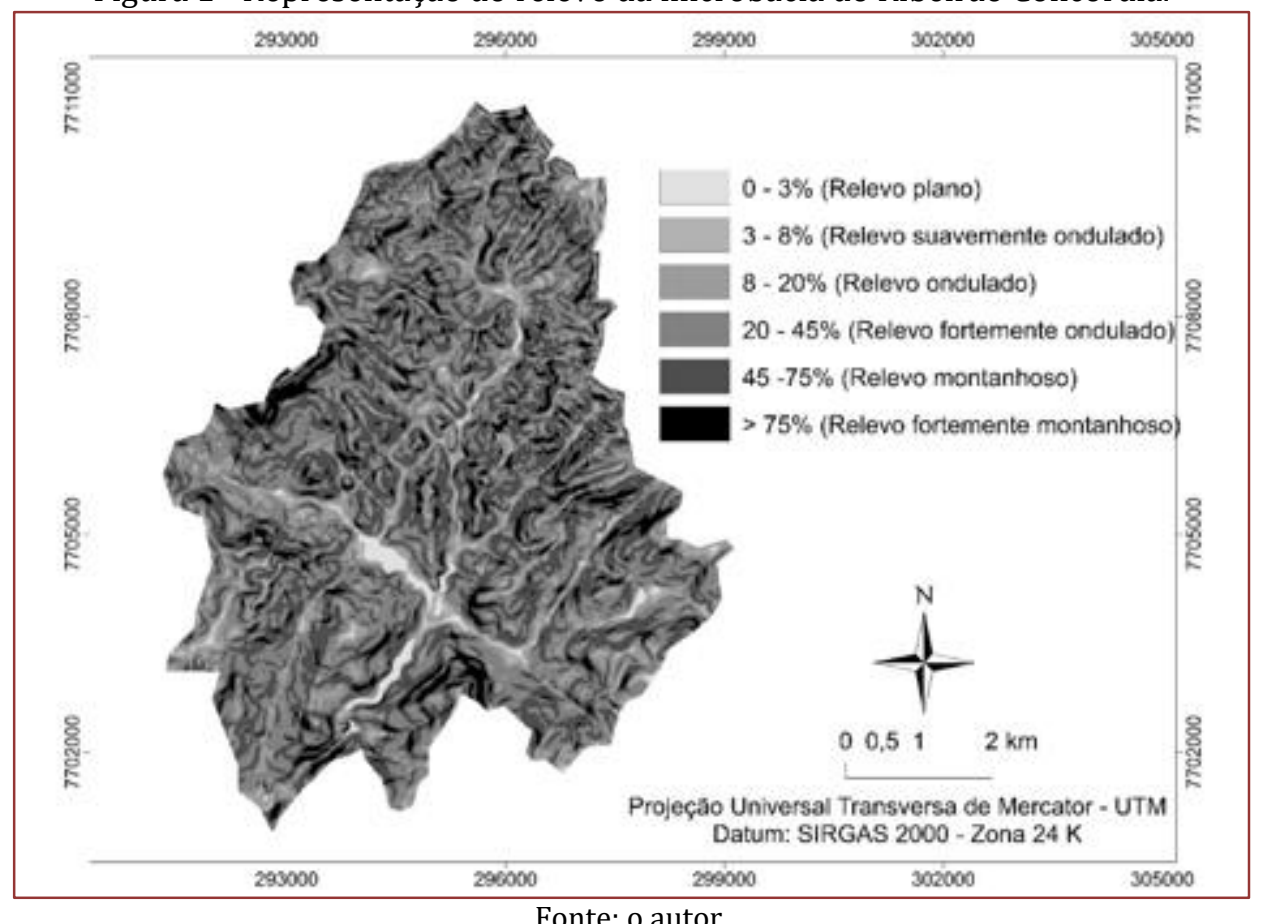

Os índices morfométricos obtidos pelo mapa de relevo e declividade da microbacia estão descritos na Tabela 3. Foi encontrado coeficiente de rugosidade (Cr) de 61,20, que segundo Pissarra et al. (2004), indica solos apropriados para reflorestamentos.

0 índice de rugosidade (HD) obtido foi de 2868,13. Valores elevados de HD, podem ser indicativos de vertentes íngremes e de longa extensão, embora possam acontecer que, áreas com alta densidade de drenagem (Dd) e baixo valor de amplitude altimétrica (H) também sejam tão rugosas quanto aquelas com baixa Dd e elevado valor de H (CHRISTOFOLETTI, 1980).

Tabela 3 - Índices morfométricos relacionados ao relevo da microbacia hidrográfica do Ribeirão Concórdia (Espírito Santo, Brasil).

\begin{tabular}{|l|c|}
\hline \multicolumn{2}{|c|}{ Características de relevo } \\
\hline Altitude média (Hmédia) & $621,65 \mathrm{~m}$ \\
\hline Altitude máxima (H $\left.\mathrm{H}_{\text {máx }}\right)$ & $1142,19 \mathrm{~m}$ \\
\hline Altitude mínima ( $\mathrm{H}_{\text {min }}$ ) & $90,15 \mathrm{~m}$ \\
\hline Declividade média (Imédia) & $42,66 \%$ \\
\hline Declividade máxima (Imáx) & $194,21 \%$ \\
\hline Declividade mínima (Imín) & $0,047 \%$ \\
\hline Razão de relevo (Rr) & $0,05 \mathrm{~m}_{\mathrm{m}}^{-1}$ \\
\hline İndice de rugosidade (HD) & 2868,13 \\
\hline Coeficiente de rugosidade (Cr) & 116,30 \\
\hline
\end{tabular}

Fonte: o autor.

\section{DISCUSSÃO}

Observa-se na caracterização geométrica, que o coeficiente de compacidade foi de 1,48, que reflete a tendência mediana da ocorrência de grandes enchentes (SILVA \& MELLO, 2006), considerando os padrões normais de precipitação pluviométrica. Já o fator de forma $(0,42)$ e o índice de circularidade $(0,45)$, indicam que a bacia do Ribeirão Concórdia apresenta baixa propensão à ocorrência de cheias em função de sua forma alongada (SILVA \& MELLO, 2006). Segundo Cardoso et al. (2006), bacias com formato alongado possuem baixa probabilidade de chuvas intensas ocorrerem em toda sua extensão, concentrando grande volume de água no tributário principal. Entretanto, para a avaliação da propensão a enchentes em uma bacia, deve-se levar em consideração outros fatores além de sua forma. 
A densidade hidrográfica apresentou valor de 2,92 cursos por $\mathrm{km}^{2}$, indicando baixa capacidade em gerar novos cursos d'águas. Índices de rugosidade elevados, implicam em maior potencial de erosão por processos hídricos (ROCHA \& KURTZ, 2001). Coutinho et al. (2011) encontraram na bacia hidrográfica do rio da Prata (Castelo, ES), mesma macrorregião da microbacia do Ribeirão Concórdia, valor de HD elevado $(4235,13)$. A razão de relevo $(\mathrm{Rr})$ foi de $0,05 \mathrm{~m} \cdot \mathrm{m}-1$, dessa maneira pode-se inferir que o relevo é considerado alto de acordo com Rossi \& Pfeifer (1999).

\section{CONCLUSÃO}

Os índices morfométricos indicaram pouca tendência a enchentes na microbacia hidrográfica do Ribeirão Concórdia, considerando padrões normais da precipitação. Além disso, de acordo com índices de hidrografia, a microbacia possui boa drenagem, canais pouco sinuosos e baixa capacidade de gerar novos cursos d'água. A microbacia apresentou elevado índice de rugosidade, que está associado em maior potencial de erosão por processos hídricos em áreas íngremes. ${ }^{-2}$

\section{REFERÊNCIAS}

[1] ABUD, E.A.; LANI, J.L.; ARAÚJO, E.A.; AMARAL, E.E.; BARDALES. N.G.; FERNANDES FILHO, E.I. Caracterização morfométrica das sub-bacias no município de Xapuri: subsídios à gestão territorial na Amazônia Ocidental. Revista Ambiente \& Água, v.10, n.2, 2015

[2] AlvareS, C. A.; STAPE, J. L.; SENTElhAS, P. C.; GONÇALVES, J. L. M.; SPAROVEK, G. Köppen's climate classification map for Brazil. Meteorologische Zeitschrift, v. 22, n. 6, p. 711-728, 2013.

[3] BENATTI, D. P.; TONELLO, K. C.; LEITE, E. C.; FARIA, L. C. Morfometria e uso e cobertura de uma microbacia no município de Sete Barras, São Paulo. Irriga, v. 21, p. 21-32, 2015.

[4] CARDOSO, C.A.; DIAS, H.C.T.; SOARES, C.P.B.; MARTINS, S.V. Caracterização morfométrica da bacia hidrográfica do rio Debossan, Nova Friburgo, RJ. Revista Árvore, v.30, n.2, p.241-248, 2006.

[5] CHRISTOFOLETTI, A. Geomorfologia. São Paulo: Edgar Blücher Ltda, 1980. 188p.

[6] COUTINHO, L.M.; CECÍLIO, R.A.; XAVIER, A.L.; ZANETTI, S.S.; GARCIA, G.O.G. Caracterização morfométrica da bacia hidrográfica do rio da Prata, Castelo, ES. Irriga, v.16, p. 369-381, 2011.

[7] EMPRESA BRASILEIRA DE PESQUISA AGROPECUÁRIA - EMBRAPA. Serviço Nacional de Levantamento e Conservação de Solos (Rio de Janeiro, RJ). In: REUNIÃO TÉCNICA DE LEVANTAMENTO DE SOLOS, 10., 1979, Rio de Janeiro. Súmula... Rio de Janeiro, 1979. 83 p. (EMBRAPA-SNLCS. Micelânea, 1).

[8] GUERRA, A.T.; GUERRA, A.J.T. Novo dicionário geológico-geomorfológico. Rio de Janeiro: Bertrand Brasil, 3.ed., 2003. 652p.

[9] IBGE - Instituto Brasileiro de Geografia e Estatística. Carta topográfica da Folha SF-24-V-A-V-4 (Cachoeiro de Itapemirim). Escala 1:50.000. IBGE - Diretoria de Geodésia e Cartografia - Superintendência de Cartografia, 1978.

[10] LORENZON, A. S.; FRAGA, M. S.; MOREIRA, A. R.; ULIANA, E. M.; DA SILVA, D. D.; RIBEIRO, C. A. A. S.; BORGES, A. C. Influência das características morfométricas da bacia hidrográfica do rio Benevente nas enchentes no município de Alfredo Chaves-ES. Revista Ambiente \& Água, v. 10, p. 195-206, 2015.

[11] OLIVEIRA, L. F. C.; CALIL, P. M.; RODRIGUES, C.; LIEMANN, H. J.; OLIVEIRA, V. A. Potencial do uso dos solos da bacia hidrográfica do alto Rio Meia Ponte, Goiás. Revista Ambiente \& Água, v.8, n.1, p.222-238, 2013.

[12] PELUZIO, T.M.O.; SANTOS, A.R.; FIEDLER, N.C; COELHO, A.L.N.; EUGENIO, F.C.; LOUZADA, F.L.R.O.; SAITO, N.S.; FERRARI, J.L.; JUNIOR, P.Q.; BATISTA, R.S. Mapeamento de áreas de preservação permanente no ARCGIS 9.3. Alegre: CAUFES, $2010.58 \mathrm{p}$.

[13] PISSARRA, T.C.T.; POLITANO, W.; FERRAUDO, A.S. Avaliação de características morfométricas na relação solo-superfície da bacia hidrográfica do Córrego Rico, Jaboticabal-SP. Revista Brasileira de Ciência do Solo, n.28, p. 297-305, 2004.

[14] ROCHA, J.S.M.; KURTZ, S.M.D.J.M. Manual de manejo integrado de bacias hidrográficas. 4. ed. Santa Maria: CCR/UFSM, 2001.302p.

[15] ROSSI, M.; PFEIFER, R.M. Remoção de material erodido dos solos de pequenas bacias hidrográficas no Parque Estadual da Serra do Mar em Cubatão (SP). Bragantia, v. 58, n.1, p. 141-156, 1999.

[16] SANTOS, A.R.; LOUZADA, F.L.R.O.; EUGENIO, F.C. ArcGIS 9.3 total: aplicações para dados espaciais. 2. ed. Alegre: CAUFES, 2010. 184p. 
[17] SARMENTO-SOARES, L. M.; MARTINS-PINHEIRO, R. F. Distribuição e endemismo de peixes de riacho do Espírito Santo. In: Contribuição ao conhecimento das bacias hidrográficas do Espírito Santo. 2012. 39p.

[18] SILVA, A.M.; MELLO, C.R. Apostila de Hidrologia. Minas Gerais: Universidade Federal de Lavras, 2006.

[19] TONELLO, K. C.; DIAS, H. C. T.; SOUZA, A. L.; RIBEIRO, C.A.A.S.; LEITE, F.P. Morfometria da bacia hidrográfica da Cachoeira das Pombas, Guanhães - MG. Revista Árvore, v.30, p.849-857, 2006.

[20] VILLELA, S. M.; MATTOS, A. Hidrologia aplicada. São Paulo: McGraw-Hill, 1975. 245p. 


\section{Capítulo 2}

Aplicação de Inteligência Geoespacial na análise da declividade da Bacia do Rio Montividiu, Goiás, Brasil

\section{Hevrli da Silva Carneiro Pilatti \\ Wellmo dos Santos Alves \\ Maria Antonia Balbino Pereira \\ Wilker Alves Morais \\ Derick Martins Borges Moura}

Resumo: 0 manejo de bacias hidrográficas tem relação com a declividade, pois a topografia influencia no tipo de atividade a ser desenvolvida, as quais podem ser favorecidas pela composição do relevo ou sofrerem limitações quanto ao uso. Assim, objetivou-se analisar a declividade da Bacia Hidrográfica do Rio Montividiu, no município de Montividiu, Sudoeste do estado de Goiás (Brasil). Esse rio é a principal fonte de abastecimento público de água $\left(60 \mathrm{L.s}^{-1}\right)$ desse município, além de atender a demandas do agronegócio. Na fase de processamento digital foram utilizados produtos e técnicas de Inteligência Geoespacial, sendo os resultados comparados com valores de referência. As classes de relevo predominantes são suave ondulado (34.094,05 ha) e plano $(26.172,49 \mathrm{ha})$, e com menor representatividade, as classes ondulado $(9.006,49$ ha) e forte ondulado (229,76 ha). Nas áreas com as maiores declividades, as ações antrópicas devem ser alinhadas com modernas técnicas de conservação do solo.

Palavras-chave: Análise Geoespacial; Aspecto do Relevo; Recursos Hídricos. 


\section{INTRODUÇÃO}

A declividade é definida como o ângulo de inclinação da superfície do terreno em relação à horizontal (FLORENZANO, 2008; VALERIANO, 2008). Seus valores podem variar de $0^{\circ}$ a $90^{\circ}$, embora seja mais comumente expressa em porcentagem, de zero a infinito. Com uso do Modelo Digital de Elevação (MDE), sua estimativa se baseia na análise dos desníveis entre pixels vizinhos (VALERIANO, 2008). A declividade pode influenciar diretamente no desenvolvimento das redes de drenagem e distribuição do escoamento superficial que, por sua vez, estão relacionados com as perdas de solo (RÖMKENS; HELMING; PRASAD, 2001; HÖFIG; ARAUJO JÚNIOR, 2015; XU et al., 2015).

A declividade também influencia na quantidade de água pluvial infiltrada no solo, pois condiz com o tempo de concentração da água na bacia até chegar à rede de drenagem, e determina a velocidade de escoamento superficial por gravidade, favorecendo ou não a ocorrência de erosões (LEAL; TONELLO, 2016; ALVES et al., 2018). Além disso, subsidia análises por meio de modelagem hidrológica (exemplo, Soil and Water Assessment Tool e Universal Soil Loss Equation). Como supracitado, além da umidade superficial do solo ser altamente influenciada pela inclinação do terreno (GREWER et al., 2018), influencia diretamente na velocidade de infiltração e escoamento superficial durante períodos de grande volume de precipitações pluviais. Em outras palavras, o declive do terreno altera a umidade do solo e o regime hidrológico de escoamento simultaneamente (VAEZI et al., 2017). Terrenos com topografia íngreme podem resultar em escoamento superficial rápido e baixa drenagem subsuperficial, o que leva à perda de nutrientes do solo para cursos aquáticos de bacias hidrográficas, podendo causar a eutrofização dos cursos hídricos (WU et al., 2018).

A Inteligência Geoespacial permite investigar a declividade do terreno, a fim de verificar áreas propícias a processos erosivos e disponibilizar dados para o planejamento e a gestão de bacias hidrográficas (ALVES et al., 2019). Assim, as classes de declividade na bacia hidrográfica são distribuídas espacialmente (DESTA; FETENE, 2020).

Nesse contexto, o trabalho objetivou analisar a declividade da Bacia Hidrográfica do Rio Montividiu (BHRM), localizada no município de Montividiu, na microrregião Sudoeste de Goiás, Brasil, por meio de Inteligência Geoespacial, disponibilizando dados técnico-científicos para os gestores de recursos hídricos, outros estudos e população em geral.

\section{MATERIAL E MÉTODOS}

A área de estudo $\left(695,021 \mathrm{~km}^{2}\right)$ está localizada na microrregião Sudoeste de Goiás, especificamente no município de Montividiu (Figura 1), o qual tem, conforme IBGE (2020), uma população estimada em 13.672 habitantes. A nascente da BHRM encontra-se nas coordenadas geográficas $51^{\circ} 39^{\prime} 50.82^{\prime \prime} 0 /$ 17²1'34.37"S, com foz no Rio Verde (também conhecido como Rio Verdão), sendo a principal fonte de captação de água para abastecimento público desse município, com outorga de 60 L.s ${ }^{-1}$, de acordo com o processo no 18922015 de 26/12/2015 (SEMAD, 2018). Além disso, o corpo hídrico é fonte de água para produção agrícola irrigada e pecuária, sendo sua área de drenagem intensamente explorada por essas atividades. 
Figura 1. Mapa de localização da bacia hidrográfica do Rio Montividiu, Sudoeste de Goiás.

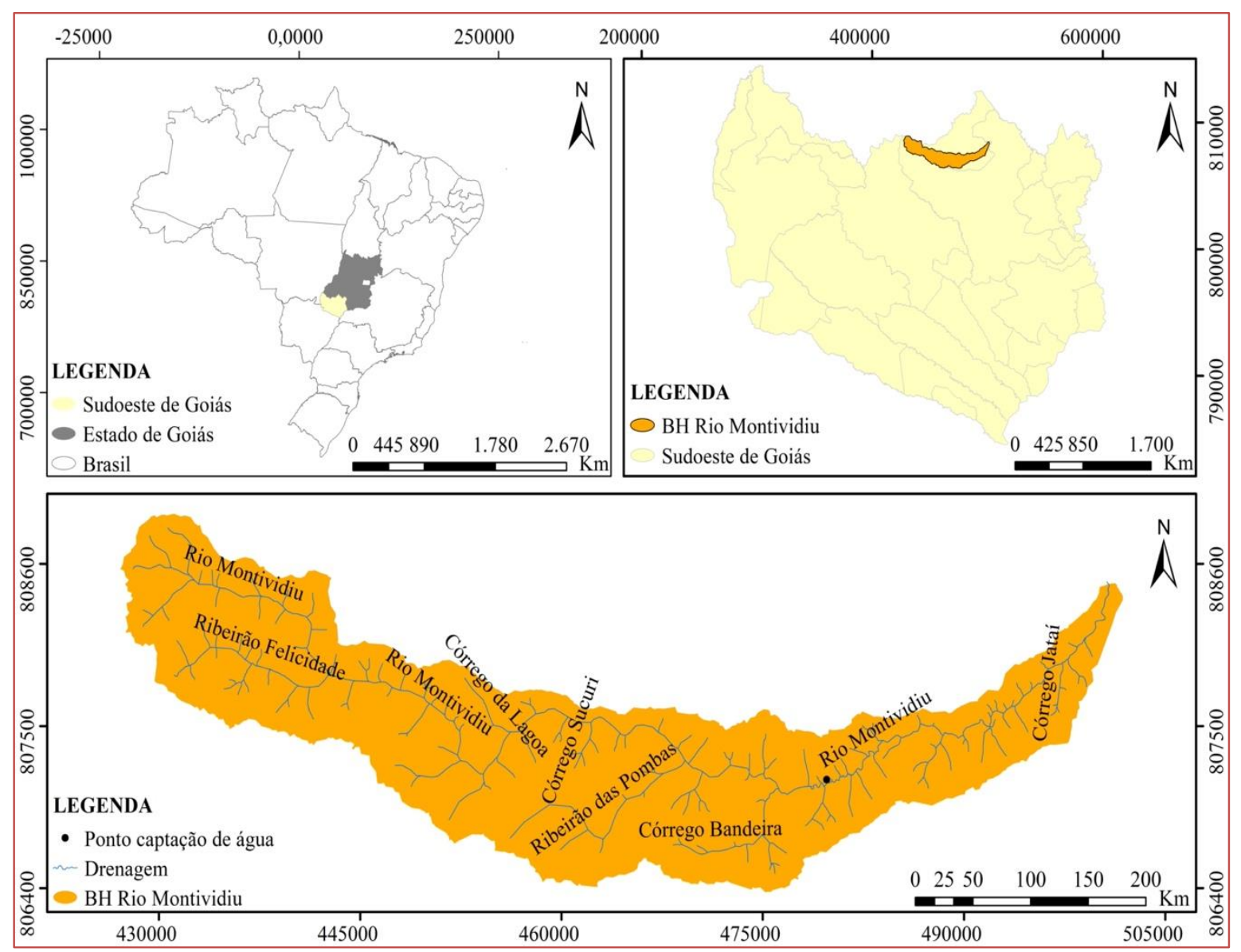

Elaborado na projeção UTM, Datum SIRGAS 2000, Zona 22S e precisão gráfica de 1:150.000.

Fonte: Organizado a partir de dados disponibilizados pelo Sistema Estadual de Geoinformação de Goiás (SIEG, 2020), sendo a área de estudo delimitada pelos autores.

O estudo foi elaborado com o uso de Inteligência Geoespacial: Sistema de Informação Geográfica - SIG, rede de drenagem de Goiás disponibilizada pelo Sistema Estadual de Geoinformação de Goiás - SIEG (2020), modelos Shuttle Radar Topography Mission - SRTM gerados pela National Aeronautics and Space Administration - NASA (2000) e disponibilizados pelo United States Geological Survey - USGS (2020) e imagens obtidas por meio do Google Earth Pro (Google, 2020). 0 mapeamento digital da declividade foi realizado no Sistema de Coordenadas Projetadas: Sistema de Referência Geocêntrico para as Américas (Sirgas) 2000, projeção Universal Transversa de Mercator (UTM), Zona 22 Sul (S) e precisão gráfica de 1:150.000, sendo que a classificação baseou-se nos valores de referência propostos por Santos et al. (2018): relevo plano ( $0 \%$ a $3 \%)$, suave ondulado (3\% a $8 \%)$, ondulado $(8 \%$ a $20 \%)$, forte ondulado $(20 \%$ a $45 \%$ ), montanhoso ( $45 \%$ a $75 \%$ ) e escarpado ( $>75 \%$ ).

\section{RESULTADOS E DISCUSSÃO}

Os resultados obtidos são apresentados na Figura 2 e Tabela 1. Foram observadas declividade mínima de 0\% e máxima de $41 \%$ e, em conformidade com a proposta de Santos et al. (2018), predominância de áreas com relevo suave ondulado, seguido, em ordem decrescente, da classe de relevo plano, ondulado e forte ondulado, não apresentado as classes do tipo montanhoso e escarpado. As áreas abrangidas pelas classes de relevo plano e suave ondulado estão distribuídas por toda a bacia, com concentração nos interflúvios com baixa densidade hidrográfica. As áreas com as classes ondulado e forte ondulado se concentram próximas aos canais hidrográficos, onde a densidade de drenagem é mais alta, principalmente na porção leste da bacia, à jusante da cidade de Montividiu. 
Figura 2. Declividade da Bacia Hidrográfica do Rio Montividiu, Sudoeste de Goiás, Brasil.

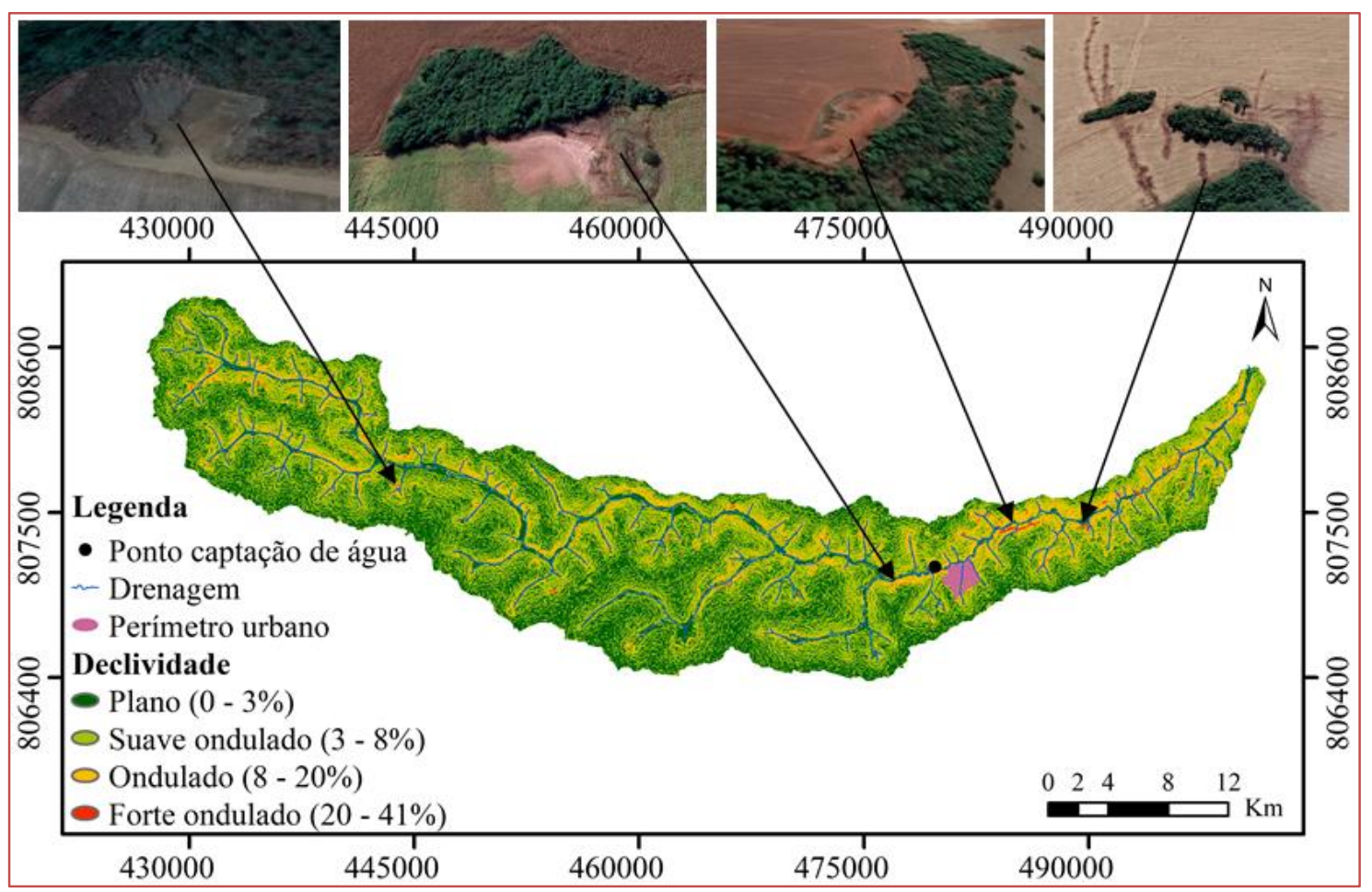

Elaborado na projeção UTM, Datum SIRGAS 2000, Zona 22 S e precisão gráfica de 1:150.000.

Fonte: Mapa elaborado pelos autores; imagens obtidas por meio do Google Earth Pro (Google, 2020).

Tabela 1. Classes de declividade da bacia hidrográfica do Rio Montividiu, Sudoeste de Goiás, Brasil

\begin{tabular}{|l|l|l|l|}
\hline \multicolumn{1}{|c|}{ Declividade (\%) } & \multicolumn{1}{c|}{ ha } & \multicolumn{1}{c|}{$\%$} \\
\hline $0-3$ & Plano & $26.172,49$ & 37,66 \\
\hline $3-8$ & Suave ondulado & $34.094,05$ & 49,05 \\
\hline $8-20$ & Ondulado & $9.006,49$ & 12,96 \\
\hline $20-45$ & Forte ondulado & 229,76 & 0,33 \\
\hline $45-75$ & Montanhoso & - & - \\
\hline$>75$ & Escarpado & - & - \\
\hline Total & - & $65.502,79$ & 100 \\
\hline
\end{tabular}

Fonte: Elaborada pelos autores conforme a classificação de Santos et al. (2018).

Conforme Alves et al. (2019), a representatividade do relevo suave ondulado e plano, que totalizam $60.266,54$ ha $(86,71 \%)$ da BHRM, favorecem atividades pecuárias e o cultivo agrícola respectivamente, com adoção de práticas conservacionistas mais simples. Além disso, a baixa declividade implica em menor probabilidade de ocorrências de erosões hídricas, maior infiltração de águas pluviais e ocorrência de inundações. No caso de relevo ondulado e forte ondulado, que representam $9.236,25$ ha $(13,29 \%$ da BHRM), há susceptibilidade a processos erosivos devido ao aumento da velocidade de escoamento superficial, o que requer a aplicação de técnicas avançadas voltadas para a conservação e a preservação ambiental, alinhando o desenvolvimento econômico, conforme a Lei no 12.651/2012 (BRASIL, 2012), com a função socioambiental da propriedade.

0 perfil de declividade predominante na BHRM (relevo suave ondulado) é também identificado com representatividade nas bacias hidrográficas Ribeirão Douradinho e Ribeirão da Laje. 0 estudo realizado por Alves et al. (2019) na bacia hidrográfica do Ribeirão Douradinho apresenta que 60,25\% da área total é classificado como relevo suave ondulado, e a pesquisa desenvolvida por Alves et al. (2018) na bacia do Ribeirão da Laje aponta que $54,71 \%$ da área total da bacia também é suave ondulado, confirmando as características sobressalentes do relevo na microrregião Sudoeste de Goiás. 
Aneseyee et al. (2020) afirmam que a magnitude da erosão e produção de sedimentos tem relação com os parâmetros físicos (como a declividade) da bacia, agravados por práticas de manejo e intensidade pluviométrica, sendo verificado em sua pesquisa que as áreas com maior declividade apresentam maior assoreamento de barragem e degradação do ecossistema na parte inferior da bacia. Para Desta e Fetene (2020), a declividade é um dos fatores topográficos com importante papel na distribuição e dinâmica das mudanças no uso e cobertura da terra. Tais mudanças podem impactar negativamente a biodiversidade, aumentar a erosão na bacia hidrográfica a ponto de assoreá-la, afetar o escoamento superficial, a recarga da água subterrânea e a qualidade da água em uma bacia.

Além da erosão, a eutrofização é uma das ameaças mais graves ao meio ambiente natural resultante das atividades e do impacto antrópico. 0 enriquecimento da água com nutrientes, especialmente compostos de nitrogênio e fósforo, podem causar o crescimento acelerado de algas e formas superiores de vida vegetal nos ecossistemas aquáticos, causando sérios problemas para qualidade ecológica e a biodiversidade das águas correntes (GERKE et al., 2021).

Por tais motivos, se faz importante a análise da declividade de bacias hidrográficas, pois é um dos fatores determinantes para carreamento de partículas do solo e deposição de nutrientes nos corpos hídricos. Nesse sentido, a análise de declividade em conjunto com outras análises geoespaciais, como as de uso e ocupação do solo, por exemplo, são subsídios para promover a adequada gestão das bacias hidrográficas.

\section{CONSIDERAÇÕES FINAIS}

O uso de produtos e técnicas de Inteligência Geoespacial proporcionou, de forma econômica e representativa, a análise geoespacial da declividade da BHRM, encontrando nesta uma declividade que varia de 0 a 41\%, com predominância das classes suave ondulado e plano, que juntas somam 86,7\% da área total. As áreas com relevo ondulado representam 12,9\% e as áreas de relevo forte ondulado apenas 0,3\% da bacia, sendo que juntas indicam presença de relevos propícios aos processos erosivos (com destaque para erosão laminar, em sulco, ravina e voçoroca). Recomenda-se que, principalmente nas áreas na categoria de relevo ondulado e forte-ondulado, o uso, cobertura, manejo e práticas conservacionistas do solo sejam condizentes com a função socioambiental do direito à propriedade. Esses resultados servirão de base para a gestão desse recurso e outros estudos.

\section{AGRADECIMENTOS}

Os autores agradecem aos programas de Pós-Graduação em Engenharia Aplicada e Sustentabilidade e de Iniciação Científica do Instituto Federal Goiano - Campus Rio Verde.

\section{REFERÊNCIAS}

[1] ALVES, Wellmo dos Santos et al. Análise morfométrica da bacia do Ribeirão da Laje, no sudoeste de Goiás, Brasil. Revista Geografia, Ensino \& Pesquisa, v. 22, e. 32, p. 01-22, 2018.

[2] ALVES, Wellmo dos Santos et al. Análise do uso da terra, da cobertura vegetal e da morfometria da bacia do Ribeirão Douradinho, no sudoeste de Goiás, Brasil. Revista Brasileira de Geografia Física, v. 12, n. 03, p. 1093-1113, 2019.

[3] ANESEYEE, Abreham Berta et al. Land use/land cover change effect on soil erosion and sediment delivery in the Winike watershed, Omo Gibe Basin, Ethiopia. Science of The Total Environment, vol. 728, 16 p., 2020.

[4] BRASIL. Lei no 12.651, de 25 de maio de 2012. Dispõe sobre a proteção da vegetação nativa, revogado o Código Florestal Brasileiro de 1965 e dá outras providências. Disponível em: <http://www.planalto.gov.br/ccivil_03/_Ato2011-2014/2012/Lei/L12651.htm>. Acesso em: 03 out. 2020.

[5] DESTA, Hayal; FETENE, Aramde. Land-use and land-cover change in Lake Ziway watershed of the Ethiopian Central Rift Valley Region and its environmental impacts. Land Use Policy, vol. 96, 12 p., 2020.

[6] FLORENZANO, T. G. Sensoriamento remoto para geomorfologia. Geomorfologia: conceitos e tecnologias atuais. São Paulo: Oficina de Textos, p. 36-71, 2008.

[7] GERKE, M.; HÜBNER, D.; SCHNEIDER, J.; WINKELMANN, C. Can top-down effects of cypriniform fish be used to mitigate eutrophication effects in medium-sized European rivers? Science of The Total Environment, v. 755, n. 10, 2021. Disponível em: https://doi.org/10.1016/j.scitotenv.2020.142547. Acesso em: 20 dez. 2020. 
[8] GREWER, D.M.; LAFRENIÈRE, M.J.; LAMOUREUX, S.F.; SIMPSON, M. J. Spatial and temporal shifts in fluvial sedimentary organic matter composition from a High Arctic watershed impacted by localized slope disturbances. Organic Geochemistry, v. 123, p. 113-125, 2018. Disponível em: https://doi.org/10.1016/j.orggeochem.2018.07.004. Acesso em: 18 dez. 2020.

[9] HÖFIG, P.; ARAUJO JÚNIOR, C. F. Classes de declividade do terreno e potencial para mecanização no estado do Paraná. Coffee Science, v.10, p.195-203, 2015.

[10] IBGE, Instituto Brasileiro de Geografia e Estatística. Cidades, População estimada [2020]: Montividiu. Disponível em: https://cidades.ibge.gov.br/brasil/go/montividiu/panorama Acesso em: 18 de dezembro de 2020.

[11] INSTITUTO BRASILEIRO DE GEOGRAFIA E ESTATÍSTICA - IBGE. Brasil. População 2019 (estimativa). 2020. Disponível em: <https://www.ibge.gov.br/cidades-e-estados/go/montividiu.html>. Acesso em: 25 set. 2020.

[12] LEAL, M. S.; TONELLO, K. C. Análise da morfometria e do uso e cobertura da terra da microbacia do Córrego Ipaneminha de Baixo, Sorocaba, SP. Revista Floresta, Curitiba, PR, v. 46, n. 4, p. 439 - 446, 2016.

[13] NATIONAL AERONAUTICS AND SPACE ADMINISTRATION - NASA. Shuttle Radar Topography Mission. 2000. Disponível em: < https://www2.jpl.nasa.gov/srtm/mission.htm>. Acesso em: 05 out. 2020.

[14] RÖMKENS, M. J. M.; HELMING, K.; PRASAD, S. N. Soil erosion under different rainfall intensities, surface roughness, and soil water regimes. Catena, Cremlingen, v. 46, n. 2/3, p. 103-123, 2001.

[15] SANTOS, H. G. et al. Sistema brasileiro de classificação de solos. Brasília, DF: Embrapa, 2018.

[16] SECRETARIA DE ESTADO DE MEIO AMBIENTE E DESENVOLVIMENTO SUSTENTÁVEL - SEMAD. Goiás. Planilhas de dados: usos por bacias hidrográficas. 2018. Disponível em: <https://www.meioambiente.go.gov.br/>. Acesso em: 29 jul. 2020.

[17] SISTEMA ESTADUAL DE GEOINFORMAÇÃO DE GOIÁS - SIEG. Downloads/SIG - Shapefiles. Disponível em: <http://www.sieg.go.gov.br/siegdownloads/>. Acesso em: 25 set. 2020.

[18] UNITED STATES GEOLOGICAL SURVEY - USGS. EarthExplorer. Disponível em: <https://earthexplorer.usgs.gov/>. Acesso em: 25 set. 2020.

[19] VAEZI, A.R.; ZARRINABADI, E.; AUERSWALD, K. Interaction of land use, slope gradient and rain sequence on runoff and soil loss from weakly aggregated semi-arid soils. Soil \& Tillage Research, v. 172, p. 22-31, 2017. Disponível em: https://doi.org/10.1016/j.still.2017.05.001. Acesso em: 18 dez. 2020.

[20] VALERIANO, M. M. Topodata: guia para utilização de dados geomorfológicos locais. São José dos Campos: INPE, p. 72, 2008.

[21] WU, L., PENG, M.L.; QIAO, S.S., MA, X.Y. Assessing impacts of rainfall intensity and slope on dissolved and adsorbed nitrogen loss under bare loessial soil by simulated rainfalls. Catena, 170, p. 51-63, 2018. https://doi.org/10.1016/j.catena.2018.06.007. Acesso em: 20 dez. 2020.

[22] XU, G.; CHENG, Y.; LI, P; LI, Z; ZHANG, J; WANG, T. Effects of natural rainfall on soil and nutrient erosion on sloping cropland in a small watershed of the Dan River, China. Quaternary International, v. 380-381, n. 4, p. 327-333, 2015. Disponível em: https://doi.org/10.1016/j.quaint.2015.02.010. Acesso em: 19 dez. 2020. 


\section{Capítulo 3}

\section{Análise da declividade da Bacia Hidrográfica do Córrego Indaiá (Rio Verde, Goiás) por meio de geotecnologias}

\section{Maria Antonia Balbino Pereira \\ Wellmo dos Santos Alves \\ Hevrli da Silva Carneiro Pilatti \\ Derick Martins Borges Moura \\ Wilker Alves Morais}

Resumo: A declividade é um dos aspectos do relevo que podem influenciar fenômenos como processos erosivos e qualidade hídrica. Objetivou-se analisar a declividade da bacia hidrográfica (BH) do Córrego Indaiá, Rio Verde (GO), comparando os resultados com valores de referência. O Córrego Indaiá é um dos principais afluentes do Rio Verdinho, sendo que neste há estudos e projeto para implementação de captação de água para atender a demanda crescente da população rio-verdense. Essa pesquisa foi realizada por meio de Sistema de Informação Geográfica - SIG e modelo Shuttle Radar Topography Mission - SRTM. Foi observado predomínio de relevo suave-ondulado e plano (81,53\%), favoráveis à conservação e mecanização agrícola. Entretanto, uma parte da $\mathrm{BH}(0,82 \%)$ foi classificada como forte-ondulado, sujeita a processos erosivos, podendo comprometer a conservação ambiental e a qualidade hídrica. Este estudo irá subsidiar o planejamento e a gestão ambiental dessa BH, que tem ligação direta com a qualidade hídrica do novo projeto de captação de água.

Palavras-chave: Abastecimento de água; Análise Ambiental; Sensoriamento Remoto; SIG. 


\section{INTRODUÇÃO}

A declividade é a inclinação do relevo em relação ao plano horizontal (FLORENZANO, 2008). Devido à sua estreita associação com processos de transporte gravitacional (escoamento, erosão, deslizamento), a declividade do terreno é uma variável básica para a segmentação de áreas em praticamente todos os procedimentos de planejamento territorial (VALERIANO, 2008). É uma importante característica física do relevo, a qual pode exercer interferências em vários fenômenos. Essa característica colabora, por exemplo, com o escoamento das águas, pois quanto maior é o trecho em declive, maior será o escoamento da água pela superfície, consequentemente arrastando outros materiais para os recursos hídricos superficiais, influenciando a qualidade hídrica, a infiltração e os processos erosivos pluviais e fluviais (GARGIA, et al., 2020).

Sabe-se que a erosão do solo é um processo de desprendimento físico, transporte e deposição de partículas do solo sob influência de forças externas, como por exemplo a chuva (POESEN, 2018). Além dos fatores biofísicos, Dotterweich (2013) afirma que os fatores socioeconômicos podem ter impacto significativo na erosão do solo, podendo ser direto ou indireto, positiva ou negativa. Estes fatores socioeconômicos podem ser divididos em causas e forças motrizes de acordo com os usos do solo (CHAUDHARY et al., 2020; VÁVRA et al., 2019). As causas são baseadas no manejo do solo, como os padrões de uso, métodos de cultivo e colheita (JIU et al., 2019). Já as forças motrizes subjacentes à erosão do solo são o desenvolvimento econômico, política e cultura (VU et al., 2014). Todos esses fatores influenciam tanto os processos erosivos, quanto a qualidade dos ecossistemas aquáticos.

A declividade também está ligada ao tempo de concentração da água na bacia hidrográfica (BH), influenciando desse modo o tempo em que a água da chuva demora a atingir a rede de drenagem (LEAL e TONELLO, 2016). É também uma das principais características geomorfológicas limitantes à utilização de máquinas agrícolas, uma vez que está intimamente ligada às condições de tráfego, pois afeta a velocidade de deslocamento e a estabilidade das máquinas (HÖFIG e ARAUJO JÚNIOR, 2015). Além disso, é considerada como uma restrição natural à produtividade do solo (MUELLER et al., 2010).

Os estudos do mapeamento da declividade também são importantes para analises de reconhecimento de áreas de preservação permanente (APP) (BRASIL, 2012). E, segundo Alves et al. (2016), o mapa de declividade das vertentes auxilia o entendimento da modelagem e prevenção do deslocamento de massa, uma vez que esse processo está relacionado fortemente à gravidade. Além disso, dados de sensoriamento remoto - SR (como modelos digitais do terreno), incluindo imagens do Google Earth, são analisados por meio de Sistemas de Informação Geográfica - SIG no intuito de disponibilizar dados técnico-científicos (como os relacionados aos aspectos do relevo) para os gestores ambientais.

Assim, o objetivo desse estudo foi analisar a declividade da BH do Córrego Indaiá, localizada no Rio Verde, Goiás, por meio de geotecnologias (Sistema de Informação Geográfica - SIG e produtos de Sensoriamento Remoto - SR), comparando os dados obtidos com a classificação de Santos et al. (2018). Ressalta-se que a água dessa BH tem relação direta com a qualidade hídrica do Rio Verdinho, sendo este fonte estratégica para abastecimento público da população urbana rio-verdense.

\section{MATERIAL E MÉTODOS}

A BH do Córrego Indaiá fica inserida no município de Rio Verde (GO), no Sudoeste de Goiás, sendo esse córrego um dos principais afluentes do Rio Verdinho (Figura 1). Neste, a jusante do CI, há um projeto em fase de implementação para captação de aproximadamente 794,40 litros de água por segundo, visando atender a demanda hídrica crescente da população urbana rio-verdense, que é estimada em 241.518 pessoas (IBGE, 2020). 0 município de Rio Verde (GO) tem economia baseada na produção pecuária e agrícola, sendo modelo na produção agropecuária nacional (ALVES, 2019). 
Figura 1. Mapa de localização da bacia hidrográfica do Córrego Indaiá, Rio Verde, Goiás.

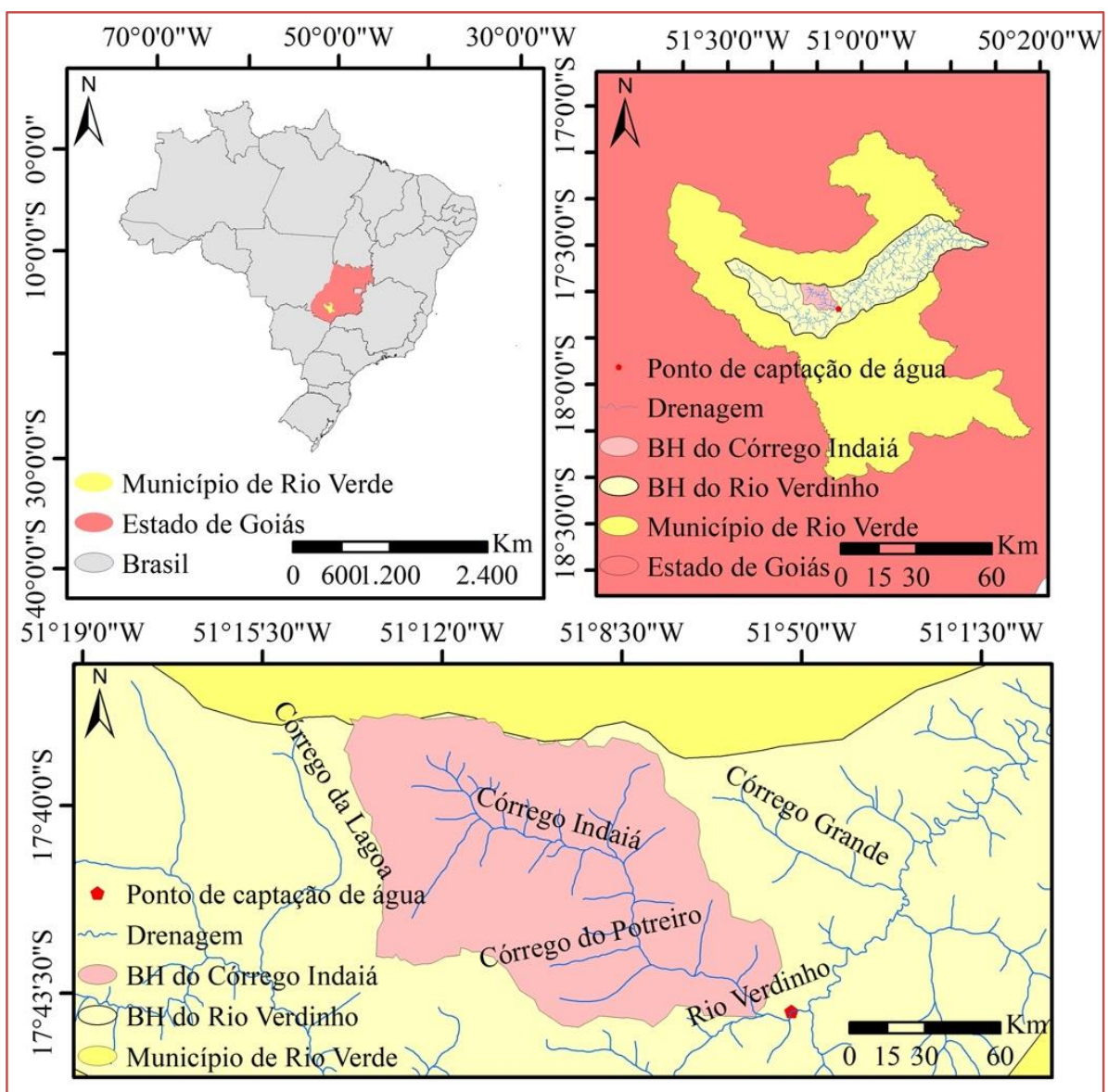

Organizado no Sistema de Coordenadas Geográficas, Datum SIRGAS 2000, Zona 22S.

Fonte: Organizado a partir de dados disponibilizados pelo Sistema Estadual de Geoinformação de Goiás (SIEG, 2020), sendo a área de estudo delimitada pelos autores.

0 clima da região é classificado conforme Köppen \& Geiger (1928), como Aw (tropical), com chuva nos meses de outubro a maio, e com seca nos meses de junho a setembro. A temperatura média anual possui pequena variação sazonal, apresentando média de $23,8^{\circ} \mathrm{C}$, concentrando os maiores valores no mês de outubro, com $24,5^{\circ} \mathrm{C}$, e os menores valores no mês de julho, com $20,8^{\circ} \mathrm{C}$. A precipitação pluvial média anual varia entre 1430 e $1650 \mathrm{~mm}$, concentrados de outubro a maio, ocasião em que são registradas mais de $80 \%$ do total das chuvas.

Todos os procedimentos metodológicos foram realizados por meio de geotecnologias (SIG, SRTM e imagens de satélite). 0 modelo digital do terreno SRTM foi gerado pela National Aeronautics and Space Administration (NASA) e disponibilizado pelo United States Geological Survey - USGS (2020), com resolução espacial de $30 \mathrm{~m}$. Também foram utilizadas imagens obtidas por meio do Google Earth (Google, 2020) para subsidiar este estudo. Para melhor entender os resultados, os valores de declividade foram analisados conforme a classificação de Santos et al. (2018), que varia entre plano (0 - 3\%), suave ondulado (3 - 8\%), ondulado (8 - 20\%), fortemente ondulado (20 - 45\%), montanhoso (45 - 75\%) e escarpado ( $>75 \%)$. O mapa foi elaborado utilizando a ferramenta de geoprocessamento Slope, no Sistema de Coordenadas Projetadas: Sistema de Referência Geocêntrico para as Américas (Sirgas) 2000, projeção Universal Transversa de Mercator (UTM), Zona 22 Sul (S) e precisão gráfica de 1:150.000.

\section{RESULTADOS E DISCUSSÃO}

A declividade da BH do Córrego Indaiá, segundo a classificação da declividade das formas de relevo proposta por Santos et al. (2018), e respectivas áreas são apresentadas na Tabela 1 e geoespacializada na Figura 2. 
Tabela 1. Classes de declividade (S) da bacia hidrográfica do Córrego Indaiá, Rio Verde, Sudoeste de Goiás

\begin{tabular}{|c|l|c|c|}
\hline \multicolumn{1}{|c|}{$\mathrm{S}(\%)$} & \multicolumn{1}{|c|}{ Aspecto do relevo } & ha & $\%$ \\
\hline $0-3$ & Plano & 4004,10 & 37,13 \\
\hline $3-8$ & Suave-ondulado & 4785,66 & 44,4 \\
\hline $8-20$ & Ondulado & 1905,03 & 17,67 \\
\hline $20-45$ & Forte-ondulado & 88,64 & 0,82 \\
\hline $45-75$ & Montanhoso & - & - \\
\hline & Forte-montanhoso & - & - \\
\hline Total & & 10783,42 & 100 \\
\hline
\end{tabular}

Fonte: Elaborada pelos autores conforme a classificação de Santos et al. (2018).

Figura 2. Mapa de declividade da bacia hidrográfica do Córrego Indaiá, Rio Verde, Goiás.

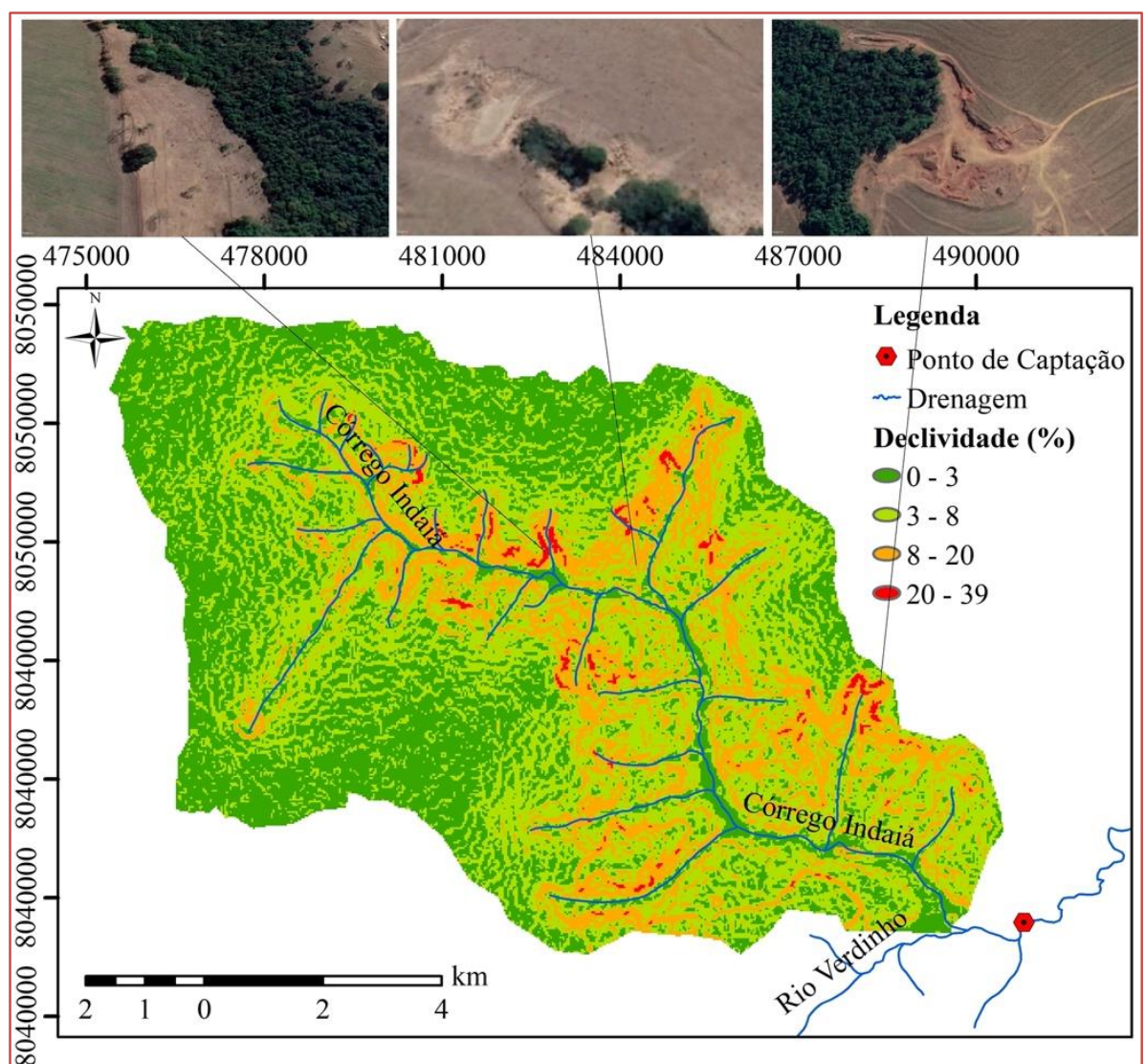

Fonte: Mapa elaborado pelos autores; imagens obtidas por meio do Google Earth (Google, 2020).

Elaborado na projeção UTM, Datum SIRGAS 2000, Zona 22 S e precisão gráfica de 1:150.000.

A maior parte da área da BH é de relevo plano e suave-ondulado $(81,53 \%)$ e se concentram em interflúvios com baixa densidade hidrográfica, na porção sudoeste, norte e noroeste da bacia, próximos aos divisores topográficos. Essas duas classes de relevo são favoráveis a infiltração da água, e, conseguinte, a pedogênese e a conservação da bacia, conforme Alves (2019). As classes Ondulado e Forte-ondulado juntas perfazem $18,47 \%$ da área da bacia, e se concentram próximas a rede hidrográfica e as nascentes dos canais fluviais, onde a densidade de drenagem é mais alta e prevalece a morfogênese.

No estudo de morfometria feito por Alves et al. (2016) sobre a BH do Ribeirão Abóboras, também inserida no município de Rio Verde (G0), a declividade predominante é a classe de relevo suave ondulado (3 - 8\%), correspondendo a 58,74\% da área total da bacia. Os autores ressaltam que esse tipo de relevo tem característica favorável a práticas agrícolas, contribuindo para a infiltração da água das chuvas e baixo risco de perda do solo. 
Segundo Silva (2016), o fator mecanização (12\%) é de suma importância para a produção agrícola atualmente, pois as colheitadeiras à disposição no mercado são adaptadas para declividade de até $12 \%$. Isso deve ser levado em consideração, uma vez que o município de Rio Verde (GO) tem a economia baseada no setor agrícola (RIO VERDE, 2020).

A classe Forte-ondulada (20 - 45\%) foi a maior declividade observada, com erosão laminar (Figura 2), podendo progredir para ravinas e voçorocas. Conforme Oliveira et al (2013), valores de declividades superiores a $20 \%$ condicionam teoricamente esses locais como vulneráveis a processos geomorfológicos de encosta, aumentando os processos de movimentos de massa e erosivos. Nessas áreas, há necessidade de maior cuidado com intervenções antrópicas, sendo mais recomendado como áreas destinadas a conservação.

A erosão do solo tem impacto na fertilidade das terras agrícolas, na qualidade hídrica e outros (SINGH e PANDA, 2017). Informações sobre perda de solo e exportação de sedimentos são fundamentais para identificar locais críticos de erosão do solo e assim informar as intervenções de conservação em uma BH (ANESEYEE et al., 2020), principalmente quando esta tem relação direta com a qualidade da água de abastecimento público.

Blanco e Letelier (2020) afirmam que uma das principais causas que influenciam na qualidade das águas de rios e lagos é a eutrofização. Os autores relatam que os principais causadores deste fenômeno é o enriquecimento das águas, principalmente com compostos de nitrogênio e fósforo, exportados das BH devido a intensificação da produção agrícola e a ausência de tratamento adequado para efluentes urbanos e industriais. Estes autores relatam ainda que a eutrofização das águas pode ser causada pelas mudanças climáticas. Estudando os impactos das mudanças climáticas na qualidade da água de superfície em relação à produção de água potável, Delpla et al. (2009) relataram que um clima mais quente promove cianobactérias sobre o fitoplâncton. Outro fator que justifica esse potencial das mudanças climáticas e a correlação encontrada por Abal et al. (2011) entre a clorofila a e a radiação.

Quando se trata de declividade, apesar da BH do Córrego Indaiá mostrar ser adequada (Tabela 1), devem ser adotadas práticas conservacionistas e manejo adequado do solo para a atividade agrícola, visto que esta BH se localiza a montante do ponto onde está sendo planejado a construção da captação de água para abastecimento da cidade de Rio Verde - Goiás.

\section{CONSIDERAÇÕES FINAIS}

O uso de SIG e modelo SRTM possibilitou analisar as classes de declividade da BH do Córrego Indaiá, sendo observado que 88,64 ha $(0,82 \%)$ correspondem a classe forte-ondulado, que tem potencialidade aos processos erosivos (como erosão em sulco, ravina e voçoroca), podendo comprometer a qualidade hídrica, caso o uso, cobertura e manejo do solo não sejam alinhados com práticas conservacionistas. Esse estudo subsidiará os gestores de recursos hídricos a implementar ações efetivas e eficientes, tendo em vista a garantia desse líquido vital em quantidade e qualidade para as gerações atuais e futuras.

\section{FINANCIADORES}

O Instituto Federal Goiano foi financiador de uma bolsa de Iniciação Científica por meio do Programa Institucional de Bolsa de Iniciação Científica (PIBIC). 


\section{REFERÊNCIAS}

[1] ABAL, G.; D'ANGELO, M.; CATALDO, J.; GUTIÉRREZ ARCE, A. Mapa solar del Uruguay: versão 1.0: memoria técnica. $\quad$ Ediciones Universitarias, $2011 . \quad$ Disponível em: https://www.colibri.udelar.edu.uy/jspui/handle/20.500.12008/21708. Acesso em: 20 dez. 2020.

[2] ALVES, W. S et al. Análise morfométrica da bacia do ribeirão das Abóboras - Rio Verde (GO). Geociências, São Paulo, v. 35, n. 4, p. 652-667, 2016.

[3] ALVES, W. S. Geotecnologias aplicadas em estudos hidrogeográficos na bacia do Rio Verdinho - Sudoeste de Goiás - Brasil. 2019. 212 f. Tese (Doutorado em Geografia) - Universidade Federal de Goiás, Jataí, 2019.

[4] ANESEYEE, A.B. et al. Land use/land cover change effect on soil erosion and sediment delivery in the Winike watershed, Omo Gibe Basin, Ethiopia. Science of The Total Environment, p. 138776, 2020.

[5] BLANCO, A. B.; LETELIER, L. C. Relevant factors in the eutrophication of the Uruguay River and the Río Negro. Science of The Total Environment. Online. 2020. Disponível em: https://doi.org/10.1016/j.scitotenv.2020.143299. Acesso em: 20 dez. 2020.

[6] BRASIL. Lei Federal no 12.651, 25 de maio de 2012. Dispõe sobre o Código Florestal. Diário Oficial (da) República Federativa do Brasil, 2012.

[7] CHAUDHARY, S.; WANG, Y.; DIXIT, A.M.; KHANAL, N.R.; XU, P.; FU, B.; YAN, K.; LIU, Q.; LU, Y.; LI, M. Uma sinopse do abandono de terras agrícolas e seus fatores determinantes no Nepal. Land, v. 9, p. 84, 2020. Disponível em: https://doi.org/10.3390/land9030084. Acesso em: 20 dez. 2020.

[8] DELPLA, I. JUNG, A.V.; BAURES, E., CLEMENT, M. THOMAS, O. Impactos das mudanças climáticas na qualidade da água de superfície em relação à produção de água potável. Environment International, v. 35, p. 1225 - $1233,2009$.

[9] DOTTERWEICH, M. The history of human-induced soil erosion: geomorphic legacies, early descriptions and research, and the development of soil conservation - a global synopsis, Geomorphology, v. 201, p. 1-34, 2013. Disponível em: https://doi.org/10.1016/j.geomorph.2013.07.021. Acesso em: 20 dez. 2020.

[10] FLORENZANO, T. G. Sensoriamento remoto para geomorfologia. Geomorfologia: conceitos e tecnologias atuais. São Paulo: Oficina de Textos, p. 36-71, 2008.

[11] GARCIA, Y.M. et al. DECLIVIDADE E POTENCIAL PARA MECANIZAÇÃO AGRÍCOLA DA BACIA HIDROGRÁFICA DO RIBEIRÃO PEDERNEIRAS-PEDERNEIRAS/SP. Revista Brasileira de Engenharia de Biossistemas, v. 14, n. 1, p. 62 72,2020 .

[12] HÖFIG, P.; ARAUJO JÚNIOR, C. F. Classes de declividade do terreno e potencial para mecanização no estado do Paraná. Coffee Science, v.10, p.195-203, 2015.

[13] IBGE, Instituto Brasileiro de Geografia e Estatística. Cidades, População estimada [2020]: Rio Verde. Disponível em: https://cidades.ibge.gov.br/brasil/go/rio-verde/panorama Acesso em: 18 de dezembro de 2020.

[14] JIU, J.; WU, H.; LI, S. The implication of land-use/land-cover change for the declining soil erosion risk in the three gorges reservoir region, China. IJERPH, v. 16, p. 1856, 2019. Disponível em: https://doi.org/10.3390/ijerph16101856. Acesso em: 19 dez. 2020.

[15] KÖPPEN, W.; GEIGER, R. Klimate der Erde. Gotha: Verlag Justus Perthes. 1928.

[16] LEAL, M.S.; TONELLO, K.C. ANÁLISE DA MORFOMETRIA E DO USO E COBERTURA DA TERRA DA MICROBACIA DO CÓRREGO IPANEMINHA DE BAIXO, SOROCABA/SP. Floresta, v. 46, n. 4, p. 439-446, 2017.

[17] MUELLER, L. et al. Assessing the productivity function of soils: a review. Agronomy for Sustainable Development, Paris, v. 30, p. 601-604, 2010.

[18] OLIVEIRA, E.D. et al. Uso das terras e aspectos fisiográficos da bacia de drenagem do Arroio do Butka, Guarapuava/PR. Ateliê Geográfico, v. 7, n. 1, p. 215-236, 2013.

[19] POESEN, J. Soil erosion in the anthropocene: research needs. Earth Surface Processes and Landforms, v. 43, p. 64-84, 2018. Disponível em: https://doi.org/10.1002/esp.4250. Acesso em: 20 dez. 2020.

[20] RIO VERDE. Cidade: história. 2020. Disponível em: https://www.rioverde.go.gov.br/historia-cidade/. Acesso em: 20 dez. 2020.

[21] SANTOS, H. G. et al. Sistema brasileiro de classificação de solos. Brasília, DF: Embrapa, 2013.

[22] SILVA, C.O. Geoprocessamento aplicado ao zoneamento agrícola para cana-de-açúcar irrigada do estado do Piauí. 2016, 72f. Tese de Doutorado. Tese (Doutorado em Agronomia-Irrigação e Drenagem). Universidade Estadual Paulista-Faculdade de Ciências Agronômicas, Botucatu, 2016.

[23] SINGH, Gurjeet; PANDA, Rabindra Kumar. Grid-cell based assessment of soil erosion potential for identification of critical erosion prone areas using USLE, GIS and remote sensing: A case study in the Kapgari watershed, India. International Soil and Water Conservation Research, v. 5, n. 3, p. 202-211, 2017. 
[24] SISTEMA ESTADUAL DE GEOINFORMAÇÃO DE GOIÁS - SIEG. Downloads/SIG - Shapefiles. Disponível em: <http://www.sieg.go.gov.br/siegdownloads/>. Acesso em: 25 set. 2020.

[25] UNITED STATES GEOLOGICAL SURVEY. EarthExplorer - USGS. Disponível em: http://earthexplorer.usgs.gov/. Acesso em: 20 ago. 2020.

[26] VALERIANO, M. M. Topodata: guia para utilização de dados geomorfológicos locais. São José dos Campos: INPE, p. 72, 2008.

[27] VÁVRA, J.; DUŽÍ, B.; LAPKA, M.; CUDLÍNOVÁ, E.; RIKOON, J.S. Socio-economic context of soil erosion: A comparative local stakeholders' case study from traditional agricultural region in the Czech Republic. Land Use Policy, v. 84, p. 127-137, 2019. Disponível em: https://doi.org/10.1016/j.landusepol.2019.03.005. Acesso em: 19 dez. 2020.

[28] VU, Q.M.; LE, Q.B.; FROSSARD, E.; VLEK, P.L.G. Socio-economic and biophysical determinants of land degradation in Vietnam: an integrated causal analysis at the national level. Land Use Policy, v. 36, p. 605-617, 2014. Disponível em: https://doi.org/10.1016/j.landusepol.2013.10.012. Acesso em: 19 dez. 2020. 


\section{Capítulo 4}

Avaliação do potencial de contaminação de águas subterrâneas por paracetamol, através de ensaios de cinética de adsorção em solo

\section{Ebenézer de França Santos}

\section{Manuella Virgínia Salgueiro Gondim}

Antônio Celso Dantas Antonino

Valmir Felix de Lima

Resumo: 0 paracetamol é um contaminante emergente largamente utilizado como analgésico e antipirético, não-esteroide, encontrado em afluentes de estações de tratamento de esgoto e em águas superficiais de diversos países. A cinética de adsorção e as isotermas foram determinadas em solo coletado no Agreste de Pernambuco/Brasil, onde efluentes de estação de tratamento de esgoto são utilizados para fertirrigação. Os ensaios foram realizados em laboratório e a concentração de paracetamol determinada por cromatografia líquida de alta eficiência. A reatividade com o solo foi avaliada através de experimentos de sorção em Batch e modelagem. Os ensaios de cinética de sorção mostraram que o equilíbrio de sorção foi alcançado em $60 \mathrm{~h}$, não sendo considerado, portanto, instantâneo. 0 paracetamol foi pouco retido no solo, com isoterma de adsorção mais bem representada pelo modelo cinético de segunda ordem, pelos modelos de Freundlich e de Langmuir, que anunciam biodisponibilidade e mobilidade significativas, evidenciando o risco potencial de contaminação de águas subterrâneas.

Palavras-chave: Contaminantes emergentes, cinética de adsorção, isotermas de adsorçãa. 


\section{INTRODUÇÃO}

Dentre os compostos classificados como contaminantes emergentes estão os fármacos de diferentes classes como analgésicos, anti-inflamatórios, drogas psiquiátricas, anti-lipêmicos, antibióticos de uso humano e veterinário e contrastes de raio $\mathrm{x}$, que depois de administrados são transformados em um ou mais metabólitos e excretados através da urina e fezes em uma mistura contendo o fármaco que não foi metabolizado pelo organismo e seus metabólitos.

Muitos produtos farmacêuticos têm sido encontrados em diversos compartimentos ambientais com o auxílio de técnicas analíticas mais sensíveis, capazes de determinar concentrações de até ng. $\mathrm{L}^{-1}$. Atualmente, muitos grupos de pesquisas e órgãos ambientais vêm estudando não apenas os níveis de concentração desses compostos no meio, mas a sua origem, destino e seus efeitos adversos, principalmente à biota (RAIMUNDO, 2007).

As formas farmacêuticas para veicular paracetamol atendem pacientes adultos e, especialmente, crianças. Os comprimidos são apresentados nas quantidades de 125, 235, 250, 325, 500 e $750 \mathrm{mg}$. As soluções ou suspensões orais estão disponíveis nas concentrações de 100, 120 e $200 \mathrm{mg}^{\mathrm{mL}} \mathrm{m}^{-1}$. Por ser largamente utilizado, o paracetamol tem sido encontrado em afluentes de estações de tratamento de esgoto e em menor concentração em águas superficiais de diversos países (KALANT, 1991; KATZUNG, 2003; CRAIG e STITZEL, 2005).

\section{MATERIAIS E MÉTODOS}

O soluto estudado foi o paracetamol (com pureza de 99,26\%), denominação dada a molécula N-(4hidroxifenil) etanamida, é um analgésico e antipirético, não-esteroide, cuja molécula, ilustrada na Figura 1, é complexa, contendo vários grupos funcionais: grupo carbonila $(\mathrm{C}=\mathrm{O})$ e hidroxila $(\mathrm{O}-\mathrm{H})$, uma estrutura aromática (anel benzeno) e uma nitrila $(-\mathrm{CN})$. 0 grupo Hidroxila $(\mathrm{OH})$ é característico de alcoóis, e a Carbonila $(\mathrm{C}=\mathrm{O})$ juntamente com a presença do Nitrogênio $(\mathrm{N})$ classificam o composto como uma Amida, daí a nomenclatura N-(4-hidroxifenil) etanamida.

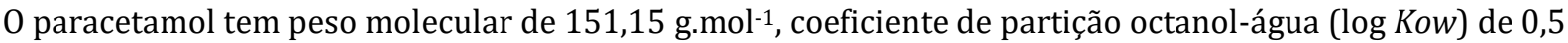
(RAIMUNDO, 2007), e por possuir log Kow menor do que 2,5, possui baixo potencial de sorção ao lodo (ROGERS, 1996). É um ácido fraco que possui apenas um grupo ionizável em sua molécula e possui constante de ionização (pKa) igual a 10,0 (PRADO, 2006).

Figura 1 - Estrutura química da molécula N-(4-hidroxifenil) etanamida

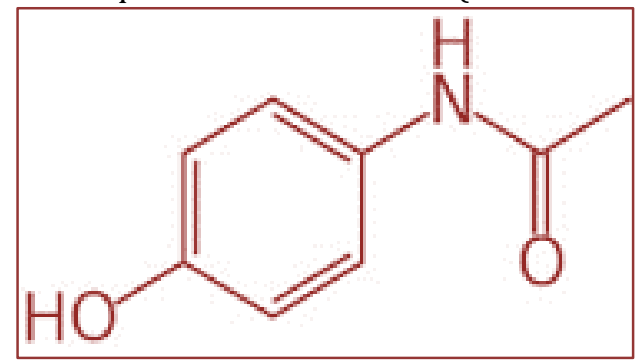

Fonte: Ellis (2002) apud Cruz (2015)

As amostras de solo, classificado como Regossolo (EMBRAPA, 2001), foram extraídas na Fazenda São Francisco, localizada à Rodovia PE $200\left(8^{\circ} 17^{\prime} 02.71^{\prime \prime}\right.$ S e $36^{\circ} 34^{\prime} 42,00^{\prime \prime}$ W), no distrito de Mutuca, Zona Rural do Município de Pesqueira, Agreste de Pernambuco, onde o esgoto doméstico é reutilizado na fértilirrigação para fins produtivos, coletadas na camada superficial $(0,0$ a $0,20 \mathrm{~m})$ e na camada de 0,20 a 0,40 m. As amostras indeformadas para determinação da umidade mássica foram extraídas com uso de Coletor de Uhland.

Após a coleta, as amostras foram secas ao ar, destorroadas e peneiradas em peneira de 2,0 $\mathrm{mm}$, a fim de se separar e descartar eventuais plantas, raízes e pequenas pedras. Em seguida o solo foi homogeneizado e cuidadosamente armazenado à temperatura ambiente. 
A massa específica foi determinada pelo método do anel volumétrico, enquanto a análise granulométrica foi realizada através do método do densímetro (EMBRAPA, 2011).

A superfície específica das frações argila foi determinada por meio de adsorção e dessorção de $\mathrm{N}_{2}$ no solo, para construção de isotermas.

O paracetamol foi quantificado por Cromatografia Líquida de Alta Eficiência (CLAE) em um Cromatógrafo Dynamax, modelo SD-200 e um detector UV modelo UV-1 Rainin.

As amostras foram centrifugadas a $7.000 \mathrm{rpm}$ por $10 \mathrm{~min}$. Em seguida foram realizadas as análises quantitativas do sobrenadante, com as seguintes condições cromatográficas: coluna Fenomenex GEMINI C18, com $150 \mathrm{~mm}$ de comprimento, $2 \mathrm{~mm}$ de diâmetro e $5 \mu \mathrm{m}$ de espessura do filme de fase estacionária.

A fase móvel foi composta de 10\% de água e 89,9\% de metanol e 0,1\% ácido fórmico. As detecções foram por absorção ultravioleta, com comprimento de onda de $254 \mathrm{~nm}$, numa taxa de fluxo de 1,0 $\mathrm{mLmin}^{-1}$. 0 volume de injeção foi de $20 \mu \mathrm{L}$ e cada amostra foi analisada em triplicata.

\subsection{CINÉTICA DE SORÇÃO}

A cinética de sorção foi realizada a $24{ }^{\circ} \mathrm{C}$, seguindo o protocolo experimental adotado por Gondim (2014), à concentração de $50 \mathrm{mg} . \mathrm{L}^{-1}$. A relação solo:solução foi de 1:10 $5 \mathrm{~g}$ de solo para $50 \mathrm{~mL}$ de solução de paracetamol).

Os recipientes foram colocados em mesa agitadora a $200 \mathrm{rpm}$ e nos intervalos de tempo de $0 \mathrm{~h}, 0,17 \mathrm{~h}$, 0,33 h, 0,50 h, 0,67 h, 1 h, 2 h, 3 h, 4 h, 5 h, 6 h, 8 h, 10 h, 12 h, 24 h, 36 h, 48 h, 60 h foram coletadas alíquotas de $1,0 \mathrm{ml}$, que foram centrifugadas a $7000 \mathrm{rpm}$ por 10 minutos. Após a centrifugação, as concentrações de paracetamol foram determinadas por CLAE, nas condições descritas acima.

\subsection{ISOTERMAS DE SORÇ̃̃O}

As isotermas de adsorção foram determinadas de acordo com o procedimento experimental descrito por Gondim (2014). Foram misturados 5 g de solo seco com $50 \mathrm{~mL}$ de solução de paracetamol (razão solo/solução de 10) em diferentes concentrações. As amostras foram preparadas em triplicatas a concentrações iniciais $\left(C_{0}\right)$ de $5,10,20,30,40,50,60$ e $70 \mathrm{mg} . \mathrm{L}^{-1}$. As amostras foram agitadas a $200 \mathrm{rpm}$ em mesa agitadora, por $60 \mathrm{~h}$ e centrifugadas a $7000 \mathrm{rpm}$ por $10 \mathrm{~min}$; o sobrenadante foi filtrado através de um filtro PVDF de 0,45 $\mu \mathrm{m}$ e depois analisado por CLAE, utilizando as mesmas condições da cinética de sorção. Assim, obtiveram-se as concentrações de paracetamol sorvidas ao solo (S), utilizando-se a Equação (1):

$$
\mathrm{S}=\left(\mathrm{C}_{0}-\mathrm{C}_{\mathrm{e}}\right) \mathrm{FD}
$$

Em que $\mathrm{S}$ é a quantidade de paracetamol sorvida pelo solo (mg.kg-1); $\mathrm{C}_{0}$ é a concentração de paracetamol da solução colocada em contato com o solo $\left(m g . L^{-1}\right) ; C_{e}$ é a concentração de paracetamol na solução após o equilíbrio (mg. $\mathrm{L}^{-1}$ ) e FD é o fator de diluição, considerando-se a relação solução:solo, neste caso, FD = 50:5 $=10$.

\subsection{MODELAGEM DA SORÇÃO}

A relação entre a concentração de soluto na fase líquida e a fase sólida é denominada isoterma de sorção e pode ser descrita pela Equação 2 em que $K_{D}$ é o coeficiente de solução de solo de divisão e $\eta$ e $\beta$ são coeficientes empíricos que determinam três diferentes tipos de isoterma de sorção: a isoterma de Freundlich $(\eta=0)$, a isoterma de sorção de Langmuir $\left(\beta^{\prime}=1\right)$ e a isoterma de sorção linear $(\eta=0$ e $\beta=1)$.

$$
\mathrm{S}=\frac{\mathrm{K}_{\mathrm{D}} \cdot \mathrm{C}_{e}{ }^{\beta^{\prime}}}{1+\eta \mathrm{C}^{\beta^{\prime}}}
$$


Em que $\mathrm{S}$ é a concentração do soluto adsorvida $\left(\mathrm{mg} \cdot \mathrm{kg}^{-1}\right), \mathrm{C}_{e}$ é a concentração de paracetamol na solução após o equilíbrio (mg. $\mathrm{L}^{-1}$ ) e $\mathrm{K}_{\mathrm{D}}$ é o coeficiente de partição solo-solução, igual a 10, neste caso. $\mathrm{S}$ também pode ser determinado usando a Equação 3 (MARTINS, MERMOUD, 1999):

$$
\mathrm{S}=\left(\mathrm{C}_{0}-\mathrm{C}_{\mathrm{e}}\right) \mathrm{FD}
$$

Em que $\mathrm{C}_{0}$ a concentração inicial de paracetamol na solução após o equilíbrio (mg.L-1).

0 processo de cinética de sorção pode ser representado matematicamente usando o modelo de primeira ordem apresentado na Equação 4 (YANEVA E KOUMANOVA, 2006):

$$
\frac{d \mathrm{~S}_{\mathrm{t}}}{d \mathrm{t}}=\mathrm{k}_{1}\left(\mathrm{~S}_{\mathrm{e} 1}-\mathrm{S}_{\mathrm{t}}\right)
$$

Em que, $S_{\text {e1 }}$ e $S_{t}$ são a capacidade de sorção $\left(M^{-} M^{-1}\right)$ no equilíbrio e no tempo t, respectivamente, e k é a constante de taxa de sorção de primeira ordem $\left(\mathrm{T}^{-1}\right)$. Após a integração e aplicação das condições de contorno $\mathrm{t}=0 \mathrm{at}=\mathrm{t}$ e $\mathrm{S}_{\mathrm{t}}=0 \mathrm{a} \mathrm{S}_{\mathrm{t}}=\mathrm{S}_{\mathrm{t}}$, a Equação 4 pode ser escrita como:

$$
\ln \left(S_{e 1}-S_{t}\right)=\ln S_{e 1}-\frac{k_{1}}{2,303} t .
$$

Para obter as constantes de taxa de sorção, $\ln \left(S_{e 1}-S_{t}\right)$ foi elaborado o gráfico da sorção de paracetamol pelo $t$, sendo $\mathrm{k}_{1}$ a inclinação da curva linear obtida. Se a taxa de sorção segue um mecanismo de segunda ordem, a cinética de sorção é expressa como (YANEVA E KOUMANOVA, 2006):

$$
\frac{d \mathrm{~S}_{\mathrm{t}}}{d \mathrm{t}}=\mathrm{k}_{\mathrm{s}}\left(\mathrm{S}_{\mathrm{e} 2}-\mathrm{S}_{\mathrm{t}}\right)^{2}
$$

Em que, $S_{\text {e2 }}$ e $S_{t}$ são a capacidade de sorção $\left(M M^{-1}\right)$ no equilíbrio e no tempo t, respectivamente, e k2 é a constante de taxa de sorção de segunda ordem (M.M-1.T-1). Após a integração e aplicação das condições de contorno $\mathrm{t}=0 \mathrm{a} \mathrm{t}=\mathrm{t}$ e St $=0 \mathrm{a} \mathrm{St}=\mathrm{St}$, Equação (6) é escrita na forma da Equação 7:

$$
\frac{1}{\mathrm{~s}_{\mathrm{e} 2}-\mathrm{S}_{\mathrm{t}}}=\frac{1}{\mathrm{~S}_{\mathrm{e} 2}}+\mathrm{k}_{2} \mathrm{t}
$$

Podendo ser reescrita de forma linear, através da Equação 8:

$$
\frac{\mathrm{t}}{\mathrm{s}_{\mathrm{t}}}=\frac{1}{\mathrm{k}_{\mathrm{s}}}+\frac{1}{\mathrm{~S}_{\mathrm{e} 2}} \mathrm{t}, \mathrm{com} \mathrm{k}_{\mathrm{s}}=\mathrm{k}_{2} \mathrm{~S}_{\mathrm{e} 2}^{2}
$$

Em que, $\mathrm{k}_{\text {s }}$ pode ser considerado como a taxa de sorção inicial t $\mathrm{S} t \rightarrow 0$ (YANEVA E KOUMANOVA, 2006).

\section{RESULTADOS E DISCUSSÃO}

Na Tabela 1 são apresentados os resultados da análise granulométrica do solo, de acordo com a classificação utilizada pelo United States Department of Agriculture (USDA), adotada pela Sociedade Brasileira de Ciência do Solo (SBCS). 
Tabela 1 - Caracterização granulométrica do solo estudado

\begin{tabular}{|c|c|c|c|c|c|c|}
\hline Camadas(m) & Argila (\%) & Silte(\%) & $\begin{array}{c}\text { Areia } \\
\text { Fina (\%) }\end{array}$ & $\begin{array}{c}\text { Areia } \\
\text { Média (\%) }\end{array}$ & $\begin{array}{c}\text { Areia Grossa } \\
(\%)\end{array}$ & Classificação \\
\hline $0,00-0,20$ & 10,4 & 11,2 & 12,3 & 13,7 & 52,4 & Franco Arenoso \\
\hline $0,20-0,40$ & 12,5 & 13,8 & 14,7 & 15,2 & 43,8 & Franco Arenoso \\
\hline
\end{tabular}

Na Tabela 2 são apresentados os resultados da caracterização química do solo, em que foram quantificados os valores do potencial hidrogeniônico $(\mathrm{pH})$, do carbono oxidável e da matéria orgânica das duas camadas do solo, observando-se pela diferença entre o $\mathrm{pH}$ em $\mathrm{KCl}$ e em água, que a carga líquida nas duas camadas foi negativa. Isto é condizente com os resultados granulométricos do solo Franco Arenoso, apresentados na Tabela 1.

Tabela 2 - Caracterização química do solo estudado

\begin{tabular}{|c|c|c|c|c|c|}
\hline \multirow{2}{*}{ Camadas $(\mathrm{m})$} & $\mathrm{pH}\left(\mathrm{H}_{2} \mathrm{O}\right)$ & $\mathrm{pH}(\mathrm{KCl})$ & $\mathrm{CO}\left(\mathrm{g} \mathrm{kg}^{-1}\right)$ & $\mathrm{MO}\left(\mathrm{g} \mathrm{kg}^{-1}\right)$ & Área Superficial $\left(\mathrm{m}^{2} \mathrm{~g}^{-1}\right)$ \\
\hline $0,00-0,20$ & 7,24 & 6,75 & 10,19 & 17,57 & 4,33 \\
\hline $0,20-0,40$ & 8,01 & 7,28 & 8,59 & 14,81 & 4,49 \\
\hline
\end{tabular}

\subsection{ADSORÇÃO DO PARACETAMOL}

As cinéticas de adsorção do paracetamol (Figura 2) se apresentaram idênticas nas duas camadas do solo, sugerindo o envolvimento de mecanismos de adsorção semelhantes. Os resultados mostraram que, no equilíbrio, a camada $0,00-0,20 \mathrm{~m}$ sorve um pouco mais de paracetamol ( $\mathrm{S}_{\mathrm{e} 2}$ igual a $69,93 \mathrm{mgkg}^{-1}$ ) em relação a camada 0,20 - 0,40 m ( $\mathrm{S}_{\mathrm{e} 2}$ igual a 55,25 $\left.\mathrm{mg} \mathrm{kg}^{-1}\right)$, constatando-se que o equilíbrio de adsorção do paracetamol foi alcançado em 60 h, não sendo considerado, portanto, instantâneo.

Os parâmetros correspondentes são apresentados na Tabela 3. Os dados se ajustaram melhor ao modelo de segunda ordem, apresentando maiores valores de $\mathrm{R}^{2}$, quando comparado ao modelo de primeira ordem.

Figura 2 - Cinética de sorção do Paracetamol nas camadas 0-20 cm e 20-40 cm

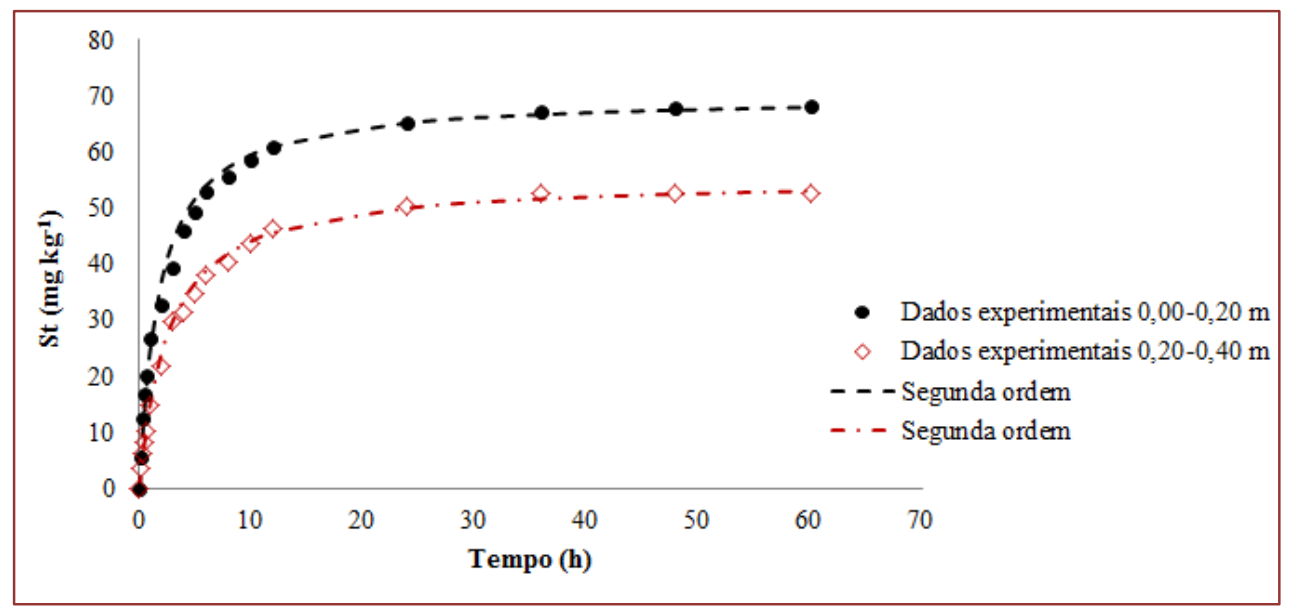

Observando-se os dados da Tabela 3, constata-se que resultados satisfatórios foram obtidos com a aplicação dos modelos cinéticos de primeira e segunda ordem, em que os coeficientes de determinação foram maiores no modelo de segunda ordem. 
Tabela 3 - Valores das capacidades de sorção do PCM em equilíbrio, $\mathrm{S}_{\mathrm{e} 1}$ e $\mathrm{S}_{\mathrm{e} 2}$; das taxas constantes de sorção, $\mathrm{k}_{1}$ e k2; e dos coeficientes de determinação, $\mathrm{R}^{2}$, para os dois modelos e ambas camadas.

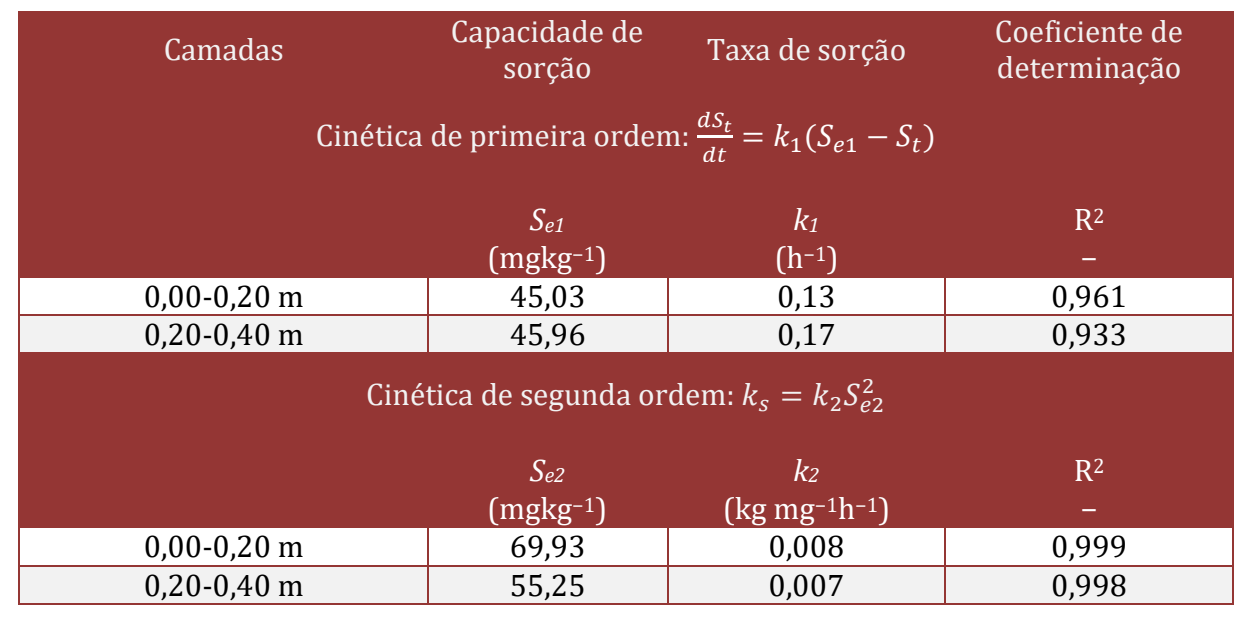

As isotermas de adsorção do paracetamol segundo o modelo linear para as duas camadas podem ser observadas na Figura 3, enquanto as isotermas segundo os modelos de Freundlich e Langmuir podem ser observadas nas Figuras 4 e 5, respectivamente.

Figura 3 - Isotermas de adsorção do paracetamol segundo modelo linear

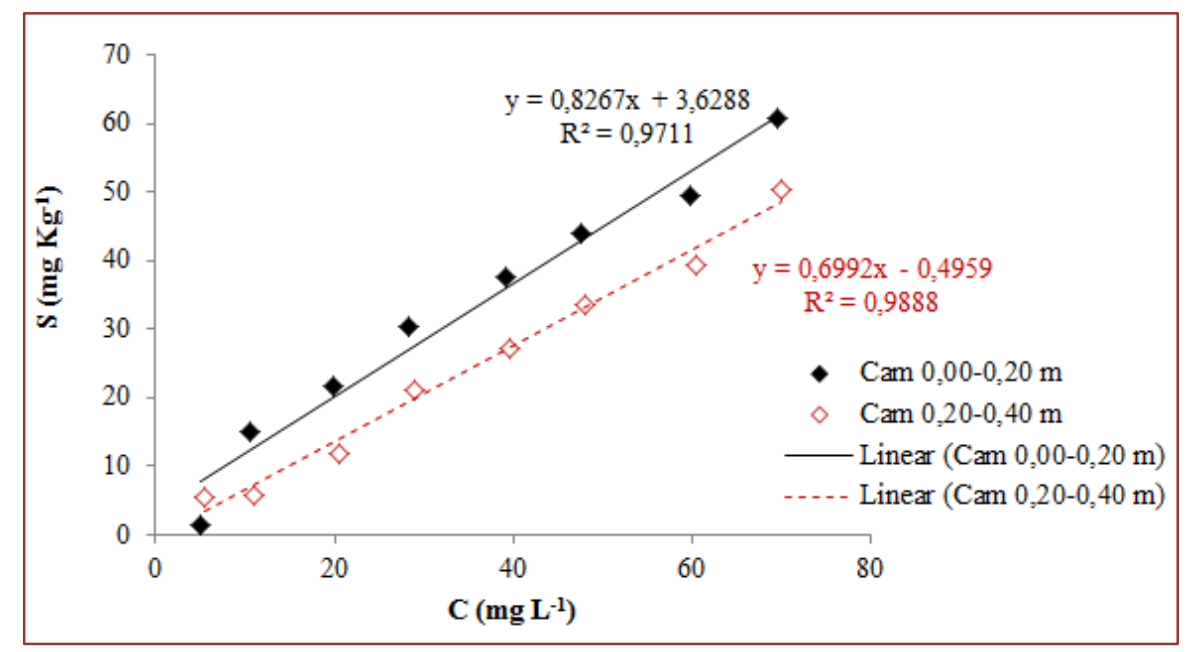


Figura 4 - Isotermas de adsorção do paracetamol segundo modelo Freundlich

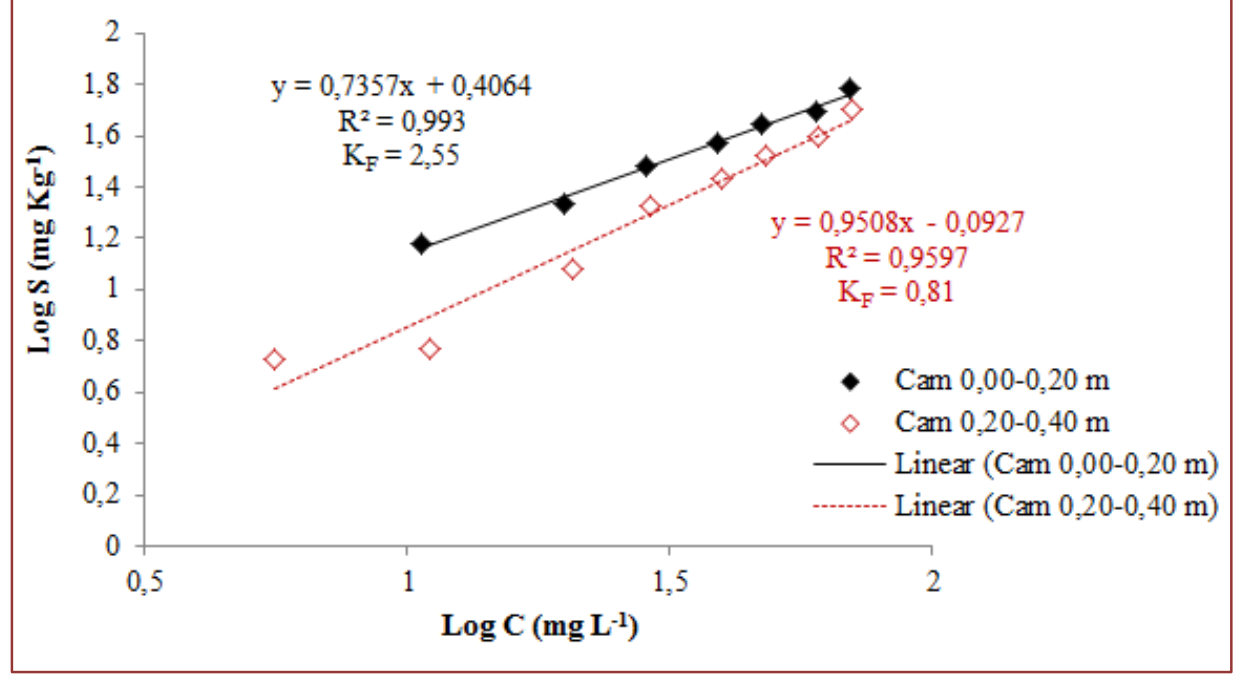

Figura 5 - Isotermas de adsorção do paracetamol segundo modelo Langmuir

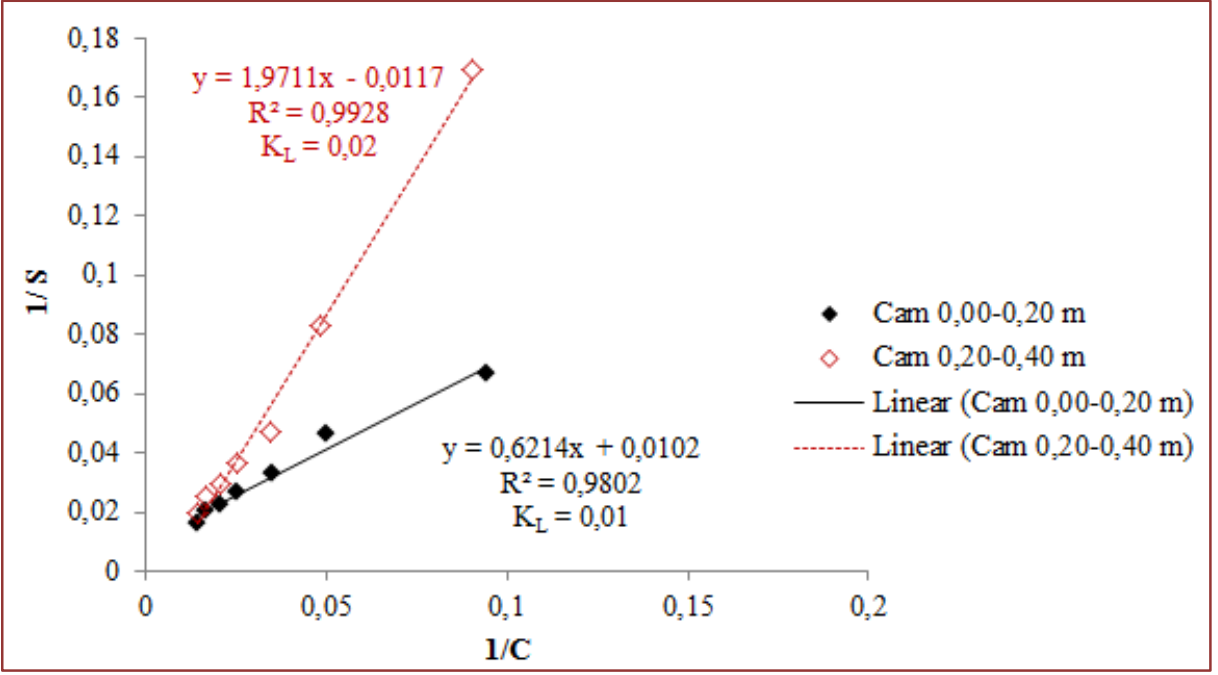

0 modelo de Freundlich apresentou o maior coeficiente de determinação para a camada 0,00-0,20 m, com valor de $\mathrm{K}_{\mathrm{F}}$ de 3,04, enquanto para camada 0,20-0,40 m o modelo de Langmuir apresentou o maior coeficiente de determinação, através do qual se constatou o $\mathrm{K}_{\mathrm{L}}$ de 0,01 , demonstrando desta forma baixa capacidade de adsorção pelo solo.

\section{CONCLUSÃO}

Os ensaios de cinética de adsorção mostraram que o equilíbrio de adsorção do paracetamol foi alcançado em 60 horas, não sendo considerados, portanto, instantâneo. 0 paracetamol foi pouco retido no solo, com isotermas de adsorção não instantâneas, melhor representadas pelo modelo cinético de segunda ordem, bem representadas pelos modelos de Freundlich e de Langmuir, que anunciam biodisponibilidade significativa e mobilidade deste fármaco, evidenciando o risco potencial de contaminação da água subterrânea e dos organismos presentes nesta matriz ambiental. 


\section{REFERÊNCIAS}

[1] CRAIG, Charles R; STITZEL, Robert E (Ed.). Farmacologia moderna. 6. ed. Rio de Janeiro: Guanabara Koogan, 2005.

[2] CRUZ, P.C.F. Aplicação de um novo reator de fluxo oscilatório no controle da qualidade e tamanho dos cristais de Paracetamol. Tese de Mestrado. Universidade do Porto, 2015.

[3] EMBRAPA. Manual de métodos de análise de solo. Centro Nacional de Pesquisa de Solos. 2. ed. Rio de Janeiro, 2011.

[4] EMBRAPA. Mapa Exploratório - Reconhecimento de solos do município de Pesqueira, PE. Embrapa Solos, UEP. Recife, 2001.

[5] GONDIM, M.V.S. Estudo das transferências e transformações do antibiótico sulfametoxazol em solos no context tropical e temperado. Tese (Doutorado). Universidade Federal de Pernambuco. Recife, 2014.

[6] KALANT, Harold; ROSCHLAU, Walter H. E. Princípios de farmacologia médica. 5. ed. Rio de Janeiro: Guanabara Koogan, 1991.

[7] KATZUNG, Bertram G. Farmacologia básica \& clínica. 8. ed. Rio de Janeiro: Guanabara Koogan, 2003.

[8] MARTINS, J. M. F.; MERMOUD, A.; Sorption and degradation of four nitroaromatic herbicides in mono and multi-solute saturated/unsaturated soil batch systems, Journal of Contaminant Hydrology, v. 33, p. 187-210, 1999.

[9] PRADO, M.A.F. Verificação da influência do pH e do pKa na ionização de fármacos. Universidade Federal de Minas Gerais, 2006.

[10] RAIMUNDO, C.C.M. Ocorrência de interferentes endócrinos e produtos farmacêuticos nas águas superficiais na bacia do rio Atibaia. Universidade Estadual de Campinas. Campinas, 2007.

[11] ROGERS, H.R. Sources, behaviour and fate of organic contaminants during sewage treatment and in sewage sludges. Science of the Total Environment, (1996) v. 185, n. 1-3, p. 3-26.

[12] YANEVA, Z., AND B. KOUMANOVA. Comparative modelling of mono- and dinitrophenols sorption on yellow bentonite from aqueous solutions. J. Colloid Interface Sci. 293:303-311, 2006. 


\section{Capítulo 5}

Qualidade da água e comunidades de macroalgas em recursos hídricos na área urbana de Manaus/AM

\section{Domitila Pascoaloto \\ Núbia Abrantes Gomes \\ Climéia Corrêa Soares}

RESUMO: Neste estudo foram investigadas, entre maio/2013 e abril/2014, a qualidade da água e as comunidades de macroalgas no rio Negro, em seu leito e próximo à foz dos igarapés São Raimundo e Educandos, e nos dois igarapés mais poluídos da cidade de Manaus, Mindu e Quarenta. As análises confirmaram que houve uma piora na qualidade dessas águas em relação aos estudos realizados há dez anos atrás. Os resultados obtidos também indicaram que o rio Negro representa um sistema frágil, suscetível a alterações devido a entrada de águas contaminadas. Não foram registradas macroalgas nos igarapés Mindu e Quarenta. No rio Negro, espécimes da fase carposporofítica da rodofícea Batrachospermum spp. estiveram presentes por todo o período de estudo no sítio amostral Ceasa e no período da cheia no sítio amostral Ponta Negra, entretanto a fase gametofítica só foi observada no período de vazante. A macroalga mais frequente na área de inundação do rio Negro próximo à foz foi a clorofícea Schizomeris leibleinii, a qual costuma ocorrer em locais com condutividade elétrica superior à registrada nas águas naturais do rio Negro, indicando o aporte de nutrientes nesses locais; essa mesma alga foi registrada na parte inferior das bacias do São Raimundo e Educandos.

Palavras-chave: Poluição Hídrica, algas, Bacia Amazônica 


\section{INTRODUÇÃO}

O município de Manaus está localizado na região Norte do Brasil, no centro geográfico da Amazônia. A superfície total do município (11.458,5 $\mathrm{km}^{2}$ ) equivale a 0,73\% do território do Estado do Amazonas, porém contém mais da metade (51,72\%) da população. A área urbana de Manaus se estende por $377 \mathrm{~km}^{2}$, correspondendo apenas a 3,3\% do território municipal e abriga mais de 99\% da população (IBGE, 2011). Sem planejamento, a cidade cresceu desordenadamente, sobretudo a partir dos anos 1970, com a instalação da Zona Franca de Manaus (Andrade, 2012). Uma das consequências gerada por esse crescimento foi a mudança da qualidade da água, tendo em vista que a maior parte da população se estabeleceu à beira dos igarapés (Nogueira et al., 2007).

Os igarapés Mindu e Quarenta pertencem às microbacias dos igarapés São Raimundo e Educandos, respectivamente, e estão entre os mais representativos da área urbana de Manaus, sobretudo no que se refere aos impactos da ocupação do solo na região, o que se reflete na alteração da qualidade de suas águas ao longo da bacia hidrográfica (Pascoaloto et al., 2004; Melo et al., 2006). Ambos recebem cargas de efluentes domésticos desde a parte superior das bacias, sendo que, embora o curso do igarapé Mindu seja mais longo, no igarapé Quarenta também há o aporte dos efluentes industriais de empresas estabelecidas no Polo Industrial de Manaus (PIM), sendo que, ainda que atualmente a maioria dessas empresas tratem seus efluentes, devido as estabelecidas pela legislação ambiental, os sedimentos ainda retratam a entrada dos metais pesados que começaram entrar em suas águas na década de 1970 (Silva et al., 2009; Santana, 2006, 2016; Silva, 2010).

Todos os igarapés da área urbana de Manaus desaguam, direta ou indiretamente, no rio Negro, principal contribuinte da margem esquerda do rio Amazonas e um dos quatro rios com maior vazão da bacia hidrográfica amazônica. Devido a esse grande volume de água, alguns pesquisadores acreditam que ele possua capacidade de autodepuração (Fonseca et al., 1982), enquanto outros afirmam que ele já apresenta indícios de poluição (ex.: Pinto et al., 2009).

0 estudo de cunho ecológico das comunidades de macroalgas em ambientes lóticos na região de Manaus e arredores iniciou na década de 1990, envolvendo macroalgas verdadeiras em fragmentos florestais, o que reduziu a comunidade a espécies da divisão Rhodophyta (Pascoaloto, 1999). Estudos posteriores revelaram a presença de macroalgas em igarapés sob diversos graus de eutrofização (Pascoaloto, 2001; Pascoaloto et al., 2004, 2008, 2015). Para o rio Negro, existem registros de macroalgas apenas para a parte superior da bacia (Pascoaloto e Bringel, 2010; Bringel \& Pascoaloto, 2012).

No presente trabalho teve por objetivo verificar a qualidade da água e das comunidades de algas nos igarapés Mindu (principal formador do igarapé São Raimundo) e Quarenta (principal formador do igarapé Educandos) e no rio Negro, em área com e sem influência desses igarapés. Neste estudo também foi comparada a qualidade da água e comunidades de macroalgas desses igarapés após um intervalo de dez anos.

\section{MATERIAL E MÉTODOS}

O presente estudo foi desenvolvido em oito sítios amostrais na cidade de Manaus, no período de maio/2013 a maio/2014 (Figuras $1-3$ ).

Os igarapés Mindu (com área de 116,46Km²) e Quarenta (com área de 43,80 $\mathrm{Km}^{2}$ ) são os principais formadores das microbacias hidrográficas dos igarapés São Raimundo e Educandos, respectivamente (Alcântara \& Marques Filho, 2003), as quais, salvo algumas nascentes localizadas em área de expansão, apresentam todos os cursos de água em área urbana. Neste estudo foram investigados os sítios amostrais Petro, no igarapé do Mindu, e Seduc, no igarapé do Quarenta. Também foram realizadas, no período de águas altas, coletas de algas e água nos igarapés São Raimundo e Educandos, próximo à foz (Figuras 1-2). 
Figura 1: Localização dos sítios amostrais.

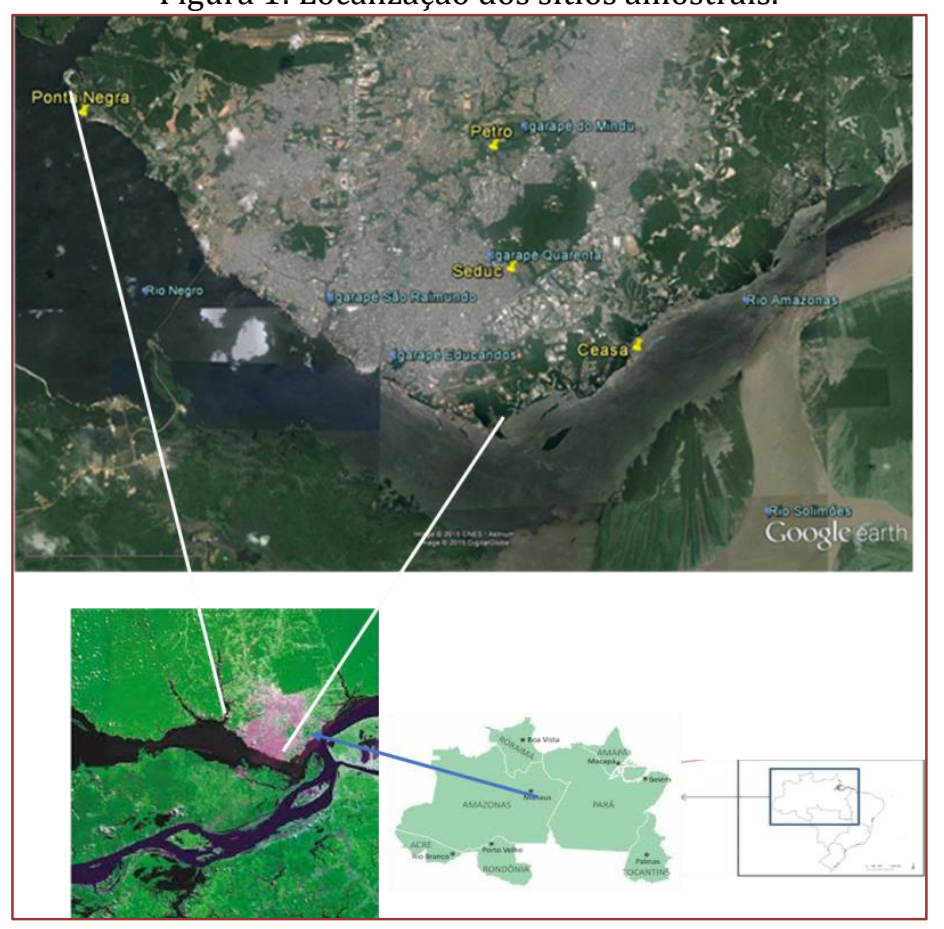

(Organizado por Domitila Pascoaloto, com base na imagem do satélite CBERS-2/INPE).

O rio Negro é o principal recurso hídrico do município de Manaus. Nele aportam, direta ou indiretamente, os igarapés do município, com exceção do rio Puraquequara, cuja foz encontra-se a jusante do encontro do Negro com o Solimões, ou seja, já no rio Amazonas. Os sítios amostrais investigados no rio Negro (Ponta Negra e Ceasa) estão localizados a montante e a jusante dos aportes dos igarapés que compõem as duas microbacias totalmente urbanas do município, São Raimundo e Educandos (Figuras 1-2).

As amostras de água foram coletadas com garrafa tipo Van Dorn, acondicionadas em frascos de polietileno quimicamente limpos e transportadas para laboratório de Química Ambiental (CDAM/INPA) para determinação de pH, condutividade elétrica, turbidez, cálcio, magnésio, sódio, potássio, amônia, nitrato, fosfato, silicato, ferro dissolvido, fósforo total, nitrogênio total, conforme APHA et al. (2005). A determinação do oxigênio dissolvido foi feita pelo método de Winkler modificado Golterman et al. (1978). A determinação de coliformes totais e fecais foi feita segundo a técnica do número mais provável (tubos múltiplos) (APHA et al., 2005).

As macroalgas foram coletadas com as mãos ou com auxílio de espátula, procurando-se destacar plantas inteiras. 0 material foi levado para o Laboratório de Limnologia (CDAM/INPA) em água do próprio local e fixado em solução de formalina a 4\% (Johanson, 1982). 
Figura 2: Configuração dos locais (período de águas altas, 2013).
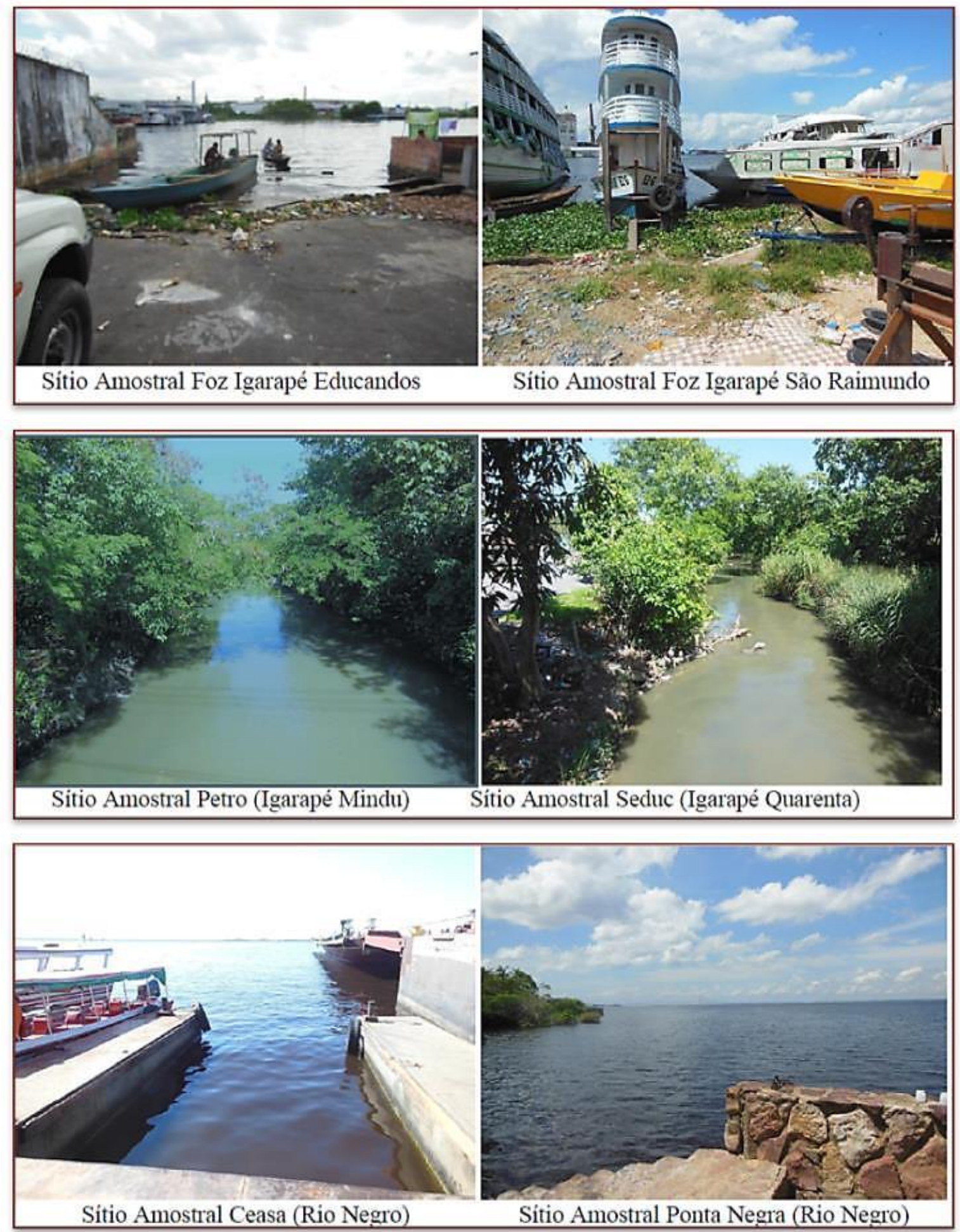

Fonte: Fotografados por: Domitila Pascoaloto 
Figura 3: Região de inundação do rio Negro no porto da Ceasa (sítios amostrais Ceasa_Algas e Ceasa AA) (Fotografados por Domitila Pascoaloto).

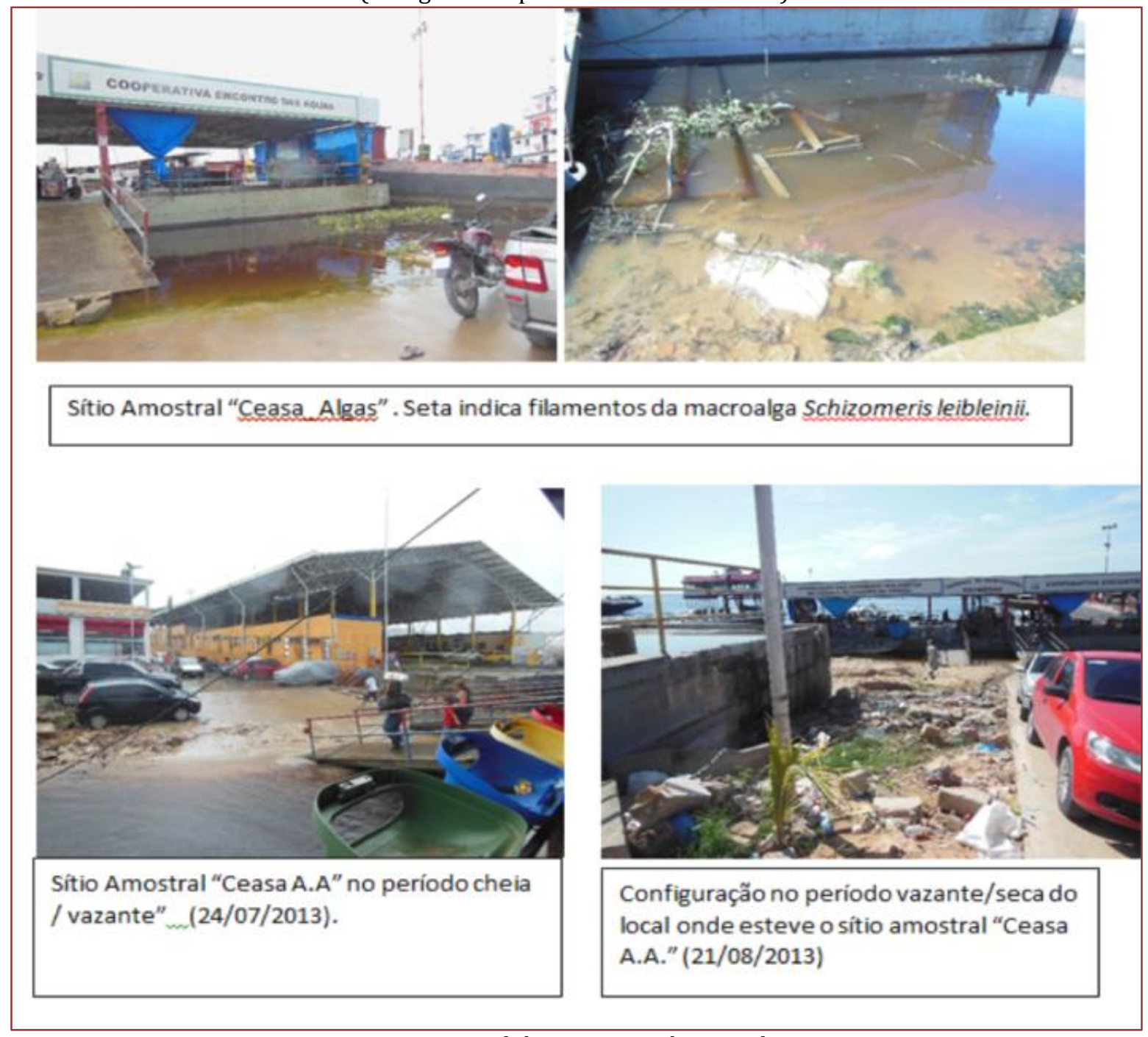

Fonte: Fotografados por: Domitila Pascoaloto

\section{RESULTADOS E DISCUSSÃO}

Foram registradas cinco entidades ecológicas de macroalgas no rio Negro (Tabela 1). Não foram observadas macroalgas nos sítios amostrais Petro e Seduc. Ocasionalmente foram observados sedimentos com provável presença de cianobactérias fazendo parte da comunidade perifítica (com base na coloração), no entanto, além desse material não se encaixar no conceito macroalgas (espécime visível a olho nu), não foi realizada a coleta da amostra devido à impossibilidade de acesso ao local. 
TABELA 1: Entidades de macroalgas nos locais de estudo.

\begin{tabular}{|c|c|c|c|c|c|}
\hline Entidade Ecológica/Local & Ceasa & $\begin{array}{c}\text { Ceasa/ } \\
\text { Algas }\end{array}$ & $\begin{array}{c}\text { Foz } \\
\text { Educandos }\end{array}$ & $\begin{array}{c}\text { Foz São } \\
\text { Raimundo }\end{array}$ & $\begin{array}{l}\text { Ponta } \\
\text { Negra }\end{array}$ \\
\hline \multicolumn{6}{|l|}{ Chlorophyceae } \\
\hline Microspora sp. & & $\mathrm{X}$ & & & \\
\hline Schizomeris leibleinii Kützing & & $\mathrm{X}$ & $\mathrm{X}$ & $\mathrm{X}$ & $\mathrm{x}$ \\
\hline \multicolumn{6}{|l|}{ Rhodophyceae } \\
\hline Batrachospermum sp.* & & $\mathrm{x}$ & & & \\
\hline Batrachospermum cf. cayennense Montagne & & $\mathrm{x}$ & & & $\mathrm{X}$ \\
\hline Fase "Chantransia" de Batrachospermum spp. & $\mathrm{x}$ & $\mathrm{x}$ & & & $\mathrm{X}$ \\
\hline
\end{tabular}

(Organizada por Domitila Pascoaloto).

Os valores médios observados para as variáveis ambientais nos locais estudados encontram-se na Tabela 2.

Os igarapés Mindu e Quarenta foram investigados em estudos anteriores (Franken, 2004; Cunha, 2006). Cabral e Cunha (2004) e Melo et al. (2005) registraram para os locais Petro e Seduc valores de pH 6,38 7,20 e 5,8 - 6,8, respectivamente; condutividade elétrica no intervalo 74,80 - 266,00 e 93,7 - 236,00 $\mu \mathrm{S} / \mathrm{cm}$, respectivamente; oxigênio dissolvido entre 0,46 - 3,95 mg/L e 0,00 - 3,14 mg/L, respectivamente). Em relação às comunidades de macroalgas, Pascoaloto et al. (2004) registraram seis espécies (sendo uma cianobactéria e cinco clorofíceas) para o sítio amostral Seduc (igarapé do Quarenta) e duas espécies de cianobactérias para o sítio amostral Petro (igarapé do Mindu) e relataram que, após uma ação da prefeitura para limpeza do leito do igarapé do Quarenta a vegetação ciliar, bem como a vegetação aquática, foi retirada e a partir dessa data não foram mais observadas macroalgas no sítio amostral Seduc.

TABELA 2: Valores médios das variáveis ambientais nos locais estudados.

\begin{tabular}{|c|c|c|c|c|c|c|c|}
\hline Local & $\mathrm{pH}$ & $\begin{array}{c}\text { C.E. } \\
\mu \mathrm{S} / \mathrm{cm}\end{array}$ & $\begin{array}{l}\text { Alcalinidade } \\
\mathrm{mgHCO}_{3} / \mathrm{L}\end{array}$ & $\begin{array}{c}\text { Cor } \\
\mathrm{mgPt} / \mathrm{L}\end{array}$ & $\begin{array}{c}\text { Turbidez } \\
\text { NTU }\end{array}$ & $\begin{array}{l}\text { S.S. } \\
\mathrm{Mg} / \mathrm{L}\end{array}$ & $\begin{array}{c}\mathrm{O}_{2} \\
\mathrm{mg} / \mathrm{L}\end{array}$ \\
\hline Petro & 7,05 & 195,79 & 97,91 & 64,77 & 91,38 & --- & 0,89 \\
\hline Seduc & 6,84 & 241,57 & 86,74 & 71,85 & 58,89 & --- & 1,38 \\
\hline Ponta Negra & 5,22 & 8,53 & 3,99 & 141,16 & 3,05 & 4,37 & 4,16 \\
\hline Ceasa & 5,46 & 9,22 & 4,58 & 143,72 & 4,01 & 6,34 & 3,46 \\
\hline Ceasa_Algas & 5,80 & 16,51 & 7,02 & 161,27 & 16,46 & 16,89 & --- \\
\hline Ceasa (A.A*) & 5,39 & 8,68 & 3,60 & 141,88 & 4,29 & 5,42 & 3,54 \\
\hline São Raimundo & 6,11 & 27,52 & 12,81 & 139,88 & 3,77 & 4,34 & 1,67 \\
\hline Educandos & 6,27 & 55,46 & 12,29 & 127,54 & 7,41 & 8,26 & 0,72 \\
\hline Local & $\begin{array}{c}\mathrm{DQO} \\
\mathrm{mg} / \mathrm{L}\end{array}$ & $\begin{array}{c}\mathrm{Si}(\mathrm{OH})_{4} \\
\mathrm{mg} / \mathrm{L}\end{array}$ & $\begin{array}{c}\text { Dureza } \\
\text { mgCaCo3/L }\end{array}$ & $\begin{array}{c}\mathrm{Ca}^{++} \\
\mathrm{mg} / \mathrm{L}\end{array}$ & $\begin{array}{l}\mathrm{Mg}^{++} \\
\mathrm{mg} / \mathrm{L}\end{array}$ & $\begin{array}{c}\mathrm{Cl}^{-} \\
\mathrm{mg} / \mathrm{L}\end{array}$ & $\begin{array}{c}\mathrm{K}^{+} \\
\mathrm{mg} / \mathrm{L}\end{array}$ \\
\hline Petro & 112,46 & 7,21 & 55,04 & 16,80 & 1,84 & 15,46 & 6,35 \\
\hline Seduc & 50,72 & 4,92 & 51,51 & 15,15 & 2,07 & 12,15 & 5,19 \\
\hline Ponta Negra & 50,05 & 2,85 & 2,63 & 0,32 & 0,43 & 0,97 & 0,39 \\
\hline Ceasa & 50,84 & 2,73 & 2,27 & 0,16 & 0,40 & 1,31 & 0,41 \\
\hline Ceasa_Algas & 55,72 & 3,07 & 5,50 & 0,46 & 0,91 & 2,58 & 0,31 \\
\hline Ceasa (A.A*) & 54,25 & 2,85 & 3,38 & 0,06 & 0,70 & 1,33 & 0,46 \\
\hline São Raimundo & 40,24 & 3,10 & 6,46 & 0,72 & 0,97 & 3,12 & 0,88 \\
\hline Educandos & 40,05 & 3,47 & 13,58 & 3,05 & 1,12 & 5,85 & 1,61 \\
\hline Local & $\begin{array}{c}\mathrm{Na}^{+} \\
\mathrm{mg} / \mathrm{L}\end{array}$ & $\begin{array}{l}\mathrm{NO}_{3}^{-} \\
\mathrm{mg} / \mathrm{L}\end{array}$ & $\begin{array}{l}\mathrm{NO}_{2}^{-} \\
\mathrm{mg} / \mathrm{L}\end{array}$ & $\begin{array}{l}\mathrm{NH}^{+}{ }^{+} \\
\mathrm{mg} / \mathrm{L}\end{array}$ & $\begin{array}{l}\mathrm{PO}_{4}^{--} \\
\mathrm{mg} / \mathrm{L}\end{array}$ & $\begin{array}{l}\text { P Total } \\
\mathrm{mg} / \mathrm{L}\end{array}$ & $\begin{array}{c}\mathrm{N} \text { Total } \\
\mathrm{mg} / \mathrm{L}\end{array}$ \\
\hline Petro & 22,13 & 4,53 & 3,64 & 6,45 & 0,34 & 0,62 & 7,69 \\
\hline Seduc & 22,57 & 1,12 & 0,01 & 5,73 & 0,15 & 0,85 & 11,53 \\
\hline Ponta Negra & 0,71 & 0,04 & 0,04 & 0,40 & 0,01 & 0,06 & 0,55 \\
\hline Ceasa & 0,86 & 0,04 & 0,02 & 0,41 & 0,01 & 0,05 & 0,51 \\
\hline Ceasa_Algas & 3,13 & 0,05 & 0,01 & 0,45 & 0,01 & --- & --- \\
\hline Ceasa $($ A.A*) & 0,98 & 0,05 & 0,01 & 0,43 & 0,02 & 0,06 & 0,60 \\
\hline São Raimundo & 2,92 & 0,71 & 0,01 & 1,00 & 0,02 & 0,08 & 0,60 \\
\hline Educandos & 5,38 & 2,30 & 0,00 & 2,17 & 0,08 & 0,18 & 1,51 \\
\hline
\end{tabular}

* A.A.= período de águas altas (médias no sítio amostral Ceasa quando estiveram presentes filamentos de macroalgas no local Ceasa-Algas)

(C.E.= Condutividade Elétrica; DQO= Demanda Química de Oxigênio).

(Organizada por Domitila Pascoaloto). 
O estudo realizado nos igarapés Mindu e Quarenta, no período 2013-2014, não foi tão sistemático quanto aqueles realizados por Silva et al. (2004), pois esteve mais relacionado com atividades de extensão (Pascoaloto et al., 2014); entretanto os resultados obtidos indicaram ligeiro aumento de $\mathrm{pH}$ e condutividade elétrica entre o período de 2002-2003 (Costa et al., 2016) e os nossos (valores máximos de pH 7,15 e 7,19 no Petro e 6,66 e 6,87, respectivamente e valores máximos de condutividade elétrica 233,92 e $321,70 \mu \mathrm{S} / \mathrm{cm}$ no Petro, respectivamente, e 283,38 e 337,20 $\mu \mathrm{S} / \mathrm{cm}$ no Seduc, respectivamente). Em nenhum desses locais foram observadas macroalgas, embora na comunidade perifítica (presente em galhos e nas estruturas das pontes) tenham sido observados filamentos de cianobactérias. 0 fato de não terem sido observadas macroalgas no sítio amostral Mindu sugere que o equilíbrio ecológico foi quebrado em 2003 e que a supressão dos substratos nessa ocasião extinguiu a comunidade de macroalgas no local. Quanto ao sítio amostral Petro, ainda existem cianobactérias no local (fazem parte da comunidade perifítica que existe em área revestida por cimento, no alicerce da ponte), porém essas não apresentam dimensões para serem consideradas macroalgas; ressalta-se que no estudo realizado no período de 20022003 os espécimes estavam aderidos a troncos e raízes, semelhante ao observado no sítio amostral Seduc).

A proposta inicial para estudo seria coletar amostras de água no leito do rio Negro desde o trecho mais a montante da orla da cidade de Manaus até próximo à confluência com o Solimões (trecho entre a foz do rio Tarumã-Açu e a foz do rio Negro, em locais onde fosse possível coletar água na margem do rio), como parte de um projeto mais amplo, que visa verificar a influência da cidade sobre as águas de seu principal recurso hídrico em períodos de inundação. Entretanto as visitas realizadas ao sítio amostral Ceasa revelaram, no período de águas altas, a presença de macroalgas (em geral a clorofícea Schizomeris leibleinii) na região por trás do flutuante onde atracam os barcos (Figura 3) (a parte da frente é o sítio amostral "Ceasa"). Por essa razão, nessas ocasiões foram coletadas amostras de água também nesse local (Ceasa_Algas), sendo que esses resultados não devem ser incluídos como qualidade da água do rio Negro propriamente dita, visto que não se trata da água coletada em seu leito, mas sim em área de inundação (especificamente em área que propiciou o aparecimento de macroalgas em terreno urbano).

Filamentos de $S$. leibleinii já haviam sido observados nas imediações do rio Negro em área inundada no centro da cidade, tanto em 2010 (n. publ.), quando houve a segunda maior enchente do rio Negro e as ruas mais próximas à orla ficaram inundadas por uma mistura da água do rio Negro com os efluentes que vazaram das galerias, quanto em 2012-2014, principalmente na sarjeta e na calçada (onde algumas pessoas ainda insistem em urinar) da rua mais próxima à ponte pela qual trafegam os veículos que transportam mercadoria para as embarcações no período de águas baixas. Ressalta-se que o fato de termos observado essa alga apenas em locais impactados na bacia hidrográfica do rio Negro, tanto neste estudo (onde os filamentos dessa espécie foram registrados em locais onde existem aportes de efluentes domésticos ou de estabelecimentos comerciais ou possível acúmulo de amônia por ação antrópica localizada) como em estudos anteriores (ex.: Pascoaloto et al., 2004; Silva et al., 2005; Pascoaloto e Silva, 2016) indica a possibilidade, caso a água do rio Negro venha a sofrer aumento da carga de nutrientes (que entram com os esgotos domésticos), de aumento na proliferação de macroalgas, bem como a de cianobactérias, uma vez é comum se observar no substrato onde se encontram os filamentos dessa macroalga a presença de cianobactérias no perifíton. Assim é importante que haja ação dos órgãos de gestão para que as águas dos igarapés da cidade sejam tratadas antes de entrarem no rio, sendo que o prétratamento (que impede a entrada de sólidos com tamanho superior à abertura do retentor) não impedirá a entrada dessa carga iônica (nem tampouco a dos microrganismos patogênicos).

Não foram verificadas grandes alterações na qualidade da água do rio Negro (pH e condutividade elétrica) entre os sítios amostrais "Ponta Negra" e "Ceasa" no nosso estudo em relação àquele realizado por Pinto et al. (2009) em locais próximos a esses sítios amostrais e a diferença pode estar relacionada ao fato de que esses autores realizaram as coletas de barco (mais distante da margem) enquanto as nossas foram realizadas próximas à margem. Entretanto, quando se compara os resultados obtidos entre os dois locais (ver tabela 2), pode-se observar que houve uma sensível diferença entre eles, como a redução no teor de oxigênio dissolvido, o que tanto pode estar relacionado com o fato do rio Negro ter menor velocidade próximo à foz (sítio amostral Ceasa), onde ele pode estar sendo represado (ou "empurrado") pelo rio Solimões como ao consumo do oxigênio para degradação da matéria orgânica, uma vez que entre esses dois sítios amostrais existem as entradas dos dois igarapés mais poluídos de Manaus (São Raimundo e Educandos), sendo a segunda hipótese mais provável, uma vez que também houve um ligeiro aumento do pH e da condutividade elétrica entre esses dois locais. 
Ressalta-se, contudo, que, embora os valores médios de $\mathrm{pH}$ e condutividade elétrica não tenham sido muito diferentes entre os sítios amostrais "Ceasa" (água do rio Negro, em frente ao flutuante "Porto Ceasa") e "Ceasa_A.A" (área de inundação, atrás do flutuante "Porto Ceasa, que está conectada com o rio Negro no período de águas altas e abrange a área de estacionamento da feira do CEASA), distantes cerca de 15 a 20 metros, eles foram inferiores àqueles registrados os sítios amostrais no Ceasa-Algas (área de inundação presente no período de águas baixas, região afetada pelo sedimento, vegetação e escoamento de água de chuva e/ou lavagem de veículos no estacionamento e objetos nos estabelecimentos comerciais na feira e arredores). Embora os valores registrados no sítio amostral "Ceasa-Algas" tenham sido inferiores aos registrados para os sítios amostrais "Foz São Raimundo" e "Foz Educandos", eles foram superiores àqueles registrados por Pinto et al. (2009).

Apesar da diferença relativamente pequena observada no $\mathrm{pH}$, alcalinidade e condutividade entre os sítios amostrais Ceasa e Ceasa_Algas, alguns resultados obtidos indicam a entrada de "águas enriquecidas" no local (os resultados indicam que o Ceasa-Algas foi mais rico em sódio, magnésio e cloreto, porém apresentou menor teor de potássio; ambos os locais apresentaram concentrações similares de íons amônio, nitrito, nitrato e fosfato), fato corroborado pela presença e frequência de espécimes de Schizomeris leibleinii (os filamentos da clorofícea foram observados ao longo de toda a extensão do flutuante), o que sugere que esse aporte foi constante durante todo o período de estudo. Devido, principalmente, ao fato que o flutuante muda constantemente de posição, é difícil determinar de onde viria esse aporte de nutrientes. 0 enriquecimento tanto poderia estar relacionado com a manipulação de peixes na "feira" que fica na proximidade (Figura 3), quanto ao uso indevido das imediações para "mictório". Novos estudos devem ser realizados para investigar a origem do escoamento e devem incluir autorização do comitê de ética para interação com os comerciantes locais, pois existe a possibilidade que esse esgotamento seja oriundo dos pequenos restaurantes estabelecidos na feira.

Quanto à presença de $S$. leibleinii alga no sítio amostral Ponta Negra, a mesma foi observada apenas duas vezes (em intervalo de uma semana), em uma área onde tanto hóspedes quanto turistas frequentam e até mesmo moradores costumam utilizar o píer para embarcar em lanchas particulares (ressalta-se que essa área só se apresenta inundada próximo à cheia do rio, nas demais ocasiões ela faz parte o pátio onde fica o mirante). Como a frequência aumenta no mês junho, quando ocorre uma festa popular no município de Parintins, a qual atrai turistas do mundo todo, é provável que a presença dos filamentos de $S$. leibleinii reflitam essa pressão antrópica sobre a água do rio, hipótese corroborada pelo fato que na coleta realizada três dias antes dessa festa (quando várias embarcações e grande e médio porte estavam partindo de Manaus para levar os "brincantes") foram registrados 1400000 NMP de coliformes fecais no sítio amostral Ponta Negra, enquanto no Ceasa o valor foi de 240000 (sendo que nas demais coletas o mínimo foi de 2300 NMP em ambas os locais e máximo foi de 7500 no Ponta Negra e 39000 no Ceasa).

\section{CONCLUSÃO}

A prefeitura da cidade de Manaus vem investindo, sobretudo a partir de 2006, em obras que, oficialmente, visam revitalizar os igarapés da cidade. Os resultados obtidos neste estudo demonstram que não apenas os igarapés Mindu e Quarenta não foram revitalizados, como também que a qualidade da água piorou.

Não existem registros sobre a comunidade de macroalgas no baixo rio Negro para se verificar se houve mudanças ao longo destes dez anos, entretanto, em relação aos igarapés, a diversidade diminuiu (no caso dos dois sítios amostrais investigados, deixou de existir) e presença de algas que se encontram atracadas a algum substrato ficou reduzida a cianobactérias perifíticas. Todavia. não é possível afirmar se ausência de macroalgas nos sítios amostrais está relacionada à qualidade da água, pois nessa comunidade a atracação se dá ao acaso, uma vez que os "esporos" não tem capacidade de se direcionar a um substrato adequado para desenvolvimento da espécie. A presença de filamentos de S.leibleinii próximo à foz do igarapé não necessariamente sugere que a água do igarapé seja favorável ao desenvolvimento da espécie, uma vez que na ocasião o local se encontrava inundado pelas águas do rio Negro.

O grande volume de água do rio Negro não tem sido suficiente para diluir a carga de esgotos que está entrando por meio dos igarapés urbanos, conforme demostraram tanto a análise da água quanto a presença constante de filamentos de Schizomeris leibleinii na área de inundação do rio Negro próximo à sua foz (bem como em sua área de influência próximo à foz dos igarapés São Raimundo e Educandos). Embora essa macroalga que só tenha sido observada durante o período águas altas (cheia e início da vazante) tanto na foz do rio quanto no centro da cidade, ela indica que houve aumento de nutrientes (geralmente nitrogênio e fósforo, mas também metais como sódio, potássio, etc.). Embora essa macroalga não seja nociva à saúde humana ela serve de alerta, pois em geral nessas condições também há a presença 
de cianobactérias, as quais poderão se proliferar caso aumente o aporte de efluentes orgânicos no canal do rio. A presença dessa alga em vários locais de influência do rio Negro também sugere que ela seja melhor investigada nessa bacia hidrográfica, a fim de se aumentar o conhecimento ecológico sobre a espécie e determinar se ela pode ser um bioindicador adequado para a região.

O rio Negro é um dos cinco rios mais volumosos da bacia Amazônica, entretanto as características de suas águas, sobretudo a acidez e variáveis correlatas, tornam suas águas extremamente frágeis, o que limita sua capacidade de autodepuração e de diluição dos solutos que entram em seu leito sobretudo devido ao aporte de seus tributários. Por essa razão é de fundamental importância que os órgãos de gestão encontrem mecanismos para que a água dos igarapés seja tratada (tratamento efetivo, não apenas um prétratamento) antes de serem lançadas no principal recurso hídrico da cidade.

\section{AGRADECIMENTOS}

À FAPEAM, ao CNPq e ao MCTI/INPA pelo suporte financeiro. Ao Dr. Luiz Zanini Branco pela identificação das cianobactérias. Aos técnicos do LQA pelas análises das amostras de água e a Andrea Clara de Guadalupe Gomes de Leiros, Soraya Rondon Pirangy e Walter Jorge do Nascimento Filho pelo apoio em campo.

\section{OBRAS CITADAS}

[1] ALCÂNTARA, J.M.; MARQUES FILHO, A.O. CLIMA HIDROLOGIA DA ÁREA URBANA DE MANAUS. XII Jornada de Iniciação Científica do PIBIC/INPA/CNPq. 2003.

[2] ANDRADE, A.O. Migração para Manaus e seus reflexos socioambientais. Somanlu, ano 12, n. 2, jul./dez. 2012 , pp. 85-102.

[3] APHA - American Public Health Association; WWA - American Water Work Association; WOCF - Water Pollution Control Federation. Standard methods for the examination of water and wastewater. Washington, American Public Health Association, 21 ${ }^{\text {st }}$ edition. CD-rom. 2005.

[4] BRINGEL, S. R. B. ; PASCOALOTO, D. 2012. As águas transfronteiriças do rio negro. In: Souza, L.A.G.; CASTELLÓN, E.G. (ORG.). Desvendando as fronteiras do conhecimento na região amazônica do Alto Rio Negro. 1.ed. Manaus: INPA, p. 7-22.

[5] CABRAL, F.N.; CUNHA, H.B. 2004. Avaliação das variáveis químicas e da colimetria em igarapés nas bacias do São Raimundo, Educandos e Tarumã. XIII Jornada de Iniciação Científica do PIBIC/INPA/CNPq.

[6] ChaVeS, E. V. ; SAnTANA, G. P. . Comportamento dos Metais Pesados Cd, Co, Cr, Cu, Fe, Mn, Ni, Pb e Zn em Solos Contaminados do Aterro Sanitário e Pólo Industrial de Manaus. Revista Brasileira de Educação Profissional e Tecnológica, v. 1, p. 8-17, 2010.

[7] CUNHA, H. 2006. Elaboração de índices de qualidade da água no município de Manaus (AM). Manaus: FAPEAM. Relatório Final de Projeto (Modalidade PIPT), 96 p.

[8] FONSECA, O.P.M.; SALEM, J.L. e GUARIM, V.L. Poluição e autopurificação do rio Negro nas cercanias de Manaus. Acta Amazônica, vl.12, n. 2, pp 271-278, 1982.

[9] FRANKEN, W.K. Recursos Hídricos de Manaus: identificação e controle da poluição. Manaus: CNPq. 2004. Relatório Final de Projeto (Modalidade PNOPG), 78 p.

[10] GOLTERMAN, H.L., CLYMO, R.S., OHSNTAD, M.A.M. Methods for chemical analysis of fresh waters. Boston: Blackwell, 1978 (IBP handbook, 8).

[11] INSTITUTO BRASILEIRO DE GEOGRAFIA E ESTATÍSTICA - IBGE. (2011). Censo Demográfico 2010 - Sinopse do Censo e Resultados Preliminares do Universo. IBGE, Rio de Janeiro, 36p.

[12] JOHANSON, C. Attached algal vegetation in running waters of Jämtland, Sweden. Acta Phytogeographyca Suecica, vl. 71, pp 1-83, 1982.

[13] MELO, E.G.F.; SILVA, M. S. R. ; MIRANDA, S.F. (2005). Influência Antrópica sobre águas de Igarapés na Cidade de Manaus-Amazonas. Caminhos da Geografia: 5 (16): 40-47, 2005

[14] NOGUEIRA, A.C.F.; SANSON, F.; PESSOA, K. 2007. A expansão urbana e demográfica da cidade de Manaus e seus impactos ambientais. In: Anais XIII Simpósio Brasileiro de Sensoriamento Remoto. INPE, Florianópolis, p. 54275434.

[15] PASCOALOTO, D. ; SILVA, M. S. R. ; PINTO, A.G.N.; GONCALVES, T. J. ; LINS, V. K. C. ; LINS, J. F. ; SILVA, R. K. B. ; TAKANO, E.E.A. 2009. Macroalgas e qualidade da água em três comunidades ribeirinhas na bacia do Tarumã-Mirim, Manaus (AM). Caminhos de Geografia (UFU. Online), vl. 10, pp 135-143. 
[16] PASCOALOTO, D. Comunidades de macroalgas de igarapés de terra firme nas regiões de Manaus, Rio preto da Eva e Presidente Figueiredo, estado do Amazonas: composição, sazonalidade e distribuição. (Relatório Final). Manaus: CNPq, 2001, 24p.

[17] PASCOALOTO, D. 1999. Sazonalidade e distribuição de macroalgas em igarapés de terra firme em áreas de reserva florestal nas cercanias de Manaus, Estado do Amazonas. Instituto Nacional de Pesquisas da Amazônia (INPA)/Fundação Universidade do Amazonas (FUA). Tese (Doutorado). 231 p.

[18] PASCOALOTO, D.; BRINGEL, S.B. (2010). "Macroalgas e qualidade da água na bacia do rio Negro, município de São Gabriel da Cachoeira (AM)". Caminhos de Geografia 11, pp. 318-33

[19] PASCOALOTO, D.; PINTO, A.G.N.; TAKANO, E.E.A. 2008. Características físicas e comunidades de macroalgas em um igarapé de terra firme na reserva florestal Adolpho Ducke (MANAUS/AM).. Caminhos da Geografia (UFU. Online), vl. 9, pp 108-114.

[20] PASCOALOTO, D.; SOARES, C.C.; SILVA, J.C.; FREITAS,R.C. 2004. Macroalgas e fitoplâncton de igarapés com diferentes tipos de impactos ambientais em Manaus (AM).. In: VII Simpósio de Recursos Hídricos do Nordeste, 2004, São Luís. CD do VII Simpósio de Recursos Hídricos do Nordeste. São Luís: ABRH,

[21] PASCOALOTO, D.; SOARES, C.C.; SILVA, M.S.R. (2014). Oficina “Águas da Amazônia”: levando aos estudantes dos ensinos fundamental e médio informações sobre os ecossistemas aquáticos da região amazônica. In: Caderno Eletrônico de Anais do 1을 Workshop Ocas do Conhecimento: socializando saberes na construção de espaços ambientais sustentáveis. Manaus, SEMED, pp. 39-43.

[22] PINTO, AGN.; HORBE, A.M.C.; SILVA, M.S.R.; MIRANDA, S.A.F.; PASCOALOTO, D.; SANTOS, H.M.C 2009. Efeitos da ação antrópica sobre a hidrogeoquímica do rio Negro na orla de Manaus/AM. Acta Amazônica, v. 39, n. 3, pp 627 638.

[23] SANTANA, G. (2006). "Estudo de metais pesados na região do Distrito Industrial de Manaus (AM)" in Anais eletrônicos da 29a Reunião Anual da Sociedade Brasileira de Química, Águas de Lindóia-SP, Maio 2006, p.1.

[24] SANTANA, G. P. 2016. Heavy metal distribution in the sediment and Hoplosternum littorale from Manaus Industrial District. Journal of Chemical Engineering and Chemistry, v. 2, p. 73-87.

[25] SILVA, J.C.; PASCOALOTO, D.P.; SILVA, M.S.R.. (2004). Seleção de Espécies de Macroalgas para Elaboração de Índice de Proteção à Vida Aquática (IVA) na Região de Manaus/AM. In Anais da XIII Jornada de Iniciação Científica do INPA. CNPq/FAPEAM/INPA, Manaus - AM, Jul 2004, pp. 33-34.

[26] SILVA. A.D.G.; PASCOALOTO, D.; SOARES, C.C. 2005. Macroalgas e fitoplâncton do igarapé Bindá. Relatório final de estágio. Manaus, INPA, 12p.

[27] SILVA, M. S. R. ; RAMOS, J. F. ; PINTO, A. G. N. (1999). "Metais de Transição nos sedimentos de igarapés de Manaus-AM". Acta Limnologica Brasiliensia, 11(2), pp. 89-100.

[28] SILVA, M.B. (2010). Análise dos níveis de metais potencialmente tóxicos e análise microbiológica nas águas da bacia do Educandos (Manaus - AM). Dissertação. MBT Manaus - AM, 100p. 


\title{
Capítulo 6
}

\section{Alterações em tratamentos do tipo lagoa estabilizada devido à influência de chuvas}

\author{
Diogo Botelho Correa de Oliveira \\ Marco Aurélio Calixto Ribeiro de Holanda \\ Camila Barrêtto Rique de Barros \\ Ariela Rocha Cavalcanti \\ Willames de Albuquerque Soares
}

Resumo: 0 manejo correto das águas de origem pluvial é de grande relevância para o bom funcionamento de diversas atividades antrópicas. Quando há direcionamentos indevidos das águas das chuvas para canalizações como a de coleta de esgoto, diversas alterações são identificadas nas estações de tratamento de esgotos. 0 presente estudo avaliou 4 ETE's do tipo lagoa de estabilização, comparando seus desempenhos em períodos secos e chuvosos. Identificou-se que a vazão de entrada pode ser incrementada de 21 a 166\% em relação aos dias sem precipitações. Em relação a eficiência do tratamento, utilizou-se intervalo de confiança entre os dois grupos amostrais, identificando que as estações de médio porte, ou de efluentes de origem industrial, essa contribuição pluvial é benéfica, aumentando a eficiência do tratamento do afluente em até 9\%. Já nas de pequeno porte, não foram identificadas diferenças significativas que interfiram nos seus desempenhos.

Palavras-Chave: tratamento de efluentes, lagoas de Estabilização, sistema separador absoluto, influência da pluviometria. 


\section{INTRODUÇÃO}

Dentro das principais necessidades antrópicas de gerir os processos da água no meio urbano, destaca-se o manejo das pluviais dentro do espaço urbano. Com o avanço da urbanização e consequente impermeabilização de camadas drenantes do solo, necessita-se ampliar e expandir os sistemas de infraestrutura destinados a coletar e transportar os diversos tipos de fluídos gerados por esse crescimento (Holanda e Soares, 2019; Tucci, 2007).

As galerias de águas pluviais (GAP) podem ser classificadas e dimensionadas quanto a sua interação, ou não, com o sistema de coleta de esgoto. Existem alguns fatores que influenciam a sua concepção e projeto, como a posição geográfica do local de demanda e sua situação econômica. A partir disso os sistemas podem ser classificados: combinados, separadores mistos e separadores absolutos. 0 sistema combinado tem melhor desempenho em regiões subtropicais e de alto poder econômico, onde todos os lançamentos de águas residuais pluviais são direcionados para as redes de esgoto, devido ao menor volume de chuva incidente. Já em áreas tropicais, onde os índices pluviométricos são mais significativos e existe limitação ou redirecionamento de recursos financeiros à infraestrutura, pode-se utilizar os sistemas separadores mistos (ou parciais) ou separadores absolutos (Menezes et al, 2018; Ribeiro e Peixoto, 2018; Jamwal et al, 2015).

No Brasil é utilizado na grande maioria das situações o separador absoluto. Apesar disso, existem diversas interferências e comunicações entre o sistema de GAP e coleta de esgotos, causando prejuízo para ambos. No primeiro, o esgoto é conduzido pelos condutos e despejado diretamente nos corpos receptores sem nenhum tipo de tratamento adequado, enquanto que para o segundo a contribuição acarreta na sobrecarga das tubulações de esgoto, estações elevatórias e de tratamento e no custo operacional de manutenção, além de interferir diretamente no desempenho do tratamento afluente (Oliveira et al, 2020; Vieira et al, 2016).

Apesar de não alterar a eficiência do tratamento (remoção de carga orgânica) em sistemas de tratamentos mais avançados (como o de lodos ativados), em períodos de chuva é notório o aumento dos custos operacionais e de manutenção, além da redução do tempo de detenção do esgoto no tratamento (Oliveira et al, 2020; Saliba e Sperling, 2017; Mines et al, 2007).

Poucos estudos abordam essa interferência, quantitativamente, em processos de tratamento mais simples, como os de lagoas de estabilização (Tonetti et al, 2012). A partir disso, o estudo visa analisar as alterações identificadas na eficiência de tratamento de 4 ETE's pertencentes ao Sistema de Esgotamento Sanitário da Região Metropolitana do Recife.

\section{METODOLOGIA}

Foram analisadas quatro estações de tratamento de esgotos compreendidas dentro da Região Metropolitana do Recife (RMR), sendo elas ETEJ-05 (Igarassu), ETES-13 (Moreno), ETES-15 (Multifabril) e ETE NSÓ (Nossa Senhora do Ó), as quais utilizam o sistema de lagoas de estabilização (anaeróbias e/ou facultativas). Foram realizadas comparações de 2 parâmetros do efluente: vazão de entrada e eficiência do tratamento entre dias considerados secos (DS) e chuvosos (DC).

A distinção entre os DS e DC foi sistematizada de acordo com a pluviometria diária da bacia de contribuição de cada ETE, onde precipitações superiores a $10 \mathrm{~mm}$ foram consideradas significantes, pois influenciam diretamente em diversos setores relevantes como os sistemas de drenagem, recarga de barragens e lençol freático, tráfego e coleta de esgotos (Souza et al. (2015).

Os dados de chuva foram disponibilizados pela APAC (Agência Pernambucana de Águas e Clima), onde os postos pluviométricos (PP) foram associados de acordo com a proximidade à bacia de coleta da estação e pela disponibilidade dos dados, pois não são todos os PP's que possuem os dados de chuvas referentes a todo o período estudado. Na Figura 1 é possível visualizar as estações (marcador rosa, destacado na área em vermelho) e os PP's (marcador azul, destacado na área em azul), além da distância linear entre eles.

O período de estudo foi de janeiro de 2015 a dezembro de 2018, onde foi realizado um ensaio mensal para verificação de atendimento às normas e análise do efluente, sendo as coletas e testes realizados pela COMPESA e fornecidos através do pedido de acesso à informação no 201919324. A DBO foi aferida através de um medidor Oxitop, através de ensaio padrão (APHA, 2012), a DQO pela oxidação do esgoto em solução de Dicromato de potássio com auxílio de um espectrofotômetro (HACH DR/3900) para leitura. A temperatura e o pH são registrados diretamente nos pontos de coleta das ETE's através de aparelho específico (Thermo Scientific Orion Star A221). Os dados de vazão, quando existentes, foram coletados por meio de sensor eletromagnético instalado em calha Parshall. A eficiência do tratamento depende 
diretamente dos resultados da DBO, sendo o indicador de maior importância para os órgãos ambientais a nível federal (CONAMA) e estadual (CPRH).

Para verificar se existem diferenças significativas entre as eficiências no tratamento de efluentes entre os dias com e sem chuva, utilizou-se os intervalos de confiança entre as duas amostras (DS e DC), com nível de 90\% de significância (um-sigma), já que a incidência de dias chuvosos não é bastante recorrente nos dias de coleta, podendo variar de 3 a 8 dias (Montgomery e Runger, 2012).

Figura 1 - ETE's (Vermelho) e Postos Pluviométricos (azul) e suas respectivas distâncias: ETEJ-05 (a), ETES-13 (b), ETES-15 (c), ETE NSÓ (d).
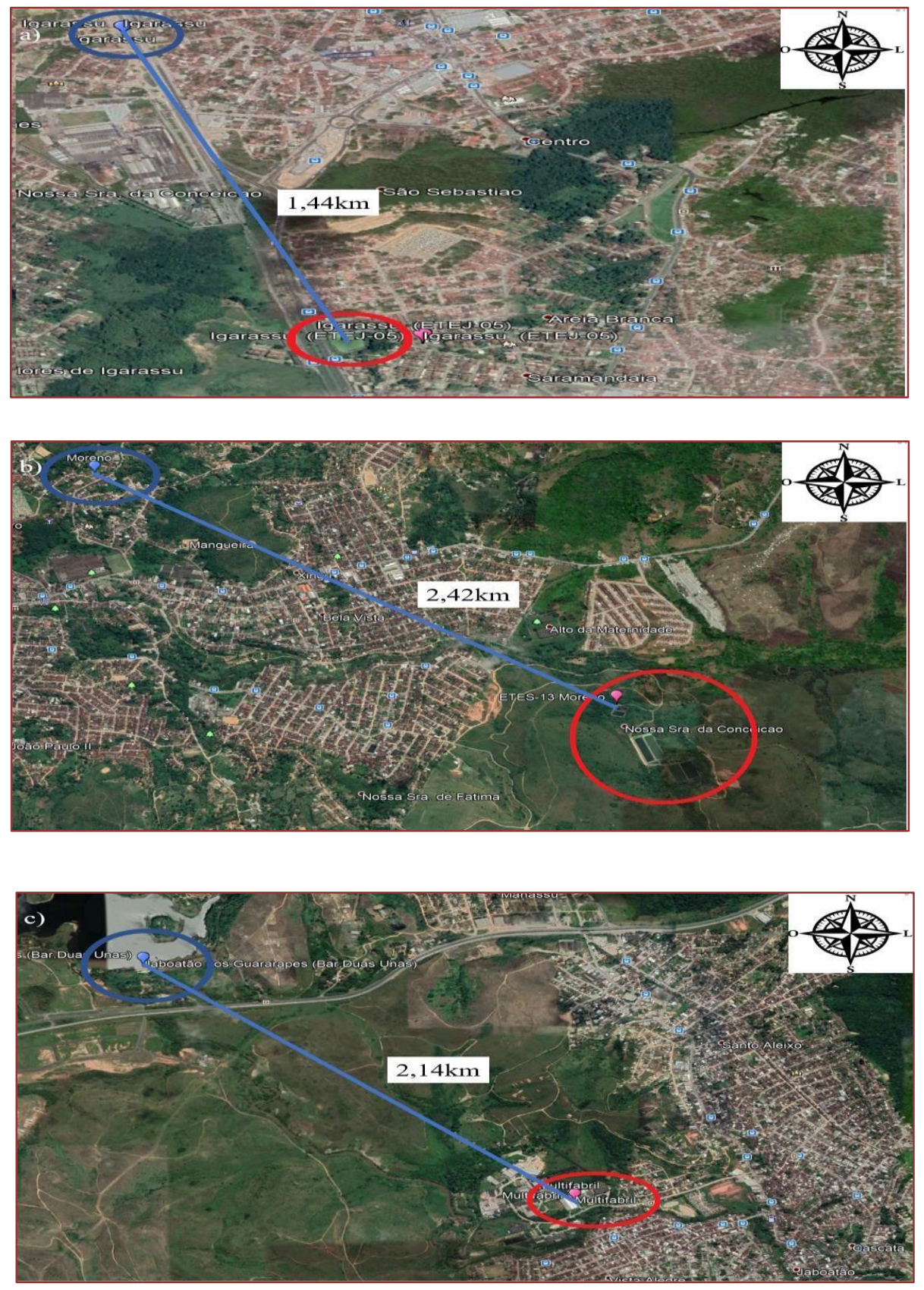


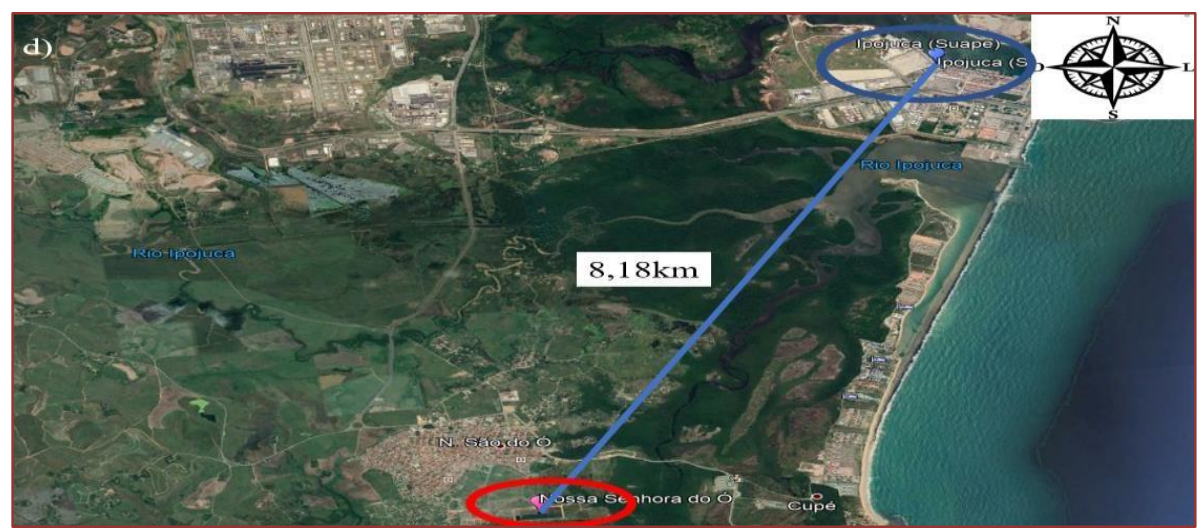

As ETE’s possuem características específicas em relação à vazão de projeto, nível e distribuição das lagoas, demanda atendida, rede de coleta, conservação estrutural e posto pluviométrico (Tabela 1).

Dentre as demais particularidades de cada estação, destacam-se: o medidor de vazão da ETEJ- 05, que se encontra na saída da lagoa, pois sua entrada é afogada, impossibilitando sua instalação à montante; na ETES-15, devido à origem do afluente ser industrial, as concentrações de carga orgânica são bastante superiores às demais.

A ETE NSÓ possui projeto com vazão bastante superior, sendo formada por bacias coletoras que possuem sistema de recalque composto por 4 estações elevatórias de esgotos, induzindo à maior contribuição em dias chuvosos quando os sistemas de bombeamento estiverem em uso.

Tabela 1 - Características das ETE's.

\begin{tabular}{|c|c|c|c|c|}
\hline & ETEJ-05 & ETES-13 & ETES-15 & ETE NSÓ \\
\hline Vazão de Projeto (L/s) & 3,10 & 3,50 & 4,79 & 64,00 \\
\hline Lagoa Anaeróbia & N/A & 2 & 1 & 2 \\
\hline Lagoa Facultativa & 1 & 4 & 3 & 2 \\
\hline Afluentes & Doméstico & Doméstico & Industrial & $\begin{array}{c}\text { Doméstico/ } \\
\text { industrial }\end{array}$ \\
\hline Pluviômetro & Igarassu & Moreno & Jaboatão (Barragem duas unas) & Ipojuca (Suape) \\
\hline Classe & Primário & Secundário & Secundário & Secundário \\
\hline
\end{tabular}

\section{RESULTADOS E DISCUSSÃO}

0 primeiro indicador a ser avaliado quanto às alterações devido à entrada de águas pluviais no sistema de coleta de esgotos é a vazão de entrada das ETE's (Figura 2). Como o registro desses dados depende da instalação de uma calha parshall e medidor de vazão eletromagnético (MVE), os períodos disponíveis são particulares para cada uma, onde as ETEJ-05 e ETES-15 registram desde março de 2016, a ETE NSÓ agosto de 2016 e ETES-13 janeiro de 2018.

Como a ETEJ-05 possui o MVE instalado na saída do tratamento, não foram registrados aumentos significativos de vazão em dias chuvosos, resultando em médias para dias secos superiores aos chuvosos. Para as demais estações, os DC apresentaram incremento de 21,5\% (NSÓ), 29,1\% (ETES-15) e 166,7\% (ETES-13) em relação aos DS. 
Figura 2 - Histórico de vazões, suas médias em dias secos e chuvosos e pluviometria para as ETE’s.
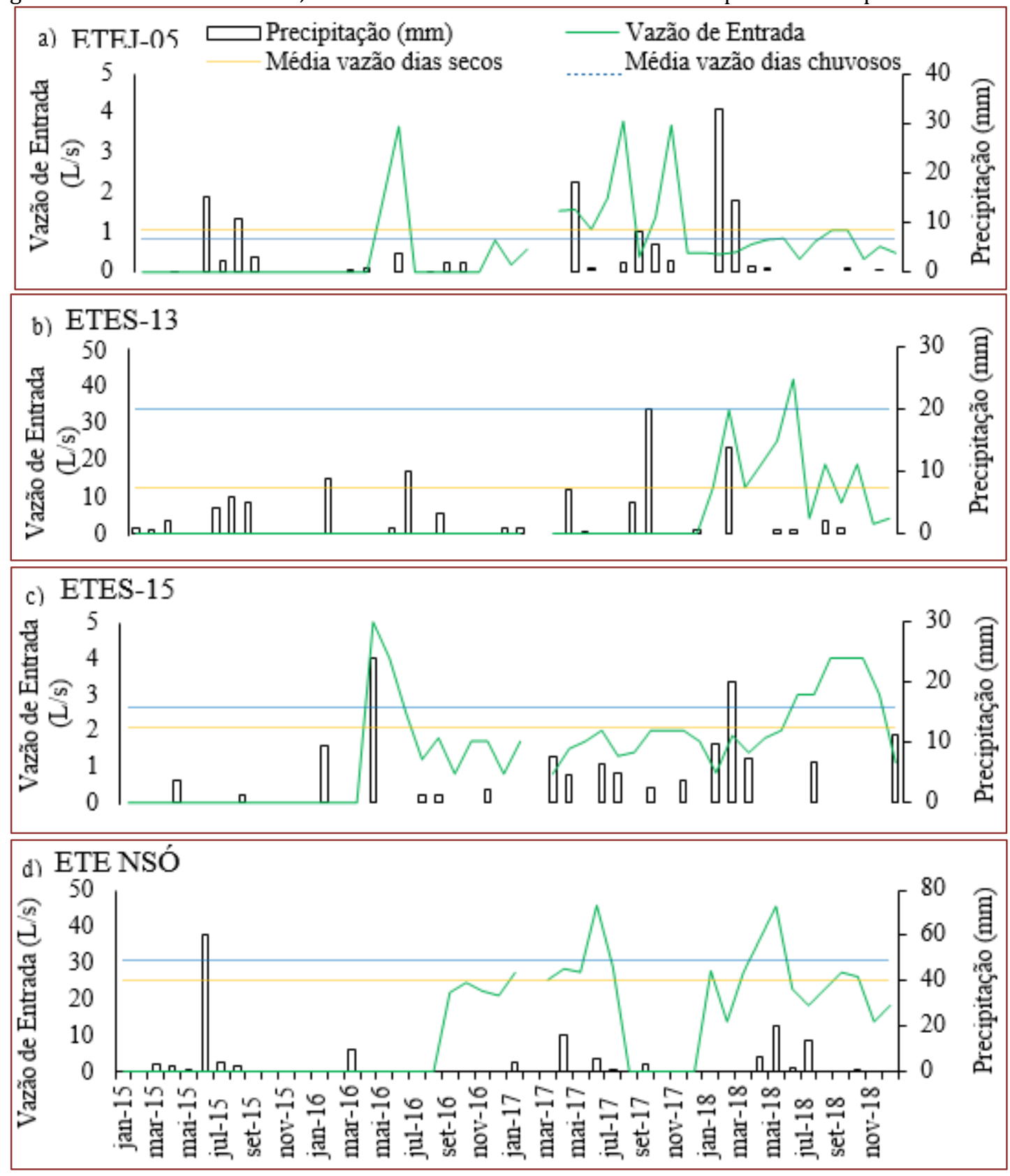

0 aumento expressivo da vazão de entrada na ETES-13, em relação às demais, justifica-se devido à pouca quantidade de registros dos dados, onde 11 ocorreram em DS e 1 em DC. Com relação às vazões médias, ela opera em $354 \%$ da sua capacidade em DS. As demais estações funcionam em vazões médias abaixo do projetado, variando de $27 \%$ a $76 \%$ da sua capacidade total.

A eficiência do tratamento das estações apresentou poucas flutuações (Figura 3), variando de 80\% a 97\% de remoção de carga orgânica ao longo do período de estudo (destaque apenas para o evento em maio de 2016, onde NSÓ atingiu 68\%), com exceção da ETES-15, que apresentou desempenho crítico no ano de 2015, permeou de 60 a 80\% em diversas ocasiões de 2016 a 2017 e sendo regularizada no ano de 2018, onde aumenta sua operação para valores superiores a $84 \%$ em todo o ano.

Com relação às médias de eficiência de tratamento (Tabela 2), para a ETEJ-05 e a ETES-13, que são estações de pequeno porte e esgotos domésticos, as médias em dias secos foram superiores aos dias chuvosos, reduzindo em 1,1\% e 3\%, respectivamente, esse indicador. A ETE NSÓ apresentou leve melhora no seu tratamento nos DC, incrementando em 1,6\% a sua eficiência, obtendo médias superiores a $90 \%$ de remoção de carga orgânica. 
Na ETES-15, que é uma estação de afluentes de maior parte de origem industrial, a média de eficiência de tratamento foi superior para dias chuvosos em relação aos dias secos em 8,9\%. Isto ocorreu devido às altas concentrações de DBO de entrada. Enquanto nas demais a DBO média de entrada varia de 400 a $560 \mathrm{mg} \mathrm{02/L}$, a média dessa estação é de $1551 \mathrm{mg} \mathrm{02/L,} \mathrm{podendo} \mathrm{chegar} \mathrm{a} \mathrm{mais} \mathrm{de} 10.000 \mathrm{mg}$ 02/L. Esse registro em particular também foi o dia com maior vazão de entrada e precipitação (abril, 2016). 0 grande aumento das concentrações pode ter sido causado pelo arrasto de material excedente nos coletores e no ambiente externo, reforçado pelo incremento das águas pluviais. Destaca-se que o período de 2015 não foi considerado para esta análise, já que o histórico mostra problemas na sua operação devido aos baixos indicadores atingidos.

O intervalo de confiança (Figura 4) apresentou comportamentos distintos para cada situação neste tipo de tratamento (lagoas de estabilização). A ETEJ-05 e a ETES-13 são de pequeno porte, mas com vazões médias bastante diferentes entre si, onde a primeira possui vazão de projeto de 3,10 L/s e a segunda de 3,5 L/s. As vazões apresentadas pela ETES-13 se mostraram bastante superiores a qual foi projetada, apesar de não mostrar problemas operacionais em relação a isso. As duas ETE's não apresentaram diferenças significativas entre os dias com e sem chuva, apesar do intervalo de DC da ETES-13 se mostrar abrangente, indicando grandes oscilações destes dados, já que dependem diretamente dos índices pluviométricos incidentes.

Figura 3 - Histórico de eficiência de tratamento e suas respectivas médias em dias chuvosos e secos para as ETE's.

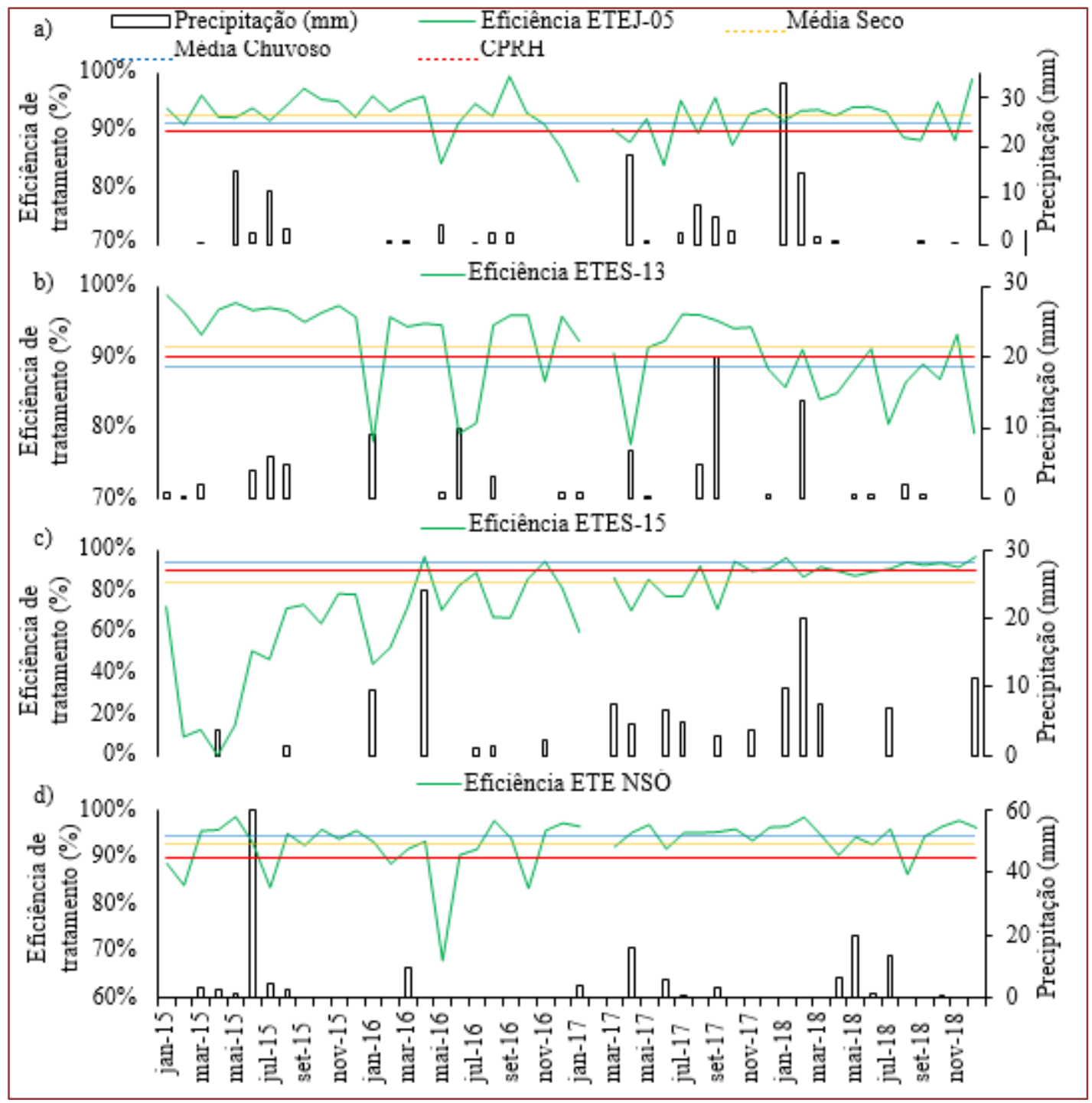


Para a ETES-15 houve diferenças significativas, já que seu desempenho é consideravelmente superior nos dias chuvosos em comparação aos secos. Na ETE NSÓ as diferenças entre os DS e DC também foi significante pelo intervalo de confiança, apesar das médias de eficiências de tratamento serem bastante próximas (Tabela 2). Nas duas ETE's que as diferenças de tratamento foram significativas, houve incremento da eficiência nos dias chuvosos. Na ETE NSÓ essa melhoria é de forma sensível (1,6\%), e na ETES-15 é de forma mais expressiva $(8,9 \%)$.

Figura 4 - Intervalo de Confiança para eficiência do tratamento das ETE's.

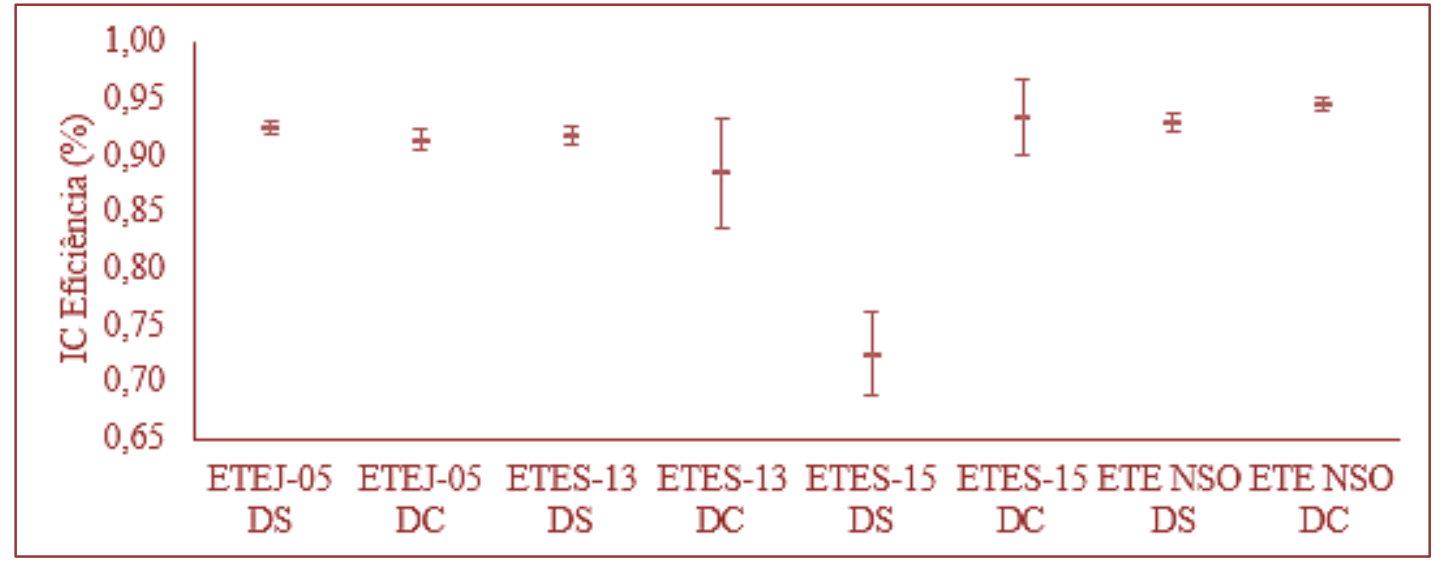

Tabela 2 - Resumo dos indicadores médios e significância do intervalo de confiança para as ETE's.

\begin{tabular}{|c|c|c|c|c|c|}
\hline ETE & Média vazão DS (L/s) Média vazão DC (L/s) Média eficiência DS (\%) Média eficiência DC (\%) & IC \\
\hline ETEJ-05 & 1,06 & 0,84 & 92,5 & 91,4 & NS \\
\hline ETES 13 & 12,42 & 33,13 & 91,6 & 88,6 & NS \\
\hline ETES-15 & 2,06 & 2,66 & 84,5 & 93,4 & S \\
\hline ETE NSÓ & 25,26 & 30,69 & 93,0 & 94,6 & S \\
\hline
\end{tabular}

\section{CONCLUSÕES}

As lagoas de estabilização se mostraram com comportamentos diferentes entre si. Para tratamento de esgotos de origem industrial, as diferenças são significativas e a chuva auxilia no desempenho dela. 0 mesmo acontece em unidades que possuam bacia mais complexa, composta por sistemas de recalque, apesar do baixo incremento de eficiência (1,6\%). Nas demais lagoas, que são de pequeno porte e de tratamento de esgotos domésticos, as chuvas se mostraram insuficientes em prejudicar o desempenho dessas ETE's. Isto ocorre devido contribuição externa de águas pluviais serem em menor escala, devido à extensão da rede coletora.

\section{AGRADECIMENTOS}

Os autores agradecem ao Programa de Pós-graduação em Engenharia Civil (PEC) da Escola Politécnica de Pernambuco (POLI-UPE) pelo apoio.

\section{REFERÊNCIAS}

[1] APAC, Agência Pernambucana de Águas e Clima, 2019. Disponível em: http://www.apac.pe.gov.br/meteorologia/monitoramento-pluvio.php. Acesso em: 31 maio 2019.

[2] APHA (2012). Standart Methods for the examination of water and wastewater. American Public Health Association, American Water Works Association, Water Environmental Federation, 22 ${ }^{\circ}$ ed., Pharmabooks, 1496p.

[3] HOLANDA, M. A. C. R.; SOARES, W. A. (2019). "Analysis of the effect of impermeability of urban soils on the infiltration of Rainwater in the city of Recife, PE”, Revista Ambiente e Água, 14 (4), pp. 1-10.

[4] JAMWAL, P.; ZUHAIL, T. M. D.; URS, P. R.; SRINIVASAN, V.; LELE, S. (2015)."Contribution of sewage treatment to pollution abatement of urban streams". Current Science, 108 (4), pp. 677-685. 
[5] MENEZES, A. M.; SODRÉ, M. A. C.; MACIEL, T. S.; ABREU, M. S. D.; SOUZA, G. H.;

[6] SILVA, J. M. A. (2018). "Impactos negativos em obras do sistema sanitário do bairro do Bessa, João Pessoa-PB". Revista campo do saber, 4 (4), pp. 133-145.

[7] MINES, R. O.; LACKEY, L. W.; BEHREND, G. R. (2007). "The impact of rainfall on flows and loadings at Georgia's wastewater treatment plants". Water, Air, and Soil Pollution, Berna, 179 (1), pp. 135-157.

[8] MONTGOMERY, D. C.; RUNGER, G. C (2012). Estatística aplicada e probabilidade para Engenheiros, $5^{\circ}$ edição, Rio de Janeiro, 548p.

[9] OLIVEIRA, D. B. C.; SOARES, W. A.; HOLANDA, M. A. C. R. (2020). "Effects of Rainwater intrusion on an activated sludge sewer treatment system". Revista Ambiente e Água, 15 (3), pp. 1- 12.

[10] RIBEIRO, V. O.; PEIXOTO, M. S. (2018). “Avaliação da contribuição pluvial parasitária no sistema de esgotamento sanitário efluente à ETE Guaxinim, Dourado/MS". Revista de engenharia e tecnologia, 10 (3), pp. 144-155.

[11] SALIBA, P. D.; SPERLING, M. (2017). "Performance evaluation of a large sewage treatment plant in Brazil, consisting of a UASB reactor followed by activated sludge”. Water Science \& Tecnology, 76 (8), pp. 2003-2014.

[12] SOUZA, J. O. P.; ALMEIDA, J. D. M.; CORREA, A. C. B. (2015). “Caracterização e Espacialização da precipitação em bacia hidrográfica com relevo complexo: sertão central pernambucano - Bacia do Riacho do Saco". Revista de Geografia, 32 (2), pp. 106-126.

[13] TONETTI, A. L.; CORAUCCI FILHO, B.; NICOLAU, C. E.; BARBOSA, M.; TONON, D.(2012). “Tratamento de esgoto e produção de água de reuso com emprego de filtros de areia". Revista de Engenharia Sanitária e Ambiental, 17 (3), pp. 287-294.

[14] TUCCI, C. E. M. (2014). Hidrologia: ciência e aplicação. UFRGS/ABRH, $4^{\circ}$ ed., 944p.

[15] VIEIRA, B. F.; SILICIANO, B. G.; NETO, N. C.; GOULART, R. M. (2016). "Impacto da intrusão de águas pluviais na vazão e na qualidade do esgoto tratado". In Anais of XIV Internacional conference on engineering and technology education, Salvador, 2016, pp. 1-6. 


\section{Capítulo 7}

Viabilidade econômica de um sistema de aproveitamento de água pluvial em condomínio do Programa Minha Casa Minha Vida, Rio de Janeiro

\section{Diego Sebastian Carvalho de Souza \\ Celso Romanel}

Ricardo de Freitas Cabral

Resumo: A pesquisa analisou a possibilidade da implantação de um sistema de aproveitamento de água pluvial em condomínio do Programa Minha Casa Minha Vida (PMCMV), já construído, na cidade do Rio de Janeiro. Como métrica foram utilizados os seguintes indicadores de viabilidade econômica: valor presente (VP), valor presente líquido (VPL), taxa interna de retorno (TIR), índice de lucratividade (IL) e o payback simples. Justifica-se esta pesquisa pelo valor estratégico da água e a sua importância para manutenção da vida e das atividades que estruturam a sociedade. No Brasil, desde 2014 vários centros urbanos que não possuíam histórico de seca passaram a enfrentá-la. Este fenômeno, de origem climática, é acentuado pela má gestão de recursos hídricos. $\mathrm{Na}$ cidade do Rio de Janeiro, a crise de água teve forte impacto no abastecimento, pois a maior parte da cidade é abastecida por uma única fonte, o Rio Guandu. Entretanto, a prefeitura municipal decidiu isentar os condomínios PMCMV da obrigatoriedade de aproveitar a água de chuva, modificando o Decreto 23940/2004, cujo o objetivo era fazer com que novas edificações aproveitassem este recurso. Com a implantação dos sistemas propostos na presente pesquisa espera-se redução do consumo da água tratada e a consequente diminuição da conta de água nos condomínios. Os principais resultados obtidos foram a redução de 3,6\% no consumo de água tratada do condomínio e a viabilidade econômica demonstrada (VLP) foi de R\$14.258,04.

Palavras-chave: Chuva; Economia; Indicadores. 


\section{INTRODUÇÃO}

A Organização das Nações Unidas - ONU (2018) estima a demanda mundial de água em torno de 4.600 $\mathrm{km}^{3}$ /ano, com perspectiva de aumento anual entre $20 \%$ a $30 \%$ até 2050 . A preservação e utilização eficiente dos recursos hídricos deve ser prioridade para manter a sustentabilidade da vida no planeta. A sociedade deve utilizar fontes alternativas de água para manter o ecossistema equilibrado e evitar a escassez deste importante recurso. 0 aproveitamento das águas pluviais em condomínios residenciais pode ser uma alternativa viável para redução do consumo de água potável, pois o uso doméstico corresponde a $10 \%$ da água tratada em todo mundo.

Com a implantação de sistemas de aproveitamento de águas pluviais, além de diminuir a demanda de água nos mananciais e os gastos com contas do fornecimento de água potável, ainda há possibilidade da redução da vazão das cheias, contribuindo para melhorar a gestão por parte do poder público.

No Brasil, a norma técnica que parametriza esses sistemas é a NBR 15527 (água da chuva aproveitamento de cobertura em áreas urbanas para fins não potáveis - requisitos), publicada pela ABNT Associação Brasileira de Normas Técnicas, em 2007 e revisada 2019. Consiste em uma série de requisitos sobre equipamentos, parâmetros de vazão e inclinação de telhados. Como são sistemas que dependem diretamente das condições hidrológicas e climatológicas regionais, não podem substituir a totalidade do abastecimento de água.

A água pluvial pode ser aproveitada para descargas em vasos sanitários, irrigação de gramados e plantas ornamentais, lavagem de veículos, limpeza de calçadas, ruas e pátios. Seu uso requer parâmetros mínimos de qualidade, recomenda-se descartar os primeiros $2 \mathrm{~mm} / \mathrm{m}^{2}$ de chuva devido à presença de poluentes da atmosfera. Sistemas de aproveitamento de águas pluviais deveriam ter implementação estimulada em obras públicas como o PMCMV.

Entretanto, não é isso que ocorre na cidade do Rio de Janeiro, pois o Decreto Municipal n 23.940, que definia a obrigatoriedade de um sistema de aproveitamento de água de chuva para novas edificações multifamiliares, foi alterado pelo Decreto Municipal $n^{\circ} 26168 / 06$, isentando os empreendimentos do PMCMV da obrigatoriedade da construção de reservatórios de retardo e captação de águas pluviais.

Esta pesquisa teve como objetivo analisar a viabilidade econômico da implantação de um sistema de aproveitamento de água de chuva no condomínio Park Riviera da Costa.

\section{METODOLOGIA}

Para Pertel (2020) o princípio do sistema de aproveitamento de água de chuva deve ser associado ao conceito de saneamento ecológico. Pelas suas características de individualização e interdependência, trata-se de um sistema de abastecimento centralizado.

Segundo Tomaz (2018), a análise da viabilidade de um projeto de aproveitamento de água de chuva deve se pautar na redução da demanda de água e no valor economizado pelo condomínio. Para tal, faz-se necessário conhecer as características das edificações e da população residente, visando à elaboração de orçamentos para basear estudos de viabilidade econômica.

A pesquisa utilizou-se de um estudo de caso o Condomínio Park Riviera da Costa, que é um conjunto de edifícios residenciais com 218 apartamentos, localizado no bairro de Campo Grande, o mais populoso da cidade do Rio de Janeiro. Como pode ser visto pela Figura 1. 
Figura 1- Localização do Park Riviera Costa.

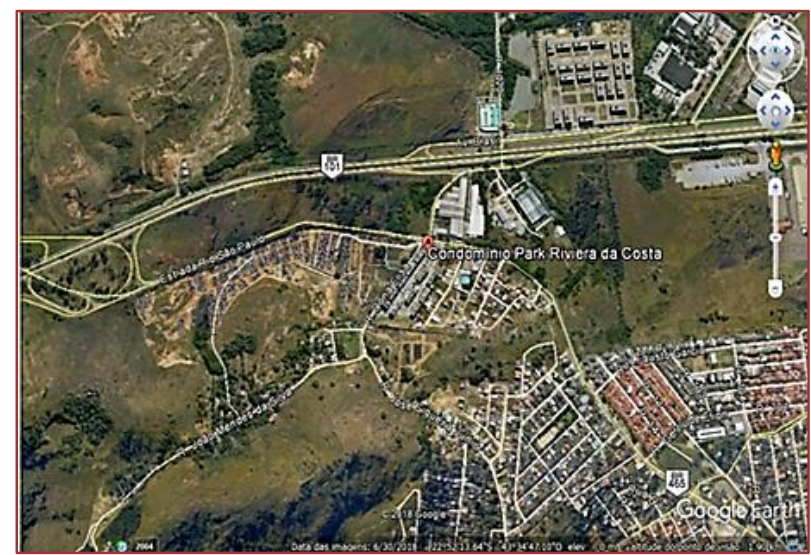

Fonte:https://www.google.com.br/maps/place/Condom\%C3\%ADnio+Park+Riviera+da+Costa/@22.868422,-

43.5878444,902m/data=!3m2!1e3!4b1!4m5!3m4!1s0x9be3b158d3e935:0xabb246ec4d88636e!8m2!3d22.868422!4d-43. 5856557.Acesso,10/08/2019.

Nesta pesquisa, foram utilizadas as tabelas de orçamentação da Empresa de Obras Públicas do Estado do Rio de Janeiro (EMOP), do Sistema Nacional de Custos e Índices da Construção Civil (SINAP) e do mercado da construção civil e projetos. No decorrer deste processo, foi necessário orçar todos os componentes do sistema, incluindo mão de obra para adequação do sistema hidráulico existente no condomínio.

Para a SINDIUSCON (2005), ao iniciar uma simulação financeira é importante comparar os valores estimados de redução da água com uma redução futura provocada pelas intervenções (Fluxo de Benefício) determinados com base nas tarifas do prestador de serviços de água e do valor de correção utilizado pela empresa.

\section{RESULTADOS E DISCUSSÃO}

A implantação de um sistema de aproveitamento de água pluvial não é justificada apenas pelo consumo e a demanda de uma edificação, mas sim pelo impacto da redução de água, dos valores empenhados e reembolsados ao longo do tempo. Por isso, é necessária uma estimativa do impacto da redução e de uma análise da viabilidade econômica da implantação.

No bairro de Campo Grande a cobrança de água e esgoto é realizada pela empresa Zona Oeste Mais. 0 cálculo da tarifa é feito atualmente pela multiplicação do valor consumido de água por R\$3,99 $\mathrm{m}^{3}$ e do esgoto por $\mathrm{R} \$ 3,129 \mathrm{~m}^{3}$. No caso do condomínio Park Riviera da Costa o consumo mensal de água é cerca de $109 \mathrm{~m}^{3}$.

O benefício mensal estimado com a implantação da um sistema de aproveitamento de águas pluviais foi de R\$ 924,42 no primeiro ano de projeto, descontando-se o tempo estimado em 3 meses para implantação física do sistema. As Tabelas 1 e 2 apresentam os valores calculados de fluxo de benefício e respectivos impactos da redução.

Tabela 1 - Fluxo de Benefício.

\begin{tabular}{|l|c|}
\hline \multicolumn{2}{|c|}{ Fluxo de Benefício } \\
\hline Dados & Valores em Reais \\
\hline C1 - valor médio da conta de água antes da intervenção & $\mathrm{R} \$ 25.577,91$ \\
\hline C2 - valor esperado da conta de água após a intervenção & $\mathrm{R} \$ 24.653,49$ \\
\hline Benefício- Mês & $\mathrm{R} \$ 924,42$ \\
\hline Benefício Ano & $\mathrm{R} \$ 11.093,00$ \\
\hline
\end{tabular}


Tabela 2 -Impacto de Redução de Água (IR)

\section{Impacto de Redução de Água - IR}

ICAP= Indicador de consumo antes das intervenções; ICDP = Indicador de consumo depois das intervenções IR - Impacto de Redução de Água em \%

Para analisar a viabilidade econômica foram obtidos, pela Tabela 3, os indicadores VP (Valor Presente), VPL (Valor Presente Líquido), TIR (Taxa Interna de Retorno) e Payback simples.

Tabela 3-Indicadores de viabilidade econômica

\begin{tabular}{|c|c|c|}
\hline \multicolumn{3}{|c|}{ Indicadores de Viabilidade } \\
\hline Ano & Fluxo de Caixa & Valor acumulado \\
\hline 0 & -R\$192.962,25 & -R\$192.962,25 \\
\hline 1 & $\mathrm{R} \$ 8.320,24$ & $-\mathrm{R} \$ 184.642,01$ \\
\hline 2 & $\mathrm{R} \$ 11.410,38$ & $-\mathrm{R} \$ 173.231,63$ \\
\hline 3 & $\mathrm{R} \$ 11.736,14$ & $-\mathrm{R} \$ 161.495,49$ \\
\hline 4 & $\mathrm{R} \$ 12.071,21$ & $-\mathrm{R} \$ 149.424,28$ \\
\hline 5 & $\mathrm{R} \$ 12.415,84$ & $-\mathrm{R} \$ 137.008,44$ \\
\hline 6 & $\mathrm{R} \$ 12.770,31$ & $-\mathrm{R} \$ 124.238,13$ \\
\hline 7 & $\mathrm{R} \$ 13.134,91$ & $-\mathrm{R} \$ 111.103,22$ \\
\hline 8 & $\mathrm{R} \$ 13.509,91$ & -R\$97.593,31 \\
\hline 9 & $\mathrm{R} \$ 13.895,62$ & $-\mathrm{R} \$ 83.697,70$ \\
\hline 10 & $\mathrm{R} \$ 14.292,34$ & -R\$ 69.405,36 \\
\hline 11 & $\mathrm{R} \$ 14.700,38$ & $-\mathrm{R} \$ 54.704,98$ \\
\hline 12 & $\mathrm{R} \$ 15.120,08$ & $-\mathrm{R} \$ 39.584,90$ \\
\hline 13 & $\mathrm{R} \$ 15.551,76$ & $-\mathrm{R} \$ 24.033,14$ \\
\hline 14 & $\mathrm{R} \$ 15.995,76$ & $-\mathrm{R} \$ 8.037,39$ \\
\hline 15 & $\mathrm{R} \$ 16.452,44$ & $\mathrm{R} \$ 8.415,05$ \\
\hline 16 & $\mathrm{R} \$ 16.922,15$ & $\mathrm{R} \$ 25.337,21$ \\
\hline 17 & $\mathrm{R} \$ 17.405,28$ & $\mathrm{R} \$ 42.742,49$ \\
\hline 18 & $\mathrm{R} \$ 17.902,20$ & $\mathrm{R} \$ 60.644,69$ \\
\hline 19 & $\mathrm{R} \$ 18.413,31$ & $\mathrm{R} \$ 79.058,00$ \\
\hline 20 & $\mathrm{R} \$ 18.939,01$ & $\mathrm{R} \$ 97.997,02$ \\
\hline 21 & $\mathrm{R} \$ 19.479,72$ & $\mathrm{R} \$ 117.476,74$ \\
\hline 22 & $\mathrm{R} \$ 20.035,87$ & $\mathrm{R} \$ 137.512,60$ \\
\hline 23 & $\mathrm{R} \$ 20.607,89$ & $\mathrm{R} \$ 158.120,49$ \\
\hline 24 & $\mathrm{R} \$ 21.196,25$ & $\mathrm{R} \$ 179.316,74$ \\
\hline 25 & $\mathrm{R} \$ 21.801,40$ & $\mathrm{R} \$ 201.118,13$ \\
\hline 26 & $\mathrm{R} \$ 22.423,83$ & $\mathrm{R} \$ 223.541,96$ \\
\hline 27 & $\mathrm{R} \$ 23.064,03$ & $\mathrm{R} \$ 246.605,99$ \\
\hline 28 & $\mathrm{R} \$ 23.722,51$ & $\mathrm{R} \$ 270.328,50$ \\
\hline 29 & $\mathrm{R} \$ 24.399,78$ & $\mathrm{R} \$ 294.728,28$ \\
\hline 30 & $\mathrm{R} \$ 25.096,40$ & $\mathrm{R} \$ 319.824,68$ \\
\hline TMA /i & & \\
\hline VPL & $\mathrm{R} \$$ & 8,04 \\
\hline TIR & & \\
\hline IL & & \\
\hline VP & $\mathrm{R} \$ 2$ & 20,29 \\
\hline Payback & 14 anos/ & es/26 dias \\
\hline
\end{tabular}

Segundo Rego (2013), não se pode utilizar somente o VP como indicador da viabilidade do projeto, porque se o valor for positivo e baixo para um projeto de longa duração, pode acontecer que durante muito tempo 
o fluxo de caixa fique negativo para recuperar o investimento. Daí a razão da Tabela 4 apresentar os resultados com diversos indicadores de viabilidade.

O cálculo do VP apresentou um resultado positivo, compreendendo-se preliminarmente que se trata de projeto economicamente viável. Nesta análise, as estimativas de custos e receitas foi transformada para um valor equivalente tendo como referência a data atual, resultando no valor $\mathrm{R} \$ 207.220,29$ superior ao valor atual do projeto de $\mathrm{R} \$ 192.962,25$. Se na análise for também associado o indicador VPL (R\$ 14.258,04) a implantação do projeto passa a ser atrativa, o que acontece quando VPL é positivo de acordo com Rego (2013).

De forma complementar, analisou-se também a viabilidade econômica do empreendimento por meio do TIR, uma taxa composta de retorno anual, que resultou superior à inflação estimada de $5 \%$, ou seja, confirmando a viabilidade econômica do sistema.

A finalidade do Payback é conhecer quando o projeto começará a dar o retorno do investimento que, no presente estudo de caso, foi de aproximadamente 14,5 anos, menos da metade do tempo médio de financiamento de 30 anos.

O IL consiste de um índice obtido com divisão entre o VP e o investimento em módulo, com o objetivo de analisar se o investimento será recuperado em relação a determinada taxa exigida pelo investidor (TMA). Quando o IL for superior a 1 (um), é porque sua TIR será superior à TMA e o VPL resultará positivo.

\section{CONCLUSÕES}

No estudo de caso da presente pesquisa, um condomínio de 218 apartamentos do Programa Minha Casa Minha Vida na cidade do Rio de Janeiro, comprovou-se a viabilidade econômica da implantação de um sistema de aproveitamento de água da chuva. Todos os indicadores analisados apresentaram resultado positivo: VPL (R\$ 14.258,04), VP (R\$ 207.220,29), IL (1,07) e as taxas TIR (7\%) e TMA (6\%) ficaram acima da inflação.

O Payback da implantação do sistema de aproveitamento de água está previsto para 14 anos, 6 meses e 26 dias, menos da metade do tempo médio do financiamento de 30 anos. Com a implantação do sistema, haveria redução do consumo de água potável em 3,6\% e uma diminuição prevista na conta de água e esgoto no valor de $\mathrm{R} \$ 924,42$, que poderia aumentar considerando futuros reajustes nas tarifas de fornecimento de água.

A atual decisão da Prefeitura da Cidade do Rio de Janeiro, de isentar os empreendimentos do PCMV do Decreto 23940/2004, é, portanto, equivocada, prejudicando moradores e a própria gestão pública do município.

\section{REFERÊNCIAS}

[1] ASSOCIAÇÃO BRASILEIRA DE NORMAS TÉCNICAS. NBR. 15527.Aproveitamento de Água da Chuva de Coberturas em Áreas Urbanas Para Fins Não Potáveis -Requisitos. Rio de Janeiro, 2007

[2] ASSOCIAÇÃO BRASILEIRA DE NORMAS TÉCNICAS. NBR. 15527.Aproveitamento de Água de Chuva de Coberturas em Áreas Urbanas Para Fins Não Potáveis -Requisitos. Rio de Janeiro, 2019

[3] BRASIL. Prefeitura do Rio de Janeiro. Decreto № 23.940 - Torna obrigatório, nos casos previstos, a adoção de reservatórios que permitam o retardo do escoamento das águas pluviais para a rede de drenagem. Rio de Janeiro, 2004.

[4] BRASIL. Prefeitura do Rio de Janeiro. Decreto № 26168 - Isenta da obrigatoriedade da adoção dos reservatórios previstos no Decreto n.o 23.940 de 30 de janeiro de 2004 os empreendimentos habitacionais beneficiados pela Lei Complementar n.․ 40. Rio de Janeiro, 2006.

[5] MALLET, Pedro; PERTEL, Monica. Aproveitamento de águas pluviais, uma alternativa viável para a preservação hídrica. Revista Boletim do Gerenciamento no 13, 2020.

[6] ORGANIZAÇÃO DAS NAÇÕES UNIDAS. ONU. https://nacoesunidas.org/acao/agua/. Acesso, 2018.

[7] REGO. Ricardo Bordeaux. Viabilidade Econômica- Financeiras de Projetos. FGV Editora. 2013.

[8] SIDUSCON. Conservação e reuso de água em edificações. 2005.

[9] TOMAZ. Plínio. Água de Chuva: Aproveitamento de Água da chuva Para Áreas Urbanas e Fins não Potáveis. Livros digitais. 2011. http://www.pliniotomaz.com.br/livros-digitais/. Acesso, 15/12/2018. 
[10] https://www.google.com.br/maps/place/Condom\%C3\%ADnio+Park+Riviera+da+Costa/@-22.868422,43.5878444,902m/data=!3m2!1e3!4b1!4m5!3m4!1s0x9be3b158d3e935:0xabb246ec4d88636e!8m2!3d22.868422!4d-43. 5856557.Acesso,10/08/2019. 


\section{Capítulo 8}

Reúso de água nas indústrias: Desafios e oportunidades

\section{Maria Gabriela de Souza Damaceno \\ Karla Alcione da Silva Cruvinel}

Resumo: Na indústria, a água cumpre muitas funções que requerem quantidade e qualidade diferentes. Depois de utilizada a água se transforma em efluente, cujas características variam de acordo com a tipologia de indústria e, uma vez descartada diretamente nos cursos d'água, pode ocasionar sérios danos ambientais. Uma alternativa para promover a diminuição da captação de água e a redução associada na emissão de efluentes nos corpos receptores é a utilização do reúso da água, sendo reúso o aproveitamento de águas previamente utilizadas para suprir as necessidades de outros usos. Nesse contexto, o presente artigo tem como objetivo analisar as lacunas para a aplicação do reúso nas indústrias, utilizando a pesquisa bibliográfica como método para a coleta de informações. Fez-se um levantamento de aspectos conceituais, normativos e aplicações do reúso de água em diferentes setores, com enfoque para a indústria. Chegando-se às conclusões que o estabelecimento de critérios para reúso da água é um desafio devido à ausência de uma ampla cobertura internacional de regulamentos e diretrizes e que, para que a prática de reúso seja desenvolvida de forma adequada no Brasil, é necessária a criação de uma legislação federal mais específica e eficiente.

Palavras-chave: água na indústria; legislação; efluente industrial. 


\section{INTRODUÇÃO}

Na indústria, a água cumpre muitas funções que requerem quantidade e qualidade diferentes. Dentre os usos mais comuns, cita-se seu uso como: matéria-prima, para limpeza, refrigeração/aquecimento e como fluido auxiliar (BECKER et al., 2019).

Após a utilização, a água se transforma em efluente, cujas características variam de acordo com a tipologia de indústria, podendo conter grandes quantidades de produtos químicos, materiais provenientes de lavagens, entre outros. Uma vez descartado diretamente nos cursos d'água, o efluente pode ocasionar sérios danos ambientais (METCALF; EDDY, 2016).

Nessa perspectiva, faz-se necessária a utilização dos recursos hídricos da forma mais eficiente e eficaz possível, permitindo a manutenção e, até mesmo, a otimização da oferta hídrica aos múltiplos usos e usuários (CIRILO, 2015).

Uma estratégia para atender a estes desafios é realizar a gestão integrada da água na indústria, que considera interações, interdependências e potenciais entre os diferentes tipos de demanda e oferta de água. Para aumentar a eficiência são necessárias medidas para promover a diminuição da captação de água e a redução associada na emissão de efluentes nos corpos receptores, sendo o reúso uma das alternativas aplicáveis (BECKER et al., 2019).

Dentre os principais benefícios do reúso na indústria cita-se: a redução do lançamento de efluentes em corpos hídricos; a redução de captação de água para a indústria, o que gera o aumento da disponibilidade de água para usos mais exigentes; a conformidade ambiental em relação aos padrões e normas estabelecidas; a redução dos custos de produção e consumo; aumento de competitividade e possibilidade de receber incentivos na cobrança da água (INTERÁGUAS, 2016).

Nesse sentido a utilização do reúso de água se apresenta como uma oportunidade para o setor industrial, uma das três tipologias que mais consomem água no país, juntamente com agricultura e abastecimento urbano.

Sendo reúso de água, segundo Resolução no 54 (BRASIL, 2005), “a utilização de água residuária”, e água residuária: "esgoto, água descartada, efluentes líquidos de edificações, indústrias, agroindústrias e agropecuária, tratados ou não". Para NBR 16.783 (ABNT, 2019), reúso de água é "reutilização, mediante tratamento adequado, de água previamente utilizada".

Assim, reúso é o aproveitamento de águas já utilizadas para suprir as necessidades de outros usos, que pode ser potável ou não potável (LAVRADOR FILHO, 1987). Para Telles e Costa (2010) o reúso pode ocorrer de forma direta ou indireta, bem como decorrer de ações planejadas ou não.

Nesse contexto, o presente artigo tem como objetivo levantar os principais desafios para a aplicação do reúso de água nas indústrias no cenário brasileiro.

\section{MATERIAIS E MÉTODOS}

Utilizou-se o método de abordagem dedutiva, onde pressupõe-se que existam verdades gerais já afirmadas e, a partir dessas verdades, pode-se chegar a novos conhecimentos.

Quanto ao procedimento para coleta de informações, o mesmo ocorreu por meio da pesquisa bibliográfica. Sendo que, para Gil (2010), na pesquisa bibliográfica utiliza-se dados que já receberam tratamento analítico, ou seja, é uma pesquisa baseada em material (artigos científicos e livros) já publicados.

Para tal, foram selecionados artigos de relevância nacional e internacional a partir da busca na base de dados Scopus, com a utilização das seguintes palavras-chave: "water management", "water in industry", "water uses in industry", "water reuse”, "effluent reuse”, "industry reuse", "water recycling”, dentre outros.

\section{RESULTADOS E DISCUSSÕES}

Como o objetivo é analisar as lacunas para aplicação do reúso industrial, faz-se necessário um levantamento de aspectos conceituais, normativos e aplicações do reúso de água em diferentes setores, com enfoque para a indústria 


\subsection{ASPECTOS HISTÓRICOS}

O conhecimento sobre tratamento e reutilização de águas residuárias é algo que foi desenvolvido concomitantemente à história da humanidade. Os efluentes domésticos têm sido utilizados para irrigação e aquicultura por várias civilizações antigas, que datam períodos de 3200-1100 a.C., incluindo aqueles que se desenvolveram na China, Oriente, Egito e Mesopotâmia. Os efluentes continuaram a ser utilizados na irrigação e fertilização pela civilização grega e, posteriormente, romana, no período de 1000 a.C. - 330 d.C. (ANGELAKIS et al., 2018).

No século XIX, na Inglaterra e Alemanha e, posteriormente, nos EUA, foram desenvolvidos os métodos modernos de tratamento de esgoto, devido às grandes epidemias em várias regiões do mundo. Durante esse período, as autoridades reconheceram a necessidade de saneamento e isso levou ao desenvolvimento da disposição e reúso de efluentes. Fatores como grande população das cidades, área disponível para o tratamento limitada e grande demanda para irrigação, intensificaram o interesse pelo desenvolvimento de sistemas e métodos de tratamento dos efluentes mais eficientes (ANGELAKIS et al., 2018).

No entanto, apenas no final do século XX e início do século XXI, devido ao crescimento populacional, a urbanização, o crescimento de megacidades, mudanças climáticas e a crescente demanda de água para diferentes usos, as tecnologias de recuperação e reutilização de água foram desenvolvidas. Hoje, os projetos de recuperação e reúso de água são implementados em todo o mundo, sendo utilizada para diversas finalidades, incluindo o uso potável (ANGELAKIS et al., 2018).

\subsection{APLICAÇõES DO REÚSO}

Em 2008, cerca de 58 milhões de $\mathrm{m}^{3}$ /dia de efluentes foram utilizados para reúso no mundo. Destes, 21 milhões de $\mathrm{m}^{3} /$ dia foram utilizados após tratamento, em mais de 43 países, sendo os Estados Unidos da América (EUA) o país que mais utilizou água de reúso. Em países como Singapura e Kuwait, a água de reúso representava mais de $10 \%$ da água utilizada. Os outros 29 milhões de $\mathrm{m}^{3} /$ dia de efluente foram utilizados, em 2008, na agricultura, principalmente no México e na China (NRC, 2012). Historicamente, a irrigação agrícola tem sido e continua a ser o maior uso de águas residuárias que são reutilizadas (ANGELAKIS et al., 2018).

Na Califórnia, EUA, em 2009, a vazão de efluente sanitário reutilizada, após tratamento, era de aproximadamente $26 \mathrm{~m}^{3} / \mathrm{s}$ para uma grande variedade de modalidades de reúso, sendo cerca de $55 \%$ para irrigação e $13 \%$ para fins industriais. Tendo como objetivo atingir 39 e $51 \mathrm{~m}^{3} / \mathrm{s}$, em 2020 e 2030 , respectivamente (DWR, 2013).

Em 2010, na Arábia Saudita, 30\% do efluente sanitário municipal era reutilizado após tratamento, com meta de $100 \%$ até 2030 . Para efluente industrial, a meta de reúso é de $80 \%$ até 2030.0 reúso de esgoto tratado em países de clima desértico como Arábia Saudita, Egito, Israel, Síria, entre outros, vem crescendo cada vez mais devido à sua maior eficiência energética em comparação com a dessalinização (NRC, 2012).

No Brasil eram reutilizados apenas cerca de $1,6 \mathrm{~m}^{3} / \mathrm{s}$ de efluentes, em 2015. Estimativas do potencial de reúso no Brasil apontam vazões na ordem de 28 a $31 \mathrm{~m}^{3} / \mathrm{s}$ de reúso de efluente após tratamento, sendo os principais usos da água de reúso fins agrícolas, industriais e urbanos (INTERÁGUAS, 2017b).

O Projeto Reúso, integrante do INTERÁGUAS, que tem como objetivo dar subsídios para que o Governo Federal Brasileiro possa instituir o reúso como uma política de Estado, desenvolveu uma série de estudos sobre o reúso no Brasil e no mundo.

A Figura 1 apresenta as principais modalidades de reúso e aplicações que são tipicamente consideradas ao redor do mundo, segundo dados do Produto II - Experiências de Reúso, desenvolvido no Projeto Reúso. 
Figura 1 - Aplicação de Reúso

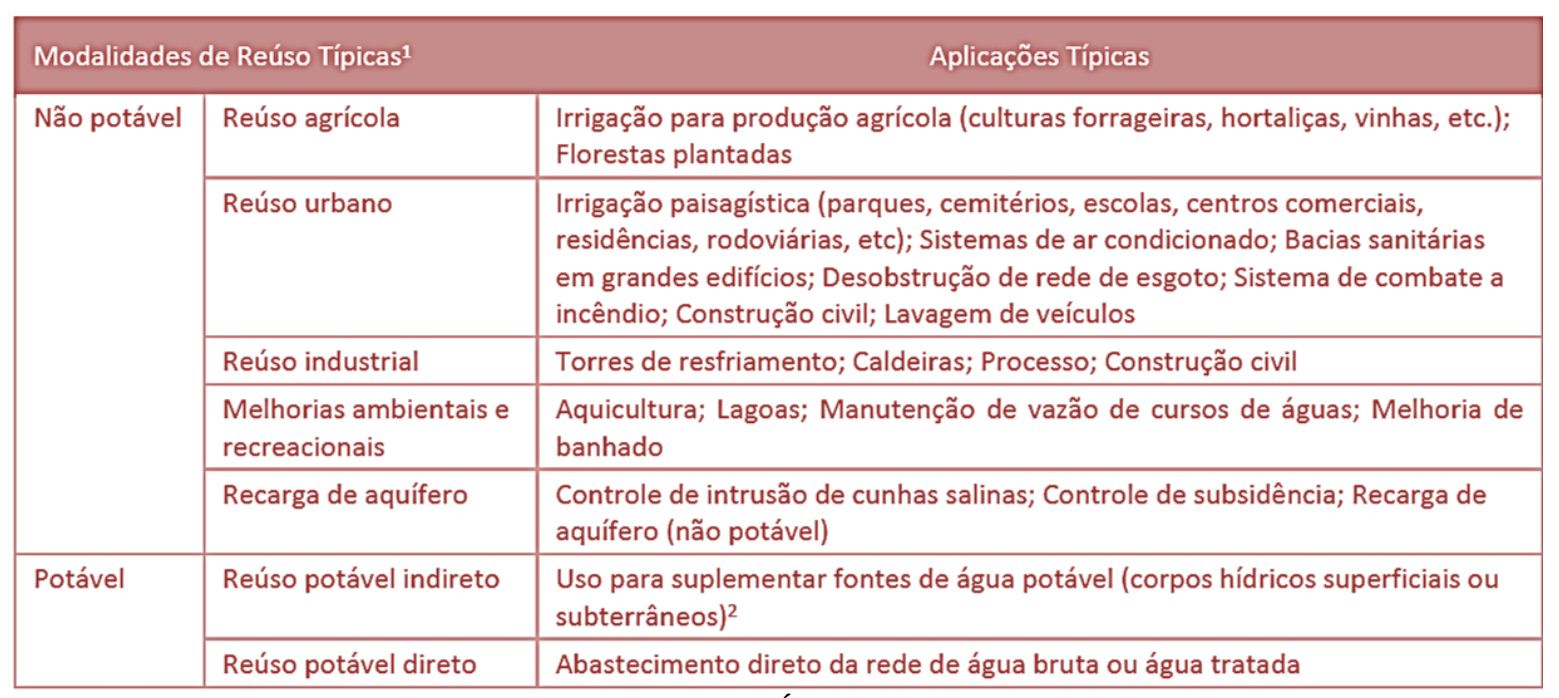

(Fonte: INTEÁGUAS, 2016)

\subsection{REÚSO DE ÁGUA NA INDÚSTRIA}

Conforme observado na Figura 1, o reúso não potável em indústria se dá, principalmente, em torres de resfriamento, caldeiras, durante o processo produtivo. Uma vez que as indústrias têm reconhecido que a água de reúso é um recurso que pode substituir a água potável mais cara, sem degradar o desempenho dos usos pretendidos.

A maioria dos processos produtivos industriais utiliza volumes consideráveis de água, normalmente aplicado para refrigeração de máquinas e equipamentos, em que variam muito quanto à qualidade da água requerida. Neste caso, grande parte da água utilizada é tratada in house e reutilizada no próprio processo produtivo ou aplicada em outros setores da organização (CERQUEIRA, 2010).

De acordo com a necessidade da indústria, diferentes modalidades de reúso podem ser adotadas, sendo mais comum o reúso indireto, onde os efluentes tratados são lançados em rios e lagos e, posteriormente, captados, tratados e utilizados. No reúso direto, ou em cascata, o efluente de uma determinada atividade é utilizado em outra com menor exigência, podendo ou não ocorrer o tratamento prévio do efluente. 0 efluente bruto deve passar por tratamento quando não apresentar características adequadas à qualidade exigida para sua aplicação (ROCHA et al., 2019; TELLES; COSTA, 2010).

Os efluentes líquidos industriais possuem elevado potencial de poluição, devido aos processos que levaram a sua formação. Conforme a NBR 9.800 (ABNT, 1987), efluente líquido industrial é “o despejo líquido proveniente do estabelecimento industrial, compreendendo emanações de processo industrial, águas de refrigeração poluídas, águas pluviais poluídas e esgoto doméstico".

Assim sendo, as características desses efluentes variam, de acordo com a tipologia de indústria, podendo conter grandes quantidades de produtos químicos, materiais provenientes de lavagens, entre outros. Uma vez descartado diretamente nos cursos d'água, o efluente pode ocasionar danos ambientais (METCALF; EDDY, 2016).

O Brasil não possui legislações a nível federal que abordem os critérios de qualidade da água para fins de reúso, o que se utiliza são normativas internacionais ou diretrizes propostas em estudos. Para se considerar reúso industrial, primeiramente, faz-se necessário caracterizar o efluente de interesse. Pode-se utilizar, de uma forma geral para as indústrias, como parâmetros a condutividade elétrica ou da concentração de sais dissolvidos totais, que representam os compostos inorgânicos e a Demanda Química de Oxigênio (DQO), para representar as substâncias orgânicas. Além destes, realizar a análise do Potencial Hidrogeniônico $(\mathrm{pH})$, a turbidez e a cor também podem ser úteis no estágio inicial para avaliação do potencial de reúso (CNI, 2017). 
Contudo, de uma forma geral, no Brasil se utiliza os critérios de qualidade da água de reúso estipuladas pela agencia de proteção ambiental americana USEPA, que publicou, em 2004, com atualização em 2012, diretrizes para nível de tratamento e critérios de qualidade de água para vários tipos de reúso, inclusive o reúso industrial. Os parâmetros estão apresentados no Quadro 1.

Quanto ao tratamento é recomendado um nível secundário, utilizando por exemplo o sistema de lodos ativados, e a desinfeção para destruição, remoção ou inativação de microrganismos patogênicos, sendo possível a utilização de cloração, ozonização, radiação ultravioleta, dentre outros (USEPA, 2012).

Quadro 1 - Qualidade da água para reúso industrial segundo USEPA

\begin{tabular}{|l|c|}
\multicolumn{2}{|c|}{ Parâmetro } \\
\hline $\mathrm{pH}$ & 6 a 9 \\
\hline DBO (mg/L) & $<30$ \\
\hline SST (mg/L) & $<30$ \\
\hline Cloro Residual Total (mg/L) & $>1$ \\
\hline Coliforme Termotolerante (NPM/100mL) & $<200$ \\
\hline
\end{tabular}

(Fonte: adaptado de USEPA, 2012).

Um exemplo de reúso de água na indústria para atender às metas de energia e sustentabilidade é o projeto desenvolvido na Coca-Cola, que instalou sistemas de reúso que permitem que as instalações reutilizem a água processada em torres de resfriamento, caldeiras ou para a limpeza, economizando, por ano, uma média de 220 milhões de litros de água por sistema (USEPA, 2012).

O maior exemplo de reúso industrial na América Latina é o Aquapolo, sendo o único projeto de grande porte (vazão acima de $0,5 \mathrm{~m}^{3} / \mathrm{s}$ ) de reúso de efluente sanitário no Brasil. Este é um projeto de reúso de água que visa promover a gestão sustentável da água na área do ABC Paulista, em São Paulo, Brasil, uma região que constantemente passa por cenários de escassez hídrica. Para tal, o esgoto doméstico gerado na bacia do $\mathrm{ABC}$ é tratado com sistema de lodos ativados com membrana de ultrafiltração e osmose reversa, sendo a desinfecção por Dióxido de Cloro. Posteriormente, o efluente é distribuído, com uma vazão de $1 \mathrm{~m}^{3} / \mathrm{s}$, para as empresas do Polo Petroquímico de Capuava, considerado o maior consumidor de água da região (MELO; RODRIGUEZ, 2017).

\subsection{ASPECTOS NORMATIVOS DO REÚSO}

O Brasil não apresenta uma legislação federal sobre o reúso, conta apenas com algumas resoluções e normas regulamentadoras, sendo esta, portanto, a maior lacuna para aplicação do reúso no Brasil. Existem algumas legislações estaduais e/ou municipais, como por exemplo nos estados do Ceará e São Paulo, que abordam o tema, inclusive com alguns parâmetros de qualidade para a água de reúso. Os regulamentos brasileiros sobre qualidade da água, abastecimento e serviços de água e esgoto, relacionados direta ou indiretamente com o tema reúso de água, estão apresentados no Quadro 3.

O principal instrumento utilizado, para a prática, até pouco tempo era a Norma Brasileira NBR 13.969 (ABNT, 1997), listado no Quadro 2, a qual aborda o tema reúso de efluentes como alternativa à disposição final dos efluentes essencialmente domésticos de tanque séptico.

Em 2005, o Conselho Nacional de Recursos Hídricos (CNRH) implementou a Resolução no 54 (BRASIL, 2005), que definiu, a nível nacional, as modalidades, diretrizes e critérios gerais para a prática de reúso direto não potável de água residuária, que é definido como esgoto, água descartada, efluentes líquidos de edificações, indústrias, agroindústrias e agropecuária, tratados ou não. Essa Resolução define as modalidades de reúso, porém, não apresenta parâmetros de qualidade de água.

A NBR 16.783 (ABNT, 2019), que dispõe sobre o "uso de fontes alternativas de água não potável em edificações", apresenta os potenciais usos que as fontes alternativas de água não potável poderiam assumir em uma edificação, apresentando alguns parâmetros de qualidade para a água de reúso e opções de tratamento. 
Quadro 2 - Normativas relacionados ao reúso

\begin{tabular}{|c|c|c|}
\hline Relevância & & s, normas e regulamentos federais \\
\hline $\begin{array}{l}\text { Abastecimento } \\
\text { de água e gestão } \\
\text { de recursos } \\
\text { hídricos }\end{array}$ & $\begin{array}{lll}\text { Lei no } & 9.433 / 1997 & \text { (Lei } \\
\text { das Águas) } & & \\
\text { Resolução } & \text { CNRH } & \text { no } \\
54 / 2005 & & \\
\begin{array}{l}\text { Resolução } \\
\text { 121/2010 }\end{array} & \text { CNRH } & \text { no } \\
& & \end{array}$ & 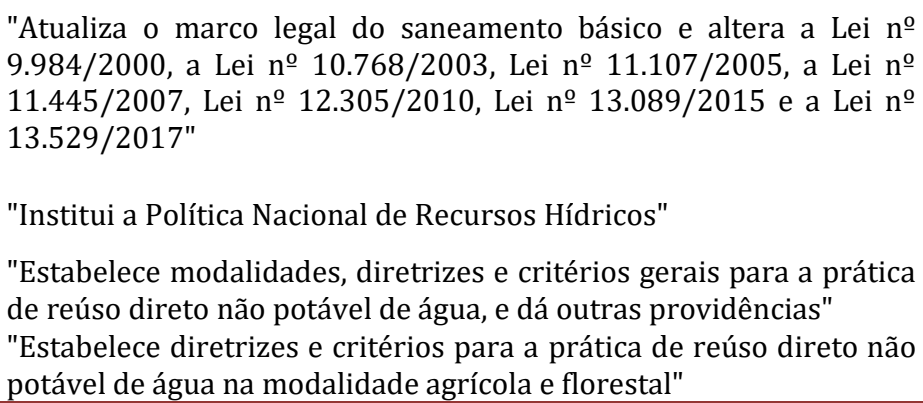 \\
\hline $\begin{array}{l}\text { Qualidade do } \\
\text { descarte de } \\
\text { efluente e } \\
\text { proteção dos } \\
\text { corpos hídricos }\end{array}$ & $\begin{array}{lll}\text { Resolução } & \text { CONAMA } & \text { nº } \\
357 / 2005 & & \\
& & \\
\text { Resolução } & \text { CONAMA } & \text { no } \\
430 / 2011 & & \end{array}$ & $\begin{array}{l}\text { "Dispõe sobre a classificação dos corpos de água e diretrizes } \\
\text { ambientais para o seu enquadramento" } \\
\text { "Dispõe sobre as condições e padrões de lançamento de efluentes, } \\
\text { complementa e altera a Resolução no } 357 \text {, de } 17 \text { de marco de } 2005 \text {, } \\
\text { do CONAMA" }\end{array}$ \\
\hline $\begin{array}{l}\text { Serviço de água e } \\
\text { esgoto }\end{array}$ & $\begin{array}{l}\text { Lei } n^{\circ} 11.445 / 2007 \text { (Lei } \\
\text { do Saneamento) } \\
\text { Decreto no } 7.217 / 2010 \\
\text { NBR no } 13.969 / 97 \\
\text { NBR n } 16.783 / 2019\end{array}$ & $\begin{array}{l}\text { "Estabelece diretrizes nacionais para o saneamento básico" } \\
\text { "Regulamenta a Lei no } 11.445 " \\
\text { "Tanques sépticos - Unidades de tratamento complementar e } \\
\text { disposição final dos efluentes líquidos - Projeto, construção e } \\
\text { operação" } \\
\text { "Uso de fontes alternativas de água não potável em edificações" }\end{array}$ \\
\hline
\end{tabular}

(Fonte: adaptado de INTERÁGUAS, 2017a).

As principais lacunas levantadas com base na comparação entre os quadros regulatórios atuais no Brasil para controle da qualidade da água de reúso são relacionadas à falta de definição do nível de envolvimento e competências dos órgãos; à falta de um processo de licenciamento e outorga para projetos de reúso e à falta de definição das exigências normativas para controle de qualidade, monitoramento e de controle/conformidade específicos para reúso a nível federal (INTERÁGUAS, 2017a).

\section{CONSIDERAÇÕES FINAIS}

Apesar da necessidade de atender aos critérios de qualidade da água, a água de reúso tem o potencial de atender as demandas menos exigentes e, em alguns casos, sem a necessidade até mesmo de realizar um tratamento prévio.

Nesse sentido, o reúso pode contribuir com a diminuição da quantidade de água captada em mananciais destinados ao abastecimento, promovendo a compatibilização entre a oferta e demanda de água, o que diminui custos financeiros e ambientais na indústria, além de diminuir os riscos de contaminação dos recursos hídricos por lançamento de efluentes industriais no meio ambiente.

O estabelecimento de critérios para reúso da água é um desafio devido à ausência de uma ampla cobertura internacional de regulamentos e diretrizes, além de um consenso científico sobre a abordagem que deve ser adotada para emitir esses critérios.

No Brasil, não existem normas regulamentadoras, leis ou portarias que regulamentem ou orientem o reúso na indústria. Devido a essa falta de instrumentos reguladores no país, muitas vezes, faz-se necessária a utilização de normativas internacionais ou, até mesmo, o uso de documento norteadores, como o material da PROSAB e INTERÁGUAS.

Contudo, para que a prática de reúso seja desenvolvida de forma adequada no Brasil é necessária a criação de uma legislação federal mais específica e eficiente com normas e diretrizes que definam os conceitos, parâmetros e restrições ao reúso das águas, de acordo com as diferentes aplicações do reúso. 


\section{REFERÊNCIAS BIBLIOGRÁFICAS}

[1] ASSOCIAÇÃO BRASILEIRA DE NORMAS TÉCNICAS - ABNT. NBR 9.800. Critérios para lançamento de efluentes líquidos industriais no sistema coletor público de esgoto sanitário. Rio de Janeiro, 1987.

[2] ASSOCIAÇÃO BRASILEIRA DE NORMAS TÉCNICAS - ABNT. NBR 16.783: Uso de fontes alternativas de água não potável em edificações. Rio de Janeiro, 2019.

[3] ANGELAKIS, A.; ASANO, T.; BAHRI, A.; JIMÉNEZ, B.; TCHOBANOGLOUS, G. Water Reuse: From Ancient to Modern Times and the Future. Frontiers in Environmental Science, v. 6, n. 26, may. 2018.

[4] BECKER, D.; JUNGFER, C.; TRACK, T. Integrated Industrial Water Management - Challenges, Solutions, and Future Priorities. Chemie Ingenieur Technik, v. 91, n.10, p.1367-1374, oct. 2019.

[5] CERQUEIRA, V. Reciclagem de Polímeros: Questões socioambientais em relação ao desenvolvimento de produtos. In: CONGRESSO BRASILEIRO DE PESQUISA E DESENVOLVIMENTO EM DESIGN, 9, 2010. São Paulo: Blucher Universidade Anhembi Morumbi, 2010. Disponível em: http:<//resol.com.br/textos/70092.pdf>. Acesso em: 15 de jul. de 2020 .

[6] CIRILO, J. A. Crise Hídrica: desafios e superação. Revista USP, São Paulo, n. 106, p. 45-58, jul/ago/set 2015.

[7] CNI. Confederação Nacional da Indústria. O uso racional da água no setor industrial. Federação das Indústrias do Estado de São Paulo. 2 ${ }^{\underline{a}}$ ed. Brasília: CNI, 2017. 236 p.

[8] BRASIL. Conselho Nacional de Recursos Hídricos-CNRH. Resolução n 54, de 28 de novembro de 2005. Estabelece modalidades, diretrizes e critérios gerais para a prática de reúso direto não potável de água, e dá outras providências. Disponível em: <http://www.ceivap.org.br/ligislacao/Resolucoes-CNRH/Resolucao-CNRH\%2054.pdf.> Acesso em 19 de jul de 2020.

[9] DWR. California Drinking Water Regulations. Title 22. California: Code of Regulations, 2013.

[10] GIL, A. C. Como elaborar projetos de pesquisa. 5. ed. São Paulo: Atlas, 2010.

[11] INTERÁGUAS. Ministério das Cidades e Instituto Interamericano de Cooperação para a Agricultura - IICA. Produto II - Experiências de Reúso. Elaboração de Proposta do Plano de Ações para Instituir uma Política de Reúso de Efluente Sanitário Tratado no Brasil. INTERÁGUAS, 2016. Disponível em: <https://www.mdr.gov.br/saneamento/projeto-interaguas/projeto-reuso>. Acesso em 20 de jul. de 2020.

[12] INTERÁGUAS. Ministério das Cidades e Instituto Interamericano de Cooperação para a Agricultura - IICA. Produto III - Critérios de Qualidade da Água de Reúso. Elaboração de Proposta do Plano de Ações para Instituir uma Política de Reúso de Efluente Sanitário Tratado no Brasil. INTERÁGUAS, 2017a. Disponível em: <https://www.mdr.gov.br/saneamento/projeto-interaguas/projeto-reuso>. Acesso em 20 de jul. de 2020.

[13] INTERÁGUAS. Ministério das Cidades e Instituto Interamericano de Cooperação para a Agricultura - IICA. Produto VI - Avaliação do Potencial de Reúso. Elaboração de Proposta do Plano de Ações para Instituir uma Política de Reúso de Efluente Sanitário Tratado no Brasil. INTERÁGUAS, 2017b. Disponível em: <https://www.mdr.gov.br/saneamento/projeto-interaguas/projeto-reuso>. Acesso em 20 de jul. de 2020.

[14] LAVRADOR FILHO, J. Contribuição para o Entendimento do Reúso Planejado da Água e algumas Considerações Sobre suas Possibilidades no Brasil. 1987. 191 f. Dissertação (Mestrado em Engenharia) - Escola Politécnica, Universidade de São Paulo, São Paulo, 1987.

[15] MELO, R. O. C. A.; RODRIGUEZ, J. Envision Sustainability Assessment of Aquapolo Ambiental, an Urban Water Reuse Infrastructure in São Paulo. International Conference on Sustainable Infrastructure, 2017, p. 126-137.

[16] METCALF, L.; EDDY, H. P. Tratamento de efluentes e recuperação de recursos. 5. ed. Porto Alegre: AMGH Editora Ltda, 2016.

[17] NATIONAL RESEARCH COUNCIL. (NRC). Water Reuse: Potential for Expanding the Nation's Water Supply Through Reuse of Municipal Wastewater. Washington D.C.: National Academy Press, 2012.

[18] ROCHA, A. C. L.; KLIGERMAN, D.C.; OLIVEIRA, J. L. M. Panorama da pesquisa sobre tratamento e reúso de efluentes da indústria de antibióticos. Saúde Debate, Rio de Janeiro, v. 43, n. especial 3, p. 165-180, dez. 2019.

[19] TELLES, D. D.; COSTA, R. P. Reúso de Água: Conceitos, Teorias e Práticas. 2. ed. São Paulo: Blucher, 2010.

[20] UNITED STATES ENVIRONMENTAL PROTECTION AGENCY. (USEPA). 2012 Guidelines for Water Reuse. Washington D.C.: USEPA, 2012. 


\section{Capítulo 9}

Fontes naturais de águas em área urbana e nossas expectativas de uso

\section{Cícero Wislei Fernandes Guerellus}

\section{Grasiele da Silva Gouveia}

\section{Lucas Caillot Schroeder}

Maria Magdalena Ribas Döll

Resumo: Esse projeto teve o objetivo de atender as necessidades das instituições de ensino, Escola Municipal Prof. Paulo Grott e Grupo Jovens com uma Missão (JOCUM), os quais pretendiam usar suas fontes naturais de água para irrigação, recreação ou consumo. Assim, amostras de água foram coletadas das nascentes e realizadas análises de qualidade de acordo com normas internacionais. As análises mostraram um retrato da qualidade atual da água, o que permitiu classificá-las de acordo com a Resolução Conama $\mathrm{n}^{\circ} 357$, bem como indicar seus possíveis usos e necessidades de tratamento. A nascente da Escola Municipal se enquadrou como Classe 3 usada apenas para navegação e harmonia paisagística e a da JOCUM como classe 2 para pesca amadora e à recreação de contato secundário.

Palavras-chave: Saneamento. Esgoto sanitário. Meio ambiente. 


\section{INTRODUÇÃO}

Este trabalho foi executado em duas instituições de ensino: a Escola Municipal Prof. Paulo Grott e a base missionária de Jovens Com Uma Missão (JOCUM).

O Saneamento Solidário é um projeto de extensão dentro dos Objetivos de Desenvolvimento Sustentável (ODS) que visa a água potável e saneamento, saúde e bem estar, cidades e comunidades sustentáveis, além de atender diversos outros objetivos indiretamente.

A grande motivação do projeto é desenvolver ações locais que controlem ou minimizem possíveis efeitos nocivos sobre o bem-estar, físico, mental e social dos indivíduos, como preconiza a Organização Mundial de Saúde ou do inglês World Health Organization (WHO, 2013).

Desta forma, as potencialidades trabalhadas neste trabalho foram as avaliações qualitativas e indicações das possibilidades de uso das águas naturais como respostas às expectativas das instituições que têm como público-alvo crianças e adolescentes que porventura podem ser beneficiar de alguma forma das fontes d’água nas instituições de ensino.

O propósito principal do projeto de Extensão "Saneamento Solidário" da Universidade Estadual de Ponta Grossa é o atendimento voluntário de diversas demandas externas da sociedade que exigem soluções técnicas efetivas e gratuitas. Assim, a equipe do projeto atuou na avaliação de águas naturais de duas instituições para avaliar as potencialidades para consumo humano e de animais, irrigação, lazer, recreação ou apenas paisagístico.

Assim, este trabalho que foi executado por acadêmicos dos cursos de Engenharia Civil e de Agronomia sob supervisão com os objetivos de responder os questionamentos das instituições: Tecnicamente, as fontes naturais de águas podem ser utilizadas nas instituições? Se sim, para que finalidades? Se não, quais seriam as soluções para tornar possíveis seus usos?

\section{METODOLOGIA}

A equipe atuou na Escola Municipal Prof. Paulo Grott, no Núcleo Monteiro Lobato em Ponta Grossa, que tem uma fonte natural de água de qualidade desconhecida, mas que se encontrava bem protegida por uma estrutura de concreto (Figura 1, detalhe A) indicando que os gestores da escola prezavam pela sua preservação e pretendiam usar esta água para irrigação da horta e do pomar da escola como atividade de educação ambiental para os alunos.

As amostras da água foram coletadas em um único ponto no próprio reservatório de concreto nos dias 30/09/2019 e 09/10/2019. As análises realizadas nas amostras foram: pH, CE, turbidez, coliformes totais, fecais e E. coli, DQO (Demanda Química de Oxigênio: medida indireta de matéria orgânica) e DBO (Demanda Bioquímica de Oxigênio: medida da quantidade de oxigênio consumido na degradação da matéria orgânica no meio aquático por processos biológicos) segundo Standard Methods for the Examination of Water and Wastewater (APHA, 2015).

Sequencialmente, a equipe visitou a JOCUM no dia 13/11/2019 em que foram coletadas e analisadas a água de três diferentes pontos sendo a nascente (P1), saída do primeiro tanque (P2) e saída do segundo tanque (P3) (Figura 1, detalhe B), as quais seus dirigentes tinham como expectativa, usá-las como fontes de água potável, balneabilidade e no abastecimento de dois tanques de peixes ligados em série entre si. 
Figura 1 - Fotos dos pontos de coleta de amostras, sendo A) nascente da Escola Paulo Grott e B) JOCUM em três pontos (P1 - nascente, P2 - saída do primeiro tanque e P3 saída do segundo tanque).

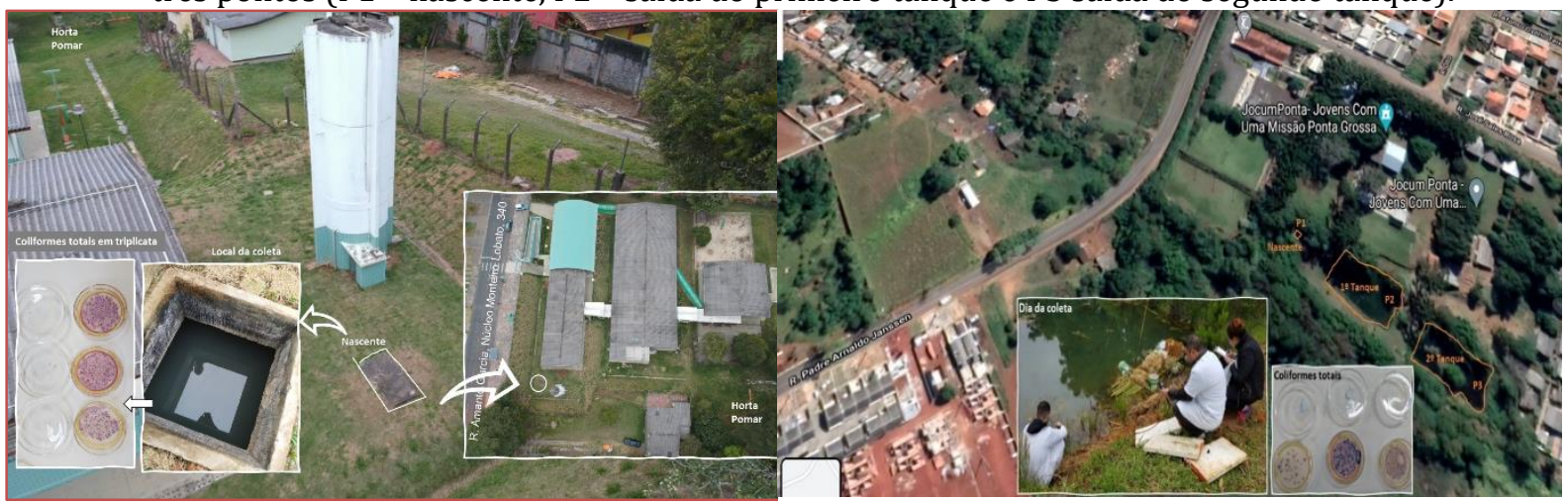

(A)

(B)

\section{RESULTADOS E DISCUSSÃO}

Em geral, as nascentes de água deveriam ser classificadas como Especial destinadas ao consumo humano, com desinfecção; à preservação do equilíbrio aquático e à preservação dos ambientes aquáticos, segundo a Resolução CONAMA no 357 (Brasil, 2005). Entretanto, os valores máximos para esta classe nem são citados, portanto, deduz-se que devem estar ausentes.

De acordo com a referida Resolução a fonte da Escola Paulo Grott se enquadraria na Classe 3, destinada a navegação e harmonia paisagística, devido ao valor alto de coliformes fecais.

Porém, ao observar a comparação na Tabela 1 com a Classe 1, observa-se que excetuando-se este parâmetro, os demais apresentaram excelentes valores que enquadram nesta classe. Assim, caso fosse realizado um tratamento para a remoção de Coliformes Fecais, esta água poderia ser classificada como Classe 1 e ser destinada à recreação de contato primário (natação, esqui aquático e mergulho), à proteção das comunidades aquáticas, à aquicultura e à atividade de pesca, ao abastecimento para consumo humano após tratamento convencional ou avançado, à irrigação de hortaliças e de parques, jardins, campos de esporte e lazer, com os quais o público possa vir a ter contato direto.

Tabela 1 - Resultados das análises de qualidade de água da nascente da Escola Paulo Grott, Ponta Grossa, Paraná em 30/09/2019 e 09/10/2019.

\begin{tabular}{|c|c|c|c|c|c|}
\hline Análises & Unidade & Resultado & $\begin{array}{l}\text { Classe } 1 \\
\text { VMP** }\end{array}$ & Resolução CONAMA & Condição de Uso \\
\hline $\mathrm{pH}$ & - & 8,97 & 6,0 a 9,0 & $\mathrm{n}^{\circ} 357(2005)$ & aceitável \\
\hline Condutividade Elétrica & $\mu \mathrm{S} / \mathrm{cm}$ & 249,5 & - & - & sem parâmetro \\
\hline Turbidez & NTU & 4,23 & Até 40 & $n^{\circ} 357(2005)$ & aceitável \\
\hline Cloro Residual & - & n.d.* & Até 0,01 & $n^{\circ} 357(2005)$ & aceitável \\
\hline DQO & $\mathrm{mg} / \mathrm{L}$ & 0 & - & & sem parâmetro \\
\hline DBO & $\mathrm{mg} / \mathrm{L}$ & 0 & Até 3,0 & $n^{\circ} 357(2005)$ & aceitável \\
\hline Coliformes totais & $\mathrm{UFC} / 100 \mathrm{~mL}$ & 1910 & - & - & sem parâmetro \\
\hline Coliformes fecais & UFC/100mL & 1900 & Até 200 & $\mathrm{n}^{\circ} 357$ (2005) & inaceitável \\
\hline Escherichia coli & $\mathrm{UFC} / 100 \mathrm{~mL}$ & 10 & Até 800 & $n^{\circ} 274(2000)$ & aceitável \\
\hline
\end{tabular}

* n.d. - Não detectado pelo método usado. ** VMP valor máximo permitido pelas Resolução CONAMA n³57 para classe 1, exceto para Escherichia coli que foi usada a Resolução CONAMA nº 274 para água doce destinada a balneabilidade.

Fonte: Os autores (2020).

Von Sperling (2005) esclarece que os coliformes fecais são chamados de termotolerantes, ex. Escherichia coli e algumas bactérias do gênero Klebsiella, Citrobacter e Enterobacter que estão presentes em fezes humanas e animais de sangue quente. Mas, podem não ser oriundas de fezes, pois ocorrem também em solos e plantas. Assim, com base nos coliformes termotolerantes é difícil fazer qualquer inferência. Todavia, a detecção de Escherichia coli na água indicou que houve despejo de esgoto sanitário em algum ponto da bacia de contribuição à nascente, devido esta bactéria viver essencialmente no intestino humano. 
Apesar disso, o valor de Escherichia coli foi considerado satisfatório para contato primário como balneabilidade segundo a Resolução CONAMA no 274 (BRASIL, 2000) para águas doces, cujo limite é de 800 UFC/100 mL (Unidades Formadoras de Colônia por $100 \mathrm{~mL}$ da amostra). De acordo com esta Resolução a escola poderia aproveitar a água para piscina visando a natação.

Já o uso desta água para irrigação de hortaliças requereria um tratamento de desinfecção como a cloração ou ozonização para reduzir o valor abaixo de 200 UFC/100 mL. Além disso, alerta-se que um período mais longo de monitoramento da água deve ser realizado bimestralmente para maior segurança nas afirmações de uso.

Na Tabela 2 estão os resultados encontrados nos três pontos (P1, P2 e P3) amostrados da água da propriedade da JOCUM.

Tabela 2 - Resultados das análises de qualidade de água da nascente da Jocum, Ponta Grossa em $13 / 11 / 2019$.

\begin{tabular}{|l|c|c|c|c|c|c|}
\hline Análises & Unidade & $\mathrm{P} 1$ & $\mathrm{P} 2$ & $\mathrm{P} 3$ & VMP* & Condição de Uso \\
\hline Temperatura da água na coleta & $\mathrm{oC}$ & 21,4 & 21,6 & 21,9 & 40 & aceitável \\
\hline $\mathrm{pH}$ & - & 5,0 & 5,1 & 5,7 & 6,0 a 9,0 & inaceitável \\
\hline Condutividade elétrica & $\mathrm{MS} / \mathrm{cm}$ & 111,2 & 83,0 & 74,2 & - & sem parâmetro \\
\hline Turbidez & $\mathrm{NTU}$ & 0,46 & 1,76 & 5,86 & $<100$ & aceitável \\
\hline Dureza & $\mathrm{mgCaCO3/L}$ & 10,9 & 8,5 & 17,0 & - & sem parâmetro \\
\hline Oxigênio dissolvido (OD) & $\mathrm{mg} / \mathrm{L}$ & 5,55 & 8,03 & 2,85 & $>5,00$ & aceitável \\
\hline Nitrogênio amoniacal & $\mathrm{mgNH+/L}$ & 4,4 & 1,3 & 2,1 & $<2,0$ & inaceitável \\
\hline Fósforo inorgânico & $\mathrm{mg} / \mathrm{L}$ & 0,015 & 0,011 & 0,011 & $<0,030$ & aceitável \\
\hline DQ0 & $\mathrm{mg} / \mathrm{L}$ & 6,30 & 10,1 & 15,6 & - & sem parâmetro \\
\hline Escherichia coli & UFC/100mL & 6,0 & 31,0 & 13,0 & Até 800 & aceitável \\
\hline
\end{tabular}

* VMP valor máximo permitido pela Resolução CONAMA n³57 para água doce de classe 2 comparando-se com a nascente (P1), exceto para Escherichia coli que foi usada a Resolução CONAMA n²74 para água doce destinada a balneabilidade.

Fonte: Os autores (2020).

De acordo com os resultados, a nascente (sem tratamento) se enquadrou na Classe 2 que pode ser destinada à pesca amadora e à recreação de contato secundário (BRASIL, 2005).

0 pH estava ácido e o oxigênio dissolvido do P3 está abaixo do VMP. O nitrogênio amoniacal e a DQO indicam que havia pouca quantidade de matéria orgânica possivelmente oriunda da degradação de folhas caídas nas superfícies dos tanques, dejetos de animas, ou esgoto sanitário que caíram na água. Os cuidados de proteção para preservar a qualidade da água deveriam ser melhorados.

Porém, o que mais prejudicou a qualidade da água é que foram determinadas várias colônias de Escherichia coli, cujo habitat exclusivo é o intestino humano e de animais homeotérmicos, o que indica provável contaminação das águas por esgoto sanitário.

Assim, a recomendação é ouso muito criterioso e um sistema completo de tratamento, inclusive com um tratamento de desinfecção efetivo, caso estas águas sejam usadas para consumo humano porque estes microrganismos devem estar ausentes segundo o Anexo XX da Portaria de Consolidação no 5 do Ministério da Saúde (BRASIL, 2017) que dispõe sobre a qualidade da água para consumo humano e seu padrão de potabilidade.

Ressaltamos que os trabalhos foram realizados somente com a finalidade de consulta prévia sobre a qualidade das águas a fim de responder as questões das instituições. Os resultados são apenas informativos e não podem ser usados como laudo técnico ou para outros fins semelhantes. As demais análises da legislação pertinente devem ser realizadas caso haja maior interesse, inclusive com a frequência recomendada pelos órgãos competentes.

\section{CONCLUSÃO}

De acordo com as análises realizadas nas datas das coletas, a nascente da Escola Municipal se enquadrou como Classe 3 usada apenas para navegação e harmonia paisagística e a da JOCUM como Classe 2 para pesca amadora e à recreação de contato secundário, segundo a resolução CONAMA no 357 de 2005. 
As análises retratam a situação momentânea das fontes de águas naturais que podem apresentar valores diferentes em outras datas devido aos efeitos das condições climáticas precipitação e temperatura. Além disso, caso haja melhorias na infraestrutura local e das cidades como a tubulação de fontes de esgoto doméstico, bloqueio de lançamentos de poluentes nas galerias de águas pluviais, medidas que evitem o depósito de folhas e plantas nos tanques, a qualidade da água pode melhorar.

\section{REFERÊNCIAS}

[1] WHO; UNICEF. Ending Preventable Child Deaths from Pneumonia and Diarrhoea by 2025. 2013, 64p. Disponível em: https://www.unicef.org/media/files/Final_GAPPD_main_Report-_EN-8_April_2013.pdf. Acesso em 25 jan. 2019.

[2] Lojanetlab. Chromocult coliform agar cromogênico 500gr Merck. Disponível em: https://www.lojanetlab.com.br/reagentes-e-meios/agar-meio-de-cultura/chromocult-coliform-agar-cromogenico500gr-merck-1104260500. Acesso em 22 set. 2020.

[3] BRASIL. Resolução CONAMA no 357, de17 de março de 2005. Dispõe sobre a classificação dos corpos de água e diretrizes ambientais para o seu enquadramento, bem como estabelece as condições e padrões de lançamento de efluentes, e dá outras providências. Brasília, 23p. 2005.

[4] BRASIL. Resolução CONAMA no 274, de 29 de novembro de 2000. Define os critérios de balneabilidade em águas brasileiras. Brasília, 3p. 2000. 


\section{Capítulo 10}

Pluviosidade histórica do município de Campina Grande-PB

\section{Edgleidson Lima Rodrigues}

Renato Francisco Cândido Lopes

Francisco de Assis Salviano de Sousa

Resumo: 0 objetivo do trabalho foi analisar a precipitação pluviométrica em campina grande, município localizado no estado da paraíba, a partir de série histórica (1994 a 2018) associado a técnicas de estatística. a partir dos dados pluviométricos analisados têm-se que o maior índice pluviométrico do acumulado total anual do período foi observado no ano de 2011 com 1494,4 mm, e o ano que apresentou o menor valor de precipitação foi 1998 com 360,8 mm. os meses que apresentaram os maiores valores de precipitação do município foram de março a julho, e o que apresentou a maior ausência de chuvas durante os 25 anos analisados foi o mês novembro. 


\section{INTRODUÇÃO}

A precipitação pluviométrica é uma das variáveis meteorológicas de maior relevância para a sociedade em decorrência de sua ação direta sobre vários aspectos e atividades associadas aos seres humanos, como a agricultura, pecuária, etc. 0 excesso ou escassez de chuvas ocasionam danos econômicos e ambientais de grande magnitude. Uma importante ferramenta que auxilia na previsão desses eventos extremos é o monitoramento diário do regime pluviométrico sobre uma dada localidade (Vianello, 1991).

O Estado da Paraíba possui cerca de $80 \%$ da sua área inserida no semiárido nordestino e apresenta alta irregularidade pluviométrica (Azevedo \& Silva, 2004). A delimitação do semiárido tem como critérios o índice pluviométrico, o índice de aridez e o risco de seca (Brasil, 2005). O Agreste paraibano é tido como uma área de transição entre a zona da mata e a zona das caatingas, com trechos quase tão úmidos como no litoral e outros secos como no sertão (Pereira et al., 2002), essa semelhança com o clima do Litoral e do Sertão revelam o quanto as chuvas nessa sub-região apresentam variabilidade espaço-temporal e dessa forma dificulta ainda mais a previsibilidade e monitoramento dos eventos de secas e chuvas no âmbito do semiárido paraibano.

Entre os anos de 1998 e 1999, a cidade de Campina Grande, localizada no Agreste Paraibano, quase entrou em colapso, por conta de eventos de seca na região, e isso seria uma situação constrangedora para a segunda maior cidade do Estado da Paraíba, apontada como um dos grandes pólos tecnológico e industrial do Nordeste.

A distribuição da precipitação está associada à interação entre a atmosfera, os oceanos e a fisiografia, como evidenciado em anos de fenômenos El Niño e La Niña e nas alterações do Dipolo do Atlântico. Além disso, é interessante salientar que de alguma forma esses fenômenos tem uma influência pontual (Cerqueira, 2010; Neto et al. 2007).

A precipitação pluviométrica no Nordeste também sofre a influência das ondas de Leste, que são áreas de instabilidade provenientes do continente africano que atravessam todo o Oceano Atlântico carregando umidade.

Assim, o objetivo deste trabalho é analisar a pluviosidade histórica do município de Campina Grande-PB durante 25 anos, utilizando o software surfer13, e partir da planilha de cálculo Excel realizar analises estatísticas.

\section{MATERIAIS E MÉTODOS}

Foram usados os totais mensais da precipitação observados na estação da Embrapa, localizada no município de Campina Grande-PB (7ํ14'S, 35ํ5'W e 552 m), região Agreste paraibana. Para destacar onde se encontra Campina Grande no mapa da paraíba utilizou-se do software Surfer13 (Figura1). Esses dados pluviométricos se encontram disponíveis na Agência Executiva de Gestão das Águas do Estado da Paraíba (AESA), que está situada na Universidade Federal de Campina Grande (UFCG). A série de dados apresenta período de registro entre os anos de 1994 e 2018. 
Figura 1. Localização geográfica da cidade de Campina Grande - PB.

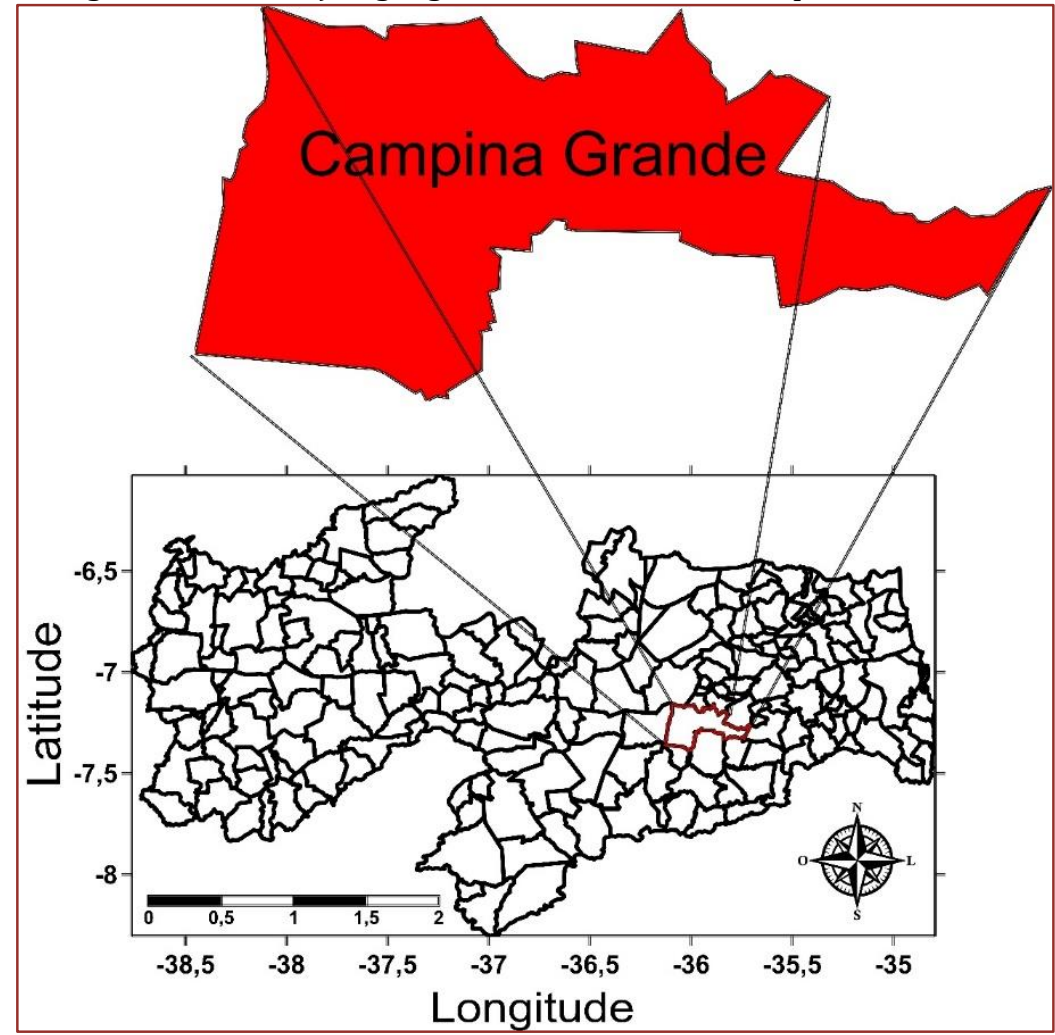

Esse estudo da precipitação pluvial da cidade de Campina Grande foi realizado com base nesses dados obtidos junto a AESA. Com base nestas séries, foram realizadas as análises estatísticas através de diversos parâmetros para o período, tais como: média, desvio padrão e coeficiente de variação. Estes métodos foram efetuados a partir da planilha de cálculo Excel.

\section{RESULTADOS E DISCUSSÃO}

A Figura-2 apresenta o acumulado total de precipitação anual observado ao longo dos 25 anos na cidade de Campina Grande, verifica-se claramente que na cidade de Campina Grande, chuvas excessivas durante os anos de análise foram verificadas em 2000, 2004 e 2011, enquanto que os menores valores de precipitação total anual são observados nos anos de 1998 e 1999, anos esses que a cidade de Campina Grande quase entrou em colapso por conta dos eventos de seca na região. Acredita-se que esse comportamento é resultante da influência direta de algum fenômeno meteorológico que atuou na cidades em estudo, gerando, portanto, o aumento e a redução da precipitação na região. 
Figura 2. Acumulado total de precipitação pluviométrica para de Campina Grande.

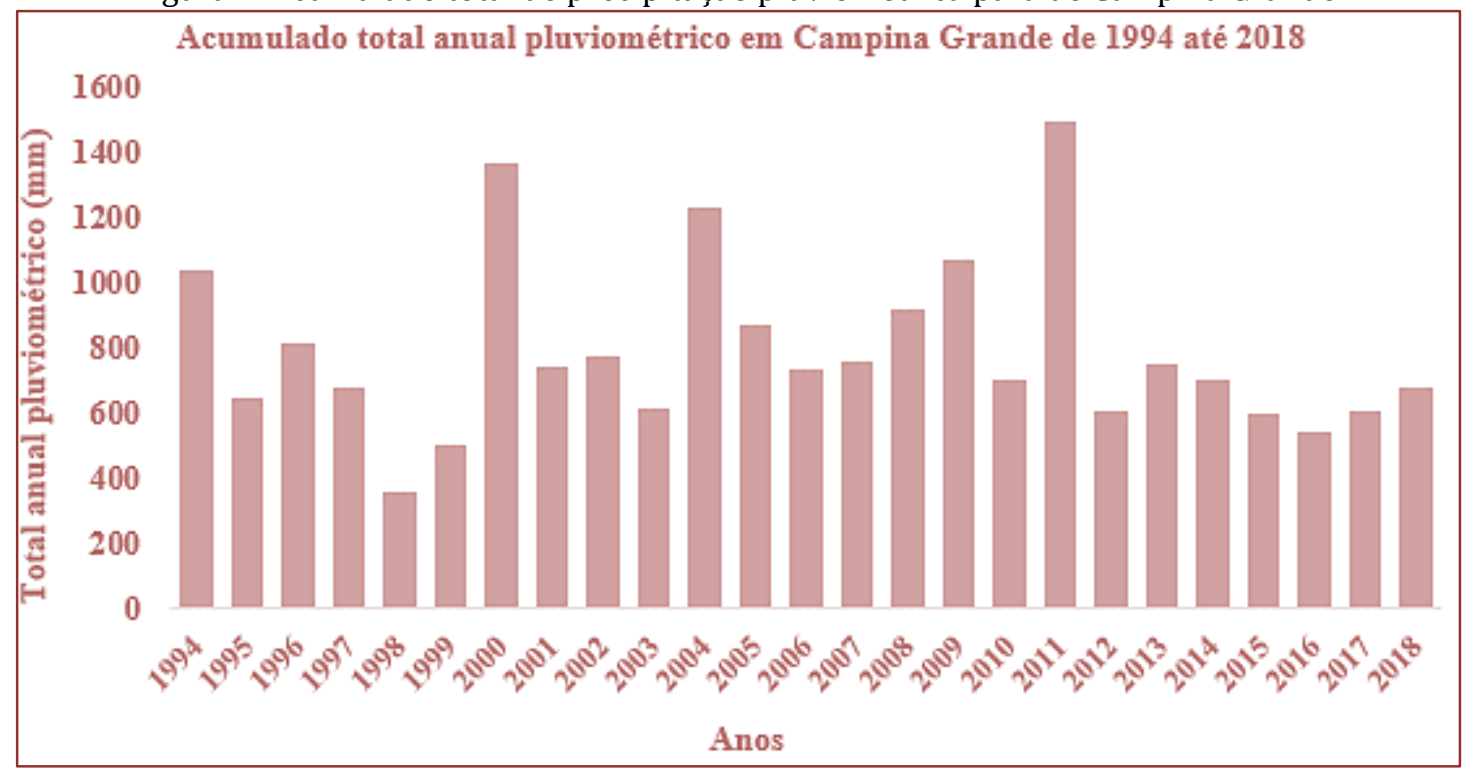

A partir dos dados dos postos pluviométricos analisados, também foi possível estabelecer parâmetros estatísticos mensais dos anos de 1994 até 2018 como os exibidos na Figura 3 e Tabela 1. A média mensal de precipitação aponta os meses de, maio, junho e julho como os mais chuvosos. Em contrapartida, os meses de setembro, outubro e novembro foram aqueles que apresentaram os menores totais de precipitação quando comparados aos demais meses analisados.

0 desvio padrão, por ser uma medida de dispersão, mostra a variação, com valores mais próximos da média, tendo sido possível constatar que o mês de junho apresentou o maior desvio padrão em relação aos demais meses.

Entre março a julho observa-se pouca diferença no coeficiente de variação (CV), pois é onde se concentra o período chuvoso, por outro lado, a partir de agosto nota-se um aumento no valor do CV devido redução do volume precipitado.

Figura 3. Médias mensais de Precipitação pluviométrica em Campina Grande.

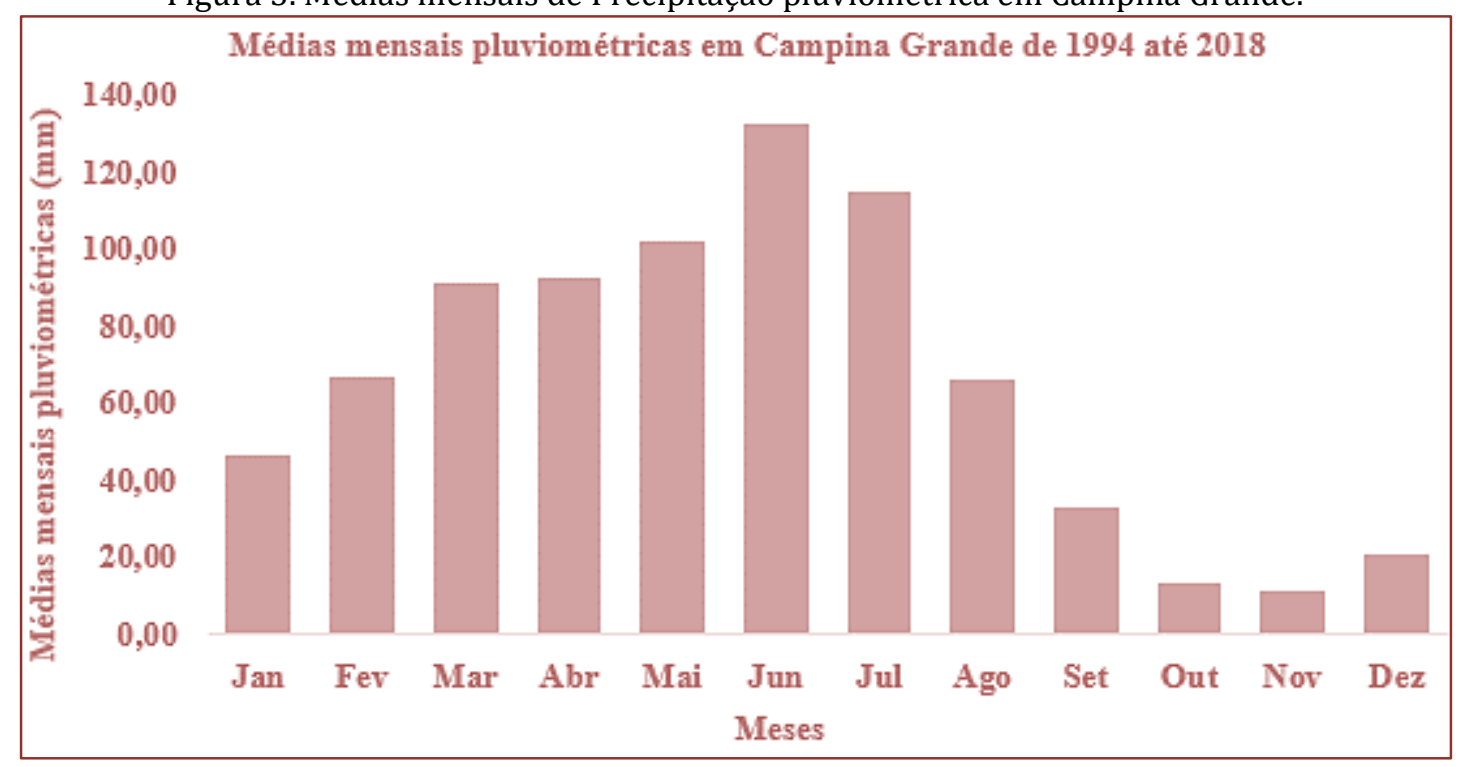


Tabela1. Parâmetros estatísticos da precipitação média mensal (mm)

\begin{tabular}{|l|c|c|c|c|}
\hline \multicolumn{1}{|c|}{ Mês } & $\mathrm{n}$ & \multicolumn{1}{c|}{ Média $(\mathrm{mm})$} & D. Padrão $(\mathrm{mm})$ & $\mathrm{CV}(\%)$ \\
\hline Janeiro & 25 & 46,82 & 56,34 & 120,35 \\
\hline Fevereiro & 25 & 66,99 & 70,62 & 105,41 \\
\hline Março & 25 & 90,99 & 54,46 & 59,85 \\
\hline Abril & 25 & 92,48 & 55,91 & 60,45 \\
\hline Maio & 25 & 101,98 & 71,04 & 69,66 \\
\hline Junho & 25 & 132,74 & 68,11 & 51,31 \\
\hline Julho & 25 & 114,93 & 67,20 & 58,47 \\
\hline Agosto & 25 & 66,19 & 44,52 & 67,27 \\
\hline Setembro & 25 & 33,22 & 35,56 & 107,04 \\
\hline Outubro & 25 & 13,17 & 11,60 & 88,08 \\
\hline Novembro & 25 & 11,57 & 16,14 & 139,56 \\
\hline Dezembro & 25 & 20,73 & 18,95 & 91,56 \\
\hline
\end{tabular}

0 presente estudo possibilitou a realização da análise da s precipitações na cidade de campina grande a partir de parâmetros estatísticos, tomando como referência a série histórica de 1994 a 2018. Constatou-se que os valores apresentados possuem grande variação em relação às médias estabelecidas devido as precipitações pluviais serem maiores nos meses do meio do ano, haja vista que o período chuvoso da cidade está compreendido entre os meses de maio e julho, eventos predominantemente causados pelas Ondas de Leste.

0 trabalho mostrou-se importante no que diz respeito à análise das precipitações, sendo esse um dos principais fatores que influenciam na vida humana e no planejamento e gestão dos recursos hídricos ao longo dos anos.

\section{CONSIDERAÇÕES FINAIS}

A análise da precipitação pluviométrica histórica para uma determinada região possibilita um melhor planejamento da agricultura, assim como de armazenamento de água de chuva, na região minimizando os impactos ocasionados pela seca que pode se prolongar por anos no semiárido.

A partir dos dados pluviométricos analisados têm-se que o maior índice pluviométrico do acumulado total anual do período foi observado no ano de $2011 \mathrm{com} 1494,4 \mathrm{~mm}$, e o ano que apresentou o menor valor de precipitação foi 1998 com 360,8 mm.

Os meses que apresentaram os maiores valores de precipitação do município foram de março a julho, e o que apresentou a maior ausência de chuvas durante os 25 anos analisados foi o mês novembro.

Percebe-se um alto nível de irregularidade na precipitação pluviométrica no município, enfatizando a importância do desenvolvimento de ações que objetivem o melhor aproveitamento da água nessa localidade. Palavras-chave: Precipitação; estatística, histórica, desvio padrão.

\section{REFERÊNCIAS}

[1] VIANELLO, R. L. Meteorologia básica e aplicações. 1aㅡ Ed. Viçosa: Imprensa Universitária, 1991. 449 p.

[2] AZEVEDO, P. V.; SILVA, V. P. R. Índice seca para a microrregião do agreste da borborema no estado da Paraíba. Revista Brasileira de Meteorologia, v.9, n.1, p. 66-72, 1994.

[3] BRASIL. Ministério da Integração Nacional/SDR. Relatório Final do Grupo de Trabalho Interministerial para Redelimitação do Semi-árido Nordestino e do Polígono das Secas. Brasília, DF, 2005. p.118.

[4] PEREIRA, I. M.; ANDRADE, L. A.; BARBOSA, M. R. V.; SAMPAIO, E. V. S. B. Composição florística e análise fitossociológica do componente arbustivo-arbóreo de um remanescente florestal no Agreste Paraibano. Acta Botânica Brasilica, v.16, n.3, p. 357-369, 2002.

[5] CERQUEIRA, H. D. V. Modulação da temperatura da superfície do mar do pacífico e atlântico tropical na precipitação no estado da Paraíba. Dissertação (Mestrado em Meteorologia) - Universidade Federal de Campina Grande, Campina Grande, 2010. 
[6] NETO, J. M. M.; BARBOSA, M. P.; ARAÚJO A. E. Efeito dos eventos ENOS e das TSM na variação pluviométrica do semi-árido paraibano. Revista Brasileira de Engenharia Agrícola e Ambiental, v.11, n.1, p.61-66, 2007.

[7] IBGE. Instituto Brasileiro de Geografia e Estatística. Cidades. Paraíba/ Campina Grande. Disponívelem:http://www.cidades.ibge.gov.br/xtras/perfil.php?lang=\&codmun=251080\&search=paraiba $\mid \mathrm{cm}$ pinagrande .Acesso em: 12 de mar. 2016. 


\section{Capítulo 11}

Características dos principais afluentes da margem esquerda da bacia do médio Rio Negro, Amazônia Central

\section{Domitila Pascoaloto \\ Núbia Abrantes Gomes \\ Hillândia Brandão da Cunha}

Resumo: 0 rio Negro é um dos quatro rios mais caudalosos da Amazônia e também o maior rio de água preta do mundo. 0 estudo foi desenvolvido na margem esquerda do médio rio Negro, em período de águas altas (vazante), no intuito de verificar se esses rios podem ser classificados como água "preta", igual ao Negro e ou de "água branca", como se acreditava ser seu maior afluente, o rio Branco, recentemente classificado como de "água clara". Foram visitados 14 sítios amostrais, incluindo os rios Negro e Branco, entre os municípios de Santa Isabel do Rio Negro e Barcelos (AM), no limite dos estados do Amazonas e de Roraima. Com esse objetivo, para cada tributário pressuposto como tendo "água clara", foi selecionado um afluente supostamente de "água preta" (identificados por imagens de satélite), com exceção dos rios Daraá, Jufari e Branco. Com base nos resultados obtidos (cor verdadeira/pH/condutividade elétrica), pode-se confirmar que os recursos hídricos mais próximos à classificação de "água clara" foram o rio Branco e o igarapé Claro, seguidos pelos tributários Jufari, Marauiá e Padauari.

Palavras-Chave: Limnologia, Rio de Água preta, Bacia Hidrográfica Amazônica 


\section{INTRODUÇÃO}

Principal afluente da margem esquerda do rio Solimões/Amazonas, o rio Negro pode ser caracterizado como o maior rio de água preta do mundo, ocupando também a quinta posição na lista dos rios com maior vazão no globo (Meade et al., 1991); sua descarga é de cerca de 4240-64380 m³/s (Guyot et al., 1994, 1996), representando até 30\% do total da contribuição da Amazônia para o oceano (Mounier et al., 1999). Com cerca de $1700 \mathrm{~km}$ de extensão, dos quais aproximadamente $1200 \mathrm{~km}$ correm em terreno brasileiro, o rio Negro nasce na serra do Junaí, na Colômbia e, por todo seu curso, até a confluência com o rio Solimões, drena áreas de baixo relevo e terrenos consolidados, o que reflete na sua velocidade e erosão (Cunha e Pascoaloto, 2009). Devido ao intenso intemperismo regional, ele transporta quantidade muito pequena de minerais e é rico em matéria orgânica, o que lhe concede sua cor escura típica marrom (Furch, 1984). A natureza geológica da área de drenagem conferiu a essas águas, além da cor, características físicas e químicas peculiares, principalmente baixa condutividade (entre 6 e $12 \mu \mathrm{S} / \mathrm{cm}$ ), pH ácido (entre 4,0 e 5,5), baixo teor de sais minerais, entre eles potássio, sódio, cálcio e magnésio (Leenher e Santos, 1980; Pascoaloto et al., 2018).

O principal tributário da margem esquerda do rio Negro é rio Branco, o qual apresenta hidroquímica diferente daquela observada no rio Negro e seus demais afluentes, principalmente no que se refere à menor acidez e coloração clara (Santos et al., 1984; Gomes et al., 2011). Ele não possui uma "nascente" propriamente dita, é formado a partir da confluência de dois rios, Uraricoera (com nascente próximo à fronteira da Venezuela onde ocorrem algumas serras do lado brasileiro, com fontes que dão origem a nascente do rio Parima, que na Serra de Pacaraima, no planalto das Guianas, muda de direção e passa a ser denominado rio Uraricoera; esse rio é divisor de águas entre as bacias hidrográficas Amazônica e do Orinoco) e Tacutu (com nascente na Serra do Acaraí - fronteira Brasil/Guiana, no limite entre os Municípios de Caroebe, Caracaraí e Bonfim no Brasil e cidade de Lethem, na Guiana) (RadamBrasil, 1975). Ambos os formadores apresentam águas menos ácidas e condutividade elétrica mais elevada do que as águas do rio Negro, embora não significativamente diferentes entre si (Santos et al., 1985); no entanto, o teor de sólidos em suspensão é mais elevado no rio Uraricoera em relação ao Tacutu (Gomes et al., 2011). De fato, os rios Uraricoera e Tacutu drenam terrenos geologicamente distintos. Enquanto o Uraricoera drena terrenos do cenozóico (planalto das Guianas - com terrenos cristalinos), o Tacutu está no gráben do Tacutu, que possui um arcabouço estrutural de caráter predominantemente distensivo correspondente a um rifteintracontinetal implantado no Mesozóico, numa zona de reativação do domínio Guiana Central, enquanto ao longo do Terciário Inferior foram depositados os sedimentos arenosos da Formação Boa Vista em ambientes de água rasas (CPRM, 1999).

Os afluentes da margem esquerda do médio rio Negro apresentam declividade que favorece a instalação de hidrelétricas, projeto idealizado na época do governo militar e com projetos para instalação desde o início da década de 2000 (ANEL, 2005; IHU, 2011; Fearnside, 2015).

Impressionados com a biodiversidade encontrada em algumas microbacias hidrográficas na margem esquerda do médio rio Negro, onde a tonalidade da água dos principais tributários indicava se tratarem de rios de água clara (enquanto o Negro é de água preta) alguns pesquisadores do INPA resolveram investigar esses rios, incluindo o estudo limnológico, onde seria avaliado se esses tributários se assemelhariam mais ao rio Branco ou se seriam mais semelhantes ao rio Negro. 0 presente trabalho apresenta os resultados dessa investigação em relação à qualidade da água desses tributários.

\section{MATERIAL E MÉTODOS}

0 estudo foi realizado em 14 sítios amostrais (Tabela 1, Figuras 1-2), ao longo de duas semanas em período de águas altas (início da vazante). As variáveis ambientais investigadas, as técnicas analíticas e suas referências encontram-se na Tabela 2. Uma vez que a excursão durou 15 dias, foram realizadas no barco as determinações de oxigênio dissolvido e demanda bioquímica de oxigênio, bem como a filtração das amostras. Foram feitas no local de coleta as determinações de temperatura da água, $\mathrm{pH}$ e condutividade elétrica. As amostras para as determinações das demais variáveis foram mantidas resfriadas (em caixa de isopor com gelo) até serem transportadas para o Laboratório de Química Ambiental (LQA - CODAM/INPA). 
A transparência da água foi determinada com disco de Secchi (média de cinco medidas), a partir de cujo valor foi determinado o coeficiente vertical de atenuação (K) (Esteves, 2011), a partir da equação:

$$
\mathrm{K}=1,7 /(\mathrm{Zds})
$$

Onde:

Zds = profundidade do disco de Secchi

$1,7=$ constante calculada.

Tabela 1. Locais de estudo

\begin{tabular}{|c|c|c|c|c|c|}
\hline \multirow{2}{*}{ Local } & \multirow{2}{*}{ Referência } & \multirow{2}{*}{ Microbacia } & \multirow{2}{*}{ Município } & \multicolumn{2}{|c|}{ Coordenadas } \\
\hline & & & & Latitude & Longitude \\
\hline 1 & Rio Marauiá & \multirow{3}{*}{ rio Marauiá } & \multirow{5}{*}{$\begin{array}{c}\text { Santa Isabel do } \\
\text { Rio Negro }\end{array}$} & $-0,3164$ & $-65,1203$ \\
\hline 2 & Encontro Marauiá/paraná & & & $-0,3925$ & $-65,2021$ \\
\hline 3 & Igapó - Igarapé Juradir & & & $-0,3795$ & $-65,2102$ \\
\hline 4 & Rio Negro - Mont. Rio Daraá & (curso principal - rio Negro) & & $-0,4818$ & $-64,8006$ \\
\hline 5 & Rio Daraá & rio Daraá & & $-0,3857$ & $-64,7897$ \\
\hline 6 & Rio Padauarí & \multirow{2}{*}{ rio Padauari } & \multirow{9}{*}{ Barcelos } & $-0,1344$ & $-64,0664$ \\
\hline 7 & Rio Preto & & & $-0,1071$ & $-64,1245$ \\
\hline 8 & Rio Aracá & \multirow{2}{*}{ rio Demeni } & & $-0,3676$ & $-62,9636$ \\
\hline 9 & Rio Demeni & & & $-0,3959$ & $-62,8764$ \\
\hline 10 & Lago B Jufari & \multirow{2}{*}{ rio Jufari } & & $-0,1045$ & $-62,1328$ \\
\hline 11 & Igarapé Claro & & & $-0,9721$ & $-62,1123$ \\
\hline 12 & Negro Jus. Rio Branco & (curso principal - rio Negro) & & $-13,945$ & $-61,8375$ \\
\hline 13 & Rio Branco & Branco & & $-13,167$ & $-61,8693$ \\
\hline 14 & Negro Mont. Rio Branco & (curso principal - rio Negro) & & $-13,938$ & $-61,8605$ \\
\hline
\end{tabular}

Para a análise do balanço iônico e gráficos dos cátions e íons os valores foram convertidos para meq.l-1. Para cálculo das médias os valores de pH de cada amostra foram convertidos para antilog na base 10 (concentração de $\mathrm{H}+$ na solução) e depois expressos em -log ${ }^{\left({ }^{+}\right)}$. A análise hidroquímica quanto ao íon das amostras foi feita com auxílio do programa Qualigraf_2017 (FUNCEME), de uso livre.

Figura 1: Localização dos sítios amostrais na margem esquerda do médio Rio Negro. Legendas dos locais conforme Tabela 1. (Organizada por Domitila Pascoaloto)

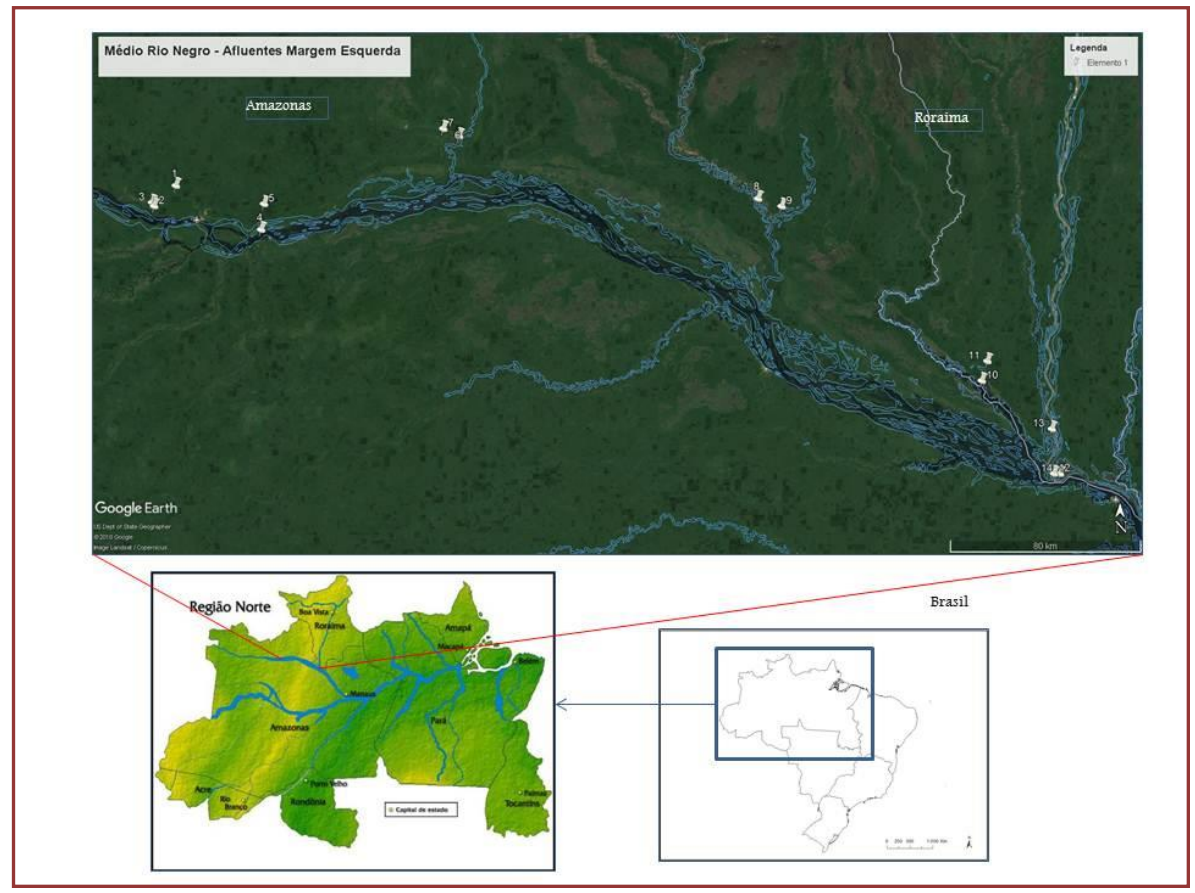


Figura 2: Configuração de alguns dos sítios amostrais.

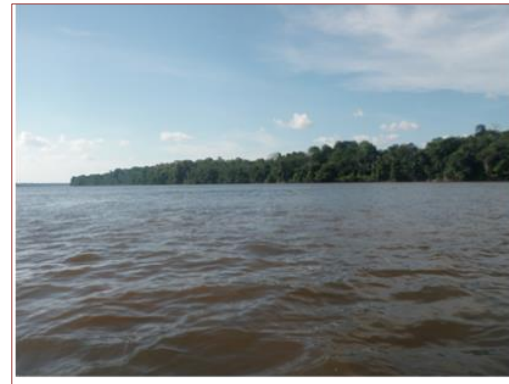

Rio Branco

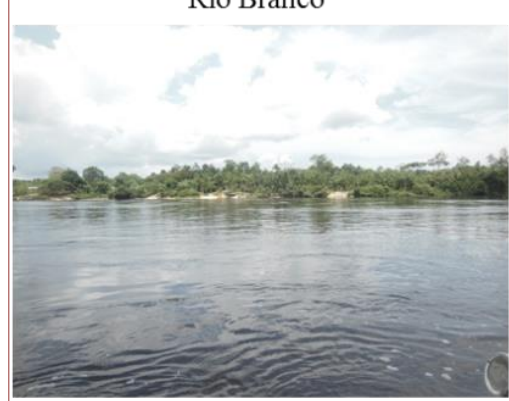

Rio Marauiá

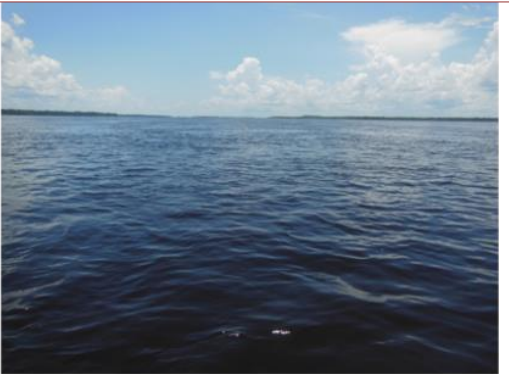

Rio Negro - Montante Daraá

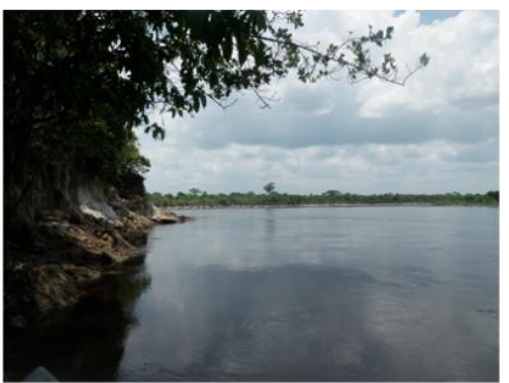

Rio Demeni

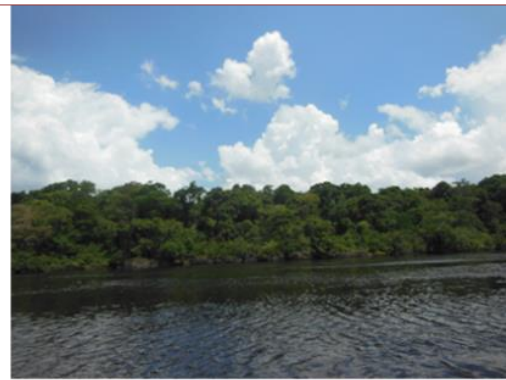

Rio Daraá

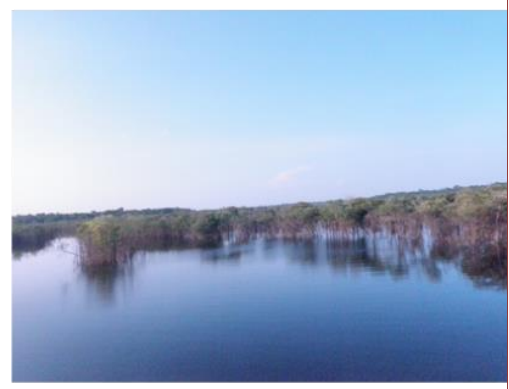

Rio Jufari (área lacustre)

(Organizada por Domitila Pascoaloto)

Tabela 2. Variáveis ambientais e técnicas analíticas utilizadas

\begin{tabular}{|c|c|c|}
\hline VARIÁVEL AMBIENTAL & TÉCNICA ANALÍTICA & UNIDADE \\
\hline $\mathrm{pH}$ & Direto, Potenciométrico & \\
\hline Condutividade Elétrica (CE) & Direto, Potenciométrico & $\mu \mathrm{S} / \mathrm{cm}$ \\
\hline Oxigênio Dissolvido (OD) & Standard Methods (Rice, 2012), Titulométrico & $\mathrm{mg} / \mathrm{L}$ \\
\hline Demanda Bioquímica de Oxigênio (DBO) & Standard Methods (Rice, 2012), Titulométrico & $\mathrm{mg} / \mathrm{L}$ \\
\hline Alcalinidade & Standard Methods (Rice, 2012), Potenciométrico & $\mathrm{mg} \mathrm{H}_{2} \mathrm{CO}_{3}-/ \mathrm{L}$ \\
\hline Turbidez & Standard Methods (Rice, 2012), Nefelométrico & NTU \\
\hline Cor verdadeira & Standard Methods (Rice, 2012), Espectrofotométrico & mg Pt/L \\
\hline Sólidos totais em suspensão (SST) & Standard Methods (Rice, 2012), Gravimétrico & $\mathrm{mg} / \mathrm{L}$ \\
\hline Demanda Química de Oxigênio (DQO) & Standard Methods (Rice, 2012), Refluxo Aberto & $\mathrm{mg} / \mathrm{L}$ \\
\hline Carbono Inorgânico (PNOC) & Standard Methods (Rice, 2012), Oxidação úmida & $\mathrm{mg} / \mathrm{L}$ \\
\hline Cátions $\mathrm{Na}^{+} \mathrm{K}^{+} \mathrm{Ca}^{+} \mathrm{Mg}^{++} \mathrm{NH}_{4}^{+}$ & Standard Methods (Rice, 2012), Fotometria de Chama & $\mathrm{mg} / \mathrm{L}$ \\
\hline Ânions $\left(\mathrm{HCO}_{3}^{-} \mathrm{CO}_{3}^{-} \mathrm{NO}_{3}^{-} \mathrm{Cl}^{-} \mathrm{PO}_{4}^{--}\right.$ & Standard Methods (Rice, 2012), Fotometria de Chama & $\mathrm{mg} / \mathrm{L}$ \\
\hline $\mathrm{Si}(\mathrm{OH})_{4}$ & Standard Methods (Rice, 2012), Titulométrico & $\mathrm{mg} / \mathrm{L}$ \\
\hline N-Total & Valderrama (1980), Espectrofotométrico & $\mathrm{mg} / \mathrm{L}$ \\
\hline P-Total & Valderrama (1980), Espectrofotometria & $\mathrm{mg} / \mathrm{L}$ \\
\hline
\end{tabular}

\section{RESULTADOS E DISCUSSÃO}

O local mais transparente (com maior zona eufótica) foi o sítio amostral 12 (rio Negro a montante do Rio Branco (Figura 3), o que provavelmente esteve relacionado à influência do rio Jufari (de água cristalina e com forte correnteza, o que reduz a quantidade de sólidos totais em suspensão na água do rio Negro em área de influência) sobre as águas do Negro; de fato, os práticos que dirigem embarcações na região evitam a foz do rio Jufari, preferindo acessar o canal do rio por meio de paranás. Ressalta-se que, apesar da margem esquerda do rio Jufari se encontrar integralmente no estado de Roraima (esse rio faz divisa entre os estados de Roraima e Amazonas), praticamente não estudos nessa bacia hidrográfica, o que, provavelmente, está relacionado à dificuldade de acesso e navegação em sua bacia. Ressalta-se que durante a excursão foi necessário que o comandante da nossa embarcação fosse até a comunidade para contratar um prático pois, mesmo com o recurso de utilizar um GPS náutico, estávamos com dificuldade de acessar a região da bacia selecionada para o estudo; essa também foi a razão de nossa equipe não ter resultados sobre um igarapé de "água escura" nessa bacia. 
Devido à entrada do Rio Branco (o qual apresenta maior carga de sólidos totais do que o rio Negro), acredita-se que o sítio amostral 14 seria aquele com menor zona eufótica, no entanto, por questões logísticas, não foi possível verificar a transparência com o disco de Secchi nesse local.

Figura 3: Zona eufótica nos locais de estudo.

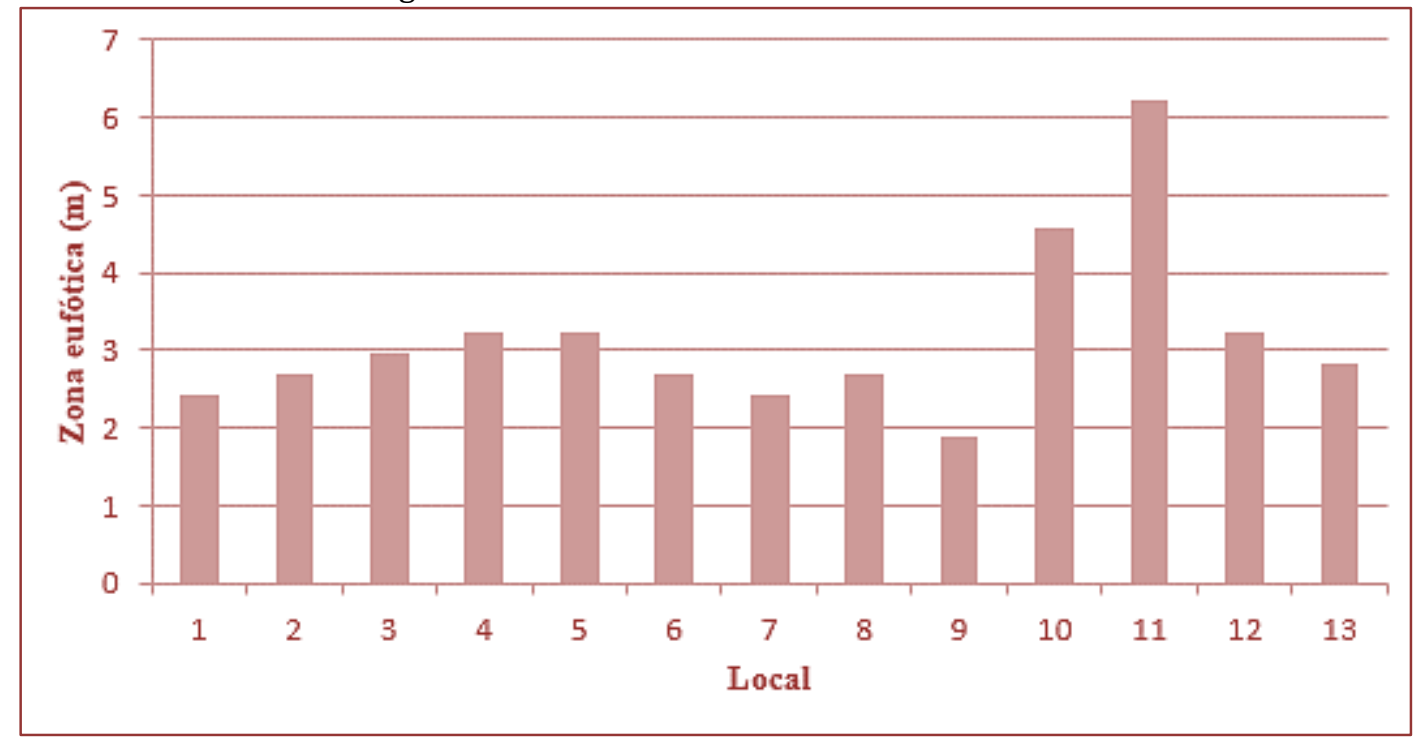

(Legendas dos locais conforme Tabela 1).

Os resultados das amostras de água analisadas no LQA/INPA podem ser observados na figura 4. Os sítios amostrais 12 e 14 (Rio Branco, a montante e a jusante do rio Negro) não foram incluídos, a fim de que os dados do rio Negro sem a interferência do rio Branco (ou do Jufari) pudessem ser utilizados como referência (ver linhas de referência para os rios Negro e Branco para cada gráfico na figura 4). Ressalta-se que as características do rio Negro mudaram após a entrada do rio Branco, principalmente quanto ao $\mathrm{pH}$ (4,66 e 6,00, respectivamente), cor verdadeira (146,2 e 54,57 mgPt.l-1) e alcalinidade $\left(3,66\right.$ e 9,76 $\mathrm{mgHCO}_{3}^{-}$ .$^{-1}$ ). Não foi possível coletar água para medir o carbono orgânico (NPOC) no sítio amostral 13, mas pode-se notar a redução desse componente do sítio amostral 4 para o 12 (11,98 e 9,59 mgCO2.1-1), sendo que o valor registrado para o rio Branco foi o mais baixo $\left(3,01 \mathrm{mgCO}_{2} . \mathrm{l}^{-1}\right)$. Ressalta-se que também oi possível observar algumas alterações na qualidade da água do rio Negro (sítio amostral 12) após a entrada do rio Jufari (em cuja bacia hidrográfica se encontram os sítios amostrais 10 e 11), como: redução do valor da DQO (58,03 $\mathrm{mgO}_{2} . \mathrm{l}^{-1}$ no sítio amostral 4 para $47,94 \mathrm{mgO}_{2} . \mathrm{l}^{-1}$ no amostral 12 ) e aumento do silicato (de 1,678 para 2,03 $\mathrm{mgSiO}_{4} . \mathrm{l}^{-1}$ ), sugerindo que as águas do rio Negro também são afetadas por outros rios de água clara e por essa razão não é correto afirmar que todas as mudanças verificadas na água do Rio Negro em estudos realizados a jusante da foz do rio Branco sejam decorrentes unicamente desse tributário (com exceção da condutividade elétrica e sólidos totais, variáveis que de fato apresentam valores mais elevados do que aqueles observados em outros tributários, em estado natural, na bacia do rio Negro).

A classificação hidroquímica (Figura 5) da maioria dos locais foi água bicarbonatada sódica, com exceção do sítio amostral 4 (magnesiana cloretada) e dos sítios amostrais 5, 8 e 9 (sódica cloretada). Os três sítios amostrais do rio Negro (4,12 e 14) apresentaram classificações diferentes, sendo bicarbonatada magnesiana que no segmento mais a montante (município de Santa Isabel do Rio Negro) e bicarbonatada sódica nos outros dois sítios amostrais (município de Barcelos). Ressalta-se que apenas os rios Negro (no trecho localizado em Santa Isabel do Rio Negro) e Preto (sítios amostrais 4 e 7, respectivamente) apresentaram magnésio como cátion predominante e apenas o rio Negro, após a confluência com o rio Branco (sítio amostral 14), apresentou característica mista em relação aos cátions. Os dados diferem daqueles registrados por Santos et al. (1984), que encontraram potássio e sódio como íons dominantes nas bacias do médio e baixo rio Negro. 
Figura 4: Qualidade da água nos sítios amostrais na margem esquerda do médio Rio Negro em relação ao Rio Negro (sítio amostral 4) e Rio Branco (sítio amostral 13).

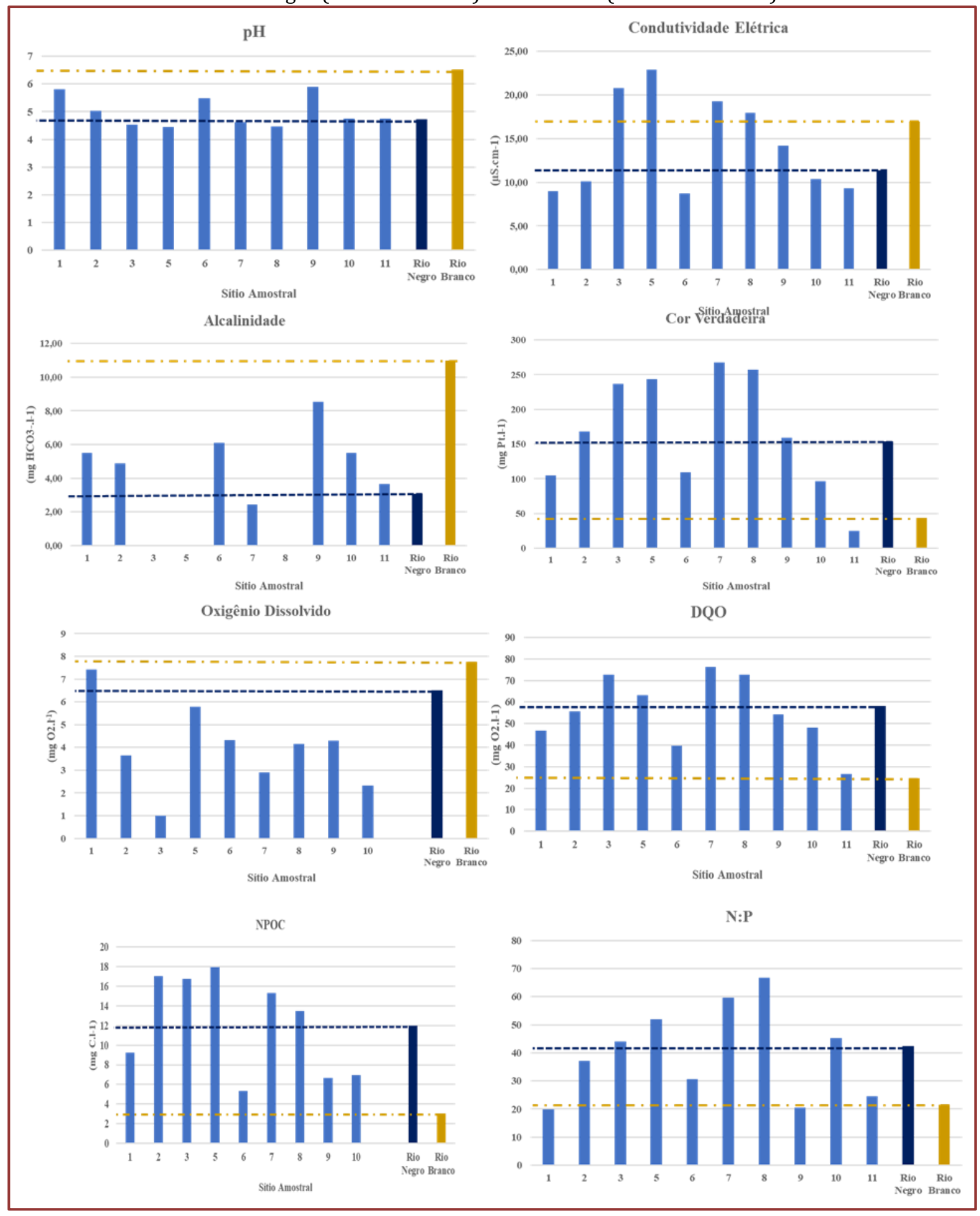

(Legendas dos locais conforme Tabela 1). 
Figura 5: Diagrama de Piper (classificação hidroquímica).

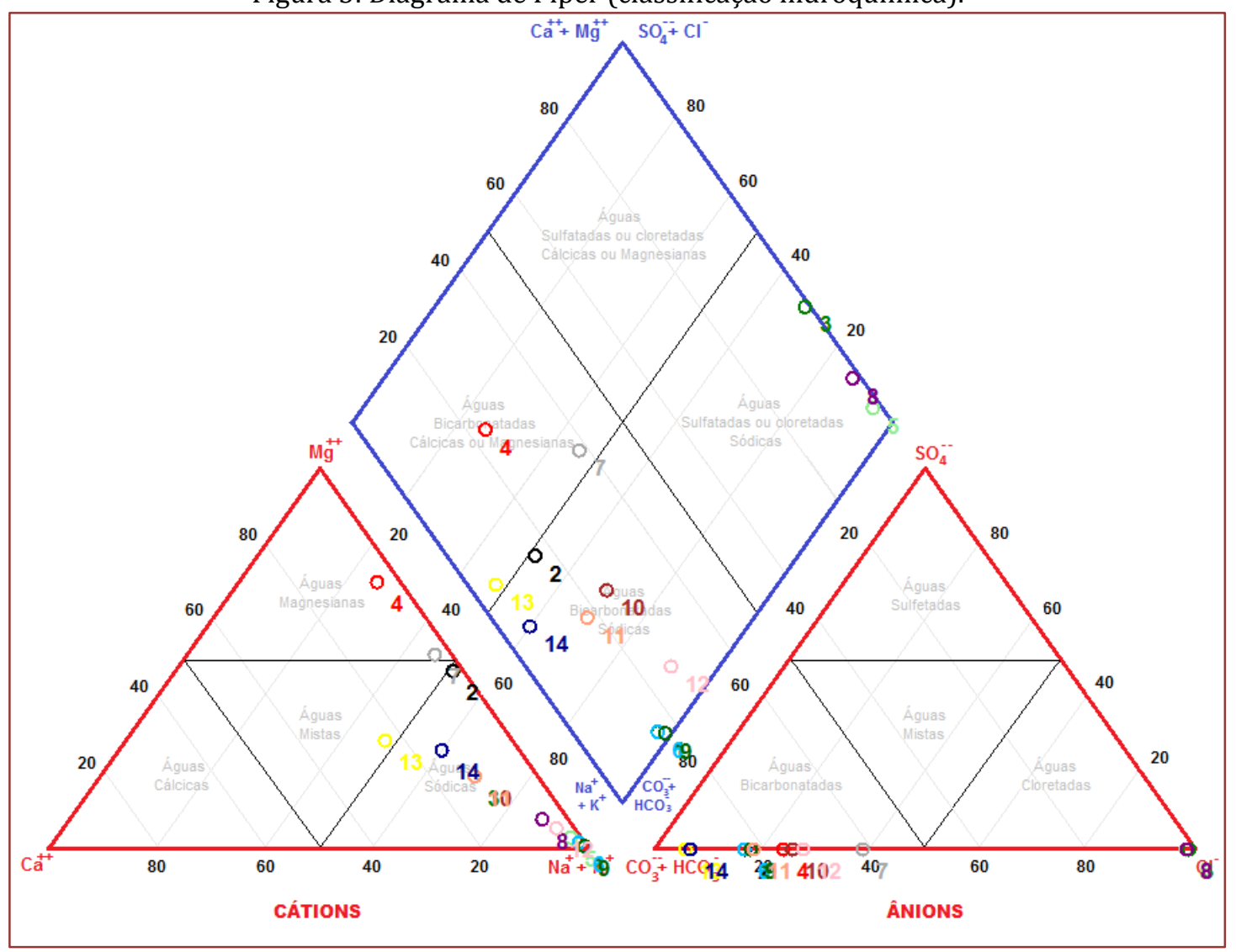

(Legendas dos locais conforme Tabela 1).

Embora existam autores que se refiram ao rio Branco como sendo de "água branca" (ex.: Sioli, 1984; Santos et al., 1985), nossos resultados corroboram com aqueles que o definem como sendo de água clara, ou, ocasionalmente, mista (ex.: Silva et al., 2015); classificação essa que vem sendo pouca aceita pelos pesquisadores da Amazônia, que ainda preferem a definição clássica "água branca", "água preta" e "água clara", seguindo a classificação de Sioli (1950), por ser mais facilmente compreendido ("visualizado") pela população em geral. No entanto é importante ressaltar que, segundo os trabalhos supra citados de Sioli, o que define um rio de "água preta" é sua água (ainda que numa pequena amostra) apresentar cor "de café", e não a aparente tonalidade escura que se possa se perceber em sua superfície (enquanto a amostra da água se apresenta incolor ou com tonalidade referente apenas às partículas em suspensão, principalmente algas), como acontece em muitos rios de água clara, como, por exemplo, o rio Trombetas (Pascoaloto et al., 2012).

\section{CONCLUSÃO}

Não foi possível diferenciar os rios supostamente de água clara com seus afluentes supostamente de água preta com base na classificação hidroquímica; de fato, o próprio rio Negro apresentou classificações diferentes em cada um dos sítios amostrais investigados. A concentração dos cátions e do somatório dos íons carbonato e bicarbonato após a confluência com o rio Branco foi, inclusive, superior àquela observada no próprio rio Branco, fato esse que pode estar relacionado aos depósitos de areia presentes a jusante do sítio amostral nesse rio, depósitos esses que são visíveis em foto de satélite até próximo à Manaus, chegando a interferir na cor d’água entre as ilhas da margem esquerda do arquipélago de Anavilhanas (Novo Airão/AM).

Nossos resultados também evidenciaram a interferência do rio Branco sobre a qualidade da água do rio Negro, servindo de alerta para que, na caracterização geral do rio Negro, esse ambiente seja sempre tratado à parte, para não interferir na média do rio Negro em termos de gestão (dando margem a que substâncias poluentes sejam lançadas sem que isso interfira no intervalo do parâmetro observado em regiões naturais). 
Por fim, os resultados indicaram que dos quatro tributários investigados podem ser considerados de "água clara" o rio Jufari, de água preta (com características observadas no alto rio Negro), o rio Daraá (bem como os seguinte tributários: igarapé Juradir e rios Preto e Aracá, afluentes dos rios Marauiá, Padauari e Demeni, respectivamente). Os demais rios estudados apresentaram características mais semelhantes às do rio Negro no município de Santa Isabel do rio Negro (início do trecho médio da bacia), principalmente o rio Demeni.

Sugerem-se para a região estudos sistemáticos ao longo de, no mínimo, dois anos hidrológicos com séries históricas deverão ser feitos para melhor gestão deste recurso.

\section{AGRADECIMENTOS}

À FAPEAM, ao CNPq, à FINEP, ao MCTIC/INPA pelo suporte financeiro e/ou logístico que permitiram este trabalho. Aos técnicos do LQA/INPA pelas análises das amostras de água, especialmente a Walter Jorge e Maria Carmendes pelo apoio em campo e análises da amostras durante a expedição. Ao colega Dr. Efrem Ferreira, pelo convite para participarmos dessa expedição e a todos os membros das outras equipes e à tripulação da embarcação "Victória Amazônica” pelo poio durante a expedição.

\section{REFERÊNCIAS}

[1] ANEEL - Agência Nacional de Energia Elétrica (2005). Atlas de energia elétrica do Brasil. 2ª ed. ANEEL Brasília-DF, 243 p.

[2] CPRM - Serviço Geológico do Brasil. (1999). "Roraima Central: Folhas NA.20-X-B e NA.20-X-C, NA.21-V-A e NA.21-V-C (Parciais). Estado de Roraima. Escala 1:500.000", in: Programa Levantamentos Geológicos Básicos do Brasil PLGB. CPRM, Brasília (disponível em <cprm.gov.br/publique/Geologia/Geologia basica/Projeto-Roraima_central562.html>).

[3] CUNHA. H.B.; PASCOALOTO, D. (2009). "Hidroquímica dos rios da Amazônia”. CCPA, Manaus, 160p.

[4] ESTEVES. F. A (2011). "Fundamentos de limnologia”, 2ª Ed. - Rio de Janeiro : Interciência, 790p.

[5] FEARNSIDE, PHILIP M. (2015). Tropical hydropower in the clean development mechanism: Brazil?s Santo Antônio Dam as an example of the need for change. Climatic Change, 131 (4): 575-589.

[6] FURCH, K. (1984). "Water chemistry of the Amazon basin: the distribution of chemical elements among freshwaters", in The Amazon. Org. por Sioli, H., Springer, Netherlands, pp. 167-199.

[7] GOMES, N. A.; SILVA, M. S. R.; PINTO, A.G.N.; CUNHA, H. B.; BRINGEL, S.B.; PASCOALOTO, D. (2011). "Hidroquímica do rio Branco e outros afluentes do rio Negro/Roraima-Brasil" in Anais eletrônicos do XIX Simpósio Brasileiro de Recursos Hídricos, Maceió, Nov. 2000, pp. 1-8.

[8] GUYOT, J.L., FILIZOLA N., GUIMARÃES, V.S. (1996). Quinta campanha de medições de vazão e amostragem de água e sedimentos na bacia do rio Negro e no rio Amazonas. Publ. HiBAm, Brasília, 59p. 1996.

[9] GUYOT, J.L.; GUIMARÃES, V.S.; SANTOS, J.B.R.; LONGUINHOS, R.S.; CONCEIÇÃO, S. (1994). Primeira campanha de medições de vazão com ADCP (correntômetro com efeito Doppler) no Rio Amazonas. Publ. HiBAm, Brasília, 29 p. 1996.

[10] IHU - Instituto Humanidas Unisinos. (2011). "Hidrelétricas na bacia hidrográfica do rio Branco". Revista IHU on line. Disponível em <http://www.ihu.unisinos.br/noticias/39883-hidreletricas-na-bacia-hidrografica-do-riobranco>, acessado em 20/05/2018.

[11] LEENHER, J.A.; SANTOS, U. M. (1980). “Considerações sobre os processos de sedimentação na água preta ácida do rio Negro (Amazônia Central)". Acta Amazônica 10 (2), pp. 343-355.

[12] MEADE, R.H.; RAIOL, J.M.; CONCEIÇÃO, S.C.; NATIVIDADE, J.R.G. (1991). "Back water effects in the Amazon River Basin". Environ. Geol. Water Sci. 8 (2), pp. 105-114.

[13] MOUNIER, S.; BRAUCHER, M, R.; and BENAÎ̀, J. Y. (1999). "Differentiation do organic matter's properties of the rio Negro basin by cross-flow ultra-filtration and UV-spectrofluorescence”. Wat. Res. 33 (10), pp. 2363-2373.

[14] PASCOALOTO, D.; SILVA, M. L. ; MIRANDA, S. A. F. (2012). Tópicos em Recursos Hídricos: uma abordagem para professores dos ensinos fundamental e médio na Amazônia. Editora INPA, Manaus, 143 p.

[15] PASCOALOTO, D.; SOARES, C.C.; GOMES, N.A. (2018). "Qualidade da água e macroalgas em recursos hídricos na área urbana de Manaus/AM". In: Anais do XII Encontro Nacional de Águas Urbanas, Maceió, Nov. 2018, pp.1-10.

[16] RADAMBRASIL (1975). "v. 8 - Folha NA.20 Boa Vista e partedasfolhas NA.21 Tumucumaque, NB.20 Roraima e NB. 21", in: Levantamento de Recurso naturais. Projeto RADAMBRASIL. DNPM/MME, Brasília - DF, v. 8. 509 p. 
[17] RICE, E.W.; BAIRD, R.B.; EATON, A.D., CLESCERI, L.S. (2012). "Standard Methods for Examination of Water and Wastewater" (org). 22 a ed. American Public Health Association - APHA, American Water Works Association AWWA e Water Environment Federation - WEF, Maryland, 1496 p.

[18] SANTOS, U. M.; BRINGEL, S. R. B.; RIBEIRO, M. N. G.; SILVA, M. N. P.(1985). "Rios da Bacia Amazonica II. Os afluentes do rio Branco". Acta Amazonica 15 (1-2), pp. 147-156.

[19] SANTOS, U.M.; BRINGEL, S.R.B.; BERGAMIN FILHO, H,; RIBEIRO, N. M. G.; BANANEIRA, M. (1984). "Rios da Bacia Amazônica I. Afluentes do rio Negro". Acta Amazonica 141 (2), pp. 222-237.

[20] SILVA, M. S. R. ; CUNHA, H. B. ; MIRANDA, S. A. F. ; GOMES, N. A. ; PASCOALOTO, D. ; SANTANA, G. P. (2015). "Recursos hídricos da Amazônia: uma classificação dos tipos de águas segundo a carga iônica-Brasill". In: Anais Eletrônicos do XXI Simpósio Brasileiro de Recursos Hídricos, Brasília, Nov. 2015, pp. 1-8.

[21] SIOLI, H. (1950). "Das Wasser in Amazonasgebiet". Fortschr. 26, pp. 274-280.

[22] SIOLI, H. (1984). "The Amazon and its main affluents: Hydrography, morphology of the river courses, and river types". In: The Amazon. Limnology and landscape ecology of a mighty tropical river and its basin. Ed. por Sioli, H., Monogr. Biol. 56. Dr. W. Junk Publ., Dordrecht. pp. 127-165.

[23] VALDERRAMA, J.C. (1980). "The simultaneous analysis of total nitrogen and total phosphorus in natural waters". Mar. Chem. 10, pp. 109-122. 


\section{Capítulo 12}

Efeito da redução da vazão de restrição defluente da Barragem de Xingó na salinidade da água no baixo trecho do Rio São Francisco

\section{Sândira Lívia Moraes Fonseca}

Aline Almeida de Jesus Magalhães

Vânia Palmeira Campos

Yvonilde Dantas Pinto Medeiros

Resumo : Entre os parâmetros de qualidade da água sujeitos a alterações com mudanças no fluxo do rio, a salinidade se destaca por ser intrinsicamente associada à qualidade do ecossistema. No entanto, a salinização pode causar danos irreversíveis à estrutura e função das comunidades aquáticas. Este trabalho avaliou o efeito das sucessivas reduções de vazões defluentes da barragem de Xingó na salinidade da água, no baixo trecho do rio São Francisco, Brasil. Analisou-se a salinidade a jusante da barragem, a relação entre as reduções de vazões defluentes e a salinidade, além da evolução espacial da salinidade, em função da distância dos pontos amostrais até a foz. Dados secundários de qualidade da água de 17 pontos de monitoramento foram analisados, além da realização de coletas de campo e análises em laboratório. Com as reduções das vazões defluentes, a partir de 2013, houve considerável aumento da salinidade no ponto amostral distante da foz $9 \mathrm{~km}$, e com a continuidade das reduções de vazões, pontos mais afastados da foz apresentaram valores elevados de salinidade, tanto no fundo quanto na superfície Este estudo indica valores de salinidade acima dos limites de água doce (0,5 \%o), estabelecido pela Resolução 357 do CONAMA, para consumo humano

Palavras-chave: Cunha salina, Estuário, Rio São Francisco, vazão defluente de barragem

Artigo foi publicado originalmente na Revista Brasileira de Recuros Hidricos em inglês: https://www.scielo.br/scielo.php?script=sci arttext\&pid=S2318-03312020000100209. 


\section{INTRODUÇÃO}

A alteração de fluxo dos rios é o fator que mais impacta os ecossistemas (GEDDES e BUTLER, 1984; ATTRILL et al., 1996; BUNN e ARTHINGTON, 2002), uma vez que a redução de seu fluxo possui grande efeito na dinâmica dos estuários, afetando grandes grupos de organismos, desde as plantas até os peixes, inclusive facilitando a introdução de espécies invasoras, como mudanças repentinas na aglomeração de plantas e animais (JUNK et al., 1989, POFF et al., 1997; LUNDQVIST, 1998; AL-TAANI, 2014). Entre as consequências da alteração das vazões de rios, destaca-se a salinidade que está entre os principais parâmetros suscetíveis de sofrer alterações (OLIVEIRA, 2003; ALMEIDA e SILVA JUNIOR, 2007; MEDEIROS et al., 2008; OLIVEIRA et al., 2008; KINGSFORD e HANKIN, 2010; SILVA et al., 2015; KHANOM, 2016; AL-NASRAWI et al., 2016; CAMPO et al., 2016; CHEEK e TAYLOR, 2016; WEDDERBURN et al., 2016).

A salinidade é um componente abiótico fundamental em todos os corpos d'água e fator crítico das características do estuário (MIRANDA et al., 2002). A variação sazonal da salinidade nos estuários é controlada pelo fluxo de água doce dos rios, podendo exercer impactos na manutenção do equilíbrio do ecossistema (ALBER 2002; BATE et al., 2002; GILLANDERS e KINGSFORD, 2002; WHITFIELD 2005; ZHANG et al., 2011). A biota aquática possui diferenças de preferência de faixas de salinidade, sendo comumente classificada nessas faixas (KEFFORD, et al., 2012; SCHRÖDER, et al., 2015).

Diversos autores têm relatado os efeitos negativos da salinização da água nos ecossistemas aquáticos (WILLIAMS, 1987; PISCART et al., 2005; WHITFIELD, 2005; KEFFORD et al., 2012; SCHRÖDER, et al., 2015; WEDDERBURN et al., 2016). 0 deslocamento na isohalina, por exemplo, causado por alterações de fluxo da água doce, interfere na distribuição da vegetação enraizada e de organismos sésseis, surtindo assim efeitos em toda cadeia alimentar aquática (ALBER, 2002). Estudos de DIMAGGIO et al., (2016) mostram resultados experimentais indicando que a sobrevivência de embriões e larvas de arenque de rio pode ser possível em áreas de influência de maré, a depender da fase de desenvolvimento e da taxa de exposição à salinidade. Outro estudo, realizado por CHEEK E TAYLOR (2016) no baixo trecho do rio Pecos, Texas, confirmou que a variação temporal em grupos de peixes sofreu uma mudança acentuada ao longo de um intervalo de tempo de 24 anos. As mudanças distributivas foram relacionadas com a intolerância ao aumento da salinidade.

De acordo com GHASSEMI et al. (1995) apud BLINN et al. (2004) a salinização tem o potencial de causar danos irreversíveis à estrutura e à função das comunidades aquáticas em regiões áridas e representa uma das maiores ameaças aos rios e zonas úmidas. SCHRÖDER et al. (2015) afirma que algumas espécies são tão sensíveis ao aumento dos níveis de salinidade, que chega a diminuir ou até mesmo desaparecer da população.

Algumas pesquisas exemplificam o efeito das mudanças de faixas de salinidade na biota aquática, por exemplo, em relação aos macroinvertebrados, PISCARTet al. (2005) verificaram que a contaminação permanente de sal afeta a estrutura das comunidades de macroinvertebrados bentônicos com o desaparecimento de vários táxons a partir de uma salinidade maior do que 1,4 g L-1.SCHRÖDER, et al. (2015) analisaram o efeito da poluição salina nas comunidades de macroinvertebrados e diatomáceas do rio Lippe, Alemanha. Seus resultados indicaram que ambos os macroinvertebrados e diatomáceas sofreram uma mudança distinta na composição com condutividade entre 900 e $1000 \mathrm{~S}$ cm-1. Já ZINCHENKO E GOLOVATYUK (2013) indicaram que o nível crítico de salinidade para o desenvolvimento de hidrobiontes em rios em diferentes regiões áridas varia de 10 a 15 g L-1.

KEFFORD et al. (2012) buscaram determinar se as tolerâncias de salinidade das comunidades de macroinvertebrados e grupos taxonômicos diferiam entre as regiões. Eles estudaram, utilizando o mesmo método, amostras de águas doces no leste da Austrália, França, Israel e África do Sul, porém não foram encontradas evidências de tolerância generalizada à salinidade nos diversos táxons.

Existe certa dificuldade em afirmar com certeza as faixas gerais de salinidade onde ocorrem mudanças específicas nas diversas espécies que compõem a biota aquática, pois além de haver grande variedade de tolerância à salinidade entre as espécies (SCHRÖDER et al., 2015; ZINCHENKO E GOLOVATYUK, 2013; KEFFORD et al., 2012), outros fatores interferem, por exemplo, o tempo de salinização a qual a região está submetida (KEFFORD et al., 2012). Além do mais, estudos sobre a interferência da salinidade na biota aquática são raros, desta forma, os efeitos da salinização nos ecossistemas fluviais são poucos conhecidos (PISCART et al., 2005; BAILEY et al., 2006; KEFFORD et al., 2012; SCHRÖDER et al., 2015). KEFFORD et al. (2012) salienta ainda que os dados de sensibilidade à salinidade pouco existentes são produtos de metodologias distintas, o que impede uma compreensão clara dos efeitos da salinização na biota aquática, visto que a sensibilidade à salinidade depende também do método utilizado. 
Sob o ponto de vista dos impactos às populações humanas, mudanças na faixa de salinidade das águas podem comprometer os usos, consuntivos e/ou não consuntivos, como por exemplo, abastecimento humano e pesca de comunidades ribeirinhas.

A salinização pode ocorrer pelo aumento da evaporação, em função de altas temperaturas ambientais, lançamento de resíduos, mas, principalmente, pela intrusão salina causada pelo avanço do nível do mar, devido a mudanças climáticas e ações humanas. Diversos autores constataram que o aumento de salinidade da água de rios pode estar relacionado com a intervenção e operação de reservatórios construídos para gerar energia elétrica e também atender a outros usos, como irrigação, abastecimento humano e navegação (SILVA et al., 2015; AL-NASRAWI et al., 2016; CAMPO et al., 2016; CHEEK e TAYLOR, 2016; KHANOM, 2016; WEDDERBURN et al., 2016).

A implantação e/ou operação de reservatórios dessa natureza geram vários impactos na bacia, por exemplo: interferência nos processos sedimentológicos (MEDEIROS et al., 2007), alteração na configuração da dinâmica e da morfologia da foz (OLIVEIRA 2003; FELIPPE et al., 2009), alteração do pulso de inundação (JUNK, et al., 1989; POFF e WARD, 1989; CALLISTO et al., 2009) e modificação do regime fluvial e alteração do comportamento hidráulico (GENZ, 2006; GRAF, 2006).

Os sistemas ambientais a jusante de reservatórios são também prejudicados em decorrência da sua implantação (BRANDT, 2005; GENZ, 2006; GRAF, 2006; BACHMAN e RAND, 2008; ROBINSON e UEHLINGER, 2008; LIMA et al., 2010; KINGSFORD e HANKIN, 2010), podendo ocorrer alteração da qualidade da água, destacando-se entre os diversos parâmetros, a salinidade (GENZ, 2006; PINHEIRO e MORAES, 2010; RAHMAN et al. 2011).

É importante ressaltar que operar um reservatório ou um conjunto de reservatórios significa utilizar regras, baseadas no volume do reservatório ou na vazão defluente estabelecida para determinado intervalo de tempo (LOUCKS et al., 1981). Essas regras são específicas para o atendimento a níveis de água e liberação de determinada quantidade de água a jusante, a fim de atender aos usos ou objetivos de gestão hídrica da bacia hidrográfica, operação esta que enfrenta grandes desafios em épocas de estiagem ou de crise hídrica.

Neste contexto, o rio São Francisco, de grande importância para o Brasil, principalmente no que se refere à produção de energia e disponibilidade de água doce para o Nordeste brasileiro (CAMPOS, 1995), possui um sistema de barragens em cascata para atendimentos múltiplos. Entretanto, os níveis de água nos reservatórios têm sofrido diminuição devido a uma intensa seca, iniciada em 2012 (ANA, 2017).

0 nível de chuvas na região diminuiu consideravelmente nos trechos alto e médio do rio São Francisco, regiões que mais contribuem com as vazões na bacia. Diante desta situação, foi necessário operar o sistema de forma a manter os reservatórios com acúmulo de água suficiente para atendimento da demanda aos usos múltiplos da bacia. Por conseguinte, os órgãos ambientais responsáveis (ANA e IBAMA), autorizaram a partir do ano de 2013, sucessivas reduções da vazão defluente nos reservatórios de Sobradinho e Xingó, no médio e baixo trecho do rio (ANA, 2017). Desde então surgiram na região do baixo trecho, queixas da população ribeirinha, relativas ao aumento da salinidade da água (CBHSF, 2016).

Nesse sentido, este estudo buscou avaliar o efeito no comportamento da salinidade a jusante do reservatório de Xingó, em decorrência das sucessivas reduções das vazões defluentes resultantes da operação dos reservatórios na bacia do rio São Francisco, buscando (1) analisar o comportamento da salinidade durante o período de 2008 a 2017, nas marés de quadratura e de sizígia; (2) avaliar a influência da sazonalidade na salinidade; (3) analisar a relação entre a redução da vazão defluente do reservatório e a salinidade, possibilitando perceber o comportamento temporal e espacial da salinidade no baixo trecho do rio São Francisco.

Os estudos sobre a salinidade das águas dos rios podem subsidiar a tomada de decisão na gestão dos recursos hídricos, de forma a contribuir para a proteção da população ribeirinha e a conservação do ecossistema.

\section{MATERIAIS E MÉTODOS}

\section{1. ÁREA DE ESTUDO}

A área de estudo estende-se da estação fluviométrica de Piranhas (CHESF), a jusante da barragem de Xingó, situada entre Sergipe e Alagoas até a foz do rio São Francisco com uma extensão de aproximadamente $200 \mathrm{~km}$ inclusos o trecho fluvial e o trecho estuarino, cuja área incremental é 29866,5 
$\mathrm{km}^{2}$ (Figura 1). De acordo com OLIVEIRA et al. (2008) o trecho estuarino do rio São Francisco estende-se cerca de $75 \mathrm{~km}$ a partir da foz.

As seções escolhidas no trecho longitudinal (Figura 1a) foram baseadas em pesquisas realizadas no baixo trecho da bacia do rio São Francisco iniciadas com a rede Ecovazão, uma rede de pesquisa composta por universidades federais, com o objetivo principal de estabelecer um regime de vazão ambiental para o baixo trecho do Rio São Francisco.

As mesmas seções no trecho longitudinal, numeradas de montante para jusante, foram trabalhadas no Projeto "Hidrograma Ecológico e Modelagem Quali-Quantitativa de Bacias" (HIDROECO), financiado pela FINEP, cujo objetivo foi desenvolver hidrogramas ambientais para diferentes bacias hidrográficas brasileiras, inserido no qual, o subprojeto "Avaliação dos Impactos Hidrológicos da Implantação do Hidrograma Ambiental do baixo rio São Francisco" (AIHA), com a participação de pesquisadores da UFBA, trabalhou na adequação da metodologia Building Block Methodology (BBM) para avaliação do hidrograma ambiental (KING et al., 2008).

O presente trabalho está inserido dentro do subprojeto AIHA, com acréscimo de novos pontos amostrais, PAs, no estuário (Figura 1d) para o estudo do comportamento da salinidade no contexto das reduções das vazões defluentes na barragem de Xingó.

Figura 1. Localização da área de estudo: Baixo trecho do rio São Francisco com as seções no trecho fluvial (a). Baixo trecho na bacia do rio São Francisco (b). Bacia do rio São Francisco no Brasil, América do Sul (c). Pontos no estuário (d).

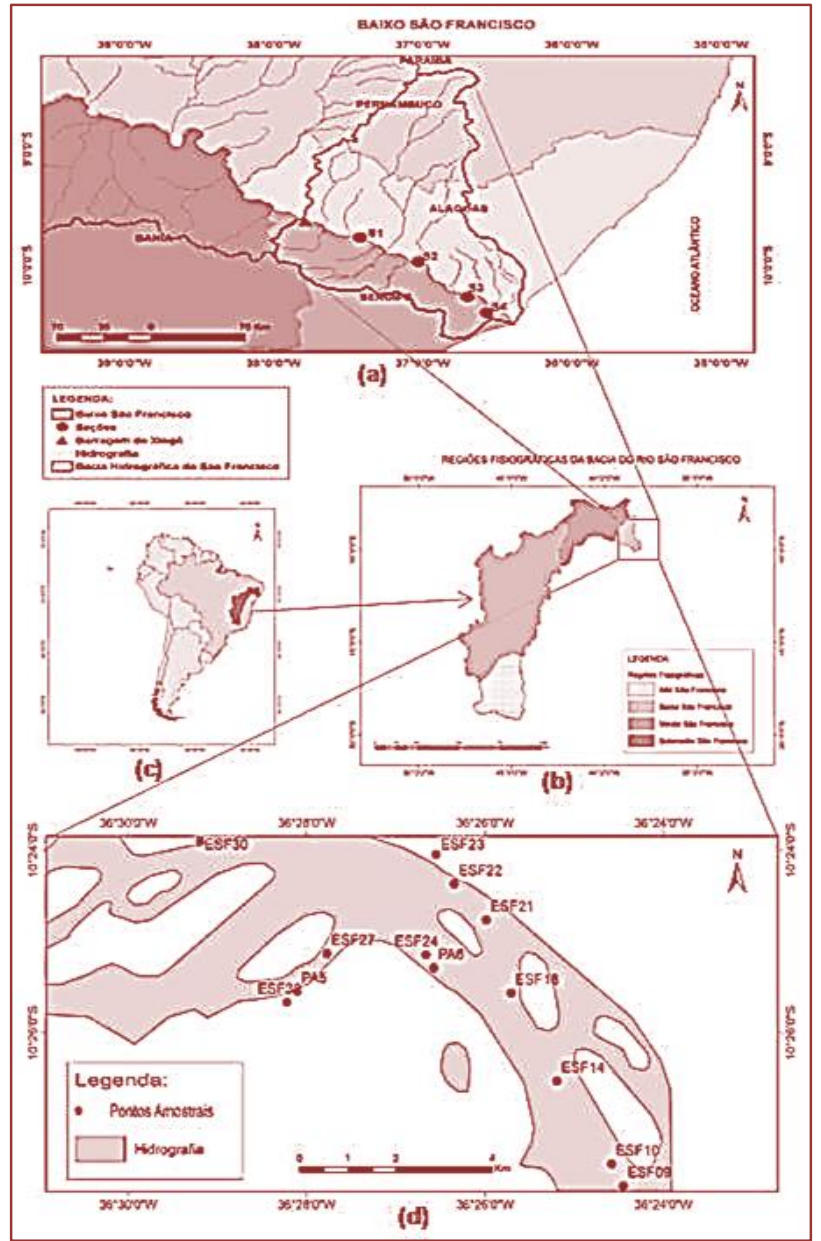

Nas Tabelas 1 e 2 estão representados as seções no trecho fluvial e os pontos estudados no estuário, respectivamente. 
Tabela 1. Informações sobre os trechos do rio com seus respectivos pontos de amostragem: Baixo Rio São Francisco.

\begin{tabular}{|c|c|c|c|c|c|c|}
\hline \multirow{2}{*}{ Seção } & \multirow{2}{*}{$\begin{array}{c}\text { Distância até a foz } \\
\text { do rio } \\
(\mathrm{km})\end{array}$} & \multirow{2}{*}{ Localização } & \multirow{2}{*}{ Posição } & \multirow{2}{*}{$\begin{array}{c}\text { Ponto de } \\
\text { Amostragem }\end{array}$} & \multicolumn{2}{|c|}{ Coordenadas } \\
\hline & & & & & Leste & Norte \\
\hline 1 & 160,2 & Niterói-SE - Pão de Açúcar-AL & \multirow{4}{*}{ Meio da seção } & PA1 & 672559,0 & 8920766,0 \\
\hline 2 & 102,3 & Gararu-SE - Traipu-AL & & PA2 & 720484,0 & 8896277,0 \\
\hline 3 & 54,6 & Pindoba-SE - Xinaré-AL & & PA3 & 750928,0 & 8863884,0 \\
\hline 4 & 21,6 & Ilha das Flores-SE - Penedo-AL & & PA4 & 770148,0 & 8846167,0 \\
\hline
\end{tabular}

Tabela 2. Informações sobre o trecho estuarino, com seus respectivos pontos de amostragem. Localização Baixo Rio São Francisco.

\begin{tabular}{|c|c|c|c|c|c|c|}
\hline \multirow[b]{2}{*}{ Seção } & \multirow{2}{*}{$\begin{array}{l}\text { Distância até a } \\
\text { foz d, rio } \\
(\mathrm{km})\end{array}$} & \multirow[b]{2}{*}{ Localização } & \multirow[b]{2}{*}{ Posição (banco) } & \multirow[b]{2}{*}{$\begin{array}{c}\text { Ponto de } \\
\text { Amostragem }\end{array}$} & \multicolumn{2}{|c|}{ Coordenadas } \\
\hline & & & & & Leste & Norte \\
\hline \multirow{2}{*}{5} & \multirow{2}{*}{15,5} & \multirow{13}{*}{$\begin{array}{l}\text { Brejo Grande-SE- } \\
\text { Piaçabuçu-AL }\end{array}$} & Esquerdo & ESF32 & 776957,0 & 8846188,0 \\
\hline & & & Direito & ESF30 & 775210,2 & 8849445,5 \\
\hline 6 & 15,2 & & Esquerdo & PA5 & 777165,0 & 8846404,0 \\
\hline 7 & 14,4 & & Esquerdo & ESF27 & 777790,5 & 8847161,2 \\
\hline 8 & 11,8 & & Direito & ESF23 & 780041,1 & 8849149,3 \\
\hline \multirow{2}{*}{9} & \multirow{2}{*}{11,0} & & Esquerdo & ESF24 & 779811,0 & 8847124,0 \\
\hline & & & Direito & ESF22 & 780404,0 & 8848550,0 \\
\hline \multirow{2}{*}{10} & \multirow{2}{*}{10,5} & & Esquerdo & PA6 & 779969,0 & 8846856,0 \\
\hline & & & Direito & ESF21 & 781052,0 & 8847816,0 \\
\hline 11 & 9,3 & & \multirow{4}{*}{ Meio da seção } & ESF18 & 781549,0 & 8846336,0 \\
\hline 12 & 7,3 & & & ESF14 & 782474,0 & 8844550,0 \\
\hline 13 & 5,3 & & & ESF10 & 783580,0 & 8842864,0 \\
\hline 14 & 4,3 & & & ESF09 & 783816,0 & 8842421,0 \\
\hline
\end{tabular}

\subsection{ANÁliSE DA EVOLUÇÃo DAS REDUÇõES DE VAZÕES DEFLUENTES A JUSANTE DO RESERVATÓRIO DE XINGÓ}

Os dados de vazão diária foram fornecidos pela Chesf, que é responsável pela manutenção e operação das estações. 0 posto fluviométrico de Piranhas foi escolhido por ser o mais próximo de Xingó, devendo representar melhor as vazões defluentes do reservatório. Apresentou-se graficamente a vazão defluente diária entre os anos de 1994, início de operação do reservatório, até o mês de maio de 2017, período final deste estudo. Para compreensão da influência da operação do reservatório no comportamento da salinidade da água, foram estudados dois períodos de tempo: antes e depois das consecutivas reduções de vazões defluentes, de 2008 a 2010 e de 2013 a maio de 2017, respectivamente e para visualizar a distribuição dos valores de vazão utilizada para o período do estudo construiu-se gráfico boxplot com as vazões ocorridas no período.

\subsection{ANÁLISE DA VARIAÇÃO TEMPORAL E ESPACIAL DA SALINIDADE NO TRECHO ESTUARINO}

Os dados secundários de salinidade usados (superfície e fundo) foram extraídos de relatórios de monitoramento da qualidade de água da CHESF, referentes a cinco campanhas de medição, distribuídas nos anos de 2008 a 2010, perodo anterior às reduções de vazões, e nos anos de 2013 a 2017, período das reduções das vazões defluentes.

\subsection{ESTUDO NO TRECHO DE REFERÊNCIA}

Inicialmente foi estudado o trecho no estuário que vai de 4,8 $\mathrm{km}$ até 9,3 $\mathrm{km}$ de distância até a foz. Nesse trecho existem dez pontos amostrais (ESF09 a ESF18), monitorados pela CHESF. A fim de representar a variação da salinidade em todo o período estudado, construiu-se um gráfico boxplot com os dados de todos estes pontos, incluindo todos os valores de salinidade nas marés de quadratura e sizígia. Após esta 
análise, dentre os dez pontos amostrais, foram escolhidas três seções para representar o trecho de referência: a seção 13, por onde passa o ponto amostral ESF10, distante da foz 5,3 Km; a seção 12, por onde passa o ponto amostral ESF14, distante da foz 7,3 Km; e a seção 11, por onde passa o ponto amostral ESF18, distante da foz $9,3 \mathrm{Km}$. Neste trecho fez-se todo o estudo, sempre comparando o período antes e após a redução de vazão. 0 estudo no trecho de referência serviu para subsidiar a avaliação do avanço da cunha salina nas seções mais afastadas da foz.

No trecho de referência foram realizadas as seguintes análises:

- Análise segundo o período de medição: os dados foram separados por período de medição na maré de quadratura e na maré de sizígia

- Análise da influência da sazonalidade: distribuição dos valores de salinidade nos períodos úmido e seco na preamar de sizígia.

- Análise da relação entre as reduções das vazões defluentes e a salinidade da água no trecho de referência: para tanto, os dados de salinidade na preamar de sizígia foram relacionados com as vazões medidas na estação fluviométrica de Piranhas. Foi aplicado o teste de significância sobre o valor do $r_{s}$, coeficiente de determinação de Spearman, para verificar se havia correlação significativa ao nível de confiança de $95 \%$ ( $<$ < 5\%) entre as vazões defluentes diárias e os valores de salinidade (superfície e fundo) nos pontos ESF10, ESF14 e ESF18.

- Análise do comportamento e do avanço da cunha salina no trecho estuarino: para tanto, considerou-se seções numeradas nos respectivos pontos de referência ESF 10, ESF 14, e ESF 18, passando a partir daí, toda a análise de salinidade, a ser realizada por seção; nesse caso, foram utilizadas as seções 11, 12 e 13, que representam as seções que passam pelos pontos ESF 18, ESF 14, e ESF 10, respectivamente. Foi feito um gráfico de linhas da salinidade na superfície das três seções, antes e depois das reduções de vazão, chegando-se à extensão do avanço da cunha salina. Foi realizada também uma análise da salinidade na seção 11 (ESF18), para referenciar o estudo nas seções mais distantes da foz.

\subsection{LEVANTAMENTO DE DADOS PRIMÁRIOS}

A campanha no estuário ocorreu nos dias 27 e 28 de maio de 2017, quando foram realizadas medições fixas de 10 a 12 horas nas seções 6 e 10.

Foram medidos os parâmetros: sólidos totais dissolvidos $\left(\mathrm{mg} \mathrm{L}^{-1}\right)$, condutividade $\left(\mu \mathrm{S} \mathrm{cm}^{-1}\right)$, salinidade (\%o), pH e temperatura $\left({ }^{\circ} \mathrm{C}\right)$ com sensor multiparamétrico. A profundidade foi estimada por meio de corda amarrada a uma âncora e medido com uma trena.

Com o objetivo de validar as medições de campo, a cada hora foram coletadas e acondicionadas amostras da superfície, meio e fundo, além de serem realizadas medições in loco dos parâmetros já mencionados. As amostras foram levadas a laboratório e analisadas para condutividade e sólidos totais dissolvidos aleatoriamente, a fim de comparar com as medidas feitas in loco.

Em posse dos resultados, calculou-se a salinidade pela seguinte equação, obtida da investigação feita por WILLIAMS (1986) em 109 amostras de lagos salino australiano e sua aplicação aos dados deste trabalho apresentou bons resultados:

$$
S=\left(C^{1,0878}\right) * 0,4665
$$

Onde:

$\mathrm{S}=$ salinidade em $\mathrm{g} \mathrm{L}^{-1}(\%)$

$\mathrm{C}=$ condutividade em $\mathrm{mS} \mathrm{cm}^{-1}$ a $25^{\circ} \mathrm{C}$.

A fim de conferir as medições no condutivímetro foram realizadas medidas aleatórias dos sólidos totais dissolvidos (STD) em amostras dos pontos amostrais PA5 e PA6. Neste caso, a salinidade foi obtida exatamente, em partes por mil (\%o ou $\left.\mathrm{g} \mathrm{L}^{-1}\right)$, dividindo-se o valor dos STD por mil:

$$
\mathrm{S}=\mathrm{STD}\left(\mathrm{mg} \mathrm{L}^{-1}\right) / 1000
$$


Foi feita uma correlação com os dados de salinidade obtidos com as medidas de condutividade e de sólidos totais dissolvidos e aos resultados de condutividade obtidos em laboratório e em campo foi aplicado o teste de significância sobre o coeficiente $\left(\mathrm{r}_{\mathrm{s}}\right)$ de Spearman. A condutividade em bancada e in loco deram correlação positiva significativa $(p<0,05)$ com $R$ igual a 0,97 .

\subsection{ANÁLISE DA VARIAÇÃO TEMPORAL E ESPACIAL DA SALINIDADE NO TRECHO FLUVIAL}

Neste trecho foi realizada apenas análise de dados primários. A campanha ocorreu nos dias 25/04 a 28/04 de 2017. Foram realizadas medidas duas vezes ao dia (maré baixa e maré alta) em três profundidades (superfície, meio e fundo) no meio das quatro seções definidas no âmbito do projeto AIHA (2017), sendo as seções 4, 3, 2 e 1 de jusante para montante e os pontos amostrais PA4, PA3, PA2 e PA1 nas localidades mostradas na tabela 1 , compreenderam o trecho longitudinal.

Foram medidos os parâmetros sólidos totais dissolvidos $\left(\mathrm{mg} \mathrm{L}^{-1}\right)$, condutividade $\left(\mu \mathrm{S} \mathrm{cm}^{-1}\right)$, salinidade $(\%)$, pH e temperatura $\left({ }^{\circ} \mathrm{C}\right)$ com sensor multiparamétrico. A profundidade foi estimada por meio de corda amarrada a uma âncora e medido com uma trena.

Os resultados de salinidade são apresentados de jusante para montante, isto é, dos pontos mais próximos para os mais afastados da foz no trecho estuarino.

\section{RESULTADOS E DISCUSSÃO}

\subsection{ANÁLISE DA EVOLUÇÃO DAS VAZÕES DEFLUENTES A JUSANTE DO RESERVATÓRIO DE XINGÓ}

Antes da construção dos reservatórios na bacia do rio São Francisco, as vazões naturais do rio atingiam limites inferiores na faixa de $900 \mathrm{~m}^{3} \mathrm{~s}^{-1}$ no período seco, a $8000 \mathrm{~m}^{3} \mathrm{~s}^{-1}$ no período úmido, alcançando picos máximos de $15000 \mathrm{~m}^{3} \mathrm{~s}^{-1}$. Com o rio já regularizado, antes da construção da barragem de Xingó, a última do sistema, a vazão média mensal natural do rio foi reduzida para $2980 \mathrm{~m}^{3} \mathrm{~s}^{-1}$ (CHESF 1992). Com o início da operação do reservatório de Xingó em 16 de dezembro de 1994, a vazão mínima defluente era de 1300 $\mathrm{m}^{3} \mathrm{~s}^{-1}$.

A fim de visualizar claramente a dimensão da variação das vazões antes e depois das reduções, construiuse o gráfico boxplot com a distribuição das vazões defluentes diárias nos anos que abrangem o período deste estudo (Figura 2).

Figura 2. Distribuição da vazão defluente diária $\left(\mathrm{m}^{3} \mathrm{~s}^{-1}\right)$ na estação fluviométrica de Piranhas no período do estudo. Rio São Francisco, janeiro de 2008 a maio de 2017

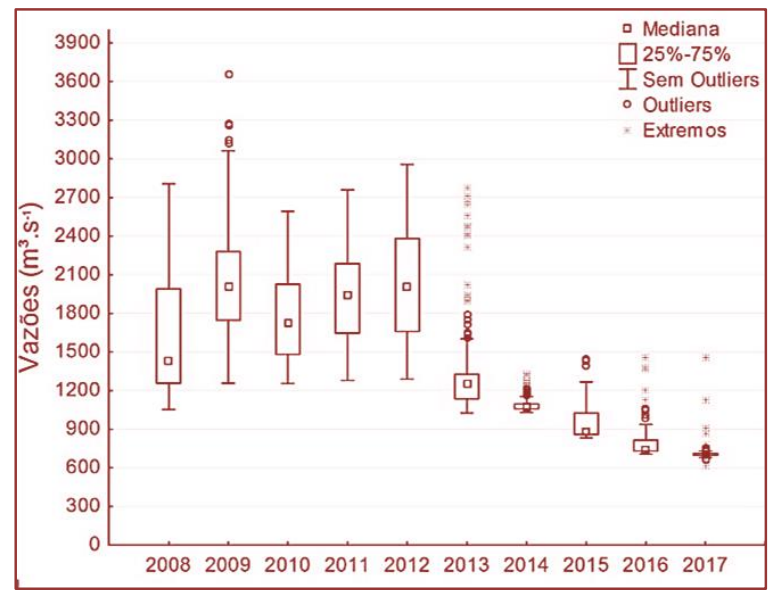

Como pode ser observado na Figura 2, os valores medianos da vazão se concentraram entre 1200 e 2400 $\mathrm{m}^{3} \mathrm{~s}^{-1}$, nos anos de 2008 a 2012, anos de operação sem redução da vazão de restrição mínima; e de 600 a $800 \mathrm{~m}^{3} \mathrm{~s}^{-1}$ nos anos de 2013 a maio de 2017, período da operação com vazões reduzidas (Figura 2). Assim, os valores medianos da vazão defluente sofreram redução em quase 50\% no período de 2008 a 2017 , reduzindo de forma considerável o forçante fluvial do rio, este que é um importante fator no equilíbrio salino no estuário e sua redução faz prevalecer o forçante da maré, o que favorece o avanço da cunha salina. A operação com vazão defluente reduzida de Xingó foi mantida até o fim do ano de 2018. De acordo 
com com estudos realizados, mudanças nas vazões do rio podem resultar em alterações na qualidade da água, especialmente na salinidade (GENZ, 2006; PINHEIRO e MORAES, 2010; RAHMAN et al. 2011).

\subsection{ANÁLISE DA VARIAÇÃO TEMPORAL E ESPACIAL DA SALINIDADE NO TRECHO ESTUARINO}

\subsubsection{DISTRIBUIÇÃO DA SALINIDADE NOS PERÍODOS 2008-2014 E 2013-2017}

Buscando compreender a distribuição da salinidade na superfície e do fundo, nos períodos de 2008a 2010 e 2013 a 2017, em todos os pontos monitorados, ao longo do trecho de referência do estudo (do ponto ESF09, distante 4,8 km da foz, ao ponto ESF18, distante 9,3 km da foz), foi construído o diagrama boxplot apresentado na Figura 3.

Figura 3. Distribuição de salinidade (\%o) na superfície e no fundo durante a maré de quadratura e sizígia ao longo do trecho de referência. Rio São Francisco, 2008-2010 e 2013-2017.

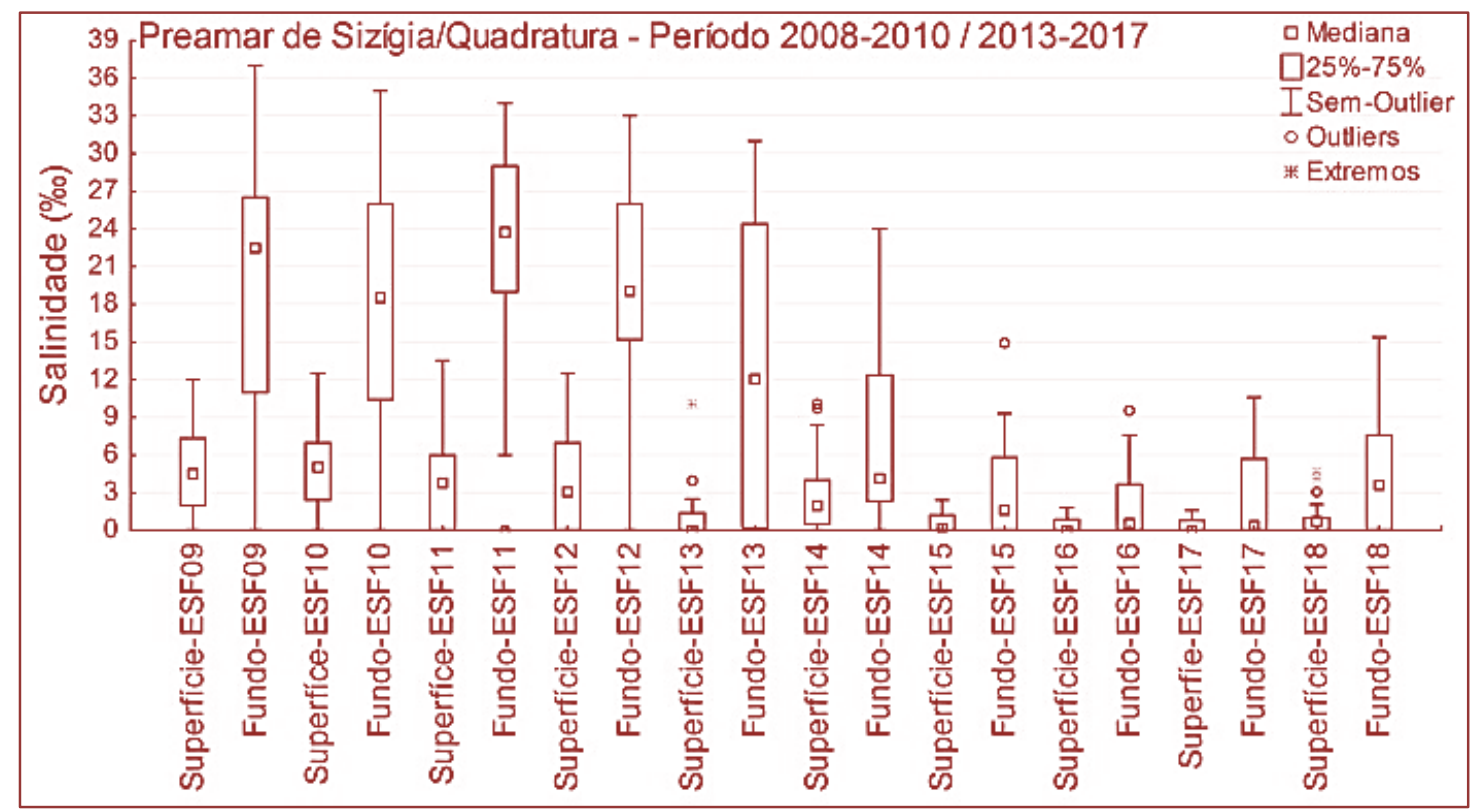

Pode-se observar na Figura 3 que os pontos ESF15 ao ESF18 apresentaram menor variação de salinidade, o que é justificado pelo seu afastamento da foz (7,8 km a 9,3 km respectivamente). Já os pontos ESF09 a ESF 14, distantes da foz 4,8 e 7,3 km, respectivamente, apresentaram maior variação na distribuição da salinidade, com destaque para o ponto ESF09 e ESF10, com a salinidade variando entre 0,03 e 36\% no fundo e 0,03 a $12 \%$ na superfície. Estes resultados estão compatíveis com os obtidos por CAVALCANTE et al., (2014 e 2017) e MELO (2017), que encontraram grande variação de salinidade no estuário do rio São Francisco. No entanto, percebe-se que o ponto ESF18, embora seja o mais afastado da foz, apresentou valores de salinidade elevados, próximos a 5\% e a $16 \%$ na superfície e fundo respectivamente, o que pode evidenciar a ocorrência do avanço da cunha salina no manancial. Embora os níveis de salinidade nos estuários dependam da ação da maré (Miranda et. al. 2002), dos padrões de circulação e dos forçantes, associadas aos períodos de oscilações diárias, semanais e semestrais das marés (FETTWEIS et al., 1998), observa-se pela Figura 3 que ocorreu uma grande variação dos valores de salinidade em todos os pontos, fazendo a água variar de doce (salinidade até $0,5 \%$ ) a salina (salinidade $>30 \%$ ) nos pontos mais próximos à foz e de doce a salobra (salinidade entre 0,5 a $30 \%$ ) nos pontos mais afastados. 


\subsubsection{DISTRIBUIÇÃO DA SALINIDADE NAS MARÉS DE QUADRATURA E SIZÍGIA NO TRECHO DE REFERÊNCIA}

A fim de verificar se existiam diferenças significativas nos valores de salinidade nos diferentes tipos de marés, quadratura e sizígia, foram construídos dois diagramas boxplots para os pontos ESF10, ESF14 e ESF18, escolhidos como representantes do trecho de referência, na superfície e fundo: um para o período em preamar de quadratura e outro para o período em preamar de sizígia (Figura 4).

Figura 4. Distribuição da salinidade na superfície e no fundo nos pontos ESF10, ESF14 e ESF18, durante a preamar de quadratura (a) e de sizígia (b). Rio São Francisco, 2008-2010 e 2013-2017.

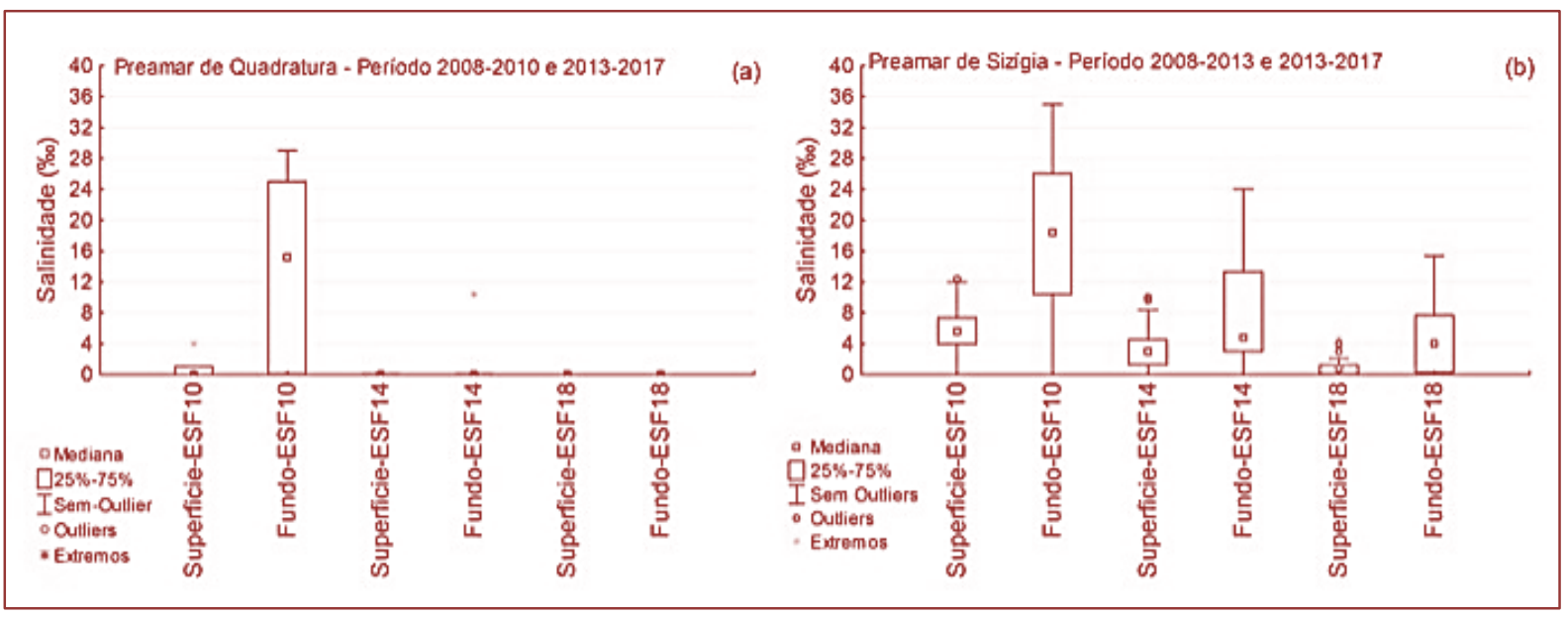

Observou-se que a influência da salinidade durante a maré de quadratura só é acentuada nos pontos próximos à foz. Os valores elevados de salinidade ocorrem na preamar de sizígia (Figura 5 b), comportamento já observado por OLIVEIRA et al., (2008) e FROTA (2013). Como esperado, nos períodos de sizígia, a força da maré é maior, aumentando a salinidade, sendo este o período mais crítico para a análise do avanço da cunha salina na região de estudo. Em função disso, a partir do ano de 2013 as campanhas realizadas pela CHESF foram feitas apenas em condições de maré de sizígia e dessa forma os próximos tópicos deste trabalho referem-se às análises de dados coletados nessas condições.

\subsubsection{INFLUÊNCIA DA SAZONALIDADE NO COMPORTAMENTO DA SALINIDADE NO TRECHO DE REFERÊNCIA}

Na região do baixo São Francisco, o período chuvoso corresponde aos meses de dezembro a abril; e o período seco, aos meses de maio a novembro (CHESF 1992). Buscando compreender a distribuição da salinidade nos períodos de 2008 a 2010 e 2013 a 2017, que englobam os anos com e sem redução de vazão defluente, foram construídos quatro diagramas boxplots um para a superfície e outro para o fundo, considerando os períodos úmido e seco, antes (Figuras 5a e 5b) e depois (Figuras 5c e 5d) das reduções das vazões. 
Figura 5. Distribuição da salinidade nos períodos úmido e seco, no trecho de referência (pontos ESF10, ESF14 e ESF18), durante a preamar de sizígia, na superfície e no fundo antes (a, b) e após (c, d) reduções de vazões. Rio São Francisco, 2013-2017.

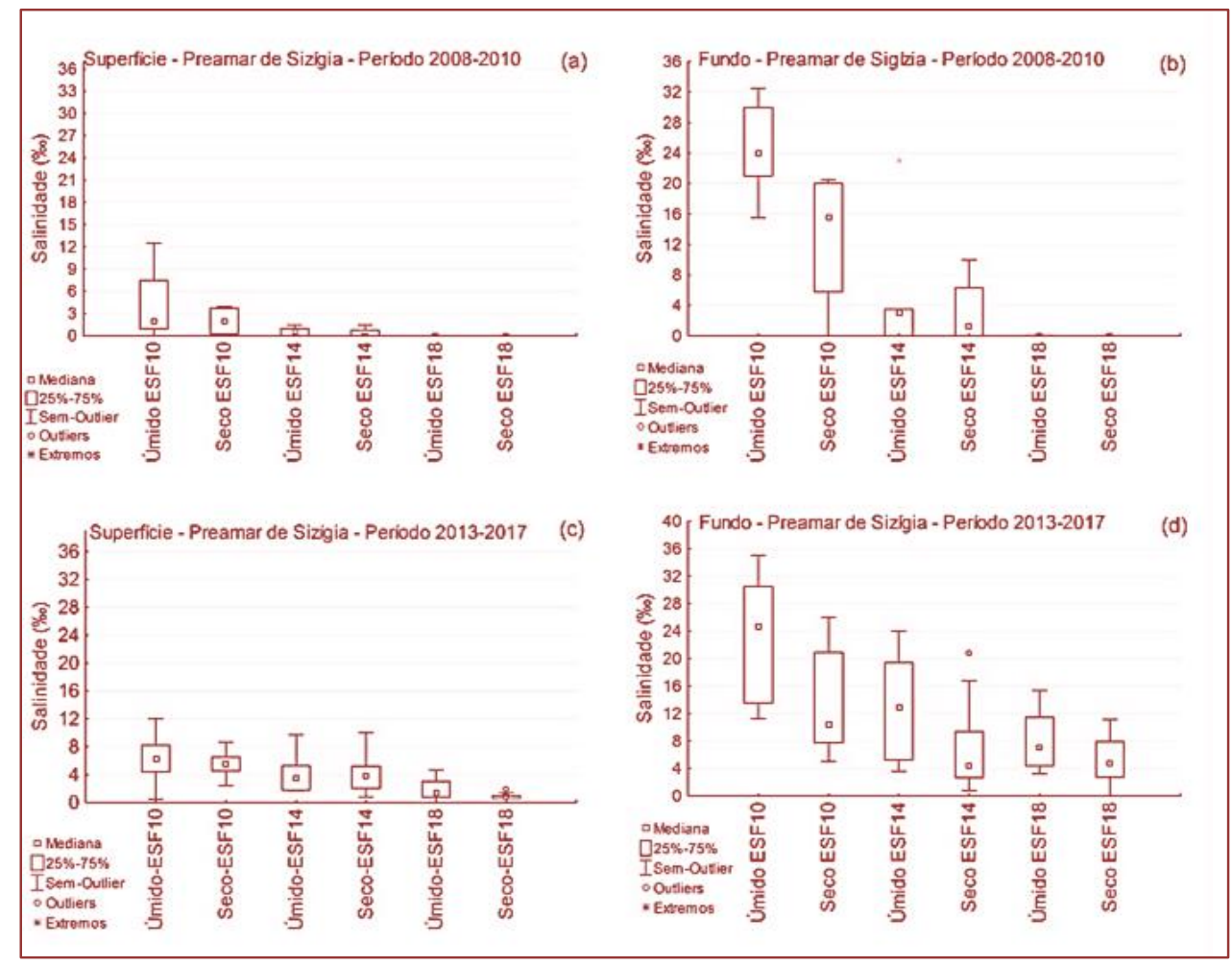

É importante salientar que a variação de salinidade observada nos pontos ESF10 e ESF14 ocorrem naturalmente no período de 2008 a 2010, em função das características naturais que classificam o estuário: baixo estuário, também denominado, estuário marinho, possui conexão livre com o mar aberto; o médio estuário, onde ocorrem intensas misturas de água doce e salgada; e o alto estuário, denominado estuário fluvial, área sujeita à ação da maré, mas sem a presença de água salina (DIONNE 1963 in FAIRBRIDGE 1980 apud PERILLO 1995, p. 25). Pode-se relacionar esta classificação com a de MIRANDA et. al.(2002) que subdivide o estuário em zonas de salinidade e dessa forma relacionar com as observações obtidas no baixo rio São Francisco: quando a salinidade situa-se acima de 35 \%o, significa que a força da maré é marcante. Esta região localiza-se na desembocadura do estuário e se estende até o limite da pluma estuarina denominada Zona de Maré Oceânica ou Costeira, que é a região equivalente ao baixo estuário. Pode-se observar que o ponto ESF9, distante 4,3 Km da foz (Figura 3), apresenta estas características.

0 ponto ESF10, distante da foz 5,3 Km, apresenta salinidade variando até $35 \%$, onde ocorrem misturas das massas d'água e equivalência dos forçantes fluvial e de maré, que corresponde à Zona de Mistura (MIRANDA et. al. 2002) e equivale ao médio estuário. Observa-se que o ponto ESF14, distante da foz 7,3 Km também pertence a esta zona, porém sofreu acentuado aumento de salinidade, na superfície e no fundo com as reduções de vazões (Figura5).

Já o ponto ESF18, distante da foz 7,3 Km, apresentou valores de salinidade com características de água doce (até 0,5\%) antes da redução das vazões (Figuras 5 a, b), característica da Zona de Maré do Rio (estuário fluvial), onde a salinidade varia até $1 \%$ o. Nesta zona ocorre a influência da maré, porém com domínio do forçante fluvial (MIRANDA et. al.2002).Após as reduções das vazões (Figura 5 c, d) este ponto do estuário perde suas características de estuário fluvial e passa a ter características da Zona de Mistura com salinidades chegando a $5 \%$ na superfície a e a $15 \%$ no fundo.

Outra observação que pode ser feita a partir da avaliação dos dados é em relação aos padrões de variação vertical da salinidade na coluna d'água. Observa-se que o estuário do rio São Francisco é estratificado, ou seja, em forma de cunha salina. Neste tipo de estuário, a força fluvial predomina em relação à da maré, logo, na superfície, os valores de salinidade são menores em relação ao fundo e no perfil da coluna d'água 
vertical ocorre grande variação salina (PRITCHARD, 1955; DYER, 1997). Sendo assim, presume-se que apesar da força da maré ter aumentado com as reduções de vazões ocorridas no período de 2013 a 2017 , alterando os valores de salinidade no estuário, o forçante fluvial ainda prevalece, impedindo que o estuário se torne homogêneo, isto é, quando a força da maré é predominante em relação à força do rio, dessa forma, os valores de salinidade no fundo e na superfície são semelhantes, não havendo variação vertical significativa ao longo da coluna d'água, apesar de poder existir variação na direção longitudinal (PRITCHARD,1955; DYER, 1997).

Em relação à influência da sazonalidade, no ponto mais próximo à foz (ESF10) e no ponto mais afastado (ESF18), os valores de salinidade são mais elevados no período úmido, sendo que neste último ponto esta observação só é possível de ser realizada nos períodos de redução de vazão (Figura 5c, d). No ponto intermediário, ESF14 distante da foz 7,3 km, a salinidade antes das reduções de vazão apresentou-se mais elevada no período seco do que no período úmido. No entanto, após as reduções de vazão a salinidade passou a ser mais alta no período úmido.

Não existe apenas uma causa para o aumento da salinidade no rio. Por exemplo, no período úmido pode-se esperar um aumento da salinidade devido ao carreamento de sólidos dissolvidos para dentro do rio, em função do aumento das precipitações e manejo do solo na bacia hidrográfica. Por outro lado, seria possível esperar que no período seco houvesse uma concentração dos sais no manancial devido à maior probabilidade de evaporação das águas, em função de temperaturas mais elevadas. Com as reduções das vazões defluentes, seria esperado ainda que houvesse o desequilíbrio entre as forças fluviais e oceânicas, com aporte maior de sal no estuário, podendo haver avanço considerável da cunha salina em trechos que antes não apresentavam histórico salino acima de certos limites, o que aumentaria a salinidade em ambos os períodos (KNOPPERS et al., 2005; OLIVEIRA et al., 2008), das correntes, SOUZA (2015).

\subsubsection{ANÁLISE DA RELAÇÃo ENTRE AS REDUÇõES DAS VAZÕES DEFLUENTES E A SALINIDADE DA ÁGUA NO TRECHO DE REFERÊNCIA}

Com a finalidade de visualizar graficamente as relações existentes entre as vazões defluentes diárias e os valores de salinidade na superfície e no fundo no trecho de referência (pontos ESF10, ESF14 e ESF18), foram construídos gráficos de dispersão para os períodos de 2008 a 2010 e 2013 a 2017 (Figura 6). Adicionalmente, foi realizada análise de correlação de Spearman para identificar relações significativas entre esses parâmetros.

Os gráficos de dispersão apresentados na Figura 6 mostram que os valores de salinidade da superfície no ponto ESF10 (5,3 km da foz), apresentam relação negativa com as vazões defluentes, embora a correlação de Spearman não tenha sido significativa $\left(n=45 ; r_{s}=-0,2757 ; p>0,05\right)$. Já no fundo, os valores de salinidade foram correlacionados significativamente com as vazões ( $\left.n=45, r_{s}=0,4187 ; p<0,05\right)$, indicando que nesta profundidade os valores de salinidade podem estar sendo afetados positivamente pelas vazões. Assim, mesmo em pontos próximos à foz, as vazões defluentes podem estar influenciando os valores da salinidade no fundo, embora possam também estar sob influência da formação da cunha salina, uma vez que, sendo a água do mar mais densa, o fundo do rio fica sujeito por maior tempo a valores de salinidade elevados e em seções mais próximas à foz, é natural que no fundo haja maior permanência de sais.

Pelas Figuras 6 (c,d) e (e,f), referentes a pontos mais afastados da foz (ESF14 e ESF18, distantes da foz 7,3 e 9,3 km, respectivamente) observa-se que há uma tendência linear inversa entre vazões e salinidade, tanto na superfície como no fundo, indicando que as reduções de vazões exercem forte influência no aumento dos níveis de salinidade nestas seções. No ponto ESF10, intermediário na área de referência, a correlação negativa entre as vazões e a salinidade foi significativa apenas na superfície $\left(n=45, r_{s}=-\right.$ 0,6788; $\mathrm{p}<0,05)$; já no ponto mais afastado da foz (ESF18) a correlação negativa mostrou-se ainda mais significativa, tanto na superfície, $\left(n=45, r_{s}=-0,6223 ; p<0,05\right)$, como no fundo $\left(n=45, r_{s}=-0,8685 ; p<\right.$ 0,05), respectivamente, evidenciando, como seria esperado, influência mais forte das reduções das vazões defluentes nesta seção mais distante da foz. 
Figura 6. Relações lineares entre vazões defluentes diárias $\left(\mathrm{m}^{3} \mathrm{~s}^{-1}\right)$ e salinidade (\%o) na superfície e no fundo, respectivamente, no trecho de referência: no ponto ESF10 a 5,3 km da foz (a, b); no ponto ESF14,

7,3 km da foz (c, d); no ponto ESF18, 9,3 km da foz (e, f). Rio São Francisco, 2008-2010 a 2013-2017.
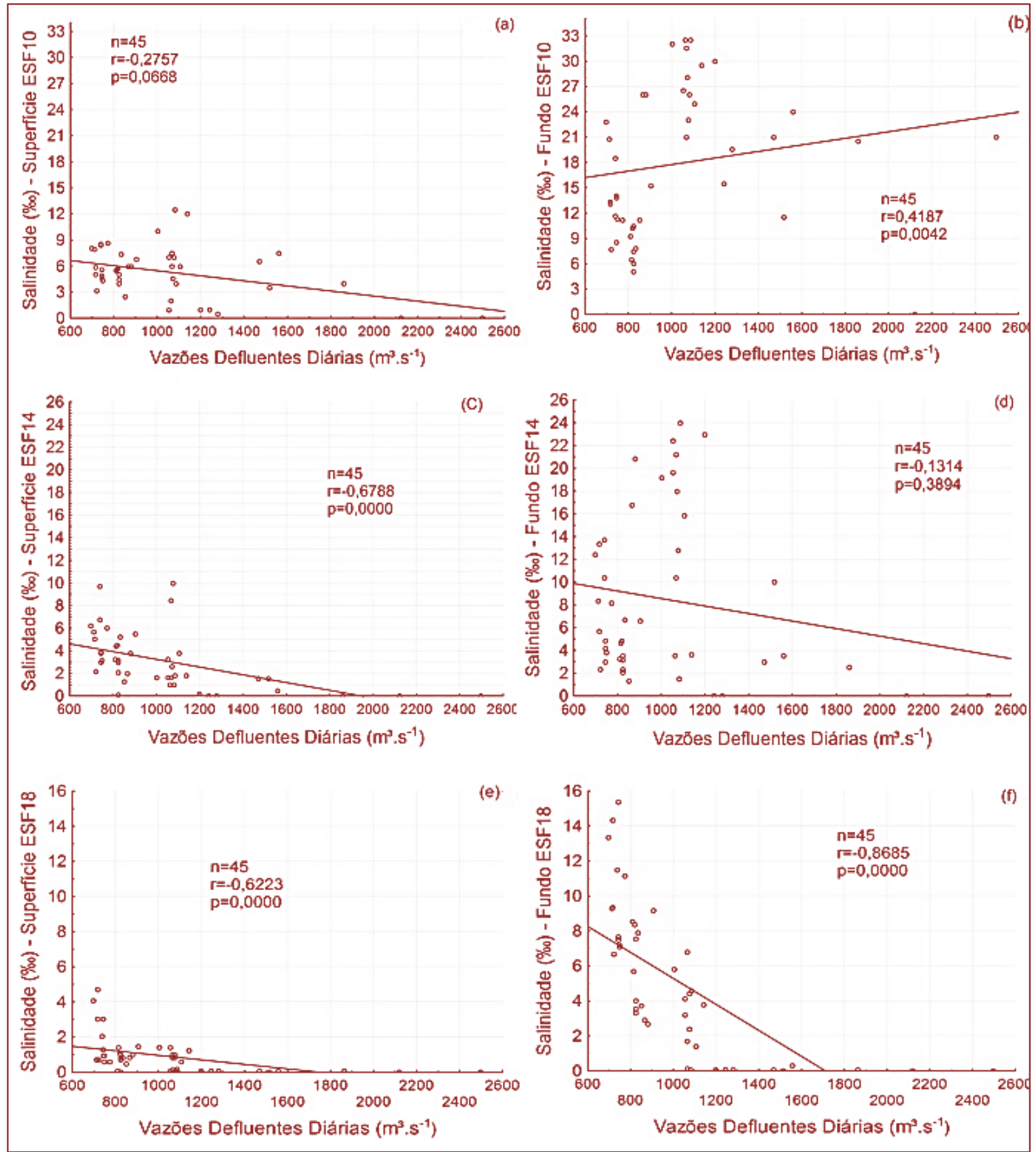


\subsubsection{ANÁLISE DO AVANÇO DA CUNHA SALINA NO TRECHO DE REFERÊNCIA}

O comportamento da salinidade na superfície, nas três seções que compõem o trecho de referência, correspondendo aos pontos anteriormente estudados, ESF10, ESF14 e ESF18 (tabela 2), encontra-se representado na Figura 7.

Figura 7. Distribuição da salinidade na superfície durante a preamar de sizígia, respectivamente, nas seções 13 (ponto ESF10), 12 (ponto ESF14) e 11 (ponto ESF18) durante os períodos Rio São Francisco, 2008-2010 e 2013-2017.

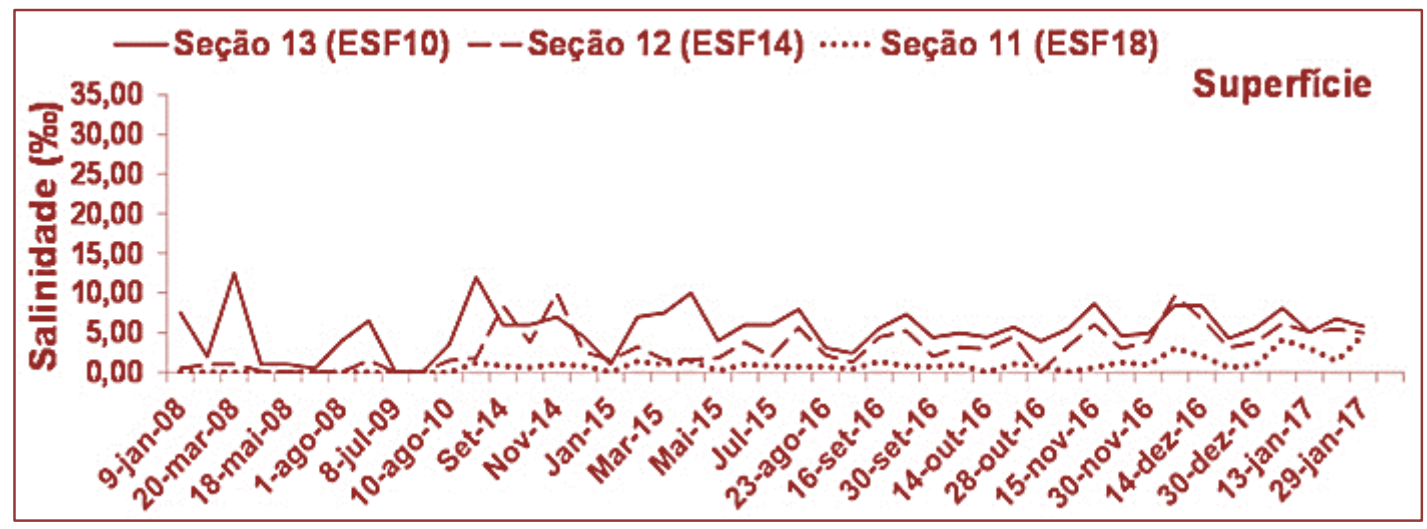

Os valores de salinidade na seção 13 (ESF10), distante da foz 5,3 km apresentaram oscilação no período de janeiro de 2008 a maio de 2013. Esse resultado é corroborado por BARBOSA (2011), que estudou a salinidade em um ponto próximo a esse, distante da foz cerca de 5,1 km e encontrou salinidade abaixo de 0,1\%o em março, julho e outubro de 2008, abril e julho de 2009; em janeiro de 2009, encontrou valores iguas a $5 \%$ na superficie e $10 \%$ no fundo. No caso deste estudo, observa-se pela Figura 7 que no ínicio da redução das vazões, havia uma tendência da salinidade oscilar entre 5 a $10 \%$.

Na seção 12 (ESF14), distante da foz 7,3 km, os valores de salinidade no período de 2008 a 2010 (antes das reduções de vazão) prevaleciam abaixo de 1 \%o; já no período de 2013 a 2017 (depois das reduções), os valores) eram mais altos do que $5 \%$ (Figura 7). Na seção 11 (ESF18), mais distante da foz (9,3 km), os valores eram baixos e menores do que 0,05 \% no periodo sem redução de vazão (2008 a 2013), resultados compatíveis com BARBOSA (2011), que estudou também a salinidade a 8,1 km da foz e encontrou resultados abaixo de 0,1 \%o, tanto na superfície quanto no fundo, nos anos de 2008 e 2009.

No entanto, com as reduções de vazão, é possivel perceber uma elevação dos valores de salinidade nos anos 2016 e 2017, nas mesmas seções analizadas anteriormente. Observa-se que na seção 11, à medida que as vazões eram reduzidas (anos 2013 a 2017), o comportamento da salinidade se tornava gradativamente semelhante ao das seções mais próximas da foz, principalmente a partir de agosto de 2016, com a intensificação da redução da vazão. É possível também observar que a seção 12, distante da foz 7,3 km, após o início das reduções da vazão defluente, em Xingó, em 2013, passou a apresentar comportamento de salinidade semelhante à seção 13, indicando que após o início das reduções da vazão defluente, houve aumento significativo da salinidade nas seções 12 e 11, atingindo a superfície do estuário, evidenciando o avanço da cunha salina no trecho de referência por cerca de 4 km, a partir da seção 13.

Acrescenta-se ainda que a seção 11, estando localizada mais distante da foz, a jusante 5,5 km da cidade de Brejo Grande-SE e a 2,3 km da cidade de Piaçabuçu-AL, consiste em uma seção estratégica para avaliação do avanço da cunha salina nas seções mais afastadas da foz. Dessa forma, a Figura 8 apresenta a evolução da salinidade na seção 11 onde os dados de salinidade do ponto amostral ESF18, inserido no trecho de referência, foram relacionados com as vazões defluentes em Xingó. 
Figura 8. Relação entre salinidade na superfície e fundo e vazões defluentes no ponto ESF18, localizado em Piranhas, distante 9,3 km da foz e integrante da seção 11 (entre Brejo Grande-SE e Piaçabuçu-AL).

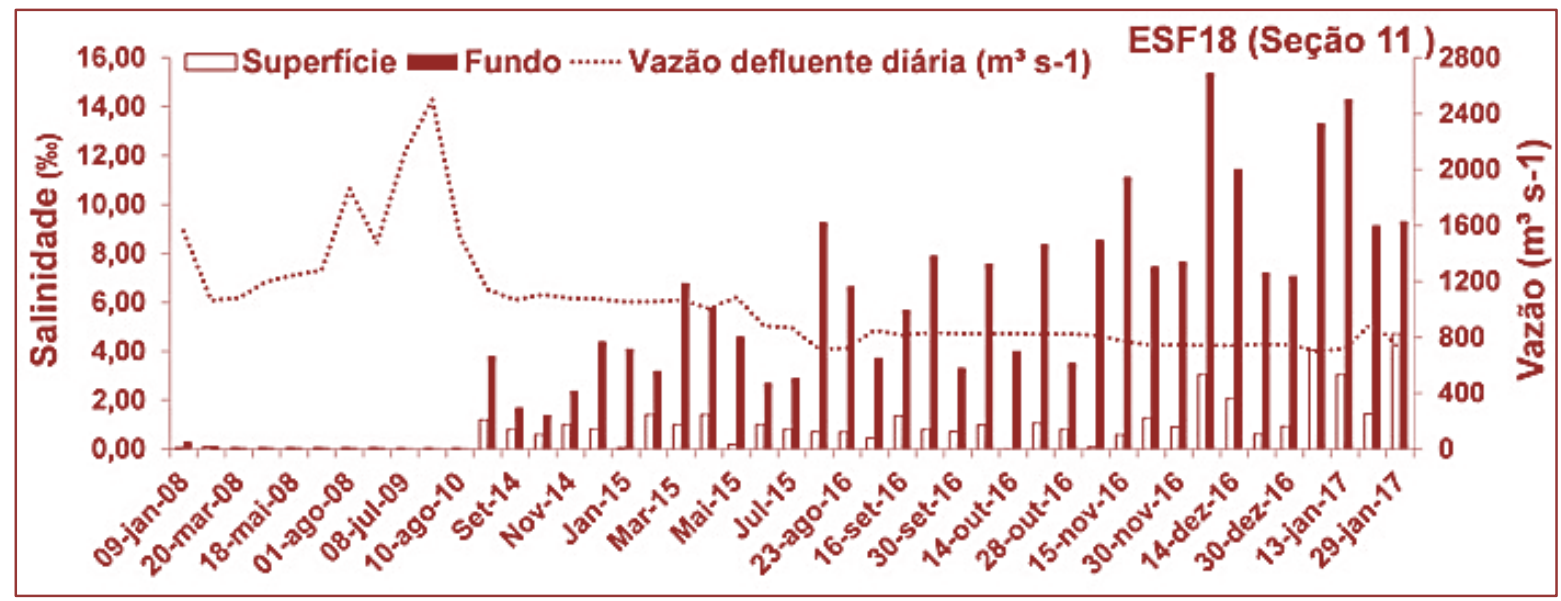

Observa-se na Figura 8 que no período de 2008 a 2010 os valores de salinidade na seção 11, tanto na superfície quanto no fundo estavam abaixo de $0,1 \%$, dentro do limite de água doce, resultados que corroboram com BARBOSA (2011). Após o início das reduções da vazão defluente em Xingó (ano 2013), os valores de salinidade do fundo na seção 11 se apresentaram cerca de 8 a 64 vezes mais altos que no período sem redução de vazão (2008 a 2010). Dentro do período com redução de vazão (2013 a 2017), a salinidade no fundo variou de 1,4 \%o, para vazão de $1105 \mathrm{~m}^{3} \mathrm{~s}^{-1}$ em outubro de 2014, a 15,4 \%o para vazão de $741 \mathrm{~m}^{3} \mathrm{~s}^{-1}$ em dezembro de 2016.

Na superfície, a salinidade passou a apresentar valores acima de 0,5 \%o a partir de 2014 com vazão de restrição mínima de $1100 \mathrm{~m}^{3} \mathrm{~s}^{-1}$, chegando a 4,7\%o, com vazão defluente de $717 \mathrm{~m}^{3} \mathrm{~s}^{-1}$. No período sem redução de vazão, a salinidade se manteve em torno de 0,03\%o. Observou-se ainda que apesar das vazões praticamente estáveis (em torno de $700 \mathrm{~m}^{3} \mathrm{~s}^{-1}$ ), no ano de 2016, ainda assim a salinidade tendeu a aumentar, ocorrendo provavelmente além do avanço da cunha salina, acúmulo de sais nesta seção, intensificando ainda mais os impactos causados pela alteração de fluxo nas imediações dessa localidade.

\subsubsection{ANÁLISE DO AVANÇO DA CUNHA SALINA NO TRECHO ESTUARINO}

Com o propósito de avaliar as reduções das vazões defluentes apresentou efeitos negativos nos pontos mais afastados da foz, foram analisados os dados secundários de salinidade disponíveis nas seções a montante, seguindo pelas localidades de Brejo Grande-SE (margem direita) e Piaçabuçu-AL (margem esquerda), além de levantamento de dados primários em dois pontos amostrais em Brejo Grande-SE.

A Figura 9 apresenta o levantamento dos dados secundários do ponto amostral ESF 21, a partir do qual foram iniciadas pela CHESF as medições, em 2014, com o objetivo de monitorar a salinidade durante o período de vazão reduzida. Este ponto está localizado na margem esquerda da seção 10, no início da cidade de Piaçabuçu, a jusante de Brejo Grande-SE.

Observa-se pela Figura 9 que com a manutenção da vazão de restrição mínima entre $1100 \mathrm{~m}^{3} \mathrm{~s}^{-1}$, que estava em vigor em setembro de 2014 até março de 2015, e $1000 \mathrm{~m}^{3} \mathrm{~s}^{-1}$, em vigor de março a junho de 2015, a salinidade no fundo variou de 0,5 a $4 \%$. Entretanto, com a continuidade da redução das vazões com vazões entre 900 a $700 \mathrm{~m}^{3} \mathrm{~s}^{-1}$ entre julho de 2015 a janeiro de 2017, a salinidade no fundo passou a variar com valores próximos de 3 a $25 \%$. Na superfície, onde a salinidade, com as vazões em torno de $1000 \mathrm{~m}^{3} \mathrm{~s}^{-1}$ chegavam a 0,2\%, passaram a alcançar valores acima do limite de água doce, chegando a 2,3 \%o em janeiro de 2017, com a vazão defluente em torno de $700 \mathrm{~m}^{3} \mathrm{~s}^{-1}$. Apesar de não haver medições nessa seção antes das reduções das vazões defluentes (período de 2008 a 2010), é possível inferir que se na seção 11 distante da foz $9,3 \mathrm{~km}$ a água apresentava salinidade tanto na superfície quanto no fundo em torno de $0,05 \%$, a seção 10 , distante da foz 10,5 km, deve ter apresentado também valores baixos de salinidade para o mesmo período. Logo, pode-se concluir que a cunha salina pode ter avançado da seção 11 , mais 1,6 km até a seção 10, pela margem esquerda, após as reduções de vazões. 
Figura 9. Relação entre salinidade da superfície e fundo e vazões defluentes no ponto ESF21 em Piaçabuçu-AL, margem esquerda da seção 10, distante 10,6 km da foz. Rio São Francisco, 2014 a 2017.

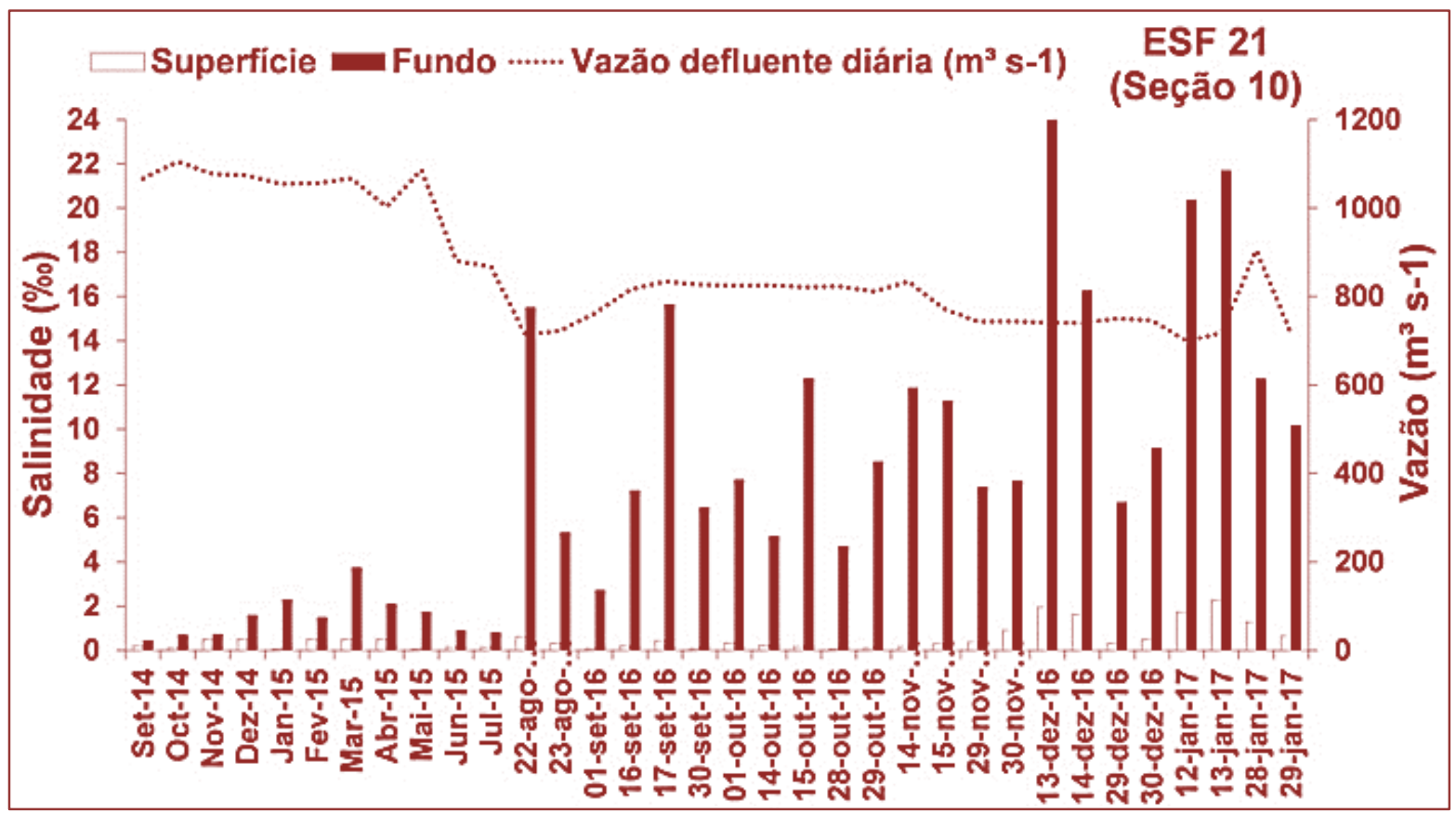

Na margem direita foram obtidos dados primários de perfil de salinidade no ponto amostral PA6, distante da foz 10,6 km. O perfil de salinidade apresentou valores elevados, acima do limite de água doce na superfície, no meio e fundo, onde os valores chegaram a 1,7 \%o e na superfície a 0,7 \%o na maré cheia. Na maré baixa, os valores de salinidade se mantiveram em torno 0,1\%o. Estes resultados indicam que a cunha salina avançou cerca de 1,4 km pela margem direita desde a seção 11 até a 10.

A seção 9, distante da foz $11 \mathrm{~km}$, apresenta como ponto amostral mais próximo o ESF22, localizado na margem esquerda em Piaçabuçu-AL, e o ponto amostral ESF24 na margem direita em Brejo Grande-SE. A Figura 10 apresenta os valores de salinidade obtidos pela Chesf no período de setembro de 2014 a janeiro 2017 no ponto ESF 22

A Figura 10 mostra os valores mais altos alcançados, tanto no fundo quanto na superfície, ocorrendo em dezembro de 2016 a janeiro de 2017, com vazão defluente em torno de 700 a $800 \mathrm{~m}^{3} \mathrm{~s}^{-1}$. A oscilação observada para a salinidade justifica-se provavelmente, devido à forma com que foram feitas as medidas: os dados do ponto amostral ESF 22 foram obtidos via monitoramento móvel; dessa maneira, nem sempre, as medições foram realizadas no melhor horário da maré cheia. Ainda assim, é possível verificar que houve aumento considerável na salinidade, intensificando a cunha salina em relação à seção 11, de referência, em torno de 2,7 km pela margem esquerda. 
Figura 10. Relação entre salinidade da superfície e fundo e vazões defluentes no ponto ESF21 em Piaçabuçu-AL, marm esquerda da seção

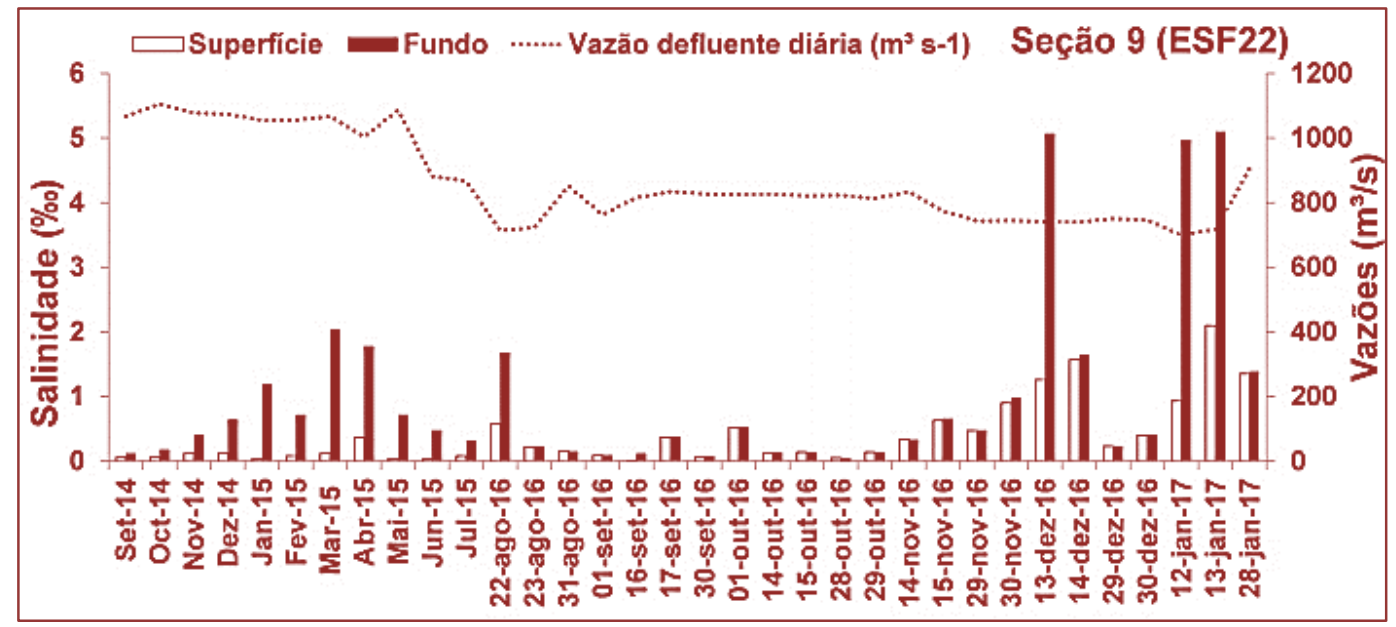

Os valores de salinidade do ponto amostral ESF 24 encontram-se ilustrados na Figura 11.

Figura 11. Relação entre salinidade da superfície e fundo e vazões defluentes no ponto ESF24 emBrejo Grande-SE, distante 11 km da foz, margem esquerda da seção 9. Rio São Francisco, 2014 a 2017.

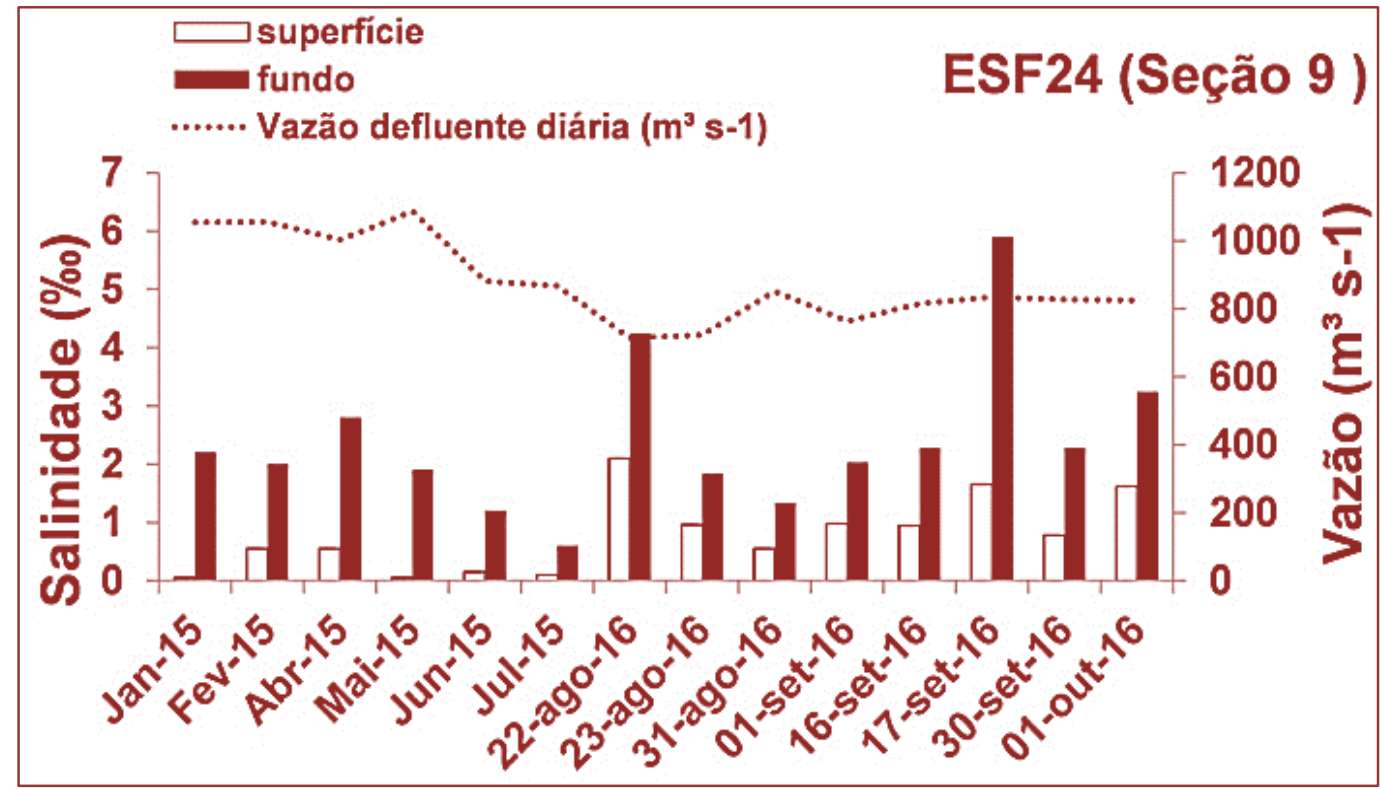

De forma similar, nas análises realizadas para as demais seções, nota-se que antes das reduções de vazão não foram constatados valores de salinidade acima de 0,5\%o, ou seja, a água era sempre doce. Durante o monitoramento da Sali9nidade no período de vazão reduzida, porém, no ano de 2015, com vazões defluentes em torno de $1000 \mathrm{~m}^{3} \mathrm{~s}^{-1}$, foram verificados valores acima de 0,5\%o no fundo, embora na superfície os valores tivessem sido mantidos dentro do limite de água doce. Já em 2016, com vazão reduzida em torno de $800 \mathrm{~m}^{3} \mathrm{~s}^{-1}$, foram encontrados valores elevados de salinidade na superfície e no fundo, chegando a $6 \%$ no fundo e acima de $2 \%$ na superfície. Em relação à seção 11 , de referência, houve um avanço da cunha salina pela margem direita em torno de 2,1 km. 
Quanto à seção 8, distante da foz 11,8 km, passando na margem esquerda em frente ao ponto de captação de água para abastecimento humano em Piaçabuçu-AL e seguindo transversalmente até a margem direita em Brejo Grande-SE, foram analisados apenas os dados de salinidade da margem esquerda. Os valores de salinidade na seção 8 foram obtidos do ponto amostral ESF23, o mais próximo da captação de água. A Figura 12 mostra os resultados mais críticos do monitoramento fixo na preamar de sizígia no ponto ESF23.

Figura 12. Relação entre salinidade da superfície e fundo e vazões defluentes no ponto ESF23 em Brejo Grande-SE, Piaçabuçu-AL, distante 12,4 km da foz, margem esquerda da seção 8. Rio São Francisco, 2014 a 2017.

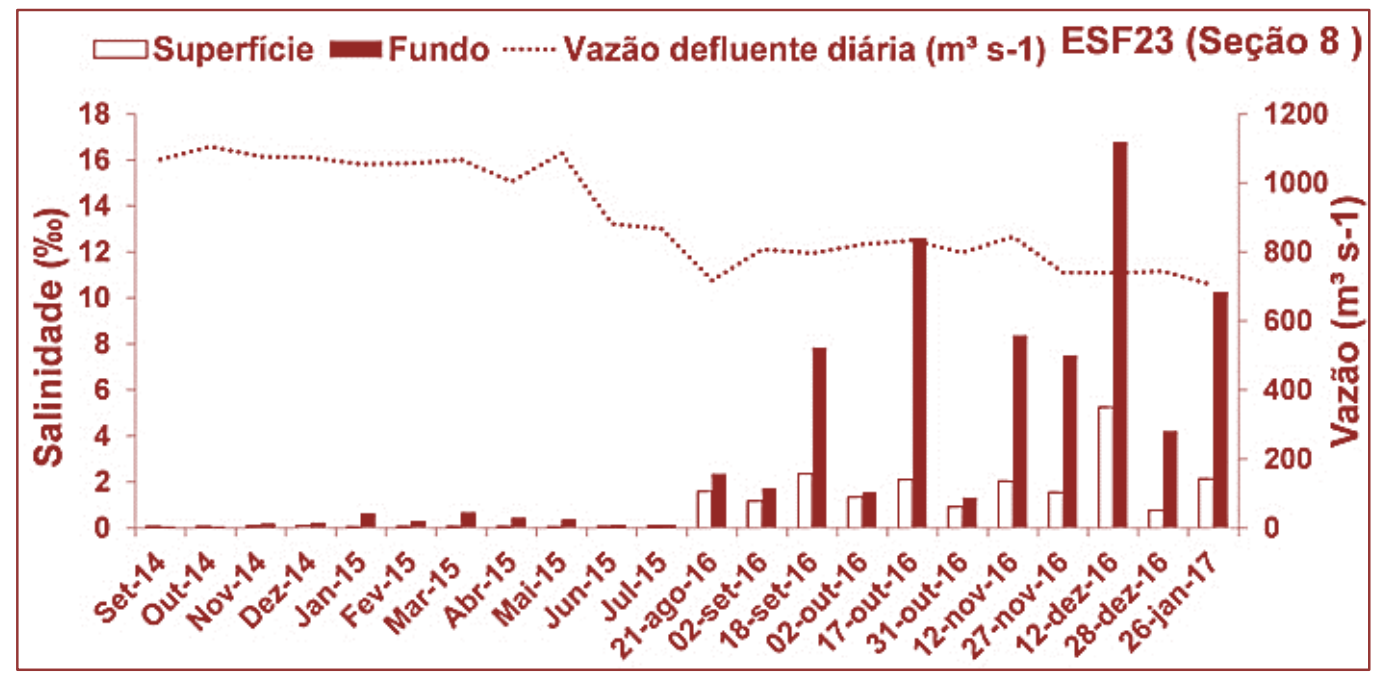

A Figura 12 mostra resultados da salinidade em 2014, concordantes com BARBOSA (2011), que apresentou valores abaixo de $0,05 \%$, tanto na superfície quanto no fundo no mesmo período de estudo. Observa-se que com a vazão defluente em torno de 1000 a $1100 \mathrm{~m}^{3} \mathrm{~s}^{-1}$, os valores de salinidade se mantêm abaixo de 0,5 \%o na maior parte do tempo, nas duas posições, podendo chegar a $1 \%$ no fundo; no entanto, a partir de novembro de 2016 , com a vazão defluente em torno de 700 a $800 \mathrm{~m}^{3} \mathrm{~s}^{-1}$, observou-se picos de salinidade chegando a cerca de $18 \%$ no fundo e acima de 0,5 \%o na superfície (Figura 12).

As seções 7, 6 e 5 passam próximo ao centro da cidade de Brejo Grande-SE e chegam a Piaçabuçu-AL na margem esquerda. Na seção 7, distante da foz $14,4 \mathrm{~km}$, foram avaliados dados secundários no ponto amostral ESF27, na margem direita. Os valores de salinidade da água se mantiveram dentro do limite de água doce. Na seção 6 distante da foz 15,2 km, foram levantados dados primários apenas no ponto amostral PA5, na margem direita. Os valores no perfil de salinidade permaneceram abaixo de 0,5\%o, tanto na baixa mar quanto na preamar, indicando característica de água doce.

Na seção 5, distante da foz 15,5 km, a análise na margem esquerda foi realizada com dados disponíveis no ponto amostral ESF30. Os valores de salinidade permanecem em torno de 0,05 \%o, o que evidencia que a maré não tem força, até o momento, para atingir a margem esquerda da seção. 0 ponto ESF32, próximo à captação de água, foi utilizado para o estudo na margem direita da seção. Os valores de salinidade nesse ponto também estão abaixo do limite de água doce, apesar do trecho sofrer a influência da maré. Este comportamento foi verificado tanto no período seco quanto no úmido.

\subsubsection{ANÁLISE DA VARIAÇÃO ESPACIAL DA SALINIDADE NO TRECHO FLUVIAL}

Subindo o rio, a montante, as seções com os respectivos pontos amostrais localizados no meio da calha do rio, vão de PA4 a PA1 (Tabela 1).

Os resultados obtidos nesta campanha não indicaram valores elevados de salinidade em nenhuma das seções analisadas, os quais permaneceram abaixo de 0,05\%, cerca de dez vezes menor que o limite de salinidade $(0,5 \%)$ estabelecido para água doce. 
Os resultados indicam que no trecho fluvial não houve influência da maré no período em que as amostras foram coletadas, em abril de 2017; porém, seria necessário realizar monitoramento fixo na seção 4; isto é, medições de 13 horas na superfície, meio e fundo na maré de sizígia, a fim de validar estes resultados. Os resultados de dados secundários obtidos no alto do estuário indicam que a cunha salina ainda não alcançou a seção 5, o que implica que a seção 4 e as subsequentes, provavelmente não sofrem com o avanço da cunha salina.

\section{CONCLUSÕES}

Após as reduções das vazões defluentes, em 2013, os pontos mais afastados da foz, no trecho de referência, ES14 e ESF18, distantes 7,3 e 9,3 km, respectivamente, passaram a apresentar o mesmo comportamento do ponto ESF10, mais próximo da foz, mostrando tanto na superfície quanto no fundo do rio a forte influência da redução daquelas vazões, evidenciando o avanço da cunha salina em cerca de 4 $\mathrm{km}$.

No ponto mais próximo da foz (ESF10), os valores de salinidade, em geral, se apresentaram mais altos no período úmido, o que pode ser explicado pela proximidade do ponto com as margens, influenciada pela intensidade das chuvas, que transportam sedimentos e sólidos totais dissolvidos para a calha do rio. Outra possibilidade, é que o manejo e uso do solo estejam influenciando nesses valores, além de poder acumular sais no médio estuário.

As correlações encontradas entre as vazões defluentes e a salinidade no estuário, mostram que as reduções de vazões defluentes exercem forte influência no aumento da salinidade no trecho compreendido entre a seção 12 e 11, distantes respectivamente 7,3 e 9,3 $\mathrm{Km}$ da foz. Com a continuidade das reduções de vazões, pontos mais afastados da foz passaram a apresentar valores elevados de salinidade, tanto no fundo quanto na superfície, mostrando que as reduções das vazões defluentes, a partir do ano de 2013, contribuíram para o aumento da salinidade na seção 11, distante 9,3 Km de da foz.

Nas imediações da cidade de Piaçabuçu-AL, pode-se inferir pelos resultados anteriores às reduções de vazão, entre os quais não haviam valores de salinidade acima de 0,5\%o, que a água era sempre doce. Após as reduções de vazões, iniciadas em 2013, apesar dos valores de salinidade oscilarem com características de água doce à água salobra, valores elevados de salinidade ocorreram não apenas no fundo, chegando a atingir $18 \%$, mas também na superfície, chegando a $13 \%$ No período seco, os valores também ficavam acima de 0,5\%o, principalmente na preamar de sizígia, sendo mais elevados no período úmido, nos anos de 2016 e 2017. Nos horários de baixa-mar, as características do rio nas imediações da cidade de Piaçabuçu (distante 11,8 km da foz) são de água doce.

Evidencia-se que a situação de escassez de água que levou às mudanças de regras na operação da barragem teve como consequência o avanço da cunha salina com forte impacto na qualidade da água em termos de salinidade, modificando as características do estuário, passando parte do trecho com características de Alto Estuário, ou seja, Zona de Maré do Rio (de 9,3 a 11,8 Km) para Médio Estuário (Zona de Mistura).

\section{AGRADECIMENTOS}

Agradeço à FINEP por ter financiado este estudo, ao Instituto Federal da Bahia (IFBA) pelo tempo concedido para a realização deste trabalho, à CHESF pela concessão dos dados e à Universidade Federal da Bahia pelo apoio, orientação, e uso dos equipamentos e laboratório, ao geógrafo Sival Senna, pela contribuição na elaboração do mapa e ao designer Jonas Fonseca pela arte final. 


\section{REFERÊNCIAS}

[1] ALBER, M. A. Conceptual Model of Estuarine Freshwater In flow Management. Estuaries, v. 25, n. 6B, p. 12461261, 2002.

[2] ALMEIDA, G. M.; SILVA JUNIOR, G. C. Fatores Hidrogeológicos no Estudo da Intrusão Salina em Aquíferos Costeiros da Região Litorânea do Município de Maricá - RJ. Anuário do Instituto de Geociências- UFRJ. v. 30_ 2, p. 104$117,2007$.

[3] AL-NASRAWI, A. K. M.; JONESA, B. G.; ALYAZICHIA, Y. M; HAMYLTONA, S. M.; JAMEEL, M. T.; HAMMADIC, A. F. Civil-GIS incorporated approach for water resource management in a developed catchment for urban-geomorphic sustainability: Tallowa

[4] Dam, southeastern Australia. International Soil and Water Conservation Research, n.4, p. 304-313, 2016.

[5] AL-TAANI, A. A. Trend analysis in water quality of Al-Wehda Dam, north of Jordan.EnvironMonitAssess, $\mathrm{n}$. 186, p. 6223-6239, 2014

[6] ANA. Agência Nacional de Águas. Relatório da ANA apresenta situação das águas do Brasil no contexto de crise hídrica (04/12/2017). Disponível em: http://www3.ana.gov.br/portal/ANA/noticias/relatorio-da-anaapresenta-situacao-das-aguas-do-brasil-no-contexto-de-crise-hidrica. Acesso em: 5 dez. 2017.

[7] ATTRILL, M. J.; RUNDLE, S. D.; THOMAS, R. M.The influence of drought-induced low freshwater flow on an upper-estuarine macroinvertebrate community.Water Research, n.30, p. 261-268, 1996.

[8] BACHMAN, P.M.; RAND, G, M. Effects of salinity on native estuarine fish species in South Florida. Ecotoxicology, v.17, p. 591-597, 2008.

[9] BARBOSA, W. F. A. Estrutura da comunidade fitoplanctônica do estuário do rio São Francisco. 2011. Dissertação (Mestrado em Oceanografia) - Centro de Tecnologia e Geociências, Universidade Federal de Pernambuco.2011.

[10] BATE, G.C.; WHITFIELD, A.K; ADAMS, J.B.; HUIZINGA, P.; WOOLDRIDGE, T.H. The importance of the riverestuary interface (REI) zone in estuaries.Water SA, n. 28, p. 271-279, 2002.

[11] BRANDT, S. A. Conceptualization of hydraulic and sedimentary processes in downstream reaches during flushing of reservoirs. In: XXXI International Association of Hydraulic Engineering and Research Congress, Water Engineering for the Future: Choices and Challenges.Seoul, Korea. 2005.

[12] BUNN, S.E.; ARTHInGTON, A.H. Basic Principles and Ecological Consequences of Altered Flow Regimes for Aquatic Biodiversity.Environmental Management, v. 30, n. 4, p. 492-507, 2002.

[13] CALLISTO, M.; REGINA, D.; GOMES, V. Macroinvertebrados bentônicos bioindicadores de qualidade de água: subsídios para a vazão ecológica no baixo rio São Francisco. In: XXVIII SIMPÓSIO BRASILEIRO DE RECURSOS HÍDRICOS. 2009, Disponível em:https://abrh.s3.sa-east1.amazonaws.com/Sumarios/110/329de21f2a7f192618688fbd624af9a6_5b58a08b19927cc562682fc9977ce8c7.pdf. Acesso em: 04 abril 2017.

[14] CAMPO, J.; LORENZO, M.; PÉREZ, F.; PICÓ, Y.; FARRÉ, M.; BARCELÓ, D. Analysis of the presence of perfluoroalkyl substances in water, sediment and biota of the Jucar River (E Spain).Sources, partitioning and relationships with water physical characteristics. Environmental research, v. 147, p. 503-512, 2016.

[15] CAMPOS, J.N.S. Vulnerabilidade do semi-árido às secas, sob o ponto de vista dos recursos hídricos. Brasília, Projeto Áridas - RH, SEPLAN/PR, 1995 in BRASIL. Caderno da Região Hidrográfica do São Francisco / Ministério do Meio Ambiente, Secretaria de Recursos Hídricos. - Brasília: MMA, 2006. Disponível em: http://www.mma.gov.br/estruturas/161/_publicacao/161_publicacao0303201 023538.pdf. Acesso em: 5 nov. 2015.

[16] CAVALCANTE, G., MEDEIROS, P. R. P., SOUZA, R. M. G. Circulation and salt intrusion under low river discharge conditions, São Francisco River Estuary (NE Brazil). In: VI Congresso Brasileiro de Oceanografia, n. 7,Anais. Associação Brasileira de Oceanografia, 2014.

[17] CAVAlCANTE, G.; MIRANDA, L.B.; MEDEIROS, P.R.P. Circulationandsalt balance in the São Francisco riverEstuary (NE/Brazil). BrazilianJournalofWaterResources, v. 22, e 31, 2017.

[18] CBHSF - Comitê de Bacia Hidrográfica do Rio São Francisco. Plano de Recursos Hídricos da Bacia Hidrográfica do Rio São Francisco. Apresentação Plano Decenal de Recursos Hídricos da Bacia Hidrográfica do Rio São Francisco PBHSF (2016-2025). CBHSF: 2016.

[19] CHESF- Companhia Hidrelétrica do São Francisco.Inventário dos Ecossistemas Aquáticos do Baixo São Francisco Relatório Trianual. Dezembro/2007 a Novembro/2010. CT-I- 92.2007.3540.00. Janeiro/2011. Relatório de Impacto Ambiental -RIMA,1992.

[21] _. Autorização Especial para operação das usinas hidrelétricas da Chesf no rio São Francisco. Relatório mensal 1.Junho/2013. 
[22] . Continuação dos serviços do Programa de monitoramento do rio São Francisco durante o período de vazão reduzida. Setembro de 2014/Julho de 2015. CTNI - 92.2014.0050.00 Agosto/2015.

[23] - Monitoramento do rio São Francisco. Disponível em http://www.chesf.gov.br/sustentabilidade/Pages/MeioAmbiente/Monitoramento-do Rio-Sao-Francisco.aspx. Acesso: jul de 2017.

[24] _ Envio dos dados de vazão para o Projeto AHIA da Rede HIDROECO-UFBA. sonali@chesf.gov.b Recebido em: 20 de abril e 06 de setembro de 2017.

[25] __ Envio dos dados de qualidade da água para o Projeto AHIA da Rede HIDROECO -UFBA. thiagov@chesf.gov.br Recebido em: 12 de junho de 2017.

[26] __ Programa de Monitoramento dos Ecossistemas Aquáticos do Reservatório de Xingó e Baixo São Francisco. $1^{\circ}$ RelatórioQuadrimestral 2013/2014.Abril/2014.

[27] CHEEK, C.A., TAYLOR, C.M.: Salinity and geomorphology drive long-term changes to local and regional fish assemblage attributes in the lower Pecos River, Texas. Ecology of Freshwater Fish, n.25, p. 340-35, 2016.

[28] DYER, K. R., Estuaries: A Physical Introduction. Chichester, England, John Wiley \& Sons Ltd, n.2, p.195, 1997.

[29] DIMAGGIO, M. A., BRETON, T. S., K,ENTER L. W., DIESSNER, C.G., BURGESS A. I., BERLINSKY, D.L. The effects of elevated salinity on river herring embryo and larval survival.Environmental BiologyofFishes, n. 99, p. 451-461, 2016.

[30] FELIPPE M. F.; MAIA-RODRIGUES, A. B.; MAGALHÃES H. P.Uso de técnicas de sensoriamento remoto na análise da dinâmica morfológica da foz do rio São Francisco no período de 1979 a 2008. Anais XIV Simpósio Brasileiro de Sensoriamento Remoto, Natal, Brasil, INPE, p. 3737-3744, 2009.

[31] FETTWEIS, M; SAS, M. \& MONBALIU, J., 1998. Seasonal, Neap-spring and Tidal Variation of Cohesive Sediment Concentration in the Scheldt Estuary, Belgium Estuarine, Coastal and Shelf.Science, n. 47, p. 21- 36.

[32] FROTA, F. F; PAIVA, B. P.; SCHETTINI, C.A.F. Intra-tidal variation of stratification in a semi-arid estuary under the impact of flow regulation.Brazilian journal of oceanography, v. 61, n. 1, p. 23-33, 2013

[33] GEDDES, M.C.; BUTLER, A.J. Physicochemical and biological studies on the Coorong lagoons, South Australia, and the effect of salinity on the distribution of the macrobenthos. Trans. R. Soc. S. Austrália, n.108, p. 51-62, 1984.

[34] GENZ, F. Avaliação dos Efeitos da Barragem Pedra do Cavalo Sobre a Circulação Estuarina do Rio Paraguaçu e Baia de Iguape.2006. Tese (Doutorado em Geologia). Instituto de Geociências, Universidade Federal da Bahia, Salvador, Bahia, 2006.

[35] GHASSEMI, F.; JAKEMAN, A. J.; NIX H. A. Salinisation of Land and Water Resources: Human Causes, Extent, Management and Case Studies. University of New South Wales Press Ltd., Sydney, Australia: 1995.

[36] GILLANDERS, B.M.; KINGSFORD, M.J. Impact of changes in flow of freshwater on estuarine and open coastal habitats and the associated organisms.Oceanography Marine Biology Annual Review, n. 40, p. 233-309, 2002.

[37] GRAF W. L. Downstream hydrologic and geomorphic effects of large dams on American rivers.Geomorphology, n.79, p. 336-360, 2006.

[38] HOAGSTROM, C.W. Historical and recent fish fauna of the lower Pecos. In: Contributed papers from a special session within the THIRTY-THIRD ANNUAL SYMPOSIUM OF THE DESERT FISHES COUNCIL. Alpine, TX: Sul Ross State University. Occasional Papers, Museum of Texas Tech University.p. 21, 2003.

[39] JUNK, W. J.; BAYLEY, P. B.; SPARKS, R. E.The flood pulse concept in river floodplain systems.Canadian special publication of fisheries and aquatic sciences, Canadá, v. 106, p. 110-127, 1989.

[40] KEFFORD, B.J.; HICKEY, G.L.; GASITH, A.; BEN-DAVID, E.; DUNLOP, J.E.; PALMER, C.G.; PISCART, C. Global scale variation in the salinity sensitivity of riverine macroinvertebrates: Eastern Australia, France, Israel and South Africa. PLoS ONE, v.7, n.5, p. 35224, 2012.

[41] HOAGSTROM, C.W. Causes and impacts of salinization in the lower Pecos River.Great Plains Research, v.19, p. 27-44, 2009.

[42] KHANOM, T, Effect of salinity on food security in the context of interior coast of Bangladesh, Ocean \& Coastal Management, n. 130 p. 205 e 212, 2016.

[43] KING, J.M., THARME, R.E., de VILLIERS M.S. (Ed.).Environmental Flow Assessments for Rivers: Manual for The Building Block Methodology. WRC Report No TT 354/08. August 2008.

[44] KINGSFORD, R. T.; HANKIN, C. The impact of the proposed Tillegra Dam on the Hunter River Estuary, its Ramsar wetland and migratory shorebirds. Australian Wetlands and Rivers Centre, University of NSW, Sydney, 
2010.Disponívelem: https://www.ecosystem.unsw.edu.au/content/the-impact-of-the-proposed-tillegra-dam-on-thehunter-river-estuary-its-ramsar-wetland-and-migratory-shorebirds. Acesso em: 03 jan. 2018.

[45] KNOPPERS, B.; MEDEIROS, P. R. P.; SOUZA, W. F. L.; JENNERJAHN, T. The São Francisco estuary, Brazil. In: WANGERSKY, P. (Ed.). The handbook of environmental chemistry - Water Pollution: estuaries.Berlin: Springer Verlag, v. 5 p. $1-20,2005$.

[46] LIMA, G. M. P.; LESSAAC, G. C.; FRANKLINA, T. S. Avaliação dos impactos da barragem de Santa Helena no trecho estuarino do rio Jacuípe, litoral norte da Bahia - Brasil. Quaternary and Environmental Geosciences, v. 2, n.1, p.40-54, 2010.

[47] LOUCKS, D. P.; STEDINGER, J. R.; HAITH, D. A. Water resource systems planning and analysis. Prentice-Hall Inc., New Jersey, p.559, 1981.

[48] LUNDQVIST, J. Avert looming hydrocide. Ambion. v. 27, p. 428- 433, 1998

[49] MEDEIROS, P. R. P. In: I CONGRESSO IBERO-AMERICANO DE OCEANOGRAFIA. Anais do III Congresso IberoAmericano de Oceanografia, Fortaleza-CE. 2008.

[50] MEDEIROS, P. R. P. KNOPPERS, B. A.; SANTOS JÚNIOR, R. C.; SOUZA, W.F.L. Aporte fluvial e dispersão da matéria particulada em suspensão na zona costeira do estuário do rio São Francisco (SE/AL). Geochimica Brasiliensis, v.21, n. 2, p. 209- 228, 2007.

[51] MELO, E. R. Processos hidrodinâmicos e implicações na carga de nutrientes no estuário do rio São Francisco decorrente das reduções de vazões. 2017- Dissertação (Mestrado em Meteorologia), Programa de Pós-Graduação em Meteorologia, Universidade Federal de Alagoas, Maceió - AL, 2017.

[52] MIRANDA, L.B.; CASTRO, B.M.; KJERFVE, B. Princípios de oceanografia física de estuários. EDUSP - Editora da Universidade de São Paulo. São Paulo, Brasil: 2002. 424 p. ISBN: 85-314-0675-7

[53] MIYAMOTO, S. Flow, salts, and trace elements in the Rio Grande: a review. Technical Report TR-169, Texas: Water Resources Institute,1995.

[54] OLIVEIRA, A. M. Estudo Hidrodinâmico-Sedimentológico do Baixo São Francisco, Estuário e Zona Costeira Adjacente (AL/SE). Projeto GEF São Francisco (ANA/ GEF/ PNUMA /OEA). UFAL: 2003. 81 p. (Relatório Final).

[55] OLIVEIRA, A.M.; MEDEIROS, P.R.P.; LIMA, E.L.R.; HERNANDEZ, A.O. Dinâmica da formação da cunha salina no estuário do rio São Francisco. In: CONGRESSO BRASILEIRO DE OCEANOGRAFIA 3, Fortaleza. Anais. Fortaleza: AOCEANO, 2008.

[56] PERILLO, G. M. E. Definitions and Geomorphologic Classification of Estuaries.In: Geomorphology and Sedimentology of Estuaries.Chapter 2.Developments in Sedimentology, v 53. p. 17-47,1995.

[57] PINHEIRO, Lidriana de Souza; MORAIS, J. O. Interferências de barramentos no regime hidrológico do estuário do rio Catú-Ceará-Nordeste do Brasil. Sociedade \& natureza,v. 22, p. 237-250, 2010. Disponível em://www.seer.ufu.br/index.php/sociedadenatureza/article/view/9762. Acesso 12 dez 2016.

[58] PISCART, C., MORETEAU, J.C., BEISEL, J.N.: Biodiversity and structure of macroinvertebrate communities along a small permanent salinity gradient (Meurthe River, France). Hydrobiologia, v. 551, n.1, p. 227-236, 2005.

[59] POFF NL, WARD JV. Implications of streamflow variability and predictability for lotic community structure: a regional analysis of streamflow patterns. Canadian Journal of Fisheries and Aquatic Sciences, n. 46, p.1805-1818, 1989.

[60] PRITCHARD, D. W. Estuarine Circulation Patterns. Proc. Am. Soc. Civ. Emg, v. 87, n.717, p.1-11, 1955.

[61] RAHMAN M. H.; LUNDB, T.; BRYCESON, I. Salinity impacts on agro-biodiversity in three coastal, rural villages of Bangladesh.Ocean \& Coastal Management, v. 54, n. 455 e 468, 2011.

[62] ROBINSON C. T.; UEHLINGER U. Experimental floods cause ecosystem regime shift in a regulate driver. Ecological Applications, v.18, n. 2, p. 511-526, 2008.

[63] SCHRÖDER, M., SONDERMANN, M., SURES, B., HERING, D.: Effects of salinity gradients on benthic invertebrate and diatom communities in a German lowland river. Ecological Indicators, n. 57, p. 236-248, 2015.

[64] WILLIAMS, W.D. Australian salt lakes conductivity and salinity. Australian. Journal of Marine and Freshwater Research, v.2, n. 37, p. $177-182,1986$

[65] WILLIAMS, W.D. Salinization of rivers and streams: an important environmental hazard. Ambio, v.16, p.180$185,1987$.

[66] SILVA, T. R.; COUTO, G. A.; CAMPOS, V.P.; MEDEIROS, Y.D.P.: Influência do regime de vazão da usina hidrelétrica de Pedra do Cavalo no comportamento espacial e temporal da salinidade no trecho fluvio estuarino do baixo curso do rio Paraguaçu à baía do Iguape. RBRH - Revista Brasileira de Recursos Hídricos. Porto Alegre, p. 310 319. jun. 2015. 
[67] SOUZA, R. M. G. Caracterização hidrodinâmica e estimativa do transporte de sal no estuário do rio São Francisco. 2015. (Dissertação em Meteorologia)- Programa de Pós Graduação em Meteorologia, Universidade Federal de Alagoas, 2015.

[68] WEDDERBURN, S. D.; BAILEY, C. P.; DELEAN, S.; PATON D. C. Population and osmoregulatory responses of a euryhaline fish to extreme salinity fluctuations in coastal lagoons of the Coorong, Australia. Estuarine, Coastal and Shelf Science, v.168, p. 50-57, 2016.

[69] WHITFIELD, A.K. Fishes and freshwater in southern African estuaries: a review. Aquatic Living Resources, n.18, p. 275-289, 2005.

[70] ZHANG, T.; ZHUANG, P.; ZHANG, L.; HOU, J.; WANG Y. The underlying fish community structure characteristics in the Yangtze Estuary Chinese sturgeon nature reserve. Acta Ecologica Sinica, v. 31, p.1687-1694, 2011.

Tabela 3. Resultados do monitoramento longitudinal de salinidade (\%o) na maré baixa e alta de Sizígia nas seções PA4, PA3, PA2 e P1, distantes da foz, respectivamente 21,6 km, 54,6 km, 102,3 km e 160,2 km

\begin{tabular}{|c|c|c|c|c|c|c|c|c|c|}
\hline \multirow[t]{2}{*}{ Seção } & \multirow[t]{2}{*}{$\begin{array}{l}\text { Ponto } \\
\text { amostral }\end{array}$} & \multirow{2}{*}{$\begin{array}{l}\text { Localização (meio da } \\
\text { calha) }\end{array}$} & \multirow{2}{*}{$\begin{array}{l}\text { Data da } \\
\text { medição }\end{array}$} & \multicolumn{3}{|c|}{ Maréalta } & \multicolumn{3}{|c|}{ Marébaixa } \\
\hline & & & & Superfície & Meio & Fundo & Superfície & Meio & Fundo \\
\hline 4 & PA4 & $\begin{array}{l}\text { Ilha das Flores-SE - } \\
\text { Penedo-AL }\end{array}$ & $28 / 04 / 2017$ & 0,030 & 0,032 & 0,037 & 0,030 & 0,030 & 0,031 \\
\hline 3 & PA3 & $\begin{array}{c}\text { Pindoba-SE - Xinaré- } \\
\text { AL }\end{array}$ & $27 / 04 / 2017$ & 0,029 & 0,033 & 0,032 & 0,032 & 0,031 & 0,031 \\
\hline 2 & PA2 & $\begin{array}{c}\text { Gararu-SE- Traipu- } \\
\text { AL }\end{array}$ & $26 / 04 / 2017$ & 0,035 & 0,031 & 0,032 & 0,030 & 0,030 & 0,030 \\
\hline 1 & PA1 & $\begin{array}{l}\text { Niterói-SE-Pão de } \\
\text { Açúcar-AL }\end{array}$ & $25 / 04 / 2017$ & 0,029 & 0,033 & 0,033 & 0,030 & 0,030 & 0,030 \\
\hline
\end{tabular}




\section{Capítulo 13}

\section{História e principais legislações da defesa do meio ambiente no Brasil}

\section{Antonio Jorge Barbosa da Silva \\ Ires Paula de Andrade Miranda}

Resumo: 0 meio ambiente atualmente é um dos assuntos que mais se destaca, e a justificativa para isso são o desenvolvimento industrial, o agronegócio e o consumo em massa, tendo na maioria das vezes como consequência, uma degradação do ambiente. Assim, o objetivo do presente estudo é uma explanação sobre a história e principais legislações de defesa do meio ambiente Brasil. Dentre esses objetivos contextualiza-se sobre os problemas relacionados com a questão ambiental, os aspectos históricos de defesa do meio ambiente, apontando as principais leis ambienteis do Brasil. A metodologia aplicada ocorreu por meio de uma revisão da literatura, com procedimentos descritivos e comparativos. As principais Lei Ambientais pontuadas ao

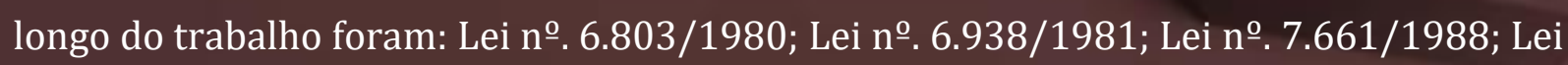
nº. 9.605/1998; e Lei n⿳o.10.650/2003. As legislações ambientais do Brasil são consideradas recentes e foram fruto de luta pela preservação do meio ambiente sendo consideradas instrumentos de proteção que surgiram como resposta à necessidade, cada vez mais premente de minimizar a devastação da floresta nativa. As referidas leis tem como objetivo prover os cidadãos com instrumentos jurídicos necessários à proteção da natureza, oferecendo respostas públicas contra ações que lhe sejam prejudiciais.

Palavras-chave: Meio Ambiente, Legislação Ambiental, Defesa do Meio Ambiente. 


\section{INTRODUÇÃO}

Com a busca incessante de alternativas econômicas, principalmente durante a revolução industrial, a grande maioria dos seres humanos distanciaram-se durante muito tempo da realidade de perda de recursos naturais, os quais são finitos e consequentemente, só começaram a ser vistos como algo preocupante a partir do século XX. A poluição e a degradação ambiental em algumas cidades por combustíveis fósseis e outros elementos industriais, estavam excedendo a capacidade do meio ambiente de assimilá-las e de se regenerar, surgindo assim os primeiros indícios de perturbações globais, difíceis de evitar. De acordo com Betiol (2017) a degradação ambiental conduziu à conscientização da imutabilidade do planeta e dos recursos naturais e o surgimento de uma preocupação com o rumo que a humanidade vinha tomando na busca pelo desenvolvimento a qualquer custo.

O campo do conhecimento em Ciências Ambientais tem crescido em todo o mundo, em decorrência da crescente preocupação com questões ambientais, advinda da utilização de recursos naturais e sua relação com o desenvolvimento, tecnológico na busca da melhoria da qualidade de vida das sociedades (ROSA e FRACETO, 2009).

Nesse contexto, surge as leis de proteção ambiental na qual segundo Barsano e Barbosa (2014), essas leis, normas, técnicas e outras regulações, têm como objetivo a prevenção do meio ambiente e o melhor aproveitamento dos recursos naturais no decorrer dos anos. Foram consequência de acontecimentos históricos específicos de diversos países, que foram sendo induzidos ao ajuste de condutas, conforme as necessidades e a análise dos interesses de todos os entes envolvidos como os poderes públicos, a iniciativa privada e a sociedade civil.

Dado o exposto, essa pesquisa irá discutir sobre a temática das leis, normas e políticas ambientais aplicadas no Brasil, pois refere-se as medidas que impacta a vida da sociedade comum um todo. Logo, à relevância da pesquisa consistirá em apresentar instrumentos essenciais, buscando a construção do conhecimento acadêmico de forma a favorecer uma leitura mais acurada, através da pesquisa e embasamentos técnicos e teóricos sobre o tema proposto.

Como contribuição a referida pesquisa traz uma tentativa de incentivar as organizações na conscientização, bem como a responsabilização com os danos decorrentes de suas atividades, e desta maneira buscar melhorias para evitar prejuízos. A pesquisa constata que através do cumprimento dessas leis, os cidadãos e as organizações podem usufruir de uma diminuição de custos e benefícios, além de demonstrar uma imagem sustentável para as demais organizações e principalmente aos seus clientes.

A metodologia aplicada ocorreu por meio de uma revisão da literatura, com procedimento descritivo e comparativo, utilizando como fonte de dados à bibliografia enriquecida com os dispositivos legais aplicáveis, tanto os encontrados na literatura ambiental quando jurídica, encontrados em material didático físicos e eletrônicos, como: livros, artigos científicos e páginas de websites.

\section{HISTÓRIA E PRINCIPAIS LEGISLAÇõES DA DEFESA DO MEIO AMBIENTE NO BRASIL}

\subsection{O MEIO AMBIENTE}

A questão ambiental ou do meio ambiente está relacionada a conjunção de fatores de ordem técnicocientífica, econômica, social, cultural e política, dentre outros, criando em algumas situações, tensões crescentes nas relações de convivência da espécie humana com os demais componentes do ecossistema da Terra, resultando em riscos globais e ameaças à sobrevivência de ambas as partes (RODRIGUES, 2017).

A larga escala da industrialização verificada no século XIX, o crescimento da população humana, e a expansão da economia, os quais resultaram na elevação dos níveis de consumo, fizeram com que a presença do homem fosse sentida em todas as partes, promovendo a transformação do meio ambiente natural de forma perigosa. 0 forte processo de urbanização induzido pela Revolução Industrial passou a responder pela má qualidade do ar, o congestionamento do trânsito e a insalubridade das aglomerações urbanas então criadas, tornando o espaço urbano danoso à saúde (BETIOL, 2017).

Os problemas relacionados com a questão ambiental podem ocasionar danos a natureza e muitos deles irreversíveis. Muitos biólogos acreditam que a sexta maior onda de extinção, desde o princípio da vida na Terra está ocorrendo agora, e que está sendo causada pela ação humana, problemas mais visíveis causados pelas empresas com relação a destinação dos resíduos, e de processos que afetam o meio ambiente (RODRIGUES, 2017). 
Dados os problemas existentes, o homem está em um momento de sua história evolutiva em que é necessária uma mudança no paradigma a respeito da sua inter-relação com o meio ambiente e seu uso, pois os recursos naturais não são mais capazes de manter a sustentabilidade dos ecossistemas e, ao mesmo tempo, suprir a demanda cada vez mais intensa de consumo imposta pelos padrões da vida moderna (ROSA e FRACETO, 2009).

0 conceito de meio ambiente requer um olhar sistêmico, pois influencia e é influenciado por diversas ações do ponto de vista das ciências das engenharias, arquitetura, química, física, biológica, etc., relacionando-se com distintos ramos do conhecimento em constante alteração, dadas as evoluções das práticas sociais, da própria ciência e das tecnologias (STRUCHEL e MENEZES, 2019).

A Lei da Política Nacional de Meio Ambiente (Lei $n^{\circ}$ 6.938/1981), em seu artigo $3^{\circ}$, inciso I, definem o meio ambiente como "o conjunto de condições, leis, influências e interações de ordem física, química e biológica, que permite, abriga e rege a vida em toda as suas formas".

A defesa do direito do meio ambiente consolidou-se como uma das principais reivindicações dos movimentos sociais da atualidade, devendo tal direto ser compreendido não como uma simples referência à natureza, mas como gênero abrangente de todas as relações e interações do homem, nelas incluídas as relações trabalho (ROJAS, 2014).

\subsubsection{PROBLEMAS AMBIENTAIS}

O campo de conhecimento em ciências ambientais tem se expandido em todo o mundo, em decorrência da crescente preocupação com questões advindas da utilização de recursos naturais e suas relações com o desenvolvimento tecnológico, na busca do aumento da produção industrial para atender as necessidades e modernização da sociedade (ROSA e FRACETO, MOSCHINI-CARLOS, 2009).

Contudo, a crença que a natureza existe para servir o ser humano contribui para o estado de degradação ambiental que hoje se observa. Entretanto, certamente foi o aumento da escala de produção e consumo que provocaram os problemas ambientais que hoje conhecemos (BARBIERI, 2017).

É comum apontar a revolução industrial como marco importante na intensificação dos problemas ambientais. A maior parcela de emissões ácidas de gases de efeito estufa e de substâncias tóxicas, resultam das atividades industriais em todo o mundo. 0 lixo gerado pela população cada vez mais está composto por restos de embalagens plásticas e produtos industrializados. Segundo Barbieri (2017) o uso de inseticidas, herbicidas, fertilizantes, implementos e outros produtos industrializados, fazem com que a agricultura se torne uma atividade intensiva de degradação ambiental.

De conformidade com Souza (2014) em suma, problemas ambientais relacionados a infração das leis da biodiversidade, como poluição, desmatamento, extinção de espécie, inundação, vazamento radioativo, escassez de recursos naturais e energéticos, tráfico de animais silvestres, esgoto a céu aberto, mau uso dos resíduos sólidos, enfim, uma extensa série de ameaças não apenas ao meio ambiente, mas também a própria raça humana e suas gerações futuras necessitam de um ajustamento de conduta compatíveis com a harmonia entre ser humano e natureza.

A mineração, também, é um dos problemas ambientais, porque essa atividade utiliza diversos processos que produzem impacto de diversas formas e intensidades, como emanação de poluentes das atividades, esgotamento das reservas, movimento da terra ou rochas e contaminação do solo e lençol freático, pelo uso de substâncias químicas (GAMA e NAVARRO, 2005).

Diversos cientistas sociais e ambientais têm reportado a deterioração ecológica decorrente do padrão de intensificação humana sobre o meio ambiente, em especial em período de aceleração do crescimento econômico. Por esse motivo, muito se discute, qual seria o modelo de desenvolvimento capaz de atender a demanda da população sem comprometer ao mesmo tempo a qualidade ambiental, bem como a atividade econômica (VIEIRA, 2015).

Devido essas mudanças a sociedade impõe às entidades privadas que atuem como parte da solução do problema, para um planeta mais sustentável. Nesse sentido, Bensusan $(2006$, p. 316) esclarece que as organizações devem realizar investimentos em prol da biodiversidade. A economia e o mundo dos negócios necessitam oferecer a sociedade em geral, bem como aos acionistas, clientes e empregadores uma visão clara do volume de investimentos, para a mitigação do impacto ambiental que a organização oferecerá, na proteção e recuperação da biodiversidade afetada no Brasil e no mundo. 
Dessa forma, a busca pelo desenvolvimento sustentável vem mobilizando, também, diversas esferas do poder público (federal, municipal e estadual), no sentido de vislumbrar novas possibilidades de ações que priorizem a sustentabilidade (VIEIRA, 2015).

\subsection{HISTÓRIA DA DEFESA DO MEIO AMBIENTE NO PAÍS}

A Revolução Industrial promoveu um crescimento econômico, novas perspectivas, porém, a indústria degradou o meio ambiente. A industrialização trouxe vários problemas ambientais como, consumo excessivo de recursos naturais, sendo alguns não renováveis, alta concentração populacional, devido a urbanização acelerada, contaminação do ar, do solo, das águas, e do desflorestamento, entre outros. A industrialização se tornou um problema por causa dos resíduos dos processos produtivos. Estudos apontavam que o modelo de crescimento econômico se mostrava como um dos maiores fatores para a escassez dos recursos extraídos da natureza (BETIOL, 2017).

Do ponto de vista ambiental, questionava-se cada vez mais o mito da abundância do capital natural, e constatava-se que o modelo de crescimento econômico até então adotado provocou agravamento da deterioração ambiental, com o aumento da contaminação e a possibilidade do esgotamento dos recursos naturais (RODRIGUES, 2017).

A partir daí deu-se início a vários trabalhos de instituições e organizações com o intuito de proteger o meio ambiente. Segundo dados da Conferência da Organização das Nações Unidas (ONU), no início dos anos 70, apenas 10 países contavam com organismos ambientais nacionais - órgãos especializados, departamentos, comitês etc. No fim de 1974 eram 60 e no final da década aproximadamente 100 . Consequentemente, a questão ambiental começou a ser discutida na Conferência de Estocolmo, onde ganhou evidência em todos os seus aspectos. Essa questão ganhou espaço na ONU na reunião de Estocolmo em 1972, que por vinte anos agitou debates, fundamentou programas de governos, etc. (BETIOL, 2017).

Na década de 70, criou-se o decreto no 73.030/73 da Secretaria do Meio Ambiente (SEMA) subordinada ao Ministério do Interior. Juntamente com a SEMA criou-se o Conselho Consultivo do Meio Ambiente (CCMA). As suas competências abrangentes estavam elencadas no Art. $4^{\circ}$ do Decreto. Este estabelecia o uso racional dos recursos naturais, a elaboração e estabelecimento das normas padrões relativos à preservação do meio-ambiente, em especial dos recursos hídricos, que assegurem o bem-estar das populações e o seu desenvolvimento econômico e social. Além da colaboração com os órgãos especializados no controle e fiscalização das normas padrões e a promoção, em todos os níveis; a formação e treinamento de técnicos e especialistas no assunto, relativo à preservação do meio ambiente (RAMOS, 2009, p.102).

Em 1992, com a realização da Rio-92, surge a perspectiva de resolução das questões ambientais. A Rio-92 vislumbrou novas esperanças para o enfrentamento da questão ambiental. Mas ainda persiste um problema não resolvido para a população humana, pois as pessoas dependem dos recursos naturais e são responsáveis pelas mudanças que ocorrem no meio ambiente. 0 aumento da população e o consumo, são alguns fatores que influenciam a relação do homem com a natureza (ROSA e FRACETO, 2009).

Durante a Conferência das Nações Unidas sobre o Meio Ambiente e o Desenvolvimento (CNUMAD), foram aprovados documentos importantes sobre questões globais na perspectiva do desenvolvimento sustentável, entre eles a declaração do Rio de Janeiro sobre o Meio Ambiente e o Desenvolvimento; a Confederação sobre Mudanças Climáticas; a Convenção de Biodiversidade e a Agenda 21. A agenda 21 apresenta recomendações especificas para diferentes níveis de atuação como assentamentos humanos, erradicação da pobreza, desertificação, água doce, oceanos, atmosfera, poluição, e outras questões socioambientais. Para acompanhar a implementação da Agenda 21, foi criada ao final de 1991, a Comissão de Desenvolvimento Sustentável (BARBIERI, 2017).

A Constituição Federal de 1988, contemplou os valores ambientais como uma das dimensões da dignidade humana, expressa no direito que todos têm de viver e de laborar em um meio ambiente equilibrado e saudável. Além da previsão no texto constitucional, diversas foram as leis editadas a fim de proteger o meio ambiente (ROJAS, 2014).

A introdução dos instrumentos legislativos de efetiva proteção ao meio ambiente é consequência da reivindicação de profundas transformações político-jurídicas e econômicas, pleiteadas pela sociedade e identificadas pelo direito em seu diálogo com meio social, levando à construção dos denominados direitos fundamentais de terceira geração, como os direitos a qualidade de vida (BETIOL, 2017). 


\subsection{DIREITO AMBIENTAL E SUA EVOLUÇÃO}

As constituições brasileiras de 1824 e de 1891, influenciada pelo liberalismo econômico e pela não intervenção do estado, nada trazia a respeito da proteção ambiental, sendo o direito de propriedade protegido de forma quase absoluta. A Constituição de 1934, primeira Constituição social brasileira, por refletir mudanças ideológicas mundiais decorrentes do fracasso do liberalismo econômico, previu a intervenção do estado no domínio econômico. Nas constituições de 1937, de 1946 e de 1967/69, a evolução do princípio social da propriedade revelou-se fundamental para o surgimento de normas infraconstitucionais de proteção ambiental, mas nada suscitou de forma expressa acerca da tutela ambiental (LEITE, 2017).

Seguindo a tendência mundial, a tutela do meio ambiente foi içada a categoria de direito e expressamente protegida da Constituição, tendo o legislador reservado um capítulo inteiro para o seu tratamento, o artigo 255, uma vez que na Constituição anterior, o assunto era tratado de modo espaço e sem a menor preocupação sistemática. Apenas na carta de 1969 é que se utilizou pela primeira vez a palavra ecológico quando se cuidava da função agrícola das terras (RODRIGUES e LENZA, 2018).

0 art. 255 da Constituição Federal de 1988, expressa que: "todos têm direito ao meio ambiente ecologicamente equilibrado, bem de uso comum do povo e essencial à sadia qualidade de vida, impondo-se ao Poder Público e à coletividade o dever de defendê-lo e preservá-lo para as presentes e futuras gerações".

A primeira definição legal de meio ambiente no Brasil, ocorreu com a edição da Lei no 6.938 de 1981, segundo essa legislação o meio ambiente é o "patrimônio público a ser necessariamente assegurado e protegido tendo em vista o uso coletivo" (art. $2^{\circ}$, inciso I). Para os fins previstos nesta Lei, entende-se por meio ambiente: "o conjunto de condições, leis, influências e interações de ordem físico-química e biológica, que permitem, abrigar e reger a vida em todas as suas formas". (art. 3ํㅡ, inciso I).

Diante da prerrogativa apresentada, compreende-se que a Lei no 6.938 de 1981, representou um marco inicial, pois com o advento da Constituição de 1988, trouxe o arcabouço jurídico que faltava para o direito ambiental, dando status de constitucional da ciência autônoma, o complemento de tutela material necessário à proteção sistemática do meio ambiente (RODRIGUES e LENZA, 2018).

Contudo, com o passar dos tempos verifica-se que tais conceituações não abrangia toda a importância do direito ambiental. Atualmente, a Lei no 6.938 /81, em seu art. 3o, e seus incisos, entende o meio ambiente com: "in verbis"

I Meio ambiente, o conjunto de condições, leis, influências e interações de ordem física, química e biológica, que permite, abriga e rege a vida em todas as suas formas;

II Degradação da qualidade ambiental, a alteração adversa das características do meio ambiente;

III Poluição, a degradação da qualidade ambiental resultante de atividades que direta ou indiretamente:

a) prejudiquem a saúde, a segurança e o bem-estar da população;

b) criem condições adversas às atividades sociais e econômicas;

c) afetem desfavoravelmente a biota;

d) afetem as condições estéticas ou sanitárias do meio ambiente;

e) lancem matérias ou energia em desacordo com os padrões ambientais estabelecidos;

IV Poluidor, a pessoa física ou jurídica, de direito público ou privado, responsável, direta ou indiretamente, por atividade causadora de degradação ambiental;

V Recursos ambientais: a atmosfera, as águas interiores, superficiais e subterrâneas, os estuários, o mar territorial, o solo, o subsolo, os elementos da biosfera, a fauna e a flora.

Hoje, o direito ambiental é visto como um sistema de normas e princípios que regem as relações dos seres humanos com esses elementos que compõem um ambiente natural. Trata-se de um sistema, e não um conjunto de normas e princípios, porque esses elementos possuem uma lógica que os vinculam entre si, o que vai além das simples existências de algumas características (LEUZINGER e CUREAU, 2013).

No sistema normativo brasileiro, os princípios de direito ambiental são encontrados, principalmente, na Constituição da República, nos tratados e nos documentos internacionais, retificados pelo Brasil bem como lei da Política Nacional do Meio Ambiente (Lei nº 6.938 /81). 
Moura (2009. p.12) simplifica que o direito ambiental é um direito sistematizador, ou seja, é uma disciplina que procura enfatizar a integração de legislação, da doutrina e da jurisprudência relativa ao meio ambiente, evitando assim que haja uma interpretação isolada de cada matéria específica.

Destaca-se como fonte primária do direito ambiental brasileiro os princípios fundamentais como: princípio da informação e da participação; princípio da precaução; princípio da prevenção; princípio da responsabilização; princípio do poluidor-pagador; princípio do usuário-pagador; princípio do protetor recebedor; princípio da cooperação; princípio da função socioambiental da propriedade; princípio do mínimo existencial; princípio da equidade intergeracional e o princípio da proibição de retrocesso ambiental (LEITE, 2017).

\subsection{LEIS AMBIENTAIS}

Apesar de atualmente observarmos a questão ambiental ser tratada exaustivamente até na mídia mais popular, e nos depararmos em nosso corpo legislativo com nomes de vanguarda na proteção ao meio ambiente, foi longo o caminho trilhado pelo legislador para que fosse possível alcançar esse nível normativo de proteção. Especialmente tendo em conta o real objetivo das primeiras leis que disciplinaram o meio ambiente e os recursos naturais em nosso país (BETIOL, 2017).

Para Barsano e Barbosa (2014), as primeiras iniciativas dos poderes públicos na preservação do meio ambiente, remetem à década de 1930, quando a industrialização brasileira começava a se intensificar conforme a realidade política e econômica da época, visando geralmente mais motivos econômicos do que a conscientização ambiental, panorama que permaneceria até final da década de 1970. 0 Brasil tinha como objetivo desenvolver-se industrialmente, para ampliar seus interesses na economia mundial, acelerar o crescimento do país e com isso, fortalecer o Estado.

Contudo, pode-se dizer, de início, que as Constituições que precederam a de 1988, não se preocuparam com a proteção do meio ambiente de forma especifica e global (STRUCHEL e MENEZES, 2019).

Apesar de tímidas, as primeiras Leis de proteção ambiental apresentam algumas preocupações de âmbito de preservação dos recursos naturais, como a aplicação de penas fiscais e criminais em caso de destruição de florestas de preservação permanente no Código Florestal, e o controle da poluição no Código de Pesca (BARSANO e BARBOSA, 2014).

Rocha, Filho e Cazetta (2007, p.340) relatam que:

"As mais recentes leis do direito ambiental foram erigidas no patamar do direito fundamental pela nova ordem constitucional, tendo surgido, também neste contexto, um pacto trangeracional de sustentabilidade ambiental. A inserção do pacto trangeracional no texto constitucional dá suporte ao princípio da responsabilidade entre gerações atuais e futuras, o qual consubstancia-se no impedimento de que o modelo de desenvolvimento econômico social, levando a efeito para atender às necessidades e padrão de consumo do presente, comprometa ou inviabilize a existência de gerações futuras, ou pelo menos a dignidades dessa existência"

As leis foram criadas com a finalidade de proteger o meio ambiente. As principais leis ambientais são as do tipo ordinária. A Tabela 1 enfatiza algumas das principais leis ambientais. 
Tabela 1. Principais leis ambientais.

\begin{tabular}{|c|c|c|}
\hline ITEM & LEI & DESCRIÇÃO \\
\hline 1 & Lei no 6.803, de 02.07.1980 & $\begin{array}{l}\text { Dispõe sobre as diretrizes básicas para o zoneamento industrial nas } \\
\text { áreas críticas de poluição e estabelece outras providências. }\end{array}$ \\
\hline 2 & Lei no 6.938, de 31.08.1981 & Lei da Política Nacional do Meio Ambiente - LPNMA. \\
\hline 3 & Lei $\mathrm{n}^{0}$ 6.938/81 & Institui o Sistema Nacional de Meio Ambiente-Sisnama. \\
\hline 4 & Lei no 7661 , de 16.05 .1988 & $\begin{array}{l}\text { Institui o plano nacional de gerenciamento, prevendo o zoneamento de } \\
\text { usos e atividades na Zona costeira. Decreto no 9.193, de } 27.03 .1990 \text {, } \\
\text { que dispõe sobre a atividade relacionada ao zoneamento Ecológico- } \\
\text { Econômico, e decreto no } 99.540 \text {, de } 21.09 .1990 \text {, que institui a comissão } \\
\text { coordenadora do Zoneamento Ecológico-Econômico do território } \\
\text { nacional. }\end{array}$ \\
\hline 5 & Lei. $\mathrm{n}$ o 9.605, de 12.02 .1998 & $\begin{array}{l}\text { Lei de crimes ambientais - LCA. } \\
\text { Essas leis são regulamentadas por decretos: } \\
\text { Decreto no 99.274, de 06.06.1990, que dispõe sobre a Lei da Política } \\
\text { Nacional do Meio Ambiente (LPNMA) e ainda compreende as três } \\
\text { espécies de licenciamento ambiental: a Previa (LP); a de Instalação } \\
\text { (LI); e a de Operação (LO) } \\
\text { Decreto no 9.760 11.04. 2019 - Altera Regras de Conversão de Multa } \\
\text { Ambiental em Prestação de Serviços Ambientais } \\
\text { Decreto no 99.733, de 12.02.1998, que dispõe sobre a inclusão, no } \\
\text { orçamento, de projetos e obras federais, de recursos destinados a } \\
\text { prevenir ou corrigir os prejuízos de natureza ambiental e social, } \\
\text { decorrentes da execução desses projetos e obras. }\end{array}$ \\
\hline 6 & Lei no. 10.650 , de 16.04 .2003 & Lei de acesso à Informação Ambiental. \\
\hline
\end{tabular}

Fonte: Autor (2020)

0 item 1, da Tabela 1, destaca a Lei no 6.803, de 02.07.1980 que trata das diretrizes básicas para o Zoneamento Industrial nas áreas críticas de poluição e estabelece outras providências. Segundo Honora (2018) é exemplo de iniciativa do poder público no sentido de prevenir a degradação ambiental por intermédio de ações de planejamento territorial.

O item 2, da Tabela 1, destaca a Lei no 6.938, de 31.08.1981 que trata da Lei da Política Nacional do Meio Ambiente (LPNMA). Para Leite (2017) a LPNMA, ao sintetizar conceitos centrais, órgãos e entidades vocacionais à proteção ambiental, enumera instrumentos dedicados à consecução dos objetivos por ela traçados; inovou em inúmeros aspectos os quais estabelecem um sistema de valores que informam e conformam toda interpretação e aplicação das normas ambientais.

O item 3, da Tabela 1, destaca a Lei no 6.938/81 que trata da instituição do Sistema Nacional de Meio Ambiente (Sisnama). De acordo com Rios e Irigaray (2005), o objetivo do Sisnama é a implementação de regra, que tornem possível o desenvolvimento sustentável por meio de instrumentos e mecanismos capazes de conferir ao meio ambiente mais proteção. Além disso, o Sisnama possui normas e planos destinados a orientar entes públicos da federação, em conformidade com princípios elencados na Lei supracitada.

O item 4, da Tabela 1, destaca a Lei no 7661, de 16.05.1988, que trata da instituição do plano nacional de gerenciamento, prevendo o zoneamento de usos e atividades na Zona costeira. Araújo (2011), enfatiza que o Plano Nacional de Gerenciamento Costeiro (GERCO) prevê o zoneamento de toda esta extensa área, trazendo normas para o uso do solo, da água e do subsolo, de modo a priorizar a proteção e a conservação dos recursos naturais. Além do patrimônio histórico, paleontológico, arqueológico, cultural e paisagístico. Permite aos estados e municípios costeiros, instituírem seus próprios planos de gerenciamento, desde que prevaleçam as normas mais restritivas. As praias são bens públicos de uso do povo, assegurando-se o livre acesso a eles e ao mar. 0 gerenciamento costeiro deve obedecer às normas do Conselho Nacional do Meio Ambiente (Conama).

O item 5, da Tabela1, destaca-se a Lei no 9.605, de 12.02.1998, Lei de Crimes Ambientais (LCA). De acordo com Schneider (2011), as LCA são de grande relevância para o direto ambiental brasileiro, definindo condutas lesivas ao meio ambiente, com aplicação de penas restritivas de direito, ou de prestação de 
serviços à comunidade, ou de multa, dependendo do potencial ofensivo do crime praticado. Para determinar o crime ambiental pode ser definido como um fato típico antijurídico que causa danos ao meio ambiente, a conduta lesiva deve estar expressamente prevista na Lei dos Crimes Ambientais.

0 item 6, da Tabela 1, destaca a Lei no 10.650, de 16.04.2003, Lei de acesso à informação ambiental. Para Sarlet; Machado e Fensterseifer (2017), essa lei representa um marco legal ao meio ambiente na edificação de um sistema político-institucional de índole democrático-participativa. Pela lei supracitada, toda entidade da administração pública, ficam obrigados a permitir o acesso público aos documentos e fornecer todas as informações que estejam sob sua guarda. 0 vínculo entre a questão ambiental e a lei de acesso à informação está demostrado pelo fato de que a proteção transporta a natureza de interesse público; portanto qualquer informação ambiental de posse de entidade pública passa a ser acionável com amparo na Lei.

\section{CONSIDERAÇÕES FINAIS}

O meio ambiente é um dos assuntos que mais se destaca na mídia internacional, e a justificativa para isso é muito simples: o desenvolvimento industrial e o consumo em massa, elevaram a produção de bens a níveis jamais vistos, causando como consequência uma degradação ambiental elevada. Dado esses problemas o objetivo central do estudo foi explanar sobre a história e principais legislações da defesa do meio ambiente do Brasil.

Com a pesquisa compreendeu-se que a intervenção do homem sobre a natureza com a produção de bens de consumo, vem aumentando os problemas causando sérios danos ao clima, à biodiversidade e aos seres humanos. Urge a necessidade de ampliação organizacional da economia versus meio ambiente, além da efetividade da aplicação das Leis já consolidadas. Conhecer a legislação ambiental por meio de conscientização da sociedade, propicia condições para que a degradação seja evitada. Além disso, este conhecimento possibilita a determinação de procedimentos necessários para escolher os meios de recuperação mais favoráveis, e a obtenção de resultados mais efetivos.

As legislações ambientais do Brasil são consideradas recentes e são instrumentos de proteção que surgiram como resposta as necessidades, face as mudanças climáticas e catástrofes ambientais cada vez mais evidenciadas no planeta. A aplicação dos instrumentos jurídicos, catalisa o dever de cada cidadão na proteção da vida humana e da biodiversidade. Somente com o cumprimento das leis e sanções por desobediência as mesmas; à proteção a vida, natureza e ao ser humano estará resguardada para as gerações futuras.

Ao final da pesquisa pode-se concluir que todos os objetivos foram alcançados, porque se discutiu a questão do meio ambiente e as legislações ambientais, além de sua importância na atualidade, bem como se destacou a Lei da Política Nacional do Meio Ambiente, que foi desenvolvida para mitigar os impactos que as indústrias e empresas impõe ao meio ambiente.

Para estudos futuros, sugere-se a pesquisa sobre os incentivos que as empresas recebem do governo, para realizar as ações colaborativas de mitigação, uma vez que os apoios são primordiais para influenciar novas empresas a aplicarem os princípios da sustentabilidade.

\section{REFERÊNCIAS}

[1] ARAÚJO, Giovanni Moraes de. Regulamentação do Transporte Terrestre de Produtos Perigosos. 1aㅡ edição. Rio de Janeiro: Editora: Gerenciamento Verde, 2011, 530 p.

[2] BARBIERI, José Carlos. Gestão ambiental empresarial. São Paulo: Editora Saraiva, 2017, 312 p.

[3] BARSANO, Paulo Roberto; BARBOSA, Rildo Pereira. Gestão ambiental. São Paulo: Editora Érica, 2014, 128 p.

[4] BRASIL, Constituição (1988) Constituição da República Federativa do Brasil. Brasília: Senado, 1988, 498 p.

[5] BRASIL, Lei 10.406, de 10 de janeiro de 2002. Código Civil Brasileiro. Brasília: Senado, 2002, 616 p.

[6] BRASIL, Lei 6.938, de 31 de agosto de 1981. Dispõe sobre a Política Nacional do Meio Ambiente, Brasília, 31 ago. 1981,47 .

[7] BRASIL, Lei no 9.605. Dispõe sobre a Lei de Crimes Ambientais. Brasília: Senado, 12 de fevereiro de 1998, 16 
[8] BENSUSAN, Nurit. Biodiversidade: é para comer, vestir ou para passar no cabelo?: para mudar o mundo!. Editora Petrópolis, 2006, 418 p.

[9] BETIOL, Luciana Stocco. Responsabilidade Civil e Proteção Ao Meio Ambiente. São Paulo: Editora Saraiva, 2017, 380 p.

[10] DIAS, Reinaldo. Gestão Ambiental: responsabilidade social e sustentabilidade. 1 ed. São Paulo: Atlas, 2006, $232 \mathrm{p}$.

[11] GAMA, Carlos Dinis da; NAVARRO, Vidal. Engenharia ambiental subterrânea e aplicações. CYTED-CETEM, 2005, $542 \mathrm{p}$.

[12] HONORA, Ana Carolina de Campos. Avaliação de impactos socioambientais da atividade turística. São Paulo: Senac, 2018, $133 \mathrm{p}$

[13] LEITE, José Rubens Morato. Manual de direito ambiental. São Paulo: Editora Saraiva, 2017, 1.204 p.

[14] LEUZINGER, Márcia; CUREAU, Sandra. Direito ambiental. Elsevier Brasil, 2013, 339p.

[15] MOURA, Cid Capobiango Soares de. Responsabilidade Civil Extracontratual Da Administração Pública Pelo Dano Ambiental Coletivo. Clube de Autores, 2009, 134 p.

[16] RAMOS, Erasmo Marcos. Direito ambiental comparado (Brasil-Alemanha-EUA): uma análise exemplificada dos instrumentos ambientais brasileiros à luz do direito comparado. Erasmo Marcos Ramos, 2009, 259 p.

[17] RIOS, Aurélio Virgílio Veiga; IRIGARAY, Carlos Teodoro Hugueney. 0 direito e o desenvolvimento sustentável: curso de direito ambiental. Editora Peirópolis LTDA, 2005, 488 p.

[18] ROCHA, João Carlos de Carvalho; FILHO, Tarcísio Humberto Parreiras Henriques; CAZETTA, Ubiratan. Política nacional do meio ambiente: 25 anos da Lei. Editora del Rey, 2007, 627 p.

[19] RODRIGUES, Arlete Moysés. A questão ambiental e a (re) descoberta do espaço: uma nova relação sociedade/natureza?. Boletim Paulista de Geografia, n. 73, 2017, p.35-72.

[20] RODRIGUES, Marcelo Abelha; LENZA, Coord Pedro. Direito ambiental esquematizado. Saraiva Educação SA, 2018, $645 \mathrm{p}$.

[21] ROJAS, Ana Paula. A atuação do Ministério Público do Trabalho na defesa do meio ambiente laboral. Buqui Livros Digitais, 2014, 116 p.

[22] ROSA, André Henrique; FRACETO, Leonardo F.; MOSCHINI-CARLOS, Viviane. Meio ambiente e sustentabilidade. Artmed Editora, 2009, 412 p.

[23] SOUZA, Lucas da Arcela Seixas de. A gestão ambiental e a solução para os diversos problemas ambientais. Editora Lucas da Arcela Seixas de Souza, 2014, 52 p.

[24] SARLET, Ingo Wolfgang; MACHADO, Paulo Affonso Leme; FENSTERSEIFER, Tiago. Constituição e legislação ambiental comentadas. São Paulo: Editora Saraiva, 2017, 1.204 p.

[25] SCHNEIDER, Rodolfo Herberto. Abordagens atuais em segurança pública. EDIPUCRS, 2011, 572 p.

[26] STRUCHEL, Andréa Cristina de Oliveira; MENEZES, Rogério. Gestão ambiental para cidades sustentáveis. Oficina de Textos, 2019, $208 \mathrm{p}$.

[27] VIEIRA, Allan Sarmento. Gestão Ambiental: Uma Visão Multidisciplinar. Clube de Autores (managed), 2015, 285 p. 


\section{Capítulo 14}

A institucionalização do Programa Ambiente Legal, no âmbito do Ministério Público do Estado do Amazonas: Um estudo de caso sob o enfoque socialconstrucionista

\section{Edson de Paula Rodrigues Mendes}

Resumo: Esse estudo analisa como se deu o processo de institucionalização das ações propostas pelo programa Ambiente Legal, no âmbito do Ministério Público do Estado do Amazonas, numa abordagem intraorganizacional e social-construcionista. Nela, foi privilegiada a interpretação que, destas ações, tiveram os membros e servidores do órgão. Para tanto, foi realizado o aporte da Teoria Institucional, em que se utilizou o modelo de processos inerentes à institucionalização, de Tolbert e Zucker (1999), ancorado nas contribuições do construcionismo social de Berger e Luckmann (1967), e nos legados de autores neoinstitucionalistas, sobretudo Meyer e Rowan (1977). A pesquisa teve caráter qualitativo, de bases interpretativistas, em que a estratégia adotada foi o estudo de caso. Quanto a sua finalidade, o estudo teve caráter exploratóriodescritivo. Os dados foram coletados por meio de entrevistas semiestruturadas, análise de documentos e de fotografias, e analisados mediante os recursos da análise de conteúdo temática. Os resultados demonstraram que as ações do programa, predominantemente, não se manifestaram habitualizadas a partir das expectativas de membros e servidores do MPE/AM, segundo as características que tipificam os processos inerentes à institucionalização, de Tolbert e Zucker (1999). Foram destacados os significados atribuídos pelos sujeitos da pesquisa às ações propostas pelo programa, na tentativa de contornar a subjacência humana na construção das instituições sociais que demarcam a realidade invisível que prevalece nos estudos organizacionais. A ênfase que o estudo deu ao protagonismo humano na construção intersubjetiva da realidade organizacional permitiu concluir que as ações propostas pelo programa Ambiente Legal não foram capazes de gerar um compartilhamento de significados que resultassem na incorporação de valores socioambientais na organização pesquisada, ressalvada a dedicação do grupo responsável por sua implementação.

Palavras-chave: Processo de Institucionalização. Construcionismo Social. Novos Valores. Ministério Público do Estado do Amazonas. 


\section{INTRODUÇÃO}

Esta pesquisa tem como objeto de estudo, o processo de institucionalização do programa Ambiente Legal, idealizado e desenvolvido a partir de maio de 2009, no âmbito do Ministério Público do Estado do Amazonas, atendendo a Recomendação № 06, de 22 de outubro de 2007, emitida pelo Conselho Nacional do Ministério Público.

O MPE/AM criou um órgão institucional de gestão ambiental, cujas atividades resultaram no programa Ambiente Legal, baseando-se, ainda, nas diretrizes da $\mathrm{A}_{3} \mathrm{P}$ - Agenda Ambiental da Administração Pública: uma iniciativa do Governo Federal que apoia organizações públicas na elaboração e adoção de práticas administrativas, que sejam consoantes à sustentabilidade.

Dessa forma, o programa foi concebido para propor ações que viabilizassem: (i) a coleta seletiva adequada de resíduos; (ii) o uso de papel reciclado; (iii) o consumo racional de bens e serviços disponíveis, e; (iv) o bem-estar do servidor do MPE/AM. De acordo com a nova orientação administrativa advogada pelo CNMP, tais ações só podem se concretizar mediante a conscientização institucional: esse, portanto, foi o objetivo que norteou as ações propostas pelo programa.

Este trabalho pretende discutir a institucionalização das ações propostas pelo programa Ambiente Legal, a partir do entendimento, que delas tiveram, os membros e servidores do MPE/AM. Para tanto, foram utilizados os suportes da Teoria Institucional, sobretudo em sua abordagem sociológica. Neste capítulo, estão elencados a caracterização do problema investigado, os objetivos geral e específicos da pesquisa e a justificativa da mesma. Há também, o referencial teórico que norteia a investigação, envolvendo: (i) A abordagem interpretativista no institucionalismo sociológico; (ii) o conceito de instituições e processo de institucionalização, em Berger e Luckmann; (iii) o novo institucionalismo sociológico e o construcionismo social; (iv) as contribuições de Tolbert e Zucker, no estudo do processo de institucionalização, e; (v) o processo de institucionalização, no contexto do Programa Ambiente Legal e ainda, a apresentação dos procedimentos metodológicos, além da explanação dos resultados analisados e discutidos com as conclusões e considerações finais do estudo realizado.

\subsection{CARACTERIZAÇÃO DO PROBLEMA INVESTIGADO}

As organizações têm sido cada vez mais pressionadas, por setores da sociedade, para que adotem uma postura de maior respeito pela causa ambiental. 0 conjunto de eventos que redundaram em prejuízos ambientais e, consequentemente, trouxeram graves sequelas para o bem estar das sociedades de diversos países, se configurou num fator que passou a exigir, daquelas, um debate que tem revelado maior cuidado com o tema.

Dentre tais eventos, pode-se destacar: o envenenamento por metais, da Baía de Minamata, no Japão (década de 1950); o enorme derramamento de óleo na costa oeste da Inglaterra, (final da década de 1960); os quarenta milhões de litros de petróleo derramados pelo navio Exxon Valdez, no Alasca (1989), além do maior acidente nuclear da história, em Chernobil, na antiga URSS (1986) (BERNARDES; FERREIRA, 2003).

Recentemente, os acidentes com a plataforma petroleira Deepwater Horizon (abril de 2010), que explodiu no Golfo do México, deixando vazar quase cinco milhões de barris de petróleo na costa norte-americana, e os cento e quarenta mil litros de petróleo despejados pela empresa Chevron na Bacia de Campos, no Rio de Janeiro (novembro de 2011), causaram indignação e reforçaram o sentimento de vigilância com que a sociedade cobra, do Estado e das organizações, maior responsabilidade com a questão ambiental.

Estas ocorrências têm evidenciado a gravidade e os efeitos das agressões ao meio ambiente, motivo pelo qual diversos países se mobilizaram, na tentativa de estabelecer agendas oficiais que permitissem medidas de proteção aos biomas existentes no planeta. Logo, em resposta a estes acidentes, foram realizadas, ao longo da história: a Conferência sobre Biosfera, em Paris (1968); o relatório denominado Os Limites do Crescimento, produzido pelo Clube de Roma (1972); a primeira Conferência das Nações Unidas sobre Meio Ambiente, em Estocolmo (1972).

0 Protocolo de Kioto, que deu tratativa à emissão de gases poluentes, a Conferência de Joanesburgo (2002), que revisou as metas propostas pela Agenda 21 e, mais recentemente, a COP 15, realizada em Copenhage (2009), e a COP 17, realizada em Durban, na África do Sul (2011) ambas para discutir as consequências do desmatamento e efeito estufa, são exemplos de que a preocupação com a questão ambiental ganhou, definitivamente, contornos universais. 
No caso brasileiro, o Estado tem procurado manifestar o seu poder para defender o meio ambiente, um patrimônio caracterizado como um direito difuso e coletivo, editando diversas leis para regulamentar tal proteção: Lei Federal no 6.938/81 (Política Nacional do Meio Ambiente); Lei no 7.347/85 (Lei da Ação Civil Pública); Lei 9.795/99 (que torna obrigatória a educação ambiental nas redes de ensino), além da edição da nova Constituição Federal, de 05/10/1988 (CUNHA; GUERRA, 2005; SCHENINI; NASCIMENTO, 2002).

Outras fontes de pressões que têm contribuído, para que as organizações se adeqüem às causas ambientais, buscando inovar em práticas de sustentabilidade, remetem às ações do Ministério Público, à procura crescente por produtos certificados, por parte dos países desenvolvidos e, por fim, à nova escola de dirigentes empresariais (VEIGA, 2007).

A atuação do Ministério Público, robustecida pela maior autonomia orçamentária e administrativa dada pela Constituição Federal de 1988, ganhou relevância ainda maior com a criação da CONAMP - Associação Nacional dos Membros do Ministério Público. Dentre as finalidades institucionais da associação, encontrase o desenvolvimento de ações para a defesa do meio-ambiente (BRASIL. Disponível em <http:// http://www.conamp.org.br> Acesso em 20 de jun. 2012).

A CONAMP prima pela busca de soluções para os problemas decorrentes do mau uso dos recursos naturais, articulando-as com os esforços que, juntos, envidam os Poderes Judiciário, Legislativo e Executivo. Para tanto, dispõe de uma Comissão que trata, especificamente, dos temas relacionados ao Meio Ambiente e ao Código Florestal.

A partir das reuniões da CONAMP durante os preparativos da RIO 92, surgiu o interesse de membros do Ministério Público, nas esferas estadual e federal, em compartilhar suas experiências na área especializada em meio ambiente.

0 interesse em comum, aliado ao intercâmbio de ideias e à necessidade de harmonizar procedimentos na área de defesa ambiental, redundou na criação da ABRAMPA - Associação Brasileira dos Membros de Ministério Público de Meio Ambiente, entidade concebida em 1992, mas concretizada apenas em 1997 (BRASIL. Disponível em <http://http://www.abrampa.org.br> Acesso em 21 de jun. 2012).

Tal instituição tem caráter científico, técnico e pedagógico, e visa à proteção do meio ambiente, além de bens e direitos de valor artístico, estético, histórico, turístico e paisagístico. Também promove a integração de seus associados, mediante a realização de eventos que primem pelo aperfeiçoamento de seus membros (BRASIL. Disponível em <http:// http://www.abrampa.org.br> Acesso em 21 de jun. 2012).

Dessa forma, o Ministério Público passou a incrementar mecanismos de defesa e proteção ao meio ambiente, combatendo as posturas nocivas perpetradas pelos agentes sociais, aqui incluídas as organizações, em prejuízo dos recursos naturais.

Reagindo a estas pressões, as organizações passaram a reconsiderar suas atuações, implementando medidas que redundassem numa nova orientação, em face do contexto social que dá, à questão ambiental, notável relevância.

Por conta deste cenário, surgiram diversos programas de qualidade e de gestão ambiental que têm evidenciado, nas agendas organizacionais, a busca pela adoção de ações inovadoras que deem respostas à sociedade, em nome da própria sobrevivência das organizações: a existência destas já não pode estar desvinculada dos valores ambientais, propugnados pela emergência com que a sociedade os reclama e advoga.

No tocante às organizações públicas, a RIO 92 culminou com o estabelecimento da já mencionada Agenda 21, documento considerado de vanguarda na caracterização das organizações públicas, enquanto protagonistas do movimento em favor de uma sociedade com qualidade de vida melhor, mediante uma postura de respeito ao meio ambiente (SCHENINI; NASCIMENTO, 2002).

É importante destacar que as organizações públicas também são vetores neste processo de resgate da cidadania, pelo fato de o conceito de poluidor, previsto no artigo art. $3^{\circ}$, IV, da Lei $n^{\circ} 6.938 / 81$, incluir as pessoas jurídicas de direito público. Dessa forma, o atendimento aos pressupostos da legislação ambiental alcança tanto as empresas privadas quanto as organizações públicas. 0 compromisso ético pelas práticas de sustentabilidade cabe, também, aos agentes estatais, no que tange a uma gestão pública articulada com a responsabilidade ambiental. 
Outro fator tem evidenciado a pressão exercida pela sociedade, por uma gestão pública criteriosa, articulada com a sustentabilidade: a criação da $\mathrm{A}_{3} \mathrm{P}$ - Agenda Ambiental da Administração Pública, concebida no ano de 1999, e regulamentada através da Portaria 510/2002. As diretrizes da $\mathrm{A}_{3} \mathrm{P}$ são adotadas pelas organizações públicas voluntariamente. Suas prerrogativas estão disponíveis no sítio eletrônico do Ministério do Meio Ambiente, que assinala:

\begin{abstract}
A Agenda Ambiental na Administração Pública - $\mathrm{A}_{3} \mathrm{P}$ - é um programa que visa implementar a gestão socioambiental sustentável das atividades administrativas e operacionais do Governo. A $\mathrm{A}_{3} \mathrm{P}$ tem como princípios a inserção dos critérios ambientais que vão desde uma mudança nos investimentos, compras e contratação de serviços pelo governo, até uma gestão adequada dos resíduos gerados e dos recursos naturais utilizados tendo como principal objetivo a melhoria na qualidade de vida no ambiente de trabalho (BRASIL. Disponível em <http://www.mma.gov.br/asp> Acesso em 20 de mar. 2011)
\end{abstract}

$\mathrm{A} \mathrm{A}_{3} \mathrm{P}$ possui cinco eixos temáticos: uso racional dos recursos, gestão adequada dos resíduos, qualidade de vida no ambiente de trabalho, sensibilização e capacitação dos servidores e licitação sustentável. Assim, tal agenda surgiu com a finalidade de estabelecer nova cultura institucional na Administração Pública, pela via da conscientização dos servidores públicos no que concerne a princípios ecoeficientes de gestão. Dentre estes, se destacam o aumento da qualidade de vida no trabalho e, sobretudo, o combate ao desperdício de recursos nas atividades laborais. A ideia é transformar as entidades governamentais em referências no assunto, para a sociedade e iniciativa privada (BARATA et al, 2007; ESTEVES, 2009).

Enquanto órgão público sujeito às demandas do CNMP, o MPE/AM foi alcançado por tal recomendação, que traz, dentre as suas sugestões,

[...] a criação, no âmbito das respectivas Administrações, de Comissões Institucionais de Gestão Ambiental, integradas por membros e servidores com a tarefa de estudar, sugerir e acompanhar a implementação de medidas administrativas voltadas à adoção de hábitos ecologicamente sustentáveis, tais como a reutilização e reciclagem de resíduos, e utilização de papel reciclado e outras medidas de consumo de bens e serviços de forma sustentável, todas no sentido de fomentar a conscientização institucional da preservação ambiental.

A intenção do CNMP, portanto, foi a de promover práticas administrativas sustentáveis e ações propositivas de inovação organizacional no Ministério Público do Estado do Amazonas, mediante a conscientização institucional, conforme se verifica no texto em destaque. Para atingir tal objetivo, o MPE/AM acatou a sugestão do CNMP e criou uma comissão institucional de gestão ambiental, cujas atividades resultaram no programa de gestão socioambiental ${ }^{2}$, denominado Ambiente Legal. 0 programa articulou, junto aos membros, servidores e colaboradores do MPE/AM, ações propositivas para inovação, todas elas relacionadas a práticas administrativas eivadas de hábitos ecologicamente sustentáveis.

Dessa forma, as organizações públicas, enquanto corresponsáveis pela preservação ambiental, ao buscarem inovar em suas práticas, adotam novos arranjos estruturais para atender a estas demandas e, por tabela, ajudar na resolução destes problemas. Assim, o programa Ambiente Legal se caracteriza como um destes novos arranjos estruturais, dentro da estrutura organizacional do MPE/AM. Configura-se num agrupamento de procedimentos, concebido formalmente pelo Poder Público e chancelado pelos seus mandatários. Tem, como finalidade, atingir os objetivos propostos pela $\mathrm{A}_{3} \mathrm{P}$ e a Recomendação $\mathrm{n}^{\underline{0}}$ 06/2007.

Tal processo se realiza, em sua plenitude, com o estágio de sedimentação: neste, os arranjos estruturais adotados se firmam historicamente, mediante a contínua avaliação positiva de seus resultados. Os defensores de sua adoção se revelam em maior número que seus opositores, o que não significa que, futuramente, não possam ser reavaliados (TOLBERT; ZUCKER, 1999). Estes processos inerentes à institucionalização, idealizados por Tolbert e Zucker (1999) e aplicados na realidade organizacional, foram fortemente influenciados pela obra de Berger e Luckmann (1967), que compuseram o processo de institucionalização entre atores individuais.

Os indivíduos estão submissos ao hábito, e a realidade socialmente construída se manifesta como produto da ação humana, mas com esta não se confunde, pois assume vida própria, manifestada em instituições que, uma vez exteriorizadas, revisitam o imaginários das pessoas, que tornam a processá-las e reinventálas (BERGER; LUCKMANN, 1967). Neste exercício, estas instituições sociais se configuram como legados 
naturais e certos, tipificando "como são as coisas", convencionalmente: os cumprimentos, as celebrações, as posturas, os hábitos, enfim.

Tais ações estão agrupadas num conjunto de quatro diretrizes: (i) a aquisição de bens e serviços socioambientalmente corretos; (ii) a coleta apropriada de resíduos produzidos por suas atividades; (iii) o uso racional dos recursos disponíveis e; (iv) as campanhas de cunho socioambiental empreendidas, visando o bem-estar do servidor no ambiente de trabalho.

Diante do exposto, emerge a seguinte pergunta de pesquisa: de que forma tem se configurado o processo de institucionalização das ações de gestão socioambiental, propostas pelo programa Ambiente Legal, no contexto do MPE/AM?

Para viabilizar tal análise, foi utilizado o método estudo de caso, alinhado a abordagem construcionista social de pesquisa. Também foram utilizadas as técnicas de pesquisa documental e fotografias, além de entrevistas semiestruturadas, para a coleta de informações. No tocante a análise dos dados coletados, foi utilizada a análise de conteúdo.

A seguir, são apresentados os objetivos geral e específicos, além da justificativa para a realização desta pesquisa.

\section{OBJETIVOS}

\subsection{GERAL}

Analisar de que forma tem se configurado o processo de institucionalização das ações de gestão socioambiental, propostas pelo programa Ambiente Legal, no contexto do MPE/AM.

\subsection{ESPECÍFICOS}

1)Caracterizar as ações de gestão socioambiental propostas pelo programa Ambiente Legal, a partir do exame dos eventos pertinentes à sua implantação;

2)Identificar em qual estágio se encontra o processo de institucionalização das ações de gestão socioambiental, propostas pelo programa;

3)Identificar quais significados foram atribuídos ao programa Ambiente Legal, pelos membros e servidores do MPE/AM.

\subsection{JUSTIFICATIVA}

Este estudo se justifica pela possibilidade de fornecer subsídios importantes para, uma vez articuladas as atividades de pesquisa, viabilizar o entendimento quanto ao alcance de uma nova consciência institucional, numa organização pública, mediante a incorporação de novos valores organizacionais. Os resultados que advirão desta pesquisa, também são viáveis por força do apoio doado pelo MPE/AM, onde foi concebido o programa Ambiente Legal, e pela acessibilidade aos dados e fontes de que usufrui o pesquisador.

Academicamente, essa pesquisa justifica-se por discutir a operacionalização de modelos inerentes à institucionalização, de onde podem fluir achados que expliquem as crises ou oportunidades, relacionadas aos esforços empreendidos em campanhas e programas, patrocinados por órgãos governamentais. Justifica-se, ainda academicamente, pela exígua literatura publicada na área de gestão socioambiental na Administração Pública.

Para o MPE/AM, esta pesquisa pode fornecer elementos essenciais para avaliação e monitoramento dos processos organizacionais, com o fito de otimizar suas ações gerenciais e as diretrizes de seu planejamento a longo prazo, dentro do tema discutido. Como contribuição social, esta pesquisa se propõe a enriquecer o debate acerca de um setor público mais articulado com a sustentabilidade e responsabilidade socioambiental, e dos mecanismos disponíveis para atingir tais objetivos. 


\section{REFERENCIAL TEÓRICO}

Neste capítulo, serão discutidas as nuances do institucionalismo sociológico, desde a orientação funcionalista até o construcionismo social de Berger e Luckmann (1967), sobretudo no que diz respeito ao conceito de instituição e ao processo de institucionalização, para os autores. Também serão analisadas as influências destes, para os trabalhos posteriores de Meyer e Rowan (1977) e Tolbert e Zucker (1999), sem prejuízo, certamente, da contribuição de outros estudiosos consagrados na matéria. Este capítulo é concluído, com a contextualização do processo de institucionalização do programa de gestão socioambiental Ambiente Legal, do MPE/AM, utilizando o modelo de processos inerentes à institucionalização, de Tolbert e Zucker (1999).

\section{1 A ABORDAGEM INTERPRETATIVISTA NO INSTITUCIONALISMO SOCIOLÓGICO}

O estudo das organizações só ganhou status de objeto de estudo próprio, dentro do campo da Sociologia, a partir dos trabalhos de Robert Merton e seus discípulos. Anteriormente, eram tratadas como componentes de um contexto mais amplo, relacionadas a "problemas sociais gerais, tais como desigualdade social, relações entre comunidades, desvio social, etc: o foco da análise não estava nas organizações como organizações" (TOLBERT E ZUCKER, 1999, p.196).

A tradição funcionalista, ao dar às organizações status de objeto próprio no campo da Sociologia, incrementou a interlocução destas com o ambiente, tornando-as mais suscetíveis às influências ambientais no formato de suas estruturas, estabelecendo contornos contingencialistas para obter, na sociedade, elementos condicionantes dos passos organizacionais.

Ainda para os mesmos autores, a institucionalização, no contexto parsoniano, decorre do temor dos atores em se desviarem dos sistemas de valores e normas (instituições) enraizados na sociedade, motivo pelo qual internalizam e reproduzem ações prescritas como certas ou mais apropriadas, promovendo, nesses moldes, a interação social.

Como se reconhece, a abordagem funcionalista parsoniana negligencia a percepção que os indivíduos têm da realidade social que os cerca. 0 contexto por meio do qual as pessoas interagem em sociedade, permeando seus comportamentos e condutas, lhes é apresentado de forma externa. Dessa forma, surge a dificuldade destas pessoas em compreender tal contexto, e em que medida seus comportamentos se firmam segundo as interpretações que deveriam fluir da interação com seus pares, e entre estes e o ambiente que a todos cerca.

Outro representante do funcionalismo, Selznick (1972), observa uma organização como detentora de vida própria, dotada de valores sociais que nascem da interação desta com o ambiente, desvinculados da concepção racionalista. Embora mantendo a noção normativista de ação, Selznick se distancia do rigor proposto, originalmente, por Parsons (FONSECA, 1999; CRUBELLATE, 2007).

Segundo o clássico autor, uma organização, ainda que atuando sob lógica instrumental ao iniciar suas atividades, tende a sofrer influências culturais da comunidade em que atua, interagindo efetivamente com o ambiente, o que resulta numa infusão de valores (FACHIN; MENDONÇA, 2003; CARVALHO; ANDRADE; MARIZ, 2005).

Essa infusão permite que a organização adquira uma identidade própria, em que critérios técnicos coexistem ao lado de valores e crenças, fortalecidos e compartilhados pela cultura ambiental. A abordagem institucional na vertente sociológica, ainda que mantendo contornos funcionalistas, passa a caracterizar a construção da realidade organizacional em que estes valores são manifestos (FACHIN; MENDONÇA, 2003; CARVALHO; ANDRADE; MARIZ, 2005).

Logo, a construção desta realidade se perfaz pela incorporação de traços institucionais às feições organizacionais. Enquanto as organizações reúnem recursos para atingir fins específicos e instrumentais, como produtos e serviços, as instituições resultam das pressões exercidas pelo ambiente social, em que prevalecem as condicionantes da ação que dão contornos à identidade da organização.

Esta mesma ausência é superada por outra perspectiva histórica, que analisa o fenômeno institucional na teoria das organizações: a visão interpretativista. Tal perspectiva mantém a relevância dos condicionantes sociais, mas também enfatiza a autonomia dos indivíduos e seus posicionamentos, ao interpretarem as ações e o processo que lhes dá significação (CRUBELLATE, 2007). 
Partindo do pressuposto de que as organizações são compostas por indivíduos, os comportamentos destes são moldados por padrões criados e compartilhados no convívio social, tanto quanto a atuação daquelas, num processo em que ambos estão sujeitos às demandas ambientais. Tal processo sempre estará mediado pela ascendência de normas e valores (visão funcionalista), mas também de hábitos e crenças (visão interpretativista). Os condicionantes da ação se estabelecem não apenas no ambiente, mas também a partir da interpretação que as pessoas dele fazem, gerando estatutos sociais a que podemos designar de instituições

Finalmente, o pilar cognitivo, que retrata o fortalecimento das instituições a partir da interpretação que delas fazem os atores envolvidos: estes constroem socialmente a realidade, mediante o compartilhamento de ações tornadas habituais. Uma vez habitualizadas, tais ações geram significados relevantes que redundam em valores que permeiam as instituições norteadoras do convívio social.

Assim, os elementos cognitivos, sem excluir as normas e valores que também permeiam o diálogo entre atores, organizações e sociedade, também passam a fundamentar a construção social das instituições na modelagem organizacional, nos moldes propostos pelos paradigmas ${ }^{5}$ que baseiam a visão interpretativista, na abordagem sociológica da teoria institucional.

Dentre tais paradigmas, destaca-se o construcionismo social de Berger e Luckmann, que definiram o processo de institucionalização, e também o produto deste, as instituições. A obra destes autores se refere aos legados que fundamentam a coexistência no plano individual, mas contribuiu decisivamente para os estudos no plano organizacional.

\subsection{AS CONTRIBUIÇÕES DO NOVO INSTITUCIONALISMO SOCIOLÓGICO}

As contribuições trazidas por Berger e Luckmann (1967), para os estudos organizacionais, influenciaram trabalhos posteriores de autores como Meyer (1977), Meyer e Rowan (1977), Zucker (1977) e Tolbert e Zucker (1999), em que pese o fato de haverem situado o processo de institucionalização no nível individual (MACHADO-DA-SILVA; GONÇALVES, 1999; MENDES et al, 2009).

Estes autores firmaram tratados em que se primou pelo foco nos princípios da ação social. As organizações formais, uma vez eivadas dos princípios institucionais, passaram a ser consideradas elos de conexão entre os indivíduos e a sociedade. As instituições tornaram-se elementos centrais para o entendimento da realidade socialmente construída (QUINELLO, 2007; OLIVEIRA; ZAQUETTO FILHO, 2010). Dessa forma, a mesma intersubjetividade, que promove instituições no plano interpessoal, ganha destaque também no plano organizacional. A formalidade, que caracteriza as estruturas organizacionais, é tocada pelo exame da simbologia presente nos significados socialmente compartilhados pelas pessoas.

Com tal exame, há uma ampliação do entendimento da realidade organizacional, agora analisada não apenas sob o enfoque funcionalista, mas também pela proeminência dos símbolos e valores presentes nas relações intra e interorganizacionais. Com isso, o legado de Berger e Luckmann (1967) se reflete na obra de autores neoinstitucionalistas, como Meyer e Rowan (1977), "que discutem a institucionalização como processo em que estruturas são legitimadas não por conta de sua eficiência, mas pelos sentimentos dos atores organizacionais com relação a elas.

A realidade socialmente construída tem seus pressupostos aplicados não apenas à vida dos indivíduos, em coletividade. Tais pressupostos passam também a fundamentar a vida das organizações que, para angariar legitimidade (que lhes dê estabilidade e garantias de sobrevivência), buscam incorporar, às suas estruturas, instituições proliferadas nos setores em que atua, sob aquelas formas taken for granted. Estas instituições, como ocorre em nível pessoal, dão às organizações uma existência pautada em fórmulas consagradas: o sucesso e a sobrevivência organizacionais, se afirmam mediante escolhas nas quais se opta por convenções reconhecidamente indicadas para sanar incertezas e afastar ameaças.

Ainda ancorados no trabalho de Berger e Luckmann (1967), os neoinstitucionalistas definem a institucionalização como "o processo pelo qual processos sociais, obrigações ou circunstâncias assumem o status de norma no pensamento e na ação sociais" (MEYER; ROWAN, 1999, p. 80). Há um distanciamento do conceito selznickiano, pelo prejuízo manifesto ao determinismo ambiental, retirando, deste, a supremacia na formação das instituições (CARVALHO; VIEIRA; GOULART, 2005). Os mesmos autores asseveram que "as organizações respondem a influências do ambiente, mas não apenas a variáveis concretas, como tecnologia, tamanho, mas também e, em alguns casos com maior ênfase, a valores, crenças e mitos compartilhados" (ibidem, p. 864). 


\subsection{MODELO DE TOLBERT E ZUCKER, NO CONTEXTO DO PROGRAMA AMBIENTE LEGAL}

O modelo de processos inerentes à institucionalização, proposto por Tolbert e Zucker (1999), discutido na seção anterior e ilustrado na figura 1, abaixo, foi utilizado nesta pesquisa para contextualizar a institucionalização das ações propostas pelo programa Ambiente Legal.

Figura 01. Processos inerente à institucionalização

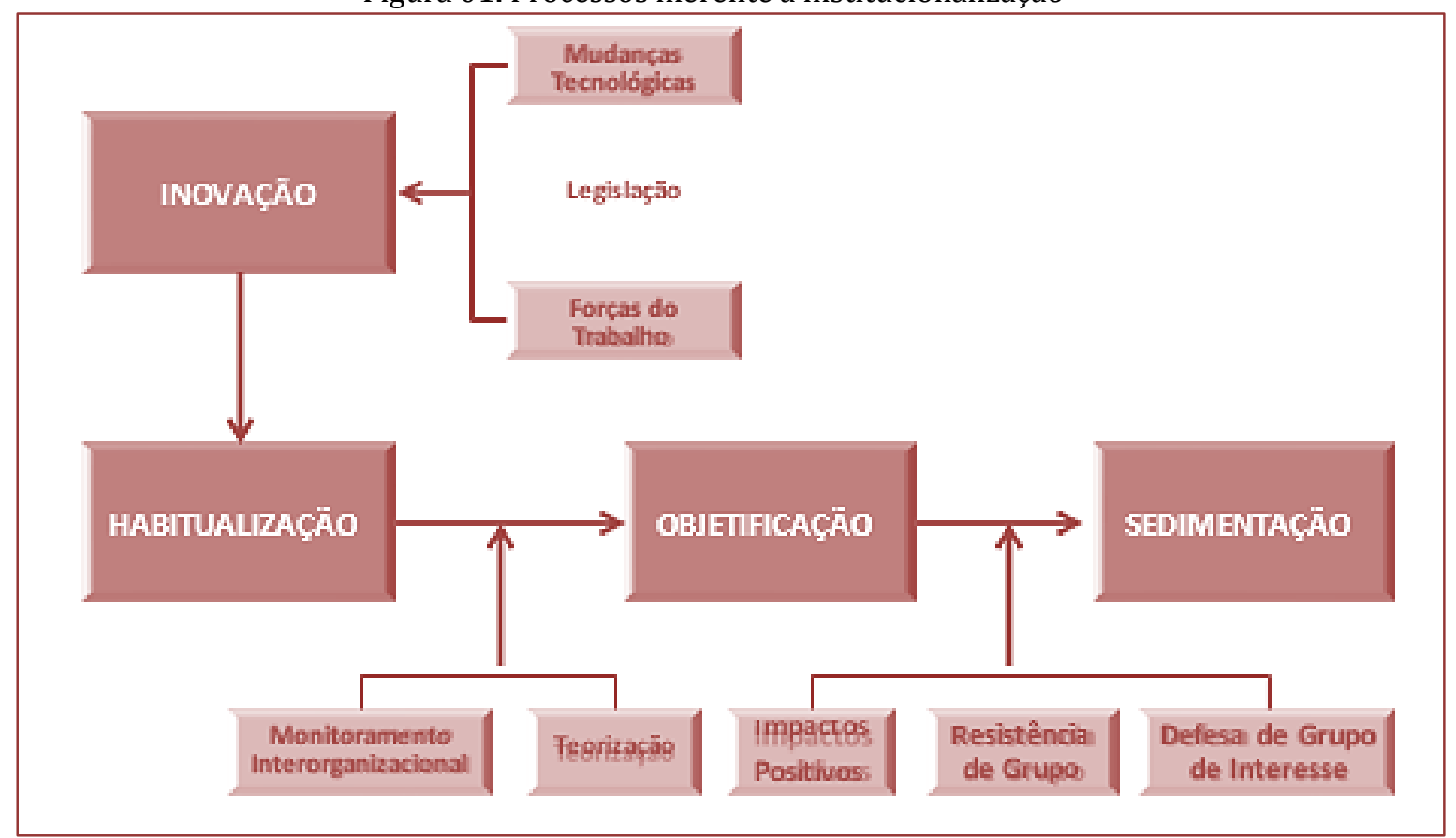

Fonte: Tolbert e Zucker (1999, p.205).

\section{MÉTODO UTILIZADO}

A opção pelo método de estudo de caso se deu na medida em que os problemas aqui estudados emergiram do cotidiano, ilustrando o ânimo de se pesquisar os desdobramentos do evento estudado, a partir da prática verificada no dia a dia organizacional específico (GODOY, 2006). A utilização do estudo de caso pode envolver tanto uma pessoa ou grupos de pessoas, instituições, programas ou uma empresa, que compartilhem tanto do mesmo ambiente quanto da mesma experiência.

O interesse do pesquisador está voltado para a compreensão dos processos sociais que se entrelaçam em determinado contexto, na interpretação e na descoberta, em prejuízo da verificação de hipóteses. A proposta é pela valorização dos significados que determinada situação suscita nos envolvidos no processo (STAKE, 2000; MERRIAN, 1998). A escolha pelo método de estudo de caso se baseia na orientação de Stake (2000), pelo fato de o autor manifestar maior afinidade com o construcionismo social, paradigma que baseia esta pesquisa (ALVES-MAZZOTTI, 2006).

A proposta é pela compreensão dos fenômenos, ao invés de promover a sua generalização, em que pese o fato de o autor não se referir ao estudo de caso como opção metodológica, mas como um objeto a ser estudado, sob as formas descritas no parágrafo anterior. Ao sustentar-se na tipologia de Stake (2000), classifica-se este estudo de caso como instrumental, buscando, na sua utilização, apoio para se compreender, mais profundamente, o contexto ora pesquisado.

Levam-se em consideração as perspectivas históricas que permeiam este contexto, promovendo insights sobre o assunto para estabelecer achados que refinem a teoria, ampliando, à luz de seus legados, a compreensão do problema investigado. Para Stake (2000), não se deve generalizar os resultados obtidos, para além do caso estudado. Neste ponto, incorre-se num argumento distinto do defendido por Yin (1994). Para este autor, a generalização de casos estudados é possível: não a partir dos resultados alcançados, mas das proposições teóricas que, geradas por estes, atenderiam a outros contextos (ALVES-MAZZOTTI, 2006).

Enquanto referência obrigatória na matéria, Yin (1994) classifica os estudos de caso em quatro tipos: caso único, com (i) enfoque global ou (ii) incorporado e caso múltiplo, com os mesmos enfoques. $\mathrm{O}$ autor 
aponta três situações, em que há pertinência no uso de estudos de caso: (i) quando este for crítico, para testar uma teoria ou hipótese previamente explicitada; (ii) quando for extremo ou único, comum em Psicologia Clínica; e (iii) revelador, quando o investigador tem acesso a uma situação ou fenômeno até então inacessíveis à investigação científica.

Logo, a classificação defendida pelo autor não se enquadra nos pressupostos aqui discutidos. Ademais, o mesmo é mais identificado com o paradigma pós-positivista, no que se distancia dos propósitos desta investigação, de bases mais interpretativistas (ALVES- MAZZOTTI, 2006). Os objetivos desta pesquisa, em identificar os significados atribuídos pelos servidores e membros do MPE/AM, quando diante das ações propostas pelo programa Ambiente Legal, à luz dos postulados do neoinstitucionalismo, denotam um sentido de construção coletiva destes significados. Também neste quesito, o estudo reflete maior convergência à proposta defendida por Stake (2000).

Desta forma, esta investigação tem contornos de natureza qualitativa e caráter exploratório-descritivo, com o uso do método de estudo de caso instrumental, encadeado à perspectiva do construcionismo social, nos estudos organizacionais.

\subsection{LOCUS DE PESQUISA}

A escolha do caso foi determinada pela facilidade de acesso do pesquisador à organização investigada, o Ministério Público do Estado do Amazonas - na qual o mesmo exerce o cargo de administrador - em que se intentou implantar um programa de gestão socioambiental.

A organização ofereceu todos os requisitos para que esta pesquisa fosse realizada, tanto no que diz respeito à caracterização do problema investigado e aos objetivos propostos pela pesquisa, quanto às condições operacionais: a autorização concedida para o trânsito em seus domínios, o acesso às pessoas entrevistadas e a todos os dados relacionados ao programa.

\subsection{PLANO DE COLETA DE DADOS}

A coleta de dados denota a vital importância do papel do pesquisador e seus passos "incluem estabelecer as fronteiras para o estudo, coletar informações por meio de observações e entrevistas semiestruturadas, documentos e materiais visuais, bem como estabelecer o protocolo para registrar informações" (CRESWELL; 2007, p. 189). O investigador deve escolher as técnicas mais adequadas para atingir seus objetivos de pesquisa, sempre que a abordagem metodológica envolver análise de informações, dados e evidências empíricas, a fim de obter o melhor resultado possível. Em se tratando de investigações orientadas por estratégias não convencionais (estudo de caso, por exemplo), a coleta de dados pode ser realizada ao mesmo tempo que outras etapas da pesquisa (MARTINS; THEÓPHILO, 2009).

Em se tratando especificamente do método estudo de caso qualitativo, na pesquisa se fez a utilização de diversas fontes de informação, reunidas em três grandes grupos de evidência: observação, entrevistas e documentos. Também é ressaltado o uso de imagens paradas, como fotografias e imagens publicitárias (GODOY, 2006). A coleta de dados ocorreu no período compreendido entre os meses de setembro e outubro de 2011, e os membros e servidores do MPE/AM forneceram as principais fontes de dados primários, coletados mediante entrevistas semiestruturadas, agendadas e realizadas no local de trabalho dos participantes. Também foram coletados documentos oficiais, relatórios, atas de reunião e fotografias, todos relacionados ao programa Ambiente Legal, e que se constituíram em fontes de dados secundários, para serem posteriormente analisados.

Entendem-se, por dados primários, aqueles que ainda não se encontram em poder do investigador e, portanto, não foram ainda utilizados em pesquisas. São aqueles colhidos diretamente na fonte, ainda inéditos. Por outro lado, os dados secundários são aqueles já disponíveis para o pesquisador, organizados em arquivos, banco de dados, anuários estatísticos e relatórios (MARTINS; THEOPHILO, 2009). Os dados primários, que nesta pesquisa foram coletados a partir das entrevistas realizadas, são assim denominados quando o investigador está diretamente envolvido em todas as etapas da transformação dos dados em conhecimento, da escolha dos instrumentos de coleta à interpretação dos dados, obtendo-os em primeira mão (HAIR et al, 2003; DIEHL; TATIM, 2006).

Portanto, neste estudo, as técnicas de coleta de dados envolveram entrevistas, para obtenção de dados primários, e pesquisa documental e de dados visuais, para obtenção de dados secundários. Estas técnicas, que perfazem a triangulação dos dados indicada no início deste capítulo, serão discutidas mais 
detalhadamente na próxima seção.

\subsection{PESQUISA DOCUMENTAL}

A documentação é um conjunto importante de dados para que se alcancem os objetivos da pesquisa sob o método estudo de caso, por sinalizar várias informações importantes para decodificar o evento estudado, a partir do exame de seus registros e ocorrências ao longo do tempo em que este perdura. Constitui-se num instrumento que prima pela história e pela memória da organização estudada.

O levantamento documental corresponde a uma extensa categoria de materiais: jornais, reportagens, correspondências, relatórios e documentos administrativos, além de itens iconográficos, como fotografias, que serão analisadas na seção seguinte mais detalhadamente (GODOY, 2006).

Neste particular, a análise documental foi realizada mediante o exame de documentos arquivados nos setores e Promotorias do MPE/AM, que estiveram diretamente envolvidos na concepção, criação e gestão do programa Ambiente Legal, notadamente atos oficiais como: recomendações, portarias, instrumentos governamentais, atas de reunião, relatórios de atividades e administrativos, ofícios e memorandos. Também foram analisados materiais impressos de divulgação do programa: cartazes, cartilhas e folders, além de comunicados veiculados na internet, tendo como fontes o site do MPE/AM (www.mp.am.gov.br) e o blog do programa (ambientelegal.mp.am.gov.br).

A pesquisa de documentos se diferencia do levantamento bibliográfico por que este trata de material editado, enquanto o levantamento documental "busca material que não foi editado, como cartas, memorandos, correspondências de outros tipos, avisos, agendas, propostas, relatórios, estudos, avaliações, etc." (MARTINS; THEÓPHILO, 2009, p. 85). Os mesmos autores afirmam que essa modalidade de coleta de dados é bastante pertinente em pesquisas pautadas por estratégias participativas, como o estudo de caso.

O pesquisador pode desenvolver um estudo exclusivamente com levantamento documental, como pode também buscar auxílio nesse tipo de dados de forma auxiliar, subsidiariamente, corroborando ou reafirmando achados havidos a partir de outras fontes, aumentando a confiabilidade da pesquisa mediante triangulação de dados e resultados (MARTINS; THEÓPHILO, 2009; GODOY, 2006).

Foi solicitada, dos setores e Promotorias, somente aquela documentação pertinente aos objetivos da pesquisa, bem como aos seus fundamentos teóricos. Na medida em que as ocorrências e citações relacionadas a esses fundamentos se manifestaram, foram destacadas para tornar possível, e satisfatória, a análise dos resultados. Os dados documentais relacionados à gênese e às atividades do programa Ambiente Legal trataram dos eventos ocorridos no período compreendido entre janeiro de 2009, data em que houve a primeira manifestação efetiva em direção à criação do programa, registrada em documento oficial de tramitação interna, até os dias atuais, com exceção da Recomendação no 06, do CNMP, datada de outubro de 2007. 0 Quadro 1, abaixo, sintetiza os procedimentos metodológicos, as técnicas de coleta e análise de dados, bem como as fontes destes, tomando como base os objetivos específicos da pesquisa realizada.

Quadro 1 - Síntese dos procedimentos metodológicos por objetivos específicos

\begin{tabular}{|c|c|c|c|c|}
\hline Objetivos Específicos & Técnica de Coleta & Fontes de Dados & $\begin{array}{l}\text { Método da } \\
\text { Pesquisa }\end{array}$ & Técnica de Análise \\
\hline $\begin{array}{l}\text { 1- Caracterizar as ações de } \\
\text { gestão socioambiental } \\
\text { propostas pelo programa, a } \\
\text { partir do exame dos } \\
\text { documentos pertinentes à sua } \\
\text { implantação. }\end{array}$ & $\begin{array}{l}\text { Pesquisa documental e de } \\
\text { dados visuais }\end{array}$ & $\begin{array}{l}\text { Documentos e fotografias do } \\
\text { acervo MPE/AM }\end{array}$ & \multirow{3}{*}{$\begin{array}{l}\text { Estudo de caso } \\
\text { alinhado ao } \\
\text { construcionismo } \\
\text { social. }\end{array}$} & \multirow{3}{*}{$\begin{array}{l}\text { Análise de } \\
\text { Conteúdo. }\end{array}$} \\
\hline $\begin{array}{l}\text { 2- Identificar em qual estágio se } \\
\text { encontra o processo de } \\
\text { institucionalização das ações } \\
\text { De gestão socioambiental, } \\
\text { propostas pelo programa. }\end{array}$ & $\begin{array}{l}\text { Pesquisa documental e de } \\
\text { dados visuais; Entrevistas }\end{array}$ & $\begin{array}{l}\text { Documentos e fotografias do } \\
\text { Acervo do MPE/AM; Site do } \\
\text { MPE/AM; } \\
\text { Blog do programa; Fala dos } \\
\text { membros e servidores do } \\
\text { MPE/AM }\end{array}$ & & \\
\hline 3- Identificar os significados & Entrevistas & Servidores MPE & & \\
\hline
\end{tabular}

Fonte: elaborado pelo autor (2012) 
Como se pode pode perceber, no quadro acima, esta pesquisa buscou a triangulação: (i) nas fontes de dados, valendo-se de documentos, de dados visuais (fotografias), além das entrevistas realizadas; e (ii) no método de pesquisa, pelo alinhamento do estudo de caso ao construcionismo social. Os dados foram analisados, como já exposto, mediante a análise de conteúdo. A triangulação reforça a análise mais abrangente dos fenômenos estudados nas organizações, na medida em que a busca por verdades objetivas dá espaço às abordagens interpretativas.

\section{ANÁLISE E DISCUSSÃO DOS RESULTADOS}

Este capítulo foi reservado para a análise dos dados obtidos na organização estudada, discutidos segundo a orientação do neoinstitucionalismo sociológico. Foi firmada uma abordagem interpretativa, para investigar como tem se configurado o processo de institucionalização das ações propostas pelo programa Ambiente Legal, a partir da visão de seus membros e servidores. Com isso, intentou-se atingir os objetivos da pesquisa, primando pela articulação entre as opiniões dos atores sociais e as demais fontes de dados, permeadas pelo que preconiza a teoria que fundamentou a investigação.

No primeiro momento foi feita a caracterização do caso estudado, em que se estabelecem os contornos constitucionais do Ministério Público de um modo geral para, então, contextualizar o Ministério Público do Estado do Amazonas. A seguir, foi traçado um panorama do programa Ambiente Legal, suas origens e objetivos, além de uma cronologia de suas principais atividades, baseando-se em dados documentais e visuais. Uma vez examinado o programa, foi sugerida uma caracterização de suas ações. Estas foram analisadas mediante o critério da significação com que os sujeitos entrevistados as interpretaram. Ao final, as ações foram posicionadas nos estágios inerentes ao processo de institucionalização, seguindo o critério adotado e o modelo proposto por Tolbert e Zucker (1999).

\subsection{CARACTERIZAÇÃO DO CASO ESTUDADO}

O Ministério Público tem a sua natureza e funções previstas na Constituição Federal Brasileira de 1988, mais precisamente no Título IV, Capítulo IV, reservado às Funções Essenciais à Justiça. É uma entidade independente em relação aos demais Poderes constituídos do país, considerada uma instituição permanente, essencial à função jurisdicional do Estado (função essencial à Justiça). Sob sua responsabilidade está a defesa da ordem jurídica, do regime democrático e dos interesses sociais e individuais indisponíveis. Dentre as suas funções institucionais, destaca-se a proteção ao meio ambiente, além de outros interesses difusos e coletivos, relacionados à: consumidor, patrimônio histórico, turístico e paisagístico, pessoa portadora de necessidades especiais, criança e adolescente, comunidades indígenas e demais minorias etnossociais (SALES, 1999; MAZZILLI, 2001).

Dentre os grandes papéis do Ministério Público, a titularidade dos inquéritos civis para apurar atos de improbidade administrativa merece destaque, da mesma forma a atuação nos casos em que há danos ao meio ambiente, ao consumidor e ao patrimônio histórico (MAZZILLI, 2001). Diz, ainda, a Carta Maior de 1988, em seu art. 128, que o Ministério Público abrange dois grandes grupos: (i) Um representado pelo Ministério Público da União, que compreende: o Ministério Público Federal, o Ministério Público do Trabalho, o Ministério Público Militar e o Ministério Público do Distrito Federal e Territórios; e (ii) o grupo composto pelos Ministérios Públicos dos Estados. Neste segundo grupo se encontra o Ministério Público do Estado do Amazonas, instituição em que se deu esta pesquisa.

\section{CONCLUSÕES}

A primeira década do século XXI tem sida marcada pela vigilância, cada vez mais acentuada, de setores da sociedade que cobram, das organizações, uma postura mais responsável em relação às consequências que suas atividades trazem ao meio ambiente. A inovação nas ações organizacionais já não é mais motivada somente por fatores de pressão identificados com a lógica das organizações privadas.

Neste particular, as novas tecnologias são adotadas para que se melhore a competitividade empresarial; o atendimento à legislação é um fator coercitivo, e as forças mercadológicas são assimiladas em nome da própria sobrevivência das empresas. A edição da Recomendação no 6, do CNMP, veio para sinalizar que organizações públicas, como o MPE/AM, também são poluidoras, portanto corresponsáveis tanto pela degradação ambiental que marca nossa sociedade, quanto pela adoção de práticas mais sustentáveis. 
Entretanto, este documento não lida com tendências tecnológicas, não tem o efeito vinculativo (obrigatório) da lei, ou trata de ação orientada pelo mercado. Apenas sugere que as organizações que perfazem seu público-alvo, adotem novas práticas e hábitos sustentáveis, visando à conscientização institucional. É um documento que sinaliza uma pressão por inovação, de natureza precipuamente social: é endereçado a organizações dispostas a adotar as práticas socioambientais nele sugeridas. Foi o que pretendeu o MPE/AM, ao conceber o programa Ambiente Legal.

0 programa foi idealizado de acordo com as influências do meio em que atua o MPE/AM. Constituiu-se num arranjo estrutural (com recursos, pessoal e equipamentos) voltado para atingir um objetivo maior: um novo modo de atuação administrativa, com a incorporação de hábitos sustentáveis no dia-a-dia organizacional, que fomentasse o surgimento de novos valores (de cunho socioambiental) na organização que o concebeu. Para tanto, seus gestores articularam procedimentos e métodos já utilizados por outras organizações, consubstanciando um modelo, cujos contornos são consagrados, racionalizados na sociedade. Um modelo, portanto, ideal para resolver os mesmos problemas, enfrentados por outras organizações.

Esta pesquisa procurou investigar como se deu o processo de institucionalização das ações propostas pelo programa, levando em conta o modelo adotado e, principalmente, os discursos dos atores que vivenciaram esta experiência: os membros e servidores do MPE/AM. Desde o início, firmou-se, nesta análise, uma orientação construcionista, pra privilegiar os significados atribuídos por estes atores, às referidas ações propostas, destacando o cognitivismo que marca o neoinstitucionalismo sem, no entanto, descuidar-se das pressões ambientais que influenciaram na caracterização do programa.

Em outras palavras, a análise deste processo considerou tanto o determinismo ambiental que pontuou a criação do programa, quanto a percepção que, destas ações, tiveram os sujeitos da pesquisa. A análise dos resultados demonstrou que as ações do programa, predominantemente, não se tornaram habituais na prática administrativa verificada no cotidiano do MPE/AM. À exceção da adoção dos papéis e envelopes reciclados, que revelou um grau de consenso razoável junto aos sujeitos entrevistados, as demais ações não atingiram sequer o estágio de habitualização.

0 uso de material de escritório reciclado, no âmbito do MPE/AM, se mostrou um reflexo dos valores que os sujeitos entrevistados já cultivavam em seu cotidiano, construídos anteriormente. As pessoas já haviam firmado, intersubjetivamente, um conjunto de significados compartilhados, que se constituíram em referências para orientá-las em suas práticas diárias, dentro de um contexto em que já viviam e interagiam. Por isso, a adoção de material reciclado foi caracterizada no estágio de habitualização (TOLBERT; ZUCKER, 1999).

Logo, infere-se que novos valores só se incorporam à realidade organizacional, mediante o construcionismo social: há a necessidade de se firmar, interpessoal e intersubjetivamente, estas novas instituições. 0 protagonismo deste processo é dos sujeitos sociais, que transbordam suas convicções para a vida organizacional. Nenhum programa de gestão, uma vez concebido racionalmente e mitificado na sociedade, teria este condão (BERGER; LUCKMANN, 1967; MEYER; ROWAN, 1977).

Os champions, em suas atividades de teorização comum, ganham relevância neste contexto, por encarnarem aquela parcela inquieta do coletivo: pessoas que desejam a mudança, embora nem sempre utilizem a melhor estratégia para obtê-la. De suas habilidades para constituir meios adequados de comunicação com os atores organizacionais, promovendo canais de informação para empreender e educar, depende o sucesso na busca pela incorporação destes novos valores.

Por conta de uma teorização equivocada, tem-se privilegiado a adoção de arranjos estruturais já consagrados no ambiente em que atuam as organizações, como se deu com o programa Ambiente Legal. Os desajustes que tipificaram a coleta seletiva de resíduos, a adoção de canecas pessoais e os investimentos na área externa do prédio, são exemplos do que ora se afirma.

Estas ações restaram bastante desacopladas da estrutura do MPE/AM, manifestando grande distanciamento entre o que foi proposto e o resultado obtido. As sugestões foram descumpridas, cumpridas apenas parcialmente ou mal implementadas. Os novos valores nelas implicados foram vencidos pela prática cristalizada, o hábito incutido, o costume firmado intersubjetivamente pela coletividade. Assim, frases como "o copo descartável traz mais comodidade"; "se os outros misturam resíduos sólidos e líquidos, o que posso fazer?"; "árvores tiram vagas para estacionar os carros", sugerem que a mudança desta mentalidade, no meio organizacional, passa pelo reexame dos hábitos e costumes, na esfera interpessoal. 
As respostas a estas possibilidades estão nas mãos dos sujeitos que foram entrevistados, e, consequentemente, do sistema em que vigoram os grupos de defesa destas medidas, e dos que as combatem. As expectativas geradas pela Recomendação no 06, nasceram num plano maior, representado pelo CNMP, e tornaram-se dependentes das expectativas geradas em um plano menor, o MPE/AM.

É neste segundo plano que se encontram as respostas para solucionar os problemas relacionados a uma gestão socioambientalmente responsável, mediada por práticas administrativas sustentáveis. Sem o protagonismo dos sujeitos sociais representados por membros e servidores do MPE/AM, na construção intersubjetiva desta nova realidade, não há que se falar em incorporação de novos valores.

Esta discussão faz ressaltar a importância da genética social do indivíduo, formada pela associação entre seus saberes mais próprios (relacionados às experiências pessoais e valores construídos ao longo de sua existência) e os saberes construídos na escola e na convivência com seus pares. São estas as experiências que o remetem a incorporação de novos padrões de conduta, impulsionados pela reinvenção de suas necessidades (THOMPSON; MENDES; THOMPSON, 2011). São estes valores, constituídos na formação genético-social do indivíduo e firmados intersubjetivamente, ao longo de sua convivência em coletividade, que se manifestarão incorporados na vida organizacional. Assim, o contexto institucional precisa ser minuciosamente considerado, por ser parte constituinte, inclusive, das organizações públicas.

Sem que se leve em conta a participação dos atores envolvidos neste processo de incorporação, o ambiente institucional permanecerá subjacente na construção destes significados compartilhados. Neste cenário, torna-se improvável habitualizar práticas administrativas que promovam a ação sustentável, condição sine qua non para gerar instituições nas organizações públicas.

Espera-se que esta pesquisa tenha contribuído para gerar indicativos para nortear os passos do órgão investigado, no sentido de, em futuras atividades, estabelecer novas práticas e propostas mais articuladas com os anseios de seus membros e servidores. Dessa forma, se poderá aplicar melhor o dinheiro público no MPE/AM, bem como economizar tempo, dois recursos importantes para a vida organizacional.

Em suas conclusões, esta pesquisa sugere:

a) Que a proposta do programa Ambiente Legal seja retomada pela Administração Superior do MPE/AM, agora sob a forma de um setor fixo na estrutura do órgão, e não mais de caráter temporário. Em que pese a contribuição dos champions em levar os trabalhos adiante, os mesmos precisaram dividir o tempo disponível, entre as suas atividades normais, e aquelas relacionadas ao programa, especificamente;

b) Que se estabeleçam canais mais apropriados para a atuação deste possível novo setor, bem como para a participação mais efetiva dos membros e servidores, na propositura de medidas que facilitem a incorporação de novos valores na estrutura do órgão;

c) Como contribuições para pesquisas futuras, um estudo longitudinal sobre o processo de institucionalização das ações de cunho socioambiental no âmbito do MPE/AM, caso o programa assuma contornos de um setor fixo dentro do órgão, e;

d) Uma abordagem de natureza fenomenológica, em que se busque a essência dos significados atribuídos, pelos membros e servidores do MPE/AM, às ações que tenham, por finalidade, a incorporação de novos valores no MPE

\section{REFERÊNCIAS}

[1] ALVES-MAZZOTTI, A. J. Usos e abusos dos estudos de caso. Cadernos de Pesquisa. v. 36, no 129, p. 637-651, 2006.

[2] BARATA, M. M. de L.; KLINGERMAN, D. C.; MINAYO-GÓMEZ, C. A gestão ambiental no setor público: uma questão de relevância social e econômica. Ciência e Saúde Coletiva, 12 (1), 165-170, 2007.

[3] BERGER, P. L.; LUCKMANN, T. A construção social da realidade. 32ª Ed. São Paulo: Vozes, 2010.

[4] BERNARDES, J. A.; FERREIRA, F. P. M. Sociedade e Natureza. In: CUNHA, S. B.; BRASIL. Sítio da Associação Nacional dos Membros do Ministério Público - CONAMP.

[5] CARVALHO, C. A.; ANDRADE, J. A. de; MARIZ, L. A. A mudança na Teoria Institucional. In: ENCONTRO DA ANPAD. Rio de Janeiro. Anais. Rio de Janeiro: ANPAD, 2005.

[6] CRESWELL, J. W. Projeto de pesquisa: métodos qualitativo, quantitativo e misto. 2 ed. Porto Alegre: Bookman, 2007. 
[7] CRUBELLATE, J. M. Três contribuições conceituais neofuncionalistas à Teoria Institucional em organizações. RAC, 1a Edição Especial 2007: 199-222.

[8] CUNHA, S. B. da; GUERRA, A. J. T.A Questão ambiental. 2ª ed. Rio de Janeiro: Bertrand Brasil, 2005.

[9] DIEHL, A.A.; TATIM, D. C. Pesquisa em ciências sociais aplicadas: métodos e técnicas. São Paulo: Pearson Prentice Hall, 2006

[10] ESTEVES, Deise Ferreira. Gestão ambiental na administração pública: sua institucionalização no Tribunal Regional Federal da 5a Região. Recife: 0 Autor, 2009. 89 p. Dissertação (Mestrado) - Universidade Federal de Pernambuco. CCSA. Administração, 2009.

[11] FACHIN, R. C.; MENDONÇA, J. R. C. de. Selznick: uma visão da vida e da obra dos percursos da perspectiva institucional na teoria organizacional. In: VIEIRA, M. M. F.; CARVALHO, C. A. (Orgs.) Organizações, instituições e poder no Brasil. Rio de Janeiro, FGV Editora, 2003.

[12] FONSECA, V. S. da; MACHADO-DA-SILVA, C. Conversaçăo entre Abordagens da Estratégia em Organizaç̋es: Escolha Estratégica, Cogniçăo e Instituiçăo. RAC, Curitiba, Edição Especial 1999, art. 3, pp. 51-75.

[13] GODOY, A.S. Estudo de caso qualitativo. In: GODOI, C. K.; BANDEIRA-DE-MELLO, R. \& SILVA, A. B. da. (org.). Pesquisa qualitativa em estudos organizacionais: paradigmas, estratégias e métodos. São Paulo: Saraiva, 2006.

[14] GUERRA, A. J. T. A questão ambiental: diferentes abordagens. 5aㅡ. Ed. Rio de Janeiro: Bertrand Brasil, 2003.

[15] HAIR, J. F.; BABIN, B.; MONEY, A. H.; SAMOUEL, P. Métodos de pesquisa em administração. Bookman: Porto Alegre, 2003.

[16] MARTINS, G. A.; THEÓPHILO, C. R. Metodologia da investigação científica para ciências sociais aplicadas. São Paulo: Atlas, 2009.

[17] MAZZILLI, H. N. Regime jurídico do Ministério Público. 5. ed. rev., ampl. e atual. São Paulo: Saraiva, 2001.

[18] MERRIAM, S. B. Qualitative research and case study applications in education: revised and expanded from case study research in education. 2. ed. São Francisco-CA: Jossey-Bass Education Series and TheJosey-Bass Higher Education Series, 1998.

[19] MEYER, J. W.; ROWAN, B. Organizaciones institucionalizadas: la estructura formal como mito y ceremonia. In: POWELL W. W.; DIMAGGIO, P. J. El nuevo institucionalismo em el análisis organizacional. Editora FCE, México, 1991.

[20] OLIVEIRA, F. P.; ZAQUETTO FILHO H. Gestão de relacionamento comprador-fornecedor em ambientes com contratos estruturados: o caso de uma grande multinacional. In: SIMPOI/FGV, Anais, São Paulo, 2010.

[21] QUINELLO, R. A Teoria institucional aplicada à administração: entenda como o mundo invisível impacta na gestão dos negócios. São Paulo: Novatec Editora, 2007.

[22] SALES, C. A. de. Entre a razão e a utopia: a formação histórica do Ministério Público. In: MACEDO JÚNIOR, R. P.; VIGLIAR, J. M. M. (Coords.). Ministério Público II - Democracia. São Paulo: Atlas, 1999.

[23] SCHENINI, P. C.; NASCIMENTO, D. T. Gestão Pública Sustentável. In: Revista de Ciências da Administração v.4, n.08, jul/dez 2002.

[24] SELZNICK, P. A liderança na administração: uma interpretação sociológica. Rio de Janeiro: FGV, 1972.

[25] STAKE, R. Case studies. In: DENZIN, N. K.; LINCOLN, Y. S. (ed). Handbook of qualitative research. London: Sage, p. 435-454, 2000.

[26] THOMPSON, A. C. R. T. da F.; MENDES, E. de P. R.; THOMPSON, C. E. M. Os Processos de institucionalização como mecanismo de conversão do conhecimento individual em conhecimento organizacional: contribuições da aprendizagem e da gestão do conhecimento. In: ENCONTRO DA ANPAD. Rio de Janeiro. Anais. Rio de Janeiro: ANPAD, 2011.

[27] TOLBERT, P. S. \& ZUCKER, L. G. A institucionalização da teoria institucional. In CLEGG, S., HARDY, C. \& NORDY, W. Handbook de Estudos Organizacionais. São Paulo: Atlas, p. 196-219, 1999.

[28] VEIGA, J. E. da. A emergência socioambiental. São Paulo: Editora Senac São Paulo, 2007.

[29] YIN, R. K. Case study research: design and methods. London: Sage, 1994. 


\section{Capítulo 15}

\section{As servidões por utilidade pública nos assentamentos da reforma agrária}

\section{David Hermes Depiné \\ Fabiana Telles David Depiné}

Resumo: 0 objetivo do presente trabalho é demonstrar a legitimidade jurídica dos assentados em proteger a posse e as riquezas da área rural onde exerce suas atividades, isso, quando da efetivação de uma servidão administrativa levada a cabo em razão da necessidade de um serviço público que acaba por interferir na disposição do bem. Assim, se de um lado, em razão do interesse público o Estado pode utilizar-se da propriedade existente em um assentamento da reforma agrária, de outro, os prejuízos havidos em razão desta interferência são sofridos pelo assentado, e não pelo INCRA. Então, deve o assentado ser legítimo a figurar no polo, tanto ativo quanto passivo, de ações judiciais e administrativas que tratem dos efeitos da referida servidão. Através de pesquisa bibliográfica e análise de legislação e decisões judiciais, foi possível concluir que aquele que trabalha e gera riqueza no lote da reforma agrária, é quem deve ser legítimo a defendê-lo.

Palavras-chave: servidão de passagem; legitimidade jurídica; interesse público. 


\section{INTRODUÇÃO}

A servidão de passagem, é um instrumento utilizado pelo poder público quando há necessidade de implantação de um serviço público que possa interferir na propriedade alheia, como por exemplo as redes de transmissão de energia elétrica que cortam uma propriedade agrícola.

Conceitualmente, trata-se de "direito real de gozo, de natureza pública, instituído sobre imóvel de propriedade alheia, com base em lei, por entidade pública ou por seus delegados, em face de um serviço público ou de um bem afetado a fim de utilidade pública". (DI PIETRO,2008, on-line).

Ou seja, a servidão administrativa é o direito real que autoriza o Poder Público a usar a propriedade privada para permitir a execução de obras e serviços de interesse coletivo.

Via de regra, após decreto do poder público reconhecendo a utilidade pública, o proprietário é notificado, para querendo, contratar administrativamente a instituição da servidão, recebendo os valores que lhe são oferecidos pelo ente estatal, ou então, caso não concorde, este último buscará uma decisão judicial que lhe permita adentrar a propriedade alheia em razão da supremacia do interesse público sobre o privado, depositando previamente o valor da indenização.

Instituída a servidão, esta deve ser registrada na matrícula do imóvel, para que dela se de publicidade.

Ou seja, caso haja a construção de uma obra pública sobre uma propriedade, devem ser indenizados todos os prejuízos observados pelo proprietário, como destruição de barracões, plantações, desvalorização do imóvel, dentre várias outras possibilidades.

Ainda, deve ser indenizado ao proprietário a limitação de uso da faixa de segurança e manutenção da aludida rede.

Contudo, frisa-se, o proprietário não perde a propriedade do bem, mas sim sofre limitação em seu uso, devendo, portanto, ser indenizado.

Vejamos:

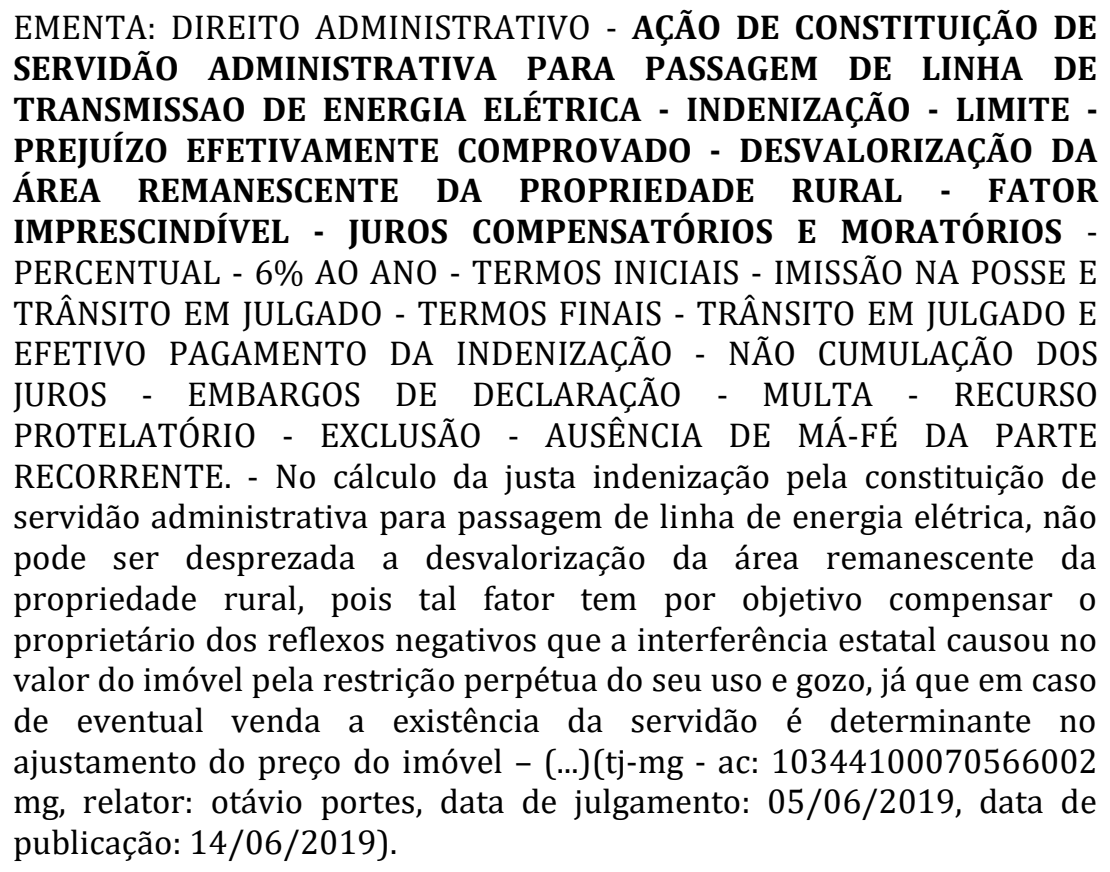

Superior Tribunal de Justiça. SÚMULAN.56 Na desapropriação para instituir servidão administrativa são devidos os juros compensatórios pela limitação de uso da propriedade.

O procedimento referente a servidão referida, está regulamentado no Decreto Lei 3.365/1941 e Decreto $35.851 / 1954$. 


\title{
2. LEGITIMIDADE PASSIVA NAS AÇÕES DE SERVIDÃO
}

Sabe-se que nos assentamentos da reforma agrária, os assentados permanecem anos trabalhando a propriedade para que, somente depois de cumpridos vários requisitos legais, esta seja devidamente intitulada em seu nome junto ao registro oficial. Lei 8629/1996:

\begin{abstract}
Art. 18. A distribuição de imóveis rurais pela reforma agrária far-se-á por meio de títulos de domínio, concessão de uso ou concessão de direito real de uso - CDRU instituído pelo art. 7o do Decreto-Lei no 271, de 28 de fevereiro de 1967. (Incluído pela Lei no 13.001, de 2014).
\end{abstract}

Neste contexto, é de se presumir que, várias poderão ser as lides em um procedimento de tamanha complexidade, que é levado a cabo de maneira genérica pelo ente público, sem muitas vezes dar atenção as particularidades de cada situação particular.

Diante disso, ajuizada a ação judicial, o Poder Judiciário analisará a casuística de cada servidão levada a sua apreciação.

Porém, há casos onde o assentado não concorda com a proposta do ente estatal, sendo que este último ajuíza ação de servidão e imissão na posse, requerendo liminar para realização das obras, mas o faz em desfavor ao INCRA, que em rasa análise, é o proprietário do bem de acordo com a titulação oficial, desprezando quem de fato sofrerá os prejuízos com a limitação de uso da propriedade.

Ocorre que, o assentado é o legítimo possuidor das áreas objeto da ação de imissão na posse, de maneira que o mesmo é figura legítima para figurar no polo passivo de uma ação que tem como tutela a posse.

Vejamos:

ACORDAM os integrantes da Décima Oitava Câmara Cível do Tribunal de Justiça do Estado do Paraná, por unanimidade, em negar provimento ao recurso, nos termos do voto do relator. EMENTA: AGRAVO DE INSTRUMENTO. AÇÃO DE EMISSÃO DE POSSE PROPOSTA EM FACE DOS ALIENANTES E DO TERCEIRO POSSUIDOR DO IMÓVEL. EXTINÇÃO DO PROCESSO SEM RESOLUÇÃO DE MÉRITO EM RELAÇÃO AOS ALIENANTES. PARTES QUE NUNCA TIVERAM A POSSE DO BEM. AÇÃO QUE DEVE SER PROPOSTA CONTRA O POSSUIDOR DIRETO, INDEPENDENTE DA RELAĈ̃̃ COM OS VENDEDORES. RECURSO CONHECIDO E NÃO PROVIDO. PODER JUDICIÁRIO TRIBUNAL DE JUSTIÇA Estado do Paraná (TJPR - 18 a C.CÍVEL - AI - 1540645-2 Colombo - Rel.: Vitor Roberto Silva - Unânime - J. 15.02.2017) (TJ-PR AI: 15406452 PR 1540645-2 (Acórdão), Relator: Vitor Roberto Silva, Data de Julgamento: 15/02/2017, 18ª Câmara Cível, Data de Publicação: DJ: 1982 06/03/2017)

Em ação judicial que tramitou nos autos no 5007527-26.2011.4.04.7002 do Tribunal Federal da 4o Região, (embargos de terceiro em reintegração de posse), já foi condenada a integrar no polo passivo da demanda os assentados do Projeto de Assentamento Companheiro Antônio Tavares, sendo os mesmos reconhecidos como legítimos à figurar no polo passivo, visto serem eles os reais interessados em eventual indenização sobre a servidão de passagem, senão vejamos:

\begin{abstract}
Ademais, sendo os embargantes os legítimos possuidores dos imóveis cuja imissão na posse se requer na ação 5023270-82.2011404.7000, tal ação deveria ter sido movida contra eles, e não somente contra o INCRA. Mormente porque, eventual indenização pela servidão de passagem, como bem referido pelos embargantes, indenizará o prejuízo dela decorrente e não a propriedade.
\end{abstract}

Portanto, não podem os embargantes terem sua posse tolhida sem a possibilidade de participar do respectivo processo judicial, até porque nele também se discute a indenização pela restrição ao exercício da posse - prejuízos decorrentes da Servidão de Passagem. (TRF4)

É evidente serem os assentados legítimos a figurar no polo passivo da demanda de imissão da posse, pois legítimos possuidores do imóvel e detentores do domínio resolúvel, já que, caso cumpram seus deveres, sua propriedade se tornará plena.

É determinação expressa no art. 189 da Constituição Federal: 
Art. 186. A função social é cumprida quando a propriedade rural atende, simultaneamente, segundo critérios e graus de exigência estabelecidos em lei, aos seguintes requisitos:

I. aproveitamento racional e adequado;

II. utilização adequada dos recursos naturais disponíveis e preservação do meio ambiente;

III. observância das disposições que regulam as relações de trabalho;

IV. exploração que favoreça o bem-estar dos proprietários e dos trabalhadores.

Art. 189. Os beneficiários da distribuição de imóveis rurais pela reforma agrária receberão títulos de domínio ou de concessão de uso, inegociáveis pelo prazo de dez anos.

Sendo assim, o título de domínio e a concessão de uso serão conferidos ao homem ou à mulher, ou a ambos, independentemente do estado civil, nos termos e condições previsto em lei.

Conclui-se, portanto que, quem deve ser indenizado pela passagem da rede elétrica é o assentado que ali reside, pois este é quem será lesado na diminuição da serventia do imóvel, pois eles é que possuem o domínio, mesmo que resolúvel do bem que terá o uso diminuído.

Até porque, em última análise, o Estatuto da Terra, art. 2ํㅗ § 1, alínea “a”, delimita que a propriedade desempenha sua função social, se favorecer o bem estar dos proprietários e dos trabalhadores que nela labutam.

\section{DO MINIFÚNDIO}

Se para o interesse social o latifúndio improdutivo é odioso, tão quanto deve ser o minifúndio que impede o sustento digno de uma família.

Deve-se se ter em mente que, em muitos casos, a propriedade dos assentados lhes foi entregue pelo INCRA e deverá ser paga como terra amplamente produtiva, sem nenhuma limitação.

Assim, estas áreas, se possuírem servidão, devem levar em conta sua existência, pois, do contrário, os assentados pagarão por estas áreas valores superiores aos outros assentados, já que não fora computada e compensada esta limitação da posse.

Ou ainda, a existência de uma servidão não levada em consideração no cálculo da área disponibilizada ao assentado, levará a criação de um evidente minifúndio.

Isso porque, em muitos casos as áreas entregues aos assentados o foram de acordo com a fração mínima de parcelamento e de acordo com o módulo rural do local.

A Lei 4504/64 (Estatuto da Terra) é simples ao delimitar que:

Art. 4ํㅡㄹ Para efeitos desta Lei, definem-se:

II. "Propriedade Familiar", o imóvel rural que, direta e pessoalmente explorado pelo agricultor e sua família, lhes absorva toda a força de trabalho, garantindo-lhes a subsistência e o progresso social e econômico, com área máxima fixada para cada região e tipo de exploração, e eventualmente trabalho com a ajuda de terceiros;

III. "Módulo Rural", a área fixada nos termos do inciso anterior;

IV. "Minifúndio", o imóvel rural de área e possibilidades inferiores às da propriedade familiar;

A simples existência de uma servidão, por si, ao limitar a utilização do bem que configura-se como o mínimo necessário a exploração familiar digna, já torna o bem incapaz de cumprir a função social que a Constituição Federal consagra, visto que seu grau de utilização e eficiência estarão eminentemente comprometidos, de acordo com os arts. 4ํㅜ , 5ํㅜ e 9o da IN 11/2003 do INCRA. 
Assim, proceder a Reforma Agrária desconsiderando o GUT, o GEE, o módulo rural e o conceito de propriedade familiar é simplesmente utilizar dinheiro público de maneira ineficiente.

0 art. 6ำ 9o e 17 da Lei 8629/93 são claros em delimitar nesse sentido. (Art. 6ํo Considera-se propriedade produtiva aquela que, explorada econômica e racionalmente, atinge, simultaneamente, graus de utilização da terra e de eficiência na exploração, segundo índices fixados pelo órgão federal competente.

Art. 9o A função social é cumprida quando a propriedade rural atende, simultaneamente, segundo graus e critérios estabelecidos nesta lei, os seguintes requisitos:

I - aproveitamento racional e adequado;

\section{(...)}

$\S 1$ o Considera-se racional e adequado o aproveitamento que atinja os graus de utilização da terra e de eficiência na exploração especificados nos $\S \S 1^{\circ}$ a $7^{\circ} \underline{\text { do }}$ art. $6^{\circ}$ desta lei.

\section{(...)}

§ 5o A exploração que favorece o bem-estar dos proprietários e trabalhadores rurais é a que objetiva o atendimento das necessidades básicas dos que trabalham a terra, observa as normas de segurança do trabalho e não provoca conflitos e tensões sociais no imóvel.

$\S 6^{\circ}$ (Vetado.)

Art. 17. 0 assentamento de trabalhadores rurais deverá ser realizado em terras economicamente úteis, de preferência na região por eles habitada, observado o seguinte:)

Assim, as servidões devem constar do PDA, (Plano de Desenvolvimento de Assentamento), pois do contrário pode-se observar a implantação de um minifúndio, devendo, neste caso, a área ser compensada em terreno contínuo no próprio assentamento, quando possível, ou ainda, caso impossível a compensação, que seja a área desapropriada, indenizados os assentados com área de igual tamanho e valor, se possível, no próprio assentamento.

Vejamos:

EMBARGOS DE DECLARAÇAO. 1) OBSCURIDADE. PALAVRAS DE ACEPÇAO DUPLA OU MÚLTIPLA. INOCORRÊNCIA. 2) DESAPROPRIAÇAO. UTILIZA ÇAO DE DETERMINADA FAIXA. ÁREA RESTANTE INUTILIZADA. PERDA DA POTENCIALIDADE ECONÔMICA. DEVER DE INDENIZAR. RESTRIÇAO AO LIVRE USO. VALOR INTEGRAL DA ÁREA, E NAO DA PARCELA EFETIVAMENTE UTILIZADA. 3) INVASAO DE COMPETÊNCIA DO ÓRGAO AMBIENTAL. NAO VERIFICAÇAO. NAO INCLUSAO DE FAIXA NAO EDIFICANTE EM CONTRAPOSIÇAO AO PLEITO EXORDIAL. 4) PREQUESTIONAMENTO. AUSÊNCIA DE MÁCULA. RECURSO IMPROVIDO. 1) Não se registra, no colegiado julgamento, quaisquer dos graus reconhecidos para a obscuridade, seja uma simples ambiguidade, que pode resultar do emprego de palavras de acepção dupla ou múltipla sem que do contexto ressalte a verdadeira no caso -, seja uma completa ininteligibilidade. 2) Como dito alhures, ainda que alegue a expropriante necessitar tão-somente da faixa de 20 (vinte) metros e que o ora embargado não estará impedido de utilizar a área restante, resta evidenciada a perda da potencialidade econômica dessa parcela, diante da restrição ao uso de forma livre e desimpedida pelo proprietário, de modo que a indenização deve equivaler ao valor integral da área e não apenas da parcela efetivamente utilizada pelo expropriante. 3) Em razão disso, não houve invasão da competência de outrem, seja do órgão ambiental e quem quer que seja, pois não houve inclusão da faixa não edificante em contraposição ao pleito inicial. 4) De resto, afigura-se defeso cogitar de 
qualquer prequestionamento acerca da lide por não ostentar o acórdão qualquer das máculas elencadas no art. 535 do CPC. Recurso improvido. (TJ-ES - ED: 12069001050 ES 012069001050, Relator: RÔMULO TADDEI, Data de Julgamento: 13/03/2007, TERCEIRA CÂMARA CÍVEL, Data de Publicação: 20/03/2007)

Ou seja,

\begin{abstract}
"a indenização há que corresponder ao efetivo prejuízo causado ao imóvel, segundo sua normal destinação. Se a servidão não prejudica a utilização do bem, nada há que indenizar; se a prejudica, o pagamento deverá corresponder ao efetivo prejuízo, chegando, mesmo, a transformar-se em desapropriação indireta com indenização total da propriedade, se a inutilizou para sua exploração econômica normal".
\end{abstract} (MEIRELLES, 2002, p. 597).

\title{
4. SERVIDÃO APARENTE E SERVIDÃO JÁ EXISTENTE
}

Outrossim, existem situações onde na propriedade do assentado já existe uma servidão, que é chamada de aparente pois na realidade não foi registrada na matrícula, contudo de fato existe, além daquelas regularmente instituídas.

Nesse caso, muitas vezes, quando da construção de nova obra, ou seja, de nova servidão, o ente estatal entende que não é necessária a indenização, pois já há uma servidão existente.

Primeiramente, há que ser analisada a situação onde uma obra antiga será demolida para construção de uma nova.

Isso porque, de acordo com o art. 1388, II do CC, extinguiria a servidão quando tiver cessado a utilidade ou a comodidade, que determinou sua constituição.

Assim, constituída a servidão na forma do art. 40 do Decreto Lei 3365/41, o art. 2oㅡ, § 2o do Decreto 35851/54 enfatiza que, a servidão compreende o direito, atribuído ao concessionário, de praticar, na área por ela abrangida, todos os atos de construção, manutenção, conservação e inspeção das linhas de transmissão de energia elétricas e das linhas, sendo-lhe assegurado ainda o acesso à área da servidão, através do prédio serviente, desde que não haja outra via praticável.

Ou seja, construção e manutenção das redes que o seu decreto estatal de interesse público específico permitiu. Não se trata de um salvo conduto eterno de agressão a propriedade do assentado.

Ainda, o art. 1385 do C.C reitera que a servidão restringir-se-á o exercício às necessidades do prédio dominante, evitando-se, quanto possível, agravar o encargo ao prédio serviente e que, constituída para certo fim, a servidão não se pode ampliar a outro.

Assim, não pode o embargante inventar direitos reais, pois como se sabe, estes são taxativos. Maria Helena Diniz (2010) diz que tal preceito circunscreve-se a um conjunto de coisas que não comportam acréscimos, sendo, portanto, esta limitada quanto ao seu conteúdo ou matéria.

Dessa forma, segundo o CC, art. 1225, os direitos reais são divididos em direitos de propriedade, superfície, servidão, usufruto, uso, habitação, direito do promitente comprador do imóvel, penhor, hipoteca, anticrese, concessão de uso especial para fins de moradia e concessão de direito real de uso.

O que detinha o ente público, portanto, era o direito de realizar obras e ações no intuído de manter as redes antigas, havidas por uma servidão antiga, não podendo, portanto, agravar a situação do assentado com obras de construção de uma nova rede sem querer formalizar a servidão e indenizar o proprietário.

A mesma situação deve ser observada na servidão aparente, onde não houve a indenização e nem mesmo o registro por desídia do ente estatal, sendo que não se pode perpetuar desmandos e tentar valer-se de sua própria torpeza, conforme inteligência do art. 150 do CC.

Assim, mesmo sendo a servidão aparente e não havendo registro, deve-se respeitar a posse e também os demais desígnios acima apontados. 


\section{REFERÊNCIAS:}

[1] BRASIL. Lei 3.364 de 21 de junho de 1941. Disponível em: http://www.planalto.gov.br/ccivil_03/decretolei/del3365.htm. Acesso em: 20 jul. 2020.

[2] _. Decreto 35.851 de 16 de julho de 1954 . Disponível em: http://www.planalto.gov.br/ccivil_03/Atos/decretos/1954/D35851.html. Acesso em: 20 jul. 2020.

[3] _. Lei 8.629 de 25 de fevereiro de 1996. Disponível em: http://www.planalto.gov.br/ccivil_03/leis/L8629compilado.htm. Acesso em: 20 de jul. 2020.

[4] DINIZ, Maria Helena. Curso de direito civil brasileiro: teoria geral do direito civil. 21.ed. São Paulo: Saraiva, 2004. V. 1

[5] DI PIETRO, Maria Sylvia Zanella. Direito Administrativo. São Paulo: Atlas. 18 ed. 2008. On-line.

[6] MEIRELLES, Hely Lopes. Direito Administrativo Brasileiro. Malheiros Editores, 27aㅡ ed., 2002.

[7] TRIBUNAL REGIONAL FEDERAL 4ํREGIÃO. Apelação Cível no 5007527-26.2011.404.7002/PR. Disponível em:

<https://eproc.trf4.jus.br/eproc2trf4/controlador.php?acao=acessar_documento\&doc $=41322837327518161100000$

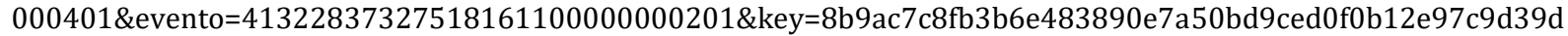
d1aa518fd726f80f96\&hash=9a959a4d89fc1b5b01551c8f4f4755e5>. Acesso em 16 jun. 2020. 


\section{Capítulo 16}

Modelo para delimitação automática de áreas de preservação permanente conforme o Novo Código Florestal: Aplicação em três municípios no Bioma Amazônia em Mato Grosso

Weslei Butturi

Vinicius de Freitas Silgueiro

Edgley Pereira da Silva

Bruno Diego Cardoso dos Santos

Sumário: 0 objetivo deste trabalho foi apresentar as características do modelo automatizado de delimitação de áreas de preservação permanente (APP) de acordo com a legislação ambiental vigente no Brasil e os resultados de sua aplicação em três municípios (Alta Floresta, Carlinda e Paranaíta) na região Norte do estado de Mato Grosso. A Lei 12.651 /2012, o "Novo Código Florestal", considerou novas variáveis para definir o quantitativo de APP. Além dos recursos hídricos, deve ser considerado o tamanho da propriedade e a data em que a área foi degradada. Dada a grande extensão territorial dos municípios que compõem a região norte de Mato Grosso, é muito importante a utilização de ferramentas automatizadas de delimitação das APPs, a fim de auxiliar na tomada de decisão quanto às atividades de restauração florestal. 0 modelo foi construído na plataforma ArcGIS usando as ferramentas buffer, union, clip, erase e dissolve. Toda a base de dados utilizada foi produzida pelo Instituto Centro de Vida (ICV) na escala 1: 25.000. Com esse modelo, foi possível calcular as áreas de APPs conservadas e as áreas de APPs degradadas (APPD) nos três municípios. 0 município de Alta Floresta apresentou o maior percentual de APPs degradadas, com 14.631 hectares, o que representa $60 \%$ de todas as APPs a serem restauradas nos três municípios. 0 modelo se mostrou eficiente na geração de APPs e APPDs e pode ser replicado para outros municípios. A qualidade dos dados obtidos com o modelo automatizado depende da qualidade da base cartográfica digital adotada.

Palavras-chave: sistema de informação geográfica, modelo automatizado, legislação ambiental, áreas de preservação permanente, sistema de informação geográfica, modelo automatizado, legislação ambiental, áreas de preservação permanente. 


\section{INTRODUÇÃO}

No Brasil, as áreas de preservação permanente (APPs) são definidas pela Lei 12.651 de 25 de maio de 2012, que revogou a Lei 4.771 de 15 de setembro de 1965. Apesar da reforma no Código Florestal, o conceito de APP se manteve o mesmo, sendo definida como a área coberta ou não por vegetação nativa com a função ambiental de preservar os recursos hídricos, a paisagem, a estabilidade geológica e a biodiversidade, facilitar o fluxo gênico de fauna e flora, proteger o solo e assegurar o bem-estar das populações humanas (BRASIL, 2012).

De acordo com Oliveira (2005) a dificuldade para delimitação das APPs no Brasil sempre esteve ligada a complexidade do processo de demarcação, que requer base de dados hidrográficos e altimétricos bastante detalhados e que o mapeamento sistemático brasileiro não possui. Além da escassez de profissionais com experiência no manuseio destas informações e também para levantamentos em campo.

Além disso, no caso da delimitação das APPs de cursos d'água e nascentes em áreas degradadas e/ou alteradas, o novo Código Florestal passou a considerar novas variáveis para definir o quantitativo a ser recomposto. Se antes somente era observado as dimensões relativas ao recurso hídrico em si, a nova lei passou a considerar também o tamanho do imóvel em que a APP está inserida, bem como a data em que a área fora degradada e/ou alterada.

Sobretudo, a regularização ambiental dos imóveis rurais se apresenta como um dos grandes desafios para implementação do Novo Código Florestal. Por meio da análise do Cadastro Ambiental Rural (CAR) deverá ser conhecido o passivo ambiental associado às APPs e áreas de reserva legal (ARLs) dos imóveis rurais.

O Instituto Centro de Vida (ICV), uma Organização da Sociedade Civil de Interesse Público (OSCIP), apoia municípios de Mato Grosso na estruturação e fortalecimento do Sistema Municipal de Meio Ambiente (SMMA), na criação e implementação de políticas públicas e instrumentos de gestão ambiental. O ICV juntamente com outras organizações, secretarias de estado e municípios, construíram o Programa Matogrossense de Municípios Sustentáveis (PMS), composto por três eixos básicos de atuação: fortalecimento da gestão ambiental municipal, regularização ambiental e fundiária e promoção de cadeias produtivas sustentáveis da agricultura familiar (SESSIN-DILASCIO et al., 2016).

Como subsídio às ações desenvolvidas, o Núcleo de Geotecnologias do ICV tem produzido e compilado bases de dados espaciais de municípios localizados no Bioma Amazônia em Mato Grosso, gerando e fornecendo informações estratégicas para o desenvolvimento sustentável dessa região. Diversas oportunidades de acesso a projetos e recursos tem se configurado para os municípios trabalharem ações relativas aos três eixos do PMS. Nesse sentido, conhecer a dimensão dos passivos ambientais enquanto os resultados da análise e validação dos CAR ainda estão em andamento, é fundamental para a elaboração e execução de projetos por parte dos municípios e sociedade civil.

Dada a grande extensão territorial dos municípios que compõem a região norte e noroeste mato-grossense é de grande valia a utilização de ferramentas automatizadas para delimitação das APPs de forma a auxiliar na tomada de decisão quanto às ações de restauração florestal das áreas em situação de degradação e/ou alteração.

Assim, o Núcleo de Geotecnologias do ICV produziu as bases de hidrografia, cobertura do solo e imóveis rurais e a partir destas bases desenvolveu um modelo para delimitação automática e posterior diagnóstico das APPs de cursos d'água, nascentes e lagoas naturais, conforme as regras estabelecidas pelo Novo Código Florestal.

O objetivo deste trabalho é apresentar as características do modelo desenvolvido e os resultados de sua aplicação para três municípios localizados no bioma Amazônia, ao norte do Estado de Mato Grosso.

\section{METODOLOGIA DE TRABALHO}

\section{1. ÁREA DE ESTUDO}

A área de estudo compreende os municípios de Alta Floresta, Carlinda e Paranaíta localizados entre as coordenadas geográficas $09^{\circ} 09^{\prime} 00^{\prime \prime}$ e $10^{\circ} 40^{\prime} 23^{\prime \prime}$ Sul e $57^{\circ} 07^{\prime} 45^{\prime \prime}$ e $55^{\circ} 34^{\prime} 46^{\prime \prime}$ Oeste na região norte do estado de Mato Grosso (Figura 1). 
O clima é do tipo Equatorial classificado como $\mathrm{Am}$ com precipitação média de $2.500 \mathrm{~mm} / \mathrm{ano}$ segundo a classificação de Köppen (BERNASCONI et al., 2009). A tipologia florestal predominante é apontada como Floresta Ombrófila Aberta, inserida no bioma amazônico. A principal atividade econômica para estes três municípios é a pecuária de corte e leite.

Figura 1. Mapa de localização da área de estudo.

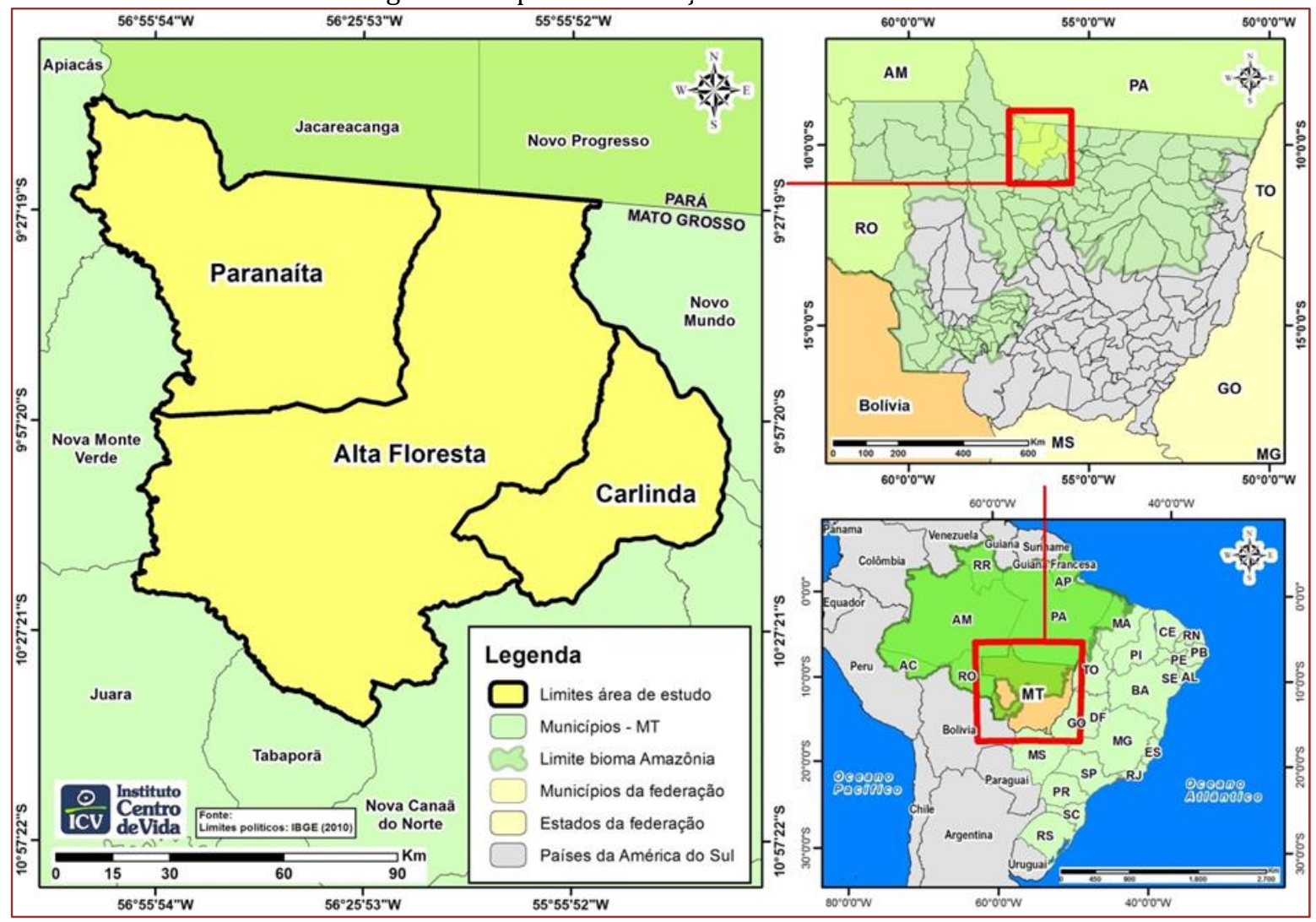

\subsection{BASES DE DADOS NECESSÁRIAS}

Além das características da hidrografia, para a delimitação das APPs segundo o Novo Código Florestal são consideradas as seguintes variáveis: o tamanho do módulo fiscal do município, o tamanho do imóvel rural e a data de supressão da vegetação nativa.

O módulo fiscal (MF) é uma unidade de medida agrária usada no Brasil expressa em hectares, variável e fixa para cada município, cujo objetivo é estabelecer um padrão mínimo que expresse a sua viabilidade como unidade produtiva, dependendo da sua localização (BRASIL, 1964). 0 tamanho do módulo fiscal para os três municípios é de 100 hectares (INCRA, 2013).

Para conhecer o tamanho dos imóveis rurais dos três municípios, foram compilados em uma base única os limites dos imóveis com CAR, com certificação no Sistema de Gestão Fundiária (SIGEF) e outras fontes de informação, como mapas analógicos e levantamentos dos vértices de imóveis realizados a campo.

A base hidrográfica foi mapeada pelo ICV na escala de 1:25.000 e apresenta os seguintes componentes: nascentes, lago ou lagoa natural, reservatório artificial, reservatório para geração de energia, cursos d'água com até 10 metros de largura, cursos d'água com largura de 10 a 50 metros, de 50 a 200 metros, de 200 a 600 metros e acima de 600 metros. 
O mapeamento da cobertura do solo foi produzido pelo ICV na mesma escala que a base hidrográfica e de acordo com as classes do CAR, conforme método apresentado por Brugnara et. al. (2016). Dessa forma, essa base apresenta as classes representativas das áreas de uso consolidado (áreas convertidas para uso alternativo do solo até 22 de julho de 2008), áreas desmatadas após 22 de julho de 2008, remanescentes de vegetação nativa, áreas abandonadas ou de pousio, áreas urbanizadas e afloramentos rochosos.

\subsection{CONSTRUÇÃO DO MODELO E PROCESSAMENTO}

De posse das bases cartográficas digitais necessárias, foi estruturado no software ArcGIS 10.4 um encadeamento de ferramentas, conhecido como Modelbuilder, para a delimitação automática das APPs de acordo com as regras estabelecidas pelo Novo Código Florestal (Tabela 1). 0 Modelbuilder apresenta a funcionalidade de criar modelos a partir de fluxos que unem uma sequência de ferramentas presentes no módulo ArcToolbox e bases de dados. Segundo Medeiros (2014), o Modelbuilder permite tanto construir fluxos de rotina de trabalho, quanto criar novas ferramentas.

Tabela 1. Variação da largura de APPs e APPDs em função do tamanho do imóvel, tipo de hidrografia e cobertura do solo segundo o Código Florestal antigo e o novo.

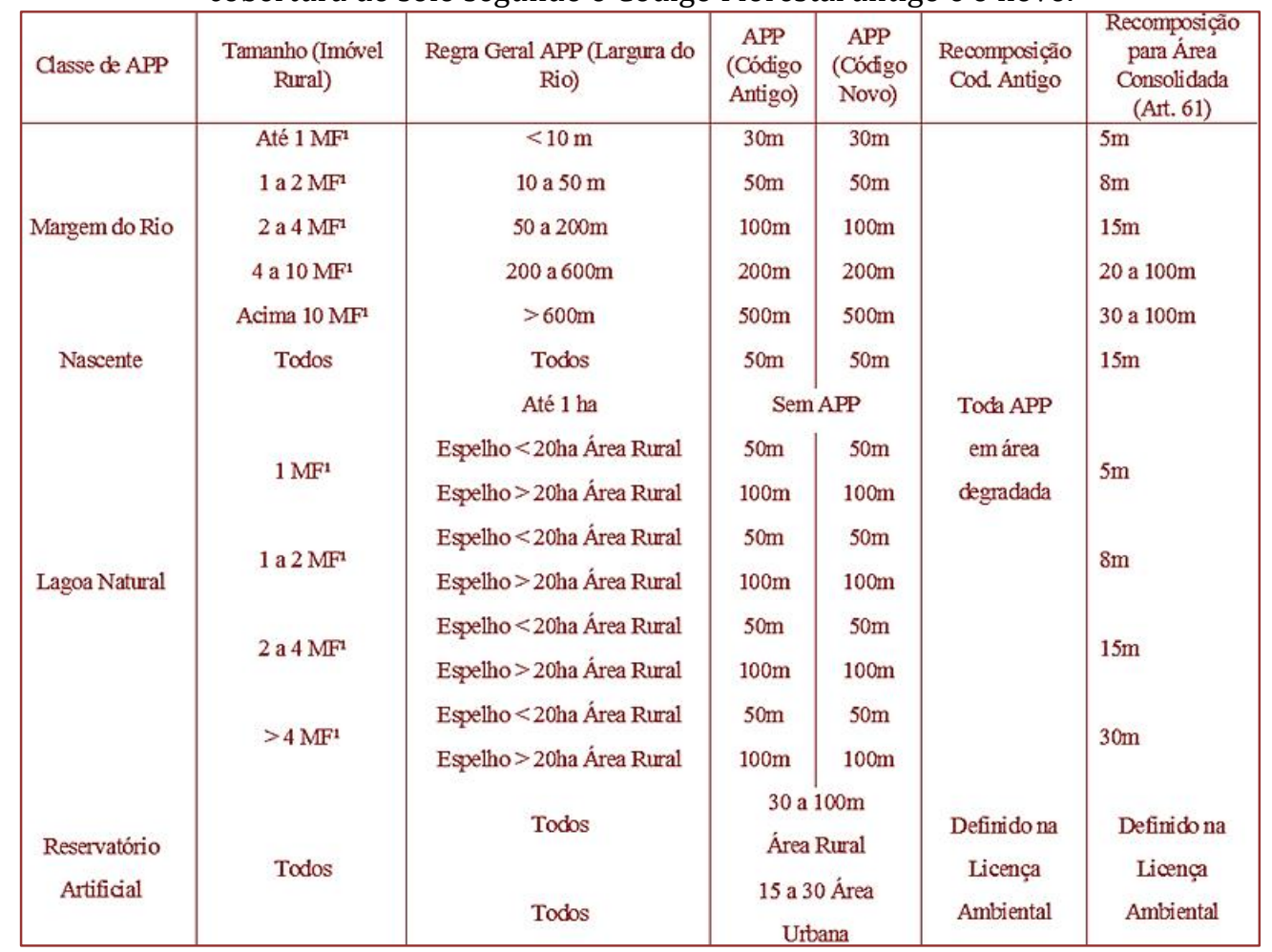

(ESTEVAM \& PEREIRA, 2015 modificada por BUTTURI, 2016)

Para inserir os dados no modelo faz-se necessário organizá-los de forma separada. Dos componentes da hidrografia, deve-se separar as nascentes, cursos d'água até 10 metros de largura, cursos d'água de 10 a 50 metros de largura, de 50 a 200, de 200 a 600 e acima de 600 metros de largura, uma camada com todos os cursos d'água reunidos, lago ou lagoa natural com área até 20 hectares e lago ou lagoa natural com área maior que 20 hectares.

Para os imóveis rurais, conforme o tamanho do módulo fiscal $(\mathrm{MF})^{1}$ de cada município, separar os imóveis com área total de até 1 módulo fiscal, de 1 a 2 módulos, de 2 a 4 módulos, de 4 a 10 módulos e acima de 10 módulos fiscais, e também uma camada que reúna todos os imóveis de todas as categorias.

Por fim, a partir do mapeamento da cobertura do solo, deve-se separar uma camada com os remanescentes de vegetação nativa, uma camada com as áreas desmatadas após 22 de julho de 2008 e uma com os afloramentos rochosos. Dessa forma, as camadas estarão aptas a serem inseridas no Modelbuilder (Figura 2). 
Figura 2. Inserção das camadas no Modelbuilder para geração automática das APPs e APPDs.

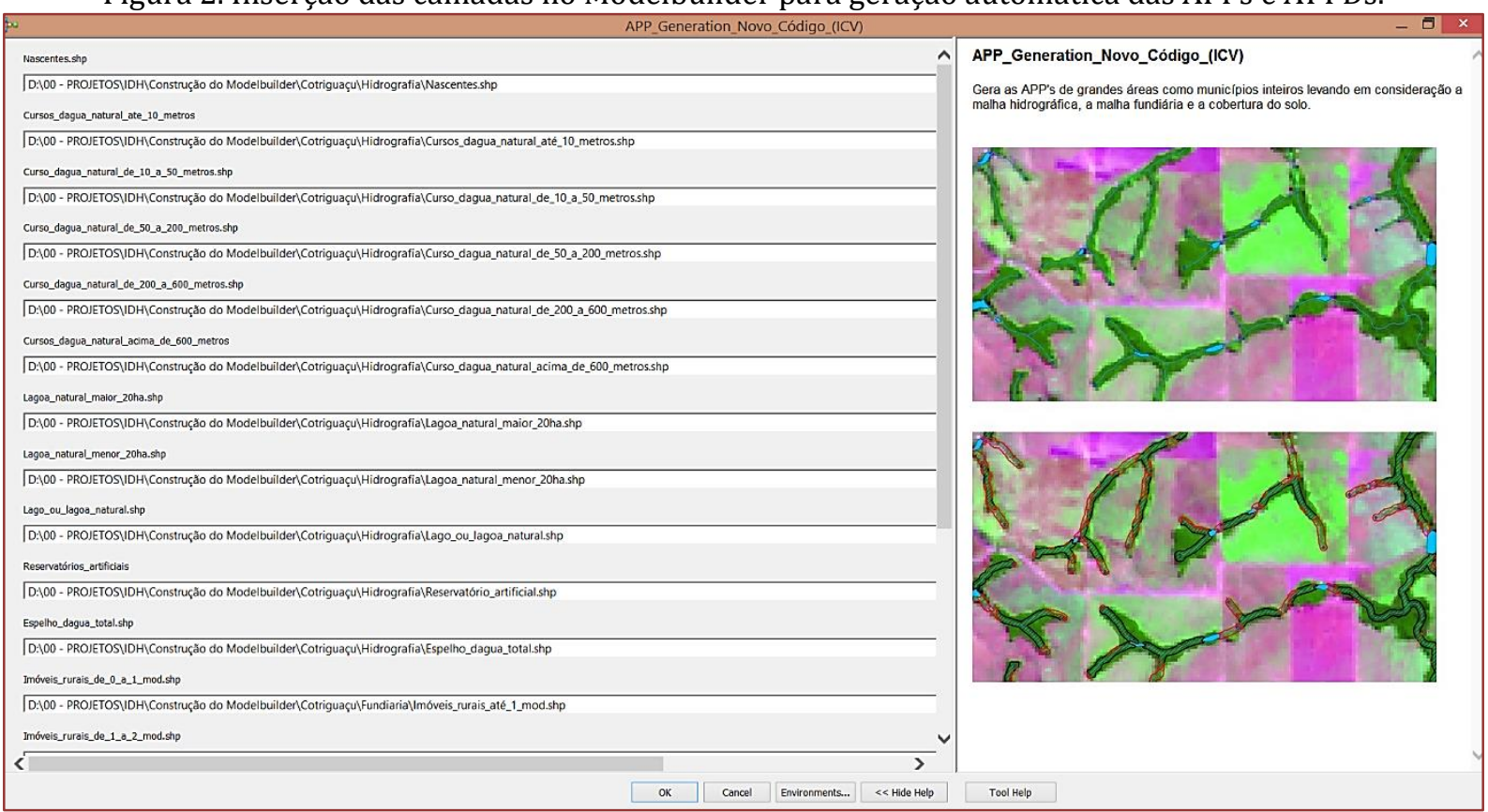

Todos os polígonos de APPs que não se sobreporem com a camada de áreas de remanescente de vegetação nativa serão denominados de APPs degradadas (APPD), sujeitos a restauração florestal. Ao passo que as APPs que incidem sobre remanescentes de vegetação nativa são denominadas de APPs Conservadas.

Para o geoprocessamento das camadas citadas acima foram utilizadas cinco ferramentas da extensão ArcToolbox ArcGIS 10.4, sendo elas buffer, union, clip, erase e dissolve, as quais foram organizadas no Modelbuilder a fim de automatizar a geração das APPs e APPDs especialmente para grandes extensões territoriais, como municípios, conjunto de municípios e estados, dependendo da disponibilidade de dados (Figura 3). Após geradas as APPs e APPDs faz-se necessária uma revisão por parte do analista para remover possíveis inconsistências que o processamento automatizado possa ter gerado, conferindo maior qualidade ao produto.

Figura 3. Etapas do processamento organizadas no Modelbuilder para geração automática das APPs e APPDs.

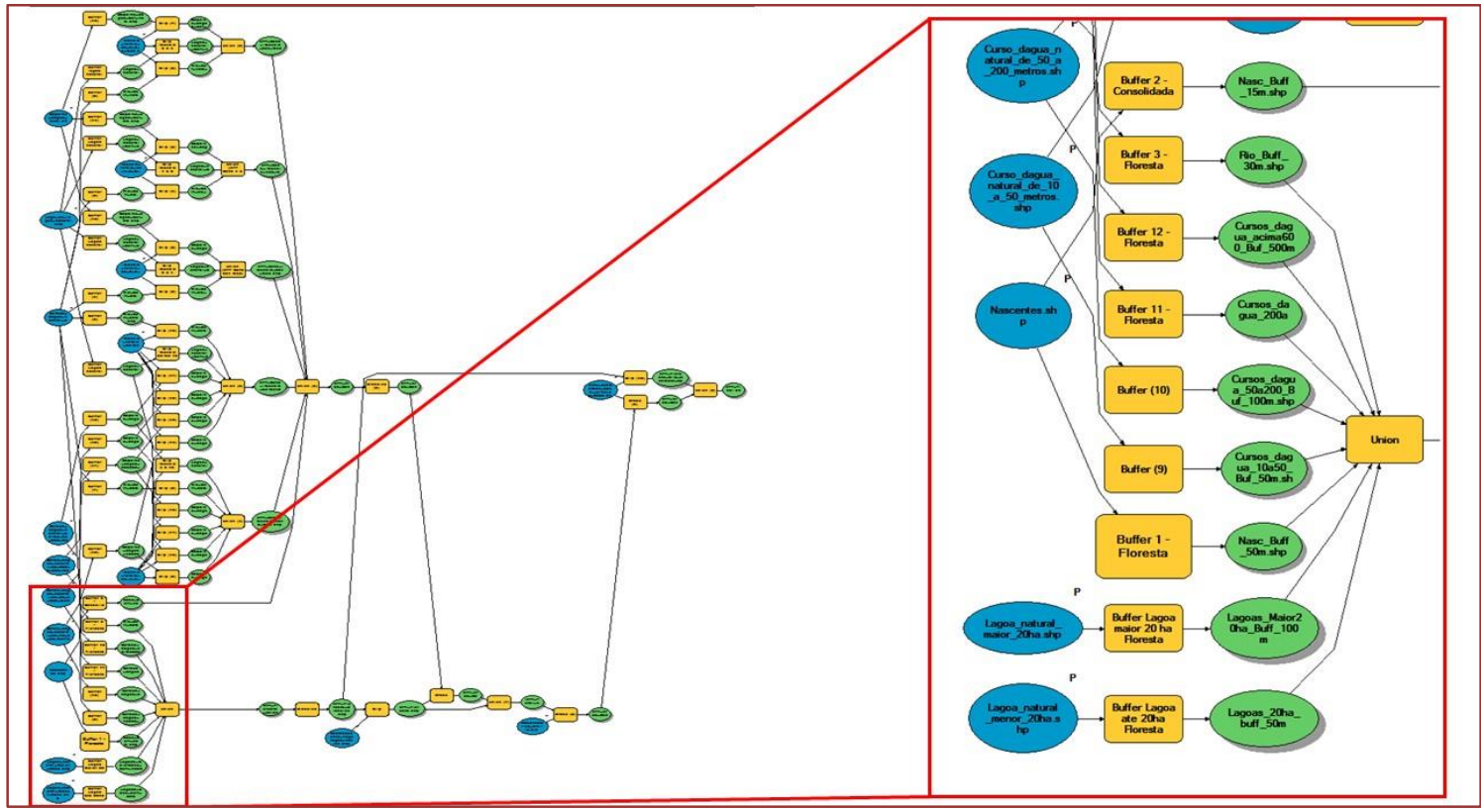




\section{RESULTADOS E DISCUSSÕES}

O uso do modelo automatizado se mostrou satisfatório pois com ele foi possível delimitar as APPs de forma relativamente rápida e calcular as áreas das APPs conservadas e as áreas das APPs degradadas nos três municípios objetos da área de estudo.

0 produto gerado apresentou algumas inconsistências localizadas em áreas principalmente ao redor de cursos d'água acima de 10 metros (representados por polígonos). São pequenas "nesgas" que podem ser editadas e eliminadas pelo analista responsável.

Não foi possível delimitar as APPs de áreas com declividade acentuada (morros, montanhas, escarpas, divisores de água) devido a falta de insumos que impossibilitaram representar estas feições na escala de $1: 25.000$.

De acordo com a Lei 12.727 de 17 de outubro de 2012, para a delimitação da largura mínima das APPs para os reservatórios artificias deve ser adotada a que foi definida em seu licenciamento ambiental. Sendo assim, não foi possível atribuir esta regra para o modelo pela falta de acesso a todas as licenças ambientais de todos os reservatórios artificiais dos três municípios, até porque a maioria deles não possuem licenciamento ambiental.

Como o tamanho do módulo fiscal para os três municípios é o mesmo (100 hectares), foi possível delimitar as APPs simultaneamente. Caso o tamanho do módulo fiscal seja diferente de um município para outro, a geração das APPs precisará ser fracionada.

A tabela 2 apresenta os valores de APPs conservadas e APPDs a restaurar para os três municípios em estudo.

Tabela 2. Número de polígonos, área em hectares e percentual de APPs conservadas e APPs degradadas nos municípios de Alta Floresta, Carlinda e Paranaíta em Mato Grosso

\begin{tabular}{|c|c|c|c|c|c|c|c|c|c|}
\hline & \multicolumn{3}{|c|}{ Alta Floresta } & \multicolumn{3}{|c|}{ Carlinda } & \multicolumn{3}{|c|}{ Paranaíta } \\
\hline & № Pol. & Área (ha) & $\%$ & $\begin{array}{c}\text { № } \\
\text { Pol. }\end{array}$ & Área (ha) & $\%$ & № Pol. & Área (ha) & $\%$ \\
\hline APP conservada & 4967 & 47691,9 & 76,5 & 2571 & 13901,1 & 77,5 & 4302 & 35206,0 & 86,3 \\
\hline APP degradada & 15244 & 14631,0 & 23,5 & 6503 & 4030,9 & 22,5 & 9161 & 5580,9 & 13,7 \\
\hline Total & 20211 & 62322,9 & 100 & 9074 & 17932,0 & 100 & 13463 & 40787,0 & 100 \\
\hline
\end{tabular}

Dos três municípios analisados, Alta Floresta foi o que apresentou o maior percentual de APPs degradadas, com área de 14.631 hectares para serem restaurados, representando 60\% de todas as APPDs (Figura 4) a serem restauradas nos três municípios.

Isso se deve porque Alta Floresta possui uma extensão territorial superior a Paranaíta e Carlinda, como também aos diferentes ciclos econômicos que o município enfrentou: exploração mineral (garimpo), exploração florestal e a pecuária extensiva. Esses ciclos contribuíram para o processo de degradação e fragmentação dos remanescentes de vegetação nativa, inclusive nas APPs (ROSA et al., 2003).

Observa-se também que os valores percentuais de APP degradadas são bem inferiores em comparação aos valores de APP conservadas. Isto pode ser explicado porque as larguras de APPs conservadas, ou seja, cobertas por remanescentes de vegetação nativa, variam de 30 a 500 metros, dependendo da largura dos cursos d'água. Já as APPs degradadas que incidem em áreas de uso consolidado, as larguras a serem restauradas variam de 5 a no máximo 100 metros, dependendo do tamanho do imóvel rural. Todos os municípios analisados possuem mais de $50 \%$ de sua área aberta caracterizada como de uso consolidado. 
Figura 4. APPs conservadas e APPs degradadas nos municípios de Alta Floresta, Carlinda e Paranaíta em Mato Grosso

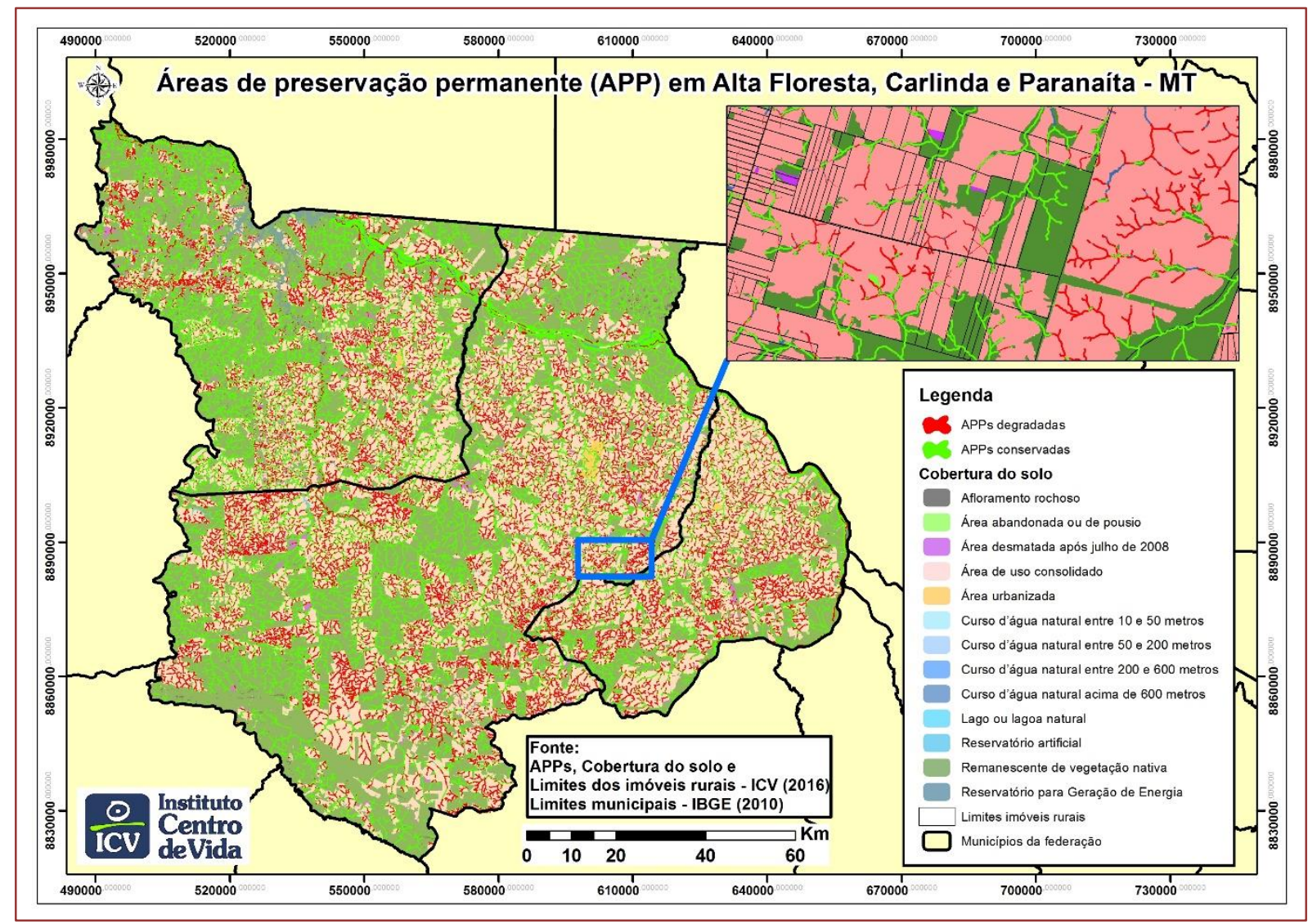

As bases de dados utilizadas influenciaram diretamente nos resultados, havendo, portanto, a necessidade de estabelecimento de padrões de mapeamento, eliminação de sobreposições e erros topológicos, nível de detalhamento adequado a escala dos imóveis rurais e maior atualização possível.

Destaca-se a grande vantagem da utilização de Sistemas de Informação Geográfica (SIG) como fundamental ferramenta no estudo de monitoramento do uso e cobertura das terras nos municípios estudados, aliado a capacidade de sobreposição de diferentes planos cartográficos e detecção de problemas de utilização das terras.

\section{CONCLUSÃO}

0 modelo se mostrou eficiente para o diagnóstico das APPs e APPDs para os municípios estudados, podendo ser replicado para outros municípios brasileiros. A qualidade dos dados obtidos através do modelo automatizado depende exclusivamente da qualidade da base cartográfica digital utilizada, a qual não pode ter sobreposições e nem erros topológicos.

0 método pode ser complementado visando diagnosticar também as APPs relativas às áreas com declividade acentuada e reservatórios artificiais. Como o tamanho do módulo fiscal varia de um município para o outro, o modelo precisará ser ajustado sempre que o módulo fiscal de um novo município for diferente do último em que foi aplicado o modelo. 


\section{REFERÊNCIAS}

[1] Bernasconi, P.; Santos, R. R.; Micol, L.; Rodrigues, J. A. Avaliação Ambiental Integrada: Território Portal da Amazônia. Alta Floresta - MT: ICV, 2009. p. 11.

[2] Brasil. Lei $N^{\circ} 12.651$ de 25 de maio de 2012. Dispõe sobre a proteção da vegetação nativa; altera as Leis nos 6.938, de 31 de agosto de 1981, 9.393, de 19 de dezembro de 1996, e 11.428, de 22 de dezembro de 2006; revoga as Leis nos 4.771, de 15 de setembro de 1965, e 7.754, de 14 de abril de 1989, e a Medida Provisória no 2.166-67, de 24 de agosto de 2001; e dá outras providências. Diário Oficial da União, Brasília, Distrito Federal. 28. maio. 2012. Disponível em: <http://www.planalto.gov.br/ccivil_03/_ato2011-2014/2012/lei/l12651.htm>.

[3] Brasil. Lei $\mathrm{N}^{\circ} 12.727$ de 17 de outubro de 2012. Altera a Lei no 12.651, de 25 de maio de 2012, que dispõe sobre a proteção da vegetação nativa; altera as Leis nos 6.938, de 31 de agosto de 1981, 9.393, de 19 de dezembro de 1996, e 11.428, de 22 de dezembro de 2006; e revoga as Leis nos 4.771, de 15 de setembro de 1965, e 7.754, de 14 de abril de 1989, a Medida Provisória no2.166-67, de 24 de agosto de 2001, o item 22 do inciso II do art. 167 da Lei no 6.015, de 31 de dezembro de 1973, e o § 2o do art. 4o da Lei no 12.651, de 25 de maio de 2012. Diário Oficial da União, Brasília, Distrito Federal. 18. outubro. 2012. Disponível em: <http://www.planalto.gov.br/ccivil_03/_ato20112014/2012/lei/L12727.htm>.

[4] Brasil. Lei $\mathrm{N}^{\circ} 4.504$ de 30 de novembro de 1964. Dispõe sobre o Estatuto da Terra, e dá outras providências. Diário Oficial da União, Brasília, Distrito Federal. 30. novembro. 1964 . Disponível em: <http://www.planalto.gov.br/ccivil_03/leis/L4504.htm>.

[5] Brugnara, E.; Santos, B. D. C.; Sousa, S. C. C.; Butturi, W.; Silgueiro, V. F.; Wojciechowski, J. C. Mapeamento das classes do Cadastro Ambiental Rural (CAR) em municípios do Território Portal da Amazônia. In: IX Semana da Biologia e I Seminário do Núcleo de Agricultura Familiar e Agroecologia, 2016, Alta Floresta - MT. Anais... Alta Floresta: Unemat, 2016. p. 144 - 149. Online. ISBN: 978-85-68739-03-7. Disponível em: $<$ http://altafloresta.unemat.br/index.php/servicos/eventos/ix-semana-da-biologia-e-i-seminario-do-nucleo-deagricultura-familiar-e-agroecologia/item/611-anais-da-iv-semana-da-biologia-e-i-seminario-do-nucleo-deagricultura-familiar-e-agroecologia>. Acesso em: 24.out.2016.

[6] Estevam, L. S.; Pereira, S. A. As áreas de preservação permanente a luz do novo código florestal. In: Simpósio Brasileiro de Sensoriamento Remoto, 17. (SBSR), 2015, João Pessoa, PB, Brasil. Anais... São José dos Campos: INPE, $2015 . \quad$ p. 2301-2308. Online. ISBN: 978-85-17-0076-8. Disponível em: <http://www.dsr.inpe.br/sbsr2015/files/p0470.pdf>. Acesso em: 19.out.2016.

[7] INSTITUTO NACIONAL DE COLONIZAÇÃO E REFORMA AGRÁRIA - INCRA. Sistema Nacional de Cadastro Rural, Índices Básicos 2013. SR $13 \quad$ Mato $\quad$ Grosso. Disponível em <http://www.incra.gov.br/sites/default/files/uploads/estrutura-fundiaria/regularizacao-fundiaria/indicescadastrais/indices_basicos_2013_por_municipio.pdf>. Acesso em: 01.nov.2016.

[8] Medeiros, A. ArcGIS: Criando um ModelBuilder - <http://andersonmedeiros.com/como-criar-modelbuilderno-arcgis/>. Acesso em: 08/09/2014.

[9] Oliveira, A. M. S. Impacto econômico da implantação de área de preservação permanente na bacia do Rio Alegre, município de Alegre - ES. 53 p. Dissertação de Mestrado em Ciência Florestal - Universidade Federal de Viçosa, Viçosa - MG. 2002.

[10] Rosa, R. D.; Perin, C. L.; Rosa, R. D. Colonizador e colonos: na fronteira da terra o limite dos sonhos de um futuro promissor. In: Revista do Programa de Ciências Agroambientais, v.2, n.1, 2003. Disponível em:< http://www.unemat.br/revistas/rcaa/docs/vol2/6_comunicacao_v2.pdf>. Acesso em: 18.jan.2011.

[11] Sessin-Dilascio, K; Valdiones, A. P. G; Duarte, I. Programa Mato-grossense de Municípios Sustentáveis: uma abordagem de governança para redução do desmatamento nos municípios da Amazônia Mato-grossense. In: IX Semana da Biologia e I Seminário do Núcleo de Agricultura Familiar e Agroecologia, 2016, Alta Floresta - MT. Anais... Alta Floresta: Unemat, 2016. p. 155-159. Online. ISBN: 978-85-68739-03-7. Disponível em: $<$ http://altafloresta.unemat.br/index.php/servicos/eventos/ix-semana-da-biologia-e-i-seminario-do-nucleo-deagricultura-familiar-e-agroecologia/item/611-anais-da-iv-semana-da-biologia-e-i-seminario-do-nucleo-deagricultura-familiar-e-agroecologia>. Acesso em: 19.out.2016. 


\section{Capítulo 17}

\section{O senso comum e conhecimento científico no contexto da pandemia}

\section{Letícia Cristina Alves de Sousa}

\section{Bruno Rogério Ferreira}

\section{Cristiana Paula Vinhal}

Fernando Antônio de Souza Ferreira

\section{Letícia Moraes de Faria}

\section{Lorena da Fonseca Ferreira}

Mariana Luize Ferreira Mamede

\section{Isabela Jube Wastowski}

Resumo : A presença de saúde permite que a pessoa exerça suas atividades cotidianas e tenha qualidade de vida. Quando se trata de saúde ou a ausência dela, fatores como senso comum e conhecimento científico constantemente são abordados. 0 presente artigo tem como objetivo geral apresentar como o senso comum e o conhecimento científico influenciam na saúde e na manutenção dela; e como objetivos específicos definir o senso comum e o conhecimento científico; correlacionar esses termos no desenvolvimento da saúde. Os termos senso comum e conhecimento científico são abordados filosoficamente, e serão expostos ao longo do artigo. A metodologia tratou-se de revisão de literatura qualitativa, foram utilizadas informações disponíveis em artigos científicos e textos da disciplina de Teoria do Conhecimento. As palavras-chaves utilizadas foram senso comum, conhecimento científico, ciência, saúde. Os termos ciência e conhecimento científico são sinônimos. 0 senso comum é a opinião particular do indivíduo sem o conhecimento científico sobre determinado assunto, ele se relaciona tanto aos sentidos, por levar em conta dados dos órgãos sensoriais, quanto à capacidade de raciocínio, de reflexão sobre os elementos de uma situação. A realidade deve ser analisada de forma a compreender o processo, o mecanismo, o funcionamento de algo ou determinada situação. 0 conhecimento científico surgiu para esclarecer aspectos problemáticos suscitados pelo senso comum, ou seja, para responder sob os cânones científicos aos seus questionamentos, bem como garantir a cientificidade das respostas produzidas para aqueles problemas. $\mathrm{Na}$ área da saúde, a divulgação dos saberes compreende todos os processos de comunicação que se dão no contato com médicos e demais profissionais; pelos meios de comunicação de massa; educação sanitária; nível de escolaridade e outras formas. Tão importante quanto as descobertas que são realizadas pela ciência, são como elas serão transmitidas e colocadas em prática pela comunidade em geral. 


\section{INTRODUÇÃO}

Rios et al. (2007) explica que a história da Humanidade remonta há pelo menos seis milênios, sendo o seu início a partir dos primeiros registros escritos e durante essa trajetória, a Humanidade acumulou uma gama de saberes que foram sistematizados como conhecimentos.

A Organização Mundial da Saúde (OMS) define saúde não apenas como a ausência de doença, mas como a situação de perfeito bem-estar físico, mental e social (SEGRE, FERRAZ, 1997). A presença de saúde permite que a pessoa exerça suas atividades cotidianas e tenha qualidade de vida. A doença seria então o desequilíbrio do bem-estar, onde alguma manifestação física ou mental no indivíduo altera negativamente o seu organismo físico e emocional.

Quando se trata de saúde ou a ausência dela, fatores como senso comum e conhecimento científico constantemente são abordados, seja pelo chá que a avó ensinou, pelo medicamento que o médico prescreveu ou o exame que foi solicitado. Desde sempre a observação fez parte da sobrevivência humana, o homem raramente experimentava ou utilizava uma planta que fosse rejeitada pelos animais, se não faz bem para o animal, também não faz bem para o homem, podendo causar, inclusive, a morte do indivíduo.

Paty (2003) afirma que não se pode conceber a compreensão ou a comunicação sem fazer referência ao senso comum, que é uma espécie de terreno fértil para o pensamento e ações humanas. Por outro lado:

A ciência busca a produção de verdades, e se a teoria em questão é confirmada de acordo com os procedimentos pertinentes ao conhecimento científico, tal teoria é tomada como uma verdade, embora na ciência as verdades sejam provisórias, porque com o passar do tempo elas deixam de ocupar o seu lugar como verdade (SILVA, 2011, p. 2).

Morais (2010) explica que atritos entre práticas científicas e valores sociais implicam em mudanças de hábitos que podem ser milenares, além de abordarem temas que podem ter ligação não com a eficácia de uma prática, mas com questões morais. Quando são abordados temas relacionados à religiosidade, os atritos ainda se tornam mais evidentes. Francelin (2004) complementa que a ciência, ao longo do tempo, se distanciou da crença religiosa, estruturando-se enquanto conhecimento autônomo e independente.

0 presente artigo tem como objetivo geral apresentar como o senso comum e o conhecimento científico influenciam na saúde e na manutenção dela; e como objetivos específicos definir o senso comum e o conhecimento científico; correlacionar esses termos no desenvolvimento da saúde. Os termos senso comum e conhecimento científico são abordados filosoficamente, e serão expostos ao longo do artigo.

O senso comum e a ciência encontram-se interligados ao longo da humanidade, saber onde cada um está no contexto da saúde se torna relevante, diante disso foi realizado uma revisão bibliográfica utilizando informações disponíveis em livros e nas bases Google Acadêmico e Scielo, entre os anos 2000 e 2020, com as palavras-chaves senso comum, conhecimento científico, ciência, saúde e pandemia; estas foram escolhidas devido a correlação com a temática abordada, uma vez que deve ocorrer a correlação entre elas. Para a construção do artigo, na íntegra, foram utilizadas 15 fontes. Os termos ciência e conhecimento científico são sinônimos.

\section{SENSO COMUM}

A filosofia nasceu por volta do século VII a.C. entre os gregos e estes produziram uma cultura de vários mitos explicativos da realidade (RIOS et al., 2007). Hessen (1978) explica que a filosofia é essencialmente distinta da arte e que ela deve a sua origem relacionada à vivência e à intuição. Essa intuição pode ser caracterizada como senso comum.

Dourado (2018) define senso comum como um pensamento simples e superficial oposto ao conhecimento científico. 0 senso comum é a opinião particular do indivíduo sem o embasamento científico sobre o assunto, adquirido a partir do conhecimento prévio através da observação e/ou passado de geração em geração.

Silva (2011) acrescenta que o senso comum é um conhecimento prático e é por meio dele que orientamos as nossas ações, ele representa a realidade que se está inserido. Ele se relaciona tanto aos sentidos, por levar em conta dados dos órgãos sensoriais, quanto à capacidade de raciocínio, de reflexão sobre os elementos de uma situação (PATY, 2003). A realidade deve ser analisada de forma a compreender o processo, o mecanismo, o funcionamento de algo ou determinada situação. 
Martins (1998) explica que o senso comum é comum não porque seja banal ou mero e exterior conhecimento e sim porque é conhecimento compartilhado entre os sujeitos da relação social; nela o significado a precede, sem significado compartilhado não há interação. Importante lembrar que os conhecimentos adquiridos durante a infância são aprendidos por meio da observação, sem nenhum conhecimento científico explicado anteriormente, até porque a criança não entende explicações complexas.

Morais (2010) esclarece que nos primórdios e milhares de anos após a existência de humanos, entre suas práticas mais importantes a ciência não estava presente, mas sim a necessidade de sentido ou resposta para fenômenos incompreensíveis. Para eles não interessava como e qual a composição do fogo, só interessava saber que servia para aquecer e cozinhar.

Francelin (2004) afirma que durante séculos a religião e a crença (no sentido de acreditar em algo) foram os caminhos utilizados pela humanidade na busca de respostas às suas perguntas e aflições. Segundo Rossi (2007), na história (ou pseudo-história) de um objeto imaginário, tudo se torna fácil, linear, progressivo; a realidade não oferece obstáculos à onipotência da epistemologia, após ter sido observado, elaboram-se teorias e estas abraçam fatos novos.

Muito do que o conhecimento científico explica, ele só explica para comprovar ou não uma ideia antes apresentada pelo senso comum. 0 senso comum é a tendência universal de todos os seres humanos de se adaptarem à sobrevivência e aos ambientes de vida comuns. É a capacidade de raciocinar e refletir sobre os elementos da situação. 0 senso comum contribui para que a ciência progrida a partir de dificuldades que emergem no dia-a-dia das pessoas (RIOS et al, 2007)

De acordo com Rossi (2007) a história, a geografia, a jurisprudência e a teologia "dependem da memória e são puramente históricas", tendo como princípios "o fato puro e simples, a instituição divina ou humana", pertencendo essas ao senso comum.

Francelin (2004) observa que nem sempre a filosofia e as ciências estiveram em lados opostos. Segundo Moles (1971, apud FRANCELIN, 2004):

Filosofia e conhecimento científico estavam localizados na linha da filosofia natural [...] A ruptura ocorreu a partir do Renascimento, no momento em que a filosofia começou a tomar um caráter mais abrangente, "[...] englobando até a ética individual e social e as partes mais subjetivas de reflexão do homem sobre si mesmo" (MOLES, 1971 apud FRANCELIN, 2004, p. 4).

Existe uma afinidade entre a filosofia e a ciência, na medida em que ambas assentam na mesma função do espírito humano, no pensamento (HESSEN, 1978). A relação entre ciência e senso comum remete à questão da divulgação do conhecimento científico para um público além daquele estritamente especializado (ARAÚJO, 2003).

Francelin (2004) explica que a ciência se tornava cada vez mais específica e operacional, criando para si um mundo próprio, passível de ser explicado, experimentável e dominável, excluindo quase que totalmente os sentidos filosóficos de mundo. Para Moles (1971, apud FRANCELIN, 2004), o "cientificismo" constituía-se como movimento contrário à filosofia "[...] considerando que toda reflexão do homem sobre seu lugar no mundo é devaneio inútil e impotente [...] se ela não os resolve hoje, deve resolvê-los amanhã"

Segundo Francelin (2004), a partir daí a filosofia já não seria necessária, pois a ciência solucionaria todos os problemas, eliminando o mito e a crença do cotidiano humano, a ciência tomou o lugar na tentativa de tudo explicar, de tudo dominar. 0 senso comum nos remete à inocência, onde apenas acreditar se faz necessário, sem questionamentos. Rossi (2007) afirma que é preciso corrigir o intelecto, é preciso limpar as mentes, tornar-se parecidos com crianças, explicitar uma filosofia que está potencialmente presente em cada homem, confiar no bom.

Mas antes do conhecimento científico, a filosofia esclarecia os fatos e acontecimentos por meio da interpretação das escrituras sagradas. É a própria palavra de Deus que autoriza o homem a conceber o saber como venatio, como procura de novidade (ROSSI, 1992). 


\section{CONHECIMENTO CIENTÍFICO}

Silva (2011) aponta que a ciência nasce no século XVII com a observação da realidade, e partir desta ação, busca-se levantar hipóteses. Rios et al. (2007) reconhece a utilidade da ciência para esclarecer aspectos problemáticos suscitados pelo senso comum, ou seja, para responder sob os cânones científicos aos seus questionamentos, bem como garantir a cientificidade das respostas produzidas para aqueles problemas.

Rossi, assim como definiu algumas ciências como pertencentes ao senso comum, também definiu as pertencentes ao conhecimento científico:

A geometria, a aritmética, a música, a física, a medicina e a arquitetura pertencem ao segundo grupo: "dependem do raciocínio" e tem por objetivo "a pesquisa $\mathrm{r}$ a descoberta de verdades ocultas". Aqui, a "autoridade é inútil" e só conhece a razão; aqui, a mente está livre para desdobrar as suas capacidades; aqui, "as invenções podem ser infinitas e ininterruptas". 0 crescimento, o progresso, a novidade e a invenção só caracterizam as ciências do segundo grupo (ROSSI, 2007, p. 180).

Francelin (2004) observa que a pesquisa científica tem início no conhecimento vulgar, porém dele se diferencia através de metodologias e princípios que visam a legitimá-la enquanto conhecimento científico. Quando uma ciência se constituiu solidamente seus especialistas esquecem o passado do próprio saber e submetem-se, todos a uma mesma ilusão, que sua especialidade exista desde sempre (ROSSI, 2007). As descobertas, que geralmente são realizadas através das observações ou informações repassadas por meio do senso comum, tem as suas histórias de origem colocadas em segundo plano e ao longo da história se tornam esquecidas e sem importância.

Este poder da ciência de produzir sentido para as ações e indagações de indivíduos e também a capacidade de modificar práticas sociais, mas, também ser influenciada por estas práticas pode ser notado em várias épocas a partir de práticas científicas que quando surgiram geraram estranhamentos, mas também admiração, a exemplo de quando surgiram os primeiros anestésicos modernos [...] E os pesquisadores deste poder do clorofórmio, também foram influenciados pelas sociedades em que viviam, pois frente ao desejo do fim da sensação de dor em procedimentos cirúrgicos, quem fosse o autor da desejada descoberta teria acesso a honrarias, apoio financeiro e legal. Fatores que funcionaram como incentivos para que isso se desse (MORAIS, 2010, p. 18-19).

Rossi (2007) explica que o progresso é progresso de algo e não progresso rumo a algo, não é necessário pensar o progresso de modo teleológico, como aproximação da verdade que seria a única "verdadeira constituição da natureza".

Outra de suas caraterísticas é a tendência de distanciamento do conhecimento comum [...] No passado, a ciência considerada de vanguarda tinha maior ligação com a experiência cotidiana [...] E à medida que os experimentos foram se tornando mais sofisticados, a técnica especializada e distante do cotidiano das pessoas se tornou mais constante [...] E em certos casos, a dificuldade de aceitação de suas afirmações não se dá apenas por incompreensão, mas também pela constatação de que, se por um lado a ciência gera benesses, por outro é limitada e sujeita a diferentes falhas (MORAIS, 2010, p. 19-21).

Esse distanciamento que o autor comenta é visível na atualidade, uma vez que se observa o isolamento dos indivíduos que tem pouco ou nenhum acesso as tecnologias, e também que a verdade descoberta hoje pode ser colocada à prova e até mesmo negada em questão de pouco tempo.

Em suma, a característica fundamental do racionalismo é que o caminho para a criação do conhecimento não vai da observação empírica à construção de teorias, mas, ao contrário, das teorias e conceitos ao exame empírico (ALBERT, MYLOPOULOS, LABERGE, 2019). Silva (2011) afirma que a ciência é tão legítima na atual sociedade, que hoje se valoriza apenas o que é ciência, sendo somente ela produtora de verdades. Acredita-se apenas no que é científico, no que é comprovado, em números, estatísticas e estudos. 
Não há dúvida de que a ciência moderna está inserida no cotidiano das pessoas, perpassando sua cultura e suas mentes e interferindo local e globalmente no planeta. (ARAÚJO, 2003). Rossi (2007) rebate que no âmbito do saber científico e remetendo ao crescimento ou ao progresso, a ciência tem validade e que no melhor dos casos, ela será inserida num contexto diverso, com verdade mais ampla e articulada.

\begin{abstract}
Abandonamos todo o nosso conhecimento prévio e a nossa vivência para aceitar e acreditar plenamente nas certezas produzidas pelo conhecimento científico. A racionalidade científica moderna é pautada na ideia hegemônica da ciência como portadora e produtora de verdades absolutas, e também como fim e meio para solucionar todas as inquietações e problemas da humanidade, estas ideias hegemônicas foram construídas nas relações sociais, para que os indivíduos tomem tais preceitos como verdade. Assim, temos uma percepção muito clara através de nossa vivência cotidiana, que a ciência criou em torno de si uma hegemonia, ela é sempre a última palavra (SILVA, 2011, p.3).
\end{abstract}

Morais (2010) complementa que os processos de se chegar as práticas científicas são obtidos a partir de algum tipo de pesquisa, orientado por teorias e conceitos, que organizam suas conclusões para a possibilidade de aplicação do conhecimento e garantir a sua validade. Com isso, pressupõe que a ciência precisa ter aplicabilidade, caso contrário, ela pode ser esquecida. Já que de uma ciência, mais do que respostas futuras para indagações do presente, se espera respostas que sejam dadas em um tempo próximo ao momento em que as indagações são efetuadas (MORAIS, 2010).

Rios et al. (2007) explica que o conhecimento é fundamentado através de pesquisas, estudos e comprovações até chegarmos ao reconhecimento da comunidade científica de que o conhecimento produzido revela a verdade sobre os fenômenos. Silva (2011) complementa que a pesquisa e a percepção dos resultados são atos de interpretação dos fatos, porém se deve também desconfiar de qualquer modelo de interpretação que afirme revelar a verdade final.

\title{
4. O SENSO COMUM E O CONHECIMENTO CIENTÍFICO NA SAÚDE
}

Os conceitos nascem no cotidiano, senso comum, são apropriados pelo meio científico e tornam-se científicos ao romperem com esse cotidiano, com esse senso comum (FRANCELIN, 2004). Paty (2003) complementa que não existe possibilidade de aparecimento de novos conhecimentos de uma certa importância, sem ultrapassar o senso comum e, portanto, sem romper com ele. Rios et al. (2007) esclarece que quanto mais refletirmos sobre esta realidade, mais podemos compreendê-la, levantar questionamentos e sugerir soluções para os problemas relacionados a ela.

O pensamento científico não se forma nem se transforma apenas pelo experimento, pelo contrário, anterior à práxis científica estão a ideia, o pensamento, o "conhecimento do conhecimento", a filosofia da ciência, que trazem à tona as discussões em torno da epistemologia, dos paradigmas, da ética, da moral, da política, enfim, características relacionadas e inter-relacionadas ao desenvolvimento do conhecimento e aos possíveis desdobramentos e consequências que possam trazer. (FRANCELIN, 2004, p. 27).

Na área da saúde, a divulgação dos saberes compreende todos os processos de comunicação que se dão no contato com médicos e demais profissionais; pelos meios de comunicação de massa; educação sanitária; nível de escolaridade e outras formas. (ARAÚJO, 2003). Os profissionais de saúde devem se manter com o conhecimento sempre atualizados para garantir o melhor atendimento possível.

No contexto atual, o pensamento dos profissionais de saúde está voltado para considerar conhecimento como aquilo cientificamente comprovado, aquilo que a literatura afirma como verdade, muitas vezes se opondo ou desprezando o senso comum, passando a negar ou tratar como erro o modo como as pessoas comuns, do saber popular, entendem e explicam o mundo, a criar abismos epistemológicos questionáveis (RIOS et al, 2007, p. 502). 
Entretanto, devido ao ser humano ser racional, o conhecimento científico é passível de mudança, de substituição e de novos questionamentos:

\begin{abstract}
Nos dias atuais, a racionalidade, como processo determinista, é amplamente criticada. [...] A crítica não é voltada à razão, mas ao uso da razão como único caminho para o conhecimento verdadeiro. Sabe-se que as verdades podem ser provisórias, e uma das funções da racionalidade é construir hipóteses que sustentem essas verdades, ao mesmo tempo em que, pela mesma via, desconstroem-se essas hipóteses e as verdades chamadas provisórias são substituídas (FRANCELIN, 2004, p. 29).
\end{abstract}

Contextos socioculturais diferentes permitem comunidades diversas experimentarem vivências únicas, formularem suas visões de mundo e, a partir destas, desenvolverem maneiras de viver. (RIOS et al., 2007). 0 entendimento é primordial para a transferência e assimilação do conhecimento, sendo que a ciência deve ser entendida pela população em geral.

\begin{abstract}
A ciência adota uma taxinomia muitas vezes impronunciável pelo senso comum, tornando complicada a compreensão desse tipo de linguagem pelos leigos e, em consequência, dificultando a comunicação entre os dois saberes. É ideal que se busquem estratégias de forma a viabilizar a comunicação entre profissionais da saúde e as comunidades envolvidas nas ações de saúde. [...] Os profissionais tornam-se detentores do saber técnico e científico, inacessíveis à população; então, tornam-se "mestres" que ditam o certo e o errado, bem como impõem comportamentos que julgam eficazes, no caso da saúde, para a melhoria da qualidade de vida e da promoção da saúde. (RIOS et al., 2007, p. 503, 505).
\end{abstract}

Em pleno ano de 2020, a população se vê enfrentando uma pandemia, onde ninguém, nem o senso comum e nem a ciência estavam preparados para tal. Um subtipo de coronavírus, designado como COVID-19 alastra pelo planeta e, em meio ao caos, observa-se que a ignorância e o oportunismo dominam o mundo. 0 motivo de abordar o quadro atual é para refletir como o senso comum e/ou a ciência podem interferir na vida da humanidade.

Dentre as medidas propostas para o enfrentamento da pandemia está o isolamento ou distanciamento social. De um lado observa-se parte da população totalmente adepta às medidas promovidas pela OMS e outras organizações e do outro lado pessoas que desafiam, colocando inclusive a vida de terceiros em risco, as mesmas recomendações.

De acordo com Silveira (2005) quando a pandemia de influenza espanhola irrompeu, em 1918, a comunidade médica internacional viu-se diante de um grande mistério: explicar como uma moléstia tão ordinariamente branda pudesse provocar tanta desordem e morte. A população aprendeu de forma dolorosa e com muitas percas que o isolamento social era necessário para conter a disseminação do vírus. Quanto mais pessoas permaneciam ativas em mais o vírus disseminava.

Evidentemente, não é improvável que alguns homens ignorassem ou negligenciassem uma doença que poderiam confundir com uma «simples constipação», e que, como principais responsáveis pelo sustento da família, continuassem a trabalhar em vez de recolherem imediatamente ao leito. Além disso, os homens das sociedades industrializadas tendem a trabalhar fora de casa e em contacto ou proximidade com muitos outros, o que os coloca em maior risco de infecção. [...] De um modo repentino, a pandemia deixou órfãs milhões de crianças em todo o mundo, um acontecimento sem precedentes na história em termos de magnitude e rapidez. [...] Na era da máquina a vapor de 1918, a pandemia disseminouse rapidamente pelo mundo [...] A investigação com vista ao isolamento do vírus e à produção de uma vacina eficaz é, pois, imperativa. (KILLINGRAY, 2009, p.49, 51, 56).

Outra pandemia que foi relembrada, na atualidade, foi a Síndrome Respiratória Aguda Grave (SARS):

Desde dezembro de 2019, a COVID-19 tem convocado instituições internacionais, governos, profissionais e populações a aplicarem estratégias e a enfrentarem dificuldades que já eram previstas e discutidas, desde de 2003. Pela perspectiva da ciência, estamos diante de 
situações que passaram a ser planejadas e amadurecidas, especialmente, após os acontecimentos que envolveram a Síndrome Respiratória Aguda Grave (SARS), mas que pareciam muito distantes quando as observamos pelas lentes do senso comum. Julgamentos à parte, vale lembrar que à época, diversos países enfrentaram uma doença surgida na Ásia, mas que, diferentemente daquilo que ocorria em anos anteriores, propagouse rapidamente pelos territórios dos países europeus e norte-americanos causando mortes e impactando as economias destes países e de outros. [...] A SARS mostrou aos envolvidos que os deslocamentos contemporâneos aceleram ou retardam o crescimento dos números de casos de infecções e, ainda, conectam distintas localidades do globo, desde as mais pobres até as mais ricas. (DARSIE; WEBER, 2020, p. 4748).

Killingray (2009) afirmou que no século XXI, com a banalização das viagens aéreas, um vírus pode ser inadvertidamente transmitido a todos os cantos do mundo numa questão de algumas horas. Sendo necessário a ampliação de investimentos para o estudo sobre o tratamento dos mais diversos tipos de vírus.

Nada mais óbvio sobre o conhecimento onde Rossi (2007) afirmou que as verdades astronômicas são encontradas pelos astrônomos e nada prejudicou mais a filosofia que as superstições ignorantes daqueles que aderem estritamente às palavras da Escritura; sendo justamente isso visualizado na atualidade, onde especialistas não são levados em consideração, em plena pandemia. A ciência deve ser exaltada.

\section{CONSIDERAÇõES FINAIS}

A pandemia de 1918 instigou os pesquisadores a investigarem a causa, o tratamento e a cura da mesma, até mesmo para que caso houvesse um novo surto, a comunidade científica estivesse preparada a ponto de reduzir as percas de vida humana.

Tão importante quanto as descobertas que são realizadas pela ciência, são como elas serão transmitidas e colocadas em prática pela comunidade em geral. Faz parte das atribuições dos profissionais da saúde transmitir o conhecimento científico para a comunidade leiga, e também relacionar o senso comum que a comunidade possui para melhoria do conhecimento da saúde. A educação em saúde deve ser item primordial nas ações relacionadas às comunidades.

A pandemia da gripe espanhola de 1918 foi constantemente abordada para as medidas adotadas contra o Covid-19. 0 isolamento e distanciamento social vem sendo recomendado para redução de transmissão do vírus, pois, quanto menor a aglomeração, menor o contágio e menor o número de indivíduos infectados. Essas recomendações foram replicadas ao longo das nações, e em casos extremos ocorreu o fechamento de portos, aeroportos e fronteiras para contenção do contágio.

Contudo, as recomendações anteriormente citadas, são questionadas diariamente, principalmente devido ao impacto econômico que essa pandemia causará. Fato é que inúmeras empresas já estão sentindo o potencial da crise que está sendo instalada, e provavelmente após a pandemia a taxa de desemprego aumentará. Instala-se crise na saúde, crise econômica e crise política, todas interligadas. Vidas importam, independentemente de qualquer crise, é necessário investir e financiar a saúde.

\section{REFERÊNCIAS BIBLIOGRÁFICAS}

[1] ARAÚJO, José Wellington de. Ciência e senso comum: a divulgação do conhecimento no campo da saúde. Perspect. ciênc. inf., Belo Horizonte, n. especial, p. 72-93, jul./dez. 2003.

[2] DARSIE, Camilo. WEBER, Douglas Luís. Doença e controle espacial: questões sobre dispersão e isolamento em tempos de pandemia. J. Infect. Control, Brasil, v. 9, n. 2, p. 47-48, Abr/Jun. 2020.

[3] DOURADO, Ivan Penteado. Senso comum e Ciência: uma análise hermenêutica e epistemológica do senso comum de oposição. Educ. rev., Curitiba, v. 34, n. 70, p. 213-229, Ago. 2018.

[4] FRANCELIN, Marivalde Moacir. Ciência, senso comum e revoluções científicas: ressonâncias e paradoxos. Ci. Inf., Brasília, v. 33, n. 3, p. 26-34, Dez. 2004.

[5] HESSEN, Johannes. Teoria do Conhecimento. 7 ed. Coimbra: Universidade de Colônia, 1978. 
[6] KILLINGRAY, David. A pandemia de gripe de 1918-1919: causas, evolução e consequências. In: SOBRAL, J. M. A Pandemia Esquecida: Olhares comparados sobre a Gripe Espanhola 1918-19 (Forgotten Pandemic: Comparative views on the Spanish 'Influenza: 1918-19). Lisboa: Imprensa de Ciências Sociais, p. 41-61, 2009.

[7] MARTINS, José de Souza. O senso comum e a vida cotidiana. Tempo soc., São Paulo, v. 10, n. 1, p. 01-08, Mai. 1998.

[8] MORAIS, Itelvides José de. As várias faces da ciência: sobre o sujeito, linguagem, teoria e método como diferentes pontos de encontro dos diferentes ramos das ciências. Anápolis: Universidade Estadual de Goiás, 2010.

[9] PATY, Michel. A ciência e as idas e voltas do senso comum. Sci. viga. São Paulo, v. 1, n. 1, p. 9-26, Mar. 2003.

[10] RIOS, Ediara Rabello Girão; FRANCHI, Kristiane Mesquita Barros; SILVA, Raimunda Magalhães da; AMORIM, Rosendo Freitas de; COSTA, Nhandeyjara de Carvalho. Senso comum, ciência e filosofia - elo dos saberes necessários à promoção da saúde. Ciência \& Saúde Coletiva, v. 12, n. 2, p.501-509, Fev. 2007.

[11] ROSSI, Paolo. A ciência e a filosofia dos tempos modernos: aspectos da Revolução Científica. Tradução: Álvaro Lorencini. São Paulo: Editora UNESP, 1992.

[12] ROSSI, Paolo. O passado, a memória, o esquecimento: seis ensaios da história das ideias. Tradução: Nilson Moulin. São Paulo: Editora UNESP, 2007. Título original: Il Passato, la memoria, l'oblio. Società Editríce Il Mulina: Bolonha, 1991.

[13] SEGRE, Marco; FERRAZ, Flávio Carvalho. O conceito de saúde. Rev. Saúde Pública, São Paulo, v. 31, n. 5, p. 538-542, Out. 1997.

[14] SILVA, Sandra Siqueira da. A relação entre ciência e senso comum. Ponto Urbe [Online], p. 1-9, Set. 2011.

[15] SILVEIRA, Anny Jackeline Torres. A medicina e a influenza espanhola de 1918. Tempo, Niterói, v. 10, n. 19, p. 91-105, Dez. 2005. 


\section{Capítulo 18}

\section{A agricultura urbana agroecológica como instrumento de concretização da função social da cidade}

\section{Vanessa de Castro Rosa \\ Cryfort Stone Ribeiro Silva}

Resumo: A agricultura urbana agroecológica se apresenta como um importante instrumento para a concretização da função social da cidade. 0 presente artigo busca analisar o conceito de agricultura urbana a partir dos princípios agroecológicos, apresentar a finalidade e importância da agricultura urbana e periurbana para o desenvolvimento urbano e a função social da cidade e verificar quais Estados possuem leis sobre agricultura urbana e periurbana. Verifica-se que ainda é um desafio a instituição de leis para incentivo à agricultura urbana e/ou agroecologia, apenas onze Estados federativos possuem leis que incentivam a agricultura urbana. A agricultura urbana agroecológica torna-se uma ferramenta importante para conferir função social à cidade. A presente pesquisa é do tipo bibliográfica e pautou-se no método críticodescritivo, para análise dos conceitos e descrição do tratamento legislativo da agricultura nos Estados brasileiros.

Palavras-Chave: Agricultura urbana. Agroecologia. Direito à cidade. 


\section{INTRODUÇÃO}

O presente artigo deseja apresentar conceitos que estruturam a agricultura urbana baseada na agroecologia, como método adequado para melhorar a relação social existente entre os seres humanos e o meio ambiente, uma vez que os dois se integram indivisivelmente, com vistas à produção de alimentos, empoderamento social e função social da cidade.

São apresentadas leis que regulamentam a interação existente entre a prática da agricultura agroecológica no contexto urbano, com a utilização desta ferramenta para concretizar o direito à cidade para que sua função social seja cumprida de forma democrática e sustentável para a sociedade e o meio ambiente.

Este trabalho foi desenvolvido através de pesquisa exploratória do tipo não experimental, tendo como método de abordagem o descritivo, a fim de levantar quais Estados possuem leis que visam promover a prática da agricultura urbana agroecológicas, e como ocorre a interação da agricultura urbana agroecológica com o espaço urbano.

Trata-se de pesquisa do tipo bibliográfica fazendo a análise de doutrina, artigos nacionais e estrangeiros, apreciando também as leis estaduais e nacionais que possibilitam a concretização da agricultura urbana agroecológica, políticas que podem promover a soberania alimentar de pessoas economicamente e socialmente vulneráveis.

Por fim, compreende-se que a legalização e regulamentação da agricultura urbana agroecológica vai ao encontro dos Objetivos de Desenvolvimento Sustentável desenvolvidos pela Organização das Nações Unidas (ONU), em 2015, na chamada Agenda 2030, entre os quais se destaca o objetivo no 2 que visa acabar com a fome erradicando assim a miséria, ao mesmo tempo que possibilita uma agricultura sustentável, democrática e inclusiva.

\section{AGRICULTURA URBANA AGROECOLÓGICA}

A agricultura urbana revela uma interação dinâmica entre agricultura e meio urbano, não se resume a mera localização das práticas agrícolas em perímetro urbano, mas uma forma própria de se estruturar a agricultura a partir das peculiaridades e proximidades do espaço urbano. Neste sentido,

A característica principal da agricultura urbana, que a distingue decisivamente da agricultura rural, é sua integração no sistema econômico e ecológico urbano (que será chamado, a seguir, de "ecossistema" urbano). Não é a localização, urbana, que distingue a AU da agricultura rural, e sim o fato de que ela está integrada e interage com o ecossistema urbano. (MOUGEOT, 2000, p. 11)

A agricultura urbana é caracterizada pelo tipo de atividade econômica, pela localização intraurbana ou periurbana, pelos tipos de área, pela escala e sistema de produção, além dos tipos e destinação dos produtos e sua comercialização (MOUGEOT, 2000, p. 9), fatores que são distintos da agricultura no meio rural.

A proximidade da cidade leva a critérios e opções à agricultura urbana, assim, são cultivados produtos em menor escala e em espaços menores, geralmente perecíveis, que atendam diretamente os desejos dos citadinos e que sejam facilmente acessados pelo consumidor. Assim, exige-se técnicas mais baratas, que permitam um melhor aproveitamento e rendimento do solo, muitas vezes, sem o uso de máquinas pesadas como tratores.

Assim, a adoção de técnicas e práticas agroecológicas tem muito a contribuir para o melhor aproveitamento do solo, sem uso de agrotóxicos e cultivando a biodiversidade do local. A agricultura agroecológica também se volta para as questões sociais, culturais e econômicas, contribuindo para a implantação de direitos sociais e ambientais.

Importante pontuar o conceito de agroecologia,

A agroecologia proporciona o conhecimento e a metodologia necessários para desenvolver uma agricultura que é ambientalmente consistente, altamente produtiva e economicamente viável. Ela abre a porta para o desenvolvimento de novos paradigmas da agricultura, em parte porque corta pela raiz a distinção entre a produção de conhecimento e a sua aplicação. Os princípios e métodos ecológicos formam a base da agroecologia. Eles são essenciais para determinar: a) se uma prática, 
insumo ou decisão de manejo agrícola é sustentável, e b) a base ecológica para o funcionamento, a longo prazo, da estratégia de manejo escolhida. Uma vez que esses estejam identificados, podem ser desenvolvias práticas que reduzam os insumos externos comprados, diminuam os impactos de tais insumos quando usados e estabeleçam uma base para desenhar sistemas que ajudem os produtores a sustentar seus cultivos e suas comunidades produtoras. (GLIESSMAN, 2000, p. 54)

Assim, a agricultura urbana agroecológica prioriza a conservação e reutilização de recursos naturais, obtendo assim a redução na utilização de produtos que podem ser nocivos para o meio ambiente e ao manuseio do solo, como é apontado por Adriana Maria de Aquino e Renato Linhares de Assis

Sistema de produção agrícola, além de processos ecológicos, envolvem também processos sociais, sendo a agricultura o resultado da coevolução de sistemas naturais e sociais. É com esse entendimento que a agroecologia na busca de agroecossistemas sustentáveis, procura estabelecer a base científica para uma agricultura que tenha como princípios básicos a menor dependência possível de insumos externos à unidade de produção agrícola e a conservação dos recursos naturais. Para isto, os sistemas agroecológicos procuram maximizar a reciclagem de energia e nutrientes, como forma de minimizar a perda destes recursos durante os processos produtivos. (2007, p. 138)

A agricultura urbana agroecológica se relaciona diretamente com o sistema econômico/social da cidade, englobando a preocupação com a conservação e reutilização de recursos naturais que podem ser reaproveitados, gerando maior sustentabilidade para o meio ambiente.

Para que a agricultura urbana agroecológica seja incentivada e desenvolvida são recomendáveis a adoção de políticas públicas, para que sejam possíveis a utilização dos espaços urbanos, por exemplo, para criação de programas de hortas comunitárias em bairros de vulnerabilidade econômica e social. Assim, "muitas vezes o primeiro passo consiste em legalizar e proteger pequenas hortas que surgiram sem planejamento ou licença" (FAO, 2012, p. 6).

Neste sentido

As políticas públicas municipais podem fortalecer e fomentar a produção da agricultura familiar e de base agroecológica e conservar os bens comuns, construir/fomentar circuitos curtos de comercialização e, consequentemente, criar dinâmicas de abastecimento alimentar mais autônomas, como também atuar de forma determinante na promoção da alimentação adequada e saudável. Muitas dessas políticas sequer pressupõem uma dotação orçamentária significativa e, ainda assim, podem ter impactos diretos sobre parcelas consideráveis da população, representando alternativas concretas para a superação das crises democrática, social, sanitária, ambiental, política e econômica que enfrentamos hoje. (LONDRES, 2020, p. 39)

A legalização de hortas que surgiram de maneira espontânea pode ser um movimento democrático e libertador para as famílias que dependem da agricultura urbana para garantir a alimentação mínima existencial, e ainda garantir a renda que possibilite a essas famílias se tornarem parte do mercado consumidor como pessoas ativas economicamente.

Neste sentido,

[...] entrevistas revelaram que as iniciativas de AU comunitária em Belo Horizonte apresentaram como principais motivações a segurança alimentar e nutricional conjugada com o envolvimento da comunidade vizinha na atividade, o aumento da renda, a limpeza de determinado terreno e a oportunidade de exercer, através das hortas, uma atividade de lazer. (ARAÚJO, p. 199, 2016)

Quando uma cidade desorganizada é observada, seja na sua infraestrutura urbana ou em sua base social, se torna claro a necessidade de criação de programas que possibilitam a inclusão social, para que a cidade 
consiga estabelecer de maneira democrática a melhoria da vida das pessoas e na utilização dos espaços públicos.

Em alguns Estados do Brasil, é possível verificar que grandes cidades possuem planos de inclusão social pautados na agricultura urbana agroecológica, como mecanismo que possibilita a inclusão social, promovendo ainda o manejo sustentável e democrático do meio ambiente, possibilitando o pleno desenvolvimento da função social da cidade, e o acesso de forma democrática aos espaços públicos.

No estado de Minas Gerais, em 2006 foi sancionada a lei 15.973, se tornando um dos primeiros Estados do Brasil a sancionar uma lei que visa promover e proteger a agricultura urbana baseada na agroecologia, legitimando assim práticas já existentes em cidades como Belo Horizonte, entre outras na qual essa prática possibilita uma melhora na vida de pessoas vulneráveis economicamente e socialmente (MINAS GERAIS, 2006).

A execução da lei em Minas Gerais possibilitou aos trabalhadores saírem da informalidade e conseguirem agregar valor aos alimentos que são produzidos e comercializados por eles, um benefício estrutural e comercial para todos agricultores urbanos que baseavam suas plantações no plano agroecológico.

Como destacou Marina Castelo Branco e Flávia A. de Alcântara "a regulamentação dessa atividade pode contribuir para o aumento da área cultivada e dos investimentos por parte dos produtores, o que pode significar a garantia da sobrevivência dos projetos no longo prazo" (2011, p. 424).

Deste modo, a agricultura urbana agroecológica se mostra como uma ferramenta essencial para garantia dignidade humana, podendo contribuir para a segurança alimentar e a preservação do espaço urbano, o que pode melhorar a interação dos seres humanos com toda estrutura natural, integrando meio ambiente, agricultura e espaço urbano.

É prudente a elaboração de programas como hortas comunitárias e espaços verdes pelo município para que exista a interação entre toda comunidade, em entrevista feita por Alessandra Silva Araújo, verificou-se que a interação de toda comunidade aumentou por diferentes motivos como

[...] tais iniciativas, apontadas pelos entrevistados, são relativas ao resgate da relação com a natureza e o campo, à "limpeza" física de espaços verdes sem uso, à criação de uma comunidade local, ao apoio à agricultura biológica e à permacultura, às práticas de lazer, e a atenuação da renda familiar por não precisarem comprar determinados alimentos. (2016, p. 194)

A criação de programas sociais como hortas comunitárias, espaços verdes verticais baseados na agroecologia podem melhorar a infraestrutura da cidade, na medida em que os alimentos que antes vinham de grandes distâncias, agora podem ser encontrados frescos em comércios locais, aumentando a qualidade da mercadoria que agora passa a agregar um valor nutritivo maior, com um custo menor para o consumidor, podendo garantir sua soberania alimentar.

Se a infraestrutura básica encontrada na cidade apresentar um planejamento inclusivo, democrático e ecologicamente sustentável, tanto a sociedade que pratica os valores ecológicos, quanto o meio ambiente poderá se beneficiar desta interação.

As práticas comunitárias são realizadas por indivíduos sem laços de parentesco. Contudo, moram em uma mesma área periférica e unem-se solidariamente para realizar atividades coletivas. Diferentemente da maioria das práticas familiares ou individuais, a produção organizada coletivamente ocorre, principalmente, em áreas vazias da cidade, próximas aos locais de moradia. (COUTINHO; COSTA, 2011, p. 91)

Assim, Natália Silva Lemos, Liza Maria da Souza de Andrade, e Valério Augusto Soares de Medeiros destacam o papel da agricultura urbana na infraestrutura urbana

A agricultura urbana, como um elemento de planejamento urbano, visa promover a integração da prática com a vida urbana. Há destaque para os benefícios da gestão ambiental e da sustentabilidade, como consequência do desenvolvimento de um zoneamento coerente com as suas definições espaciais resultantes dos atributos locais na cidade. (2015, p. 62) 
É importante salientar que tanto o desenvolvimento estrutural existente em uma cidade, quanto a existência de leis que garantam e incentivem a criação de programas sociais como os de agricultura urbana baseado na agroecologia proporciona uma melhoria na qualidade e na valorização do alimento produzindo pelos agricultores urbanos.

As hortas comunitárias permitem a aquisição de alimentos por um preço menor por conta da diminuição dos gastos de transportes, na redução de agrotóxicos e transgênicos, no reaproveitamento de materiais orgânicos para adubação por meio das práticas agroecológicas, fornecendo alimentos acessíveis economicamente e saudáveis.

Um dos propósitos para que haja o incentivo por leis estaduais como as existentes em Minas Gerais, Rio Grande do Sul, São Paulo, entre outros Estados é a diminuição direta do impacto ambiental, causado pela não utilização de terrenos baldios que podem vir a se tonar locais de descarte de lixo de forma irregular.

\section{FUNÇÃO SOCIAL DA CIDADE}

O conceito de função social é importante para entender como a cidade deve ser organizada para conseguir cumprir com o direito que a Constituição brasileira procura garantir, para que ocorra a elucidação de como a função social da cidade "nasce", é necessário valer-se do filósofo e sociólogo Henri Lefebvre, que foi quem pensou o direito da cidade.

Lefebvre apresentou em sua obra "O Direito à Cidade", como ocorre o surgimento dos direitos e garantias que podem ser identificados na atualidade, e ainda como esses direitos podem ser modificados para que a função social da cidade seja reiteradamente alcançada, uma vez que para Henri Lefebvre o direito a cidade só pode der alcançado pela constante luta da classe operária,

No seio dos efeitos sociais, devidos à pressão das massas, o individual não morre e se afirma. Surgem direitos; estes entram para os costumes ou em prescrições mais ou menos seguidas por atos, e sabe-se bem como esses "direitos" concretos vêm completar os direitos abstratos do homem e do cidadão inscritos no frontão dos edifícios pela democracia quando de seus primórdios revolucionários: direitos das idades e dos sexos (a mulher, a criança, o velho), direitos das condições (o proletário, o camponês), direitos à instrução e à educação, direito ao trabalho, à cultura, ao repouso, à saúde, à habitação. [...] A pressão da classe operária foi e continua a ser necessária (mas não suficiente) para o reconhecimento desses direitos, para a sua entrada para os costumes, para a sua inscrição nos códigos, ainda bem incompletos. (2001, p. 116117)

É possível notar na obra de Lefebvre que para ocorrer a realização da função social da cidade é necessário garantir o direito à habitação de qualidade, o direito à educação, ao trabalho, entre outros, concretizando o direito à cidade de maneira democrática,

[...] o direito à cidade se afirma como um apelo, como uma exigência. Através de surpreendentes desvios [...] 0 direito à cidade não pode ser concebido como um simples direito de visita ou de retorno às cidades tradicionais. Só pode ser formulado como direito à vida urbana, transformada, renovada. (LEFEBVRE, 2001, p. 117-118)

Sabe-se então que para Henri Lefebvre a classe operária teria como missão a luta para concretizar o direito à cidade, não deixando fechado o conceito de função social da cidade, entretanto, é possível outras interpretações como a feita por Antonio Pacheco Fiorillo que vai ao encontro do conceito lefebvriano, Fiorillo, por exemplo, apresenta critérios similares ao de Lefebvre para se cumprir a função social da cidade de maneira democrática, inclusiva e ainda ecológica.

Para que ocorra o pleno desenvolvimento da função social da cidade deve ser compreendido como um elemento fundamental para que todos os cidadãos tenham uma vida saudável e de qualidade, executando assim o que a Constituição brasileira preza como fundamentos para o estabelecimento das relações entre os indivíduos, meio urbano e meio ambiente.

Sendo também significativo e complementar o entendimento sobre a função social da cidade, partindo da ótica de Celso Antonio Pacheco Fiorillo que apresenta, 
Em linhas gerais, a função social da cidade é cumprida quando proporciona a seus habitantes uma vida com qualidade, satisfazendo os direitos fundamentais, em consonância com o que o art. 225 preceitua. Podemos identificar 5 (cinco) principais funções sociais da cidade, vinculando-a à realização: a) da habitação; b) da circulação; c) do lazer; d) do trabalho e e) do consumo. Uma cidade só cumpre a sua função social quando possibilita aos seus habitantes uma moradia digna. Para tanto, cabe ao Poder Público proporcionar condições de habitação adequada e fiscalizar sua ocupação. (2013, p. 557)

É possível identificar no art. 182, §2º da Constituição de 1988, a previsão expressa da função social da cidade atrelada à observância do plano diretor municipal, ficando o município diretamente responsável por fiscalizar como está sendo executada a função social.

O Estatuto da Cidade, lei $n^{\circ} 10.257 / 01$, estabeleceu diretrizes gerais para a construção do plano diretor e concretização da função social, em prol de leis que garantam uma cidade sustentável, com saneamento básico, o saneamento ambiental, transporte de qualidade, e o lazer para as presentes e futuras gerações (BRASIL, 2001).

É necessária também uma gestão democrática para que a função social seja cumprida, com a participação de todos os cidadãos na definição dos rumos e políticas da cidade, abrindo-se espaço para a adoção de agricultura urbana agroecológica em espaços urbanos inutilizados ou subutilizados e em comunidades carentes ou vulneráveis.

Estes parâmetros são estabelecidos para que os municípios possam manter sua autonomia legislativa competente ao conteúdo urbanístico, e não se desviem para caminhos não desejados pela Constituição, ficando expresso do art. $1^{\circ}$ ao art. $3^{\circ}$, da lei $n^{\circ} 10.257 / 01$, os deveres a serem cumpridos pelos municípios.

A cidade deve ser compreendida como um organismo que está em constante mutação, assim sendo, as diretrizes que o Estatuto da Cidade apresenta devem ser implementados para todos que habitam na cidade e ao seu redor, não podendo permitir qualquer tipo de desigualdade presente na sociedade, ou mesmo o mero simbolismo do Estatuto,

O estatuto não resolve nem elimina os conflitos, mas os retira da sombra, mostrando que a sociedade é desigualmente constituída. Reconhece, também, o predomínio da população urbana e a falta de acesso da maioria aos padrões de urbanidade vigentes. (RODRIGUES, 2004, p. 12)

O Estatuto da Cidade é um parâmetro a ser seguido, o poder legislativo e executivo de cada cidade deve fazer com que esses padrões sejam alcançados para que a desigualdade seja diminuída ou mesmo erradicada, usando de diversas ferramentas e tecnologias existentes, podendo ser usada como ferramenta a agricultura urbana agroecológica que pode proporcionar a concretização dos direitos e garantias fundamentais.

É necessário observar na prática da agricultura urbana baseado na agroecologia uma aliada contra a fome, a miséria, a poluição e a degradação ambiental, degradação essa que acontece de maneira ostensiva devido ao uso de agrotóxicos que destroem a fauna e a flora deixando marcas irreversíveis em todo ecossistema.

Para que o uso de agrotóxico seja desestimulado, é importante que haja a expansão de hortas comunitárias agroecológicas, e a formação de jovens e adultos para que se crie consciência de como o agrotóxico pode ser prejudicial para a saúde e para o meio ambiente, sendo a educação ambiental primordial para que se alcance a consciência ecológica,

[...] educar ambientalmente significa: a) reduzir os custos ambientais, à medida que a população atuará como guardiã do meio ambiente; b) efetivar o princípio da prevenção; c) fixar a ideia de consciência ecológica, que buscará sempre a utilização de tecnologias limpas; d) incentivar a realização do princípio da solidariedade, no exato sentido que perceberá que o meio ambiente é único, indivisível e de titulares indetermináveis, devendo ser justa e distributivamente acessível a todos; e) efetivar o princípio da participação, entre outras finalidades. (FIORILLO, 2013, p. 73) 
Tendo em vista a efetivação dos direitos fundamentais e do Estatuto da Cidade, a educação ambiental conciliada com o desenvolvimento de projetos relativos à agricultura urbana e hortas comunitárias são de suma importância, uma vez que todo o povo, iniciando com crianças, passando entre os jovens, até chegar aos adultos, podem desenvolver o cultivo de hortas sem o uso de agrotóxicos, contribuindo para o meio ambiente e para a garantia alimentar.

Quando a relação criada entre moradores da comunidade onde as hortas urbanas estão sendo desenvolvida se fortalece, toda comunidade consegue colher frutos desta relação de forma direta, tendo em vista que a agricultura consegue aumentar o nível de segurança da comunidade, com uma relação harmônica entre todos, diminui gastos com a manutenção de terrenos improdutivos, e ainda aumenta a renda geral da comunidade que passa a ter maior poder de compra.

Assim sendo, o que surgia como prática espontânea, agora se transforma em uma forma ecologicamente sustentável de obtenção de renda organizada, que consegue suprir as necessidades existentes na comunidade, fazendo com que as práticas de agricultura urbana agroecológicas existentes passem a ser incentivadas por leis que podem possibilitar um avanço maior dentro do direito para a agricultura urbana.

A Agenda 2030, que estabeleceu os 17 objetivos de desenvolvimento sustentável (ODS), em seu segundo objetivo, destaca a agricultura urbana sustentável e sua capacidade para contribuir no combate à fome e à desnutrição,

Durante as duas últimas décadas, o rápido crescimento econômico e o desenvolvimento da agricultura foram responsáveis pela redução pela metade da proporção de pessoas subnutridas no mundo. Entretanto, ainda há 795 milhões de pessoas no mundo que, em 2014, viviam sob o espectro da desnutrição crônica. (ONU, 2015)

A criação de programas como as hortas comunitárias, quintais verdes e a agricultura solidária, pode ser possível compreender o quão importante é para as famílias que tem acesso a programas que possibilitam a soberania alimentar e a independência financeira, uma vez que incentivos como esses pode transformar a realidade existente e possibilitar uma cidade mais democrática e equitativa, fazendo com que a função social da cidade passe a ser cumprida em sua essência.

\section{AGRICULTURA URBANA NO BRASIL: DESAFIO LEGISLATIVO}

0 atual contexto jurídico brasileiro com relação a agricultura urbana agroecológica pode ser considerado novo, uma vez que não são todas unidades federadas que possuem leis de incentivo e desenvolvimento para a agricultura urbana.

Para compreender a necessidade e a importância do estabelecimento da lei para que o desenvolvimento da agricultura urbana possa ser concretizado, é possível citar a lei 15.973/2006, que desencadeou uma mudança de paradigma em Minas Gerais.

Os artigos $1^{\circ}$ e $2^{\circ}$ da lei 15.973/2006 destacam a vocação alimentar da agricultura urbana e seu potencial para cumprir a função social da cidade e da propriedade urbana da seguinte forma:

Art. 1o Fica instituída a Política de Apoio à Agricultura Urbana do Estado de Minas Gerais como parte da política agrícola, em harmonia com a política urbana e voltada para a segurança alimentar e nutricional da população, em bases sustentáveis.

Parágrafo único. Entende-se, para efeito desta Lei, como agricultura urbana o conjunto de atividades de cultivo de hortaliças, plantas medicinais, espécies frutíferas e flores, bem como a criação de animais de pequeno porte, piscicultura e a produção artesanal de alimentos e bebidas para o consumo humano.

Art. $2^{\circ}$ A Política Estadual de Apoio à Agricultura Urbana contribuirá com o Município na ordenação do pleno desenvolvimento das funções sociais da cidade e da propriedade urbana. (MINAS GERAIS, 2006)

A existência da lei pode gerar garantia para os agricultores urbanos, e moldar a realidade vivida por cada família que realiza a agricultura agroecológica, possibilitando uma melhora na interação dos seres humanos com o meio ambiente e com a estrutura social da cidade. 
Estrutura essa que pode ser construída a partir da atuação conjunta entre Poder Público, Poder Legislativo e Judiciário, como forma de garantir leis eficazes e efetivas para a concretização da função social e o direito à cidade de forma democrática, gerando uma maior inclusão da classe social economicamente vulnerável na vida social da cidade.

Quadro 1: Estados que possuem leis ou projetos de lei sobre agricultura urbana agroecológica

\begin{tabular}{|c|c|c|}
\hline Estados & $\begin{array}{l}\text { Existência de lei sobre } \\
\text { Agricultura urbana } \\
\text { agroecológica }\end{array}$ & LEI / Projeto de lei \\
\hline Acre & Não & - \\
\hline Alagoas & Sim & Lei 8.041/2018 \\
\hline Amapá & Não & - \\
\hline Amazonas & Sim & PL 298/2019 \\
\hline Bahia & Sim & PL 23.353/2019 \\
\hline Ceará & Não & - \\
\hline Espírito Santo & Sim & Lei 10.951/2018 \\
\hline Goiás & Sim & Lei $16.476 / 2009$ \\
\hline Maranhão & Sim & Lei $10.986 / 2018$ \\
\hline Mato Grosso & Sim & Lei 10824/2019 \\
\hline Mato Grosso do Sul & Não & - \\
\hline Minas Gerais & Sim & Lei 15.973/2006 \\
\hline Pará & Não & - \\
\hline Paraíba & Não & - \\
\hline Paraná & Sim & PL 8/2019 \\
\hline Pernambuco & Não & - \\
\hline Piauí & Não & - \\
\hline Rio de Janeiro & Sim & Lei 8366/2019 \\
\hline Rio Grande do Norte & Não & - \\
\hline Rio Grande do Sul & Sim & Lei $15.222 / 2018$ \\
\hline Rondônia & Não & - \\
\hline Roraima & Não & - \\
\hline Santa Catarina & Sim & Lei 17.533/2018 \\
\hline São Paulo & Sim & Lei $16.684 / 2018$ \\
\hline Sergipe & Não & - \\
\hline Tocantins & Não & - \\
\hline Distrito Federal & Sim & Lei 4772/2012 \\
\hline
\end{tabular}

Fonte: próprio autor

A elaboração do quadro se deu por meio de pesquisa feita nas Assembleias estaduais das 27 unidades federativas do Brasil, sendo obtido o resultado de 11 Estados com leis de agricultura urbana, 3 com projetos de leis e 13 sem leis sobre o tema, o que não afasta a possibilidade de os próprios municípios instituírem suas leis de agricultura urbana e agroecológica.

Em recente estudo, a Articulação Nacional de Agroecologia, estudando as iniciativas municipais de apoio a agroecologia, identificou 42 experiências municipais com hortas comunitárias, escolares e centros de produção de alimentos, destacando que

\footnotetext{
Além de produzir e abastecer localidades com alimentos saudáveis, esses espaços permitem a prática e a organização comunitária, especialmente de mulheres, práticas de educação alimentar e nutricional e também de educação ambiental. Na região metropolitana de Belo Horizonte (MG), um processo de mais de dez anos vem incorporando a agroecologia ao planejamento metropolitano. Essa incorporação vem acontecendo no Plano Diretor Metropolitano, Macrozoneamento e nos Planos Diretores Municipais. (LONDRES, 2020, p. 30)
}

Outra forma de incentivo à agricultura urbana agroecológica está na sua inclusão no Plano Diretor para os municípios ou também no Plano de Desenvolvimento Urbano Integrado para as regiões metropolitanas, 
conforme lei 13.089/2015, o que reforça a necessidade de se pensar a agricultura urbana agroecológica como instrumento para o desenvolvimento urbano sustentável e a função social da cidade.

\section{CONSIDERAÇÕES FINAIS}

As pesquisas sobre a agricultura urbana agroecológica no contexto brasileiro são ainda muito recentes, e, praticamente metade dos Estados brasileiros (13) não possuem leis para instituição de agricultura urbana, revelando que ainda há muito para se lutar e construir.

0 direito à cidade só pode ser efetivado quando a função social da cidade for executada nos moldes definidos pelo Estatuto da Cidade e pela Constituição de 1988, possibilitando a concretização do acesso de todos a espaços não antes alcançados, propiciando a criação de uma maior interação dos seres humanos, natureza e o espaço público.

Os espaços públicos, dentro da perspectiva de agricultura urbana agroecológica, passam a ser observados como potenciais para o desenvolvimento de programas sociais e ambientais, como criação de áreas verdes urbanas, hortas comunitárias, jardins comunitários, centros de produção de alimentos, além de serem usados como ferramenta para educação ambiental.

A adoção de agricultura urbana agroecológica serve para evitar terrenos abandonados na cidade, além de trazer segurança, propicia que o imóvel cumpra a sua função social da propriedade, fortalecendo o vínculo social na comunidade, mais que um espaço de produção de alimentos saudáveis, torna-se uma referência para construção do sentimento democrático de solidariedade social.

A agricultura urbana agroecológica pode ser incentivada por meio de leis que facilitem o uso dos espaços públicos ou fomentem sua adoção em espaços privados e por políticas públicas adotadas pelos municípios, sem prejuízo da ação social organizada pelos próprios munícipes, que deve ser respeitada e facilitada pelo Poder Público, para que este não se torne um empecilho ao proibir o uso de espaços públicos, por exemplo, para a criação de hortas comunitárias em imóveis abandonados.

A sustentabilidade, que o direito e a agroecologia buscam, pode ser encontrada na forma em que as cidades se estruturam, aproveitando o seu território de maneira consciente e ecologicamente sustentável, valendo-se da força da lei para garantir o acesso dos cidadãos de maneira democrática aos espaços públicos, efetivando assim direitos postos pela Constituição da República.

Destarte, faz-se necessária a ampliação de programas e políticas públicas que fomentem a adoção de práticas agroecológicas na agricultura urbana como forma de reconectar os vínculos sociais colaborativos e o sentimento democrático de compartilhamento do espaço público, além de produzir alimentos saudáveis a baixo custo, conferindo função social à cidade ao utilizar de forma sustentável áreas inutilizadas ou subutilizadas.

\section{REFERÊNCIAS}

[1] AQUINO, Adriana Maria de; ASSIS, Renato Linhares de. Agricultura orgânica em áreas urbanas e periurbanas com base na agroecologia. Ambiente \& sociedade, v. 10, n. 1, p. 137-150, 2007. DOI: https://doi.org/10.1590/S1414753X2007000100009. Disponível em: https://www.scielo.br/scielo.php?pid=S1414753X2007000100009\&script=sci_arttext\&tlng=pt. Acesso em: 21 jul. 2020.

[2] ARAÚJO, A. S. O Planejamento Urbano e Ambiental na Construção de Cidades Sustentáveis: As Hortas Urbanas Comunitárias em Porto, Portugal, e Belo Horizonte, Brasil. URBANA: revista eletrônica do Centro Interdisciplinar de Estudos sobre a Cidade, Campinas, v. 8, n. 2, p. 190-209, 11 dez. 2016. DOI: https://doi.org/10.20396/urbana.v8i2.8647045.

https://periodicos.sbu.unicamp.br/ojs/index.php/urbana/article/view/8647045. Acesso em: 11 jun. 2020.

[3] BRANCO, M. C.; ALCÂNTARA, F. A. de. Hortas urbanas e periurbanas: o que nos diz a literatura brasileira? Horticultura Brasileira, v. 29, n. 3, p. 421-428, set. 2011 . Disponível em: https://www.scielo.br/pdf/hb/v29n3/v29n3a28.pdf. Acesso em: 05 set. 2020.

[4] BRASIL. [Constituição (1988)]. Constituição da República Federativa do Brasil de 1988. Brasília, DF: $\begin{array}{llll}\text { Presidência da } & \text { República, Disponível em: }\end{array}$ http://www.planalto.gov.br/ccivil_03/constituicao/constituicao.htm. Acesso em: 3 out. 2020.

[5] BRASIL. Lei 10.257 de 10 de julho de 2001: Regulamenta os artigos 182 e 183 da Constituição Federal, estabelece diretrizes gerais da política urbana e dá outras providências. Brasília: Congresso Nacional. Disponível em: http://www.planalto.gov.br/ccivil_03/leis/leis_2001/110257.htm. Acesso em: 3 out. 2020. 
[6] COUTINHO, Maura Neves; COSTA, Heloisa Soares de Moura. Agricultura urbana: prática espontânea, política pública e transformação de saberes rurais na cidade. Revista Geografias, p. 81-97, 2011. Disponível em: https://periodicos.ufmg.br/index.php/geografias/article/view/13322/10554. Acesso em: 21 jul. 2020.

[7] FAO. Criar cidades mais verdes. Roma: FAO, 2012. Disponível em: http://www.fao.org/3/i1610p/i1610p00.pdf. Acesso em: 22 jun. 2020.

[8] FIORILlo, Celso Antonio Pacheco. Curso de direito ambiental brasileiro. São Paulo: Saraiva Educação, 2013.

[9] GLIESSMAN, Stephen R. Agroecologia: processos ecológicos em agricultura sustentável. Ed. da Univ. Federal do Rio Grande do Sul, UFRGS, 2000.

[10] LEFEBVRE, Henri. O direito à cidade. Tradução Rubens Eduardo Frias. São Paulo: Centauro, 2001.

[11] LEMOS, N. S.; ANDRADE, L. M. S.; MEDEIROS, V. A. S. Desafios do planejamento urbano no Brasil e seus marcos legais sob a ótica da agricultura urbana. Paranoá: cadernos de arquitetura e urbanismo, Brasília, v. 14, n. 14, p. 61-70, 2015. DOI: https://doi.org/10.18830/issn.1679-0944.n14.2015.16988. Disponível em: https://periodicos.unb.br/index.php/paranoa/article/view/10902/9562. Acesso em: 24 jun. 2020.

[12] LONDRES, Flávia et al (Org.). Municípios agroecológicos e políticas de futuro. Rio de Janeiro: ANA, 2020.

[13] MINAS GERAIS. Lei 15.973, 12 de janeiro de 2006. Dispõe sobre a Política Estadual de Apoio à Agricultura Urbana. Belo Horizonte: Assembleia Legislativa do Estado de Minas Gerais, 2006. Disponível em: https://www.almg.gov.br/consulte/legislacao/completa/completa.html?tipo=LEI\&num=15973\&comp=\&ano=2006. Acesso em: 5 set. 2020

[14] MOUGEOT, L. Agricultura Urbana: conceito e definição. Revista de Agricultura Urbana, n. 1, p. 8-14, jul. 2000. Disponível em: https://ruaf.org/document/urban-agriculture-magazine-no-1/. Acesso em: 4 dez. 2020.

[15] ONU. Os 17 Objetivos de Desenvolvimento Sustentável. Nova York: ONU, 2015. Disponível em: http://www.agenda2030.com.br/. Acesso em: 26 set. 2020.

[16] SANTA CATARINA. Lei 17.533, 19 de junho de 2018. Institui a Política Estadual de Apoio à Agricultura Urbana e estabelece outras providências. Florianópolis: Assembleia Legislativa do Estado de Santa Catarina, 2018. Disponível em: http://leis.alesc.sc.gov.br/html/2018/17533_2018_lei.html. Acesso em: 27 set. 2020.

[17] RODRIGUES, Arlete Moysés. Estatuto da Cidade: função social da cidade e da propriedade. Alguns aspectos sobre população urbana e espaço. Cadernos Metrópole, n. 12, p. 9-25, 2004 . Disponível em: https://revistas.pucsp.br/index.php/metropole/article/view/8807/6528. Acesso em: 07 set. 2020. 


\section{Capítulo 19}

\section{Logística reversa de pós-consumo: Concepção dos usuários no município de Aracaju (SE)}

\section{Lucivaldo de Jesus Teixeira}

Allana Karla Costa Alves

Heloísa Thaís Rodrigues de Souza

Resumo: A Lei n. 12.305/10 que institui a Política Nacional de Resíduos Sólidos - PNRS incorpora conceitos modernos de gestão de resíduos sólidos e se dispõe a trazer novos instrumentos à legislação ambiental brasileira, como por exemplo, a responsabilidade compartilhada pelo ciclo de vida dos produtos e a logística reversa. A logística reversa é uma ferramenta que tem como objetivo principal reduzir a poluição do meio ambiente, proporcionando a reintegração de produtos ao ciclo produtivo e a reutilização de seus componentes e materiais constituintes. Nesse sentido, o propósito deste trabalho foi verificar a concepção dos usuários acerca da logística reversa com embasamento na legislação vigente, Lei n. 12.305/2010 no município de Aracaju (SE). Mediante análise qualiquantitativa, através da aplicação de um questionário semiestruturado pela plataforma Google Forms. Com o questionário, foi possível apontar que 56\% dos usuários do município de Aracaju conhecem ou já ouviram o conceito de logística reversa, porém, 64\% dos consumidores encaminham os resíduos para os pontos de entrega voluntária - PEV do município.

Palavras-chave: gestão integrada; logística reversa; consumo; resíduos sólidos. 


\section{INTRODUÇÃO}

O crescimento populacional de forma desordenada acarreta no aumento de bens de consumo, que por sua vez proporciona no aumento da geração de resíduos sólidos, principalmente nos grandes centros urbanos. Os resíduos produzidos atualmente passaram a ser constituído por elementos sintéticos e perigosos ao meio ambiente e à saúde humana, em virtude das novas tecnologias incorporadas ao cotidiano (FERREIRA e ANJOS, 2001).

No âmbito jurídico brasileiro, a temática de resíduos sólidos é regulamentada pela Lei n. 12.305/2010. A lei sancionada instituiu a Política Nacional de Resíduos Sólidos (PNRS), incorporando conceitos modernos de gestão de resíduos sólidos e se dispõe a trazer novos instrumentos à legislação ambiental brasileira, como por exemplo, a responsabilidade compartilhada pelo ciclo de vida dos produtos e a logística reversa.

Conforme o artigo 3ํinciso XVII da Lei n. 12.305/2010, a responsabilidade compartilhada pelo ciclo de vida dos produtos é definida como sendo:

conjunto de atribuições individualizadas e encadeadas dos fabricantes, importadores, distribuidores e comerciantes, dos consumidores e dos titulares dos serviços públicos de limpeza urbana e de manejo dos resíduos sólidos, para minimizar o volume de resíduos sólidos e rejeitos gerados, bem como para reduzir os impactos causados à saúde humana e à qualidade ambiental decorrentes do ciclo de vida dos produtos, nos termos desta Lei;

A logística reversa é um dos instrumentos para aplicação da responsabilidade compartilhada pelo ciclo de vida dos produtos, podendo ser definida como sendo:

instrumento de desenvolvimento econômico e social caracterizado por um conjunto de ações, procedimentos e meios destinados a viabilizar a coleta e a restituição dos resíduos sólidos ao setor empresarial, para reaproveitamento, em seu ciclo ou em outros ciclos produtivos, ou outra destinação final ambientalmente adequada. (BRASIL, 2015).

O principal objetivo da logística reversa consiste na redução da poluição do meio ambiente e no desperdício de insumos, por meio da reutilização e reciclagem de produtos (SHIBAO; MOORI; SANTOS, 2010).

De acordo com artigo $33^{\circ}$ da PNRS:

são obrigados a estruturar e implementar sistemas de logística reversa, mediante retorno dos produtos após o uso pelo consumidor, de forma independente do serviço público de limpeza urbana e de manejo dos resíduos sólidos os fabricantes, importadores, distribuidores e comerciantes de:

I - agrotóxicos, seus resíduos e embalagens, assim como outros produtos cuja embalagem, após o uso, constitua resíduo perigoso, observadas as regras de gerenciamento de resíduos perigosos previstas em lei ou regulamento;

II - pilhas e baterias;

III - pneus;

IV - óleos lubrificantes, seus resíduos e embalagens;

V - lâmpadas fluorescentes, de vapor de sódio e mercúrio e de luz mista;

VI - produtos eletroeletrônicos e seus componentes.

A utilização da logística reversa proporciona a reintegração de produtos ao ciclo produtivo e a reutilização de seus componentes e materiais constituintes. Conforme Leite (2003), esse tipo de logística reversa é denominado de logística de pós-consumo, constituído por produtos em fim de vida útil ou usados com possibilidade de utilização. Estes produtos de pós-consumo podem ser originários de bens duráveis ou descartáveis e fluírem por canais reversos de reuso, reciclagem ou até sua destinação final ambientalmente adequada. 
Dentre os produtos gerados e descartados, existem diversas possibilidades de recuperação para os referidos bens (Figura 1). Os subsistemas de reuso, a reciclagem de materiais e incineração, alimentam as vias de disposição final ambientalmente adequada em aterros sanitários ou, a reintegração ao ciclo produtivo. Por meio da reciclagem se agrega valor econômico, ecológico e logístico, permitindo a reintegração dos bens pós-consumo no ciclo produtivo, com a substituição de matérias prima novas gerando uma economia reversa. 0 reuso agrega valor de reutilização dos bens pós-consumo enquanto que a incineração agrega valor econômico, pela transformação dos resíduos em energia elétrica (LEITE, 2003).

Figura 1 - Subsistemas de recuperação dos bens

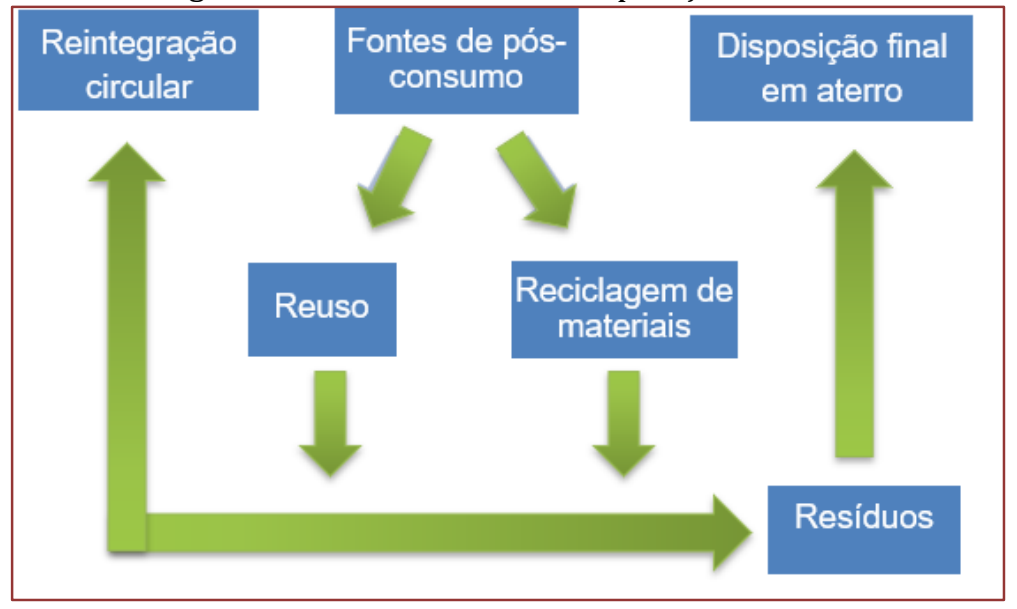

(Fonte: Adaptado de Leite, 2003, p. 47).

Em Aracaju, município do Estado de Sergipe, a Lei Estadual n. 5.857/2006, dispõe sobre a Política Estadual de Gestão Integrada de Resíduos Sólidos, e dá providências correlatas. Em seu artigo 2º inciso VII estabelece a responsabilidade pós-consumo.

Conforme o artigo 55으 da Lei n. 5.857/2006 são considerados resíduos especiais pós-consumo:

as embalagens e os produtos que, após o encerramento de sua vida útil, por suas características, necessitem de recolhimento e destinação específica, tais como:

I - os resíduos tecnológicos, assim considerados:

a) os aparelhos eletro-eletrônicos, eletrodomésticos e seus componentes;

b) os provenientes da indústria de informática;

c) os veículos automotores;

d) as baterias, pilhas e outros acumuladores de energia, bem como os produtos que contenham pilhas e baterias integradas à sua estrutura de forma nãoremovível;

e) as lâmpadas fluorescentes, de vapor de mercúrio, de sódio e luz mista;

II - as embalagens não-retornáveis;

III - os óleos lubrificantes e assemelhados;

IV - os pneumáticos.

Diante do exposto, o presente estudo teve como objetivo realizar uma análise qualiquantitativa acerca da concepção do consumidor com relação a logística reversa pós-consumo no município de Aracaju-SE. 


\section{MATERIAIS E MÉTODOS}

Para o desenvolvimento da pesquisa a metodologia empregada foi a de análise qualiquantitativa. A pesquisa qualiquantitativa é caracterizada pelo uso da quantificação e análise de casos, tanto com o uso de instrumentos de coleta de dados quanto no tratamento das informações. Objetiva a aquisição de resultados que evitem possíveis distorções de análise e interpretação e que possibilitem a maximização da margem de segurança (DIEHL, 2004). Para a presente investigação foram elencadas quatro etapas, descritas a seguir:

Etapa 1: realização de um levantamento bibliográfico através de coleta de dados secundários em artigos científicos, dissertações, teses e legislações vigentes, com temas correlatas a pesquisas tais como: resíduos sólidos, gerenciamento, logística reversa, gestão integrada, consumo, dentre outros.

\section{Etapa 2: realização de cálculo estatístico amostral.}

Considerou-se como população deste estudo os habitantes do município de Aracaju, estado de Sergipe, num total de 657.013 habitantes (IBGE, 2010). Visando-se fragmentar uma amostra que fosse representativa desse universo, utilizou-se a fórmula de Barbetta (2006), para o cálculo da amostra para aplicação dos questionários.

Onde:

$$
\begin{aligned}
& n_{0}=\left(\frac{1}{E_{O}}\right)^{2} \\
& n=\frac{P \times n_{0}}{P+n_{0}}
\end{aligned}
$$

Em que:

$$
\begin{aligned}
& n_{0}=\text { parâmetro inicial } \\
& E_{O}=\text { erro tolerável }=0.01(1 \%) \text { ou } 0,05(5 \%) \text { ou } 0,10(10 \%) \\
& \mathrm{P}=\text { População } \\
& \mathrm{n}=\text { Amostra }
\end{aligned}
$$

Levando-se em consideração o cálculo da fórmula proposta Barbetta (2006), para o cálculo da amostragem segundo o tamanho de uma população finita de 657.013 habitantes, a amostra totalizou 99 elementos, com o erro amostral de $10 \%$.

Etapa 3: aplicação dos questionários aos consumidores.

0 instrumento utilizado na coleta de dados foi um questionário online, constituído por 06 (seis) perguntas, semiestruturadas com questões objetivas da plataforma do Google Forms. A referente pesquisa utilizou como referencial a Lei n. 12.305/2010, especificamente o artigo 33으, que se trata de produtos objeto do sistema de logística reversa. Vale informar que, o público alvo da pesquisa foram os consumidores do município de Aracaju e o questionário foi aplicado durante o mês julho de 2020.

Etapa 4: análise qualitativa dos resultados.

Os dados obtidos a partir dos questionários foram tabulados e transformados em gráficos de porcentagens de frequência para análise dos resultados. Com a sintetização dos dados, foi possível verificar a concepção dos consumidores acerca da logística reversa pós-consumo no município de Aracaju, Estado de Sergipe. Analisando assim, a questão da responsabilidade socioambiental dos usuários. 


\section{RESULTADOS E DISCUSSÕES}

A presente pesquisa realizada com a população aracajuana demonstra que aproximadamente $56 \%$ dos entrevistados conhecem ou já ouviram falar sobre o conceito de logística reversa, enquanto que $44 \%$ ainda não tinham o conhecimento acerca desse instrumento (Figura 2).

Figura 2 - Representação gráfica da noção que os consumidores têm acerca da logística reserva

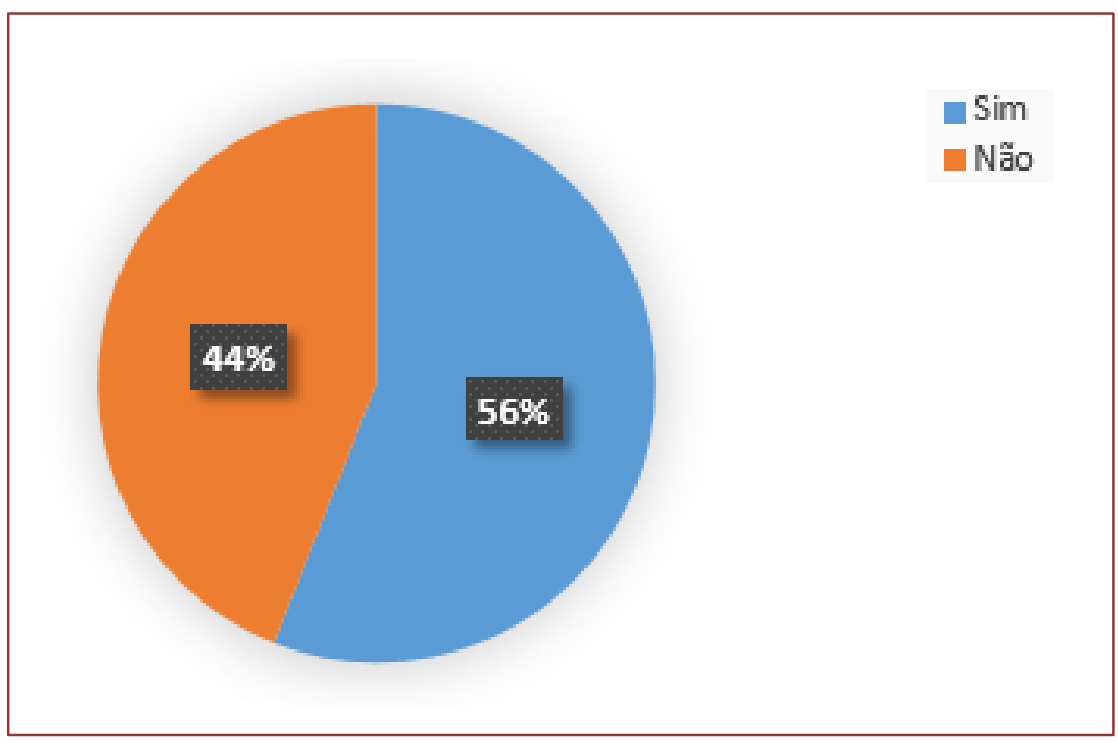

(Fonte: Autores, 2020).

Além disso, foi questionado em relação ao principal objetivo do sistema de logística reversa, e 98\% dos entrevistados foram a favor da economia circular dos resíduos (Figura 3), ou seja, que se tenha o estímulo de novas práticas de gestão que muda o conceito da relação entre a sociedade e a produção dos bens de consumo.

Figura 3 - Representação gráfica dos consumidores no que se diz respeito a economia circular

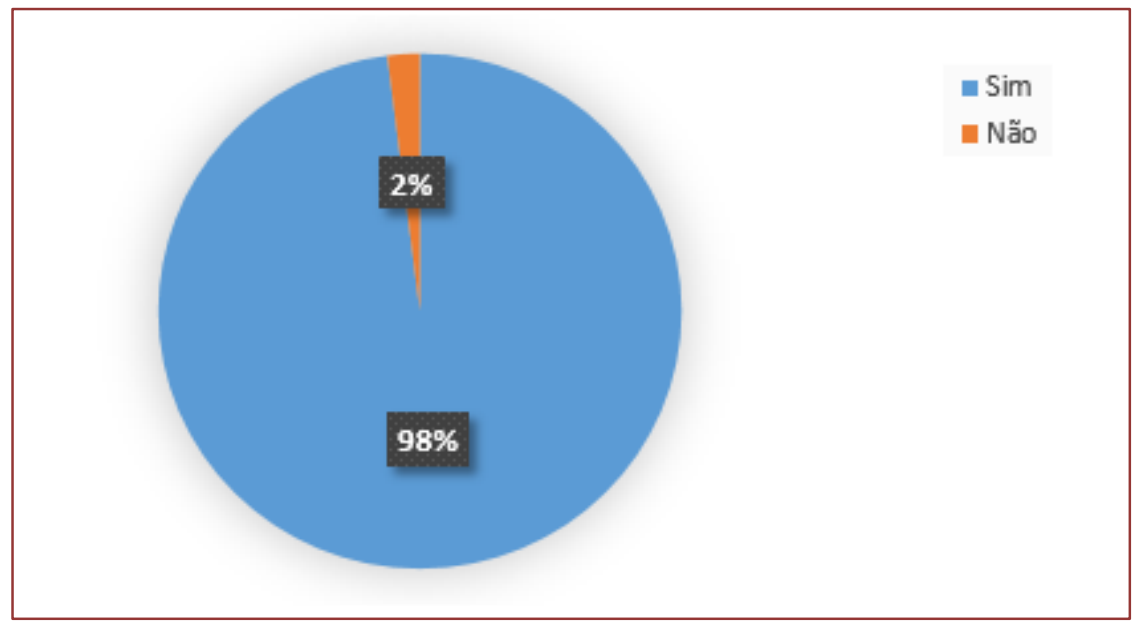

(Fonte: Autores, 2020).

Com relação ao consumo de produtos que fazem parte da logística reversa da PNRS, 29\% dos usuários afirmam ter comprado algum produto do setor de pilhas e baterias, $28 \%$ produtos eletroeletrônicos, $27 \%$ lâmpadas fluorescentes, $8 \%$ pneus, $8 \%$ óleos lubrificantes e foi inexistente dados para embalagens de agrotóxicos (Figura 4). 
Figura 4 - Representação das porcentagens dos produtos da logística reversa mais comprados

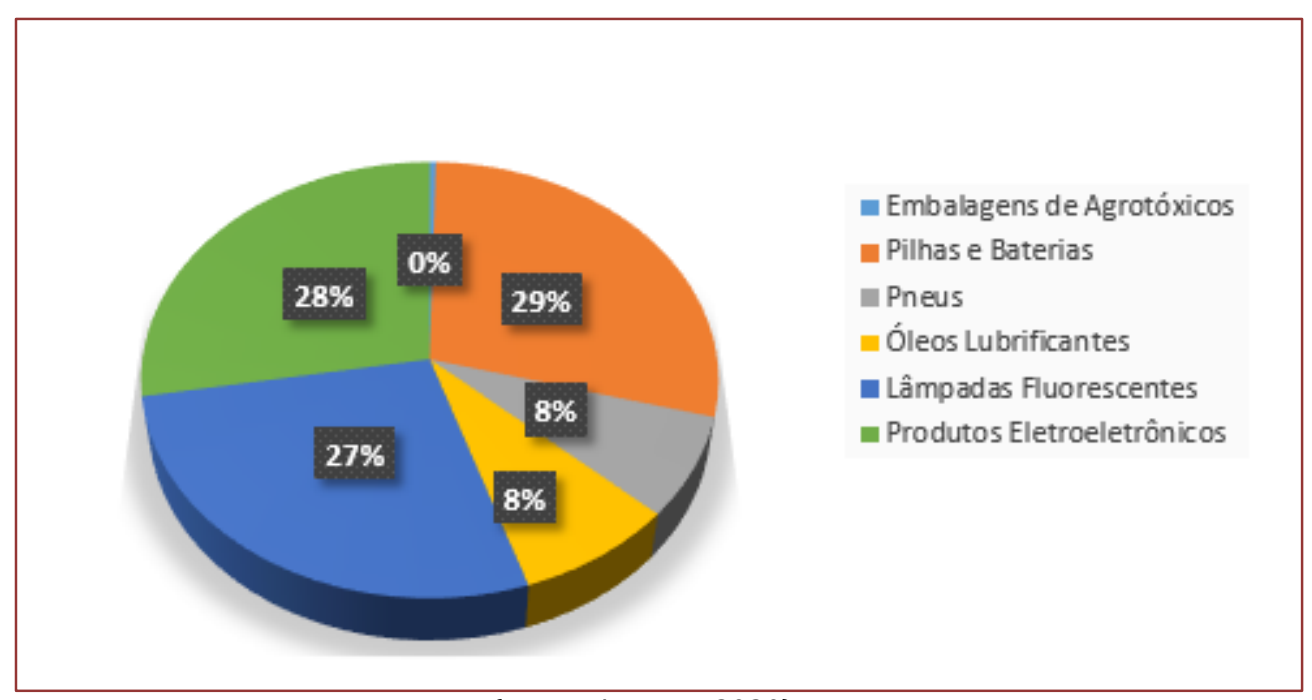

(Fonte: Autores, 2020).

Quando os entrevistados foram questionados se sabiam que os produtos: embalagens de agrotóxicos, pilhas e baterias, óleos e lubrificantes, lâmpadas fluorescentes e produtos eletroeletrônicos participavam do sistema de logística reversa, $52 \%$ dos entrevistados afirmaram que sim e $48 \%$ afirmaram que não (Figura 5).

Figura 5 - Representação gráfica dos consumidores acerca do conhecimento dos produtos participantes da logística reversa

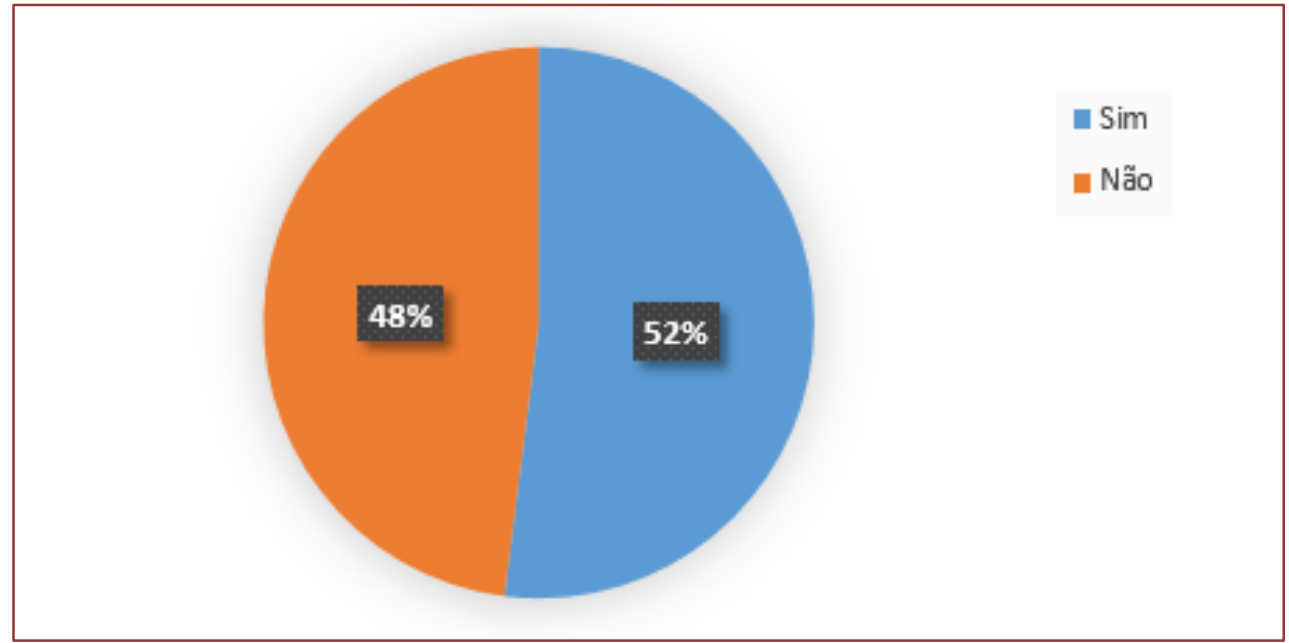

(Fonte: Autores, 2020).

Questionou-se aos entrevistados se já haviam visto algum ponto de entrega voluntária acerca dos produtos participantes da logística reversa no município de Aracaju. Segundo os dados, $36 \%$ já viu algum PEV de pilhas e baterias, $22 \%$ lâmpadas fluorescentes, $22 \%$ produtos eletroeletrônicos, $10 \%$ de pneus, $10 \%$ óleos lubrificantes e foi inexistente para embalagens de agrotóxicos (Figura 6). 
Figura 6 - Representação dos consumidores que já compraram algum dos produtos da logística reversa

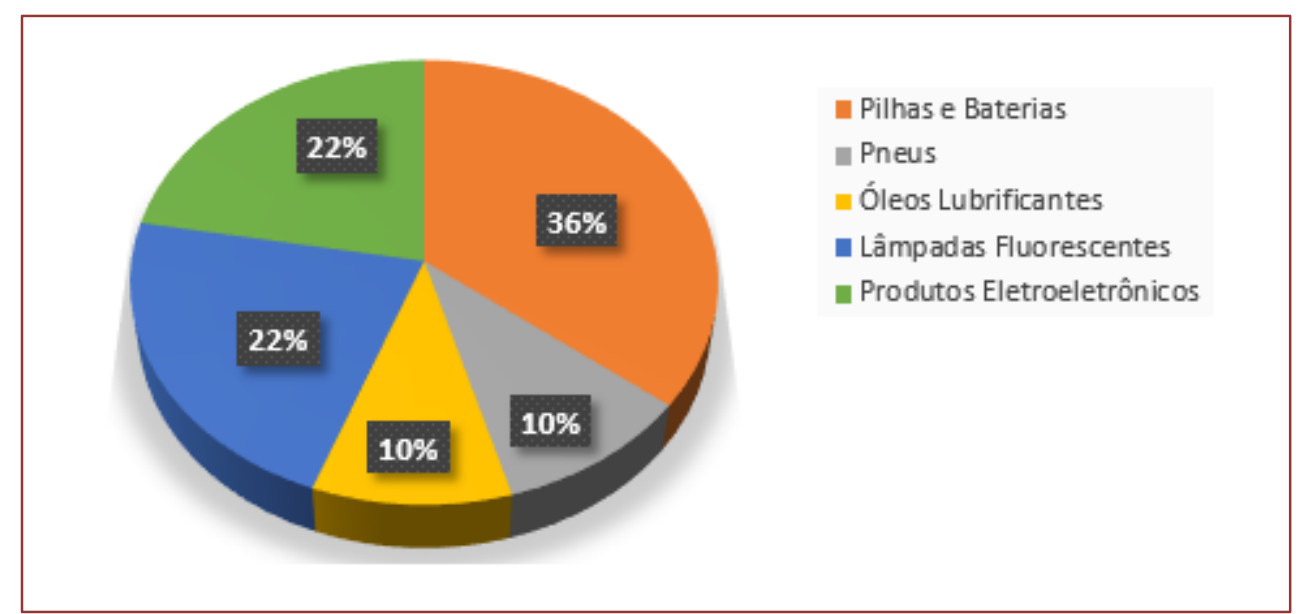

(Fonte: Autores, 2020).

Foi questionado se alguma vez os mesmos tinham encaminhado algum desses materiais para algum ponto de entrega voluntária (Figura 7), com isso, 62\% afirmaram encaminhar seus resíduos diante dos 38\% que nunca encaminharam.

Figura 7 - Representação gráfica dos consumidores que já encaminharam algum dos produtos para um ponto de entrega voluntária

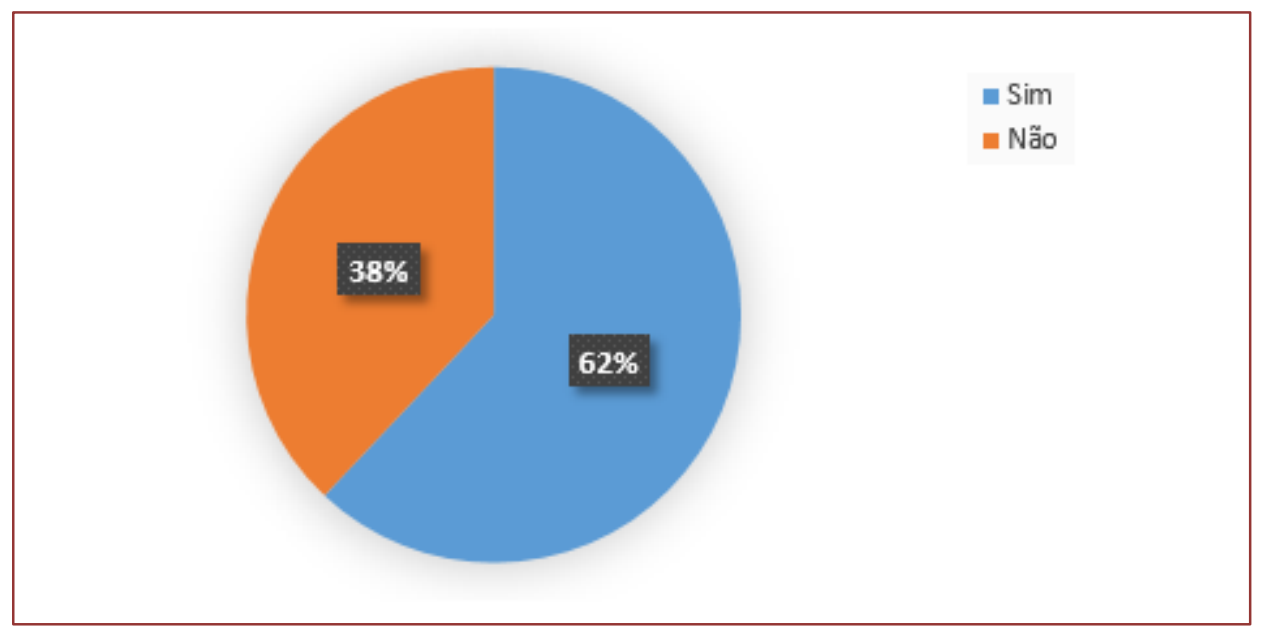

(Fonte: Autores, 2020).

Quando comparado com Trombetta et. al. (2018) percebe-se uma verossimilhança nos dados de destinação para pontos de entrega voluntária dos municípios, principalmente nos produtos de pilhas e baterias, lâmpadas fluorescentes e de produtos eletroeletrônicos. Isso ocorre por estes setores apresentarem uma cadeia reversa bem consolidada e pontos de entrega voluntária em lugares estratégicos com bastante circulação de pessoas, seja em shoppings, estabelecimentos comerciais ou ecopontos.

Para Leite (2017), a logística reversa de pneus no município de Aracaju apresenta baixos índices de recolhimento dos mesmos podem estar relacionados a problemas enfrentados pelo município com relação à gestão e à contratação de empresas terceirizadas responsáveis pela logística desse setor, como também a possibilidade da crise financeira que o Brasil enfrenta desde 2014, que causou certa retração no mercado automobilístico.

Diante do exposto, a presente pesquisa trouxe a compreensão dos usuários acerca do instrumento do sistema de logística reversa com embasamento na legislação vigente, Lei n. 12.305/2010, que dispõe sobre 
a Política Nacional de Resíduos Sólidos, com isso, foi de suma importância para que possam ser levantadas as possíveis falhas da aplicação da ferramenta.

Sendo assim, o principal embasamento da ferramenta é reinserção dos resíduos nas indústrias, assegurando que, os produtos pós-venda voltem para a cadeia produtiva, assumindo assim a responsabilidade compartilhada dos geradores, seja dos fabricantes, importadores, distribuidores, comerciantes e do cidadão.

\section{CONSIDERAÇÕES FINAIS}

Pesquisar sobre a concepção dos consumidores do município de Aracaju acerca da logística reversa pósconsumo trouxeram alguns indicadores que podem auxiliar em outras práticas sustentáveis, como mostrou-nos a presente pesquisa que existe uma parcela dos consumidores não possuem tal conhecimento sobre os produtos que são obrigados a participarem da logística reversa, e percebeu-se também que dos consumidores que conhecem e consomem tais produtos, não encaminham para o ponto de entrega voluntária.

Diante disso, um agente facilitador de recompensa econômica ajudaria a difundir mais a ideia da logística reversa e da economia circular, podendo assim, valorizar ainda os bens minerais, reduzindo consideravelmente os resíduos e rejeitos encaminhados para aterros sanitários.

O tema deste trabalho é de grande relevância, tanto para as organizações quanto para a sociedade. Portanto, sugere-se um estudo com um número amostral maior, através de uma visão sistemática, com um olhar regional e nacional acerca da logística reversa pós-consumo.

\section{REFERÊNCIAS}

[1] BARBETTA, P. A. Estatística Aplicada às Ciências Sociais. Florianópolis: Editora da UFSC, 2006.

[2] BRASIL. Lei no 11.445, de 05 de janeiro de 2007. Brasília, DF: Presidência da República, 05 jan. 2007. Disponível em: http://www.planalto.gov.br/ccivil_03/_ato2007-

[3] 2010/2007/Lei/L11445.htm. Acesso em 28 de julho de 2020.

[4] DIEHL, A. A. Pesquisa em ciências sociais aplicadas: métodos e técnicas. São Paulo: Prentice Hall, 2004.

[5] IBGE - INSTITUTO BRASILEIRO DE GEOGRAFIA E ESTATÍSTICA. Censo 2010.

[6] Disponível em: http://www.ibge.gov.br. Acesso em: 25 de jun. de 2020.

[7] FERREIRA, J.A.; ANJOS, L.A; Aspectos de saúde coletiva e ocupacional associados à gestão dos resíduos sólidos municipais. Cad Saude Publica 2001;17(3):689-696.

[8] LEITE, P. R. Logística Reversa: meio ambiente e competitividade. São Paulo: Pearson Prentice Hall, 2003.

[9] LEITE, D. T. B. S A. Indicadores de Sustentabilidade: Subsídios para o Gerenciamento da Logística Reversa de Pós-Consumo de Pneus Inservíveis no Município de Aracaju-SE. 2017. Tese (Dissertação) - Universidade de Sergipe, São Cristóvão, 2017.

[10] SERGIPE. Lei № 5.857, de 22 de março de 2006. Política Estadual de Resíduos Sólidos, 2006. Disponível em <https://al.se.leg.br/legislacao/>. Acesso em 28 de julho de 2020.

[11] SHIBAO, F. Y.; MOORI, R.G.; SANTOS, M.R.; A logística reversa e a sustentabilidade empresarial. XII SEMEAD, São Paulo, 2010.

[12] TROMBETTA, C.; RODRIGUES, A.C.; ROS, C. O.; SILVA, R.F. Estudo De Caso Da Logística Reversa No Município De Quinze De Novembro, Rio Grande Do Sul. Revista Atena, p. 132, 2019. 


\title{
Capítulo 20
}

\section{Turismo ecológico na preservação de igarapés em} Santo Antônio do Tauá-PA

\author{
Marco Valério de Albuquerque Vinagre \\ Gabriela Doce Silva Coelho de Souza \\ Edwin Hennington Pereira Malheiros \\ Fernanda Caroline de Oliveira Carneiro \\ Peri Guilherme Monteiro da Silva \\ Miroslawa Luczynski
}

Resumo: 0 turismo ecológico ou ecoturismo pode ser uma atividade que assegure a conservação de zonas naturais, pois relaciona condições humanas e ecológicas, desenvolvendo conscientização e compreensão das contribuições humanas ao meio ambiente, relacionando ganhos a economia local. A Região Norte do Brasil conta com um grande potencial para o ecoturismo, porém é necessária a realização de análises para o desenvolvimento dessa atividade econômica, diante dessa situação escolheu-se o município de Santo Antônio do Tauá no estado do Pará, pois é conhecido por ser um local com grande número de igarapés, pequenos rios de baixa profundidade na Amazônia, e muitos desses corpos hídricos contam com estabelecimentos chamados de balneário, para investigação de ecoturismo foram utilizados os quatro balneários mais indicados pela população local, verificando a situação do meio ambiente (mata próxima, aparência das águas), as formas e condição das vias de acesso, assim como das estruturas ofertadas pelos empreendimentos. É possível concluir que Santo Antônio do Tauá tem potencial para o turismo ecológico, mas deve passar por melhorias não somente de infraestrutura de acesso, mas também de participação da gestão pública, quebrando uma barreira que é a falta de educação ambiental.

Palavras chave: Ecoturismo; Sustentabilidade; Igarapé; Turismo sustentável. 


\section{INTRODUÇÃO}

O turismo ecológico representa apenas uma pequena porcentagem do turismo internacional e doméstico, trata-se de uma forma alternativa, sendo uma opção viável de desenvolvimento para todos os países do mundo, pois relaciona condições humanas e ecológicas, incentivando oportunidades econômicas para indivíduos e comunidades, além da busca pela preservação do ambiente natural ou branda adaptação de atividades econômicas.

Os primeiros debates acerca de estratégias sobre turismo e sustentabilidade vieram na década de 90 durante a conferência na Colúmbia Britânica, Canadá, onde representantes da indústria do turismo, governo, ONGs e pesquisadores discutiram a importância do meio ambiente no desenvolvimento turístico e como a exploração mal planejada pode desgastar as qualidades naturais e humanas de ambientes que atraem visitantes (FENNELL, 2007).

Dessa forma, o turismo sustentável engloba os objetivos de: desenvolver uma maior conscientização e compreensão das contribuições que o turismo pode dar ao meio ambiente e à economia; promover a equidade e o desenvolvimento; melhorar a qualidade de vida da comunidade anfitriã; fornecer alta qualidade de experiência para o visitante; e manter a qualidade do meio ambiente dos quais os objetivos anteriores dependem (GLOBE, 1990).

A economia amazônica é caracterizada por ser de fronteiras em desenvolvimento e até pouco tempo baseava-se na exploração intensiva de seus recursos naturais como se fossem inesgotáveis. Atualmente na Região Amazônica emergem pontos para o desenvolvimento turístico e serem veículos potenciais de inclusão social, porém ainda estão distantes das estatísticas mundiais de turismo (SANSOLO, 2003; IRVING, 2006).

0 processo de transformação da paisagem, especificamente nos recursos hídricos superficiais, resulta em impactos ambientais frequentes no território brasileiro, como encaixotamento dos córregos, impermeabilização do solo, redução de vegetação natural e alteração na qualidade da água (TUCCI et al., 1995).

Costa (2006) relata que "reconhecer o rio como paisagem, portanto, é habitar o rio". Assim, os rios são controladores do equilíbrio ambiental e importantes corredores biológicos da flora e da fauna, logo, os corpos hídricos superficiais deveriam ser preservados. É notável que as relações entre as cidades e as bacias hidrográficas possibilitam expandir e entrelaçar as dimensões sociais, culturais e ambientais. Portanto, constituem valioso patrimônio socioambiental.

Vale ressaltar que, atualmente, há programas sendo desenvolvidos na Amazônia que visam o estímulo do turismo, como o Programa para o Desenvolvimento do Ecoturismo na Amazônia Legal, estabelecido pelo Ministério do Meio Ambiente, objetiva-se em fomentar o setor do ecoturismo na Amazônia Legal, no qual o governo brasileiro com o apoio do Banco Interamericano de Desenvolvimento (BID) estabelecem as condições necessárias para permitir o desenvolvimento do ecoturismo em áreas naturais (BRASIL, 2011).

Tendo em vista a problemática exposta a respeito dos desafios do ecoturismo na região norte do Brasil, além da busca constante do equilíbrio antrópico e do meio natural com a preservação dos recursos hídricos, a seguinte pesquisa tem como objetivo avaliar o potencial turístico do município de Santo Antônio do Tauá, no Estado do Pará. Assim, o desenvolvimento regional através do turismo ecológico deve ser entendido como mecanismo de auxílio na aplicação das políticas públicas, do aproveitamento de recursos naturais, preservação do meio ambiente e participação da população na solução de problemas regionais.

Em razão do abordado e tendo em vista o potencial dos recursos hídricos de Santo Antônio do Tauá para o ecoturismo, foi realizado uma pesquisa de campo para levantar informações sobre os balneários localizados em igarapés para análise de fortalecimento do turismo no município de Santo Antônio do Tauá. Foram avaliadas as suas condições para o desenvolvimento do ecoturismo, em virtude da Amazônia contar com um cenário cheio de lacunas públicas em esferas estaduais e federais para o desenvolvimento do ecoturismo, e assim garantir o desenvolvimento sustentável em coesão com os recursos naturais amazônicos. 


\section{MEIO AMBIENTE E O ECOTURISMO}

O estabelecimento de conceitos como espaço e ambiente para entendimento da dinâmica sócio espacial brasileira é indispensável para a elaboração desse trabalho, além do conceito de paisagem. As regiões e áreas naturais possuem diferentes tipos e formas de distribuição, implicando em prazos distintos (curto, médio e longo) para que aconteçam os impactos causados pelas ações antrópicas sobre o meio.

Segundo Milton Santos:

O espaço é formado por um conjunto indissociável, solidário e também contraditório, de sistemas de objetos e sistemas de ações, não considerados isoladamente, mas como o quadro único no qual a história se dá. No começo era a natureza selvagem, formada por objetos naturais, que ao longo da história vão sendo substituídos por objetos fabricados, objetos técnicos, mecanizados e, depois, cibernéticos, fazendo com que a natureza artificial tenda a funcionar como máquina (2014).

Ainda de acordo com Milton Santos (2014), a paisagem é considerada a relação entre meio físico e sociedade, uma combinação dinâmica e instável dos elementos físicos, biológicos e antrópicos que interagem dialeticamente uns sobre os outros. A paisagem trata-se de um conjunto de características únicas e indissociáveis. As consequências sobre uma certa porção do espaço, da combinação dinâmica e instável dos elementos físicos, biológicos e antrópicos que interagindo dialeticamente uns sobre os outros fazem da passagem um conjunto único e indissociável em constante evolução. 0 desenvolvimento de uma sociedade deixa marcas na paisagem, a qual se encontra em constante alteração.

De acordo com Rodriguez et al. (2004), a visão sistêmica da análise ambiental considera a natureza como uma organização sistêmica, autônoma e com suas próprias lógicas de estrutura e funcionamento. 0 conceito de paisagem é configurado em sua totalidade de modo homogêneo, conformando em unidades geossistêmicas. De maneira objetiva, paisagem é definida como o "conjunto da relação entre elementos físicos, biológicos e humanos, que resultam em determinada configuração visual, estando sempre condicionada a transformações, sejam de origem local e/ou global." (FREIRE, 2007).

Portanto, é importante o estabelecimento de um planejamento territorial na organização da dinâmica sócio espacial. Afonso (1999) informa que somente com a compreensão da estrutura "homem-ambiente" e o entendimento da natureza e da cultura como processos interdependentes pode produzir as soluções almejadas. A noção dos sistemas dinâmicos é fundamental para a elaboração do conceito de impacto ambiental. Os impactos ambientais promovidos pelas aglomerações urbanas são produtos e processos de transformações dinâmicas e recíprocas do meio ambiente e da sociedade estabelecida em classes sociais (COELHO, 2001).

Historicamente, durante o ano de 1972, houve a criação do documento conhecido como The Limits to Growth, o qual foi elaborado para a primeira Conferência das Nações Unidas sobre o Meio Ambiente Urbano, em Estocolmo, que reuniu líderes políticos de diversos países para discutir situações econômicas, políticas e ambientais que formavam o sistema global. Tal documento trata-se de um relatório que estabeleceu limites ecológicos e afirmou que se mantidas as condições de crescimento da população mundial, da industrialização, poluição, produção de comida e intensidade de utilização dos recursos naturais, a capacidade de recursos do planeta seria atingida em no máximo 300 anos (MOTA et al., 2008).

A segunda conferência mundial foi a Eco-92, a qual foi realizada na cidade do Rio de Janeiro em 1992, e considerada a mais importante e promissora do século XX. Esse evento contou com a participação de representantes e governantes de 179 países, os quais discutiram, analisaram e aprovaram uma série de documentos referentes a temas ambientais bastante relevantes. Dentre esses documentos estão: a Declaração do Rio de Janeiro sobre o meio ambiente e o desenvolvimento; a Convenção sobre mudanças climáticas; a Declaração de Princípios sobre florestas e a Agenda 21. Esses documentos tentam de forma mais abrangente promover um novo padrão de desenvolvimento, denominado "desenvolvimento sustentável" (MMA, 2006; PEREIRA; CURI, 2012; MOTA, 2008).

De acordo com definições estabelecidas na Agenda 21 (BRASIL, 1992), o desenvolvimento sustentável trata-se de um novo modelo de relação entre homem e meio ambiente, construído coletivamente para mudar o padrão de desenvolvimento dos países desenvolvidos e em desenvolvimento, com adoção de princípios éticos, de forma que atenda às necessidades básicas sem prejuízo para as futuras gerações. Assim, estabelecendo uma melhoria da qualidade de vida da sociedade, criando e implantando soluções para combater a degradação ambiental e as desigualdades econômicas e sociais, em que as medidas de justiça social, proteção ambiental e eficiência econômica são aplicadas. 
A Agenda 21 ainda destaca que para fortalecer a dimensão local é necessário:

Estabelecer estratégias nacionais, regionais e municipais de desenvolvimento do turismo sustentável, nas suas diversas formas, inclusive étnicas e culturais, capacitando as comunidades e organizações da sociedade civil para implementar a gestão de atividades turísticas. (BRASIL, 1992).

De acordo com Milaré (2015), compreende-se que a sustentabilidade está associada com a durabilidade dos recursos naturais para fornecer produtos tanto para atender às próprias necessidades naturais quanto para as demandas sociais (consumo e processos de produção). "A sustentabilidade dos recursos naturais não é absoluta (...), depende da disponibilidade real e do quanto e do como eles são explorados, transformados e utilizados (MILARÉ, 2015, p. 73)".

Diante disso, ressalta-se que mesmo em se tratando de um recurso tido como renovável, ainda assim, é imperioso constatar que, na prática, isso não é uma certeza absoluta, visto que para ser, efetivamente, renovável é imprescindível que se saiba a forma como estão sendo manipulados e utilizados (MILARÉ, 2015). Para exemplificar tal assertiva, o autor explana acerca da água, que inobstante sua quantidade na Terra ser a mesma, ela está se tornando escassa, à medida que aumenta a demanda e a deterioração da qualidade dos recursos hídricos.

Observa-se, em razão do exposto que, em meio aos problemas a serem solucionados destacados pela Agenda 21, estão presentes aqueles causados pelo turismo de massa, o tipo de turismo que gera perturbações ecológicas e sociológicas, pois é feita a valorização do artificial, do consumismo, luxo, marginalizando a cultura local e a população do entorno (FENNELL, 2002).

Novas formas de turismo surgiram para que as comunidades buscassem uma reorganização de seus espaços turísticos. Propostas de turismo alternativo ao modelo do turismo de massa receberam grandes impulsos, pois passou-se a considerar que a atividade turística só deveria existir se seu objetivo fosse melhorar a qualidade de vida das populações locais (FENNELL, 2002).

Em relação a essa contraposição dos dois modelos, Pires (2002, p. 249) afirma que:

A vigência e a hegemonia do turismo de massas, ao mesmo tempo que proporcionaram um grande avanço na socialização do turismo, acarretou uma série de impactos negativos [...] que desencadeariam descontentamentos e, com eles, os anseios por mudanças na condução desse modelo de turismo que o tornassem menos pernicioso em seus impactos. Parte desse descontentamento foi canalizada para a busca de alternativas turísticas ao turismo convencional de massas, na forma de experiências turísticas diferentes em destinos não tradicionais e até mesmo desconhecidos, em que a presença de elementos naturais e culturais mais íntegros ou autênticos pudesse proporcionar uma nova dimensão para as viagens turísticas.

Segundo Campos e Ferreira (2006) o termo "ecoturismo" começou a ser usado na década 1960 para explicar a relação existente entre turismo, meio ambiente e cultura no espaço em que ocorre.

Outro conceito relacionado ao ecoturismo é o proposto pelo Grupo de Trabalho Interministerial integrado pelo Ministério da Indústria, do Comércio e do Turismo e Ministério do Meio Ambiente, dos Recursos Hídricos e da Amazônia Legal (1994). Segundo essa definição, entende-se por ecoturismo um:

"segmento da atividade turística que utiliza, de forma sustentável, o patrimônio natural e cultural, incentiva sua conservação e busca a formação de uma consciência ambientalista através da interpretação do ambiente, promovendo o bem-estar das populações envolvidas".

À vista do aludido, percebe-se então, que os conceitos supracitados, a respeito do turismo ecológico, tendem à mesma definição, a de ser uma atividade sustentável, uma atividade que busca o desenvolvimento econômico da região sem perder o equilíbrio entre a preservação do meio ambiente, a população anfitriã e os turistas. Esse tipo de turismo cresce a uma taxa de 10 a 30\% ao ano, o que sugere um crescimento do pensamento sustentável na população e busca por atividades envolvendo a natureza (CEBALLOS-LASCURÁIN, 1993; LINDBERG; HAWKINS, 2001). 
Diante do exposto, nota-se que o município de Santo Antônio do Tauá possui grande potencial para o desenvolvimento do ecoturismo, devido aos seus igarapés que na região periurbana apresentam como sua principal função o uso balneário. Segundo Ruschmann (2009), nas últimas décadas, as pessoas estão procurando um maior contato com a natureza, através da busca por áreas verdes e por atividades de lazer distantes dos tumultos dos grandes conglomerados urbanos, tentando recuperar o equilíbrio psicofísico em contato com os ambientes naturais.

É perceptível que apesar do atrativo regional, grande parte da população brasileira e, até mesmo paraense, desconhece esses locais mesmo próximos às regiões metropolitanas. Acontece que, para que o usuário dessas áreas ligadas à natureza e ao lazer possa ser adequadamente recebido, é necessário conciliar o conhecimento e a divulgação dos pontos em questão e, em alguns casos, adaptar sua infraestrutura, realizar a construção de ações voltadas para o planejamento e a gestão ambiental, uma vez que direciona para a implantação de modelos de uso e ocupação voltados à uma sustentabilidade socioambiental da área.

\section{METODOLOGIA}

A pesquisa se iniciou com a identificação de balneários localizados em igarapés que são corpos hídricos superficiais, segundo Silva et al. (2016) são espaços que apresentam características amazônicas, recursos naturais e culturais a serem potencialmente aproveitados pela prática do turismo que tenha como princípio a sustentabilidade e o envolvimento comunitário, proporcionando lazer e entretenimento tanto aos visitantes, que são turistas e moradores locais.

Foram detectados nove balneários possíveis para estudo, mas a análise sobre as condições para o ecoturismo foi realizada em quatro, esses locais foram considerados para estudo por serem os mais indicados pela população local.

As características geológicas, de clima, hidrográficas e socioeconômicas do município de Santo Antônio do Tauá foram retiradas de pesquisas que já utilizaram o município como local de estudo e em documentos oficiais.

Foi realizada pesquisa de campo para aferir sobre as condições ambientais de cada balneário para verificar as situações individuais, para ter aporte da discussão sobre os pontos positivos e negativos ao ecoturismo em Santo Antônio do Tauá. A infraestrutura de vias e as formas de acesso aos locais estudados também foi considerada para análise, pois as visitações dependem justamente da acessibilidade dada a população.

\section{LOCALIZAÇÃO E AMBIENTE}

A localização de Santo Antônio do Tauá pode ser observada na Imagem 1, o município tem uma área territorial de 537,62 $\mathrm{km}^{2}$, pertence à Macrorregião de Castanhal, situado à uma distância de $62 \mathrm{~km}$ da capital do estado do Pará. De acordo com o Censo Demográfico 2010 (IBGE, 2010) a população estimada para o ano de 2019 é de 31.482 habitantes. 
Figura 1 - Mapa de localização de Santo Antônio do Tauá

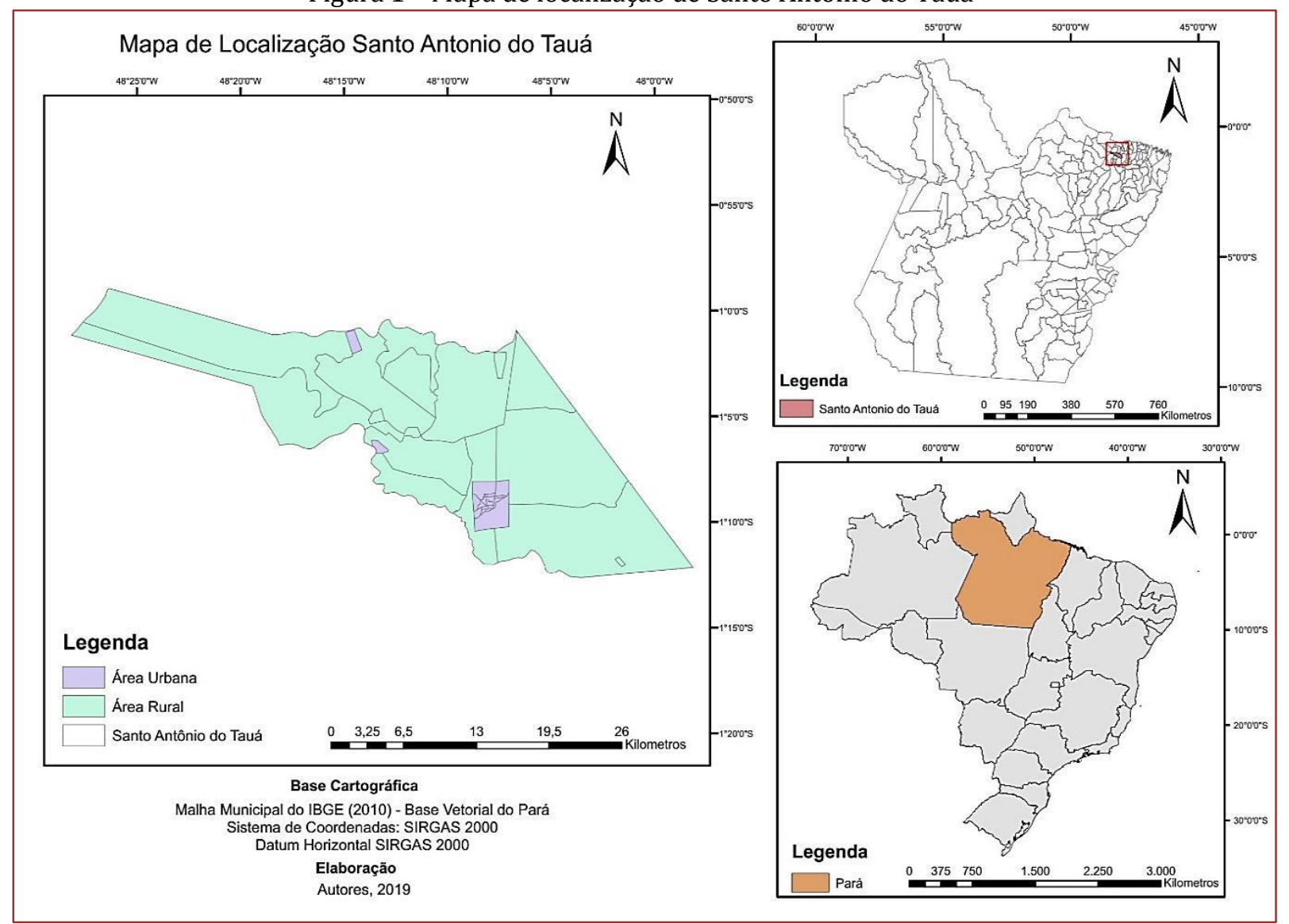

Fonte: Autores, 2019.

Os solos presentes no Município caracterizam-se, majoritariamente, pelo Latossolo Amarelo distrófico textura média. A estrutura geológica é constituída, predominantemente, pelos sedimentos da Formação Barreiras, do terciário, exceto nas áreas margeantes aos rios e igarapés que apresentam sedimentos quaternários inconsolidados. 0 relevo manifesta-se bastante singelo, parte do planalto Rebaixado da Amazônia na Zona Bragantina apresenta tabuleiros aplainados, terraços e várzeas (BRASIL, 1974).

De acordo com a classificação de Köppen, a região apresenta clima tropical chuvoso, com temperatura mínima de $18^{\circ} \mathrm{C}$, que se mantém elevada, em todos os meses do ano, com média anual em torno de $25^{\circ} \mathrm{C}$, sendo seus valores mensais de $24^{\circ} \mathrm{C}$ a $26^{\circ} \mathrm{C}$. A precipitação pluviométrica anual é de $2350 \mathrm{~mm}$. Durante o período dos meses de setembro a dezembro, as chuvas são raras e com uma curta estação seca de moderado déficit de água. A umidade relativa do ar oscila em torno de 85\% (BASTOS, 1987).

As principais atividades econômicas que movimentam o Produto Interno Bruto (PIB) do município são serviços e comércios (56,87\%), agropecuária (25,16\%) e indústria (13,23\%), sendo a primeira a principal responsável pelo dinamismo econômico de Santo Antônio do Tauá, destacando-se na produção de frutas diversas, hortaliças, dendê, e na criação de galináceos e seus produtos - aves para abate e ovos. Tendo isso em vista, a economia do Município tem uma dependência em relação às atividades da zona rural, pois sua atividade industrial gira em torno da produção de óleo de dendê (PIRES; COSTA, 2012).

A origem do Município pode explicar o cenário econômico, pois a sua ocupação em massa ocorre devido as famílias que chegaram devido à crise da economia da borracha e passaram a desenvolver atividades agrícolas e a criação de pequenos animais, atraídas pela potencialidade das terras. 
Observa-se que, não existem trabalhos voltados para a descrição da ecologia e do turismo de igarapés desse Município. Um dos poucos trabalhos que permitem descrever as condições físicas e ecológicas do terreno, na cidade de Santo Antônio do Tauá, é o de Nascimento e Santos (2017) e Leal (2006), que fizeram estudo sobre os impactos ambientais nos pequenos rios (igarapés). Outros autores fazem estudo da situação agrícola (NASCIMENTO; SANTOS, 2017; OLIVEIRA et al., 2010; CORDEIRO; SILVA, 2008) e de conflitos ambientais da região (PINTO, 2017). Do ponto de vista ecológico, dizem os autores supracitados que a cidade se caracteriza, plenamente, como um ecossistema urbano, com elevados índices de modificação da paisagem natural e no entorno do município é possível identificar cultivos da agricultura familiar e comercial.

A cidade de Santo Antônio do Tauá é conhecida popularmente como "cidade dos igarapés", a qual é constituída por diversas ramificações do rio Tauá e do rio Furo da Laura. O Município conta com mais de 30 balneários em toda a sua extensão. Em sua hidrografia, o rio mais importante é o Tauá, que nasce no Município de Santa Isabel do Pará e corre na direção SE-NW, em curso sinuoso, servindo de limite com o Município de Benevides, desde a foz do igarapé São Francisco, seu afluente direto, até a baía do Sol (ATAÍDE et al., 2017).

Toda a abundância hídrica do município de Santo Antônio do Tauá torna o ambiente econômico favorável para o desenvolvimento do turismo em igarapés da região. Entretanto, ainda são necessárias análises ambientais e turísticas do Município que visem a implementação de projetos e planos de ação e proteção do meio biótico que valorizem o ecoturismo; além da necessidade de um olhar sustentável que busque o equilíbrio dos elementos do meio biótico, cultural, econômico e histórico, objetivando a exploração de forma sustentável, valorizando as riquezas paisagísticas locais e regionais.

\section{RESULTADOS E DISCUSSÃO}

Durante a pesquisa foi constatado que o município em questão não possui Plano Diretor, lei de uso e ocupação do solo e código de postura. Se cruzarmos os recursos legais de planejamento e de gestão pública ou a ausência de alguns importantes para a administração municipal, fica mais fácil de entender as lacunas deixadas pela gestão pública sobre algumas de suas atividades, em especial o turismo.

A Lei Orgânica do Município de Santo Antônio do Tauá (1990), em seu art. 138 garante que "o município proverá e incentivará o turismo como fatos de desenvolvimento social e econômico". Além disso, assegura o desenvolvimento de atividades que objetivam o aperfeiçoamento de combates à poluição de cursos d'água, do ar e de impedir a supressão da floresta no município.

Os igarapés em Santo Antônio do Tauá possuem profundidade pequena e média, onde dificilmente atingem três metros entre a lâmina d'água e o talvegue, tratando-se de uma das maiores riquezas da localidade. Próximo a esses cursos d'agua é possível observar tratos recobertos por floresta, onde seu subtipo é a Floresta Densa de baixos platôs e florestas secundárias ou capoeiras em vários estágios de regeneração e grande atividade de desmatamento. No município existem nove balneários que se localizam nas margens dos igarapés de Santo Antônio do Tauá e que podem ser beneficiados pelo ecoturismo, eles são expostos pela Figura 2. 
Figura 2 - Localização dos balneários em Santo Antônio do Tauá

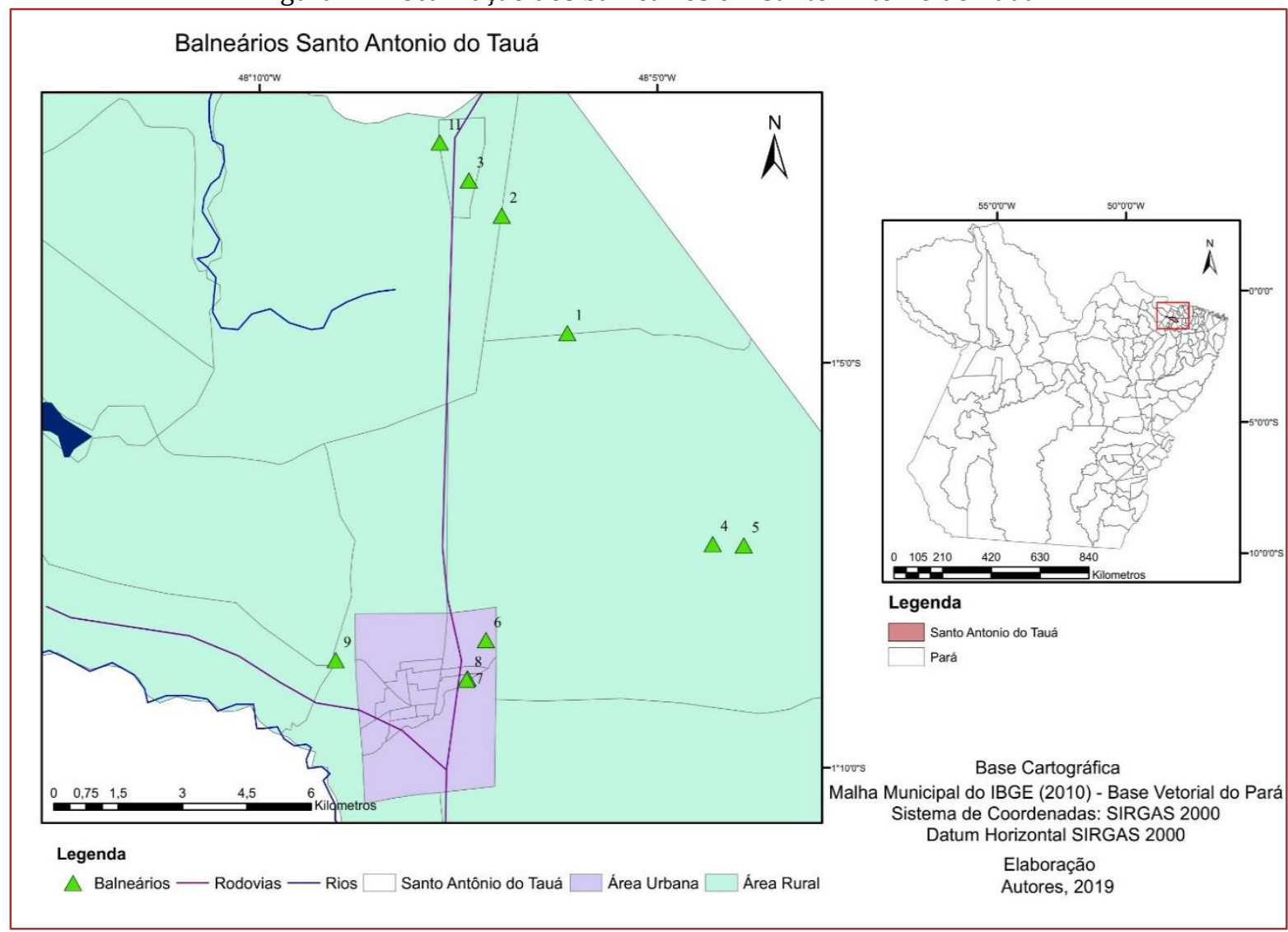

Fonte: Autores, 2019

O Quadro 1 indica os balneários 1 a 4, nesses foram realizadas análises mais aprofundadas devido a sua popularidade na região e serem o principal destino de turistas e munícipes.

Quadro 1 - Balneários analisados

\begin{tabular}{|c|c|c|c|c|}
\hline Balneário & Latitude & Longitude & Entrada & Atrativos \\
\hline 1 & $1^{\circ} 5^{\prime} 3.11^{\prime \prime} \mathrm{S}$ & $48^{\circ} 1^{\prime} 0.14^{\prime \prime} 0$ & $\begin{array}{l}\text { - Vila de São Francisco. } \\
\text { - Ramal com estrada de } \\
\text { terra. }\end{array}$ & $\begin{array}{l}\text { - Área para esportes e } \\
\text { recreação aquática; } \\
\text { - } \quad \text { Trilas ecológicas; } \\
\text { - Piscinas naturais; } \\
\text { - Preservação das nascentes; }\end{array}$ \\
\hline 2 & $1^{\circ} 3^{\prime} 10.90 " \mathrm{~S}$ & $48^{\circ} 6^{\prime} 57.54 " 0$ & $\begin{array}{l}\text { - Ramal com estrada de } \\
\text { terra }\end{array}$ & $\begin{array}{l}\text { - Área para recreação } \\
\text { aquática; } \\
\text { - Braço do igarapé } \\
\end{array}$ \\
\hline 3 & $1^{\circ} 2^{\prime} 44.78 " \mathrm{~S}$ & $48^{\circ} 7^{\prime} 22.33^{\prime \prime}$ & - Área urbanizada & $\begin{array}{l}\text { - Árvores copeiras } \\
\text { preservadas para sombra } \\
\text { Braço do igarapé } \\
\end{array}$ \\
\hline 4 & $1^{\circ} 7^{\prime} 14.26^{\prime \prime S}$ & $48^{\circ} 4^{\prime} 18.19^{\prime \prime 0}$ & $\begin{array}{l}\text { - Ramal com estrada de } \\
\text { terra }\end{array}$ & $\begin{array}{l}\text { - Trilas ecológicas; } \\
\text { - Piscinas naturais; } \\
\text { - Preservação das nascentes; }\end{array}$ \\
\hline
\end{tabular}

Fonte: Autores, 2019.

Os quatro locais estudados possuem como característica em comum o fato de serem áreas de lazer voltadas à população local e turística, com estrutura adequada para os visitantes, como: bares, restaurantes e banheiros. Entretanto, o acesso a todos é um grande obstáculo, pois a maioria dos balneários estão em áreas afastadas da cidade, necessitando de meio de transporte particular para acesso ao local. 
A infraestrutura nas estradas de Santo Antônio do Tauá apresenta-se precária, pois as vias não são pavimentadas e em muitos trechos não contam com sistema de escoamento, pois são de terra batida, resultando em cenários caóticos quando ocorrem as chuvas, devido ao município pertencer a Amazônia sabe-se que existe a época de chuvas e as vias ficam intransitáveis devido ao intenso volume pluviométrico da região amazônica, resultando em buracos e alagamentos, porém quando não é período chuvoso, há a presença de poeira, em que os motoristas por vezes não tem visibilidade total dos trechos em que trafegam, resultando em acidentes.

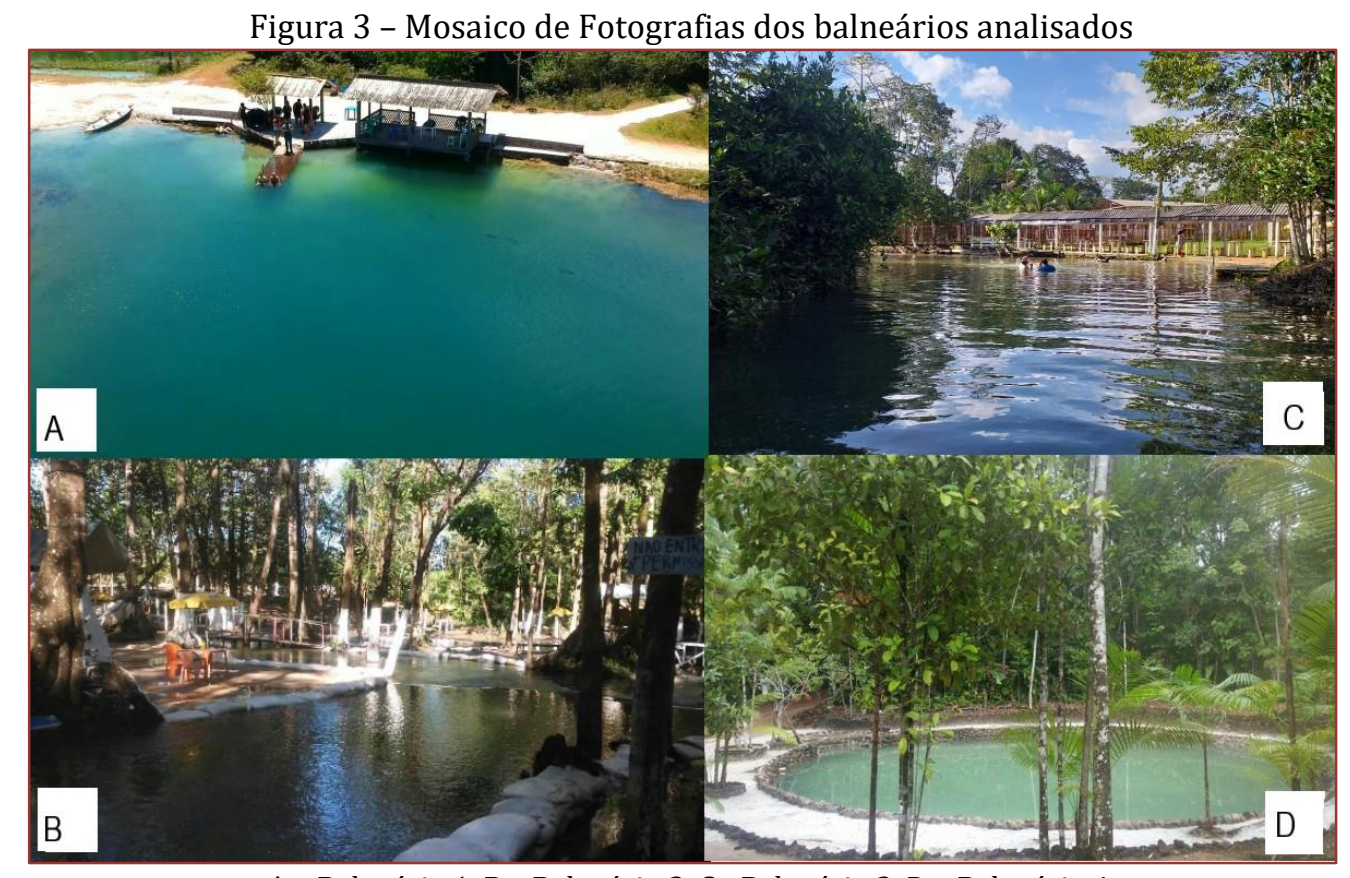

A - Balneário 1. B - Balneário 2. C - Balneário 3. D - Balneário 4.

Fontes: Acervo Próprio

Os balneários 1 e 4 contam com piscinas naturais e há um trabalho de preservação da nascente, onde a água para uso do público é barrada a partir da nascente, na qual a vegetação ao redor foi conservada. Esses balneários ainda contam com trilhas ecológicas e o potencial de uso de aproveitamento de caminho abertos pelos colonos para atividades de turismo, lazer e entretenimento, pois levam a açudes mais afastados das zonas de restaurante e bares.

Lobo e Moretti (2009) colocam o turismo como uma atividade que pode assegurar a conservação de determinadas localidades, pois ao dar valor de mercado a espaços considerados improdutivos, atua de forma indireta como agente de conservação, impedindo que tais espaços sejam destruídos pelo avanço de atividades, como pecuária, agricultura ou mineração.

Não compete ao turismo preservar o meio ambiente sozinho, ele contribui para a conservação de áreas de beleza singular, assim como as Unidades de Conservação - UCs. As áreas naturais protegidas possuem grande importância para o ecoturismo, pois, por meio delas, é possível resguardar, do ponto de vista legal, a conservação, a longo prazo, de uma determinada localidade, o que isenta tais áreas de se sujeitarem totalmente aos anseios locais que podem variar conforme os modismos econômicos. (LOBO; MORETTI, 2009).

É importante ressaltar que o Código Florestal Brasileiro (Lei Federal no 4.771/65) prevê faixas mínimas a serem mantidas e preservadas nas margens dos cursos d'água (rio, nascente, vereda, lago ou lagoa). A norma considera a conservação da vegetação para nascentes o raio mínimo de 50 metros. Tal faixa é o mínimo necessário para garantir a proteção e integridade do local onde nasce a água e para manter a sua quantidade e qualidade.

As nascentes, ainda que intermitentes, são absolutamente essenciais para a garantia do sistema hídrico e a manutenção de sua integridade mostra estreita relação com a proteção conferida pela cobertura vegetal nativa adjacente. Da mesma forma há faixas diferenciadas para os rios de acordo com a sua largura, 
iniciando com uma faixa mínima de 30 metros em cada margem para rios com até 10 metros de largura, ampliando essa faixa à medida que aumenta a largura do rio (MMA, 2011).

Os balneários 2 e 3 são braços do curso d'água vigente, sem a necessidade de barragem. Enquanto o primeiro conta com a preservação de altas árvores copeiras, as quais proporcionam sombras aos frequentadores, a segunda contém uma área de vegetação rasteira e de várzea. Em todos os balneários há uma preocupação com os resíduos sólidos, não podendo ser depositado nos igarapés e é sempre recolhido pelos funcionários locais.

A água é a característica mais marcante dos balneários estudados, pois são águas de características cristalinas e de baixa temperatura, criando o cenário agradável a banhistas. É importante ressaltar que os balneários têm uma estratégia que fomenta o turismo, o de estarem abertos não somente aos finais de semana e feriados, mas em dias úteis, porém os dias em que estão abertos, varia conforme o período de chuvas.

O fato de requerer um conhecimento apropriado sobre as questões ambientais, de preservação e conservação do ambiente, faz com que o ecoturismo seja uma atividade que exija uma postura diferenciada tanto dos visitantes quanto dos moradores do local a ser visitado. Além de ser uma prática recente no Estado do Pará, ainda sofre com a baixa escolaridade da população, o que é considerado uma barreira para o entendimento de tal atividade econômica. Dessa forma, há a necessidade permanente do incentivo do poder público a atividades de inclusão social e à prática da educação ambiental com os prestadores de serviço dos balneários, pois os resultados educacionais não acontecem de imediato, mas sim a médio e longo prazos.

\section{CONCLUSÕES}

Os igarapés, na região periurbana do Estado do Pará, apresentam como sua principal função o uso de balneário, em especial no município de Santo Antônio do Tauá, conhecido como "cidade dos igarapés", esse podendo ser considerado uma situação de ecoturismo, podendo preservar o meio ambiente e impedir o avanço do desmatamento, da agropecuária e das indústrias.

A atividade ecoturística é diferente do turismo convencional, porque considera que o meio ambiente não deve ser transformado, a fim de atender às expectativas dos visitantes ou interesses privados, que precisem ser preparados para a experiência da visitação.

Verifica-se um potencial no município de Santo Antônio do Tauá para o ecoturismo, porém para perpetuação dessa atividade econômica devem ocorrer melhorias, em especial nas vias de acesso, pois a única forma de visitantes chegarem aos balneários é por estradas sem pavimentação que em diversos momentos acabam ficando sem condições de tráfego ou com alto nível de perigo ao trânsito de pessoas e automóveis.

As comunidades locais devem ser as primeiras a participarem do planejamento a respeito da sustentabilidade socioambiental, pois somente com a participação da comunidade local será possível que todos os processos inerentes ao desenvolvimento do ecoturismo aconteçam. 0 princípio do ecoturismo, que chama a atenção, é o da utilização dos recursos hídricos de forma sustentável, oferecendo lazer e atividades aquáticas de qualidade aos visitantes, além de proporcionar benefícios econômicos para a região situação que pode ser alcançada em Santo Antônio do Tauá.

A educação ambiental e participação da gestão municipal também não podem ser negligenciadas no processo de implantação do ecoturismo, pois o meio ambiente precisa ser prioridade. No aspecto cultural, as comunidades locais devem estar bem cientes sobre a valorização de sua cultura, pois caso contrário, o contato com os turistas pode desencadear um processo de aculturação, ou seja, a perda das características locais e criação de novos procedimentos sociais.

Portanto, as políticas públicas necessitam fomentar maior incentivo social para que, dessa forma, a população do Município de Santo Antônio do Tauá tenha mais oportunidades de desenvolvimento, melhorando o acesso aos balneários, a divulgação, a comunicação e a educação ambiental, visto que tais elementos proporcionam a democratização do espaço, além de servir como importante mitigador de impactos ambientais, que podem ser eliminados e/ou minorar por meio do turismo ecológico. 


\section{REFERÊNCIAS}

[1] AFONSO, C.M. Uso e ocupação do solo na zona costeira do estado de São Paulo, uma análise ambiental. São Paulo: FADESP/Anna Blime, 1999.

[2] ATAÍDE, L.C.P.de; RODRIGUES, R.S.S.; PESSOA, F.C.L. Caracterização morfométrica da bacia hidrográfica do rio Tauá, nordeste paraense. Revista Brasileira de Gestão Ambiental, Pombal - PB, v. 11, n. 1, p. 130-138. 2017.

[3] BAHIA, M.C.; FIGUEIREDO, S.L.; JÚNIOR, A.F.; SILVA, A.C.dos S. da; CARDOSO, S.L.C. Espaços públicos urbanos: lugares de lazer, sociabilidade e memória. Novos Cadernos NAEA.v. 17, n. 2, p. 303-324, jul-dez. 2014.

[4] BASTOS, T.X., O Clima da Amazônia Brasileira segundo Köppen. Belém: EMBRAPA-CPATU, 1982. p. 42 (EMBRAPA-CPATU). Pesquisa em andamento, 1987.

[5] BRASIL, Ministério do Meio Ambiente. Turismo Sustentável. Disponível em: <https://www.mma.gov.br/informma/item/8162-proecotur.html>. Acesso em 28 de out de 2019.

[6] BRASIL. Departamento Nacional de Produção Mineral. Projeto Radam, Belém: geologia, geomorfologia, solos, vegetação e uso potencial da terra. Rio de Janeiro, 1974. (Levantamento de Recursos Naturais, 5)

[7] BRASIL. Grupo Interministerial - Ministério Da Indústria, Comércio e Do Turismo E Ministério do Meio Ambiente, dos Recursos Hídricos e da Amazônia Legal. Diretrizes para uma Política Nacional de Ecoturismo. Brasília DF: EMBRATUR/IBAMA, 1994.

[8] BRASIL. Ministério do Meio Ambiente, dos Recursos Hídricos e da Amazônia Legal. A Caminho da Agenda 21 Brasileira: Princípios e Ações 1992/97. Brasília, 1997.

[9] CEBALLOS-LASCURÁIN, H. Ecotourism in the third world: problems for sustainable tourism development. Tourism management, v. 14, n. 2, p. 85-90, 1993

[10] COELHO, M.C. Impactos ambientais em áreas urbanas - teorias, conceitos e métodos de pesquisa. In: GUERRA, A.; CUNHA, S. (Orgs.). Impactos ambientais urbanos no Brasil. Rio de Janeiro: Bertrand Brasil, 2001, p. 19-45. 2001.

[11] CORDEIRO, I.C.; SILVA, I.M. da. Avaliação econômico-financeira da cultura de curauá (ananas comosus var. Erectifolius (l. B. Smith) coppus \& leal: um estudo de caso no município de Santo Antônio do Tauá, estado do Pará. XLVI Congresso da Sociedade Brasileira de Economia Administração e Sociologia Rural (SOBER). Rio Branco, Acre. 2008.

[12] COSTA, L.M.S.A. Rios e paisagens urbanas em cidades brasileiras. Rio de Janeiro: Viana \& Mosley/PROURB, 2006.

[13] CRUZ, S.H.R.; MENDES, F.L.deS.; CAMPOS, R.I.R.de. Ecoturismo e desenvolvimento local na Floresta Nacional de Caxiuanã/Melgaço (PA). Revista Brasileira de Ecoturismo, São Paulo, v.9, n.6, nov-2016/jan-2017, p. 737-750.

[14] FENNEL, D. A. Ecoturismo: uma introdução. São Paulo: Contexto, 2002.

[15] FENNEL, D. A. Ecotourism third edition. Taylor \& Francis e-Library, New York, ed. 3, 2007.

[16] FREIRE, L.M. Paisagens de Exceção: problemas ambientais no município de Mulungu, Serra de Baturité - CE. Dissertação (Mestrado) - Centro de Ciências e Tecnologia, Universidade Estadual do Ceará, Fortaleza. 2007.

[17] FREIRE, L.M.; LIMA, J.S. de; SILVA, E.V.da. Proposta de planejamento ambiental e turístico para a Caverna do Limoeiro, Medicilândia (Pará). Revista Equador. Universidade Federal do Piauí, Teresina, vol. 8, № 2, p. 78 - 96.2019.

[18] GLOBE. An Action Strategy for Sustainable Tourism Development. Ottawa, Canada, 1990.

[19] IBGE. Brasil em síntese - Pará - Santo Antônio do Tauá - Panorama. Disponível em: <https://cidades.ibge.gov.br/brasil/pa/santo-antonio-do-taua/panorama>. Acessado em: 29 out 2019.

[20] IRVING, M.A. Áreas protegidas de fronteiras e turismo sustentável na Amazônia: entre o surrealismo e a invenção. Revista de Desenvolvimento Econômico, ano VIII, no 13, Salvador, BA. 2006.

[21] LEAL, E.B. Análise ambiental da ocupação do Bairro Santos Dumont, Santo Antônio do Tauá-Pa. 2006. Trabalho de Conclusão de Curso (Graduação em Geografia) - Campus Universitário de Castanhal. Castanhal, PA, Universidade Federal do Pará, 2006.

[22] LINDBERG, K.; HAWKINS, D.E. Ecoturismo, um guia para planejamento e gestão. São Paulo: SENAC, 2001. p.

[23] LOBO, H.A.S.; MORETTI, E.C. A natureza das políticas públicas: ecoturismo e conservação ambiental em Bonito - MS. Observatório de Inovação do Turismo - Revista Acadêmica, Rio de Janeiro, v. 4, n. 2. 2009.

[24] MEDEIROS, R. Evolução das tipologias e categorias de áreas protegidas no Brasil. Ambient. soc., Campinas, v.9, n.1, p. 41-64, 2006.

[25] MILARÉ, É. Direito do Ambiente. São Paulo: Revista dos Tribunais, 2015. 
[26] MOTA, J.A.; GAZONI, J.L.; REGANHAN, J.M.; SILVEIRA, M.T.; GÓES, G.S. Trajetória da governança ambiental. Regional e Urbano. IPEA. v. 01.2008.

[27] NASCIMENTO, L.A.B.; SANTOS, N.S.L. Impactos socioambientais em pequenos rios na cidade de Santo Antônio do Tauá - PA. 2017. 72f. Trabalho de Conclusão de Curso (Graduação em Geografia) - Centro de Ciências Sociais e Educação. Belém, Universidade do Estado do Pará, 2017

[28] OLIVEIRA, F.T.; SILVA, I.C.; MATOS, J.F.R.; HARA, F.A.S. Ecoturismo no Rio Puraquequara: suporte para inclusão social e proteção ambiental. Sociedade \& Natureza, v. 22, n. 2, 7 out. 2010.

[29] PEREIRA, S.; CURI, R.C. Meio Ambiente, Impacto Ambiental e Desenvolvimento Sustentável: Conceituações Teóricas sobre o Despertar da Consciência Ambiental. REUNIR - Revista de Administração, Contabilidade e Sustentabilidade - Vol. 2, no 4, p.35-57. 2012.

[30] PINTO, R.A. Conflitos Ambientais em Santo Antônio do Tauá (PA): Considerações a partir do Direito Ambiental. Trabalho apresentado como requisito parcial para obtenção do grau de Especialista em Direito Ambiental do curso de Pós-graduação em Direito Ambiental Departamento de Economia Rural e Extensão, Setor de Ciências Agrárias da Universidade Federal do Paraná, Curitiba, 2017.

[31] PIRES, G.; COSTA, E. Diagnóstico Socioeconômico e Ambiental da Região de Integração do Guamá. FAPESPA. Fundação Amazônia de Amparo a Estudos e Pesquisas do Pará. Pará. 2012.

[32] PIRES, P. dos S. Dimensões do ecoturismo. São Paulo: Senac São Paulo, 2002.

[33] RODRIGUEZ, J.M.M.; SILVA, E.V; CAVALCANTI, A.P.B. Geoecologia das Paisagens: uma visão geossistêmica da análise ambiental. Fortaleza, CE: Editoral UFC, 2004

[34] SANSOLO, D.G. Turismo e sustentabilidade na Amazônia: um novo conteúdo territorial e a experiência no Município de Silves, Amazonas. Revista de Turismo y Patrimonio Cultural. Universidad de La Laguna, Espanha, 2003.

[35] SANTO ANTÔNIO DO TAUÁ. Câmara Municipal. Lei Orgânica do Município de Santo Antônio do Tauá.

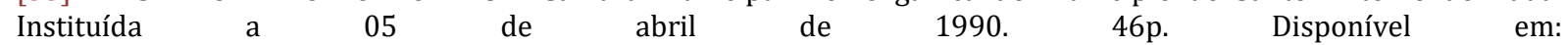
>51http://www.camarasat.pa.gov.br/docs/lei_organica/lei_organica_do_municipio_SAT.pdf<. Acesso: 01 nov. 2019.

[36] SANTOS, M. A Natureza do Espaço. Técnica e Tempo, Razão e Emoção. EDUSP; Edição: 4⿳亠丷. 2014.

[37] SILVA, G.C. da; VASCONCELOS, C.A.L.; FONSECA, H.B. Ecoturismo os atrativos naturais em Bujaru/Pará. v. 7, p. 267-Ecotorismo os A, 2016.

[38] TUCCI, C.E.M.; PORTO, R.L.L.; BARROS, M.T. Drenagem Urbana. Editora da Universidade Federal do Rio Grande do Sul, 1995. 


\section{Capítulo 21}

Aproveitamento de resíduos da lama de barragem de mineração como pigmento para tintas

\section{Jorge David Alguiar Bellido \\ Aline Cristina da Silva \\ Clara de Oliveira Hespanhol \\ Jeniffer Santos Ferreira \\ Jéssica Carolaine Vieira de Azevedo \\ Vanessa Carolina Matosinhos Gonçalves \\ Yasmim Ribeiro Meirelles}

Resumo : Com o objetivo de mitigar os impactos ambientais ocasionados pelas barragens de minério de ferro, este trabalho avalia a viabilidade da aplicação destes rejeitos como pigmentos para a produção de tintas de solo. Foi utilizado como pigmento rejeito proveniente de barragem do quadrilátero ferrífero e PVA como resina para a confecção das tintas. Fixou-se a massa de pigmento e variou-se as quantidades de água, PVA e solução de $\mathrm{NaOH}$ (utilizada como dispersante) e tais composições foram definidas por meio de planejamento experimental de misturas. Em seguida, foram realizados experimentos para definir a viscosidade e a resistência à abrasão de cada mistura. Verificou-se que a resistência à abrasão foi diretamente relacionada com a quantidade de resina utilizada em cada ensaio, ou seja, um baixo percentual de resina contribui para resultados insatisfatórios de resistência à abrasão. Também foi observado que a viscosidade é controlada, principalmente, pela água e PVA, uma vez que níveis mais elevados de água promovem a diluição e, logo, a diminuição da viscosidade, no entanto, níveis mais elevados de PVA tendem a aumentar a viscosidade, dado que a resina possui alta viscosidade.

Palavras-chave: Pigmento; Rejeito; Sustentabilidade 


\section{INTRODUÇÃO}

Durante todo o processo da extração do minério de ferro há geração de um volume na faixa de milhões de metros cúbicos de materiais extraídos e movimentados no processo de beneficiamento do minério. Sendo assim, a elevada produção dos rejeitos de minério torna viável a construção de diques para estocagem deste material formando então as barragens de rejeitos (Júnior et al., 2018). A disposição dos rejeitos de mineração em barragens de rejeitos é uma atividade altamente impactante e não sustentável devido aos prejuízos imensuráveis para a população e o meio ambiente, no entanto é uma operação essencial à economia e à vida moderna pois fornece matéria prima para os demais setores da economia (Machado, 2018).

Estudos na área do aproveitamento dos rejeitos de barragens têm mostrado soluções factíveis para a utilização destes rejeitos. Estes podem se tornar matéria prima para outros setores produtivos, como os já estudados para composição de artefatos cerâmicos (Machado, 2018) e pigmento para confecção de tintas de solo (Galvão, 2017).

As tintas de solo, são compostas apenas por resinas (em geral PVA), pigmentos (argila local) e água. Esse processo de baixo custo e impacto ambiental mínimo, compreende produtos, técnicas e metodologias que visam à transformação social, sendo uma alternativa de geração de trabalho, renda, bem como fator de cidadania, apresentando- se como uma proposta inovadora de valorização do solo (VITAL et al., 2018).

Tendo em vista os impactos ambientais, sociais e econômicos causados pelos rejeitos da mineração, o presente trabalho visa avaliar o aproveitamento de resíduos da lama de barragem de mineração como pigmento para tintas. 0 rejeito será utilizado como pigmento de baixo custo na composição típica das tintas de solo, visando ao emprego em edificações de diversos tipos, como solução sustentável para o meio ambiente e a população.

\section{METODOLOGIA}

A lama foi coletada na empresa Companhia Siderúrgica Nacional (CSN) na mina de Casa de Pedra no município de Congonhas, região do Quadrilátero Ferrífero. A polpa de minério foi preparada no laboratório de Engenharia Civil e Engenharia Química do Campus Alto Paraopeba, Ouro Branco-MG seguindo três operações, sendo elas a secagem, moagem e peneiramento. 0 rejeito da barragem de mineração foi usado como fonte de pigmentos para a produção das amostras de tintas. Os demais componentes da mistura

foram a água (solvente), a solução de $\mathrm{NaOH} 2,5 \mathrm{~mol} \mathrm{~L}^{-1}$ (dispersante) e o PVA. As proporções de pigmento foram mantidas fixas em aproximadamente $30 \%$, conforme definido por Cardoso (2015). Foi feito um teste preliminar onde os intervalos e proporções dos demais componentes foram definidos por meio de referências encontradas na literatura (Cardoso, 2015).

Elaborou-se um delineamento experimental de mistura utilizando o software Minitab 18. As variáveis analisadas neste estudo foram apenas a resina, solvente e dispersante. A confecção das amostras de tinta, a realização do teste de viscosidade e de resistência a abrasão foram realizados conforme as metodologias de Galvão (2017) e de Lopes e Colaboradores (2019).

\section{RESULTADOS E DISCUSSÃO}

De acordo com o planejamento experimental, foram geradas 13 amostras de tintas com variações de pigmento, dispersante, solvente e resina. As tintas que possuíam maiores porcentagens de resina (PVA) apresentaram maior viscosidade e consequente melhora na resistência à abrasão. Pode-se observar também, que as tintas que apresentaram quantidades nulas de dispersante $(1,5$ e 10) ocorreu o aparecimento de fungos em um período de 15 dias. Abaixo, na Tabela 1, encontram-se relacionados os resultados referentes ao teste de resistência à abrasão (número de ciclos) e viscosidade aplicados nas amostras de tintas.

Observou-se que a resistência à abrasão foi diretamente relacionada com a quantidade de resina utilizada em cada ensaio, ou seja, um baixo percentual de resina contribui para resultados insatisfatórios de resistência à abrasão. De acordo com INMETRO (2008), quando o fabricante não utiliza a quantidade suficiente de resina na formulação da tinta, para economizar custos, por exemplo, a película formada não cobre adequadamente a superfície pintada. Isso ocorre quando é utilizada uma quantidade de resina menor que a suficiente para envolver todas as partículas de pigmentos, o que resulta na aglomeração das 
partículas e no surgimento de poros, que diminuem a opacidade da película (CASTRO, 2009).

Tabela 1 - Resultados das análises de viscosidade e número de ciclos

\begin{tabular}{|c|c|c|c|c|c|c|}
\hline Ensaio & Água & PVA & $\mathrm{NaOH}$ & Viscosidade (s) & Ciclos & Desejabilidade \\
\hline 1 & 55,000 & 45,000 & 0,00 & 10,935 & 90 & 0,000000 \\
\hline 2 & 25,800 & 72,700 & 1,50 & 87,500 & 462 & 0,692299 \\
\hline 3 & 53,500 & 45,000 & 1,50 & 11,450 & 46 & 0,134316 \\
\hline 4 & 38,900 & 58,100 & 3,00 & 16,570 & 230 & 0,000000 \\
\hline 5 & 40,400 & 59,600 & 0,00 & 17,270 & 68 & 0,110415 \\
\hline 6 & 25,800 & 71,200 & 3,00 & 37,930 & 89 & 0,404926 \\
\hline 7 & 47,325 & 51,925 & 0,75 & 14,465 & 37 & 0,065980 \\
\hline 8 & 32,725 & 65,025 & 2,25 & 30,415 & 72 & 0,317534 \\
\hline 9 & 45,825 & 51,925 & 2,25 & 13,725 & 244 & 0,054325 \\
\hline 10 & 25,800 & 74,200 & 0,00 & 89,000 & 197 & 0,691813 \\
\hline 11 & 39,650 & 58,850 & 1,50 & 19,850 & 45 & 0,207167 \\
\hline 12 & 52,000 & 45,000 & 3,00 & 10,820 & 35 & 0,024747 \\
\hline 13 & 32,725 & 66,525 & 0,75 & 54,000 & 180 & 0,423197 \\
\hline
\end{tabular}

Constatou-se também que a viscosidade é controlada, principalmente, pela água e PVA, uma vez que níveis mais elevados de água promovem a diluição e, logo, a diminuição da viscosidade, no entanto, níveis mais elevados de PVA tendem a aumentar a viscosidade, dado que a resina possui alta viscosidade. Portanto, pode-se afirmar que as resinas PVA incrementaram a estabilidade das suspensões de pigmentos, agindo como emulsificantes. Segundo Cardoso (2015) ao elevar a viscosidade das misturas, as resinas diminuem as colisões entre partículas e retardaram a floculação e a sedimentação, o que é desejável para o caso das tintas.

O método Desirability foi utilizado para determinar as melhores condições de ajuste do processo (Lopes et al. 2019). Neste estudo, as melhores condições das respostas foram obtidas maximizando a viscosidade e o número de ciclos. Sendo assim, analisando-se a proporção ideal de tinta, ou seja, porcentagens ótimas de PVA, ÁGUA e NAOH, a formulação de tinta que apresentou maior desejabilidade foi com 73,5333 de resina PVA, $25,80 \%$ de água e $0,67 \%$ de $\mathrm{NaOH}$. Tal amostra apresenta uma desejabilidade total superior a 73,46\%, ou seja, atende em $73,46 \%$ as propriedades que a conferem qualidade técnica.

A figura 1 apresenta fotografia do resultado final da tinta quando pintada sobre superfície de placa cimentícia.

Figura 1 - Placa cimentícia coberta com a tinta desenvolvida.

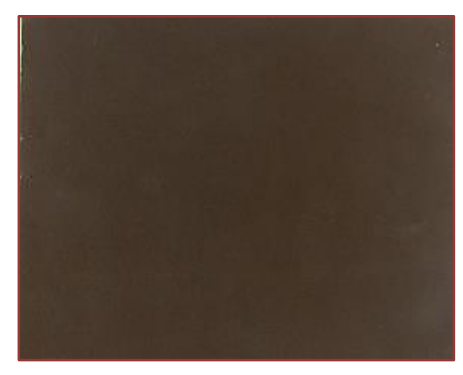




\section{CONCLUSÕES}

A tinta de solo produzida a partir de rejeito de barragem de minério de ferro, utilizando PVA como resina e $\mathrm{NaOH}$ como dispersante, apresentaram um bom desempenho na cobertura das placas. 0 teste de resistência à abrasão realizado permitiu verificar que as tintas com maior percentual de resina obtiveram um melhor desempenho, enquanto que a viscosidade é controlada pela quantidade de solvente e PVA. Portanto, a tinta de solo utilizando rejeito de barragem de minério de ferro como pigmento é uma tinta com boa aplicabilidade e uma forma sustentável e alternativa ao uso das tintas comerciais, uma vez que o rejeito pode ser misturado direto à resina e ao solvente, após passar por secagem.

\section{REFERÊNCIAS}

[1] CARDOSO, F.P. Desenvolvimento de processos de produção e avaliação do desempenho de tintas para a construção civil manufaturadas com pigmentos de solos. Tese (Dissertação de mestrado) - Universidade Federal de Viçosa, Viçosa, MG, 2015.

[2] CARVALHO, A. F. CARDOSO, F. P. MENDES, B. C. Influence of the incorporation of granite waste on the hiding power and abrasion resistance of soil pigment-based paints. Construction and Building Materials. V. 205, p. 463-474, 2019.

[3] CASTRO, C.D. Estudo da influência das propriedades de diferentes cargas minerais no poder de cobertura de um filme de tinta. 2009. 157 p. Tese 139 (Doutorado em Engenharia) - Universidade Federal do Rio Grande do Sul, Porto Alegre, RS, 2009.

[4] GALVÃO, J. L. B., Trabalho de Conclusão de Curso, Universidade Federal de Ouro Preto, 2017. INMETRO. Programa de análise de produtos. Relatório sobre análise em tintas imobiliárias látex econômicas. Rio de Janeiro, 2008. Disponível em http://www.inmetro.gov.br/consumidor/produtos/tintasImobiliarias.pdf. Acesso em 16/10/2019. JUNIOR, T. F. SOUZA; MOREIRA, E. B.; HEINECK, K. S. Barragens de contenção de rejeitos de mineração no Brasil, Holos, v.5, p. 2-39, 2018.

[5] LOPES, M. M. S. SILVA, R. C. ALVARENGA, S. A. PEDROTIA, L. G. RIBEIRO, J. C. L. Influence

[6] of the incorporation of granite waste on the hiding power and abrasion resistance of soil pigment-based paints, Construction and Building Materials, Volume 205, 2019, Pages 463-474.

[7] MACHADO, M.S. M., Tese de Mestrado, Universidade Federal de Ouro Preto, 2018.

[8] VITAL, A. M. et al. Uso não agrícola do solo: a tinta de terra como inovação tecnológica e sustentável. Brazilian Journal of Biosystems Engineering, v. 12, p.144-151, 2018. 


\section{Capítulo 22}

\section{Utilização de fibras como adjunto na produção de telhas}

Jorge David Alguiar Bellido

Lisbeth Zelayaran Melgar

Felícia Maria Silva Moreira

João Victor Sales Castro

Pamela Lopes Soares

Resumo : Até pouco tempo as telhas de fibrocimento fabricadas com amianto eram utilizadas em larga escala na construção civil em residências brasileiras. Contudo, em 2017 o Supremo Tribunal Federal (STF) proibiu seu uso e venda alegando que a mesma era precursora de diversas doenças, dentre elas o câncer de pulmão. Desta forma, o objetivo do proposto trabalho visa encontrar novas fibras para substituir o amianto, mantendo suas propriedades, além de destinar fibras orgânicas que por vezes são objeto de descarte. A metodologia utilizada se deu inicialmente ela confecção de 2 moldes de telha devidamente envelopados para padronização dos moldes de gesso, onde foram confeccionados posteriormente os corpos de prova. Estes foram produzidos empregando diferentes proporções de fibras de coco, sisal, além de água e cimento. Uma argamassadeira foi utilizada para homogeneização do material, e o mesmo foi distribuído manualmente em camadas sobre os moldes de gesso, onde permaneceram por 3 dias. Posteriormente foram imersos em água por 7 dias e por 18 dias permaneceram em ambiente externo coberto. Vale ressaltar que os resultados foram satisfatórios para todos os ensaios realizados como altura da onda, densidade, espessura, absorção e permeabilidade à água. Sendo que os melhores resultados foram obtidos para as telhas, cuja composição é de Fibras de Sisal + Coco. Conclui-se que a proposta de utilização de fibras vegetais em substituição de fibras sintéticas utilizadas em substituição ao amianto apresentou resultados favoráveis, já que para os ensaios realizados foram atendidas às exigências da legislação vigente.

Palavras-chave: Amianto; Fibras vegetais; Resíduos. 


\section{INTRODUÇÃO}

O amianto branco era utilizado em larga escala na construção civil até 2017, quando o Supremo Tribunal Federal proibiu seu uso e venda por ser precursor de diversas doenças. Tornou-se necessário encontrar substitutos para fabricação de produtos com propriedades oferecidas pelo amianto. Entre os materiais ambientalmente favoráveis que podem substituir o amianto encontram-se cinzas provenientes de vegetais como casca de arroz (ALCANTARA et al., 2018) e outros resíduos agrícolas (Ghavami, 2003) como as fibras de coco e sisal.

\subsection{FIBRA DE COCO E FIBRA DE SISAL}

A Fibra de Coco possui estrutura fechada, reduz níveis sonoros, dureza, possui baixa condutividade térmica, resistência aos ataques de bactérias e fungos, à umidade e apodrecimento e resistência à tração entre 131 a 176 MPa. Sua utilização é uma alternativa ao descarte do resíduo (PERSSON et al., 1984). Fibras residuais apresentam comprimento de 1 a $3 \mathrm{~cm}$, ideal para distribuição em matrizes cimentícias, teor de celulose e hemicelulose de $50 \%$ e 48\% de lignina. As fibras nacionais variam de 10 a $200 \mathrm{~mm}$ com diâmetro de 0,3 mm. Já as Fibras de Sisal tem mais de $80 \mathrm{~cm}$, teor de celulose de 65,8\%, hemicelulose $12 \%$ e lignina 9,9\%. Estas proporcionam melhoria à tração, elevada ductilidade e tenacidade e melhor resistência mecânica comparada com outras fibras exceto a de Bambu. (ISAIA,2017).

Objetiva-se com este trabalho produzir telhas utilizando fibras de materiais orgânicos como adjunto em diferentes proporções na composição dos corpos de prova, visando destinar produtos tratados como resíduos na composição das telhas e avaliar as propriedades que estes podem agregar ao produto final.

\section{METODOLOGIA}

\subsection{PRODUÇÃO DOS MOLDES DE GESSO, CORPOS DE PROVA E PROCESSO DE CURA}

Foi confeccionado um recorte de telha com dimensões $225 \times 225 \mathrm{~mm}$ para padronização dos moldes de gesso.

A quantidade de cimento, fibras de sisal, de coco e sisal + coco para produção de cada corpo de prova foi pesada, embalada e identificada por números individualmente. sendo $2 \%$ para cada fibra quando utilizadas individualmente e 1\% quando associadas. utilizando argamassadeira homogeneizou-se fibras de sisal e coco com água e cimento. o material obtido foi distribuído sobre moldes de gesso, passando por um processo de cura de 28 dias.

Figura 1: Corpo de Prova produzido em Fibrocimento.

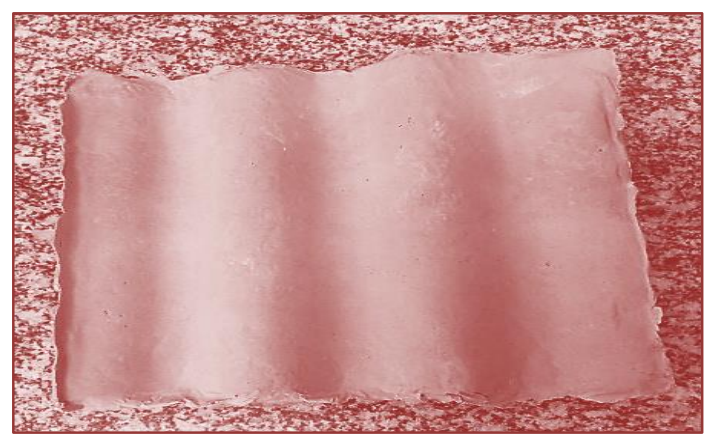

A fim de avaliar as propriedades dos corpos de prova, os ensaios de altura da onda e espessura foram realizados utilizando um paquímetro. Para a densidade foram retiradas amostras dos corpos de prova, e estas avaliadas com auxílio de uma proveta. Já na avalição da permeabilidade foi utilizado um tubo de PVC com $30 \mathrm{~mm}$ de altura, preenchido com água por 24 horas. Finalmente, o ensaio de absorção de água, consistiu em manter o corpo de prova submerso em água por 24 horas. Todos os ensaios foram realizados conforme as Normas Brasileiras (NBR's): NBR 15210-1 e NBR 15210-12 de 2005, NBR 1557-5, NBR 7581 e NBR 7581-2. 


\section{RESULTADOS E DISCUSSÃO}

A tabela 1 apresenta o resumo das NBR's e os resultados para cada ensaio realizado em triplicata. Diante dos resultados do ensaio de Absorção de Água percebe-se que a telha cuja composição era apenas de fibra de Sisal, apresentou maior teor de absorção, associado à superfície externa aberta da fibra, como apresentado por PERSSON (1984).

Tabela 1: Resumos das NBR's e resultados para cada ensaio realizado em triplicata

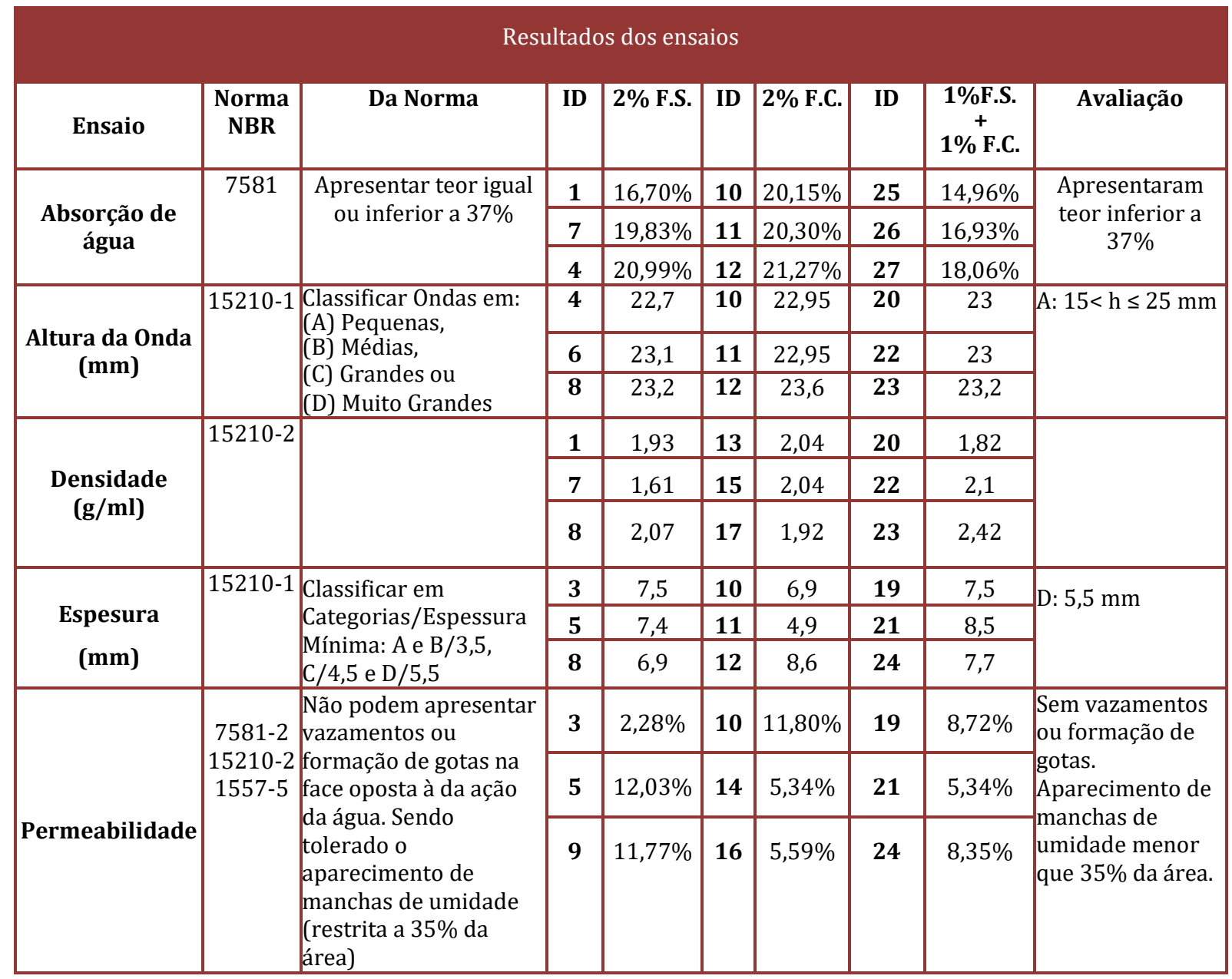

Legenda: ID: Identificação dos Corpos de Prova F.S. :Fibra de Sisal F.C.: Fibra de Coco

No ensaio de Permeabilidade observou-se manchas de até 12,03\% nos corpos de prova, entretanto, em teor bem menor que o permitido pelo pela legislação, inferior a $35 \%$ da área. Resultados similares foram apresentados por TONOLI (2006), com a utilização de fibras de sisal. Segundo PERSSON (1984), isto se deve às características das fibras escolhidas, como estrutura fechada e resistência à umidade apresentada pela fibra de coco (ISAIA,2017). Segundo PERSSON (1984), ISAIA (2017), por apresentarem comprimentos, diâmetros das fibrilas, estrutura da superfície, além de teor de celulose e lignina bem distintos, percebeu-se que a associação de ambas potencializou positivamente os resultados com números bem menores que o permitido pelos parâmetros vigentes, neste caso, inferior a 37\%.

Para a análise de altura da onda, a mesma se enquadra dentro do tamanho "A" presente na NBR 15210-1, classificada como ondas pequenas. 0 resultado já era esperado visto que a mesma foi fabricada em molde definido previamente.

\section{CONCLUSÕES}

A substituição de Fibras sintéticas utilizadas em substituição ao amianto é de confecção viável para os três tipos de telhas. Os ensaios realizados demonstram que todos os corpos de prova atenderam à legislação. 
Destaca-se melhores resultados para as telhas, cuja composição é de Fibras de Sisal + Coco, o que pode estar associado a junção das diferentes características dos dois tipos de Fibras.

\section{REFERÊNCIAS}

[1] AlCANTARA, M. A. M.; MELlO, A.B. A. e ALBUQUERQUE, M.C. F.. A influência potencial das cinzas de casca de arroz em argamassas auto adensáveis: casos da resistência mecânica e da absorção d'água. Matéria (Rio J.) [online]. 2018, vol.23, n.3, e12153. Epub 18-Out-2018. ISSN 1517-7076.

[2] ASSOCIAÇÃO BRASILEIRA DE NORMAS TÉCNICAS. NBR 7581, Telha ondulada de fibrocimento, Rio de Janeiro, 1993.

[3] ASSOCIAÇÃO BRASILEIRA DE NORMAS TÉCNICAS. NBR 7581-2, Telha ondulada de fibrocimento - Parte 2: Ensaios (em substituição à ABNT NBR 5642:1993 - Telha de fibrocimento - Verificação da impermeabilidade), Rio de Janeiro, 2012.

[4] ASSOCIAÇÃO BRASILEIRA DE NORMAS TÉCNICAS. NBR 15210, Telha ondulada de fibrocimento sem amianto e seus acessórios - Parte 1: Classificação e requisitos, Rio de Janeiro, 2014.

[5] ASSOCIAÇÃO BRASILEIRA DE NORMAS TÉCNICAS. NBR15210-2, Telha ondulada de fibrocimento sem amianto e seus acessórios Parte 2: Ensaios, Rio de Janeiro, 2016.

[6] ASSOCIAÇÃO BRASILEIRA DE NORMAS TÉCNICAS.NBR 15575-5, Edificações habitacionais - Desempenho. Parte 5: Requisitos para os sistemas de cobertura, Rio de Janeiro, 2013.

[7] GHAVAMI, K. Eco-construction and infrastructure, RIO3 - World Climate \& Energy Event, 1-5 December 2003, Rio de Janeiro, Brazil.

[8] ISAIA, G. C. Materiais de Construção Civil e Princípios de Ciência e Engenharia de Materiais Volume 2. $3^{3}$ ed. São Paulo, IBRACON, 2017.

[9] PERSSON, H. e SKARENDAHL, A. Natural fibre concrete for roofing sheets and other purposes. In: Sarec report. Natural fibre concrete. Stockholm: Sarec, 1984. cap.1, p.8-64.

[10] STF, STF declara inconstitucionalidade de dispositivo federal que disciplina uso do amianto crisotila. Disponível em: <http://www.stf.jus.br/portal/cms/verNoticiaDetalhe.asp? $=353599 \&$ caixaBusca $=\mathrm{N}$ >. Acesso em: 18 mar. 2019.

[11] TONOLI, G. H. D., Aspectos produtivos e análise de desempenho do fibrocimento sem amianto no desenvolvimento de tecnologia para telhas onduladas. Dissertação, Faculdade de Zootecnia e Engenharia de Alimentos. Universidade de São Paulo, Pirassununga, 2006. 


\section{Capítulo 23}

Sobrevivência e viabilidade de patógenos emergentes em meio aquático

\section{David Américo Nakagawa \\ Claudia Telles Benatti}

Resumo : Patógenos emergentes, em especial vírus, são agentes infecciosos causadores de doenças que podem culminar em surtos, epidemias e pandemias. Eles constituem um risco constante a saúde pública global, ameaçando a sociedade e alarmando para a necessidade de desdobramento de tecnologias de enfrentamento. Este trabalho é configurado num estudo qualitativo de revisão narrativa de 37 publicações, entre nacionais e internacionais, com informações sobre a sobrevivência e viabilidade de agentes patológicos emergentes de veiculação hídrica que representem riscos à saúde humana, em especial vírus. Como resultado, ele relaciona os principais agentes patológicos presentes em meio aquático e reúne informações sobre fatores de influência na sobrevida e reprodução dos patógenos identificados, além de descrever os principais métodos de detecção, concentração, inativação e controle dos mesmos, reportados pela literatura mais recente. Além disso, este artigo enfatiza a importância do acesso universal ao saneamento e a necessidade da continuidade do desenvolvimento de conhecimento científico para a base de dados sobre os patógenos emergentes e dados de qualidade da água, como medida de vigilância e controle.

Palavras-Chave: Patógenos emergentes. Meio aquático. Sobrevivência e viabilidade viral. 


\section{INTRODUÇÃO}

Mundo afora, diversas doenças afetam a população humana. Enquanto algumas são amplamente conhecidas pela ciência e, por consequência, seu combate já é bem determinado, outras surgem constantemente. Há ainda aquelas que não eram mais motivo de preocupação, mas que acabam retornando e causando problemas de ordem pública. Tais doenças infecciosas podem ser classificadas de acordo com o seu comportamento epidemiológico em dois tipos: doenças emergentes (novas ou recentemente identificadas) e reemergentes (reincidentes). Ambas relacionadas a agentes patológicos infecciosos (EPSTEIN, 1995).

Patógenos emergentes infecciosos transmissores de enfermidades podem ser definidos como aqueles que surgiram recentemente, ou estão aumentando rapidamente em incidência e/ou faixa geográfica, e aqueles cujas rotas de transmissão foram reconhecidas a pouco tempo. 0 surgimento destes patógenos está relacionado com uma complexidade de fatores entre o hospedeiro, o próprio patógeno e o ambiente natural de proliferação. No mundo globalizado, a circulação de micróbios é facilitada pela circulação humana e interferência do homem na composição dos ambientes, fazendo com que agentes infecciosos consigam espalhar-se com facilidade e rapidez. Entre os microorganismos, os vírus são os mais propícios a tornarem-se patógenos emergentes, pois são capazes de se adaptar não apenas por mutação, mas também por recombinação e rearranjo, podendo infectar novos hospedeiros e se adequar a novos ambientes com eficiência (LA ROSA et al., 2012).

Mesmo com o avanço no controle de agentes infecciosos no último século, as doenças transmissíveis ainda representam riscos significativos para a saúde pública. Dentre as principais doenças de alto risco a população global, pode-se afirmar que boa parte está diretamente ligada a doenças infecciosas como, por exemplo, a gripe pandêmica, o HIV, a dengue ou a malária. Portanto, as doenças infecciosas emergentes causadas por novos organismos patogênicos são motivo de grande preocupação. A Organização Mundial da Saúde (OMS) relata que desde os anos 1970, mais de 1500 novos patógenos foram descobertos e quase 40 novas doenças infecciosas foram identificadas. Muitas delas impactaram severamente as comunidades, com vários surtos importantes ocorrendo nos últimos 20 anos, incluindo síndrome respiratória aguda grave (SARS) (2002-2003), Ebola (2014-2016), gripe H1N1 (gripe suína) (2009-2010) , Zika virus (20152016) e COVID-19 (2019-2020) (SIMS, 2020).

O contágio por patógenos de veiculação hídrica pode acontecer principalmente após o consumo de água potável contaminada, ou de alimentos, incluindo desde peixes e frutos marinhos, até frutas, vegetais ou leguminosas cultivadas em solos irrigados com água de reuso sem o tratamento adequado. Os patógenos virais emergentes também podem ser transmissíveis por meio de água de recreação poluída (MARQUES, 1991; WYN-JONES e SELLWOOD, 2001).

Pessoas acometidas de infecções virais podem excretar uma enorme quantidade de partículas virais por grama de fezes. Consequentemente, as concentrações de vírus nas águas residuais que recebem matéria fecal podem ser altas. Este nível de contaminação pode variar de acordo com fatores climáticos, infraestrutura sanitária, da prevalência de infecções virais e das características dos vírus em circulação. Os sistemas de tratamento de águas residuais, mesmo quando funcionando adequadamente, removem em torno de 20 a $80 \%$ dos vírus, permitindo que uma carga viral significativa seja liberada na descarga de efluentes e espalhada no ambiente, sendo transportada pelas águas subterrâneas, pelas águas estuarinas, pelas águas do mar e pelos rios. A concentração de vírus na água pode variar significativamente em tempo e espaço, dependendo se a fonte poluidora é contínua ou o resultado de um influxo repentino de contaminação fecal. E mesmo quando há uma concentração relativamente baixa de vírus na água, esses microrganismos apresentam riscos à saúde, uma vez que têm doses infecciosas muito baixas $(10$ a 100 viriões), de modo que mesmo algumas partículas virais na água podem representar riscos para as populações circundantes. (OKOH, 2010; PAYMENT, 1986; OTTOSON et al., 2006; LA ROSA et al., 2012).

O surgimento de doenças emergentes pode também estar sendo facilitado pela degradação ambiental. Num cenário habitual, a migração de um patógeno para novos locais não garante sua sobrevivência. Sabese que a maior parte das introduções não culminam em colonizações porque as espécies não encontram um ambiente natural apropriado e morrem. Um patógeno intruso precisa encontrar um meio adequado e uma população hospedeira receptiva. Em geral, isso é mais fácil em regiões de baixa diversidade biológica, onde o transmissor encontra menos competição com as espécies nativas. Como é comum que em habitats alterados pelas atividades humanas (ou naturais) os predadores e competidores sejam eliminados ou dissipados devido a degradação do ambiente, criam-se oportunidades para novas espécies se instalarem (PIGNATTI, 2004). 


\section{OBJETIVOS}

Considerando a relevância do assunto para questões de saúde pública, o objetivo deste trabalho é revisar informações sobre a sobrevivência e viabilidade de agentes patológicos emergentes de veiculação hídrica que representem riscos à saúde humana, em especial vírus. Para tanto, pretende-se: 1) relacionar os principais agentes patológicos emergentes de veiculação hídrica; 2) reunir informações sobre fatores de influência na dinâmica da sobrevivência e reprodução dos patógenos identificados; 3) descrever os principais métodos, recentemente utilizados, de detecção, concentração, inativação e controle dos agentes; 4) relacionar a presença dos patógenos e as alterações ambientais com possíveis riscos à saúde humana.

\section{METODOLOGIA}

Este artigo configura um estudo qualitativo de revisão narrativa para discutir o estado da arte do assunto definido pela questão levantada. É composto por uma análise da literatura disponível, sem estabelecer uma metodologia rigorosa e replicável. Este método permite a aquisição e atualização do conhecimento sobre a temática específica, evidenciando novas abordagens, estudos e subtemas que têm recebido maior ou menor ênfase na literatura selecionada (VOSGERAU e ROMANOWSK, 2014).

Durante o processo de levantamento de informações, realizou-se uma busca avançada por material de leitura nas bases de dados PubMed, Scopus, Web of Science e Google Scholar. As buscas foram feitas com base em palavras-chave, composições ou termos que remetessem à "sobrevivência e viabilidade de agentes patológicos emergentes de veiculação hídrica que representem riscos à saúde humana", como exemplos: "patógenos emergentes", "sobrevivência e viabilidade de patógenos em meio aquático", "vírus de veiculação hídrica", entre outras. Ao finalizar as pesquisas em cada base, as referências duplicadas foram descartadas. '

Limite de tempo: Inicialmente, foram selecionados trabalhos publicados entre 2015 e 2020. Todavia, a partir da leitura dos materiais selecionados, outras leituras fizeram-se necessárias, para um maior entendimento dos assuntos. Em muitos casos, materiais "clássicos", de publicação anterior a este período, precisaram ser consultados e anexados dentre as referências bibliográficas.

Idiomas: Foram selecionados artigos escritos em inglês, português ou francês.

As buscas iniciais resultaram em um total de 67 arquivos selecionados. Após terem sido recuperadas as informações-alvo, realizou-se a leitura dos títulos e resumos, ocorrendo a exclusão de 28 publicações. Dentre as causas para a exclusão, destacam-se: duplicidade de referências, irrelevância, divergência entre as áreas de interesse e baixo impacto da publicação. Na sequência, fez-se a leitura completa dos demais textos. A partir daí, prosseguiu-se com a análise da fundamentação teórica dos estudos e a observação das características gerais dos artigos, tais como ano de publicação e língua, seguido de seus objetivos. Por fim, realizou-se a apreciação da metodologia aplicada, resultados obtidos e discussão. Especificamente, para analisar a produção científica identificada, não se utilizaram técnicas qualitativas e/ou quantitativas específicas de tratamento de dados, tendo sido feita a análise de cada um dos textos, tomando notas e fichamento de seu conteúdo e pontos relevantes a serem observados e reproduzidos em síntese.

\section{RESULTADOS}

\subsection{PATÓGENOS VIRAIS TRANSMITIDOS PELA ÁGUA}

Os vírus entéricos são aqueles presentes no trato gastrintestinal humano e que, após transmissão por via fecal-oral, podem causar infecções ou enfermidades em indivíduos susceptíveis (WYN-JONES; SELLWOOD, 2001). Os vírus transmitidos pela água pertencem às famílias Caliciviridae (norovírus), Picornaviridae (enterovírus e vírus da hepatite A) e Adenoviridae (adenovírus). Todos esses patógenos virais foram detectados em fontes de esgoto, águas superficiais e subterrâneas e água potável em todo o mundo (LA ROSA et al. 2012). A Tabela 01 apresenta os principais vírus infecciosos e algumas de suas características como a taxonomia, a forma de transmissão, os principais sintomas apresentados pelos infectados e as possíveis complicações na saúde dos mesmos. 
Quadro 1 - Patógenos virais transmitidos pela água

\begin{tabular}{|c|c|c|c|c|}
\hline VÍRUS & TAXONOMIA & TRANSMISSÃO & SINTOMAS & COMPLICAÇÕES \\
\hline Norovírus & $\begin{array}{l}\text { não-envelopado, } \\
\text { RNA de fita simples }\end{array}$ & $\begin{array}{l}\text { fecal-oral (ingestão de } \\
\text { água contaminada, } \\
\text { consumo de alimentos } \\
\text { contaminados ou } \\
\text { contato direto com } \\
\text { superfícies } \\
\text { contaminados); pessoa } \\
\text { para pessoa }\end{array}$ & $\begin{array}{l}\text { vômitos, diarreia, } \\
\text { febre leve, dor } \\
\text { abdominal, cólicas e } \\
\text { náuseas }\end{array}$ & $\begin{array}{l}\text { gastroenterite, } \\
\text { encefalopatia, } \\
\text { coagulação } \\
\text { intravascular } \\
\text { disseminada, } \\
\text { convulsões, } \\
\text { enterocolite } \\
\text { necrosante, síndrome } \\
\text { do intestino irritável } \\
\text { pós-infecciosa e } \\
\text { convulsões infantis. }\end{array}$ \\
\hline Enterovírus & $\begin{array}{l}\text { não-envelopado, } \\
\text { RNA de fita simples }\end{array}$ & $\begin{array}{l}\text { água contaminada; } \\
\text { pessoa para pessoa }\end{array}$ & $\begin{array}{l}\text { febre, mal-estar, dor } \\
\text { de garganta, vômito, } \\
\text { erupções cutâneas e } \\
\text { doenças do trato } \\
\text { respiratório superior, } \\
\text { gastroenterite aguda }\end{array}$ & $\begin{array}{l}\text { meningite, encefalite, } \\
\text { poliomielite e } \\
\text { miocardite, mialgia, } \\
\text { síndrome de Guillain- } \\
\text { Barré, hepatite e } \\
\text { conjuntivite }\end{array}$ \\
\hline Hepatitis A vírus & $\begin{array}{l}\text { não-envelopado, } \\
\text { RNA de fita simples }\end{array}$ & $\begin{array}{l}\text { fecal-oral, água } \\
\text { contaminada }\end{array}$ & $\begin{array}{l}\text { febre, mal-estar, } \\
\text { anorexia, náusea, } \\
\text { desconforto } \\
\text { abdominal, icterícia }\end{array}$ & $\begin{array}{l}\text { dano hepático; } \\
\text { hepatite fulminante } \\
\text { (falência hiperaguda } \\
\text { do fígado) }\end{array}$ \\
\hline Adenovirus & $\begin{array}{l}\text { envelopado, DNA de } \\
\text { fita dupla }\end{array}$ & $\begin{array}{l}\text { água contaminada, } \\
\text { esgoto }\end{array}$ & $\begin{array}{l}\text { infecções do trato } \\
\text { respiratório superior e } \\
\text { inferior, } \\
\text { gastroenterite, } \\
\text { pneumonia, infecção } \\
\text { do trato urinário, } \\
\text { conjuntivite, hepatite, } \\
\text { miocardite e encefalite }\end{array}$ & $\begin{array}{l}\text { doença grave ou com } \\
\text { risco de vida em } \\
\text { imunocomprometidos, } \\
\text { crianças e idosos }\end{array}$ \\
\hline Hepatitis E vírus & $\begin{array}{l}\text { não-envelopado, } \\
\text { RNA de fita simples }\end{array}$ & $\begin{array}{l}\text { fecal-oral, água } \\
\text { contaminada }\end{array}$ & $\begin{array}{l}\text { mal-estar, anorexia, } \\
\text { dor abdominal, } \\
\text { artralgia, febre e } \\
\text { icterícia }\end{array}$ & $\begin{array}{l}\text { mortalidade em } \\
\text { gestantes }\end{array}$ \\
\hline Influenza vírus & $\begin{array}{l}\text { envelopado, RNA de } \\
\text { fita simples }\end{array}$ & $\begin{array}{l}\text { pessoa para pessoa; } \\
\text { contato direto com } \\
\text { aves infectadas; água } \\
\text { contaminada por fezes } \\
\text { de aves }\end{array}$ & gripe & $\begin{array}{l}\text { Infecção aguda do } \\
\text { sistema respiratório }\end{array}$ \\
\hline Coronavírus & $\begin{array}{l}\text { envelopado, RNA de } \\
\text { fita simples }\end{array}$ & $\begin{array}{l}\text { pessoa para pessoa; } \\
\text { fecal-oral; potencial: } \\
\text { esgoto; ventilação; } \\
\text { água da torneira e } \\
\text { águas residuais }\end{array}$ & resfriado comum & $\begin{array}{l}\text { síndrome respiratória } \\
\text { aguda grave (SARS) }\end{array}$ \\
\hline Polyomaviruses & $\begin{array}{l}\text { não-envelopado, } \\
\text { RNA de fita dupla }\end{array}$ & $\begin{array}{l}\text { água contaminada por } \\
\text { fezes e urina }\end{array}$ & assintomático & $\begin{array}{l}\text { tumor nos rins e } \\
\text { cérebro em } \\
\text { imunocomprometidos }\end{array}$ \\
\hline Picobirnavirus & $\begin{array}{l}\text { não-envelopado, } \\
\text { RNA de fita dupla }\end{array}$ & $\begin{array}{l}\text { água contaminada por } \\
\text { fezes }\end{array}$ & gastroenterite & desconhecidas \\
\hline Papillomaviruses & $\begin{array}{l}\text { não-envelopado, } \\
\text { RNA de fita dupla }\end{array}$ & $\begin{array}{l}\text { água contaminada; } \\
\text { sexual; vertical (mãe } \\
\text { para filho) }\end{array}$ & $\begin{array}{l}\text { verrugas } \\
\text { palmoplantares, } \\
\text { verrugas orais e } \\
\text { verrugas genitais }\end{array}$ & $\begin{array}{l}\text { câncer cervicais, } \\
\text { genitais, de laringe, } \\
\text { oral e de pulmão }\end{array}$ \\
\hline
\end{tabular}




\subsection{ROTA DE TRANSMISSÃO, SOBREVIDA E VIABILIDADE EM MEIO AQUÁTICO}

Ainda que, para muitos agentes infecciosos, a principal via de transmissão seja através de gotículas de saliva e contatos próximos, a transmissão fecal-oral é a via mais conhecida de infecção por vírus entéricos transmitidos pela água. Embora outros excrementos como a urina e secreta (suor) também possam desempenhar um papel na transmissão de vírus pela água, em geral são menos estudados. A transmissão através de aerossóis e gotículas derivadas da água contaminada também pode levar à contaminação. Quando espalhados no ambiente aquático, mesmo vírus envelopados não perdem sua capacidade de sobrevivência, mutação ou eventual transmissão. Eles não podem se replicar fora dos tecidos de seus hospedeiros, mas podem sobreviver no ambiente por longos períodos de tempo, mais do que a maioria das bactérias intestinais, tornando inseguro confiar apenas nos padrões bacteriológicos de qualidade da água. Embora não se multipliquem por serem parasitas intracelulares obrigatórios, os vírus podem permanecer viáveis (potencialmente infectantes) durante certo tempo na água. Até o momento, acreditase que o coronavírus, por exemplo, pode sobreviver por apenas alguns dias no ambiente, fora das células vivas, mas seria tempo suficiente para alcançar outros organismos com "viabilidade". Nos estudos sobre a sobrevivência, uma persistência variável de vírus foi identificada, dependendo do tipo de vírus, tipo de amostra de água e temperatura do ambiente aquático. Embora esses estudos sejam dispersos e incomparáveis entre si, eles indicam que o coronavírus humano, e similares, são menos resistentes do que vírus não envelopados em ambientes aquáticos. E ainda, que sua sobrevivência geralmente é reduzida em águas com poluição orgânica e microbiana, onde a inativação viral aumenta com o aumento de temperaturas e presença de outros microrganismos concorrentes (KAMPF et al., 2020; CARDUCCI et al., 2020; MARQUES, 1991; FONG e LIPP, 2005; DE RODA HUSMAN e BARTRAM, 2007).

Duan et al. (2003) encontraram uma redução na infecciosidade de SARS-CoV até um nível indetectável após 3 ou 4 dias, em temperatura ambiente. Durante um período de 21 dias de estudo, Gundy et al. (2009) compararam a sobrevivência de HCoV-229E e FIVP com a do poliovírus 1 em água da torneira e águas residuais filtradas e não filtradas. Na água da torneira, o coronavírus mostrou uma diminuição abrupta em 10 dias a $23^{\circ} \mathrm{C}$ e, por um período mais longo (estimado $>100$ dias), em $4^{\circ} \mathrm{C}$. A persistência do SARS-CoV infeccioso foi reduzida em 2 dias, a $20^{\circ} \mathrm{C}$, em todos os tipos de água testados por Wang et al. (2005), mas a $4^{\circ} \mathrm{C}$ aumentou para 14 dias, que foi a duração de todo o período de seu estudo. Assim sendo, os estudos demonstraram que, ainda que curto, o período em que o vírus se mantém ativo no meio aquático é suficiente para alertar aos riscos decorrentes. Como já citado, a variabilidade da temperatura do ambiente tem intensa influência sobre a sobrevida do agente patológico. Um bom exemplo deste fator seria o de Casanova et al. (2009), que relataram um declínio sútil na infectividade de TGEV e MHV após mais de 15 dias em água bruta a $25^{\circ} \mathrm{C}$, mas onde a sobrevida foi fortemente prolongada a $4^{\circ} \mathrm{C}$, chegando a 49 dias. Em outro estudo subsequente, Casanova e Weaver (2015) demonstraram um declínio mais rápido da infecciosidade nas águas residuais, e pontuaram que, em amostras de esgoto pasteurizado, os vírus ficaram inativos muito mais rapidamente, indicando o possível papel de outros microrganismos (bactérias e protozoários) na inativação viral. A redução na concentração de vírus envelopados também foi significativamente mais lenta nas águas residuais a $10^{\circ} \mathrm{C}$ em comparação aos $25^{\circ} \mathrm{C}$, e os fagos não envelopados sobreviveram por mais tempo em todas as condições e matrizes.

Temperaturas mais altas significam uma redução mais rápida da população viral, assim como o aumento da luz solar implica uma maior concentração de antimicrobianos ou níveis mais altos de oxigênio. Tais fatores ambientais inativam os vírus por meio de ação direta ou indireta, em uma parte ou em toda estrutura viral: genoma, capsídeo ou envelope, se presente. Contudo, as populações virais também possuem mecanismos de resistência, geralmente envolvendo proteção física contra efeitos nocivos, dificultando sua inativação. Dentre estes mecanismos, destacam-se: agregação, adesão ou até mesmo internalização dentro de estruturas vivas (PINOT; VIALETTE, 2018).

\subsection{DETECÇÃO E CONCENTRAÇÃO DE PATÓGENOS}

Estudos sobre a detecção de vírus são importantes para auxiliar instituições e autoridades na tomada de decisão estratégica sobre a saúde pública. Sabendo que os vírus humanos transmitidos pela água são excretados nas fezes dos indivíduos infectados e transmitidos pela via fecal-oral, incluindo água e alimentos contaminados, muitos estudos se concentraram até o momento na detecção de vírus entéricos em vários tipos de ambientes aquáticos, como águas residuais brutas e tratadas, águas superficiais, subterrâneas, marítimas e até água potável tratada. Entretanto, de forma geral, os vírus estão presentes nos ambientes aquáticos em baixas concentrações. Assim, eles devem ser concentrados em volumes menores antes das aplicações de qualquer método de detecção. 0 desenvolvimento e a aplicação de 
métodos para concentrar vírus têm contribuído significativamente para a detecção de diversos vírus usando ensaios de cultura em células ou moleculares (FONG e LIPP, 2005; GERBA et al., 2013; IKNER et al., 2012; CASHDOLLAR e WYMER, 2013; MARQUES, 1991).

Os métodos convencionais para a detecção e quantificação de vírus entéricos no ambiente aquático são baseados em cultura de células ou de base molecular, e envolvem duas etapas principais: concentração de vírus e detecção de alvo. Uma variedade de técnicas de concentração de vírus está disponível, otimizada para diferentes matrizes ambientais, que aproveitam as propriedades físico-químicas dos vírus (adsorção/eluição) e utilizam separação de tamanho de partícula, como por exemplo, a filtração. Mas a eficiência do isolamento e concentração do vírus varia amplamente, com valores de 5 a $92 \%$. Embora os métodos baseados em cultura possam determinar a concentração de vírus entéricos infecciosos, eles são caros, demandam muito tempo em laboratório, atrasam resultados e não detectam com eficiência muitos dos vírus mais preocupantes transmitidos pela água, como por exemplo, norovírus humano, que ainda não foi obtido na cultura de células. Por esses motivos, os métodos moleculares, particularmente os quantitativos, tornaram-se cada vez mais populares. Os métodos mais comuns são baseados em amplificação e incluem: (transcrição reversa) (RT-) qPCR e amplificação baseada em sequência de ácido nucleico (NASBA). A limitação dos métodos qPCR e NASBA incluem tempo de laboratório, despesa de equipamento e reagentes, co-concentração de inibidores (por exemplo, húmicos, orgânicos), seleção de vírus alvo, especificidade do iniciador, padrões e controles adequados. Apesar das tentativas de remover vírus não infecciosos antes dos métodos moleculares baseados em amplificação, não existe ainda um método molecular eficaz para diferenciar vírus entéricos infecciosos e não infecciosos (SYMONDS e BREITBART, 2015; GIRONES et al., 2010; JOFRE e BLANCH, 2010).

Haramoto et al (2018) descreveram os progressos realizados no desenvolvimento de métodos de concentração e detecção de vírus entéricos humanos na água, discutindo suas aplicações para proporcionar uma melhor compreensão da prevalência dos vírus em vários tipos de água em todo o mundo. Os autores relataram que inúmeros métodos para concentrar vírus foram desenvolvidos, mas nenhum método isolado parece ser totalmente eficaz na concentração de todos os vírus entéricos humanos de interesse, nos vários tipos de amostras de água. Portanto, é importante monitorar as eficiências de recuperação dos vírus estudados, especialmente para vírus emergentes, porque as recuperações podem variar bastante entre as amostras. A concentração simultânea de vírus, protozoários e bactérias em uma única amostra de água também é de grande interesse para uma melhor compreensão da prevalência de patógenos transmitidos pela água. Eles ressalvam que, apesar dos grandes esforços, às vezes os vírus não são detectados nas amostras de água testadas. Mas esses dados, chamados "não detectáveis", devem ser considerados para estudos posteriores mais apropriados, visto que, no passado, muitos estudos desconsideraram a possibilidade de uma detecção falha e apresentaram dados que hoje se mostram invalidados. Por fim, concluem que há um número crescente de estudos ambientais que pesquisaram a diversidade genética de genomas virais, incluindo os genomas de novos vírus, em amostras de água e que, além das técnicas convencionais de sequenciamento de clonagem, os métodos NGS (nextgeneration sequencing) desenvolvidos recentemente foram utilizados com sucesso para vírus selecionados, como adenovírus e norovírus, sugerindo um papel contínuo em pesquisas futuras. Como se espera que a distribuição genotípica de vírus no esgoto bruto reflita a incidência real de casos infecciosos virais locais, é necessário realizar mais vigilância ambiental em mais regiões do mundo, o que reforça a sugestão de outros atores, a serem citados neste trabalho, sobre a importância do monitoramento de águas residuais e/ou de abastecimento.

\subsection{EPIDEMIOLOGIA DE ÁGUAS RESIDUAIS}

Considerando que pessoas infectadas podem espalhar vírus por meio de seus excrementos, seria conveniente avaliar a eficácia e as consequências do tratamento das águas residuais e lodo de esgoto, afim de evitar a disseminação subsequente de patógenos para o ambiente (AVELINO NUNES DELGADO, 2020). Bowser (2020) relatou recentemente a presença de Covid-19 nas fezes de seres humanos. Além disso, Pan et al. (2020) publicaram alguns dos primeiros resultados, também a esse respeito. Adicionalmente, Martínez-Puchol et al. (2020) afirmam que, se os vírus não são totalmente erradicados com os métodos tradicionais, seria necessário repensar uma triagem adicional focada nas águas residuais. Já Nag et al. (2020) sugerem uma triagem adicional no lodo de esgoto, para a avaliação da sobrevivência de bactérias e vírus; enquanto Corsi et al. (2014) e Givens et al. (2016) indicam tal procedimento para águas superficiais e subterrâneas à jusante das estações de tratamento de águas residuais. 
A abordagem da "epidemiologia dos esgotos" tem sido apontada como um meio para monitorar a sobrevivência de patógenos em águas residuais, pois esse conceito de monitoramento passou de um foco inicial em drogas ilícitas (VAN NUIJS et al., 2011) para a visão atual, também chamada de "epidemiologia baseada em águas residuais", abrangendo um amplo conjunto de substâncias nas águas residuais, incluindo partículas virais (DAUGHTON, 2020; SIMS e KASPRZYK-HORDERN, 2020), o que permitiria uma redução drástica no tempo necessário para desenvolver um monitoramento de contaminantes potenciais presentes nos efluentes (MAO et al., 2020).

Indo além, Hart e Halden (2020) desenvolveram um estudo de modelagem computacional e análise de custos associados a "epidemiologia baseada em águas residuais", sugerindo uma ferramenta rápida, barata e potencialmente robusta para rastrear o SARS-CoV-2 / COVID-19. A viabilidade do uso eficaz dessa ferramenta de vigilância emergente exigiria a consideração dos efeitos da temperatura para obter dados informativos consistentes. Os autores advertem que o método não pode substituir os testes clínicos, mas pode servir para alertar as equipes de resposta a emergências sobre a presença de indivíduos infectados nas cidades, áreas de drenagem específicas (grandes áreas subterrâneas) e de grandes centros metropolitanos, ou até o nível do bairro e edifício. O problema é que, como o uso efetivo do monitoramento em larga escala requer acesso a águas residuais que são coletadas, compostas e tratadas centralmente, o uso global da ferramenta, que depende de amostragem de estações de tratamento de águas residuais, fica restrito a cerca de 2,1 bilhões de pessoas ou $27 \%$ da população global que possui este tipo de serviço em suas comunidades. Bilhões de pessoas adicionais poderiam se beneficiar da análise de resíduos humanos, integrando amostras de latrinas na vigilância global da saúde, com um investimento maior em monitoramento de efluentes, através de medidas de saneamento básico.

\subsection{DESINFECÇÃO DE ÁGUA E EFLUENTES}

A oxidação com ácido hipocloroso ou ácido peracético e a inativação por irradiação ultravioleta, bem como o cloro, são considerados os meios tradicionais mais adotados para inativação de vírus. Nas estações de tratamento de águas residuais que utilizam biorreatores de membrana, os efeitos sinérgicos de microrganismos benéficos e a separação física de sólidos em suspensão filtram os vírus concentrados no lodo de esgoto. E ainda, sistemas de ponto de uso ultravioleta com eficiência energética, emissores de luz e diodos podem desinfetar a água antes de entrar no sistema público de tratamento (NADDEO e LIU, 2020).

Em estações de tratamento de água e em estações de tratamento de esgoto, o projeto e operação dos processos de desinfecção de água e efluentes são baseados nos patógenos mais resistentes presentes. Para desinfetantes oxidantes (cloro, monocloramina e dióxido de cloro), os vírus mais resistentes e nãoenvelopados, revestidos com capsídeo protéico, como o vírus da hepatite A e os coxsackieviruses, historicamente têm sido usados para definir os requisitos operacionais e de design da desinfecção. Para a irradiação UV, vírus de DNA de fita dupla, como adenovírus, têm sido historicamente usados para definir os requisitos operacionais e de projeto para desinfecção (AUSTRALIAN GOVERNMENT DEPARTMENT OF HEALTH, 2020).

As alterações ambientais afetam de forma geral a distribuição das doenças infecciosas. A dinâmica entre o desenvolvimento econômico, condicionamento ambiental e de saúde pública é muito tênue e sensível. Intervenções abruptas como a da expansão da fronteira agrícola, do desmatamento rápido ou da degradação dos entornos dos mananciais, podem provocar o deslocamento de vetores ou de agentes etiológicos, atingindo desde populações das comunidades localizadas próximas da área até periferias das grandes cidades ou populações inteiras. A escassez de políticas públicas integradas e a deficiência de medidas voltadas à promoção da Saúde Humana (incluindo a promoção do saneamento básico e conservação de ambientes naturais estratégicos) culminam em um cenário de prospectos sombrios para o futuro (PIGNATTI, 2004).

\subsection{IMPACTO GLOBAL DAS DOENÇAS E DESAFIOS DE SANEAMENTO}

É complexo avaliar o impacto global das doenças transmitidas pela água e difícil de mensurar as suas consequências diretas e indiretas. Em parte, devido à grande variedade de sintomas associadas aos vírus transmitidos pela água, a períodos longos de latência e ao fato de que, em diversos casos, doenças relacionadas à água também podem ser transmitidas por outras vias. Outro fator é que as evidências de contaminação da água nem sempre estão disponíveis no momento em que um surto de doença é caracterizado. Isso se deve, principalmente, às dificuldades relacionadas com a detecção de vírus na água. 
Além disso, os dados sobre doenças virais transmitidas pela água são fragmentados, geralmente focados em países, regiões ou patógenos específicos (CRAUN, 2010; LA ROSA et al., 2012).

Naddeo e Liu (2020) consideram que a globalização também apresenta novos riscos à saúde, bem como desafios para sistemas globalizados. Os autores pontuam que em um cenário responsável e ideal, os governos e empresariado dos países desenvolvidos devem apoiar e financiar os sistemas de água e saneamento nos países em desenvolvimento, onde os sistemas de água e saneamento são frequentemente insuficientes ou ineficazes e o risco de encontrar novos vírus é muito alto, até mesmo como forma de proteger seus próprios cidadãos, visto que o trânsito internacional é contínuo.

Ressalta-se que, apesar do progresso na tecnologia de tratamento de água e esgoto, as doenças transmitidas pela água continuam a ter consequências de longo alcance na saúde pública, em todos os países. Desse modo, utilizar dados de qualidade da água, características específicas de patógenos, dados de prevalência e dados de exposição, essas informações levarão a uma melhor compreensão dos riscos à saúde pública global relacionados aos sistemas de água, gerando melhores métodos de controle e sondagem (LA ROSA et al., 2012).

O novo coronavírus certamente não será o último vírus a surgir e a ameaçar seriamente a saúde pública global. Portanto, pesquisadores de ciência e engenharia devem adotar uma abordagem ampla e de longo prazo para entender a dinâmica dos vírus que se espalham pelo ambiente, bem como entender como os fatores ambientais moldam possíveis rotas de transmissão de vírus. De forma que, seja qual for a identidade do vírus que causa o próximo grande surto, será possível fornecer descrições mais informadas de sua persistência e recomendações sobre como mitigar sua disseminação (WIGGINTON e BOEHM, 2020).

\section{CONCLUSÕES}

A intensidade com que surgem novas ameaças microbianas à qualidade da água e à saúde das populações é preocupante. Tais patógenos emergentes e reemergentes são desafios globais para a saúde pública, visto que as suas ocorrências e persistências em meio aquático representam um risco à saúde humana devido ao contato de populações sem saneamento básico com águas contaminadas de corpos hídricos que recebem efluentes sem quaisquer tratamentos prévios. Algumas das principais causas que culminaram no cenário atual são a diminuição das barreiras internacionais proporcionada pelo fluxo das pessoas devido à globalização; as mutações e as evoluções genéticas dos patógenos; a degradação ambiental; e a falta de infraestrutura de saneamento básico e tecnologias de enfrentamento.

Um problema tão grande requer esforços conjuntos de instituições governamentais, agências reguladoras, meio acadêmico, empresas privadas e cidadãos para mudar esse quadro. Percebe-se que é papel das autoridades investir na ciência para o desenvolvimento de tecnologia para fornecer métodos válidos e reproduzíveis para a detecção, monitoramento e controle de patógenos transmitidos pela água, e outras vias, a fim de determinar a extensão dos riscos e as estratégias de mitigação da contaminação dos ambientes aquáticos. E cabe também ao poder público investir em infraestrutura de tratamento de águas de abastecimento e efluentes, garantindo o acesso universal ao saneamento básico para a população, como medida preventiva de saúde pública. Somado a isso, deve-se considerar um compromisso de todos contribuir para conservação dos recursos naturais e a preservação dos ambientes aquáticos, principalmente os arredores de mananciais e o perímetro de aquíferos e reservatórios.

Em outras palavras, são necessários esforços gerais em várias frentes, e ainda muita pesquisa para determinar formas de reduzir os efeitos de ameaças infecciosas, com ênfase na melhora da técnica de vigilância, controle e combate das agentes patológicos. Isso inclui aprimorar também as formas de investigação e notificação de surtos nos níveis local e nacional, em todo o mundo, para identificar as causas dos surtos, avaliar a dinâmica dos agentes, e entender os fatores ambientais que contribuem para esses surtos. Mesmo com todo avanço tecnológico atualmente edificado, apenas a continuidade da estruturação da base de dados sobre a qualidade da água e os mecanismos dos agentes patológicos permitirá uma melhor compreensão dos riscos à saúde pública global que tenham relação com os sistemas de água e ambientes aquáticos naturais. 


\section{REFERÊNCIAS}

[1] Carducci, A., Federigi, I., Liu, D., Thompson, J. R., Verani, M., Making Waves: Coronavirus detection, presence and persistence in the water environment: State of the art and knowledge needs for public health, Water Research, Volume 179, 2020, 115907, ISSN 0043-1354, https://doi.org/10.1016/j.watres.2020.115907. Disponível em: <http://www.sciencedirect.com/science/article/pii /S0043135420304449>. Acesso em: ago. 2020.

[2] Australian Government Department of Health. 2020. Coronavirus (COVID-19) health alert. Disponível em: <https://www.health.gov.au/news/health-alerts/novel-coronavirus-2019-ncov-healthalert>. Acesso em: ago. 2020.

[3] Bowser, A.D., 2020. Coronavirus may cause environmental contamination through fecal shedding. Medscape Medical News. Disponível em: <https://www.medscape.com/viewarticle/926390>. Acesso em: ago. 2020.

[4] Casanova, L.M., Rutala, W.A., Weber, D.J., Sobsey, M.D., 2009. Survival of surrogate coronaviruses in water. Water Res. 43 (7), 1893e1898.

[5] Casanova, L.M., Weaver, S.R., 2015. Inactivation of an enveloped surrogate virus in human sewage. Environ. Sci. Technol. Lett. 2 (3), 76e78. https://doi.org/10.1021/ acs.estlett.5b00029.

[6] Corsi, S.R., Borchardt, M.A., Spencer, S.K., Hughes, P.E., Baldwin, A.K., 2014. Human and bovine viruses in the Milwaukee River watershed: hydrologically relevant representation and relations with $\begin{array}{lllll}\text { environmental } & \text { variables. } & \text { Sci. } & \text { Total } & \text { Environ. }\end{array}$ https://doi.org/10.1016/j.scitotenv.2014.05.072.

[7] Craun GF, Brunkard JM, Yoder JS, Roberts VA, Carpenter J, Wade T, et al. Causes of outbreaks associated with drinking water in the United States from 1971 to 2006. Clin Microbiol Rev 2010;23(3):507-28. http://dx.doi.org/10.1128/CMR.00077-09.

[8] Daughton, C., 2020. The international imperative to rapidly and inexpensively monitor community-wide Covid-19 infection status and trends. Sci. Total Environ. 138149. https://doi.org/10.1016/j.scitotenv.2020.138149.

[9] de Roda Husman AM, Bartram J. Chapter 7 Global Supply of Virus-Safe Drinking Water. Perspect Med Virol. 2007;17:127-162. doi:10.1016/S0168-7069(07)17007-5

[10] Duan, S.M., Zhao, X.S., Wen, R.F., Huang, J.J., Pi, G.H., Zhang, S.X., Han, J., Bi, S.L., Ruan, L., Dong, X.P., 2003. Stability of SARS coronavirus in human specimens and environment and its sensitivity to heating and UV irradiation. Biomed. Environ. Sci. 16, $246 \mathrm{e} 255$.

[11] Epstein PR. Emerging diseases and ecosystem instability: new threats to public health. Am J Public Health. 1995;85(2):168-172. doi:10.2105/ajph.85.2.168

[12] Fong TT, Lipp EK. Enteric viruses of humans and animals in aquatic environments: health risks, detection, and potential water quality assessment tools. Microbiol Mol Biol Rev 2005;69(2):357-71. http://dx.doi.org/10.1128/MMBR.69.2.357-371.2005

[13] Givens, C.E., Kolpin, D.W., Borchardt, M.A., Duris, J.W., Moorman, T.B., Spencer, S.K., 2016. Detection of hepatitis E virus and other livestock-related pathogens in Iowa streams. Sci. Total Environ. 566-567, 1042-1051. https://doi.org/10.1016/j.scitotenv.2016.05.123.

[14] Gundy, P.M., Gerba, C.P., Pepper, I.L., 2009. Survival of coronaviruses in water and wastewater. Food Environ. Virol. 1 (1), 10e14.

[15] Haramoto, Eiji \& Kitajima, Masaaki \& Katayama, Hiroyuki \& Ito, Takafumi \& Ohgaki, S. (2009). Development of virus concentration methods for detection of koi herpesvirus in water. Journal of fish diseases. 32. 297-300. 10.1111/j.1365-2761.2008.00977.

[16] J. Jofre, A. R. Blanch, Feasibility of Methods Based on Nucleic Acid Amplification Techniques to Fulfil the Requirements for Microbiological Analysis of Water Quality, J. Appl. Microbiol. 2010, 109 (6), 1853- 1867.

[17] Kampf, G., Todt, D., Pfaender, S., Steinmann, E., 2020. Persistence of coronaviruses on inanimate surfaces and their inactivation with biocidal agents. J. Hosp. Infect. 104 (3), 246-251. https://doi.org/10.1016/j.jhin.2020.01.022. 
[18] Kang Mao, Kuankuan Zhang, Wei Du, Waqar Ali, Xinbin Feng, Hua Zhang, The potential of wastewater-based epidemiology as surveillance and early warning of infectious disease outbreaks, Current Opinion in Environmental Science \& Health, Volume 17, 2020, Pages 1-7, ISSN 2468-5844, https://doi.org/10.1016/j.coesh.2020.04.006. Disponível em: <http://www.sciencedirect.com/science/article/pii/ S2468584420300337>. Acesso em: ago. 2020.

[19] Krista R. Wigginton and Alexandria B. Boehm. Environmental Science \& Technology 202054 (7), 3736-3739. DOI: 10.1021/acs.est.0c01476

[20] La Rosa, G., Fratini, M., della Libera, S., Iaconelli, M., Muscillo, M. Emerging and potentially emerging viruses in water environments. Ann Ist Super Sanita. 2012;48(4):397-406. doi: 10.4415/ANN_12_04_07. PMID: 23247136.

[21] Marques E. A importância do estudo da presença e detecção de vírus em água e alimentos. In: IV Simpósio Brasileiro de Microbiologia de Alimentos, 2 a 5 abr. 1991; Goiânia/GO. p.129-130.

[22] Mao, Ling, et al. Neurologic manifestations of hospitalized patients with coronavirus disease 2019 in Wuhan, China. JAMA neurology 77.6 (2020): 683-690.

[23] Martínez-Puchol, S., Rusiñol, M., Fernández-Cassi, X., Timoneda, N., Itarte, M., Andrés, C., Antón, A., Abril, J.F., Girones, R., Bofill-Mas, S., 2020. Characterisation of the sewage virome: comparison of NGS tools and occurrence of significant pathogens. Sci. Total Environ. 713, 136604. https://doi.org/10.1016/j.scitotenv.2020.136604.

[24] Naddeo, Vincenzo \& Liu, Haizhou. 2020. Editorial Perspectives: 2019 novel coronavirus (SARSCoV-2): what is its fate in urban water cycle and how can the water research community respond?. Environmental Science: Water Research \& Technology. 10.1039/D0EW90015J.

[25] Nag, R., Whyte, P., Markey, B.K., O'Flaherty, V., Bolton, D., Fenton, O., Richards, K.G., eCummins, E., 2020. Ranking hazards pertaining to human health concerns from land application of anaerobic digestate. Sci. Total Environ. 710, 136297. https://doi.org/10.1016/j.scitotenv.2019.136297.

[26] Okoh AI, Sibanda T, Gusha SS. Inadequately treated wastewater as a source of human enteric viruses in the environment. Int J Environ Res Public Health 2010;7(6):2620-37. http://dx.doi.org/10.3390/ijerph7062620

[27] Olga E. Hart, Rolf U. Halden, Computational analysis of SARS-CoV-2/COVID-19 surveillance by wastewater-based epidemiology locally and globally: Feasibility, economy, opportunities and challenges, Science of The Total Environment, Volume 730, 2020, 138875, ISSN 0048-9697, https://doi.org/10.1016/j.scitotenv.2020.138875.

[28] Ottoson J, Hansen A, Bjorlenius B, Norder H, Stenstrom TA. Removal of viruses, parasitic protozoa and microbial indicators in conventional and membrane processes in a wastewater pilot plant. Water Res 2006;40(7):1449-57. Hhttp://dx.doi.org/10.1016/j.watres.2006.01.039

[29] Pan, Y., Zhang, D., Yang, P., Poon, L.L.M., Wang, Q., 2020. Viral load of SARS-CoV-2 in clinical samples. Lancet Infect. Dis. https://doi.org/10.1016/S1473-3099(20)30113-4

[30] Payment P, Fortin S, Trudel M. Elimination of human enteric viruses during conventional waste water treatment by activated sludge. Can J Microbiol 1986;32(12):922-5. http://dx.doi.org/10.1139/m86170

[31] Pignatti, Marta G. (2004). Saúde e ambiente: as doenças emergentes no Brasil. Ambiente \& Sociedade, 7(1), 133-147. https://doi.org/10.1590/S1414-753X2004000100008

[32] Pinon, A., \& Vialette, M. (2018). Survival of Viruses in Water. Intervirology, 61(5), 214-222. https://doi.org/10.1159/000484899

[33] R. Girones, M. A. Ferrús, J. L. Alonso, J. Rodriguez-Manzano, et al., Molecular Detection of Pathogens in Water - the Pros and Cons of Molecular Techniques, Water Res. 2010, 44 (15), 4325- 4339.

[34] Sims, N., Kasprzyk-Hordern, B., 2020. Future perspectives of wastewater-based epidemiology: monitoring infectious disease spread and resistance to the community level. Environ. Int. 105689. https://doi.org/10.1016/j.envint.2020.105689

[35] Symonds, E.M. and Breitbart, M. (2015), Affordable Enteric Virus Detection Techniques Are Needed to Support Changing Paradigms in Water Quality Management. Clean Soil Air Water, 43: 8-12. doi:10.1002/clen.201400235 
[36] Ivan Nuijs, A.L.N., Castiglioni, S., Tarcomnicu, I., Postigo, C., Alda, Lopez de, Neels, M.H., Zuccato, E., Barcelo, D., Covaci, A., 2011. Illicit drug consumption estimations derived from wastewater analysis: a critical review. Sci. Total Environ. 409 (19), 3564-3577. https://doi.org/10.1016/j.scitotenv.2010.05.030

[37] Vosgerau, D. S. A. R. \& Romanowski, J. P. (2014) Estudos de revisão: implicações conceituais e metodológicas. Revista de Diálogo Educacional, (14)41, 165-189.

[38] Wang, X.W., Li, J.S., Guo, T.K., Zhen, B., Kong, Q.X., Yi, B., Li, Z., Song, N., Jin, M., Xiao, W.J., 2005. Concentration and detection of SARS coronavirus in sewage from Xiao Tang Shan hospital and the 309th hospital. J. Virol. Methods 128, 156e161.

[39] Wyn-Jones AP, Sellwood J. A review: Enteric viruses in aquatic environment. J Appl Microbiol 91: 945-962, 2001. 


\title{
Capítulo 24
}

\section{Estudo do crescimento de microalgas em meio de cultivo CHU e dejeitos suínos}

\author{
Beatriz Jacob Furlan \\ Pedro Henrique Siqueira Zatta \\ Valeria Cristina Pereira Antezana \\ Lauber de Souza Martins \\ André Bellin Mariano
}

Resumo: 0 desenvolvimento tecnológico e o crescimento da população mundial trouxe consigo o aumento da demanda de energia. Não somente o conforto e bem estar da população, mas também as necessidades e serviços essenciais estão diretamente ligados a geração e distribuição de energia. Transportes, comunicações, educação e serviços de saúde tem se tornado cada vez mais eficientes mas os benefícios por eles trazidos só serão desfrutados se a demanda de energia exigida por tais avanços for gerado de modo sustentável. Sustentabilidade significa promover o desenvolvimento da sociedade atual sem comprometer os recursos naturais e o desenvolvimento das gerações futuras. Diante dessa problemática, desenvolvimento e aumento de geração de energia versus preservação de recursos naturais, microalgas têm recebido grande atenção da comunidade científica mundial. Biomassa, biodiesel e hidrogênio podem ser extraído de microalgas e usados em usinas de potência, motores a combustão interna, carros elétricos dentre outros. 0 presente estudo apresenta uma análise comparativa do crescimento de microalgas usando dois diferentes meios de cultivos, CHU e dejeto suíno. O Brasil é o $4^{\circ}$ produtor mundial e o $5^{\circ}$ consumidor mundial carne suína, sendo a região Sul o maior produtor nacional. Essa imensa produtividade apresenta um grande impacto ambiental uma vez que apenas 15\% dos produtores nacionais tratam ou reaproveitam 0 dejeto gerado pela suinocultura. Nosso estudo demonstra que o uso de dejetos suínos como meio de cultivo de microalgas é uma prática viável e promissora, mitigando os impactos ambientais da suinocultura e contribuindo para a geração de energia de modo sustentável.

Palavras-chave: microalgas; dejetos de suinocultura; biocombustíveis, biomassa, hidrogênio. 


\section{INTRODUÇÃO}

No final do século XX, o termo sustentabilidade apresentou grande destaque, apresentando como principal objetivo a utilização dos recursos naturais finitos, mas com propostas e técnicas mitigadoras para, a longo prazo, preservar e consequentemente não afetar as demandas de recursos naturais futuros (CONTANZA, 1994). $O$ interesse no cultivo de microalgas para a geração de biocombustíveis tem crescido nos últimos anos como uma alternativa ao uso de combustíveis fósseis e um modo de promover sustentabilidade. A comunidade científica tem se dedicado a várias frentes de pesquisa focadas no desenvolvimento de estratégias para o cultivo, controle, extração de biomassa e produção de biodiesel e hidrogênio (TAHER, 2013).

As microalgas são microrganismos unicelulares que apresentam a facilidade em se desenvolver ambientes adversos, dentre eles meios aquáticos salinos ou salobras. Possuem a característica de serem autótrofos, produzem seu próprio alimento, apresentando uma eficiência fotossintética relevante, além da eficiência da fixação do dióxido de carbono $\left(\mathrm{CO}_{2}\right)$ (TAHER, 2013). A suinocultura no Brasil vem se desenvolvendo e alcançando importante posição no cenário internacional, segundo o Departamento de Agricultura dos Estados Unidos (USDA), o Brasil ocupa o 4o lugar na produção de carne suína, atrás da China, União Européia e o próprio Estados Unidos. Em termos absolutos, os brasileiros consumiram 2.7 milhões de toneladas de carne suína em 2013, alcançando a 5a posição nesse ranking. Segundo o IBGE, a região sul do Brasil é responsável pela maior produção nacional de suínos (Sergio De Zen et al., 2014).

No campo agropecuário, os resíduos gerados pela suinocultura é um dos relevantes pontos problemáticos que devem ser levados em consideração para o desenvolvimento e sustentabilidade desta cultura. Os dejetos de suínos, apresentam altas concentrações de matéria orgânica, nitrogênio e fósforo (CARPENTER et al., 1998). Infelizmente, apenas $15 \%$ dos produtores de suínos realizam procedimentos para o tratamento ou reaproveitamentos desses dejetos (EMBRAPA, 2005). Quando não há um processo adequado para o tratamento do dejeto e há o contato com o ambiente, este se caracteriza como um passivo ambiental acarretando problemas de eutrofização em rios e corpos hídricos, contaminação de mananciais, solos e degradação de terras férteis devido a sobrecarga de fertilizantes (APSIMON, KRUSE e BELL, 1987).

0 aumento descontrolado de matéria orgânica em corpos hídricos, consomem oxigênio, através da oxidação bioquímica. Quando substâncias são lançados, aumenta a capacidade de autodepuração do corpo d'água, acarretando um decréscimo na concentração do oxigênio dissolvido, inviabilizando o seu desenvolvimento natural (VALENTE, 1997). Há estudos que comprovam que os dejetos provenientes da suinocultura, apresentam maior potencialidade de contaminação. Um desses estudos foi realizado entre o dejeto de suínos e o esgoto doméstico, também muito impactante quando não tratado e destinado incorretamente no meio ambiente. Quando é avaliada a demanda de bioquímica de oxigênio (DBO), resultando na carga orgânica presentes nesses efluentes, o resíduo suíno apresenta uma demanda de $40.000 \mathrm{mg} . \mathrm{L}^{-1}, 200$ vezes maior que o esgoto comum, com uma DBO de $200 \mathrm{mg}^{-1} \mathrm{~L}^{-1}$ (TECPAR, 2002). Passivos ambientais desenvolvem interferes negativos quando destinados incorretamente no ambiente. Logo, a partir dessa problemática, estudos têm sido desenvolvidos para a aplicação de ações mitigatórias e reduzir o impacto ambiental.

O presente estudo realiza análises laboratoriais em dois diferentes meios de cultivo, o de dejetos suínos e de meio sintético, CHU. A espécie de microalga com a qual se trabalhou foi a Tetradesmus obliquus, nativa da região de Curitiba - PR, Brasil. O objetivo consiste em avaliar qualitativamente os parâmetros para o desenvolvimento de uma alternativa sustentável para a destinação e reutilização dos dejetos produzidos. As análises foram realizadas no laboratório de biotecnologia do Núcleo de Pesquisa e Desenvolvimento de Energia Autossustentável (NPDEAS), localizado no campus Centro Politécnico da Universidade Federal do Paraná (UFPR) na cidade de Curitiba - PR, por uma equipe interdisciplinar de discentes dos Departamentos de Engenharia Ambiental, Engenharia de Bioprocessos e Biotecnologia e Química.

\section{MATERIAIS E MÉTODOS}

Detalhamos a seguir o método de preparação dos cultivos, medição dos parâmetros relevantes, contagem de células e medição de absorbância. 


\subsection{CULTIVO DE T. OBLIQUUS E COMPOSIÇÃO DO MEIO CHU}

De 0,9 a 1,8 L de meio CHU são produzidos e devidamente esterilizados por calor úmido em replicata. Realizamos em ambiente esterilizado a inoculação com 10\% de cultivo saturado/em começo de declínio celular em volume. Diz-se necessário um cultivo em fim de fase log devido ao estado metabólico voltado ao crescimento e ao maior número de células por volume atingível. Os cultivos são deixados em aeração filtrada constante em regime de dia/noite a $21^{\circ} \mathrm{C}$ em ambiente controlado. 0 volume de água que evapora diariamente é compensado com água deionizada e autoclavada em ambiente estéril. Medidas de absorbância e contagem celular são feitas diariamente. A composição do meio CHU encontra-se na tabela seguir:

Tabela 1 - Composição química do meio CHU

\begin{tabular}{|c|c|c|}
\hline Componente & Fórmula & Concentraçăo final $\left(\mathrm{g} \cdot \mathrm{L}^{-1}\right)$ \\
\hline Nitrato de sódio & $\mathrm{NaNO}_{3}$ & 0,25 \\
\hline Cloreto de cálcio di-hidratado & $\mathrm{CaCl}_{2} .2 \mathrm{H}_{2} \mathrm{O}$ & 0,025 \\
\hline Sulfato de magnésio hepta-hidratado & $\mathrm{MgSO}_{4} .7 \mathrm{H}_{2} \mathrm{O}$ & 0,075 \\
\hline Fosfato de potássio dibásico & $\mathrm{KH}_{2} \mathrm{PO}_{4}$ & 0,075 \\
\hline Fosfato de potássio monobásico & $\mathrm{K}_{2} \mathrm{HPO}_{4}$ & 0,175 \\
\hline $\begin{array}{c}\text { Cloreto de sódio } \\
\text { EDTA (Ácido etilenodiamino tetra- } \\
\text { acético) }\end{array}$ & $\begin{array}{c}\mathrm{NaCl} \\
\mathrm{C}_{10} \mathrm{H}_{16} \mathrm{~N}_{2} \mathrm{O}_{8}\end{array}$ & $\begin{array}{r}0,025 \\
0,05\end{array}$ \\
\hline Hidróxido de sódio & $\mathrm{KOH}$ & 0,031 \\
\hline Sulfato ferroso hepta-hidratado & $\mathrm{FeSO}_{4.7} 7 \mathrm{H}_{2} \mathrm{O}$ & 0,005 \\
\hline Ácido bórico & $\mathrm{H}_{3} \mathrm{BO}_{3}$ & 0,01142 \\
\hline Sulfato de zinco hepta-hidratado & $\mathrm{ZnSO}_{4} .7 \mathrm{H}_{2} \mathrm{O}$ & $8,82 \times 10^{-5}$ \\
\hline Cloreto de manganês tetra-hidratado & $\mathrm{MnCl}_{2} .4 \mathrm{H}_{2} \mathrm{O}$ & $1,44 \times 10^{-5}$ \\
\hline Molibdato de sódio di-hidratado & $\mathrm{NaMoO}_{4}, 2 \mathrm{H}_{2} \mathrm{O}$ & $7,1 \times 10^{-6}$ \\
\hline Sulfato de cobre penta-hidratado & $\mathrm{CuSO}_{4} .5 \mathrm{H}_{2} \mathrm{O}$ & $1,57 \times 10^{-5}$ \\
\hline Nitrato de cobalto hexa-hidratado & $\mathrm{Co}\left(\mathrm{NO}_{3}\right)_{2} \cdot 6 \mathrm{H}_{2} \mathrm{O}$ & $4,9 \times 10^{-6}$ \\
\hline
\end{tabular}

(Fonte: SANTOS, 2016).

\subsection{CULTIVO COMPARADO DE T. OBLIQUUS EM MEIO CHU E MEIO COM DEJETO SUÍNO}

Para um experimento com duas triplicatas (uma com meio CHU e outra com 10\% de dejeto suíno dissolvido em água) foram preparados 4,86 L de meio CHU como informado acima, divididos igualmente em 3 replicatas. De maneira análoga, prepara-se 4,32 L de água deionizada também dividida em 3 frascos. Separadamente, $1 \mathrm{~L}$ de dejeto suíno é preparado e filtrado para remover particulado sólido. Todos os meios são esterilizados. Em ambiente esterilizado e próprio à manipulação, 0,18 L de dejeto suíno é adicionado aos 1,44 L de água destilada para formar um meio com 1,62 L. Por fim, são adicionados 0,18 L de um mesmo cultivo de microalgas em todos os frascos, de forma que haja ao final 10\% de inóculo (v/v) em cada triplicata.

\subsection{MEDIÇÃO DIÁRIA DO DESEMPENHO DO CULTIVO}

Diariamente, colhe-se 5,50 mL de cada replicata para análises. Usamos 2,0 mL para contagem em Câmara de Neubauer e medição de absorbância a $450 \mathrm{~nm}$ e 3,0 mL para análise de peso seco do cultivo. Caso não seja possível realizar o procedimento de medição de peso seco no próprio dia, as amostras são congeladas.

\subsubsection{CONTAGEM EM CÂMARA DE NEUBAUER}

Um pequeno volume de amostra (de 15 a $40 \mu \mathrm{L}$ ) de amostra é colocado na câmara em que é observado com um aumento de 400x em microscópio ótico. Dos quadrados interiores ( $\left.\mathrm{S}=0,04 \mathrm{~mm}^{2}\right)$ são contadas as células em 5 deles, renova-se a amostra $3 \mathrm{x}$, de forma que a contagem seja feita em triplicata, tira-se a média e o valor é multiplicado $5.10^{6} \mathrm{~L}^{-1}$ para se chegar num valor de cél/ml de cultivo. 


\subsubsection{MEDIÇÃO DE ABSORBÂNCIA A 450 NM}

A amostra diária de 2,0 mL é diluída a $6 \mathrm{ml}$ em função do volume da cubeta (aprox. 1,5 ml). 0 equipamento é ligado e é estabelecido um branco (absorbância zero) com água deionizada. Em seguida um pequeno volume de amostra é usado para ambientalizar a cubeta (deve-se utilizar a mesma que foi utilizada para o branco) e evitar erros em função de água residual. A cubeta é preenchida até que pelo menos toda a parte inferior do recipiente por onde o feixe de luz passa esteja cheia. Dessa forma garantimos que toda luz que passa pela cubeta obrigatoriamente passa pela solução. Em seguida, o conteúdo da cubeta é descartado após a medida e o processo é repetido para um total de três medições usando a amostra restante, ou seja, cada amostra é medida três vezes.

\section{RESULTADOS E DISCUSSÕES}

Foram realizadas 2 bateladas de experimentos, rodando concomitantemente entre si, com cultivos à base nutricional de meio $\mathrm{CHU}$, e a base de dejeto à $10 \%$. A partir deles, foram obtidas diversas curvas de crescimentos, apresentadas conforme as figuras abaixo. A Figura 1, 2 e 3 apresentam um comparativo entre os conjuntos de dados, respectivamente sendo, contagem celular, absorbância em $540 \mathrm{~nm}$, e densidade celular em g/L. As barras de erro indicam o desvio padrão amostral calculado a partir do conjunto de dados. É válido ressaltar que o desvio padrão amostral da biomassa seca, se tornou desprezível nos dois cultivos, visto que atingiu valores na casa de 0,0006 para o cultivo CHU e 0,0005 para o cultivo com dejetos.

Figura 1 - Unidades de células ( $\times 10^{4} \mathrm{~mL}$ ) do cultivo em meio CHU vs meio em $10 \%$ de dejeto suíno

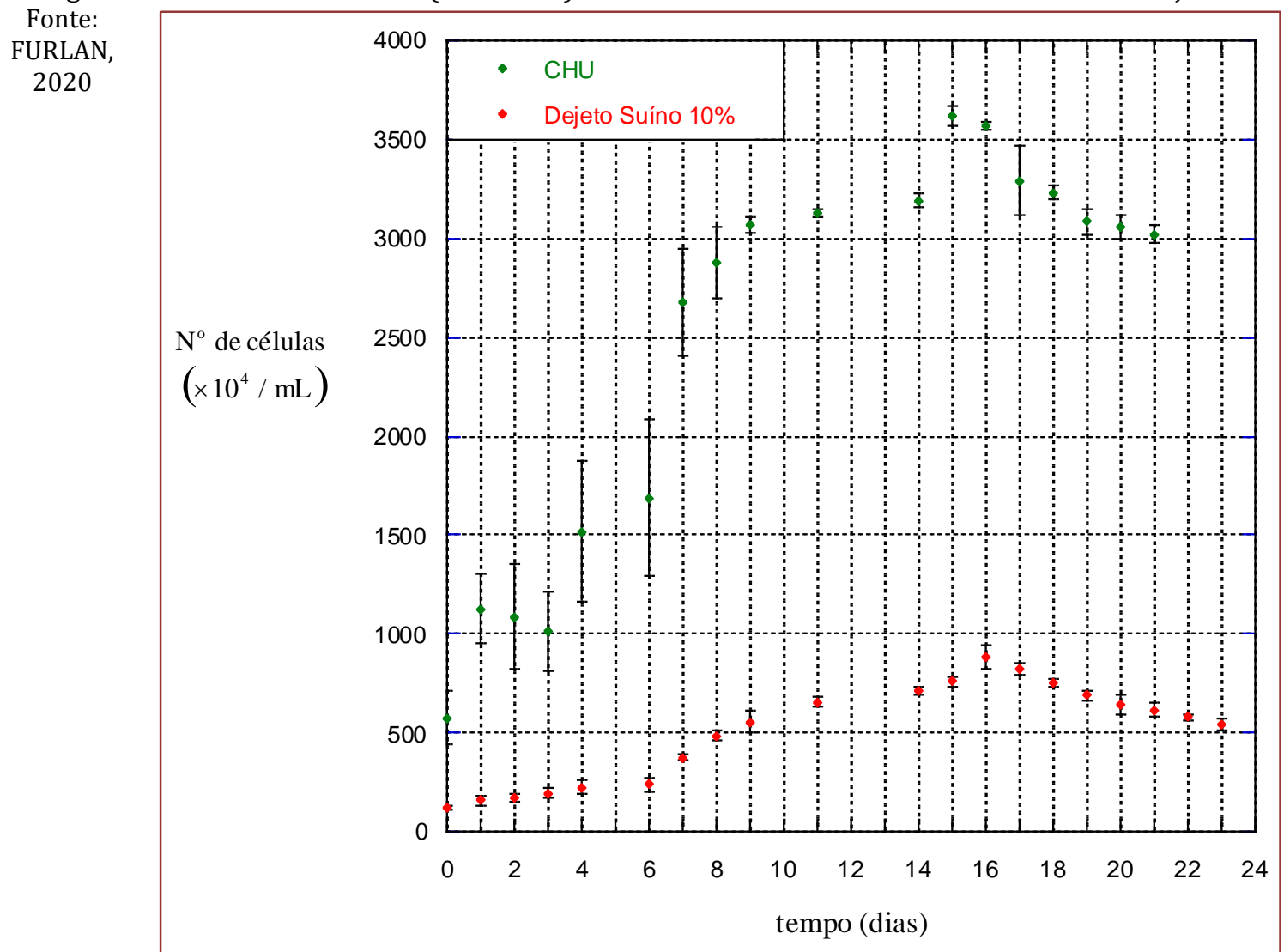


Figura 2 - Absorbância em 540 nm do cultivo em meio CHU vs meio em 10\% de dejeto suíno

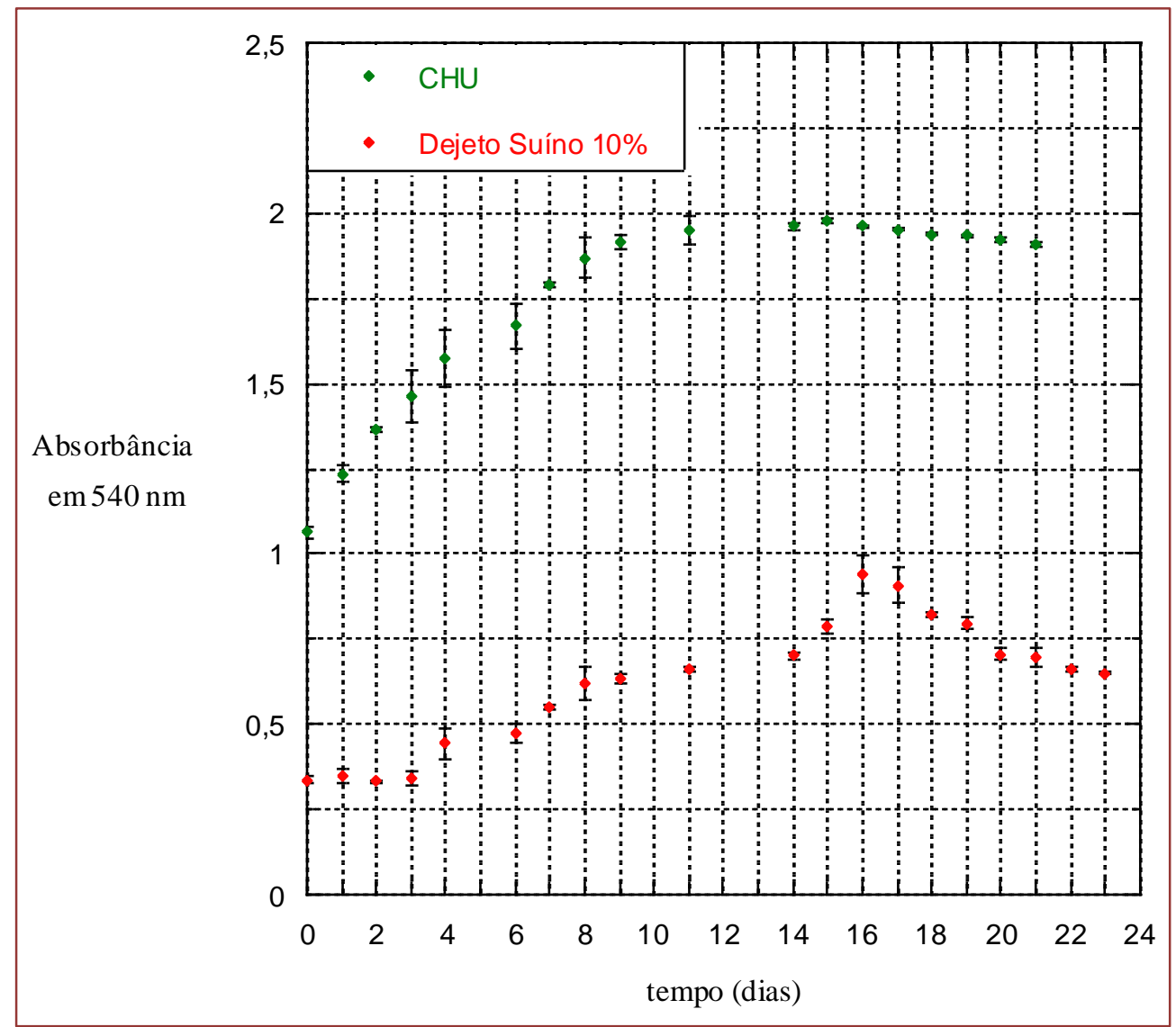

Fonte: FURLAN, 2020).

Figura 3 - Biomassa seca (g/L) em cultivo de meio CHU vs meio em 10\% de dejeto suíno

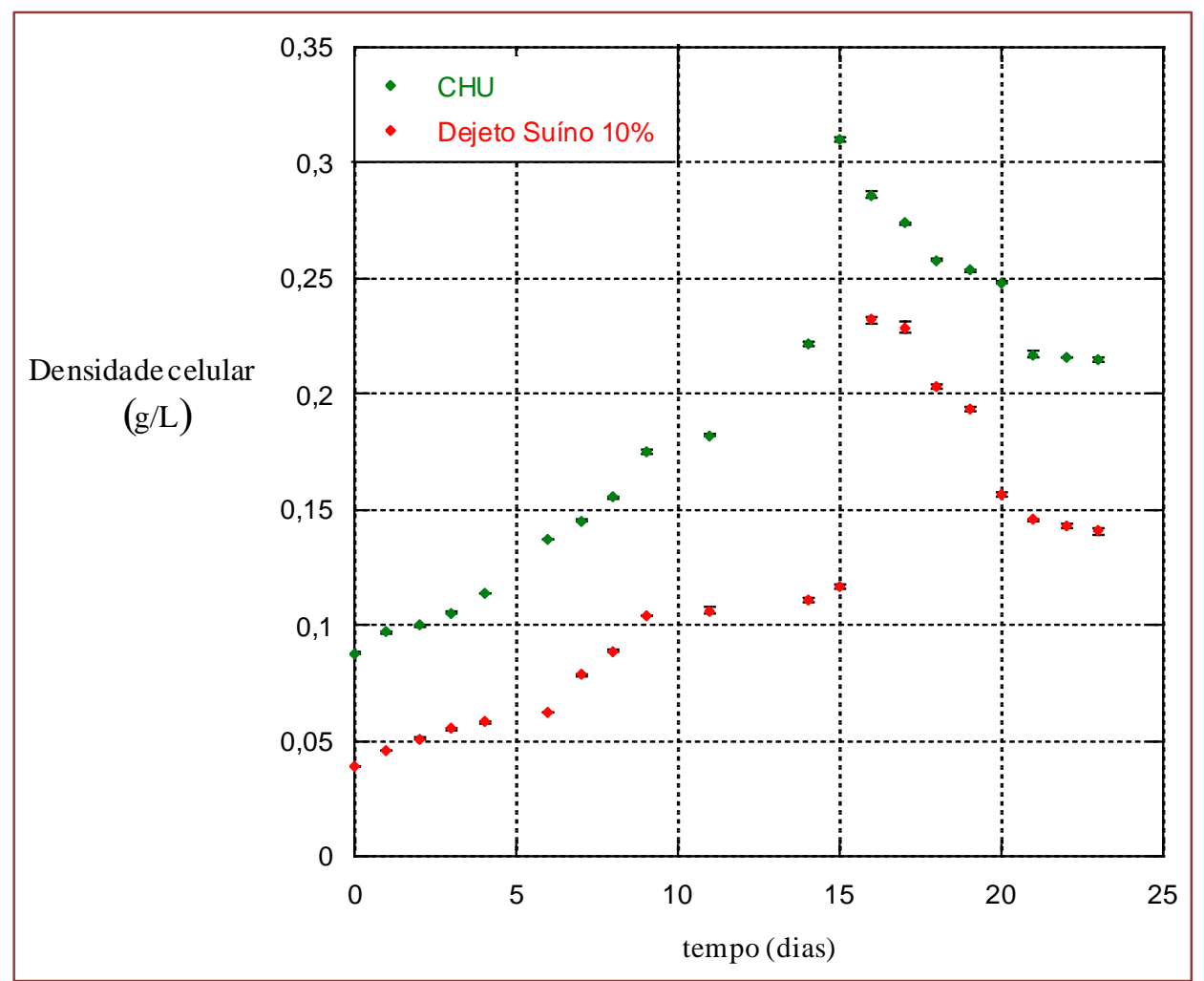

Fonte: FURLAN, 2020). 
Vê-se portanto que para a obtenção de maiores concentrações de biomassa é mais vantajoso o uso de meios químicos. Este cenário pode ser vantajoso em se objetivando a produção de biomoléculas para consumo humano ou de alto valor agregado, que podem equiparar aos custos do meio sintético.

O cultivo com dejeto suíno apresentou um crescimento menor, porém acompanhou o perfil qualitativo do cultivo em meio CHU. 0 crescimento de microalgas em meio em dejeto suíno leva ao tratamento deste rejeito agroindustrial, processo que pode ser vantajoso em seu próprio mérito, como reportado por ACIÉN FERNÁNDEZ, (2018), KHAN, (2018), ZHU, (2019) e STURM, (2011). Dessa forma, a aplicação do dejeto no cultivo de microalgas promove remediação de um problema ambiental por meio do reaproveitamento de rejeitos como insumo nutricional para a produção de bioprodutos (TAHER, 2013), tais como a biomassa seca de microalgas, que é rica em grandes quantidades de proteínas, lipídeos e carboidratos que podem ser extraídos e utilizados posteriormente em diversas aplicações (CHISTI, 2007).

Entretanto, dado que a concentração de dejeto suíno utilizada não foi explorada, pouco pode-se inferir quanto ao rendimento de biomassa em se utilizando outras concentrações, mais experimentos podem ser feitos.

\section{CONSIDERAÇÕES FINAIS}

Portanto percebe-se que o cultivo de microalgas pode ser vantajoso para a remoção de nutrientes de rejeitos agroindustriais, levando a um tratamento inicial destas águas e apresentando crescimento positivo da acumulação de biomassa, esta que pode ser utilizada para fins posteriores. Este processo deve ser mais explorado para concentrações de dejeto suíno variáveis e detalhes de escalonamento para maiores volumes e viabilidade econômica.

\section{AGRADECIMENTOS}

A realização dessa pesquisa se deve graças ao suporte do Núcleo de Pesquisa e Desenvolvimento em Energia Autossustentável - NPDEAS/ UFPR. Além disso, agradecemos ao Programa de Recursos Humanos da ANP - PRH 12.1, gestão FINEP. Agradecimentos também ao CNPq pelo financiamento das bolsas de Iniciação Científica e ao Projeto de Pesquisa 308460/2020-0.

\section{REFERÊNCIAS}

[1] ACIÉN FERNÁNDEZ, F. G.; GÓMEZ-SERRANO, C.; FERNÁNDEZ-SEVILLA, J. M. Recovery of Nutrients From Wastewaters Using Microalgae. Frontiers in Sustainable Food Systems, v. 2, p. 59, 2018. Frontiers Media S.A. Disponível <https://www.frontiersin.org/article/10.3389/fsufs.2018.00059/full>. Acesso em: 16/3/2020.

[2] APSIMON, H.M.; KRUSE, M.; BELL, J.N.B. Ammonia emissions and their role in acid deposition. Atmospheric Environment, v. 21, p. 1939-1946, 1987.

[3] CARPENTER, S.R.; CARACO, N.F.; CORRELL, D.L.; HOWARTH, R.W.; SHARPLEY,

[4] A.N.; SMITH, V.H. Nonpoint pollution of surface waters with phosphorus and nitrogen. Ecological Applications, v. 8, p. 559-568, 1998.

[5] CASTILHO. Eficiência da substituição parcial da adubação química na cultura do milho por biofertilizante a base de dejetos suínos provenientes de biodigestor. 2009. UFSCar. CHISTI, Y. Biodiesel from microalgae. Biotechnology Advances, 1. maio 2007. Elsevier. COSTANZA, R. Economia Ecológica: uma agenda de pesquisa.

[6] EMBRAPA. Introdução a fertilidade do solo. 2005. Embrapa Semi-Árido Sergio De Zen, C. B. O., Iguma, M. D., \& Suínos/Cepea, E. (2014). Gráfico 1. Produção, consumo, importação e exportação de carne suína. Fonte: FAS/USDA (2014). Elaboração: Cepea/Esalq-USP. Centro de Estudos Avançados em Economia Aplicada - www.cepea.esalq.usp.br 1. Informativo CEPEA, 1-4.

[7] KHAN, S. A.; MALLA, F. A.; RASHMI; et al. Potential of wastewater treating Chlorella minutissima for methane enrichment and CO2 sequestration of biogas and producing lipids. Energy, v. 150, p. 153-163, $2018 . \quad$ Pergamon. Disponível em: <https://www.sciencedirect.com/science/article/pii/S0360544218303608?via\%3Dihub>. Acesso em: $22 / 8 / 2019$. 
[8] SANTOS, B. Estratégias para aumentar a produtividade de biomassa de microalgas com carbono orgânico. 2016. Dissertação (Mestrado em Engenharia e Ciência dos Materiais) - UFPR, Curitiba, 2016.

[9] STURM, B. S. M.; LAMER, S. L. An energy evaluation of coupling nutrient removal from wastewater with algal biomass production. Applied Energy, v. 88, n. 10, p. 3499-3506, 2011. Disponível em:<https://linkinghub.elsevier.com/retrieve/pii/S0306261910005763>. Acesso em: 22/8/2019.

[10] TAHER, D. M. Biodiesel de microalgas cultivadas em dejeto suíno biodigerido. 2013. Dissertação (Mestrado em Engenharia e Ciência dos Materiais) - UFPR, Curitiba, 2013. Disponível em: <http://www.pipe.ufpr.br/portal/defesas/dissertacao/224.pdf> Acesso em: 31/7/2020.

[11] TECPAR - Instituto de Tecnologia do Paraná. Manual de Biossistemas Integrados na Suinocultura. Centro de Integração de Tecnologia do Paraná - CITPAR. Telus - Rede Paranaense de Projetos em Desenvolvimento Sustentável. Curitiba, Paraná - 2002. p 140.

[12] VALENTE, J. P. S.; PADILHA, P. M.; SILVA, A. M. M. Oxigênio dissolvido (OD), demanda bioquímica de oxigênio (DBO) e demanda química de oxigênio (DQO) como parâmetros de poluição no ribeirão Lavapés/Botucatu - SP. Eclet. Quím., [S. 1.], vm.22, 1997.

[13] ZHU, L.; LI, S.; HU, T.; et al. Effects of nitrogen source heterogeneity on nutrient removal and biodiesel production of mono- and mix-cultured microalgae. Energy Conversion and Management, v. 201, p. 112144, 2019. Disponível em: <https://doi.org/10.1016/j.enconman.2019.112144>. Acesso em: $16 / 3 / 2020$. 


\section{Capítulo 25}

Indicadores biológicos de qualidade de um latossolo cultivado com soja inoculada com Trichoderma ssp no cerrado do Oeste Baiano

\section{Luan dos Santos Silva \\ Diony Alves Reis \\ Roberto Bagattini Portella \\ Jackson Roberto de Souza Santos \\ Magno Rodrigues de Carvalho Filho}

Resumo: Alternativas sustentáveis de manejo do solo, que auxiliem o crescimento e o desenvolvimento das culturas agrícola no Cerrado são fundamentais. Este trabalho objetivou avaliar o efeito da inoculação da cultura da soja com diferentes microrganismos sobre a Biomassa Microbiana do Solo (BMS), o Carbono Orgânico Total (COT) e o Quociente Microbiano (qMic). Para tanto, em área experimental localizada no município de São Desidério - Bahia, Brasil, amostras de solo com estrutura não preservada foram coletadas em diferentes profundidades, na entrelinha e na linha de plantio de um Latossolo Vermelho Amarelo distrófico, de textura arenosa, para a quantificação dos parâmetros biológicos. Os resultados foram submetidos à análise de variância e as médias comparadas pelo teste de Duncan. Os resultados evidenciam que há efeito da inoculação na linha de plantio sobre a BMS, o COT e o qMic, evidenciando a importância dos microrganismos para o crescimento e o desenvolvimento das plantas, mas principalmente, para promover o a matéria orgânica do solo, contribuindo assim para a qualidade ambiental.

Palavras-chave: Biomassa Microbiana do Solo, Carbono Orgânico Total, Microbiologia do Solo, Qualidade do solo, Sustentabilidade 


\section{INTRODUÇÃO}

A qualidade e a saúde do solo têm despertado o interesse de diferentes setores da sociedade devido às interrelações com a biosfera, a atmosfera, a hidrosfera e a litosfera e devido às suas funções em promover o crescimento e o desenvolvimento das plantas, a saúde dos seres vivos, a qualidade do ar e da água, regular a temperatura do planeta e sequestrar o CO2 atmosférico (Doran e Parkin, 1994; Doran et al., 1998). Nesse sentido, a qualidade ambiental e a manutenção dos ecossistemas terrestres dependem intimamente das transformações da matéria orgânica pela biomassa microbiana do solo (BMS), dos teores de carbono orgânico total (COT) e do quociente microbiano (qMic).

A BMS é a porção viva da matéria orgânica do solo (MOS), constituída por bactérias, fungos, actinomicetos e protozoários, excluindo raízes e animais maiores do que 5 x $103 \mu \mathrm{m} 3$; o COT é o resultado do balando entre os fatores de adição e perda de matéria orgânica no solo, enquanto o qMic é a razão entre a BMS e o COT, evidenciando um ambiente favoráveis ao desenvolvimento dos microrganismos, que podem utilizar a matéria orgânica e promover os teores de C no solo (Gama-Rodrigues e Gama-Rodrigues, 2008; Kaschuk et al., 2010).

0 fungo do gênero Trichoderma ssp. tem sido utilizado como agente de controle biológico e promotor do crescimento e desenvolvimento vegetal, entretanto, a influência destes microrganismos sobre a MOS tem sido negligenciada e poucos estudos têm se dedicado à avaliação dos efeitos da inoculação do Trichoderma ssp sobre a BMS, o COT e o qMic, embora seja reconhecida sua capacidade de degradar a celulose (García-López et al., 2017; Fiorentino et al., 2018).

Portanto, este trabalho parte da hipótese de que a inoculação de soja com Trichoderma ssp. promove modificações na matéria orgânica solo. Assim sendo, este trabalho objetivou avaliar a Biomassa Microbiana do Solo (BMS), o Carbono Orgânico Total (COT) e o Quociente Microbiano (qMic) de um Latossolo Vermelho-Amarelo distrófico cultivado com soja no Bioma Cerrado, Oeste da Bahia, Brasil.

\section{METODOLOGIA}

O estudo foi realizado no distrito de Roda Velha, município de São Desidério, Bahia, Brasil, em área experimental inserida no bioma Cerrado, cujo clima é classificado como do tipo Aw, conforme a classificação climática de Köppen-Geiger (Alvares et al., 2013).

As amostras de solo com estrutura não preservada foram coletadas utilizando uma pá de corte, retiradas na linha e na entrelinha de plantio, nas camadas 0,00 a 0,10 e 0,10 a $0,20 \mathrm{~m}$, de um Latossolo Vermelho Amarelo distrófico, de relevo plano e textura franca-arenosa $\left(804 \mathrm{~g} \mathrm{~kg}^{-1}\right.$ de areia, $74 \mathrm{~g} \mathrm{~kg}^{-1}$ de silte, e $125 \mathrm{~g}$ $\mathrm{kg}^{-1}$ de argila) até a profundidade avaliada.

0 delineamento consistiu em casualização por blocos com 4 repetições, sendo os tratamentos a inoculação de Soja (Glycine max (L.) Merr.) com T1: Trichoderma asperellum + Purpurocillium lilacinus + Pochonia chlamydosporia; T2: T. asperellum e a testemunha T3, sem inoculação de soja cultivada sob plantio convencional.

A Biomassa Microbiana do Solo (BMS), foi quantificada pelo método de fumigação e extração (Vance et al., 1987), utilizando uma amostra de $10 \mathrm{~g}$ de solo e para a fumigação, $1,0 \mathrm{~mL}$ de $\mathrm{CHCl} 3$ foi aplicado diretamente sobre a amostra que ficou incubada por 24 horas em placas de Petri vedadas e em ambiente sem iluminação (De-Polli e Guerra, 2008). Para extração utilizou-se $25 \mathrm{~mL}$ de K2SO4 a 0,5 mol L-1 e 1,0 $\mathrm{mL}$ de $\mathrm{K} 2 \mathrm{Cr} 2 \mathrm{O} 7$ sendo titulada com Fe(NH4)2(SO4)2.6H2O a 0,33 mol L-1 tendo como indicador $\left(\mathrm{C}_{6} \mathrm{H}_{5}\right)_{2} \mathrm{NH}$.

O cálculo da BMS (mg kg-1) foi realizado por meio das Equações:

$$
\mathrm{BMS}=\mathrm{FC} * \mathrm{kc}^{-1}
$$

Onde:

$$
\mathrm{FC}=\mathrm{CSF}-\mathrm{CSNF}
$$


Sendo CSF o teor de C extraído do solo fumigado, CSNF o teor de C extraído do solo não fumigado e kc fator de correção, utilizando o valor de 0,33 (Silva et al., 2007).

$$
\text { CSF ou CSFN }=\frac{\left(V_{b}-V_{a}\right) \cdot M \cdot 0 \cdot 003 \cdot V_{1} \cdot 10^{6}}{P_{s} \cdot V_{2}} \quad \text { Eq. } 3
$$

Em que $\mathrm{Vb}$ - volume (mL) de (NH4)2 Fe(SO4)2.6H20 gasto na titulação da solução do ensaio em branco; Va - volume (mL) de (NH4)2 Fe(SO4)2.6H20 gasto na titulação da solução do ensaio com a amostra; M Molaridade exata do sulfato ferroso amoniacal (0.033); 0,003 - miliequivalente do carbono; V1 - volume do extrator (K2SO4) utilizado; V2 - alíquota pipetada do extrato para a titulação; Ps (g) - massa de solo seco.

O Carbono Orgânico Total (COT) foi determinado por meio da oxidação da matéria orgânica via K2Cr2O7 a 0,0667 mol L-1 em meio sulfúrico e titulado com solução padrão de Fe(NH4)2(SO4) 2.6H20 a 0,1 mol L-1 (Teixeira et al., 2017). Posterior às determinações, o Quociente Microbiano (qMic) foi calculado pela relação entre a BMS e o COT, expresso em porcentagem, Equação 4 (Insam e Domsch, 1988)

$$
\mathrm{qMic}=\left(\frac{\mathrm{BMS}}{\mathrm{COT}}\right) \times 100 \quad \text { Eq. } 4
$$

A normalidade dos dados foi verificada pelo teste de Shapiro-Wilk (W) (n $\leq 200$ ) (Razalli e Wah, 2011). Os tratamentos foram submetidos à análise de variância (Anova) e as médias comparadas pelo teste de Duncan ao nível de significância de 5\%, utilizando-se o software SAS (Statistical Analyses System Institute, 1999).

\section{RESULTADOS E DISCUSSÃO}

Valores de BMS em T1, obtidos na entrelinha de plantio, na camada de 0,00 a 0,10 m, foram maiores e estatisticamente distintos dos observados no T2 e T3, enquanto na camada de 0,10 a $0,20 \mathrm{~m}$ o T2 evidenciou o maior valor de BMS, diferindo estatisticamente do T1 e T3, que foram, de maneira geral, menores do que os observados na linha de plantio do Latossolo avaliado (Tabela 1).

Neste caso, na camada superficial da entrelinha, evidencia-se que o consórcio de microrganismos (T1) promove os valores de BMS advindos naturalmente da diversidade de organismos inoculados, sugerindo, que à medida em que a profundidade aumenta, a diversidade de microrganismos é reduzida, prevalecendo o Trichoderma asperellum sobre Purpureocillium lilacinum e Pochonia chlamydosporia e em relação à comunidade microbiana nativa do solo.

Na linha de plantio, na camada superficial, diferenças estatísticas entre os tratamentos não foram evidenciadas, entretanto, em média, maiores valores foram observados em T2 e T3, contrastando com os dados observados na camada de 0,10 a 0,20 m, onde o T3: testemunha, apresentou o maior valor de BMS e estatisticamente diferente dos observados no T1 e T2. Estes resultados podem estar relacionados à associação microrganismo-raíz, que contribui para a promoção da BMS, à medida que os fungos fornecem nutrientes e água às plantas, em troca de carboidratos exsudados essenciais aos seu crescimento e desenvolvimento, justificando, portanto, os maiores valores de BMS em T2 e T3 na linha quando comparados com os valores da entrelinha. 
Tabela 1. Médias e desvios-padrão da Biomassa Microbiana do Solo avaliada na entrelinha e na linha de plantio de um Latossolo Vermelho-Amarelo distrófico cultivado com Soja inoculada e não inoculada com microrganismos no Cerrado do Oeste da Bahia.

\begin{tabular}{|c|c|c|} 
Tratamentos & BMS - Entrelinha & $\begin{array}{c}\text { BMS - Linha } \\
\left(\mathrm{mg} \mathrm{kg}^{-1}\right) \\
0,00-0,10 \mathrm{~m}\end{array}$ \\
\hline T1 & $162,91 \pm 58,14 \mathrm{a} \mathrm{A}$ & $181,20 \pm 122,07 \mathrm{a} \mathrm{A}$ \\
\hline T2 & $120,99 \pm 28,01 \mathrm{~b} \mathrm{~B}$ & $262,57 \pm 197,37 \mathrm{a} \mathrm{A}$ \\
\hline T3 & $110,99 \pm 31,25 \mathrm{~b} \mathrm{~B}$ & $256,01 \pm 164,08 \mathrm{a} A$ \\
\hline & \multicolumn{2}{|c|}{$0,10-0,20 \mathrm{~m}$} \\
\hline T1 & $59,34 \pm 37,69 \mathrm{~b} \mathrm{~B}$ & $141,97 \pm 70,25 \mathrm{~b} \mathrm{~A}$ \\
\hline T2 & $138,03 \pm 93,24 \mathrm{a} \mathrm{A}$ & $165,82 \pm 60,26 \mathrm{~b} \mathrm{~A}$ \\
\hline T3 & $14,65 \pm 3,32 \mathrm{~b} \mathrm{~B}$ & $280,80 \pm 162,26 \mathrm{a}$ A \\
\hline
\end{tabular}

Média e desvio-padrão seguidos pela mesma letra minúscula na coluna não diferem nas camadas avaliadas, enquanto média e desvio-padrão seguidos pela mesma letra maiúscula na linha não diferem estatisticamente quanto à posição de coleta pelo teste de Duncan ao nível de 5\%. T1: Trichoderma asperellum + Purpurocillium lilacinus + Pochonia chlamydosporia; T2: T. asperellum; T3 - Testemunha. BMS - Biomassa microbiana do solo.

De acordo com Harman et al., (2004) e Hermosa et al., (2012) o Trichoderma ssp é um fungo de reprodução assexuada e de vida livre, com crescimento rápido por meio de conídios ou conidióforos e que estabelece associações com as raízes das plantas, justificando os resultados obtidos no T2 na entrelinha e linha (Tabela 1). Ao colonizar as raízes das plantas, estes fungos alteram o metabolismo vegetal, o conteúdo de hormônios, açúcares solúveis, compostos fenólicos e aminoácidos, taxa fotossintética, transpiração e teor de água (Brotman et al., 2012) e promovem a síntese de auxinas, que beneficiam o crescimento da parte e radicular (Hoyos-Carvajal et al., 2009) pela solubilização de nutrientes, principalmente P (García-López et al., 2017) e Fe favorecendo o crescimento e o desenvolvimento das plantas (Owen et al. 2015), evidenciando elevada atividade biológica na rizosfera, importante para a planta e para estes fungos.

Nas camadas avaliadas, os valores de COT observados na entrelinha e na linha não diferiram estatisticamente, por outro lado, foram maiores e estatisticamente diferentes na linha, na camada de 0,00 a 0,10 m, quando comparados com os valores observados na entrelinha de plantio (Tabela 2). Na entrelinha e na linha, maiores valores médios de COT foram observados no T3, nas duas camadas avaliadas, seguidos dos T2.

Tabela 2. Médias e desvios-padrão do Carbono Orgânico Total avaliado na entrelinha e na linha de plantio de um Latossolo Vermelho-Amarelo distrófico cultivado com Soja inoculada e não inoculada com microrganismos no Cerrado do Oeste da Bahia.

\begin{tabular}{|c|c|c|}
\hline \multirow{2}{*}{ Tratamentos } & COT - Entrelinha & COT-Linha \\
\hline & \multicolumn{2}{|c|}{$\begin{array}{c}(\mathrm{g} \mathrm{kg}-1) \\
0,00-0,10 \mathrm{~m}\end{array}$} \\
\hline T1 & $1,40 \pm 0,50$ a B & $1,80 \pm 0,29$ a A \\
\hline $\mathrm{T} 2$ & $1,51 \pm 0,31$ a B & $1,82 \pm 0,25$ a $A$ \\
\hline T3 & $1,68 \pm 0,23$ a $\mathrm{B}$ & $1,94 \pm 0,16$ a A \\
\hline & \multicolumn{2}{|c|}{$0,10-0,20 \mathrm{~m}$} \\
\hline $\mathrm{T} 1$ & $1,51 \pm 0,31$ a $A$ & $1,68 \pm 0,29$ a $A$ \\
\hline $\mathrm{T} 2$ & $1,71 \pm 0,21$ a $A$ & $1,69 \pm 0,20$ a $A$ \\
\hline T3 & $1,72 \pm 0,23$ a $A$ & $1,86 \pm 0,19$ a $A$ \\
\hline
\end{tabular}

Média e desvio-padrão seguidos pela mesma letra minúscula na coluna não diferem nas camadas avaliadas, enquanto média e desvio-padrão seguidos pela mesma letra maiúscula na linha não diferem estatisticamente quanto à posição de coleta pelo teste de Duncan ao nível de 5\%. T1: Trichoderma asperellum + Purpurocillium lilacinus + Pochonia chlamydosporia; T2: T. asperellum; T3 - Testemunha. COT - Carbono orgânico total.

De acordo com Resck et al., (2008) o estudo do COT é complexo devido à sua variação no ambiente, haja vista que a sua quantidade e qualidade são funções de fatores externos, tais como relevo, clima, vegetação e uso da terra, e internos ao solo, como textura, mineralogia e estrutura e também é devida ao fato de que 
teores e composição funcional do COT variam em profundidade (Rumpel \& Kögel-Knabner, 2011), refletindo no balanço entre quantidades de $\mathrm{C}$ aportado e estabilizado.

Como a BMS é a fração viva da MOS, ela tem como fonte de energia para o seu crescimento e desenvolvimento, o C presente no solo, porém aquele $\mathrm{C}$ que não está protegido dentro dos microagregados do solo ou que está em intima interação com a fração mineral, justificam os resultados observados no T1, que foram em média menores do que os observados nos tratamentos T2 e T3 (Tabela 2).

Ademais, considerando as características intrínsecas do T2, como o T. asperellum é saprofítico, se reproduz e se desenvolve facilmente, aumentando os valores de BMS - Linha (Tabela 1), evidencia-se sua resistência e capacidade de utilizar o C do solo, bem como mineralizá-lo, aumentando os teores de COT nas duas posições de amostragem (Tabela 2).

No que se refere ao T3, onde não houve a inoculação de microrganismo, os maiores valores de COT podem estar relacionados à estabilidade da comunidade microbiana nativa do solo, que além de aproveitar eficientemente o C, têm a capacidade de promover o COT, diferente dos tratamentos com inoculação, evidenciando que, realizar a adição de um grupo de microrganismos (T1) ou privilegiar um microrganismo (T2) imediatamente pode favorecer a BMS, porém, como estes organismos demandam de C, eles reduzem os teores de COT, contrastando com a não inoculação, T3.

Valores de qMic observados em T1, na entrelinha foram maiores e estatisticamente diferentes dos observados no T2 e T3 na camada de 0,00 a 0,10 m, enquanto na camada de 0,10 a 0,20 m o T2 apresentou o maior valor estatisticamente diferentes dos demais tratamentos (Tabela 3). Na linha de plantio, o T2 e T3, na camada superficial, que não diferiram estatisticamente, apresentaram valores estatisticamente maiores do que o observado no T1, enquanto na camada de 0,10 a $0,20 \mathrm{~m}$ o T3 apresentou valor estatisticamente maior do que o observado nos demais tratamentos.

Os maiores valores de qMic observados em T1 na entrelinha, bem como em T2 e T3 na linha (Tabela 3) evidenciam a eficiência dos microrganismos na imobilização do Carbono, enquanto valores reduzidos são ocasionados por circunstâncias em que a microbiota se encontra sob algum fator de estresse ou devido à baixa qualidade nutricional da matéria orgânica, fazendo com que a BMS se torne incapaz de utilizar o C orgânico (Sampaio et al., 2008), como pode ser observado no T2 e T3 na entrelinha.

Tabela 3. Médias e desvios-padrão do Quociente microbiano avaliado na entrelinha e na linha de plantio de um Latossolo Vermelho-Amarelo distrófico cultivado com Soja inoculada e não inoculada com microrganismos no Cerrado do Oeste da Bahia.

\begin{tabular}{|c|c|c|}
\multirow{4}{*}{ Tratamentos } & qMic-Entrelinha & qMic - Linha \\
\multicolumn{3}{|c|}{$0,00-0,10 \mathrm{~m}$} \\
\hline T1 & $11,64 \pm 1,21 \mathrm{a} \mathrm{A}$ & $10,07 \pm 2,01 \mathrm{~b} \mathrm{~A}$ \\
\hline T2 & $8,01 \pm 1,10 \mathrm{~b} \mathrm{~B}$ & $14,43 \pm 1,31 \mathrm{a} \mathrm{A}$ \\
\hline T3 & $6,61 \pm 1,93 \mathrm{~b} \mathrm{~B}$ & $13,20 \pm 1,15 \mathrm{a} A$ \\
\hline \multicolumn{3}{|c|}{$0,10-0,20 \mathrm{~m}$} \\
\hline T1 & $3,93 \pm 1,01 \mathrm{~b} \mathrm{~B}$ & $8,45 \pm 1,33 \mathrm{~b} \mathrm{~A}$ \\
\hline T2 & $8,07 \pm 1,42 \mathrm{a}$ A & $9,81 \pm 1,01 \mathrm{~b} \mathrm{~A}$ \\
\hline T3 & $0,85 \pm 1,37 \mathrm{~b} \mathrm{~B}$ & $15,1 \pm 1,72 \mathrm{a} \mathrm{A}$ \\
\hline
\end{tabular}

Média e desvio-padrão seguidos pela mesma letra minúscula na coluna não diferem entre nas camadas avaliadas, enquanto média e desvio-padrão seguidos pela mesma letra maiúscula na linha não diferem estatisticamente quanto à posição de coleta pelo teste de Duncan ao nível de 5\%. T1: Trichoderma asperellum + Purpurocillium lilacinus + Pochonia chlamydosporia; T2: T. asperellum; T3 - Testemunha. qMic - Quociente microbiano.

Os menores valores de qMic, principalmente na entrelinha, sugerem condição de estresse para a microbiota do solo, possivelmente determinada pelo manejo adotado, condições de umidade, frequente uso de agrotóxicos, bem como baixa disponibilidade de substrato orgânico de qualidade.

Nesse sentido, Sparling (1997) sugere que o qMic pode ser um indicador sensível de mudanças na dinâmica da matéria orgânica de solos submetidos a diferentes práticas de manejo; contudo, essa relação é influenciada pelo manejo do solo, umidade e grau de estabilização do C, e, para expressar uma condição de equilíbrio ou fase de degradação de C, seria necessário estabelecer um valor-base para situações específicas. 


\section{CONCLUSÕES}

Conclui-se que a inoculação de microrganismos na cultura da Soja no Latossolo avaliado, especificamente pelo Trichoderma asperellum, altera, na linha de plantio quando comparado com a entrelinha, a Biomassa Microbiana do Solo (BMS), o Carbono Orgânico Total (COT) e o Quociente Microbiano (qMic).

\section{AGRADECIMENTOS}

Os autores agradecem aos apoiadores e financiadores deste trabalho, sobretudo a empresa de Fertilizantes, JCO.

\section{REFERÊNCIAS}

[1] Alvares, C. A.; Stape, J. L.; Sentelhas, P. C.; Gonçalves, J. L. M.; Sparovek, G.. Köppen's climate classification map for Brazil. Meteorologische Zeitschrift, Stuttgart, v.22, n.6, p.711-728, 2013. DOI: http://dx.doi.org/10.1127/0941-2948/2013/0507.

[2] Brotman Y, Landau U, Cuadros-Inostroza Á, Takayuki T et al (2013) Trichoderma-plant root colonization: escaping early plant defense responses and activation of the antioxidant machinery for saline stress tolerance. PLoS Pathog 9:e1003221

[3] De-Polli, H.; Guerra, J. G. M. Carbono, nitrogênio e fósforo da biomassa microbiana do solo. 2. ed. rev. atual. ampl. In: Santos, G. de A.; Silva, L.S. da; Canellas, L.P.; Camargo, F.A.O. (Ed.). Fundamentos da matéria orgânica do solo: ecossistemas tropicais \& subtropicais. Porto Alegre: Metrópole, 2008.

[4] Doran, J.W., Liebig, M.A., Santana, D.P., 1998. Soil health and global sustainability. In: Proceedings of the 16th World Congress of Soil Science. Montepellier, France, 20-26 August 1998.

[5] Doran, J.W.; Parkin, T.B. Defining and Assessing Soil Quality. In: Doran, J.W.; Coleman, D.C.; Bezdicek, D.F.; Stewart, B.A., Eds., Defining Soil Quality for a Sustainable Environment. Soil Science Society of America Journal, Madison, 3-21, 1994.

[6] Fiorentino, N.; Ventorino, V.; Woo, S.L.; Pepe, O.; De Rosa, A.; Gioia, L.; Romano, I.; Lombardi, N.; Napolitano, M.; Colla, G.; Rouphael, Y. Trichoderma-Based Biostimulants Modulate Rhizosphere Microbial Populations and Improve N Uptake Efficiency, Yield, and Nutritional Quality of Leafy Vegetables. Frontiers in Plant Science v.9, n. 743, 2018.

[7] Gama-Rodrigues, E.F. da; Gama-Rodrigues, A.C. da. Biomassa microbiana e ciclagem de nutrientes. In: Santos, G. de A.; Silva, L.S. da; Canellas, L.P.; Camargo, F.A. de O. (Ed.). Fundamentos da matéria orgânica do solo: ecossistemas tropicais e subtropicais. 2.ed. rev. e atual. Porto Alegre: Metrópole, 2008. p.159-170.

[8] García-López, A.M.; Recena, R.; Avilés, M.; Delgado, A. Effect of Bacillus subtilis QST713 and Trichoderma asperellum T34 on P uptake by wheat and how it is modulated by soil Properties. Journal of Soils and Sediments 18(3), 2017.

[9] Harman, G. E., Howell, C. R., Viterbo, A., Chet, I., and Lorito, M. (2004). Trichoderma species Opportunistic, avirulent plant symbionts. Nat. Rev. Microbiol. 2, 43-56. doi: 10.1038/nrmicro797.

[10] Hermosa, R., Viterbo, A., Chet, I., and Monte, E. (2012). Plant-beneficial effects of Trichoderma and of its genes. Microbiology 158, 17-25. doi: 10.1099/mic.0. 052274-0

[11] Hoyos-Carvajal, L.; Orduz, S.; Bisset, J. Growth stimulation in bean (Phaseolus vulgaris L.) by Trichoderma. Biological Control, 51(3): 409-416, 2009.

[12] Insam, H.; Domsch, K. H. Relationship between soil organic carbon and microbial biomass on chronosequences of reclamation sites. Microbial Ecology, New York, v.15, n.2, p. 177-188, 1988. DOI: http://dx.doi.org/10.1007/BF02011711

[13] Owen D, Williams AP, Griffith GW, Withers PJA (2015) Use of comercial bio-inoculants to increase agricultural production through improved phosphorus acquisition. Appl Soil Ecol 86:41-54

[14] Resck, D.V.S.; Ferreira, E.A.B.; Figueiredo, C.C. \& Zinn, Y.L. Dinâmica da matéria orgânica no Cerrado. In: Santos, G.A.; Silva, L.S.; Canellas, L.P. \& Camargo, F.A.O., eds. Fundamentos da matéria orgânica do solo: Ecossistemas tropicais e subtropicais. 2.ed. Porto Alegre, Metrópole, 2008. p.359-417. 
[15] Rumpel, C. \& Kögel-Knabner, I. Deep soil organic matter - A key but poorly understood component of terrestrial C cycle. Plant Soil, 338:143-158, 2011

[16] Sampaio, D. B.; Araújo, A. S. F.; Santos, V. B. Avaliação de indicadores biológicos de qualidade do solo sob sistemas de cultivo convencional e orgânico de frutas. Ciência e Agrotecnologia, v. 32, n. 2, p. 353359, 2008

[17] Silva, E. E.; Azevedo, P. H. S.; De-Polli, H. Determinação do carbono da biomassa microbiana do solo (BMS-C). Seropédica: Embrapa Agrobiologia, 2007. 6 p. (Embrapa Agrobiologia. Comunicado Técnico, 98).

[18] Sparling, G. P. Soil microbial biomass, activity and nutrient cycling as indicators of soil health. In: Pankhurst, C.; Doube, B. M.; Gupta, V. V. S. R. (Ed.). Biological indicators of soil health. Cambridge: CAB International, 1997. p. 97-120.

[19] STATISTICAL ANALYSIS SYSTEM INSTITUTE, SAS/STAT, Procedure guide for personal computers; version 9, Cary: SAS Institute, 1999.

[20] Teixeira, P. C.Donagemma, G. K. Fontana, A. Teixeira, W. G. Manual de métodos de análise de solo /, editores técnicos. 3. ed. rev. e ampl. - Brasília, DF: Embrapa, 2017.

[21] Vance, E. D.; Brookes, P. C.; Jenkinson, D. S. An extraction method for measuring soil microbial biomass C. Soil Biology and Biochemistry, v. 19, p. 703-707, 1987. 


\section{Capítulo 26}

\section{Avaliação da emissão de metano $\left(\mathrm{CH}_{4}\right)$ pela pecuária}

no município de Anchieta, Santa Catarina

\section{Luciane Luvizon}

Silvia Mara Zanela Almeida

\section{Elisangela Bini Dorigon}

Resumo: A população mundial apresenta crescimento exponencial, bem como o consumo, o que tem promovido uma demanda maior por alimentos, principalmente de origem animal, como carne e derivados da bovinocultura. Nesse contexto, o Brasil se destaca por possuir o maior rebanho comercial bovino do mundo. Em Santa Catarina a produção de carne bovina responde por 4,6\% do VBP da agropecuária catarinense, e a mesorregião do Oeste Catarinense concentra 41,4\% dos abatedouros de bovinos do estado. Esse estudo buscou investigar, em termos de emissão, qual a taxa proveniente da atividade pecuária em Anchieta/SC, munícipio que tem sua economia centrada na agricultura familiar e pecuária de leite e de corte. Para isso, foram analisados dados disponibilizados pela CIDASC de São Miguel do Oeste-SC, assim foi possível fazer uma análise da quantidade de emissão por metano. A partir disso, foi possível também analisar as diferentes formas de diminuição desse poluente e alertar os moradores do município, que embora pequeno, tem um relevo acidentado que favorece zonas de nebulosidade e maior concentração de poluentes no inverno. Os resultados mostraram que, no ano de 2018, o município de Anchieta teve mais de duas mil toneladas de metano liberadas na atmosfera por essa atividade, sendo a pecuária de leite a maior fonte, visto que apresenta um plantel significativamente maior que a pecuária de corte no município. Para municípios pequenos e especialmente, de pecuária familiar, essa informação sobre geração de poluição atmosférica provocada por esse tipo de atividade não é algo que é discutido e avaliado pelos produtores, visto que a emissão de poluentes pela indústria também é pequena e o município não apresenta, teoricamente, problemas de poluição do ar. Considera-se com esse estudo ter um indicativo da emissão aproximada de poluentes para essa atividade e também divulgar esses dados no sindicato dos produtores e também na EPAGRI do município.

Palavras-chave: Metano, ruminantes, poluentes. 


\section{INTRODUÇÃO}

A poluição atmosférica é um dos grandes problemas da atualidade. Dentre as formas desse tipo de poluição, as fontes que emitem metano são alvo de estudos e investigações a respeito de seus efeitos. Isso porque o metano é um dos gases intensificadores do efeito estufa GEE e, consequentemente, do aquecimento global. De acordo com o Acordo do Clima de Paris, o Brasil se comprometeu a reduzir suas emissões de gases de efeito estufa em $37 \%$ até 2025 em relação a 2005, e indicou redução de $43 \%$ em 2030 em relação ao mesmo ano.

O Brasil se destaca mundialmente por possuir o maior rebanho de bovinos comercial, são 214 milhões de cabeças (IBGE, 2019). Segundo o Relatório de Emissões de Gases de Efeito Estufa no Brasil, elaborado pela SEEG (2018), os principais gases contribuintes para emissões no setor agropecuário são o metano $\left(\mathrm{CH}_{4}\right)$ emitido pela fermentação entérica na pecuária e o manejo de dejetos animais e o óxido nitroso $\left(\mathrm{N}_{2} \mathrm{O}\right)$ resultante do uso de fertilizantes nitrogenados, atividade que apresenta a maior taxa de crescimento.

Dentre as fontes de emissão de metano tem-se a pecuária de leite e de corte. No Brasil, a pecuária tem sido responsabilizada pela emissão de $96 \%$ de metano de todas as atividades agrícolas, sendo que a maior parte dessas emissões tem origem em áreas de pastagens extensivas (LIMA, 2002).

Segundo Zotti; Paulino (2009), para possibilitar o desenvolvimento de estratégias que reduzam a emissão de $\mathrm{CH}_{4}$ pelos rebanhos, é necessário quantificar a emissão das várias categorias animais sob as mais diferentes condições de manejo alimentar. Existem muitas técnicas (mensuração em câmara fechada, equações de predição e uso de gás traçador inerte) para quantificar a emissão individual ou em grupo de $\mathrm{CH}_{4}$ ruminal.

De acordo com Lima (2006), o metano é produzido em herbívoros como um subproduto da fermentação entérica, um processo digestivo pelo qual os carboidratos são decompostos por microrganismos em moléculas simples (ácido acético, ácido propiônico e butírico, principalmente) a serem absorvidos no animal. $\mathrm{O}$ autor destaca ainda que quanto maior for o consumo de alimento, maior a emissão de metano, embora a extensão da produção de metano possa também ser afetada pela dieta. 0 consumo de alimento está relacionado ao tamanho do animal, taxa de crescimento, e produção (leite, carne, crescimento de lã, ou prenhez).

Essa fermentação, que ocorre durante o metabolismo dos carboidratos ingeridos pelos ruminantes, é um processo anaeróbio. Nesse processo fermentativo, são produzidos dióxido de carbono $\left(\mathrm{CO}_{2}\right)$ e $\mathrm{CH}_{4}$, em quantidades variáveis, dependendo da concentração e das proporções relativas dos ácidos produzidos (OWENS; GOETSCH, 1988; EUN et al., 2004 in (PEDREIRA et al., 2005).

Nesse sentido, esse estudo buscou investigar, em termos de emissão, qual a taxa de emissão proveniente da atividade pecuária em Anchieta/SC, munícipio que tem sua economia centrada na agricultura familiar e pecuária de leite e de corte. Com base nos resultados, pode-se inferir sobre o potencial poluidor dessa fonte de emissão de metano e alertar os moradores do município, que embora pequeno, tem um relevo acidentado que favorece zonas de nebulosidade e maior concentração de poluentes no inverno.

\section{OBJETIVO}

Avaliar a taxa de emissão de metano $\left(\mathrm{CH}_{4}\right)$ proveniente da atividade pecuária de leite e corte no município de Anchieta/SC.

\section{METODOLOGIA}

A pesquisa foi realizada no município de Anchieta, localizado no extremo Oeste de Santa Catarina, distante $745 \mathrm{~km}$ da capital Florianópolis. O município possui uma área de $231,7 \mathrm{~km}^{2}$ e uma população de 6.360 habitantes (IBGE, 2010), sendo que a economia é voltada a atividade agrícola e pecuária, em sua grande maioria familiar.

Para realização do estudo foram analisados dados da bovinocultura de corte e de leite do município pelo período de 12 meses, correspondente aos dados registrados pela CIDASC no ano de 2018. Com isso, foi possível ter uma estimativa de todos os períodos do ano. 
Os dados foram coletados diretamente na sede da CIDASC na regional de São Miguel do Oeste, em virtude que o município está integrado naquela regional, sendo consultado o número de indivíduos, divididos entre pecuária de corte e leite. Para essa coleta de dados, foi elaborado um instrumento, no formato de tabela, para coleta de informações junto ao órgão responsável, no qual foram agrupadas e separadas todas as informações e dados necessários. Em posse dessas informações e no conhecimento da quantidade de metano emitido por cada tipo de atividade pecuária, realizou-se uma estimativa da produção de metano pela pecuária bovina no município.

Com base nos índices apresentados por Pedreira et al. (2005) (Tabela 1), calculou-se a emissão de metano para a pecuária do município de Anchieta

Tabela 1. Fator de emissão de metano $\left(\mathrm{CH}_{4}\right)$ por categoria de animal

\begin{tabular}{|l|c|c|}
\hline \multirow{2}{*}{ Categoria de animal } & \multicolumn{2}{c|}{$\begin{array}{c}\text { Fator de emissão } \\
\text { kh/cab/ano }\end{array}$} \\
\cline { 2 - 3 } Gado de corte & Fêmeas adultas & 58,00 \\
\cline { 2 - 3 } & Macho adultos & 57,00 \\
\cline { 2 - 3 } & Jovens & 42,00 \\
\hline Gado de leite & Média & 57,00 \\
\hline Ovinos & Média & 5,00 \\
\hline Caprinos & Média & 5,00 \\
\hline Suínos & Média & 1,00 \\
\hline
\end{tabular}

Fonte: PEDREIRA, et al., 2005.

Para realização dessa análise da produção de metano pelos bovinos foi utilizado o programa Excel (2018), que permitiu fazer as correlações entre produção e tipo de atividade. Após, os dados obtidos foram comparados com a literatura existente sobre o assunto, verificando se os índices de produção correspondem com o estimado para a bovinocultura e, por fim, foram propostas alternativas de controle e redução dessa emissão.

\section{RESULTADOS}

A pecuária de corte e de leite emitem diferentes concentrações de metano, por meio da fermentação entérica dos indivíduos (PEDREIRA, et al., 2005). Uma vez que a emissão de metano varia de acordo com a quantidade e a qualidade do alimento digerido, as várias modalidades de sistemas de criação de animais domésticos resultam em diferentes níveis de emissão de metano. Animais jovens ingerem mais matéria seca em porcentagem do peso vivo do que animais adultos, podendo isso resultar em maior emissão de metano por peso vivo. (PRIMAVESI, et al., 2004).

Apesar de todos os esforços em reduzir a emissão de $\mathrm{CH}_{4}$ entérico pelos ruminantes, a mensuração correta da quantidade produzida é fundamental para a comprovação da eficácia dos métodos empregados com o intuito de reduzir as emissões deste gás (PEREIRA; PEDREIRA, 2016).

A partir do fator de emissão de $\mathrm{CH}_{4}$, identificou-se que o município de Anchieta apresentou uma emissão de 2.219,116 toneladas no ano de 2018, proveniente da fermentação entérica dos animais da pecuária de corte e leite do município (Tabela 2). 
Tabela 2. Estimativa da emissão de $\mathrm{CH}_{4}$ pela pecuária de corte e leite no município de Anchieta/SC-2018.

\begin{tabular}{|c|c|c|c|c|}
\hline Categoria de animal & Quantidade cabeças & $\begin{array}{l}\text { Fator emissão ch } \\
\text { kg/cab/ano }\end{array}$ & $\begin{array}{l}\text { Emissão de } \mathrm{CH}_{4} \\
\quad(\mathrm{~kg} / \mathrm{ano})\end{array}$ & $\begin{array}{l}\text { Emissão de } \\
\mathrm{CH}_{4} \\
\text { (ton/ano) }\end{array}$ \\
\hline Pecuária de corte & 8888 & 58,00 & 505.504 & 515,50 \\
\hline Pecuária de leite & 29888 & 57,00 & $1.703,616$ & $1.703,616$ \\
\hline TOTAL & 38776 & - & & $2.219,116$ \\
\hline
\end{tabular}

Fonte: A autora, 2019.

Cabe ressaltar que a emissão de metano tem relação direta com a eficiência fermentativa ruminal, representa perda de carbono e consequentemente perda de energia, e pode resultar em menor desempenho animal. No processo fermentativo, é dissipado calor pela superfície corporal e são produzidos $\mathrm{CO}_{2}$ e $\mathrm{CH}_{4}$. A emissão de metano corresponde à perda de $4 \%$ a $9 \%$, ou até mais, da energia bruta do alimento ingerido e em média é de 6\% (PRIMAVESI, et al., 2004), ou seja, a emissão de metano é perda bruta de energia, além da poluição ambiental resultante desse processo.

A pecuária brasileira é criticada por emitir quantidades significativas de gases de efeito estufa oriunda da fermentação entérica e pelo uso subestimado de fertilizantes nitrogenados. O Brasil é indicado como um contribuinte expressivo nas emissões de gases de efeito estufa, isso em função do tamanho do rebanho, na idade ao abate que varia entre 3 e 3,5 anos e no sistema de criação em pastagens, principal forma de exploração destes animais (PEREIRA; PEDREIRA, 2016)

Os estudos realizados revelaram que a emissão de $\mathrm{CH}_{4}$ proveniente da fermentação ruminal depende principalmente do tipo de animal, nível de consumo de alimentos, tipo de carboidratos presentes na dieta, processamento da forragem, adição de lipídeos no rúmen, suprimento de minerais, manipulação da microflora ruminal e da digestibilidade dos alimentos. Por essas razões, as indicações para a redução das emissões de $\mathrm{CH}_{4}$ pela pecuária estão ligadas a medidas que refletem na melhor eficiência produtiva. (PEDREIRA et al., 2005).

A produção de $\mathrm{CH}_{4}$ entérico pelos ruminantes é dependente em grande parte do tipo de dieta disponível aos animais e do nível de ingestão, podendo ser produzida por microrganismos capazes de sintetizar o $\mathrm{CH}_{4}$, como as bactérias metanogênicas e protozoários metanogênicos. Outra forma de eliminar o $\mathrm{CH}_{4}$ é através do processo de respiração bovina. A degradação dos componentes dietéticos pela microbiota ruminal, principalmente carboidratos, resulta na produção de ácidos graxos voláteis de cadeia. No processo de fermentação são produzidos gases entre eles o $\mathrm{CH}_{4}$ que são eliminados para o ambiente (PEREIRA; PEDREIRA, 2016).

Para a redução das emissões de $\mathrm{CH}_{4}$ em sistemas de produção animal deve-se melhorar a qualidade da dieta. A criação de bovinos em pastagens, apresenta elevada emissão de $\mathrm{CH}_{4}$ entérico comparado com sistema de confinamento, devido a ingestão nesse caso de forragem, com maiores proporções de fibras estruturais, que favorecem a fermentação acética. Assim, uma indicação para reduzir o efeito da produção de $\mathrm{CH}_{4}$ pelo consumo de forrageiras é a implementação de práticas de manejo do pastejo que melhore a qualidade nutricional da forrageira. Contudo, quantidade de metano produzido por unidade de produto (leite ou carne) é reduzida se a produção ou crescimento do animal é aumentado (MACHADO et al., 2011).

A alimentação tem um efeito muito importante no que se refere a emissão de $\mathrm{CH}_{4}$ pelos bovinos. Um estudo realizado por Primavesi et al. (2004), mostrou que forrageiras de baixa qualidade têm a taxa de ingestão reduzida e, consequentemente, reduzem a taxa de emissão de $\mathrm{CH}_{4}$ por bovinos.

Uma das alternativas propostas, baseadas em experiências confirmadas por Esteves et al. (2011) seria o sistema de integração lavoura-pecuária (SILP), o qual aumentou a produção de carne e os animais com maiores ganhos diários de peso podem emitir menores quantidades de metano ruminal, reduzindo os índices de emissão para o ambiente.

Segundo Lima (2006), a emissão de $\mathrm{CH}_{4}$ por unidade de matéria seca ingerida é maior com alimento de baixa qualidade, o consumo de matéria seca por animais mais jovens é maior do que para adultos, os quais podem resultar em maior emissão de metano por peso vivo. Ainda, destaca que o melhoramento da qualidade alimentar resultará em maior consumo de matéria seca, diminuindo a emissão de metano por unidade de matéria seca, aumentando a eficiência de uso da energia bruta. 
Para Zotti; Paulino (2009), quando o animal recebe dietas com maior concentração de amido, ocorre queda do pH, tornando um ambiente mais hostil para a sobrevivência de metanogênicas, devido à baixa produção de $\mathrm{H}_{2}$ resultante dessa fermentação. Então, menos $\mathrm{CH}_{4}$ é produzido por unidade de amido do que por unidade de carboidrato estrutural. A qualidade nutricional dos alimentos tem se tornado um dos principais recursos para mitigação da emissão de $\mathrm{CH}_{4}$, sendo gerados por muitas pesquisas resultados que indicam o uso de concentrados como componente mais efetivo nesta redução. Porém, quando tratamos de um fator de grande impacto ao ambiente, como o $\mathrm{CH}_{4}$, é necessário analisarmos a cadeia produtiva como um todo, quantificando os gastos energéticos envolvidos na produção de grãos e avaliar se estes não são maiores do que a diminuição de sua inclusão na dieta sobre a emissão de $\mathrm{CH}_{4}$ ruminal.

Ainda, de acordo com o autor, para possibilitar o desenvolvimento de estratégias que reduzam a emissão de $\mathrm{CH}_{4}$ pelos rebanhos, é necessário quantificar a emissão das várias categorias animais sob as mais diferentes condições de manejo alimentar. Existem muitas técnicas (mensuração em câmara fechada, equações de predição e uso de gás traçador inerte) para quantificar a emissão individual ou em grupo de $\mathrm{CH}_{4}$ ruminal.

Para Pereira; Pedreira (2016) a produção de metano entérico por ruminantes é inevitável, por mais que o sistema de produção animal, seja controlado, no entanto os autores apresentam algumas sugestões, como: melhorar a qualidade da forragem e sua produtividade, buscar o melhoramento genético do rebanho para se ter animais mais precoces e que ganhem mais peso, reduzir a produção de metano por unidade de produto num determinado tempo.

Para municípios pequenos e especialmente, de pecuária familiar, essa informação sobre geração de poluição atmosférica provocada por esse tipo de atividade não é algo que é discutido e avaliado pelos produtores, visto que a emissão de poluentes pela indústria também é pequena e o município não apresenta, teoricamente, problemas de poluição do ar.

No entanto, com esse estudo foi possível ter um indicativo da real emissão de poluentes para essa atividade e também divulgar esses dados no sindicato dos produtores e também na EPAGRI do município, para que os produtores tenham esse conhecimento e saibam como controlar e minimizar os efeitos dessa atividade.

\section{CONCLUSÃO}

Para municípios pequenos e especialmente, de pecuária familiar, essa informação sobre geração de poluição atmosférica provocada por esse tipo de atividade não é algo que é discutido e avaliado pelos produtores, visto que a emissão de poluentes pela indústria também é pequena e o município não apresenta, teoricamente, problemas de poluição do ar.

No entanto, com esse estudo foi possível ter um indicativo da real emissão de poluentes para essa atividade e também divulgar esses dados no sindicato dos produtores e também na EPAGRI do município, para que os produtores tenham esse conhecimento e saibam como controlar e minimizar os efeitos dessa atividade.

\section{REFERÊNCIAS}

[1] ESTEVES, S. N, BERNARDI, A. C de C, VINHOLIS, M de M e PRIMAVESI, O. Estimativas da emissão de metano por bovinos criados em sistema de integração lavoura pecuária em São Carlos, SP. Belém - PA, 2011. Disponível em: https://www.alice.cnptia.embrapa.br/alice/bitstream/doc/896750/1/PROCI2011.00064.pdf.

[2] IBGE, Instituto Brasileiro de Geografia e Estatística. Censo de 2010. Disponível em: <http://www.ibge.gov.br/home/estatistica/populacao/censo2010/default.shtm>.

[3] IBGE, Instituto Brasileiro de Geografia e Estatística. Produção da pecuária municipal (PPM) 2019. Rio de Janeiro: IBGE.

[4] LIMA, M. A. Emissão de metano pela pecuária. Cuiabá: EMBRAPA Meio Ambiente, 2006. Disponível em: https://www.socioambiental.org/banco_imagens/pdfs/magda_lima.pdf.

[5] LIMA, M. A. Agropecuária brasileira e as mudanças climáticas globais: caracterização do problema, oportunidades e desafios. Cadernos de Ciência \& Tecnologia, v.19, p.451-472, 2002. 
[6] MACHADO, F. S.; PEREIRA, L. G. R.; GUIMARÃES JÚNIOR, R. et al. Emissões de metano na pecuária: conceitos, métodos de avaliação e estratégias de mitigação. Juiz de Fora: Embrapa Gado de Leite, 2011.92 p.

[7] PEDREIRA, M. S, OLIVEIRA, S. G, BERCHIELLI, T. T; PRIMAVESI, O. Aspectos relacionados com a emissão de metano de origem ruminal em sistemas de produção de bovinos (ruminal methane emission related aspects in cattle production systems). Archives of Veterinary Science, 2005. Disponível em: https://revistas.ufpr.br/veterinary/article/viewFile/5122/3868 .

[8] PEREIRA, D. H.; PEDREIRA B. C. Simpósio de Pecuária Recuperação de pastagens: anais... editore. Cuiabá, MT: Uniselva, 2016. Disponível em http://www.pecuariaintegrada.com.br.

[9] PRIMAVESI, O.; et al. Manejo alimentar de bovinos leiteiros e sua relação com produção de metano $\begin{array}{llllll}\text { ruminal. São } & \text { Carlos, } & \text { SP, } & 2004 . & \text { Disponível } & \text { em: }\end{array}$ https://www.infoteca.cnptia.embrapa.br/bitstream/doc/47010/1/Circular39.pdf.

[10] SEEG. Emissões de GEE no Brasil e suas implicações para políticas públicas e a contribuição brasileira para o Acordo de Paris. 2018. Período 1970 - 2016. Observatório do clima, 2018. Disponível em http://seeg.eco.br/wp-content/uploads/2018/08/Relatorios-SEEG-2018-Sintese-FINAL-v1.pdf.

[11] ZOTTI, C. A.; PAULINO, V. T. Metano na produção animal: Emissão e minimização de seu impacto. Instituto de Zootecnia, APTA/SAA, 2009 


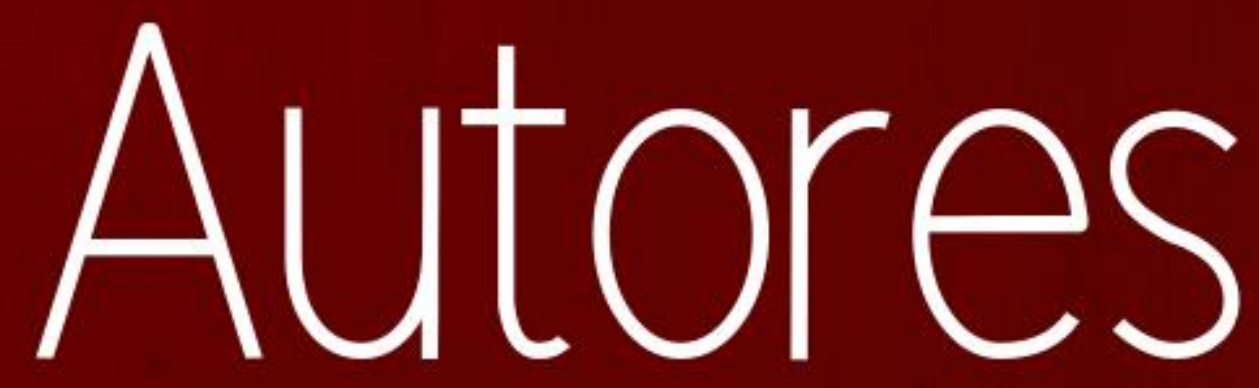




\section{JOSÉ HENRIQUE PORTO SILVEIRA (ORGANIZADOR)}

Bacharel e licenciado em Psicologia pela UFMG, Especialização em Percepção e Planejamento Urbano. Mestre em Gestão e Auditoria Ambiental, especialização em educação ambiental. Consultor em percepção e educação ambiental. Sócio diretor da Alternativa Educação e Manejo Ambiental.

\section{ALINE ALMEIDA DE JESUS MAGALHÃES}

Mestre em Meio Ambiente, Águas e Saneamento (MAASA) (2018) e graduada em Engenharia Sanitária e Ambiental (2016), ambos pela Universidade Federal da Bahia (UFBA). Professora efetiva, dedicação exclusiva do Instituto Federal da Bahia (IFBA), lotada no campus Vitória da Conquista-BA. Formação acadêmica contempla participação no programa Ciência Sem Fronteiras, como estudante de graduação em Montana State University, nos Estados Unidos. Tem experiência com regularização ambiental (licenciamento e outorga de intervenção) de barragens para fins de abastecimento público operadas pela EMBASA. Tem especial interesse de pesquisa em recursos hídricos nas áreas de florações de cianobactérias em mananciais, desenvolvimento de materiais sustentáveis para tratamento de água e remoção de contaminantes em águas para consumo humano.

\section{ALINE CRISTINA DA SILVA}

Possui Técnico em Mecânica Industrial pelo Instituto Federal de Educação, Ciência e Tecnologia de Minas Gerais (IFMG-2009), Manutenção Mecânica pelo Serviço Nacional de Aprendizagem Industrial (SENAI/OB-2008) e graduada do curso de Engenharia Química pela Universidade Federal de São João del Rei (UFSJ - 2020). É membro discente do Grupo de Pesquisa em Materiais Híbridos e Inorgânicos (GPMHI-2018), tendo como coordenadora/orientadora Dra Elidia Maria Guerra (UFSJ-CAP), desenvolvendo projetos de iniciação científica voltado à Estudo da mesoporosidade de W03 utilizando tensoativos para aplicação em baterias de lítio (2014) e Espectroeletroquímica e efeito eletrocrômico de V205, obtido via sol-gel, para aplicação em janelas inteligentes (2018)

\section{ALLANA KARLA COSTA ALVES}

Discente em Engenharia Ambiental e Sanitária pela Universidade Federal de Sergipe. Técnica em Edificações formada pelo Instituto Federal de Educação, Ciência e Tecnologia de Sergipe, campus Lagarto (2015). Bolsista da PRODAP sob a orientação da Dr. Genesio Tamara Ribeiro. Foi aluna bolsista de iniciação científica FAPITEC/IFS (2012-2013) , PIBIC/JR/IFS , PIBIC/COPES/UFS (2017-2018). Possui atuação referente a temas envolvendo as áreas de Ecotoxicologia, Resíduo Sólido e Gestão Ambiental.

\section{ANTÔNIO CELSO DANTAS ANTONINO}

Graduado em Engenharia Civil pela Universidade Federal de Pernambuco - UFPE (1984), mestre em Tecnologias Energéticas e Nucleares pela UFPE (1988) e doutor em Física do Solo pela Universidade Joseph Fourier - Grenoble I (França) (1992). Atualmente é professor titular da UFPE. Pós-doutorado no LTHE-INPG (França) no período de 03/2005 a 02/2006. Professor visitante (estagio sênior de pesquisa) no Departamento de Ciências dos Recursos Terrestres da Universidade de Guelph, Canadá no período de 4/11/2009 a 28/01/2010. Professor visitante (estagio sênior de pesquisa) no Departamento de Engenharia Civil e Ambiental da Pratt School of Engineering da Universidade de Duke, Carolina do Norte, EUA no período de 01/02 a 31/05/2012. Programa Ciências sem Fronteiras.Experiência na área de Física do Solo e de Recursos Hídricos. Atua nos seguintes temas: Modelagem matemática das transferências de água, calor e solutos no sistema solo-planta-atmosfera; Estimação dos parâmetros do escoamento da água e do transporte de solutos nos solos: Métodos de laboratório e de campo, e analíticos (Método inverso); Propriedades hidráulicas e hidrodispersivas dos solos não saturados: descrição e medidas; Modelagem hidrológica; Tomografia Computadorizada de Raios X e gama em solos; Variabilidade espacial e temporal (Estatística e Geoestatística). 


\section{ANTONIO JORGE BARBOSA DA SILVA}

Mestre em Gestão de Áreas Protegidas da Amazônia pelo Instituto Nacional de Pesquisas da Amazônia - INPA; Doutorando em Biodiversidade e Biotecnologia da Amazônia Legal (PPGBIONORTE) pela Universidade do Estado do Amazonas - UEA; Pós-Graduado em Direito Penal e Processual Penal pela Universidade Federal do Amazonas - UFAM; Pós-Graduado em Segurança Pública e Inteligência Policial pela Universidade de Cuiabá - UNIC; Bacharel em Direito pelo Centro Universitário do Norte - UNINORTE; Graduado em Gestão Ambiental pela Faculdade Salesiana Dom Bosco - FSDB; Ex-Diretor Geral do Complexo Penitenciário Anísio Jobim; Ex-Gerente de Administração e Finanças da Secretaria Municipal de Meio Ambiente e Sustentabilidade de Manaus - SEMMAS; Ex-Diretor da Guarda Civil Metropolitana de Manaus.

\section{ARIELA ROCHA CAVALCANTI}

Engenheira Civil graduada pela Universidade Católica de Pernambuco (UNICAP). Durante a graduação tive a oportunidade de desenvolver projetos de pesquisa mediante a participação nos programas de iniciação científica e tecnológica, monitoria na disciplina de Mecânica dos Solos, além dos estágios em empresas privadas. Atualmente sou aluna do Mestrado Acadêmico em Engenharia Civil da Escola Politécnica da Universidade de Pernambuco (POLI/UPE). Durante o mestrado participei de projetos de extensão acadêmica e estágio docência na disciplina de Cálculo III.

\section{BRUNO DIEGO CARDOSO DOS SANTOS}

Bacharel em Engenharia Florestal pela Universidade do Estado de Mato Grosso (UNEMAT), Atua como Técnico de Geotecnologias no Núcleo de Inteligência Territorial do ICV desde outubro de 2017.

\section{CAMILA BARRÊTTO RIQUE DE BARROS}

Mestranda em Engenharia Civil na Universidade de Pernambuco - UPE. Especialização em inspeção, manutenção e recuperação estrutural pela Universidade de Pernambuco - UPE. Graduação em engenharia Civil na Universidade Católica de Pernambuco, UNICAP, Brasil. Interesse na área de Engenharia Civil, com ênfase em linhas de pesquisa de Materiais da Construção Civil (estudo e elaboração de materiais buscando o desenvolvimento auto sustentável no ambiente construtivo) e drenagem urbana (uso de técnicas compensatórias de drenagem urbana). Participante do Grupo de Pesquisa Construção Civil e Análise Estrutural/UNICAP-PE. Bolsista de iniciação cientifica/UNICAP 2015 a 2017.

\section{CELSO ROMANEL}

Possui graduação em Engenharia Civil pela Universidade Federal do Paraná (1974), mestrado em Engenharia Civil pela Pontifícia Universidade Católica do Rio de Janeiro (1981), mestrado em Engenharia Civil - University of Arizona (1987) e doutorado em Engenharia Civil - University of Arizona (1989). Atualmente é professor associado da Pontifícia Universidade Católica do Rio de Janeiro no Departamento de Engenharia Civil e Ambiental, onde leciona as disciplinas Mecânica dos Solos, no curso de graduação, Métodos Numéricos em Geotecnia, Dinâmica dos Solos, Modelos Constitutivos para Materiais Geológicos e Mecânica dos Solos, nos cursos de mestrado e doutorado em Engenharia Civil.

\section{CÍCERO WISLEI FERNANDES GUERELLUS}

Agente universitário Técnico em Química; Universidade Estadual de Ponta Grossa (UEPG); Departamento de Engenharia Civil

\section{CLARA DE OLIVEIRA HESPANHOL}

Graduanda em Engenharia Química pela Universidade Federal de São João del Rei. 


\section{CLAUDIA TELLES BENATTI}

Possui graduação em Engenharia Civil pela Universidade Estadual de Maringá (1993), mestrado (2000) e doutorado (2005) em Engenharia Química pela Universidade Estadual de Maringá. Atualmente é professora Adjunta da Universidade Estadual de Maringá - UEM e Coordenadora do Laboratório de Saneamento Ambiental (Lasam Dec/UEM). Tem experiência em ensino, desenvolvimento de projetos e pesquisa na área de Engenharia Civil, com ênfase em hidráulica e saneamento, com destaque em Técnicas Avançadas de Tratamento de Águas e Efluentes, Tratamento Biológico de Lodo, Gestão e Tratamento de Resíduos Sólidos e Gerenciamento de Recursos Hídricos.

\section{CLIMÉIA CORRÊA SOARES}

Possui Graduação em Ciências Biológicas pela Universidade Federal do Amazonas (1984). Atualmente é pesquisadora do Instituto Nacional de Pesquisas da Amazônia-INPA. Tem experiência na área de Sistemática de Fitoplâncton, atuando principalmente nos seguintes temas: composição, diversidade, algas perifíticas, sistemas lóticos, lênticos de ecossistemas aquáticos da Amazônia brasileira.

\section{CRYFORT STONE RIBEIRO SILVA}

Graduando em Direito na UEMG (Frutal-MG). Desenvolveu a presente pesquisa em Iniciação Científica (sem bolsa).

\section{DAVID AMÉRICO NAKAGAWA}

Possui graduação em Design de Moda pela Universidade Estadual de Maringá - UEM (2007), graduação em Engenharia Civil pela Faculdade Ingá - UNINGÁ (2019) e é mestrando no Programa de Engenharia Urbana - PEU, na Universidade Estadual de Maringá - UEM. Foi aluno intercambista em engenharia civil na Universidade de Minnesota (UofM) - EUA (2015) e Illinois Institute of Technology - IIT - EUA (2016). É pesquisador em desenvolvimento de design de interfaces GUI para aparelhagem IoT de Sistemas Hidráulicos e Hidrossanitários.

\section{DAVID HERMES DEPINÉ}

Advogado, graduado em Direito pelas Faculdades Unificadas de Foz do Iguaçu, Mestre em Direitos da Personalidade pelo Centro Universitário de Maringá, Especialista em Direito Civil e Processo Civil pela Faculdade de Ciências Sociais Aplicadas de Cascavel, Especialização em Direito Previdenciário pela Faculdade de Ciências Sociais Aplicadas de Cascavel. É Professor na União Dinâmica Cataratas - UDC, Campus Medianeira-PR desde 2015, e ministra aulas nas disciplinas de Direito Civil, Direito Previdenciário e Direito Agrário, e sócio do Escritório Andrade e Depiné Advogados Associados.

\section{DERICK MARTINS BORGES DE MOURA}

Doutorando em Geografia (2017 - 2020) pela Universidade Federal de Goiás - Instituto de Estudos Sócio-ambientais (IESA). Mestre em Geografia (2017) pela Universidade Federal de Goiás, campus Jataí. Graduado em Geografia (2014) pela Universidade Estadual de Goiás, campus Iporá. Técnico em Mineração (2008) pelo Instituto Federal de Educação Ciência e Tecnologia de Goiás, campus Goiânia. Tem experiência e atua nas áreas de mapeamento utilizando geotecnologias, análise ambiental integrada, prospecção mineral e geológica, análise de bacias hidrográficas, prospecção e mapeamento de atrativos turísticos naturais. Atualmente trabalha como Técnico Ambiental efetivo na Universidade Estadual de Goiás - Campus Iporá.

\section{DIEGO SEBASTIAN CARVALHO DE SOUZA}

Possui Mestrado em Engenharia Urbana e Ambiental pela PUC-RJ (2020), Engenheiro Civil - UNIRJ (2020), Engenheiro Ambiental e Sanitário - CEUCEL (2011), MBA em Gestão Ambiental - IFRJ 
(2009), especializado em Engenharia Sanitária e Ambiental-UERJ (2015), especialista em Engenharia de Segurança do Trabalho -UCP (2012), MBA de Gestão de Projeto pela FGV, especializado em Docência do Ensino Superior pela INTERVALE (2020) e Gestão Ambiental Integrada pela UERJ/ Universidade do ambiente - INEA. Em minha trajetória profissional tenho experiência na liderança de equipes, treinamentos e aulas para instituições de diversos níveis. Atuo em processos e projetos relacionados a Engenharia de Segurança do Trabalho, Engenharia de Combate a Incêndio, Engenharia Ambiental, Engenharia Sanitária, Engenharia Hídrica e Sistemas de Gestão Integrados baseados em Normas como ISO e OSHAS.

\section{DIOGO BOTELHO CORREA DE OLIVEIRA}

Possui Mestrado em Engenharia Civil (UPE) e graduação em Engenharia Civil (UPE). Pós Graduado em Engenharia de Segurança do Trabalho (UCAM) e em Engenharia Sanitária e Ambiental (Unyleya). Foi Cadete da Academia Militar das Agulhas Negras. Atuou em obras MCMV na área de infraestrutura (drenagem, abastecimento, esgotamento, subestações, pavimentação, terraplenagem) e em programas de implantação e operação de SES. É Gerente Operacional no Grupo Alves da Cunha, responsável pela manutenção e CV de redes de esgoto na RMR. Possui experiência nas áreas de infraestrutura e saneamento. Desenvolveu pesquisas e trabalhos acadêmicos nos seguintes temas: Saneamento Ambiental, tratamento de efluentes, modelagem, matemática aplicada, infiltração de água no solo, drenagem urbana e condutividades térmica e hidráulica do solo.

\section{DIONY ALVES REIS}

É Engenheiro Agrônomo pela Universidade Federal do Pará (2008), Mestre em Solos pelo Programa de Pós-Graduação em Agronomia (2012) e Doutor pelo Programa de Pós-Graduação em Manejo e Conservação do Solo e da Água (2015), ambos pela Faculdade de Agronomia "Eliseu Maciel" da Universidade Federal de Pelotas. Tem experiência como Docente e Coordenador Pedagógico em Instituições públicas e privadas de ensino médio-técnico, graduação e pósgraduação, sobretudo ministrando disciplinas relacionadas à Ciência do Solo, Ciências Agrárias, Agronomia e Engenharia Ambiental. Também atua como Consultor em Instituições privadas voltadas para Agricultura Familiar, Meio ambiente e Mineração. É revisor científico de periódicos nacionais e internacionais que abordam a Ciência do Solo, principalmente a Física do Solo, a Dinâmica da Água no Sistema Solo-Planta-Atmosfera, a Recuperação de áreas degradadas, a Qualidade do Solo, a Fertilidade do Solo e o Manejo e Conservação do Solo e da Água. Tem pósdoutorado pelo Programa de Pós-graduação em Ciências Ambientais da Universidade Federal do Oeste da Bahia (UFOB), onde atualmente é professor substituto lotado no Centro Multidisciplinar de Barra.

\section{DOMITILA PASCOALOTO}

Possui formação em Ciências Biológicas pela Universidade de São Paulo (Licenciatura em 1987 e Bacharelado em 1988), Mestrado em Ciências (Biologia Vegetal) pela UNESP (1992) e Doutorado em Ciências (Biologia de Água de Doce e Pesca Interior) pelo Instituto Nacional de Pesquisas da Amazônia / Fundação Universidade do Amazonas (1999). Especialista em Ecologia de Macroalgas de Ambientes Lóticos e em Limnologia, desde 2002 é pesquisadora no Instituto Nacional de Pesquisas da Amazônia. Foi discente no Centro Universitário do Norte (UNINORTE), onde ministrou as disciplinas "Limnologia" e "Educação Ambiental" (2002-2008). Atualmente suas linhas de pesquisa são, principalmente: Limnologia, Ecologia de Ambientes Aquáticos, Qualidade da Água e Ecologia de algas em ecossistemas aquáticos amazônicos.

\section{EBENÉZER DE FRANÇA SANTOS}

Doutor em Tecnologias Energéticas e Nucleares pela Universidade Federal de Pernambuco (UFPE), Mestre em Tecnologia Ambiental pelo Instituto de Tecnologia de Pernambuco, Higienista Ocupacional pela Faculdade de Ciências Médicas de Minas Gerais, Certificado pela Associação Brasileira de Higienistas Ocupacionais (ABHO), Ergonomista pela UFPE, Certificado Nível III pela Associação Brasileira de Ergonomia (ABERGO), Engenheiro de Segurança do Trabalho pela Escola 
Politécnica da Universidade de Pernambuco (POLI/UPE), Tecnólogo em Sistema de Gestão Ambiental pelo Instituto Federal de Educação, Ciência e Tecnologia de Pernambuco (IFPE) e Engenheiro Civil pela POLI/UPE. Professor do Ensino Básico, Técnico e Tecnológico do IFPE/Campus Recife.

\section{EDGLEIDSON LIMA RODRIGUES}

Graduado em Meteorologia pela Universidade Federal de Campina Grande (2019). Atualmente é aluno de Mestrado no Programa de Pós-Graduação em Meteorologia pela Universidade Federal de Campina Grande, e de Graduação no curso de Licenciatura em Matemática pela Universidade Estadual da Paraíba. Tem experiência na área de Meteorologia e Meio Ambiente, com ênfase em Agrometeorologia, Climatologia, Estatística e Sensoriamento Remoto.

\section{EDGLEY PEREIRA DA SILVA}

Possui graduação em Agronomia pela Universidade Federal da Paraíba (1999), mestrado em Engenharia Agrícola (Irrigação e Drenagem-Linha de Pesquisa Sensoriamento Remoto) pela Universidade de Federal de Campina Grande (2002) e doutorado em Solos e Nutrição de Plantas (Linha de Pesquisa em Geoprocessamento) pela Universidade Federal de Viçosa (2006). Atualmente é professor efetivo na Universidade do Estado de Mato Grosso-Unemat/Campus Universitário de Alta Floresta. Realiza estudos nas linhas de pesquisa: Ciência do solo, Geoprocessamento, Climatologia e Leitura de ambiente.

\section{EDSON DE PAULA RODRIGUES MENDES}

Mestre em Administração pelo Programa de Pós-graduação em Administração da Universidade Federal de Pernambuco - PROPAD/UFPE (2012); Especialista em Administração de Recursos Humanos pela Universidade Federal do Amazonas (2002); Graduado em Direito (2008) e Ciências Sociais (2002) pela mesma instituição; Graduado em Administração de Empresas pela Universidade Nilton Lins (1994). Administrador do Ministério Público do Estado do Amazonas. Tem experiência na área de Administração Pública e na docência nas áreas de Administração e Ciências Sociais, além de haver atuado, por seis anos, como Investigador de Polícia Civil do Amazonas, na área de proteção à criança e ao adolescente. Foi eleito, em 2016, para o cargo de Prefeito do Município de Barcelos, no Estado do Amazonas, e reeleito em 2020, exercendo o mandato atualmente.

\section{EDWIN HENNINGTON PEREIRA MALHEIROS}

Mestrando no Programa de Pós-Graduação em Desenvolvimento e Meio Ambiente Urbano (UNAMA). Engenheiro Civil (UFPA, 2012). Pesquisador em Gestão de Resíduos Sólidos Urbanos, Sustentabilidade em Meio Ambiente Urbano, Ecoturismo e Saneamento Básico, Gestão Hospitalar e Resíduos Sólidos de Serviços de Saúde. Possui experiência profissional em Gestão e Controle de Obras. Atualmente Engenheiro civil do Ministério Público do Pará.

\section{ELISANGELA BINI DORIGON}

Possui graduação em Ciências Biológicas, Especialização em Fitossanidade. Especialização em Botânica, Especialização em Fitoterapia, Especialização em Ensino a Distância e Mestrado em Ciências da Saúde Humana. Atualmente é DOCENTE da UNOESC-Universidade do Oeste de Santa Catarina. Participa do grupo de pesquisa "Saúde Regional para o Desenvolvimento coletivo". Tem experiência na área de Ciências Biológicas, Engenharia Florestal, Engenharia Ambiental e Sanitária, Pedagogia, Zootecnia, Farmácia e Enfermagem, atuando principalmente nos seguintes temas: Recursos Hídricos, Botânica, Farmacognosia, Ecologia e Meio Ambiente 


\section{FABIANA TELLES DAVID DEPINÉ}

Graduação em Direito pela Faculdade Educacional de Medianeira - UDC Medianeira; Técnica em Segurança do Trabalho pelo IFPR; Pós Graduanda em Direito das Famílias e Sucessões pelo Universidade Cândido Mendes/RJ; Mestranda do Programa de Pós Graduação em Desenvolvimento Rural Sustentável da UNIOESTE de Marechal Cândido Rondon; ; Pesquisadora da International Research Network on Climate Resilient Development (RIPEDRC); Membro da Associação de Defesa do Consumidor e Meio Ambiente do Oeste do Paraná - ADECOM; Membro do Grupo de Apoio a Adoção imensidão de Amor; Presidente e idealizadora do GAASMI (Grupo de Apoio a Adoção de São Miguel do Iguaçú); Atualmente Assistente Jurídica no Escritório Andrade e Depiné Advogados Associados.

\section{FELÍCIA MARIA SILVA MOREIRA}

Graduada em Engenheira Química e Bacharela em Ciência e Tecnologia pela Universidade Federal de São João Del-Rei. Green Belt em formação, com experiência em processos e boas práticas de fabricação de alimentos e bebidas. Atuou na área de pesquisa e desenvolvimento, na viabilidade de fermentação alternativa para produção de cervejas probióticas, utilização de fibras naturais como adjunto na composição de telhas, aplicação de resíduos de mineradoras em reações oxidativas e adsorção de fármacos e corantes por biocarvões modificados quimicamente para tratamento de efluentes.

\section{FERNANDA CAROLINE DE OLIVEIRA CARNEIRO}

Bacharel em Direito (CESUPA, 2015) e Advogada. Mestre pelo programa de Pós-Graduação em Desenvolvimento e Meio Ambiente Urbano (PPDMU/UNAMA). Pesquisadora, dedicando-se aos conhecimentos, sobretudo, aos que se referem à Constituição; ao Estado Socioambiental de Direito; e ao Direito Ambiental e Animal.

\section{FRANCISCO DE ASSIS SALVIANO DE SOUSA}

Possui graduação em Bacharelado em Meteorologia pela Universidade Federal da Paraíba (1984), mestrado em Hidráulica e Saneamento pela Escola de Engenharia de São Carlos (1991) (nível 7) e doutorado em Hidráulica e Saneamento pela Universidade de São Paulo (1996) (nível 7). Atualmente é Professor Titular da Universidade Federal de Campina Grande. Tem experiência na área de Engenharia Civil, com ênfase em Hidrologia, atuando principalmente nos seguintes temas: Hidrometeorologia, modelagem hidrológica, climatologia física e estatística do Nordeste.

\section{GABRIELA DOCE SILVA COELHO DE SOUZA}

Engenheira Sanitária e Ambiental (UFPA, 2018). Atualmente é Coordenadora da Vigilância Sanitária - Secretaria Municipal de Saúde de Benevides (PA), atuando principalmente nos seguintes temas: sociedade, engenharia, prática educacional e estudo hidrogeológico.

\section{GRASIELE DA SILVA GOUVEIA}

Discente; Universidade Estadual de Ponta Grossa (UEPG); Engenharia Civil

\section{HELOÍSA THAIS RODRIGUES DE SOUZA}

Pós Doutora, Doutora e Mestre em Desenvolvimento e Meio Ambiente - PRODEMA pela Universidade Federal de Sergipe - UFS. Engenheira Florestal pela Universidade Federal de Sergipe - UFS, Bolsista do DAAD - Serviço Alemão de Intercâmbio Acadêmico (2009/2011), pesquisadora desde o ano de 2005 do GEOPLAN - Grupo de Pesquisa em Geoecologia e Planejamento Territorial (UFS/CNPq) pela Universidade Federal de Sergipe. 


\section{HEVRLI DA SILVA CARNEIRO PILATTI}

Graduação em Ciência da Computação pela Universidade do Estado de Mato Grosso - UNEMAT, Campus de Barra do Bugres (2013). Pós Graduação em Informática e Comunicação na Educação pela Universidade Candido Mendes (2017). Atuou como professora do Ensino Médio Integrado a Educação Profissional de Informática (EMIEP) pela Seduc/MT, docente auxiliar pela Universidade do Estado de Mato Grosso e, atualmente, é aluna do curso de Engenharia Civil pela Universidade do Estado de Mato Grosso campus de Nova Xavantina, mestranda no Programa de Pós-graduação em Engenharia Aplicada e Sustentabilidade (PPGEAS) pelo Instituto Federal Goiano campus Rio Verde e participante do Grupo de Pesquisa "Agricultura Familiar, Políticas Públicas e Desenvolvimento Rural Sustentável", certificado pelo Diretório de Grupos de Pesquisa do CNPq.

\section{HILLÂNDIA BRANDÃO DA CUNHA}

Possui Graduação em Tecnologa Florestal - Modalidade Industria da Madeira pelo Instituto de Tecnologia da Amazônia (1985) com especialização em Química de Produtos Naturais pela Universidade Federal do Amazonas (1986), ,Mestrado em Ciências ((Energia Nuclear na Agricultura) pela Universidade de São Paulo (1992) e Doutorado em Ciências (Energia Nuclear na Agricultura) [Cena] pela Universidade de São Paulo (1996). Atualmente é pesquisadora do Instituto Nacional de Pesquisas da Amazônia e ocupa a função de Coordenadora de Ações Estratégicas dessa instituição. Especialista balanço de massas, suas principais linhas de pesquisa são: Qualidade de Água de superfície na Amazônia, Bacia Hidrográfica, Composição Isotópica, Hidroquímica e Quimica Ambiental.

\section{IRES PAULA DE ANDRADE MIRANDA}

Doutora em Ciências Biológicas, área Botânica (Sandwich) Centre National de Recherche Scientifique (CNRS/INPA) - Museum National d'Histoire Naturelle de Paris (MNHN) e Institut Pasteur em 1993. Pesquisadora Titular III do Instituto Nacional de Pesquisas da Amazônia, Foi coordenadora do Departamento de Botânica do INPA no período (1995/1999), Líder do Grupo de Pesquisas e Laboratório de Estudos em Palmeiras da Amazônia (LABPALM/COBIO/INPA), atua em estudos bioquímicos e químicos do pólen de plantas amazônicas, inventários e mapeamento de insumos vegetais e cadeias produtivas regionais. Publicou vários artigos indexados, livros e capítulos de livros, trabalhos em anais e resumos de eventos nacionais e internacionais, produções e exposições técnicas. Orientou e orienta trabalhos de iniciação científica, especialização, mestrado e doutorado, Foi agraciada em 2011 como 1o colocada na Categoria Social com o Prêmio Professor Samuel Benchimol e Banco da Amazônia de Empreendedorismo Consciente com o projeto Criação de Núcleo Itinerante de Apoio Educacional Informal para a Modernização da Agricultura Familiar no Estado do Amazonas. Foi representante titular do Comitê Técnico da Cadeia Produtiva da Piaçava do Estado do Amazonas. Foi Membro Titular do Comitê de Assessoramento de Ciências Biológicas da FAPEAM e consultora Ad hoc. Docente e Membro do Conselho do Programa de PósGraduação da Rede Bionorte. Presidiu o Comitê do Programa Institucional de Bolsas de Iniciação Científica da Área de Botânica - PIBIC-PAIC/INPA. Coordenou vários projetos interinstitucionais e multidisciplinares nacionais e internacionais. Atua na formação de recursos humanos em cursos de Pós-graduação e graduação.

\section{ISABELA JUBÉ WASTOWSKI}

Pós-doutorado Universidade Estadual de Goiás - Unidade Laranjeiras

\section{JACKSON ROBERTO DE SOUZA SANTOS}

Graduando em Ciências Biológicas pela Universidade Federal do Oeste da Bahia (UFOB). Participou do Programa Institucional de Bolsas de Iniciação à Docência (PIBID). Atualmente, participa como voluntário do Programa Institucional de Bolsas de Iniciação Científica (PIBIC) envolvendo fungos da Classe Agaricomycetes (Basidiomycota) 


\section{JENIFFER SANTOS FERREIRA}

Graduanda em Engenharia Química pela Universidade Federal São João del-Rei (UFSJ).

\section{JÉSSICA CAROLAINE VIEIRA DE AZEVEDO}

Graduada em Engenheira Química pela Universidade Federal de São João Del Rei (2020). Bacharel Interdisciplinar em Ciência e Tecnologia pela Universidade Federal de São João Del Rei (2019). Atuou em projetos na área de tratamento de efluentes e contribuiu em assuntos desse tema a nível nacional e internacional através de trabalhos apresentados em congressos e artigos publicados. Estagiou na Polícia Civil de Minas Gerais, atuando na área de toxilogia forence, metalografia e criminalística.

\section{JOÃO VÍCTOR SALES CASTRO}

Mestrando em Engenharia Química na Universidade Federal de São João Del-Rei, graduado em Engenharia Química também pela Universidade Federal de São João Del-Rei (2020). Durante a graduação, foi monitor das disciplinas Análise Instrumental Aplicada a Bioprocessos (2016/2), Química Analítica Experimental Aplicada a Bioprocessos (2017/1 e 2017/2), Princípios de Química Orgânica (2019/1), Química Orgânica I (2019/2) e Química Orgânica Experimental (2020/1), participou do Projeto de Iniciação Científica intitulado "Modelagem e Simulação de Biorreatores em Série Para a Obtenção de Etanol Utilizando a Equação de Tosseto" (2019/2020). Além disso, foi estagiário em Engenharia Química na Secretaria Municipal de Meio Ambiente de Congonhas/MG (2018).

\section{JORGE DAVID ALGUIAR BELLIDO}

Possui graduação em Engenharia Química - Universidad Nacional de Ingenieria (1999), mestrado em Química (Química Analítica) pela Universidade de São Paulo (2004), doutorado em Ciências, área de concentração em Química (Físico-química) pelo Instituto de Química de São Carlos/Universidade de São Paulo (2008), Com estudos de pós-doutorando na Universidade de São Paulo. Atualmente é Professor adjunto do curso de Engenharia Química no campus Alto Paraopeba da Universidade Federal de São João del-Rei, Minas Gerais. Tem experiência na área de Química, com ênfase em catálise Heterogênea, atuando principalmente nos seguintes temas: produção de hidrogênio, reforma a vapor e oxidativa de etanol, preparação de catalisadores, caracterização de catalisadores através de Redução a Temperatura Programada, Difração de Raios-X pelo método do Pó, Espectroscopia de Absorção na região do ultravioleta e do visível.

\section{KARLA ALCIONE DA SILVA CRUVINEL}

Possui Graduação em Engenharia Ambiental pela Pontifícia Universidade Católica de Goiás (2004), Mestrado em Engenharia do Meio Ambiente pela Universidade Federal de Goiás (2007), Doutorado em Ciências Ambientais pela Universidade Federal de Goiás (2016). Atualmente é Docente Adjunta da Universidade Federal de Goiás (UFG) em regime de Dedicação Exclusiva, docente do Programa de Pós Graduação em Engenharia Ambiental e Sanitária (PPGEAS/UFG). Atuando principalmente nos seguintes temas: Saneamento, Conservação e Reúso de Água, Qualidade das Águas e Sistema de Abastecimento de Água.

\section{LETÍCIA CRISTINA ALVES DE SOUSA}

Graduada em Farmácia. Especialização em Farmacologia e Saúde da Família. Programa de PósGraduação Stricto Sensu em Ambiente e Sociedade. Universidade Estadual de Goiás- Campus Morrinhos. 


\section{LISBETH ZELAYARAN MELGAR}

Professora Adjunto III do curso de Engenharia Química da Universidade Federal de São João delRei (UFSJ). Tem experiência em Desenvolvimento de processo químicos, processos de intercalação de materiais lamelares com compostos orgânicos e adsorção em leito fixo, processos eletroquímicos, eletrooxidação e eletrocoagulação para tratamento de efluentes. Estão sendo estudados a capacidade de adsorção dos argilominerais modificados para adsorção de corantes e fármacos em batelada e fluxo continuo. Estudo da avaliação econômica de pre-projetos de processos químicos, visando propor vários cenários que melhorem a eficiência do processo e lucratividade.

\section{LUAN DOS SANTOS SILVA}

Possui técnico em eletroeletrônica pela Universidade Salvador - UNIFACS (2015). Graduando em Agronomia pela Universidade Federal do Oeste da Bahia (UFOB). Atualmente, participa do grupo GTAagro onde desenvolve sistemas de automação na agricultura.

\section{LUCAS CAILLOT SCHROEDER}

Discente; Universidade Estadual de Ponta Grossa (UEPG); Agronomia

\section{LUCIANE LUVIZON}

Possui graduação em Tecnologia Ambiental pela Universidade Tecnológica Federal do Paraná (UTFPR) (2006), graduação em Engenharia Ambiental e Sanitária pela FUNOESC/FACISA (2019), especialização em Gestão Ambiental e de Recursos Hídricos pela Universidade Estadual do Oeste do Paraná (UNIOESTE) (2008) e mestrado em Conservação e Manejo de Recursos Naturais pela Universidade Estadual do Oeste do Paraná (UNIOESTE) (2012). Atualmente é gerente de projetos Sociais e Ambientais no Instituto Madre Bernarda - Imabe e engenheira autônoma. Tem experiência na área de gestão de projetos, monitoramento de poluentes atmosféricos, água e efluentes, licenciamento ambiental, resíduos sólidos urbanos, economia solidária e projetos ambientais e sanitários.

\section{LUCIVALDO DE JESUS TEIXEIRA}

Discente em Engenharia Ambiental e Sanitária pela Universidade Federal de Sergipe. Técnico em Edificações formada pelo Instituto Federal de Educação, Ciência e Tecnologia de Sergipe, campus Aracaju (2015). Possui atuação referente a temas envolvendo as áreas de Ecotoxicologia, Resíduos Sólidos (na logística, gestão e gerenciamento destes), Licenciamento Ambiental e Gestão Ambiental.

\section{MAGNO RODRIGUES DE CARVALHO FILHO}

Graduação: Ciências biológicas, Faculdade da terra de Brasília, FTB. Pos graduação lato sensu: Biteotecnologia Vegetal, Faculdade Juscelino Kubitschek, JK. Mestrado e Doutorado: Fitopatogia, Universidade de Brasília, UnB.

\section{MANUELLA VIRGÍNIA SALGUEIRO GONDIM}

Possui graduação em Ciências Biológicas-Bacharelado pela Universidade Federal de Pernambuco (2006) e mestrado em Tecnologias Energéticas Nucleares pela Universidade Federal de Pernambuco (2009), com ênfase em Física do solo. Doutora em engenharia civil em ênfase em Tecnologia ambiental e recursos hídricos em regime de cotutela com a Universidade de Grenoble, França. Tem experiência nas áreas de biodegradação de compostos orgânicos e Física do Solo atuando principalmente no seguinte tema: Modelagem matemática das transferências de água e solutos no sistema solo-planta-atmosfera; Estimação dos parâmetros do escoamento da água e do transporte de solutos nos solos: Métodos de laboratório e de campo; Propriedades hidráulicas e 
hidrodispersivas dos solos saturados: descrição e medidas. Atualmente estou bolsista de de PNPD (Programa Nacional de Pós-Doutorado) com inicio em 2017 e térmico previsto para 2022.

\section{MARCO AURELIO CALIXTO RIBEIRO DE HOLANDA}

Mestrando em Engenharia Civil na Escola Politécnica de Pernambuco - UPE. Formado em Engenharia Elétrica de Telecomunicações pela Universidade de Pernambuco - UPE. Bolsista de iniciação científica da Universidade de Pernambuco de 2014 a 2017. Tem experiência na área de Engenharia Elétrica de Telecomunicações, atuando principalmente nos seguintes temas: transformada de Wavelet e modulação digital, e na área de Engenharia Civil, com ênfase em solos, transferência e calor e drenagem urbana. Participou do intercâmbio na Faculdade de Engenharia da Universidade do Porto - FEUP, através do programa Santander Universidades em 2017.

\section{MARCO VALÉRIO DE ALBUQUERQUE VINAGRE}

Engenheiro de Infra Estrutura Aeronáutica (ITA, 1982). Mestre em Engenharia Civil (Rec. Hídricos e San. Ambiental). Doutor em Engenharia de Recursos Naturais da Amazônia (UFPA). Professor da UNAMA no Programa de Mestrado e Doutorado em Desenvolvimento e Meio Ambiente Urbano. ExEngenheiro do Min. Público-PA. Membro Titular da Academia Paraense de Ciências. ExConselheiro e Ex-Diretor do CREA-PA. Ex-Presidente da Companhia de Saneamento do Pará.

\section{MARIA ANTONIA BALBINO PEREIRA}

Acadêmica de Engenharia Ambiental do Instituto Federal Goiano - Campus Rio Verde, participa de projetos de pesquisa e de extensão. Atualmente é Diretora acadêmica do Diretório acadêmico de Engenharia ambiental do Instituto Federal de Educação, Ciência e Tecnologia Goiano.

\section{MARIA GABRIELA DE SOUZA DAMACENO}

Possui Curso Técnico Integrado de Nível Médio em Controle Ambiental no Instituto Federal de Goiás (2013) e Graduação em Engenharia Ambiental e Sanitária pela Universidade Federal de Goiás (2018). Atualmente é mestranda em Engenharia Ambiental e Sanitária no Programa de Pós Graduação em Engenharia Ambiental e Sanitária-PPGEAS da Universidade Federal de Goiás. Desenvolveu estágio no Ministério Público do Estado de Goiás (2018), na Secretaria de Estado de Meio Ambiente, Recursos Hídricos, Infraestrutura, Cidades e Assuntos Metropolitanos - SECIMA (2016 a 2018) e na Agência Municipal de Meio Ambiente - AMMA (2013). Atua principalmente nos seguintes temas: Recursos Hídricos, Saneamento, Licenciamento Ambiental, Conservação e Reúso de Água.

\section{MARIA MAGDALENA RIBAS DÖLL}

Professora; Doutora em Hidráulica e Saneamento; Universidade Estadual de Ponta Grossa (UEPG); Departamento de Engenharia Civil

\section{MIROSLAWA LUCZYNSKI}

Engenheira Sanitária (UFPA, 2003). Mestre em Engenharia Civil (Saneamento Ambiental e Infraestrutura Urbana, UFPA), doutoranda do Programa de Engenharia de Recursos Naturais da Amazônia (UFPA), especialista em Eng. de Segurança do Trabalho (UNAMA, 2019). ExCoordenadora Adjunta de Engenharia Civil e Engenharia Sanitária e Ambiental na UNAMA. Atua na área de Resíduos Sólidos, Gestão e Gerenciamento de projetos, Sistemas de Saneamento Ambiental, Recuperação de Áreas Degradadas, Energias renováveis e Desenvolvimento Sustentável.

\section{NÚBIA ABRANTES GOMES}

Possui graduação em Ciências Biológicas Licenciatura pela Universidade Federal de Pernambuco (1985), graduação em Ciências Biológicas Bacharelado pela Universidade Federal de Pernambuco 
(1985), mestrado em Sistemática de Criptógamos pela Universidade Federal de Pernambuco (1989) e doutorado em Biologia de Água Doce e Pesca Interior pelo Instituto Nacional de Pesquisas da Amazônia (2000). Atualmente é professor Associado IV da Universidade Federal de Roraima. Tem experiência na área de Ecologia, com ênfase em Ecologia e Taxonomia de algas, atuando principalmente nos seguintes temas: limnologia, Ecologia de ambientes aquáticos de águas doce e marinha, botânica, algas, rios, igarapés e saneamento ambiental

\section{PAMELA LOPES SOARES}

Pamela Lopes Soares possui graduação interdisciplinar em Ciência e Tecnologia pela Universidade Federal de São João del Rei (UFSJ) desenvolveu a pesquisa "Proposta de um Compósito Biodegradável a partir do Bagaço da Cana e do Bagaço do Malte Cervejeiro". É Técnica em Química pela Escola Politécnica de Minas Gerais (Polimig) e estudante de Engenharia Química pela (UFSJ), onde desenvolveu a pesquisa "Utilização de Fibras como Adjunto na Produção de Telhas". Também possui pesquisa relativa à "Influência da Adição de Polpa Celulósica e Bentonita nas Propriedades Mecânicas de Tração, Permeabilidade ao Vapor de Água e Solubilidade em Filmes com Matrizes de Amido pela Universidade Federal de Lavras (UFLA).

\section{PERI GUILHERME MONTEIRO DA SILVA}

Engenheiro de Produção (UEPA, 2017). Especialista em Engenharia de Segurança do Trabalho. Mestre em Desenvolvimento e Meio Ambiente Urbano pelo Programa de Pós-Graduação em Desenvolvimento e Meio Ambiente Urbano (PPDMU-UNAMA). Pesquisa temáticas de Resíduos Sólidos (Gestão integrada, gestão, localização de aterros e medidas econômicas), Gestão de Qualidade (qualidade em serviços, pcp, previsão de demanda, qfd e servqual), inteligência artificial para redução de custos energéticos.

\section{RAFAEL ESTEVES DOHLER}

FORMAÇÃO ACADÊMICA: Engenheiro Florestal pela Universidade Federal do Espírito Santo - UFES (2014); Mestre em Ciências Florestais pela Universidade Federal do Espírito Santo - UFES (2016); e Doutorando em Produção Vegetal pela Universidade Federal do Espírito Santo - UFES (20172020). ÁREAS DE ATUAÇÃO: recursos hídricos, geomática (topografia), agrometeorologia e geotecnologias aplicadas.

\section{RENATO FRANCISCO CÂNDIDO LOPES}

Graduado em Meteorologia pela Universidade Federal de Campina Grande (2019). Atualmente é aluno de Mestrado no Programa de Pós-Graduação em Meteorologia pela Universidade Federal de Campina Grande, e de Graduação em Engenharia Sanitária e Ambiental pela Universidade Estadual da Paraíba. Tem experiência na área de Meteorologia e Meio Ambiente, com ênfase em Agrometeorologia, Climatologia, Estatística, e Sensoriamento Remoto, atuando principalmente nos seguintes temas: séries temporais, mudanças climáticas, e sensoriamento remoto aplicado ao clima urbano.

\section{RICARDO DE FREITAS CABRAL}

Possui Doutoramento em Ciência dos Materiais, pelo Instituto Militar de Engenharia (IME), em 2011. Possui Mestrado em Ciência dos Materiais pelo Instituto Militar de Engenharia (IME), em 2008. Possui Graduação em Física pela Universidade Federal Rural do Rio de Janeiro (UFRRJ), em 2006. É Professor Universitário na Universidade Lusíada - Norte, onde leciona nas Enhenharias Mecânica e de Gestão Industrial. Foi professor responsável Doutor do Centro Universitário de Volta Redonda (UniFOA), do Centro Universitário Geraldo di Biase (UGB) e também do Centro Universitpário Estadual da Zona Oeste (UEZO). 


\section{ROBERTO AVELINO CECÍLIO}

Possui graduação em Engenharia Agrícola (1999), mestrado em Engenharia Agrícola (2002) e doutorado em Engenharia Agrícola (2005), todos pela Universidade Federal de Viçosa (2005). Atualmente é Professor Associado da Universidade Federal do Espírito Santo. Tem experiência na área de Recursos Hídricos, atuando principalmente nos seguintes temas: modelagem hidrológica, manejo de bacias hidrográficas, agrometeorologia e geoprocessamento aplicado ao planejamento e manejo de recursos hídricos.

\section{ROBERTO BAGATTINI PORTELLA}

Possui graduação em Engenharia Civil pela Universidade do Vale do Rio dos Sinos (1988), doutorado em Engenharia Ambiental - Universitat Politecnica de Catalunya, Espanha (2007) e PósDoutorado pela UFBA-Universidade Federal da Bahia (2009). É Professor Associado da Universidade Federal do Oeste da Bahia (Centro de Ciências Exatas e de Tecnologias, Campus Reitor Edgar Santos, Barreiras, Bahia), com atuação nas áreas de Planejamento e Monitoramento Ambiental e Recursos Naturais e Energéticos; professor Colaborador do Programa de Pós Graduação em Ciências Ambientais-PPGCA/UFOB; No Laboratório de Geotecnia Ambiental da Escola Politécnica da UFBA, desenvolveu pesquisas relacionada à avaliação de risco derivada da contaminação por metais pesados em Santo Amaro-BA. Tem experiência na área de Engenharia Civil em projetos e execução de obras civis e ambientais, com ênfase no gerenciamento de áreas contaminadas, utilizando Análise de Risco à saúde humana como ferramenta de gestão na tomada de decisões em ações de remediação/mitigação. Tem experiência em pesquisas nas área de Engenharia Civil e em Engenharia Sanitária e Ambiental, atuando principalmente nos seguintes temas: compostos derivados do petróleo, metais pesados, contaminação do ar, solos e águas, Análises de Risco à saúde humana e ecossistemas, atenuação natural, inventário e recuperação de áreas degradadas, prevenção e controle da contaminação ambiental, Avaliação de Impacto Ambiental, Recursos Naturais e Energéticos, Ecologia Industrial.

\section{SÂNDIRA LÍVIA MORAES FONSECA}

Mestre em meio ambiente, águas e saneamento pela Universidade Federal da Bahia-MAASA (2018); Especialista em Gestão de Recursos Hídricos pela Faculdade Unyleya (2017), Graduada em Engenharia Sanitária e Ambiental pela Universidade Federal da Bahia (2012). Professora efetiva, dedicação exclusiva do Instituto Federal da Bahia (IFBA), lotada no campus Eunápolis-BA. Atua principalmente nas seguintes linhas de pesquisa: Qualidade da água, Uso racional de água, Hidrologia e saneamento Básico.

\section{SILVIA MARA ZANELA ALMEIDA}

Possui graduação em Ciências Biológicas Licenciatura Plena pela Universidade de Passo Fundo (1998), graduação em Ciências Biológicas Bacharelado pela Universidade de Passo Fundo (1998), mestrado em Agronomia (Fisiologia Vegetal) pela Universidade Federal de Lavras (2001) e doutorado em Agronomia (Produção Vegetal) pela Universidade Tecnológica Federal do Paraná (UTFPR Campus Pato Branco). Atualmente é docente titular da Universidade do Oeste de Santa Catarina - Campus de Xanxerê. Tem experiência na área de Botânica, com ênfase em Ecofisiologia Vegetal, atuando principalmente nos seguintes temas: sombreamento, fisiologia vegetal, sucessão ecológica e revegetação.

\section{VALMIR FELIX DE LIMA}

Doutor em Engenharia Química pela Universidade Federal de Pernambuco (UFPE) 2015, Mestre em Engenharia Química (UFPE) 2010. Possui graduação em Química Industrial pela Universidade Federal de Pernambuco (1978), graduação em Engenharia Mecânica pela Universidade de Pernambuco (1982), Especialização em Engenharia de Segurança do Trabalho pela UPE (2002). Exerce, desde 1978, funções técnicas/administrativas em vários ramos de atividades produtiva e com larga experiência em manutenção e produção, desde fabrica de alimentos a plataforma de Petróleo e gás e vendas técnicas, de produtos químicos, em diversos ramos de atividades fabris. 


\section{VANESSA CAROLINA MATOSINHOS GONÇALVES}

Graduada em Ciências e Tecnologia pela Universidade Federal de São João del Rei e graduanda em Engenharia Química pela Universidade Federal de São João del Rei. Possui experiência na área de tratamento de efluente de mineração com o projeto de análise do uso de taninos extraídos do pseudocaule da bananeira como coagulantes. Tem experiência na área de adsorção com os projetos de avaliação do diâmetro de coluna de leito fixo na remoção de fenol em carvão de ossos bovinos e avaliação da taxa de aplicação superficial em escala de bancada na remoção de compostos orgânicos refratários em carvão de ossos bovinos, sendo este foi financiado pela FAPEMIG.

\section{VANESSA DE CASTRO ROSA}

Doutora em Direito Político e Econômico no Mackenzie. Mestra em Direitos Humanos (FIEO). Especialista em Agroecologia no Cerrado (UEMG). Especialista em Direito Ambiental (UGF). Bacharela em Filosofia (Unisul). Bacharela em Direito (UNESP). Professora efetiva de Direito Ambiental e Agrário na UEMG (Frutal-MG).

\section{VÂNIA PALMEIRA CAMPOS}

Doutora em Química, Professora Titular do Departamento de Química Analítica - Instituto de Química - UFBA, onde ministra aulas na Graduação e Pós Graduação e desenvolve pesquisas em Química Analítica Ambiental, Química da Hidrosfera e Química da Atmosfera, além de desenvolvimento de técnicas de amostragem de ar e água. Publicou 39 artigos em revistas internacionais e nacionais, 5 capítulos de livros e proferiu 40 palestras/conferências em eventos internacionais e nacionais. Recebeu o Prêmio Antônio Celso Spínola Costa - Destaque em Química, Sociedade Brasileira de Química - Regional Bahia. (2016); Prêmio Mandacaru Instituto Ambiental Brasil Sustentável (2013) e Prêmio Inventor / Núcleo de Inovação e Tecnologia-UFBA (2011). É Membro da Academia de Ciências da Bahia, desde 2019.

\section{VINICIUS DE FREITAS SILGUEIRO}

Graduado em Engenharia Florestal pela Universidade Federal de Mato Grosso (UFMT). Especialista em Gestão Integrada de Sistemas Socioecológicos de Produção Familiar na Amazônia Legal pela Universidade do Estado de Mato Grosso (UNEMAT) e University of Florida (UF). No Instituto Centro de Vida (ICV) desde 2010, atualmente é Coordenador de Inteligência Territorial. Adota inovações em geotecnologias para subsidiar uma compreensão e visibilidade da dinâmica de uso e cobertura do solo nos territórios.

\section{WELLMO DOS SANTOS ALVES}

Doutor, Mestre e Bacharel em Geografia (CREA: RNP 1005596280), com ênfase em Geogr. Física, pela UFG/RJ; Engenheiro Agrônomo (CREA: 21947/D-GO) pelo IF Goiano-RV; Técnico em Agropecuária pelo CEFET-RV; professor permanente no Programa de Pós-Graduação em Geografia da Universidade Federal de Jataí; trabalha no IF Goiano - RV, onde é técnico e responsável pelo Laboratório de Águas e Efluentes, desenvolve pesquisas relacionadas aos Recursos Hídricos (linhas de pesquisa: Geoprocessamento, Engenharia Sanitária e Ambiental), coordena projetos de pesquisa e extensão e orienta estudantes em programas de iniciação científica, extensão e pósgraduação; desde 2015 desenvolve pesquisas (inicialmente como estudante/pesquisador e atualmente como pesquisador) na UFG/Regional de Jataí (atualmente UFJ) nas linhas de pesquisa Modelagem do sistema solo-planta-atmosfera e Geotecnologias aplicadas à análise, planejamento e monitoramento ambiental. Interesse nos seguintes temas relacionados ao ensino, à pesquisa, extensão, atuação técnica/consultoria por meio de Inteligência Geoespacial Aplicada: Análise e Modelagem de Sistemas Ambientais Físicos (qualidade hídrica, modelagem hidrológica e outros), Planejamento e Gestão Territorial e Geotecnologias Aplicadas à Agricultura 4.0. 


\section{WESLEI BUTTURI}

Mestrando do Programa de Pós-Graduação em Biodiversidade e Agroecossistemas Amazônicos (UNEMAT), Bacharel em Engenharia Florestal pela Universidade do Estado de Mato Grosso (UNEMAT), Especialista em Geoprocessamento pela Faculdade de Alta Floresta (FAF) e Especialista em Georreferenciamento de Imóveis Rurais pela Universidade Estadual de Maringá (UEM). Atua como Analista de Geotecnologias no Núcleo de Inteligência Territorial do Instituto Centro de Vida (ICV) desde janeiro de 2013.

\section{WILKER ALVES MORAIS}

Possui graduação em Engenharia Ambiental pela Universidade de Rio Verde (2010). Especialista em Engenharia de Segurança do trabalho pela Universidade de Rio Verde (2012). Mestrado em Ciências Agrárias - Agronomia do Instituto Federal Goiano - Campus Rio Verde (2014). Doutorado em Ciências Agrárias - Agronomia do Instituto Federal Goiano - Campus Rio Verde (2016). Pósdoutorando em Ciências Agrárias - Agronomia Instituto Federal Goiano - Campus Rio Verde.

\section{WILLAMES DE ALBUQUERQUE SOARES}

Concluiu o doutorado em Tecnologias Energéticas Nucleares pela UFPE, na área de Física dos Solos. É formado em Licenciatura plena em Matemática pela UFRPE. Atualmente é professor adjunto da Universidade de Pernambuco, em atividade na Escola Politécnica de Pernambuco POLI. Publicou diversos artigos em periódicos especializados e em anais de eventos. Recebeu 7 prêmios e/ou homenagens. Atua na área de Matemática Aplicada e computacional, com ênfase no meio ambiente. Em seu currículo Lattes os termos mais freqüentes na contextualização da produção científica, tecnológica e artístico-cultural são: Caracterização térmica e Hidrodinâmica de solos, fluxo de calor no solo, evapotranspiração e método inverso.

\section{YASMIM RIBEIRO MEIRELLES}

Graduanda em Engenharia Química pela Universidade Federal São João del-Rei. Atuou em projeto de minimização de reagentes químicos, sendo tema publica em congresso de nível nacional. Estagiou na Seção Técnica Regional e Criminalística da Polícia Civil de Minas Gerais realizando análises

\section{YVONILDE DANTAS PINTO MEDEIROS}

Doutora em Hidrologia pela University of Newcastle Upon Tyne - UK (1994), Mestre em Hidráulica e Saneamento pela Universidade de São Paulo (1984) e Graduada em Engenharia Civil pela Universidade Federal da Bahia (1975). Professora - Associado IV, Dedicação Exclusiva da Universidade Federal da Bahia, locada na Escola Politécnica, no Departamento de Engenharia Ambiental; Coordenadora do Mestrado Profissional em Rede Nacional em Gestão e Regulação de Recursos Hídricos - Polo UFBA. Coordenadora do Curso de Especialização em Segurança de Barragem. Professora do Mestrado em Meio Ambiente, Águas e Saneamento - MAASA e Professora do Doutorado Centro Interdisciplinar de Energia e Ambiente - CIEnAm . Coordenadora do Grupo de Pesquisa em Gestão de Recursos - GRH, com atuação principal nas seguintes linhas de pesquisa: Gestão Integrada dos Recursos Hídricos, Planejamento de Recursos Hídricos, Enquadramento de Corpos d’água, Hidrologia de Semiárido e Reuso de Água.. Membro titular do Comitê da Bacia Hidrográfica do Rio São Francisco, representante de Ensino do Estado da Bahia 


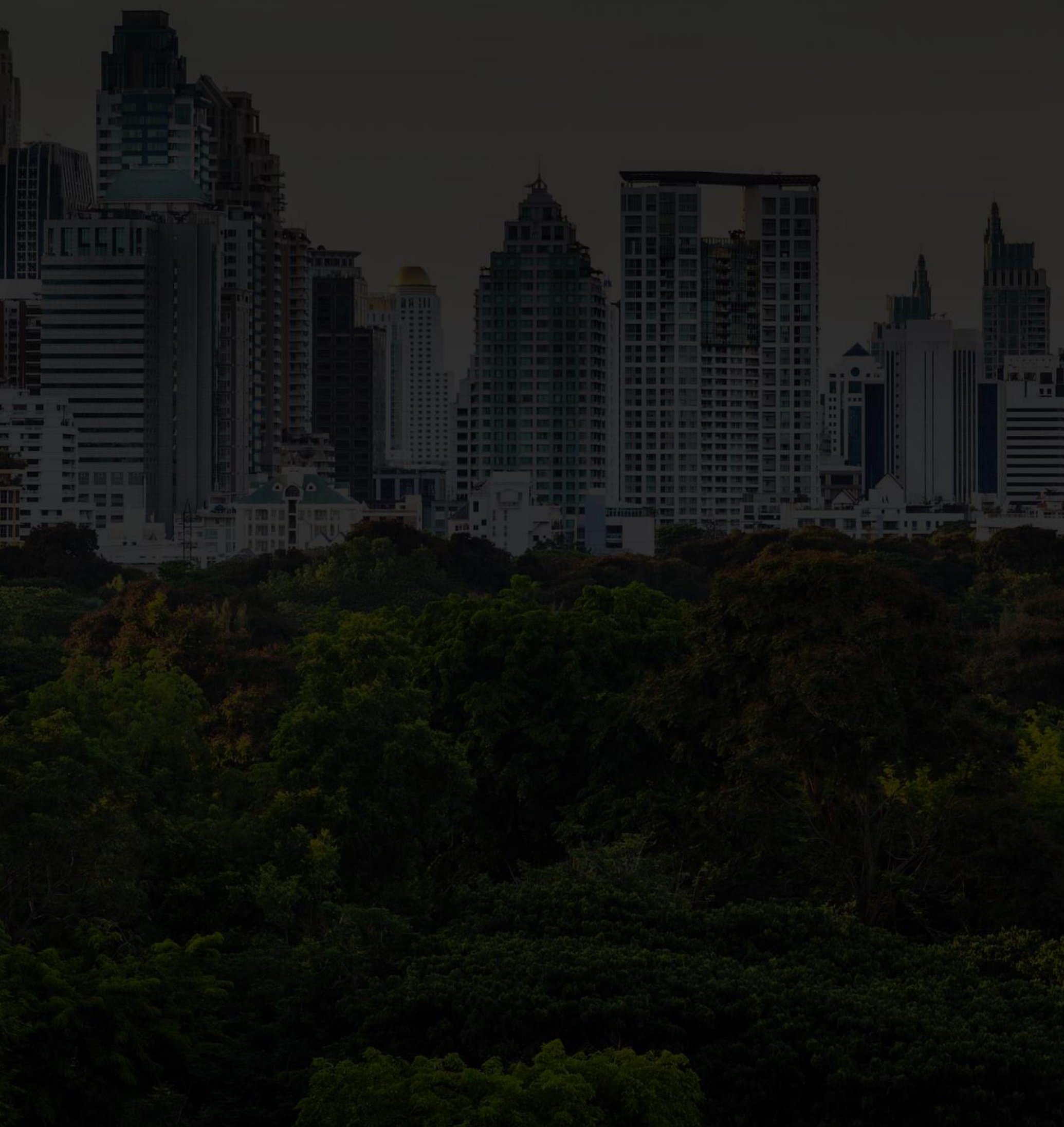

